PNL-5880

UC-11

3

\title{
An Inventory of Current Environmental Monitoring Projects in the U.S.-Canadian Transboundary Region
}

C. S. Glantz

M. Y. Ballinger

E. G. Chapman

May 1986

Prepared for

the U.S. Environmental Protection Agency

under a Related Services Agreement

with the U.S. Department of Energy

under Contract DE-AC06-76RLO 1830

Pacific Northwest Laboratory

Operated for the U.S. Department of Energy

by Battelle Memorial Institute 
Although the research described in this article has been funded wholly or in part by the United States Environmental Protection Agency (EPA), it has not been subjected to EPA review and therefore does not necessarily reflect the views of EPA and no official endorsement should be inferred.

\title{
DISCLAIMER
}

This report was prepared as an account of work sponsored by an agency of the United States Government. Neither the United States Government nor any agency thereof, nor any of their employees, makes any warranty, express or implied, or assumes any legal liability or responsibility for the accuracy, completeness, or usefulness of any information, apparatus, product, or process disclosed, or represents that its use would not infringe privately owned rights. Reference herein to any specific commercial product, process, or service by trade name, trademark, manufacturer, or otherwise, does not necessarily constitute or imply its endorsement, recommendation, or favoring by the United States Government or any agency thereof. The views and opinions of authors expressed herein do not necessarily state or reflect those of the United States Covernment or any agency thereof.

\author{
PACIFIC NORTHWEST LABORATORY \\ operated by \\ BATTELLE \\ for the \\ UNITED STATES DEPARTMENT OF ENERGY \\ under Contract DE-AC06-76RLO 1830
}

\begin{tabular}{|c|c|}
\hline \multicolumn{2}{|c|}{ Printed in the United States of America } \\
\hline \multicolumn{2}{|c|}{ Available from } \\
\hline \multirow{3}{*}{\multicolumn{2}{|c|}{$\begin{array}{c}\text { National Technical Information Service } \\
\text { United States Department of Commerce } \\
5285 \text { Port Royal Road } \\
\text { Springfield, Virginia } 22161\end{array}$}} \\
\hline & \\
\hline & \\
\hline \multicolumn{2}{|c|}{$\begin{array}{l}\text { NTIS Price Codes } \\
\text { Microfiche A07 }\end{array}$} \\
\hline \multicolumn{2}{|c|}{ Printed Copy } \\
\hline & Price \\
\hline Pages & Codes \\
\hline $001-025$ & $\mathrm{A02}$ \\
\hline $026-050$ & $\mathrm{AO3}$ \\
\hline $051-075$ & $A 04$ \\
\hline $076-100$ & A05 \\
\hline $101-125$ & $A 06$ \\
\hline $126-150$ & $\mathrm{~A} 07$ \\
\hline $157-175$ & $\mathrm{~A} 08$ \\
\hline $176-200$ & $A 09$ \\
\hline $201-225$ & A010 \\
\hline $226-250$ & $\mathrm{~A} 011$ \\
\hline $251-275$ & A 012 \\
\hline $276-300$ & $A 013$ \\
\hline
\end{tabular}


AN INVENTORY OF CURRENT ENVIRONMENTAL MONITORING PROJECTS IN THE U.S.-CANADIAN TRANSBOUNDARY REGION

C. S. Glantz

M. Y. Ballinger

E. G. Chapman

May 1986

Prepared for the U.S. Environmental Protection Agency under a Related Services Agreement with the U.S. Department of Energy Contract DE-AC06-76RLO 1830

Pacific Northwest Laboratory Richland, Washington 99352 


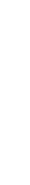


This document presents the results of a study commissioned to survey and summarize major environmental monitoring projects in the U.S.-Canadian transboundary region. Projects with field sites located within $400 \mathrm{~km}(250 \mathrm{mi})$ of the border and active after 1980 were reviewed. The types of projects included in the survey encompassed six categories: ambient air-quality monitoring, ambient water-quality monitoring, deposition monitoring, forest/vegetation monitoring and research, soil studies, and ecosystem studies. Ecosystem studies included projects involving the measurement of parameters from more than one monitoring category (e.g., studies that measured both water and soil chemistry). Individual descriptions were formulated for 184 projects meeting the spatial and temporal criteria. Descriptions included the official title for the project, its common abbreviation, program emphasis, monitoring site locations, time period conducted, parameters measured, protocols employed, frequency of sample collection, data storage information, and the principal contact for the project. A summary inventory subdivided according to the six monitoring categories was prepared using a computerized data management system. Information on major centralized data bases in the field of environmental monitoring was also obtained, and summary descriptions were prepared. The inventory and data base descriptions are presented in appendices to this document.

To maximize its usefulness, this document should be utilized in conjunction with the Concord Scientific Corporation (CSC) report entitled A Review of Atmospheric Deposition Networks in the Great Lakes Basin (1985). The CSC report details atmospheric deposition monitoring activities throughout the U.S. and Canadian Great Lakes region; together the two documents provide a preliminary survey of major environmental monitoring activities in the transboundary region.

Information on monitoring projects for this inventory was obtained by contacting researchers and administrators familiar with the current state of environmental programs, and by reviewing recent data-base source documents and monitoring overview reports. Principal investigators for individual 
projects were asked to review and verify inventory entries to ensure as accurate a compilation of projects as possible. Emphasis was placed on obtaining information on large-scale programs, where large geographic regions, long time periods, or extensive measurement programs were involved. Project coverage is thus geared toward federally funded programs, with almost two-thirds of the inventory entries funded in this manner. Emphasis was also placed on including projects related to the acid precipitation phenomenon, particularly in the areas of ecosystem impacts and pollutant transport, scavenging, and deposition.

Inventory coverage cannot be determined exactly, but we believe that the majority of pertinent large-scale, government-funded programs are included. Coverage is not as extensive for small-scale industrial, local government, or university-sponsored projects.

From the inventory entries and a survey of project characteristics it was noted that environmental monitoring is generally more widespread in the eastern transboundary region and Great Lakes Basin than in the western region. In addition, ambient air-quality, ambient water-quality, and deposition monitoring projects tend to have existed longer, be included in more comprehensive data bases, and have more developed field networks than projects in the forest/ vegetation, soils, and ecosystem impact areas. However, information obtained on recently initiated and upcoming forest and ecosystem programs suggests that projects in these areas are rapidly increasing in both number and complexity.

Comments received from researchers during preparation of the inventory indicate that there appears to be widespread support throughout the scientific community for formal international cooperation in transboundary monitoring and research. Informal cooperation via technical discussions, data exchanges, and joint publications already exists among individual scientists. There also is apparently a desire to initiate studies of protocol compatibility and laboratory comparability in order to address some of the uncertainties that arise when pooling data sets. We suggest that this atmosphere of informal cooperation continue to be fostered and that opportunities for formal 
international cooperation continue to be sought, especially in areas addressing data and protocol compatibility. We further recommend that an in-depth critique of monitoring in the transboundary region be performed to identify specific areas with insufficient coverage and specific programs where joint U.S.-Canadian ventures can be instituted. This document and the concord Scientific Corporation report (1985) on deposition monitoring in the Great Lakes Basin should provide a starting point for such a critique. 



\section{ACKNOWLEDGMENTS}

Much of the information on specific environmental monitoring projects presented in this document was obtained from scientists, engineers, and administrators associated with U.S. and Canadian government agencies, universities, and private organizations. The authors gratefully acknowledge the wealth of information provided with patience and good humor by these professionals, for without their cooperation this document could not have been produced.

The authors also acknowledge the assistance of P. J. Perrault, M. W. Schmeeckle, and S. M. Mckinnon in preparing the inventory, E. L. Owczarski and V. L. Brouns for technical editing, and W. R. Barchet, P. A. Beedlow, and H. S. Bolton for technical review. The patience of L. A. Roberts during the long hours spent typing, editing, and reorganizing this document is also gratefully acknowledged.

This project was funded by the U.S. Environmental Protection Agency under Interagency Agreement DW89931447-01-1. 


\section{CONTENTS}

SUMMARY

ACKNOWLEDGMENTS

1.0 INTRODUCTION

2.0 METHODOLOGY

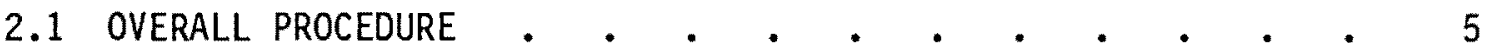

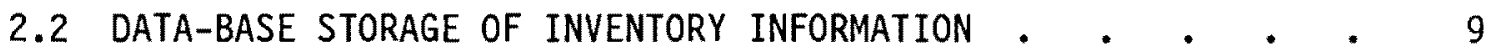

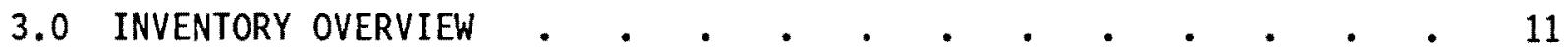

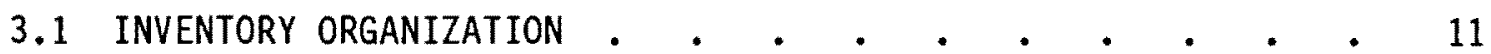

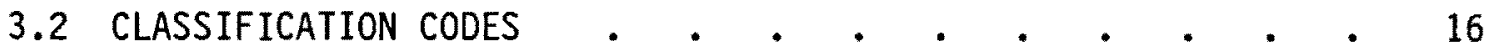

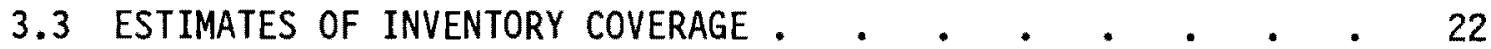

3.4 SURVEY OF INVENTORY PROJECT CHARACTERISTICS . • • • • 24

3.5 UPCOMING MAJOR PROJECTS • • • • • • • • • . . • . 28

3.6 OBSERVATIONS AND RECOMMENDATIONS • • • • • • • . 29

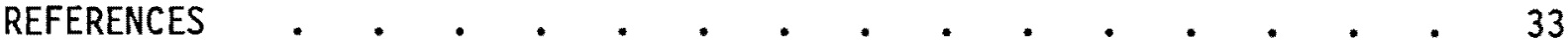

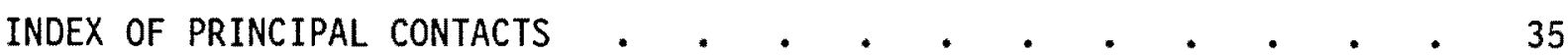

APPENDIX A - A DESCRIPTION OF SELECTED MAJOR ENVIRONMENTAL RESEARCH DATA BASES • • • • • • • • • • • A.1

APPENDIX B - INVENTORY OF TRANSBOUNDARY REGION AMBIENT AIR QUALITY PROJECTS • • • • • • • • • • • • B.1

APPENDIX C - INVENTORY OF TRANSBOUNDARY REGION AMBIENT WATER

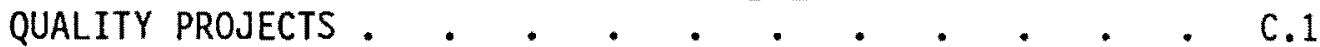

APPENDIX D - INVENTORY OF TRANSBOUNDARY REGION DEPOSITION MONITORING PROJECTS • $•$ •

APPENDIX E - INVENTORY OF TRANSBOUNDARY REGION FOREST/ VEGETATION PROJECTS • • • • • • • • • • • . E.1

APPENDIX $F$ - INVENTORY OF TRANSBOUNDARY REGION SOIL PROJECTS • • • $\quad$ F.I

APPENDIX G - INVENTORY OF TRANSBOUNDARY REGION ECOSYSTEM PROJECTS . - G.1 



\section{FIGURES}

3.1 Sample Entry for Data Base Inventory - • • • • • • • 15

3.2 Sample Entry for Environmental Monitoring Program Inventory . $\quad 17$

\section{TABLES}

1.1 Scope of Transboundary Environmental Monitoring Inventory - . 2

2.1 Major Publications Used in the Inventory Preparation . • . 6

2.2 Initial Key Contacts for Preparation of the Environmental

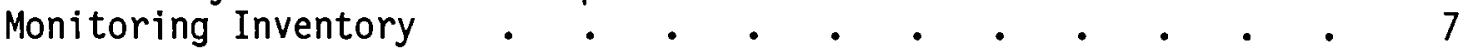

3.1 Key to Classification Codes . . . . . . . . . . . . 19

3.2 Compounds Identified as Water Quality Criteria Pollutants Based on the U.S. Environmental Protection Agency List of Priority Pollutants (Water Quality Criteria Documents; Availability 1980) • • • • • • • • • • • • 21

3.3 Overview of Inventory Project Characteristics . • • • • 25

3.4 Relative Size of Federally Sponsored Projects Included in the Inventory . • • • • • • • • • • • 26

3.5 Geographic Distributions and Measurement Emphasis of Transboundary-Region Monitoring Projects Included in the Inventory

3.6 Major Upcoming Projects Likely to Involve Monitoring Within the Transboundary Region • . • . . . . . . 30 
. 


\subsection{INTRODUCTION}

Airborne and waterborne pollutants can cause significant environmental impacts at sites far removed from their point of origin. The problem of a pollutant source within one political realm affecting areas within another political domain is of growing national and international concern. Concurrent with this increased concern has been the realization that efforts must be made to improve and better coordinate environmental monitoring activities in geographic areas split by political boundaries. Situations in which the locations of field sites are restricted by political jurisdiction, rather than optimum scientific design, need to be avoided. Joint programs and the analysis of merged data sets must be encouraged, and the technical problems associated with these efforts minimized by use of compatible protocols. A combined, coordinated approach should aid in increasing the understanding of pollutant transport and impact mechanisms, and lead to the development of better control strategies and mitigation methods.

This report presents the results of a study conducted by Pacific Northwest Laboratory (PNL) for the Office of Research and Development, U.S. Environmental Protection Agency to survey and summarize major environmental monitoring activities in the U.S.-Canadian transboundary region. The report will be submitted to the International Air Pollution Advisory Board of the International Joint Commission to aid in efforts to review and improve transboundary region monitoring programs.

The study was designed to produce an inventory of monitoring projects located within $400 \mathrm{~km}$ (250 mi) of the U.S.-Canadian border. The scope of the study in terms of the type and location of projects reviewed is summarized in Table 1.1. Emphasis was placed on gathering information for current projects rather than on conducting a historical review; thus, only projects with field stations in operation after 1980 were included. An outgrowth of inventory preparation was the identification of major centralized data bases for various areas of environmental research and the realization that the versatility of the inventory would be greatly increased by including brief descriptions of 
TABLE 1.1. Scope of Transboundary Environmental Monitoring Inventory Purpose Prepare a descriptive inventory of current environmental monitoring projects in the U.S.-Canadian transboundary region

Types of Projects Included
- Ambient air-quality monitoring

- Ambient water-quality monitoring

- Deposition monitoring

- Forest/vegetation monitoring and research

- Soil studies

- Ecosystem studies (e.g., watershed studies)

Spatial Scale

Temporal Scale
$400 \mathrm{~km}(250 \mathrm{mi})$ north and south of the U.S. -Canadian border

Post-1980 projects

these data bases. Such data bases not only provide access to actual project data but also provide avenues to similar projects both within and outside the transboundary region. Readers needing actual project data or detailed monitoring information for a specific geographic region are urged to consult organizations maintaining the data bases described in Appendix $A$ and to use the reference documents discussed in the next section.

The environmental monitoring inventory presented in this report is as complete as possible within time and budgetary constraints. Projects related to the acid precipitation phenomenon were emphasized, especially projects studying ecosystem impacts and pollutant transport, scavenging, and deposition. Representative examples of other transboundary pollutant monitoring programs were also included, but topics such as groundwater monitoring, wildlife behavioral patterns, and radioactive-substance monitoring were considered outside the scope of the inventory.

Emphasis was placed on including large-scale environmental monitoring and research efforts within the fields chosen for study. Large-scale efforts were defined as projects exhibiting at least one of the following characteristics:

- involves a large geographic region

- has existed or is likely to exist for a long time period 
- involves significant (albeit short-term) fieldwork with extensive measurement programs.

Because of the cost of conducting studies with these characteristics, projects falling into the inventory domain tended to be funded by federal or regional agencies. Inventory coverage is thus geared toward federally, provincially, or state-sponsored projects. Less emphasis was placed on obtaining information on monitoring programs administered by individual industrial firms, local government agencies, or university faculty. Inventory coverage of these smaller scale projects is accordingly less extensive.

The following three sections of the report are designed to aid interpretation of the inventory. The first section describes the methodology employed to obtain information on individual transboundary monitoring projects. The second section describes the inventory format and organization, estimates the probable inventory coverage of projects, summarizes the major characteristics of included projects, and reviews upcoming major programs with sites likely to be located in the transboundary region. Observations and recommendations based on the inventory as a whole are also presented. The third section summarizes the major findings of the study. Appendices $A$ through $G$ present data base and project listings for each environmental category listed in Table 1.1 and comprise the actual transboundary monitoring inventory.

To maximize its usefulness, this document should be used in conjunction with the Concord Scientific Corporation (CSC) report entitled A Review of Atmospheric Deposition Networks in the Great Lakes Basin (1985). The CSC report details atmospheric deposition monitoring activities throughout the U.S. and Canadian Great Lakes region. Frequent reference is made to this report in the deposition monitoring inventory. Projects fully described in the CSC report are not included in this inventory. The two documents together provide a preliminary survey of major environmental monitoring activities in the transboundary region. 


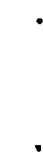




\subsection{METHODOLOGY}

This section comprises three parts: 1) a discussion of the method used in identifying, obtaining, and verifying information on environmental monitoring programs conducted in the U.S.-Canadian transboundary region, 2) a synopsis of the major publications used and a brief mention of some of the people who assisted in the data-collection efforts, and 3) a description of the data-base system used to store the collected information and to prepare the inventory listings given in this document.

\subsection{OVERALL PROCEDURE}

The search for information on transboundary region projects began with a review of recent data-base source documents and monitoring overview reports. In addition, Canadian and U.S. researchers and administrators known to be well-versed in the current state of environmental programs were consulted. These sources provided background information, additional key references, the names of "essential" contacts, and a list of projects that were candidates for inclusion in the inventory. Next, these contacts were requested, via letters and follow-up telephone calls, to provide general information about their fields of expertise, specifics about their own monitoring work, copies of pertinent publications, and suggestions of other contacts or projects relevant to the study. The process was repeated with these additional contacts. Major publications found to be especially useful in the preliminary stages of inventory compilation are summarized in Table 2.1, and initial contacts are listed in Table 2.2.

In addition to reviewing documents provided by contacts, a literature search of the Energy Data Base was conducted using the Department of Energy (DOE) RECON service. The data base was searched with the primary descriptors "acid rain/Canada" and "acid rain/United States," plus one or more of fifteen possible secondary descriptors. The search resulted in the printing of 560 abstracts that had been entered into the data base since 1980. These abstracts were reviewed to identify monitoring projects with temporal and spatial scales appropriate for inclusion in the inventory. 
TABLE 2.1. Major Publications Used in the Inventory Preparation

Publication

Caton, Riordan and Den (1984)

Concord Scientific

Corporation (1985)

Environment Canada

(1983)

Kemp (1977)

01 son (1984)

Wisniewski and

Kinsman (1982)
Synopsis

Details ongoing, recently completed or newly funded projects under the U.S. National Acid Acid Precipitation Assessment Program (NAPAP).

Reviews atmospheric deposition programs recently completed or currently being conducted in the Great Lakes region. Includes Canadian and U.S. studies.

Catalogs Canadian research projects concerned with the long-range transport of air pollutants (LRTAP).

Provides a summary of U.S. biomonitoring programs conducted in the early 1970s.

Reviews U.S. data bases that contain environmental monitoring data. Provides names of contacts for data bases relevant to the inventory.

Contains basic information on many of the North American acid deposition monitoring programs that were ongoing or recently completed in the early 1980s.

Descriptions of individual monitoring projects were prepared and compiled in a draft inventory. Information obtained from publications and in conversations with technical experts for preparing these descriptions included the following:

- official project title

- number and general location of monitoring sites

- principal parameters measured and the methodology employed

- frequency of measurement

- time period of monitoring (start/end dates)

- data availability, including storage form

- principal contact for the project. 
TABLE 2.2. Initial Key Contacts for Preparation of the Environmental Monitoring Inventory

\begin{tabular}{|c|c|c|}
\hline Contact & Address & Information Provided \\
\hline Ann Bartuska & $\begin{array}{l}\text { North Carolina State } \\
\text { University } \\
\text { Raleigh, North Carolina } 27650\end{array}$ & $\begin{array}{l}\text { NAPAP Programs } \\
\text { U.S. Water Quality } \\
\text { Survey Program }\end{array}$ \\
\hline Jacque Dupont & $\begin{array}{l}\text { Governement du Quebec } \\
\text { Ministere de I'Environnement } \\
3900 \text {, rue Marley - 5e } \\
\text { Sainte-Foy, Quebec G1X 4E4 }\end{array}$ & Quebec programs \\
\hline William Fallon & $\begin{array}{l}\text { Environmental Protection Agency } \\
401 \mathrm{M} \text { St. S.W. } \\
\text { Washington, DC } 20460\end{array}$ & $\begin{array}{l}\text { Key U.S. contacts; } \\
\text { overview documents }\end{array}$ \\
\hline Don Faulkner & $\begin{array}{l}\text { Atmospheric Environment Service } \\
\text { Suite } 700,1200 \mathrm{~W} .73 \text { Ave. } \\
\text { Vancouver, British Columbia v6P } 6 \mathrm{H} 9\end{array}$ & $\begin{array}{l}\text { British Columbia and } \\
\text { other western Canadian } \\
\text { programs }\end{array}$ \\
\hline Gary Foley & $\begin{array}{l}\text { Environmental Protection Agency } \\
401 \mathrm{M} \text { St. S.W. } \\
\text { Washington, DC } 20460\end{array}$ & $\begin{array}{l}\text { Key U.S. contacts; } \\
\text { overview documents }\end{array}$ \\
\hline Robert Goldstein & $\begin{array}{l}\text { Electric Power Research Institute } \\
3412 \text { Hillview Avenue } \\
\text { Palo Alto, California } 94304\end{array}$ & $\begin{array}{l}\text { ILWAS, RILWAS, other } \\
\text { EPRI programs }\end{array}$ \\
\hline Steven Holzhey & $\begin{array}{l}\text { National Soil Survey Laboratory } \\
\text { Federal Building Mall North } \\
\text { Lincoln, Nebraska } 68508\end{array}$ & Soil survey information \\
\hline Larry Lechner & $\begin{array}{l}\text { Pollutant Control Branch } \\
\text { Saskatchewan Environment } \\
3085 \text { Alberta St. } \\
\text { Regian, Saskatchewan S4S OB1 }\end{array}$ & $\begin{array}{l}\text { Saskatchewan and other } \\
\text { western programs }\end{array}$ \\
\hline Maris Lusis & $\begin{array}{l}\text { Ontario Ministry of the Environment } \\
880 \text { Bay Street/4th Floor } \\
\text { Toronto, Ontario M5S } 1 \text { Z8 }\end{array}$ & $\begin{array}{l}\text { APIOS Programs; } \\
\text { additional Canadian } \\
\text { contacts }\end{array}$ \\
\hline Susan Milburn & $\begin{array}{l}\text { Environment Canada } \\
4905 \text { Dufferin Street } \\
\text { Downsview, Ontario M3H 5T4 }\end{array}$ & LRTAP programs \\
\hline
\end{tabular}


TABLE 2.2. (Continued)

\begin{tabular}{|c|c|c|}
\hline Contact & Address & Information Provided \\
\hline Richard 01 son & $\begin{array}{l}\text { Oak Ridge National Laboratory } \\
\text { P.0. Box X } \\
\text { Oak Ridge, Tennessee } 37831\end{array}$ & Data bases in ADDNET \\
\hline Charles Philpot & $\begin{array}{l}\text { U.S. Forest Service } \\
\text { Forest Environment Research } \\
606-\mathrm{RPE} \\
\text { P.0. Box } 2417 \\
\text { Washington, DC } 20013\end{array}$ & Forest Survey Programs \\
\hline Charles Powers & $\begin{array}{l}\text { Environmental Protection Agency } \\
\text { Corvall is Environmental Research Lab } \\
200 \text { SW } 35 \text { th Street } \\
\text { Corvallis, Oregon } 97333\end{array}$ & NAPAP Programs \\
\hline Keith Puckett & $\begin{array}{l}\text { Environment Canada } \\
4905 \text { Dufferin Street } \\
\text { Downsview, Ontario M3H 5T4 }\end{array}$ & $\begin{array}{l}\text { Key Canadian contacts; } \\
\text { overview documents }\end{array}$ \\
\hline Peter Van Voris & $\begin{array}{l}\text { Battelle } \\
\text { Pacific Northwest Laboratories } \\
\text { P.0. Box } 999 \\
\text { Richland, Washington } 99352\end{array}$ & $\begin{array}{l}\text { Soils, forestry and } \\
\text { ecosystem contacts }\end{array}$ \\
\hline Charles Watson & $\begin{array}{l}\text { Battelle } \\
\text { Pacific Northwest Laboratories } \\
\text { P.0. Box } 999 \\
\text { Richland, Washington } 99352\end{array}$ & $\begin{array}{l}\text { Acid deposition contacts; } \\
\text { ADS data base }\end{array}$ \\
\hline Owen Williams & $\begin{array}{l}\text { U.S. Geological Survey } \\
\text { National Center, MS421 } \\
\text { Reston, Virginia } 20092\end{array}$ & $\begin{array}{l}\text { NAWDEX, STORET data } \\
\text { bases }\end{array}$ \\
\hline
\end{tabular}


To verify the accuracy of the compiled information, draft descriptions were sent to principal investigators associated with the projects for their review. An accompanying letter explained the purpose of the inventory and included examples of completed inventory entries. A similar procedure was used for verifying information on centralized data bases. Corrections or modifications indicated by principal investigators were incorporated into the final inventory descriptions included in this report. Several investigators supplied complete information on projects related to their main program, and these additional projects were added to the inventory.

\subsection{DATA-BASE STORAGE OF INVENTORY INFORMATION}

The project data base was initially stored on a Digital Electronic Corporation VAX 11/780 computer using the DATATRIEVE data-base management system. DATATRIEVE is an interactive data-base system designed for use on VAX computers. It was selected for use in this investigation because of its versatility and compatibility with other VAX software. Use of the system enabled centralized access to information by project staff and helped prevent duplication of effort. It also enabled output of the preliminary inventory data base either in its entirety or in part, in a variety of formats. As work on the data base reached its final stages, the material in the data base was copied to a personal computer and modified for publication using a word processing package.

A readily transferable data base containing the material presented in this document will be prepared for use on a personal computer using dBASE-III ${ }^{(a)}$ or equivalent data-base management system.

(a) dBASE-III is a registered trademark of Aston-Tate, Culver, Colorado. 



\subsection{INVENTORY OVERVIEW}

The appendices to this document contain an inventory of selected environmental data bases and environmental monitoring programs. In the previous section we described how the information presented there was obtained and verified. This section discusses the organization and structure of the inventory and estimates its representativeness and completeness. This discussion is followed by a survey of inventory project characteristics and a brief description of additional monitoring programs that are scheduled to begin in the near future. Observations and recommendations for future work conclude this section.

\subsection{INVENTORY ORGANIZATION}

As indicated in Table 1.1, six categories of environmental monitoring in the U.S.-Canadian transboundary region are included in this inventory: ambient air-quality monitoring, ambient water-quality monitoring, deposition monitoring, forest/vegetation monitoring and research, soil studies, and ecosystem studies. Each of the environmental-monitoring programs examined and determined to be appropriate for the inventory was placed into one of these six categories. For purposes of this study, environmental-monitoring programs that involve the measurement of parameters from more than one research category are classified as ecosystem studies.

Ambient air-quality monitoring involves the measurement of airborne pollutant concentrations in the atmosphere. Measurement includes both particulate and gaseous forms of pollutants. "Ambient" implies that the measurements are taken some distance from the direct influence of any local pollution source; emissions monitoring programs and data bases were not reviewed for this inventory. Ambient air-quality monitoring is generally performed on a routine basis by local government agencies throughout the United States and Canada. Data are usually transferred to state, provincial, and/or federal agencies for additional analysis and storage.

Ambient water-quality monitoring is concerned with the measurement of the concentration of pollutants in lakes, ponds, streams, rivers, and other surface 
waters. Groundwater studies and additional types of water-quality investigations were not specifically reviewed in this project because of the emphasis on monitoring programs related to acid precipitation impacts. Surface water monitoring is performed on a routine basis by many government agencies, private. organizations, and individual researchers throughout the United States and Canada. Many projects in this category were smaller than the large-scale projects emphasized in the inventory. In fact, many studies involve one lake where measurements are made a few times each year. We have attempted to include in the inventory a representative cross section of major ambient water-quality monitoring programs, but readers desiring a detailed listing of transboundaryregion water-quality monitoring sites are advised to consult the appropriate centralized data bases described in Appendix $A$. Readers interested in waterquality monitoring should also review the ecosystem projects described in Appendix G. Many major monitoring programs are designed to study specific aspects of water quality in detail, and also involve the measurement of other parameters, such as fish populations or sediment composition. Such programs were classified as ecosystem studies because they involve parameters from more than one of the defined research categories.

Deposition monitoring is concerned with the measurement of dry and wet depositing pollutants. Wet deposition monitoring includes studies of rain, fog, and cloudwater chemistry, and is typically performed via precipitation chemistry networks. This area of research has received intensive study within the past 10 years. Programs are generally funded by government agencies, although a number of major projects have been funded by private utility organizations. In many precipitation chemistry studies, rain samples are collected using automated samplers that separate wetfall and dryfall. However, some studies use collectors that combine wetfall and dryfall in a bulk sample. The chemical composition of collected samples is later determined by laboratory analysis. Sampling periods vary depending on the emphasis of the study; samples can be collected on a monthly, weekly, daily, or "event" basis.

Dry deposition is another important removal mechanism for atmospheric pollutants; however, fewer field sites for monitoring dry deposition are in operation. Measurement techniques tend to be more difficult to use on a routine 
basis than the procedures developed for wetfall measurements. Current drydeposition research and monitoring efforts are included in the deposition monitoring category.

Forest/vegetation monitoring and research is concerned with the impact of pollutants on plants, with an emphasis on agricultural products and forest resources. Research is conducted both in the field and in laboratory simulations. Only field investigations were included in this inventory. Through tree coring, plot inventories and other techniques, historical data on tree growth, competition, and stress are available. Research in this field is conducted by both government and private organizations.

Soil studies are concerned with the chemical composition of soils and the transport and transformation of pollutants on these soils, including the mobilization of heavy metals. The monitoring of soil chemistry has been conducted on a routine basis for a number of years on agricultural lands. However, with increasing concern about acid precipitation impacts, attention has recently been focused on the effects of pollutants on forest soils. These studies are often coupled with forest-growth monitoring. These combined projects are listed in the ecosystem category.

Ecosystem studies are concerned with biotic-abiotic interactions and how these interactions affect material and energy transport in an ecosystem. Studies often focus on the impact of pollutants on animal and plant life, ranging from impacts on one-celled organisms to impacts on fish and waterfowl. Many investigators are now studying overall watershed ecology and include nutrient budgets and element mass balances in their programs. Such studies may examine precipitation chemistry, lake sediment chemistry, stream and lake water chemistry, fish populations, tree growth, and soil chemistry within a small area. As stated previously, projects that involve measurements of parameters from more than one research category were classified as ecosystem projects.

In many cases, the best method of accessing data from environmental monitoring programs is through one of many centralized data-base systems in existence. Typically, these systems are funded by government agencies, and 
data are available to the public. These data bases are structured so that a person can request information from a specific program or request data that meet specific criteria (such as all measurements of lake water pH measured in the state of Maine during the spring of 1984). Some data bases do not contain actual environmental-monitoring results; instead, they provide information on where to obtain a certain type of data. These data bases generally provide the name of organizations or programs that collect certain types of data, information on where and how sampling is conducted, the particular parameters measured and who to contact to obtain actual data. In some cases, actual monitoring data may also be contained in the system.

Appendix A contains an inventory of environmental monitoring data bases arranged in alphabetical order. Data from many of the larger environmental monitoring programs contained in the inventory are accessible through the data bases described in this document.

A sample entry for the data-base inventory is given in Figure 3.1. The entry begins by providing the name of the data base, the popular acronym (if one exists) for the data base, the organization currently sponsoring its maintenance, the type of environmental data it contains, and the geographic area from which data are included. This information is followed by a paragraph describing the data base and providing an overview of its contents and operation. Following this paragraph are entries that provide the location of the data base and the name, address, and telephone number of an individual to contact for additional information.

Appendices B through $G$ comprise the inventory of transboundary-region monitoring projects subdivided according to each of the research categories. Within each inventory, individual monitoring programs are presented as follows:

- national-scale Canadian projects

- national-scale U.S. projects

- eastern region projects (Maritime Provinces, Quebec, New England states, New York, Pennsylvania) 


\section{FIGURE 3.1. Sample Entry for Data Base Inventory}

Information provided includes: data base name; acronym; sponsoring organization; type of data base; geographic area of sites providing data input; a general description of the data base; the location of the data base; the name, address, and telephone number of a person to contact for additional information; and a reference for a document containing additional information.

$\begin{array}{ll}\text { NAME } & \text { : Acidification Chemistry Information Data Base } \\ \text { ACRONYM } & : \text { ACID } \\ \text { SPONSOR } & : \text { National ACId Precipitation Assessment Program } \\ \text { TYPE } & : \text { Water Quality } \\ \text { GEOGRAPHICAL AREA : United States }\end{array}$

ACID is a comprehensive data base that combines data from STORET on low alkalinity waters with data sets from a variety of sources. Over 42,000 stations are represented in ACID with over 30,000 from STORET. Data include hydrology, acidity, water chemistry, limited lake and stream morphometry, station location, and other station identifiers. Data from 1900 through' 1980 are included. Quality assurance for data entry and modification into the database are described by Hendrey, Hoogendyk, and Gmur (1983).

DATA LOCATION : Brookhaven National Laboratory, Upton, New York Also in ADDNET

CONTACT NAME : George Hendrey

ADDRESS : Terrestrial and Aquatic Ecology Division Brookhaven National Laboratory Butlding 318 Upton, NY 11973

PHONE : (516) 282-3262

REFERENCE DOC : Hendrey, G. R., C. G. Hoogendyk, and N. F. Gmur. 1983. Establishing the Acidification Chemistry Information Database (ACID). BNL 51707, Brookhaven National Laboratory. Upton, Long Istand, New York.

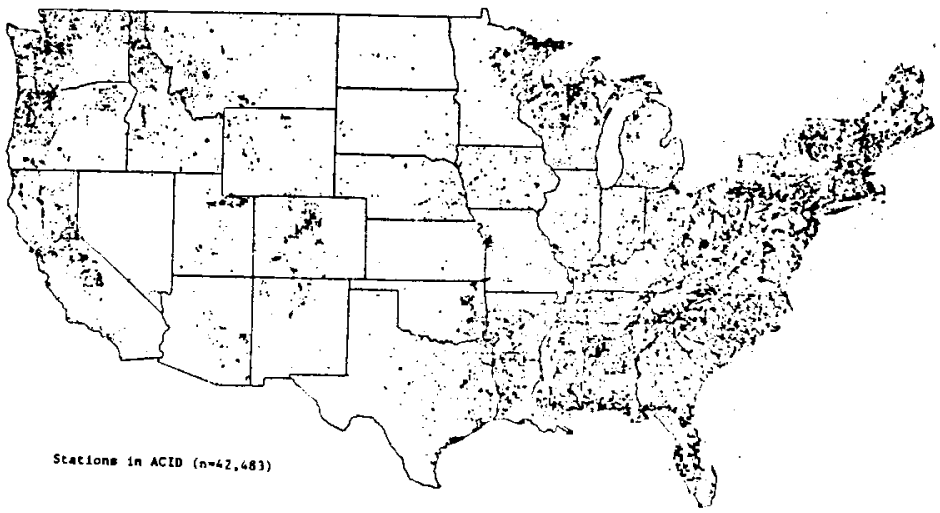


- central region projects (Ontario to Manitoba, Ohio to South Dakota)

- western region projects (Saskatchewan to British Columbia, Montana to Washington).

A sample entry for a monitoring program in one of these inventories is given in Figure 3.2.

Each entry in the inventory includes such information as the official title for the environmental monitoring program (NAME); the common abbreviation for this name, if one exists, (ABREV); a brief characterization of the emphasis of the program (TYPE); the specific parameters measured (PARAM); the geographic: or geopolitical region where monitoring is conducted (CAN or US); the sampling frequency (OFTEN); when the program was initiated and whether or not it is still active (DATES); the sample-collection and analysis methods (HOW); a brief indication if any formal quality assurance/quality control program is followed (QAQC); in what form and where the data are stored (STOR); the name, address, and telephone number of the principal investigator (CONTACT, ADDRESS, TELEPH); and the names of the funding organizations (FUNDS). Following these entries may be several lines of text describing the program in more detail (when further explanation is warranted) or relating the program to other entries (MISC). For projects with many widespread field stations, a map showing the location of monitoring sites is also included. The last line of each entry (CODE) contains a seven-parameter code that identifies the major features of each project. These codes facilitated compilation of the inventory entries and were used in a survey of inventory characteristics. Use of the codes will aid readers interested in quickly identifying interrelated projects or programs with certain characteristics, once an understanding of the codes is attained. Readers interested in using the inventory in this manner are urged to carefully study the next section; casual users of the inventory may wish to bypass the discussion of classification codes.

\subsection{CLASSIFICATION CODES}

Project features considered in the classification include the project type, the geographic area in which monitoring occurred, the parameters (or 


\section{FIGURE 3.2. Sample Entry for Environmental Monitoring Program Inventory}

Information provided includes the name of the program; an abbreviation of this name; program type, parameters measured; monitoring location (in the U.S.); measurement frequency; program duration; how sampling is conducted; QA/QC procedures followed; where data are stored; the name, address and telephone number of the person to contact for additional information; the name of the funding organization; other related information, and a coded summary of the information presented above. In this example, a map of site locations and a reference document citation are also given.
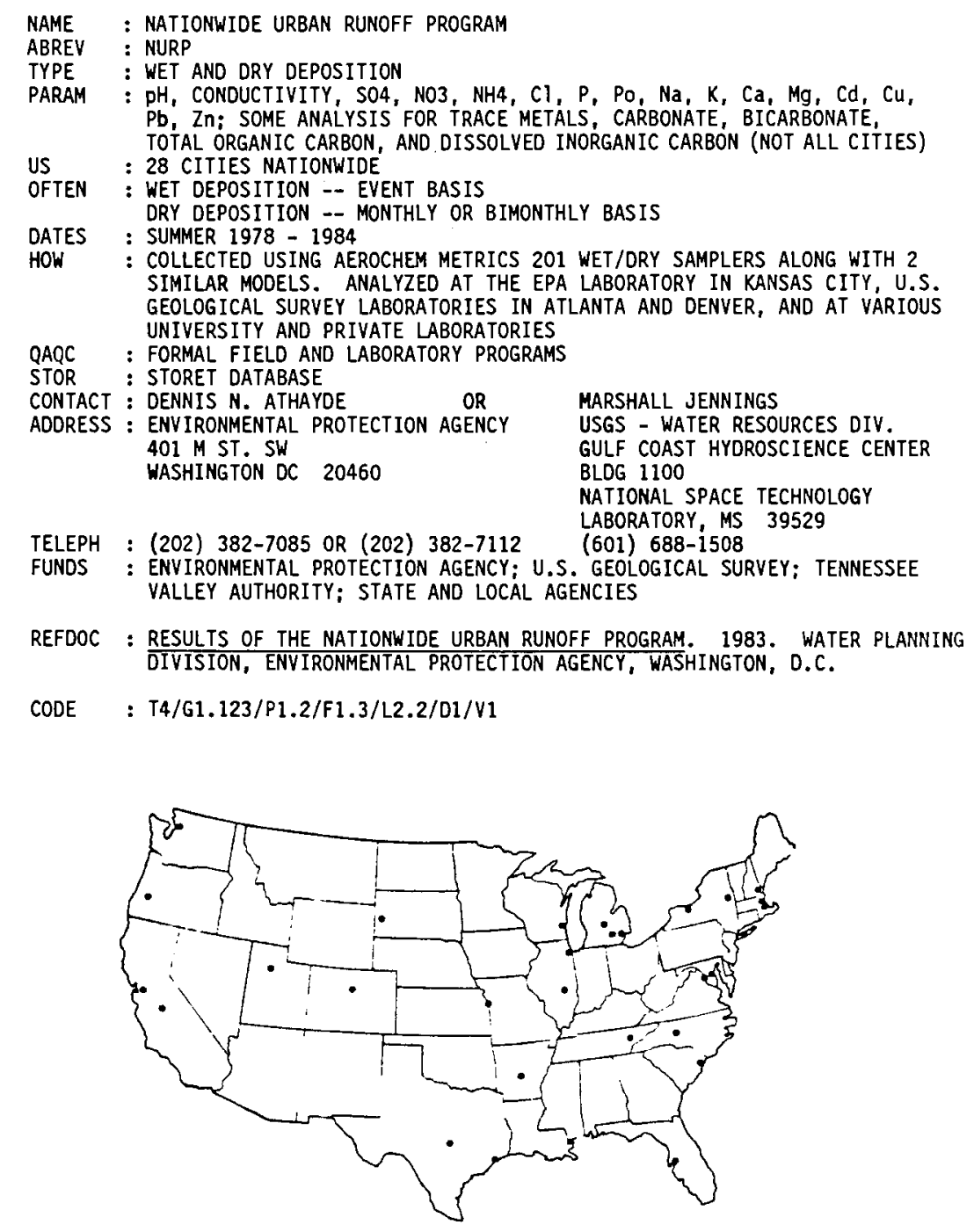
analytes) monitored, the funding source and level, the length of time over which monitoring occurred, whether or not monitoring data were placed in a centralized data base, and whether or not a verified project description was returned by the principal investigator. Table 3.1 summarizes the classification codes. As illustrated in this table, an alphanumeric coding system was employed, with letters identifying a particular project feature and numerals indicating its nature or "value." Main classification codes appear to the left of a decimal point and subclassification codes to the right. Subclassification codes are combined when a project involves more than one category. For example, the "Geographic Area" parameter "G" can take on the main classification value of 1 to signify a project with sampling sites in the United States, or a value of 2 to signify locations in Canada. The region in which the sites are located (eastern, central, or western) is indicated by subclassification codes $(.1, .2$, and .3 , respectively). Thus, a value of 1.2 for "G" indicates a project with sampling sites in the central region of the United States, while a value of 2.123 indicates a project with sites located throughout the Canadian transboundary region.

Classification codes associated with certain parameters require additional explanation. For example, when the "Project Type" feature " $T$ " is assigned the value of 7 to indicate an ecosystem project, subclassification values are used to identify the scope of the monitoring effort. This identification is necessary since ecosystem programs were defined as projects involving measurements from more than one of the five major environmental research categories. Subclassification codes correspond to the main classification codes, with the additional value of ".8" to signify a project with biological monitoring (fish counts, plankton tows, bioassays, diatom counts, etc.). For example, a value of 7.348 for the parameter " $T$ " indicates an ecosystem project where water quality, deposition chemistry, and biological monitoring occur. Subclassification codes are not assigned for the remaining research categories, as only one type of monitoring is involved.

The "Parameters Monitored" feature "P" indicates if measurements are made for compounds for which air- or water-quality standards exist. Air-quality 


\section{TABLE 3.1. Key to Classification Codes}

\begin{tabular}{|c|c|c|c|}
\hline Project Features & $\begin{array}{c}\text { Parameter } \\
\text { Abbreviation }\end{array}$ & Possible Value & Code \\
\hline Project Type & $T^{(a)}$ & $\begin{array}{l}\text { Alr } \\
\text { Water } \\
\text { Deposition } \\
\text { Forest/Vegetation } \\
\text { Solls } \\
\text { Ecosystem }\end{array}$ & $\begin{array}{l}2 \\
3 \\
4 \\
5 \\
6 \\
7\end{array}$ \\
\hline Geographic Area & $G^{(b)}$ & $\begin{array}{l}\text { U.S. } \\
\text { Canada } \\
\text { Eastern } \\
\text { Central } \\
\text { Western }\end{array}$ & $\begin{array}{l}1 \\
2 \\
.1 \\
.2 \\
.3\end{array}$ \\
\hline $\begin{array}{l}\text { Parameters } \\
\text { Monitored }\end{array}$ & $p$ & $\begin{array}{l}\text { Non-Criteria Pollutant } \\
\text { Water Quallty Criteria Pollutants } \\
\text { Primary Project Objective } \\
\text { Secondary Project Obfective } \\
\text { Air Quality Criteria Pollutants } \\
\text { Gases } \\
\text { Particulates } \\
\text { Possible Criteria Pollutants } \\
\text { (Analytes not specifled) } \\
\text { Water } \\
\text { Air }\end{array}$ & $\begin{array}{l}0 \\
1 \\
2.1 \\
2.1 \\
.2 \\
3^{.2} \\
.1 \\
.2\end{array}$ \\
\hline $\begin{array}{l}\text { Funding Source } \\
\text { and Level }\end{array}$ & $F$ & $\begin{array}{l}\text { Not Available } \\
\text { Federal } \\
\text { State/Provincial } \\
\text { Private } \\
\text { Combined } \\
\text { Not Available } \\
\text { Small } \\
\text { Medium } \\
\text { Large } \\
\text { Very Large }\end{array}$ & $\begin{array}{l}0 \\
1 \\
2 \\
3 \\
4 \\
.0 \\
.1 \\
.2 \\
.3 \\
.4\end{array}$ \\
\hline $\begin{array}{l}\text { Duration of } \\
\text { Monitoring }\end{array}$ & $L$ & $\begin{array}{l}\text { Currently Operating } \\
\text { Stopped } \\
\text { Total monitoring period }<5 \text { yrs } \\
\text { Total monitoring period } 25 \text { yrs }\end{array}$ & $\begin{array}{l}1 \\
2 \\
.1 \\
.2\end{array}$ \\
\hline $\begin{array}{l}\text { Data Located in } \\
\text { Centralized } \\
\text { Data Base }\end{array}$ & D & $\begin{array}{l}\text { No Information } \\
\text { Yes } \\
\text { No }\end{array}$ & $\begin{array}{l}0 \\
1 \\
2\end{array}$ \\
\hline $\begin{array}{l}\text { Entry Verified by } \\
\text { Project Personne? }\end{array}$ & V & $\begin{array}{l}\text { Yes } \\
\text { No }\end{array}$ & $\begin{array}{l}1 \\
0\end{array}$ \\
\hline
\end{tabular}

(a) Codes 2-6 available for subclassifying Ecosystem projects, along with "Biological - .8". See text for more information.

(b) Codes combined for multiple regions (e.g., 1.123 for sites across U.S.) 
criteria pollutants in the United States include sulfur dioxide $\left(\mathrm{SO}_{2}\right)$, nitrogen dioxide $\left(\mathrm{NO}_{2}\right)$, carbon monoxide $(\mathrm{CO})$, ozone $\left(\mathrm{O}_{3}\right)$, nonmethane hydrocarbons, total suspended particulates (TSP), and lead. The U.S. Environmental Protection Agency list of priority pollutants published in the Federal Register (Water Quality Criteria Documents; Availability 1980) was used in identifying water criteria pollutants. This list includes 64 organic compounds and metals for which water-quality standards have been promulgated in the United States, or for which standards may be promulgated once additional toxicity information is available. The water-quality priority pollutants are summarized in Table 3.2. The majority of these compounds have also been designated as either National Priority Issues or Program (Emerging) Issues by the Priority Issues Directorate of the Environmental Protection Service, Environment Canada (Environment Canada 1985), or as materials for which suggested drinking water limits have been established by the Ministry of National Health and Welfare (FederalProvincial Working Group on Drinking Water 1978). Values for the "p" feature indicate whether air-or water-quality criteria pollutants are monitored, or whether it is likely that one or more such pollutants are monitored. The latter code is applied when available project literature and information supplied by the principal investigator does not identify the specific compounds monitored, but rather uses general terms such as "trace metal analysis" or "air chemistry measurements." Subclassification codes in such cases indicate whether air-quality or water-quality parameters are involved. Subclassification codes for air-quality criteria pollutants indicate whether gases or particulates are monitored. Subclassification codes for water-quality criteria pollutants indicate whether the compounds are monitored strictly because of toxicity concerns or because information on their presence is useful in interpreting other project data. An example of the latter situation occurs frequently with the analysis of trace metals in water-quality, deposition, and soilsmonitoring studies. Often lead, mercury, and selenium (all priority pollutants) are included in the analysis list of trace elements. However, information on the concentration of these elements may be collected for other than health reasons and may be of secondary importance compared to $\mathrm{pH}$, alkalinity, or sulfate data. Subclassifications for water-quality criteria pollutants thus indicate whether or not toxicity monitoring is a major project objective. 
TABLE 3.2. Compounds Identified as Water Quality Criteria Pollutants Based on the U.S. Environmental Protection Agency List of Priority Pollutants (Water Quality Criteria Documents; Availability 1980)

Acenaphthene
Acrolein
Acrylonitrile
Aldrin/Dieldrin
Antimony
Arsenic
Asbestos
Benzene
Benzidine
Beryllium
Cadmium
Carbon tetrachloride
Chlordane
Chlorinated benzenes
Chlorinated ethanes
Chloroalkyl ethers
Chlorinated naphthalene
Chlorinated phenols
Chloroform
2-Chlorophenol
Chromium
Copper
Cyanides
Dichlorodiphenyltrichloroethane (DDT)
Dichlorobenzenes
Dichlorobenzidine
Dichloroethylenes
2,4-Dichlorophenol
Dichloropropane and
dichloropropene
2,4-Dimethylphenol
Dinitrotoluene
Diphenylhydrazine
Endosulfan

Endrin

Ethylbenzene

Fluoranthene

Haloethers

Halomethanes

Heptachlor

Hexachlorobutadiene

Hexachlorocyclohexane

Hexachlorocyclopentadiene

Isophorone

Lead

Mercury

Naphthalene

Nickel

Nitrobenzene

Nitrophenols

Nitrosamines

Pentachlorophenol

Phenol

Phthalate esters

Polychlorinated biphenyls (PCBs)

Polynuclear aromatic hydrocarbons

Selenium

Silver

Tetrachloroethylene

Thallium

Toluene

Toxaphene

Trichloroethylene

Vinyl chloride

Zinc 
The "Funding Source" feature " $F$ " is used to indicate whether the project is sponsored by federal, provincial/state, or private organizations, or some combination of these three sources. Subclassification codes are used to indicate the relative size and complexity of the project. In assigning these latter codes, consideration was given to the number of field sites, the planned duration of the project, the type and number of measurements performed, and the instrumentation needed for the monitoring effort. Available information on project budgets and capital equipment outlays was also reviewed. In general, projects designated as "smal1" have annual budgets under $\$ 50,000$ (U.S.) and relatively limited equipment needs. "Very large" projects tend to have budgets exceeding $\$ 500,000$ (U.S.) and extensive equipment or sampling requirements. "Medium" and "large" projects fall between these two extremes. Assignment of the subclassification codes was a subjective decision based on information available at the compilation of the inventory. Arguments for different assignments undoubtedly can be made; however, we tried to assign the most appropriate subclassification code based on consistent application of the above criteria.

\subsection{ESTIMATES OF INVENTORY COVERAGE}

For studies of this type, the question invariably arises as to how complete an inventory may be in its coverage of candidate entries. This question is extremely difficult to answer, as accurate and defensible coverage estimates require knowledge of the total sample domain. For the current study, this estimate implies knowing the total number of post-1980 environmental monitoring programs in the transboundary region for each of the categories considered. Since such figures are not available, it is necessary to use somewhat subjective arguments in trying to address the coverage issue. Because of this subjectivity, it is not appropriate to arbitrarily (and blindly) assign indefensible percentages to each category. Instead, an overview discussion of the likely coverage in each category is presented. Where possible, we indicate what types of projects are well-covered and what types of projects may have been missed. Known small-scale projects and comments by researchers contacted in conjunction with projects listed in the inventory were considered in preparing this following discussion. 
Appendix $D$ (deposition monitoring) contains perhaps the most complete coverage of any environmental monitoring research category considered, particularly in its coverage of large-scale programs. Deposition-monitoring networks are relatively well-developed, and information on projects with multiple sites is generally available. An excellent inventory of projects has been published by Wisniewski and Kinsman (1982). A centralized data base (the Acid Deposition System - ADS) for major programs in both the United States and Canada has recently (Watson and 01sen 1984) become operational. The ADS data base is continuing to grow; however, many older, smaller, and nongovernment-sponsored programs have not submitted data.

Actual inventory coverage of ambient air-quality and water-quality projects is not as high as in the deposition category because of the very large number of small projects that fall into these areas. We have attempted to provide a good cross-section of the types of projects conducted and have included the major, national-scale programs operating in each country. Excellent, very complete data bases contain a wealth of environmental monitoring data for these fields. Readers desiring more information are urged to consult such data bases as SAROAD, NAPS, and AQUIS for air-quality data and STORET, ACID, and NAQUADAT for water-quality data. (See Appendix A for descriptions of these data bases.)

Coverage in forest/vegetation, soils, and ecosystems is harder to assess for three reasons: 1) the recent proliferation of field projects, 2) the great number of small projects, and 3) the multitude of organizations sponsoring research in these areas. For more recent projects, open-literature publications were often not yet available. For older programs, unless they were extremely large, knowledge of the project within the scientific community is often limited. The inventory does include, however, the majority of large-scale forest, soil, and ecosystem investigations currently being conducted in the transboundary region.

As indicated throughout this report, emphasis was placed in obtaining information on large-scale, government-funded programs, and the document includes the vast majority of such programs. Although an exact percentage calculation of inventory coverages is not possible, the estimated coverage of 
appropriate studies is certainly above $70 \%$. This observation is based on the study of Canadian and U.S. government overview documents describing major environmental programs. However, as discussed previously, such an estimate must be considered subjective. Coverage of smaller programs, such as studies at one site or those programs with infrequent sampling (e.g., seasonal snow pack studies), is less extensive. Such investigations tend to be conducted by universities, colleges, private firms, and various agencies of state, provincial and local governments. Many of these projects are not published in the open literature and are not included in overview documents. Considerable effort would be required to increase the coverage of such projects to levels attained for large-scale, government-funded programs in the inventory.

\subsection{SURVEY OF INVENTORY PROJECT CHARACTERISTICS}

In addition to externally oriented questions concerning completeness of inventory coverage, internally oriented questions also arise concerning the similarities and differences of projects included in the inventory. To address the most common questions, a survey of inventory entries was conducted using the assigned project classification codes described in Section 3.2. The survey identified common project characteristics and summarized the total number of projects in each environmental monitoring research category. The major characteristics identified in this survey are summarized in Tables 3.3, 3.4, and 3.5. In reviewing these tables, it must be remembered that information contained in them refers only to the projects included in the inventory, and not to all projects in existence.

As indicated in Table 3.3, 184 projects are included in the inventory, with deposition-monitoring and ecosystem projects composing approximately $68 \%$ of the total entries. This large percentage reflects not only the inventory emphasis on acid precipitation projects but also the fact that a large number of projects involve integrated measurement programs that encompass more than one environmental monitoring category. The number of projects submitting data to the centralized data bases (61 out of 184, or 33\%) appears somewhat small on first consideration, given that such data bases were heavily used in identifying projects for inclusion in the inventory. However, principal 
IABLE 3.3. Overview of Inventory Project Characteristics

\begin{tabular}{|c|c|c|c|c|c|c|c|}
\hline \multirow[b]{2}{*}{$\begin{array}{c}\text { Project } \\
\text { Characteristic }\end{array}$} & \multicolumn{7}{|c|}{ Environmental Monitoring Category } \\
\hline & $\begin{array}{c}\text { Air } \\
\text { Quality } \\
\end{array}$ & $\begin{array}{c}\text { Water } \\
\text { Quality }\end{array}$ & Deposition & $\begin{array}{c}\text { Forest/ } \\
\text { Vegetation } \\
\end{array}$ & Soils & Ecosystem & $\begin{array}{l}\text { Inventory } \\
\text { Total } \\
\end{array}$ \\
\hline $\begin{array}{l}\text { Total Number in Each } \\
\text { Category }\end{array}$ & 9 & 33 & 55 & 6 & 10 & 71 & 184 \\
\hline $\begin{array}{l}\text { Duration } \\
\text { In operation }<5 \text { years } \\
\text { In operation }>5 \text { years } \\
\text { No longer in operation }\end{array}$ & $\begin{array}{l}4 \\
4 \\
1\end{array}$ & $\begin{array}{r}11 \\
8 \\
14\end{array}$ & $\begin{array}{l}16 \\
18 \\
21\end{array}$ & $\begin{array}{l}3 \\
1 \\
2\end{array}$ & $\begin{array}{l}2 \\
2 \\
6\end{array}$ & $\begin{array}{l}29 \\
20 \\
22\end{array}$ & $\begin{array}{l}65 \\
53 \\
66\end{array}$ \\
\hline $\begin{array}{l}\text { Criteria Pollutants } \\
\text { Water } \\
\text { - Primary Objective } \\
\text { - Secondary Objective } \\
\text { Air }\end{array}$ & $\begin{array}{l}0 \\
0 \\
9\end{array}$ & $\begin{array}{l}7 \\
1 \\
0\end{array}$ & $\begin{array}{r}2 \\
13 \\
7\end{array}$ & $\begin{array}{l}0 \\
0 \\
0\end{array}$ & $\begin{array}{l}1 \\
1 \\
0\end{array}$ & $\begin{array}{r}18 \\
25 \\
3\end{array}$ & $\begin{array}{l}28 \\
40 \\
19\end{array}$ \\
\hline $\begin{array}{l}\text { Funding Source } \\
\text { Federal } \\
\text { State/Provincial } \\
\text { Private } \\
\text { Combined }\end{array}$ & $\begin{array}{l}6 \\
2 \\
0 \\
1\end{array}$ & $\begin{array}{r}19 \\
8 \\
2 \\
4\end{array}$ & $\begin{array}{r}28 \\
13 \\
8 \\
6\end{array}$ & $\begin{array}{l}4 \\
0 \\
0 \\
2\end{array}$ & $\begin{array}{l}6 \\
3 \\
1 \\
0\end{array}$ & $\begin{array}{r}51 \\
6 \\
8 \\
6\end{array}$ & $\begin{array}{r}114 \\
32 \\
19 \\
19\end{array}$ \\
\hline $\begin{array}{l}\text { Data Available in } \\
\text { Centralized Data Base }\end{array}$ & 6 & 21 & 19 & 2 & 2 & 11 & 61 \\
\hline $\begin{array}{l}\text { Entry Verified by } \\
\text { Project Personnel }\end{array}$ & 8 & 25 & 49 & 4 & 6 & 54 & 146 \\
\hline
\end{tabular}


TABLE 3.4. Relative Size of Federally Sponsored

Size of Project

Smal1

Medium

Large

Very Large

Not Classified Due to Insufficient Information
Projects Included in the Inventory

Environmental Monitoring Category

$\begin{array}{ccc}\text { Air } & \text { Water } & \text { Forests/ } \\ \text { Quality } & \text { Quality } & \text { Deposition Vegetation Soils Ecosystem Total }\end{array}$

$0 \quad 15$

15

2

2

0

1

0

0

4

4

15

9

0

0

0

2

1

1

0

0

4
70

21

5

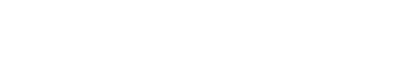


TABLE 3.5. Geographic Distributions and Measurement Emphasis of Transboundary-Region Monitoring Projects Included in the Inventory

\begin{tabular}{|c|c|c|c|}
\hline \multirow[b]{2}{*}{ Measurement Emphasis } & \multicolumn{3}{|c|}{ Region } \\
\hline & Eastern & Central & Western \\
\hline Air Quality & 6 & 9 & 6 \\
\hline Water Quality & 49 & 27 & 15 \\
\hline Deposition & 49 & 42 & 16 \\
\hline Forest/Vegetation & 17 & 11 & 4 \\
\hline Soils & 20 & 23 & 13 \\
\hline Biological & 32 & 13 & 8 \\
\hline $\begin{array}{l}\text { Total Inventory Monitor- } \\
\text { ing Efforts in Region }\end{array}$ & $\overline{173}$ & $\overline{125}$ & $\overline{62}$ \\
\hline
\end{tabular}

investigators associated with projects initially identified from such data bases often provided information on related programs conducted by their organizations. Results from these related programs often were not submitted to centralized data bases. The substantial number of these related projects is thus an indication of the degree of cooperation provided by Canadian and U.S. scientists in assembling the inventory. This cooperation is also reflected in the large number of draft inventory entries that were reviewed and returned by principal investigators in the verification process. As indicated in Table 3.3, entries for 146 of the 184 projects included in the inventory (or 79\%) were verified by cognizant Canadian or U.S. scientists. This return is much higher than that anticipated when the verification process was designed.

Emphasis on including federally sponsored programs in the inventory is reflected in both Tables 3.3 and 3.4. Almost two-thirds of the projects included in the inventory are sponsored by Canadian or U.S. government organizations. As a review of actual inventory entries will indicate, the size of these programs ranges from relatively small, short-term projects to large-scale, extremely complex monitoring efforts. 
The geographic distribution of projects included in the inventory is summarized in Table 3.5. Note that this table is organized according to measurement emphasis rather than monitoring categories. Subclassifications of ecosystem projects have been combined with information on single-monitoring category projects to present a balanced picture of the types of monitoring conducted in each of the geographic regions defined in Section 3.1. Totals in Table 3.5 do not correspond to the inventory totals presented in Table 3.3 because all ecosystem projects appear in more than one measurement emphasis classification. Similarly, projects with sites in more than one geographic region are included more than once. For example, an ecosystem project involving measurements of water-quality, deposition, and biological parameters at sites located in the eastern and central regions is counted six times--once for each region and once for each measurement category. This type of breakdown provides more information on the environmental data available in each region than does a breakdown according to monitoring category. The results of the survey illustrate that the majority of projects currently included in the inventory are located in the eastern and central regions. Study of inventory entries further indicates that while eastern projects are fairly well distributed throughout the region, central region projects are concentrated in the Great Lakes Basin.

Readers desiring information on project characteristics not included in Tables 3.3 through 3.5 may generate the figures of interest by adding or subtracting already-compiled totals. Alternatively, the codes listed at the end of each project description can be reviewed and new compilations formulated.

\subsection{UPCOMING MAJOR PROJECTS}

During preparation of the inventory, information was obtained on a number of upcoming large-scale projects. These projects currently are in the initial planning stages, and project directors are in the process of establishing program protocols. Specific field stations usually have not yet been selected, al though tentative areas for sampling may have been identified. Such projects are not in a state where a formal inventory listing can be prepared; however, some mention of the projects is an appropriate and necessary enhancement to 
the inventory. Such mention also serves to identify projects where future opportunities for international cooperation in transboundary monitoring may exist, and where such cooperation potentially can be made an integral part of the operational plan. Table 3.6 lists major upcoming projects that fall into one of the six environmental monitoring classifications considered in this investigation and potentially may have monitoring sites located in the U.S.-Canadian transboundary region. A brief description of the planned research and a principal contact for each project are given. This list is not allinclusive because a complete review of upcoming projects was outside the scope of this investigation. The list does, however, provide an overview of the types of additional projects that are likely to be conducted in the transboundary region within the next few years.

\subsection{OBSERVATIONS AND RECOMMENDATIONS}

During the preparation and compilation of the environmental monitoring inventory, several observations were made. These observations generally fall into two classes: those that resulted from a review of the inventory as a whole and those that resulted from conversations with Canadian and U.S. researchers.

The inventory observations are not the result of an in-depth critique of monitoring efforts in the transboundary region, which is beyond the scope of the current study, but rather are based on a review of inventory entries and the survey information presented in section 3.4. The first observation concerns geographic coverage; many more monitoring programs are located in the eastern transboundary region (Maritime Provinces to Quebec and New England States to Pennsylvania) and the Great Lakes Basin than are located in the western region. This observation is especially true for programs emphasizing water quality and deposition measurements. The larger number of programs in the eastern region is not surprising since concern over North American acid precipitation and the identification of potentially sensitive areas originated in this region. The higher population density and greater terrain accessibility of the eastern transboundary region may also contribute to the more extensive monitoring. The second observation concerns project type and duration. Ambient 
TABLE 3.6. Major Upcoming Projects Likely to Involve Monitoring Within the Transboundary Region

Project Title

Ory Deposition Monitoring

National Vegetation Survey

National Early Warning System

National Lakes Survey

Effects of Atmospheric Deposition on SpruceFir Forests

Ecological study of Laurentian Mountain Lakes

Hardwood Decline in the Great Lakes Hardwood Forest

Direct/Delayed Response Project
Expected Scope

Expansion of the U.S. CORE network for dry deposition monitoring.

Surveys of U.S. forest health conditions.

Nationwide Canadian system to detect acid rain impacts on forest soil, vegetation and trees.

Multi-phase U.S. program involving lake surveys: long-term stream and lake monitoring. Phase 1 in operation.

Research on the causes and effects of air pollutants and acid precipitation on U.S. northeastern sprucefir forests.

Ecological study of 158 lakes in the Laurentian Mountains of southern quebec. Initiated summer of 1985 .

Establishment of permanent observation plots at 100 sites in southern ontario.

Soil characterization study in 150 northeastern U.S. watersheds. Initiated summer of 1985 .
Principal Contact

Bruce Hicks

Atmospheric Turbulence

Diffusion Division

P.O. Box E

Oak Ridge, Tennessee 37831

Staff Biologist

U.S. Forest Service

Northeastern Forest

Experimental Station

370 Reed Road

Broomhall, Pennsylvania 19008

L. P. Magasi

Maritimes Forest

Research Centre

P.0. Box 4000

Fredericton, New Brunswick E3B 5P7

William Fallon

Environmental Protection

Agency

401 M Street SW

Washington, DC 20460

Staff Biologist

U.S. Forest Service

Northeastern Forest

Experimental Station

370 Reed Road

Broomhall, Pennsylvania 19008

Bob Hellie

Lands Directorate

Environment Canada

Place Vincete Massey

Hull, Quebec K1A OE7

S. N. Linzon

Ontario Ministry of the

Environment

880 Bay Street

Toronto, Ontario M5S 128

Robin Church

Environmental Protection Agency

Corvallis, Oregon 97333 
air-quality monitoring, ambient water-quality monitoring, and precipitation chemistry monitoring projects generally have more widespread networks, have more comprehensive data bases, and have been in operation longer than the forest, soil, or biological impact types of projects. However, as evidenced by inventory listings in these latter categories and the future projects discussed in Table 3.6, ecosystem impact projects are increasing both in number and complexity.

Two general observations can be made based on topics that repeatedly arose during conversations with both U.S. and Canadian researchers. The first observation concerns the appearance of widespread support throughout the technical community for formal international cooperation in transboundary monitoring and research. All scientists and administrators contacted throughout the course of this project were extremely helpful, and many expressed satisfaction that there was interest in reviewing the status of transboundary monitoring. Informal cooperation between individual scientists via exchanges of data and ideas is obviously occurring, as recent joint publications attest [e.g., Barrie and Hales (1984)]. The second observation arising from these conversations involves concern over the pooling of data sets without full consideration of protocol compatibility and laboratory comparability. Several scientists expressed the need for co-locating field stations and exchanging samples for analytical laboratory comparisons to address this problem. Limited intercomparability programs have already been conducted in certain fields. For example, the U.S. National Atmospheric Deposition Program (NADP) and the Canadian Network for Sampling Acid Precipitation (CANSAP) have maintained three co-located precipitation monitoring stations. There is strong interest in thoroughly analyzing the collected data and in co-locating selected NADP and Canadian Air and Precipitation Monitoring Network (CAPMON) sites. Similar comparisons in other fields may also be useful.

Based on these observations and the inventory preparation process as a whole, we suggest that the atmosphere of informal cooperation that currently exists among individual scientists continue to be fostered. We also suggest that opportunities for formal cooperation be sought, especially for co-located stations and sample exchange programs. We further recommend that an in-depth 
critique of transboundary monitoring be conducted to identify specific transboundary locations where deficient or redundant sampling exists, and to identify projects where potential joint U.S.-Canadian ventures are possible in the near future. This document and the concord Scientific Corporation report (1985) should provide a starting point for such a critique. 


\section{REFERENCES}

Barrie, L. A., and J. M. Hales. 1984. "The Spatial Distributions of Precipitation Acidity and Major Ion Wet Deposition in North America During 1980." Tellus. 36B:333-355.

Caton, G., J. Riordan and C. Oen. 1984. Operating Research Plan Vol. II: Inventory of Research Under the National Acid Precipitation Assessment Program. Prepared for the Interagency Task Force on Acid Precipitation, Oak Ridge National Laboratory, Oak Ridge, Tennessee.

Concord Scientific Corporation (CSC). 1985. A Review of Atmospheric Deposition Networks in the Great Lakes Basin. CSC.J587, Downsview, Ontario.

Environment Canada. 1983. The Canadian Research Activity Catalogue on the Long Range Transport of Air Pollutants and Acidic Precipitation. Federal LRTAP Liaison Office, Atmospheric Environment Service, Downsview, Ontario.

Environment Canada. 1985. Toxic Chemicals Projects: Inland Waters Directorate 1984-1985. Inland Waters Directorate, Ottawa, Ontario.

Federal-Provincial Working Group on Drinking Water. 1978. Guidelines for Canadian Drinking Water Quality. Catalogue No. H48-10/1978, Canadian Government Publishing Centre, Hull, Quebec.

Kemp, H. 1977. The National Inventory of Selected Biological Monitoring Programs. ORNL/TM-5792, Oak Ridge National Laboratory, Oak Ridge, Tennessee.

Magasi, L. P., and M. K. Mahendrappa. 1984. Acid Rain National Early Warning System. Maritimes Forest Research Centre, Fredericton, New Brunswick.

01son, R. 1984. Review of Existing Environmental and Natural Resource Data Bases. ORNL/TM-8928, Oak Ridge National Laboratory, Oak Ridge, Tennessee.

Water Quality Criteria Documents; Availability, 45 Fed. Reg. 79318-79365 (November 28, 1980)

Watson, C. R., and A. R. 01 sen. 1984. Acid Deposition System (ADS) for Statistical Reporting: System Design and User's Code Manual. EPA-600/8-84-023, U.S. Environmental Protection Agency, Environmental Monitoring Systems Laboratory, Office of Research and Development, Research Triangle Park, North Carolina.

Wisniewski, J., and J. Kinsman. 1982. "An Overview of Acid Rain Monitoring Activities in North America." Bulletin of the American Meteorological Society. 63:598-618. 


\section{INDEX OF PRINCIPAL CONTACTS}

Arnold, Dean E.

Pennsylvania Cooperative Fish and Wildlife Research Unit

C. $25, D .33$

Penn State University

7 Ferguson Bldg.

University Park, PA 16802

(814) $865-4511$

Arnold, Richard W.

F.1

Soil Conservation Service

P.0. Box 2890

Washington, DC 20013

(202) $382-1819$

Athayde, Dennis N.

U.S. Environmental Protection Agency

0.3

401 M St. SW

Washington, DC 20460

(202) $382-7085$

Azzaria, Louis

Department of Geology

C. 16

Laval University

Quebec, Quebec G1K 7P4

(418) $656-2913$

Baker, Joan P.

Kilkelly Environmental Associates

P.0. Box 31265

Raleigh, NC 27622

(919) $781-3150$

Barker, J.

U.S. Geological Survey

P.0. Box 1107

Harrisburg, PA 17108

(717) $782-3812$

Barrie, L. A.

Atmospheric Environment Service

D. 10

4905 Dufferin St.

Downsview, Ontario M3H 5T4

(416) $667-4988$ 
Bartuska, A. M.

E.2

North Carolina State University

Acid Deposition Program

Raleigh, NC 27606

(919) $757-3520$

Bates, Timothy

C. 38

National Oceanic and Atmospheric Administration

600 Sandpoint Way NE

Pacific Marine Environmental Laboratory

Seattle, WA 98115

(206) $442-7656$

Bayley, Suzanne

University of Manitoba

Dept. of Botany

Winnipeg, Manitoba R3T 2N6

(204) 949-5196

Benkovitz, Carmen

Brookhaven National Laboratory

0.14

Upton, NY 11973

(516) 282-2268

Bezak, David

0.43

Environmental Management Division

Dept. of Environment and Workplace Safety and Health

P.0. Box 7, Building 2, 139 Tuxedo Ave.

Winnipeg, Manitoba R3N OH6

(204) $945-7046$

Bobee, Bernard

Complex Scientific 2700

C. 15

Rue Einstein C.P. 7500

Ste. Foy, Quebec G1V 4C7

Boylen, C.

Rensselaer Polytechnic Institute

Dept. of Biology

Fresh Water Institute

Troy, NY 12181

(518) 270-6392

Bradt, Patricia T.

Chandler-U1lmann \#17

Lehigh University

Bethlehem, PA 18015

(215) $861-3650$ 
Brezonik, P. L.

University of Minnesota

Dept. of Civil and Mineral Engineering

Minneapolis, MN 55455

(612) 373-2514

Bricker, 0. P.

C.1

U.S. Geological Survey

Reston, Virginia 22092

(703) 860-6951

Brooksbank, Peter

C.8, D.2

Environment Canada

Water Quality Branch

Place Vincent Massey

351 St. Joseph Blvd.

Hul1, Quebec K1A OE7

(819) $997-3422$

Clair, T. A.

Environment Canada

C.11, G.13, G.14

Inland Waters Directorate

Box 861

Moncton, New Brunswick E1C 8N6

(506) 857-6606

Cole, Charles

Dept. of Engineering

Penn State University

Middletown, PA 17057

(717) $948-6133$

Corbett, E. S.

G.46

U.S. Forest Service

Northeastern Forest Experiment Station

Rm. 104 - Academic Projects Building

Pennsylvania State University

University Park, PA 16802

(814) 863-1933

Cronan, C. S.

University of Maine

Dept. of Botany and Plant Pathology

Deering Hall

Orono, ME 04469

(207) 581-3235 
Dana, M. Terry

D.13

Battelle, Pacific Northwest Laboratory

P.0. Box 999

Richland, WA 99352

(509) $375-3820$

Dann, Thomas

B. 4

Environmental Protection Service - Environment Canada

Pollution Measurement Division

Ottawa, Ontario K1A $1 \mathrm{C8}$

(613) $998-4705$

Desautels, Gilles

0.22

100 Boul. Alexis Nihon

3 Ieme Etage

Ville St. Laurent, Quebec H4M 2N8

(514) $333-3020$

Deutschman, Mark

D. 50

North Dakota State Department of Health

1200 Missouri Ave.

Box 5520

Bismark, ND 58502-5520

(701) 224-2366

Deziel, Jacques

Quebec Ministry of the Environment

A. 13, C. 13

3900, Marley Street

Ste. Foy, Quebec G1X 4E4

(418) 644-3306

Dillon, P. J.

Limnology Unit

$D .37, G .54, G .55$

Ontario Ministry of Environment

Dorset Research Centre

P.0. Box 39

Dorset, Ontario POA 1E0

(705) $766-2412$

Dimma, Dianne

F.4

Ontario Ministry of Environment - Air Resources

880 Bay Street, Suite 347

Toronto, Ontario M5S 128

(416) $965-4516$ 
Dixon, David

U.S. Forest Service

NE Forest Experiment Station

370 Reed Road

Brooma 11, PA 19008

(215) $461-3025$

Donini, J. C.

B. 6

St. Francis Xavier University

Antigonish, Nova Scotia B2G 1 CO

(902) $867-2124$

Dunson, W. A.

Pennsylvania State University

G.43

Department of Biology

208 Mueller Laboratory

University Park, PA 16802

(814) 865-2461

Dupont, Jacques

Quebec Ministry of the Environment

3900, Marley Street

Ste. Foy, Quebec G1X 4E4

(418) 644-3297

Easter, Richard

D. 45

Battelle, Pacific Northwest Laboratory

C.10, C.17, C.18,

C.19, C.20, C.22,

C. 23, C. .24

P.0. Box 999

Richland, WA 99352

(509) $376-5897$

Edwards, G. C.

Ontarlo Hydro Research Division

0.40

800 Kipling Ave.

Toronto, Ontario M8Z $5 S 4$

(416) 231-4111

Elliott, J.

Tissue Bank and Registry Biologist

G.3, G.9, G.56

National Wildlife Research Center

Canadian Wildlife Service

ottawa, Ontario KIA OE7

(819) 997-1095

Evans, Bob

Northern States Power Corp.

414 Nicollet Mall

Minneapolis, MN 55401

(612) 330-6906 
Fast, Don

Walter Scott Building

A. $14, A .25$

3085 Alberta Street

Regina, Saskatchewan S4S OBI

(306) 787-6178

Faulkner, Don

Atmospheric Environment Service

$D .53, D .54, D .55$

700-1200 W. 73rd Ave.

D. 56

Vancouver, British Columbia V6P $6 \mathrm{H} 9$

(604) $666-2184$

Feely, Herb

0.27

Department of Energy

Environmental Measurements Laboratory

376 Hudson Street

New York, NY 10014

(212) $620-3627$

Forest Hydrologist

Monongahela National Forest

D. 44

P.0. Box 1548

Elkins, WV 26241

(304) 636-1800

Foster, N. W.

Canadian Forestry Service

Box 490

Sault Ste. Marie, Ontario P6A 5M7

(705) $949-9461$

Freedman, Bill

Dept. of Biology

Dalhousie University

Halifax, Nova Scotia B3H 4J1

(902) 424-3829

Gelinas, Pierre

Department of Geology

Laval University

Quebec, Quebec G1K 7P4

(416) $656-2411$

G. 60

Gibson, J. H.

Natural Resource Ecology Laboratory

G.17

Colorado State University

Ft. Collins, CO 80523

(303) 491-1978

C. 16

$0.4,0.6$ 
Gilbert, Richard

100 Alexis Nihon Blvd.

3rd Floor

St. Laurent, Quebec H4M 2N8

(514) 283-1107

Gizyn, W. I.

Ontario Ministry of the Environment

Air Resources Branch

880 Bay Street, Suite 347

Toronto, Ontario M5S $1 Z 8$

(416) $965-4516$

Glass, Gary E.

C. 32

Environmental Research Laboratory, U.S. EPA

6201 Congdon Blvd

Duluth, MN 55084

(218) $720-5526$

Gloss, S. P.

Cornell University - Cooperative Fisheries Unit

204 Fernow Hall

Ithaca, NY 14853

(607) $255-2014$

Goebel, J. Jeffrey

Soil Conservation Service

A. 19, A. 20

U.S. Department of Agriculture

P.0. Box 2980

Washington, DC 20013

(202) $447-8578$

Goldstein, Robert

Electric Power Research Institute

G.6, G.8, G.37

3412 Hillview Ave.

P.0. Box 10412

Palo Alto, CA 94303

(415) 855-2593

Gorham, E.

Dept. of Ecology and Behavioral Biology

University of Minnesota

St. Paul, MN 55455

(612) $376-1743$

Graham, Richard C.

Science Research Laboratory

$D .30, D .31, D .32$

U.S. Military Academy

West Point, NY 10996

(914) $938-3739$ 
Gregg, W.

G.63

Operations Support Staff

National Park Service

Box 37127

Washington, DC 20013-7127

Grimard, Yves

Quebec Ministry of the Environment

C. $17, G .25$

3900, Marley Street

Ste. Foy, Quebec G1X 4E4

(418) 644-3303

Group Leader - Forest Inventory \& Analysis

E. 1

Forest Service - U.S. Dept. of Agriculture

P.0. Box 2417

Washington, DC 20013

(202) 382-9343

Haines, T. A.

Fish and Wildlife Service

G.26, G.27, G.28

Columbia National Fisheries Research Laboratory

University of Maine, Zoology Dept.

Orono, ME 04469

(207) $581-2578$

Halverson, H. G.

G.45

Northeast Forest Experimental Station

Pennsylvania State University

Room 104 - Academic Projects Building

State College, PA 16802

(814) $863-1933$

Heit, $M$.

Department of Energy

G.5, G. 40

Environmental Measurements Laboratory

376 Hudson Street

New York, NY 10014

(212) $620-3625$

Hendrey, George

A.9

Terrestrial and Aquatic Ecology Division

Brookhaven National Laboratory

Building 318

Upton, NY 11973

(516) 282-3262 
Hesslein, Raymond

F.8

Freshwater Institute

501 University Crescent

Winnipeg, Manitoba R3T 2N6

(204) 949-5251

Hewett, Doug

G. 61

Environment Canada

55 St. Clair Ave. East

Toronto, Ontario M4T 1 M2

(519) 253-4232

Hicks, Bruce

National Oceanic and Atmospheric Administration

$D .15,0.16$

Atmospheric Turbulence and Diffusion Laboratory

P.0. Box E

456 South Illinois Ave.

Oak Ridge, TN 37831

(615) $576-1233$

Hites, Ronald

F.5

School of Public and Environmental Affairs

Indiana University

Bloomington, IN 47405

Hoffer, A.

Environmental Studies and Assessments Dept.

Ontario Hydro, 700 University Ave.

Toronto, Ontario M5S $1 \times 6$

(416) 592-6308

Horn, Edward

New York State Department of Environmental Conservation

$G .47, G .48$

50 Wolff Road

Albany, NY 12233

(518) 457-1769

Hornbeck, Jim

G.11

U.S. Forest Service

P.0. Box 640

Durham, NH 03824

(603) 834-0797

Hornbrook, E. H.

Geological Survey of Canada

601 Booth Street

ottawa, Ontario K1A OE8

(613) 995-4521 
Horsfall, George

C. 35

Saskatchewan Power Corp.

2025 Victoria Ave.

Regina, Saskatechewan S4P OS1

(306) $566-2878$

Howell, Geoff

C. 12

Environment Canada

Box 861

Moncton, New Brunswick E1C 8N6

(506) 857-6606

Hunter, $M$.

University of Maine

G.29

Wildlife Resources

Orono, ME 04469

(207) $581-2865$

Isaac, George

G.52

Chief of Cloud Physics Research Division

Atmospheric Environment Service

4905 Dufferin St.

Downsview, Ontario M3H 5T4

(416) 667-4683

Jagels, $R$.

Department of Forest Biology

D.25

University of Maine

Orono, ME 04469

(207) 581-2881

Jennings, Marshall

U.S. Geological Survey - Water Resources Division

0.3

Gulf Coast Hydroscience Center

Bldg. 1100

National Space Technology

Laboratory, MS 39529

(601) 688-1508

Johnson, D. W.

Oak Ridge National Laboratory

G.11

P.0. BoX X - B1dg. 1505

Oak Ridge, TN 37830

(615) $574-7362$ 
Jones, H. Gerald

G.22, G.24

Institue National de la Recherche Scientific (INRS-EDU)

2700 Rue Einstein

C.P. 7500

Ste. Foy, Quebec G1V 4C7

(418) 654-2533

Kan, G. Y. P.

Inland Waters Directorate

G.69

Pacific and Yukon Regional offices

1305 Welch St.

Vancouver, British Columbia V7P 183

(604) $987-3543$

Keller, W.

Ontario Ministry of Environment

199 Larch Street

Sudbury, Ontario P3E 5P9

(705) 675-4501

Kelso, John

Department of Fisheries and Oceans

G.50, G.59

Great Lakes Fisheries Research Branch

1219 Queen St. East

Sault Ste. Marie, Ontario P6A 5M7

(705) $942-2848$

Kotturi, M. S.

Waste Management Branch, Ministry of Environment

$D .57,0.58$

810 Blanshard Street

Victoria, British Columbia V8N $1 \times 4$

(604) $387-4321$

Kurtz, Joel

Air Resources Branch

A. 6

Ministry of the Environment

125 Resources Road

Rexdale, Ontario M9W $5 \mathrm{LL}$

(416) $248-3245$

Kwik, J. K.

Ontario Hydro

F. 6

Biological Research Section

800 Kipling Avenue

Toronto, Ontario M8Z 5S4

(416) 231-4111 Ext. 6865 
Lamb, B.

B.2, B.3

Washington State University

Laboratory for Atmospheric Research

Pulliman, WA 99164

(509) 335-1526

Lamb, Maureen

A.7

Data Systems Section

Inland Waters Directorate

Water Quality Branch, 10th Floor

Place Vincent Massey

Ottawa, Ontario K1A OET

(819) 997-3422

Lander, Dixon H.

U.S. Environmental Protection Agency

G.4

200 SW 35th Street

Corvallis, OR 97333

(503) 757-4695

Langdon, R.

G.33

Vermont Agency of Environmental Conservation

Dept. of Water Resources and Environmental Engineering

State Office Building

Montpelior, VT 05602

(802) $828-2761$

Lau, Y. K.

D. 51

Air Quality Control Branch - Alberta Environment

9820-106 St.

Edmonton, Alberta T5K 2T6

(403) $427-5893$

Lechner, L. J.

B.9

Pollution Control Branch

Saskatchewan Environment

3085 Albert St.

Regina, Saskatchewan S4S OB1

(306) 787-6195

Likens, G. E.

Inst. of Ecosystem Studies, Cary Arboretum

$0.26,0.29$

Box $A B$

Millbrook, NY 12545

(914) $677-5343$ 
Linzon, S. N.

G.58

Phytotoxicology Section

Air Resources Branch

Ontario Ministry of the Environment

880 Bay Street

Toronto, Ontario M5S 128

(416) $965-4516$

Lusis, Maris

Ontario Ministry of Environment

B.7, B.8, D. 38,

Air Resources Branch

880 Bay Street

Toronto, Ontario M5S 128

(416) 965-1634

Lynch, J. A.

Pennsylvania State University

D. 34

311 Forest Resources Laboratory

University Park, PA 16802

(814) $865-8830$

Machell, J. R.

D. 19

Environment Protection Service - Environment Canada

D. $39, D .42$

45 Alderny Dr.

Dartmouth, Nova Scotia B2Y 2N6

(902) 426-6132

Mahendrappa, M. K.

Canadian Forestry Service

Maritimes Forest Research Centre

P.0. Box 4000

Fredericton, New Brunswick E3B 5P7

(506) 452-3549

Malins, Donald

Environmental Conservation Division

G.70

National Marine Fisheries Service

Seattle, WA 98112

(206) $442-7737$

Manning, Lee

A.17, G.1, G.18

U.S. Environmental Protection Agency

A. 8

Office of Water and Hazardous Materials

Washington, DC 20460

(202) $382-7220$ 
McBean, G. A.

0.52

Institute of Ocean Sciences

Atmospheric Envronmental Service

Sidney, British Columbia V8L 4B2

(604) 656-8448

McCain, Bruce

G.70

Environmental Conservation Division

National Marine Fisheries Service

Seattle, WA 98112

(206) 442-7737

McCrea, R. C.

Inland Waters Directorate

Water Quality Branch

P.0. Box 5050

Burlington, Ontario L7R 4A6

(416) 637-4678

McLaugh7in, S. B.

Oak Ridge National Laboratory

P.0. Box X - Bldg. 1505

Oak Ridge, TN 37830

(615) $574-7358$

McLean, $W$.

G.32, G.50

Vermont State Government

Department of Water Resources and Environmental Engineering

Water Quality Division, Monitoring and Surveillance

Montpelier, VT 05602

(802) $828-2761$

Melo, 0. T.

E.3, E.4, E.6

Chemical Research Dept.

Ontario Hydro Research Division

800 Kipling Avenue

Toronto, Ontario M8Z $5 S 4$

(416) 231-4111

Metcalfe, J. L.

G.7

Inland Waters Directorate

867 Lakeshore Road

P.0. Box 5050

Burlington, Ontario L7R 4A6

(416) 336-4685 
Metikosh, Serge

C. 28, C. .29

Inland Waters Directorate

867 Lake Shore Road

P.0. Box 5050

Burlington, Ontario L7R 4A6

(416) 637-4641

Meyers, Tildon

D. $15, D .16$

National Oceanic and Atmospheric Administration

Atmospheric Turbulence and Diffusion Laboratory

P.0. Box E

456 South Illinois Ave.

Oak Ridge, TN 37831

(615) $576-1233$

Moore, Jim

G.67

Alberta Environment Centre

Vegreville, Alberta TOB 4LO

(403) 632-6761

Mueller, Peter K.

Electric Power Research Institute

$D .11,0.18$

3412 Hillview Ave.

P.0. Box 10412

Palo Alto, CA 94303

(415) $855-2586$

Murdoch, Peter

G.35

U.S. Geological Survey

P.0. Box 1397

Albany, NY 12201

(518) 472-3108

Newbury, R.

Freshwater Institute

501 University Crescent

Winnipeg, Manitoba R3T 2N6

(204) 949-5219

Nichols, Dale

C. 31

North Central Forest Experimental Station

Forestry Sciences Laboratory

1831 Highway $169 \mathrm{E}$

Grand Rapids, MN 55744

(218) 326-8571 
Northrup, F. N.

Ontario Hydro Research Division

800 Kipling Ave.

Toronto, Ontario M8Z $5 \$ 4$

(416) 231-4111

Norton, Steven

F.2

University of Maine

Dept. of Geological Sciences

Orono, ME 04469

(207) 581-1954

01 sen, Anthony

A. 15

Pacific Northwest Laboratory

P.O. Box 999

Richland, WA 99352

(509) 376-4179

0lson, Richard J.

Environmental Sciences Division

A.16, A.22

Oak Ridge National Laboratory

P.O. Box $X$

Building 1505

Oak Ridge, TN 37831

(615) $574-7819$

Omernik, J. M.

C.6

U.S. Environmental Protection Agency

Environmental Research Laboratory-Corvall is

200 SW 35th St.

Corvallis, OR 97333

(503) 757-4666

Ouellet, Marcel

INRS-EAU

2700 Rue Einstein

C.P. 7500

Ste. Foy, Quebec G1V 4C7

(418) $657-2533$

Pagenkopf, G. K.

Montana State University

Dept. of Chemistry

Bozeman, MT 59717

(406) 994-4801 
Palmer, $C$.

F.9

Alberta Environment

P.0. Box 3014 - Cousins Bldg

Lethbridge, Alberta T1J 4B3

(403) $381-5322$

Patrinos, Ari

D. 35

Dept. of Applied Science

Brookhaven National Laboratory

Upton, NY 11973

(516) 282-3911

Percy, K. E.

G.16

Canadian Forest Service

Box 4000

Fredericton, New Brunswick E3B 5P7

(506) 452-3532

Peters, Norman E. (Jake)

U.S. Geological Survey - Water Resources Division

D.12

6481-B Peachtree Industrial Blvd.

Donaville, GA 30360

(404) $455-1213$

Peterson, R. H.

G.12

Dept. of Fisheries and Oceans

St. Andrews Biological Station

St. Andrews, New Brunswick EOG $2 \times 0$

(506) $529-8854$

Pierce, R. S.

G.34

NE Forest Exper. Station - Forestry Science Laboratory

Concorde-Mast Rd - Box 640

Durham, NH 03824

(603) 878-5576

Pitblado, J. Roger

Department of Geography

Laurentian University

Sudbury, Ontario P3E 2C6

(705) 675-1151

Pitelka, Lou

Electric Power Research Institute

G.10

3412 Hillview Ave.

P.0. Box 10412

Palo Alto, CA 94303

(415) $855-2969$ 
Plamondon, Andre P.

Universite Laval

Pavillon Vachon

Bureau 0868

Ste. Foy, Quebec G1K 7P4

(418) $656-7120$

Porcella, D.

Electric Power Research Institute

G. $36, G .38$

3412 Hillview Avenue

P.0. Box 10412

Palo Alto, CA 94304

(415) $855-2723$

Potvin, Paul

Quebec Ministry of Environment

G.25

3900, Marley Street

Ste. Foy, Quebec G1X 4E4

(418) 644-3303

Prahl, Fredrick

School of Oceanography

Oregon State University

Corvallis, OR 97331

(503) 754-0123

Pueschel, R. F.

NOAA, Environmental Research Laboratory

3100 Marine St.

Boulder, CO 80303

(303) 497-6189

Ray, S.

Dept. of Fisheries and Oceans

St. Andrews Biological Station

St. Andrews, New Brunswick EOG $2 \times 0$

(506) 529-8854

Robertson, John K.

Science Research Laboratory

$D .30, D .31, D .32$

U.S. Military Academy

West Point, NY 10996-5000

(914) $938-3739$

Roxborough, V. R.

Office of Systems Development

G.71

Systems Development Section

135 St. Clair Ave. West, 3rd Floor

Toronto, Ontario M4V 1 P5

(416) 965-6952 
Rubec, Clayton

F.3

Environment Canada

Lands Directorate

Place Vincent Massey

Hul1, Quebec K1A 1C8

(819) $997-2320$

Sanderson, Marie

G. 61

University of Windsor

Windsor, Ontario

(519) 253-4232

Schnoor, J.

G. 64

University of Iowa

Energy Engineering Division

Iowa City, I0 52242

(319) 353-7262

Scholfield, C. L.

Cornell University - Cooperative Fisheries Unit

G.31

204 Fernow Hall

Ithaca, NY 14853

(607) 255-2014

Schornick, J.

U.S. Geological Survey

C. $2, C .4$

Reston, VA 22092

(703) $860-6834$

Schroeder, Roy

U.S. Geological Survey

D. 28

5201 Ruffin Rd.

San Diego, CA 92123

(619) $293-6700$

Sheehan, S. W.

Inland Waters Directorate

G. 68

Pacific and Yukon Region

Rm 502 - 1001 West Pender Street

Vancouver, British Columbia V6E $2 M 9$

(604) $666-8007$

Simonon, Howard

New York State Dept. of Environmental Conservation

C. $10,6.42$

8314 Fish Hatchery Road

Rome, NY 13440

(315) $337-0910$ 
Singer, $R$.

G.31

Rensselaer Polytechnic Institute

Dept. of Biology

Fresh Water Institute

Troy, NY 12181

(518) 270-6392

Singh, S. S.

F.7

Agriculture Canada

K. W. Neatby Bldg.

ottawa, Ontario K1A OC6

(613) $995-3700$

Sisterson, Doug

Atmospheric Physics Program

D. 46

Building D-181

Argonne National Laboratory

9700 S. Cass Ave.

Argonne, IL 60439

(312) $972-5827$

Skinner, Larry

New York State Department of Environmental Conservation

$G .47, G .48$

50 Wolff Road

Albany, NY 12233

(518) $457-1769$

Smi th, Mona

A. 12

NEDRES Program Office, E/AIX3

National Ocean and Atmospheric Administration

3300 Whitehaven Street, NW

Washington, DC 20235

(202) $634-7722$

Smith-Palmer, T.

St. Francis Xavier University

Antigonish, Nova Scotia B2G 1 CO

(902) $867-2124$

Stein, J.

Laval University

G.23

School of Forestry

Pavilion Vachon

Beaurea 0870

Ste. Foy, Quebec C1K 7P4

(418) 656-2945

B. 6 
Still, Malcolm

$D .1,0.10$

Atmospheric Environment Service

4905 Dufferin St.

Downsview, Ontario M3H 5T4

(416) 667-4988

Stottlemyer, $R$.

National Park Service

Dept. of Biological Sciences

Michigan Technical University

Houghton, MI 49931

(906) 487-2478

Strachan, William M. J.

D. 36

Canadian Centre for Inland waters

867 Lake Shore Road

P.0. Box 5050

Burlington, Ontario L7R 4A6

(416) $336-4775$

Streeter, Robert C.

0.17

BCR National Laboratory

350 Hockberg Rd.

P.0. Box 278

Monroeville, PA 15146

(412) $327-1600$

Summers, Jake

Office of Air Quality, Planning and Standards

A.2

MD-14

Environmental Protection Agency

Research Triangle Park, NC 27711

(919) 541-5694

Sutherland, J. W.

New York State Dept. of Environmental Conservation

Bureau of Technical Services and Research

50 Wolff Road

Albany, NY 12233-0001

(518) $457-7470$

Talbot, Levis

Quebec Ministry of the Environment

C. $14,0.23,0.24$

3900, Marley Street

Ste. Foy, Quebec G1X 4A5

(418) 644-3309 
Taylor, F.

C.9

New England Water Works Assoc.

850 R Providence Highway

Dedham, MA 02026

(617) $329-9676$

Technical Services Branch

B.1

Environment Protection Service

Place Vincent Massey

Rue St. Joseph

Hul1, Quebec K1A 0E7

(819) $997-1831$

Tikalsky, Susan M.

D. 48

Wisconsin Power and Light Co.

P.0. Box 192

Madison, WI 53701

(608) $252-5726$

Tims, Jane Spavold

Environment Service Branch

New Brunswick Dept. of Municipal Affairs and Environment P.0. Box 6000

Fredericton, New Brunswick E3B 5H1

(506) 453-2669

Torneby, J. E.

Air Quality Control Branch - Alberta Environment

D. 51

9820-106 St.

Edmonton, Alberta T5K $2 \mathrm{~J} 6$

(403) $427-5893$

Underwood, $J$.

Nova Scotia Dept. of the Environment

P.0. Box 2107

Halifax, Nova Scotia B3J 387

(902) 424-5300

Valiela, D.

Inland Waters Directorate

C. 36

Pacific and Yukon Region

4160 Marine Drive

West Vancouver, British Columbia V5J $3 E 5$

(604) 666-8007 
Vascotto, G. L.

Ontario Hydro

Biological Research Section

800 Kipling Avenue

Toronto, Ontario M8Z 554

(416) 231-4111 Ext. 6865

Verreault, Ghislain

G.19, G.20

Champlain Harbour Station

Box 15500

Quebec, Quebec G1K 7Y7

(418) $694-3478$

Verry, E. S.

G. 66

North Central Forest Experimental Station

Forestry Science Laboratory

1831 Hwy $169 \mathrm{E}$.

Grand Rapids, MN 55744

(218) 326-8571

Vet, Robert

Atmospheric Environment Service

D. $8,0.10$

4905 Dufferin St.

Downsview, Ontario M3H 5T4

(416) $667-4801$

Watt, E. R.

Environment Canada

Water Quality Branch

Place Vincent Massey

351 St. Joseph Bivd.

Hu11, Quebec K1A 0E7

(819) $997-3422$

Watt, Walton D.

G.15

Fisheries and Oceans, Freshwater and Anadromous Division

D.2

P.0. Box 550

Halifax, Nova Scotia B3J 257

(902) $426-3606$

Wesely, M. L.

Atmospheric Physics Program

Building D-181

Argonne National Laboratory

$9700 \mathrm{~S}$. Cass Ave.

Argonne, IL 60439

(312) $972-5825$ 
Westberg, $H$.

Washington State University

B.2, B.3

Laboratory for Atmospheric Research

Pullman, WA 99164

(509) $335-1526$

Wiener, J.

G.65

Fish and Wildlife Service

Columbia National Fisheries Research Laboratory

Route 1

Columbia, MO 65201

(314) $875-5399$

Wiens, John $H$.

F.10

Waste Management Branch

British Columbia Ministry of Environment

810 Blanshard Street

Victoria, British Columbia V8V $1 \times 5$

(604) $387-4321$

Williams, Don A.

River Road Environmental Technical Center

A. 1

Technical Services Branch

Environmental Protection Service

Environment Canada

Ottawa, Ontario K1A 1 C8

(819) $998-4130$

Williams, Owen

Water Resources Division

A.10, A.11

U.S. Geological Survey

National Center, MS 421

Reston, VA 22092

(703) $648-5684$ 


\section{APPENDIX A}

A DESCRIPTION OF SELECTED MAJOR ENVIRONMENTAL RESEARCH DATA BASES 
.

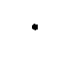




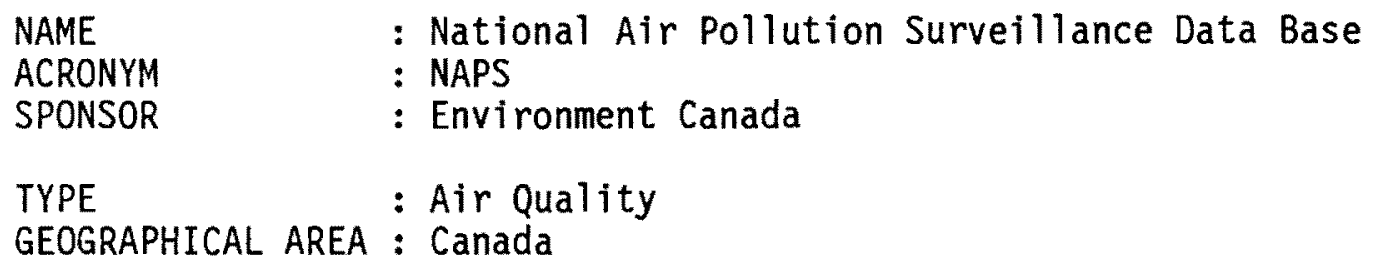

The NAPS Database contains data from the NAPS program. Sampling sites in 52 cities across ten provinces and two territories measure sulphur dioxide, carbon monoxide, nitrogen dioxide, ozone, soiling index, suspended particulates, lead, dustfall, and sulphation rate. The monitoring data are summarized on a monthly basis.

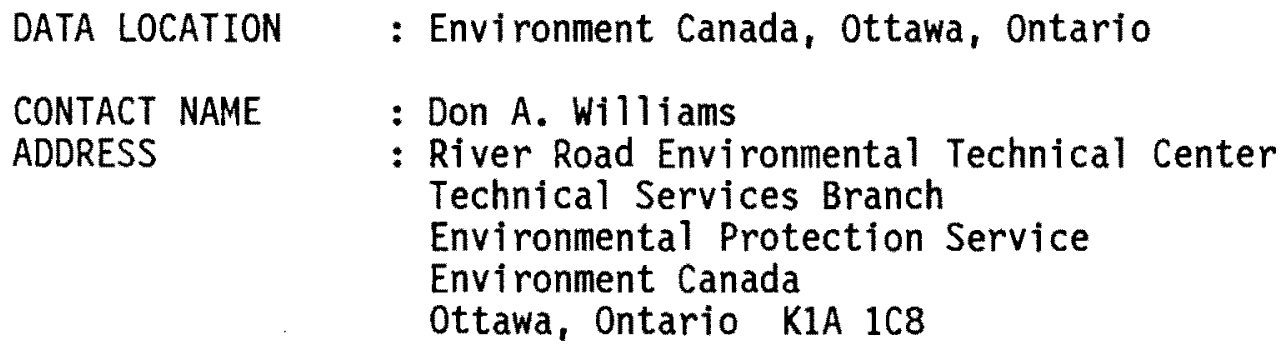

PHONE

: (819) $998-4130$

REFERENCE DOC : Environment Canada. 1984. Annual Summary National Air Pollution Surveillance. Environment Canada, Environmental Protection Service, ottawa, Ontario.

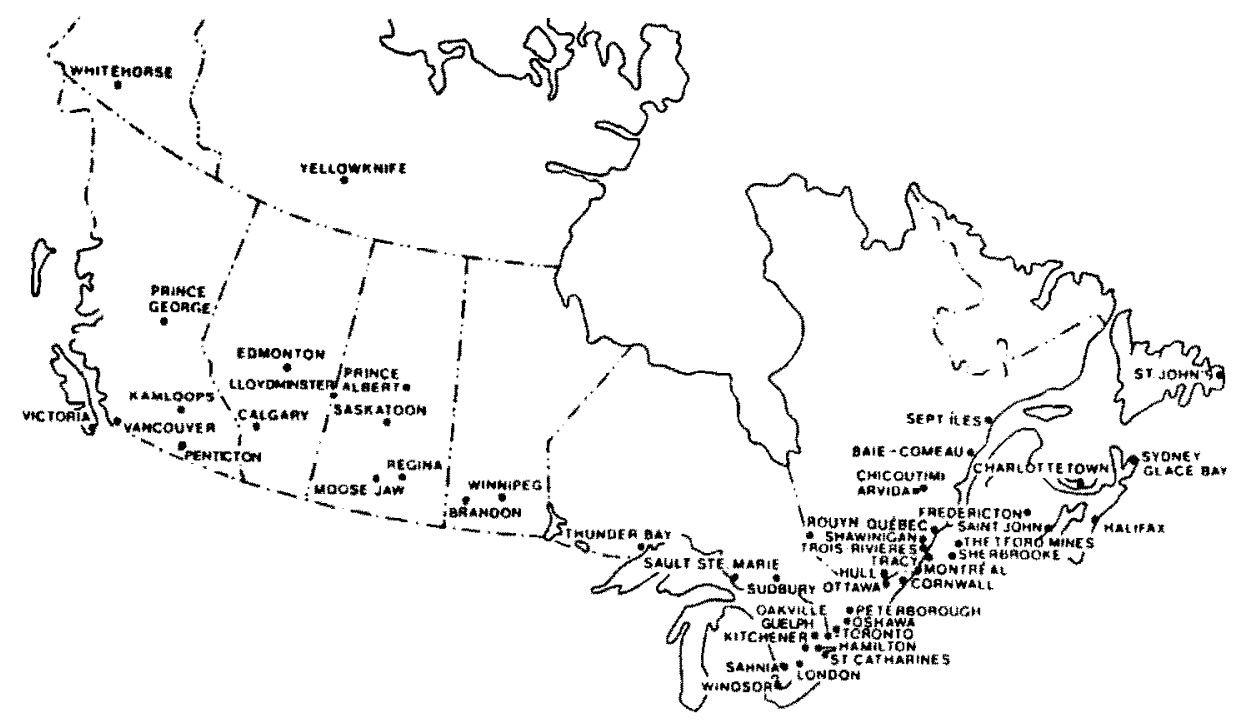


NAME

ACRONYM

SPONSOR
: Storage and Retrieval of Aerometric Data

: SAROAD

: Environmental Protection Agency

TYPE

: Air Quality

GEOGRAPHICAL AREA : United States

SAROAD contains information on concentrations of pollutants in the ambient air. The largest volume of data is for particulate, $\mathrm{SO} 2, \mathrm{CO}, \mathrm{NO2}$, hydrocarbons, and ozone. Sampling site information is also included in the data base. Data. as early as 1957 have been included for some sites, although 1970 is the earliest date for most states. Reports are published quarterly containing summary statistics for currently operating sites. Data are readily available to the public. Maps illustrating monitoring site locations are given on the next three pages. Maps were provided by the Data Analysis Section, Office of Air Quality Planning and Standards, Environmental Protection Agency.

DATA LOCATION : Envïronmental Protection Agency, Research Triangle Park, North Carolina

CONTACT NAME ADDRESS

PHONE

REFERENCE DOC
: Jacob Summers

: MD-14

Office of Air Quality, Planning and Standards

Environmental Protection Agency

Research Triangle Park, NC 27711

: (919) 541-5694

: U.S. Environmental Protection Agency. 1983. Aeros Manual Series, Volume 1: AEROS Overview (Second Edition). EPA-450/2-76-001, U.S. EPA, Office of Air and Radiation, Office of Air Quality Planning and Standards, Research Triangle Park (R.T.P.), North Carolina.

U.S. Environmental Protection Agency. 1983. AEROS Manual Series, Volume II: AEROS User's Manual. EPA- 450/2-76-029, U.S. EPA, Office of Air and Radiation, Office of Air Quality Planning and Standards, R.T.P., NC.

U.S. Environmental Protection Agency. 1983. AEROS Manual Series, Volume III: Summary and Retrieval.

EPA-450/2-76-009, U.S. EPA, Office of Air and Radiation, Office of Air Quality Planning and Standards, R.T.P., NC.

U.S. Environmental Protection Agency. 1983. AEROS Manual Series, Volume V: AEROS Manual of Codes. EPA-450/2-76-005, U.S. EPA, Office of Air and Radiation, Office of Air Quality Planning and Standards, R.T.P., NC.

U.S. Environmental Protection Agency. 1979. SAROAD, Storage and Retrieval of Aerometric Data, Information. EPA-450/4-79-005, U.S. EPA, Office of Air Quality Planning and Standards, R.T.P., NC. 
Maps Depicting Monitoring Sites for SAROAD

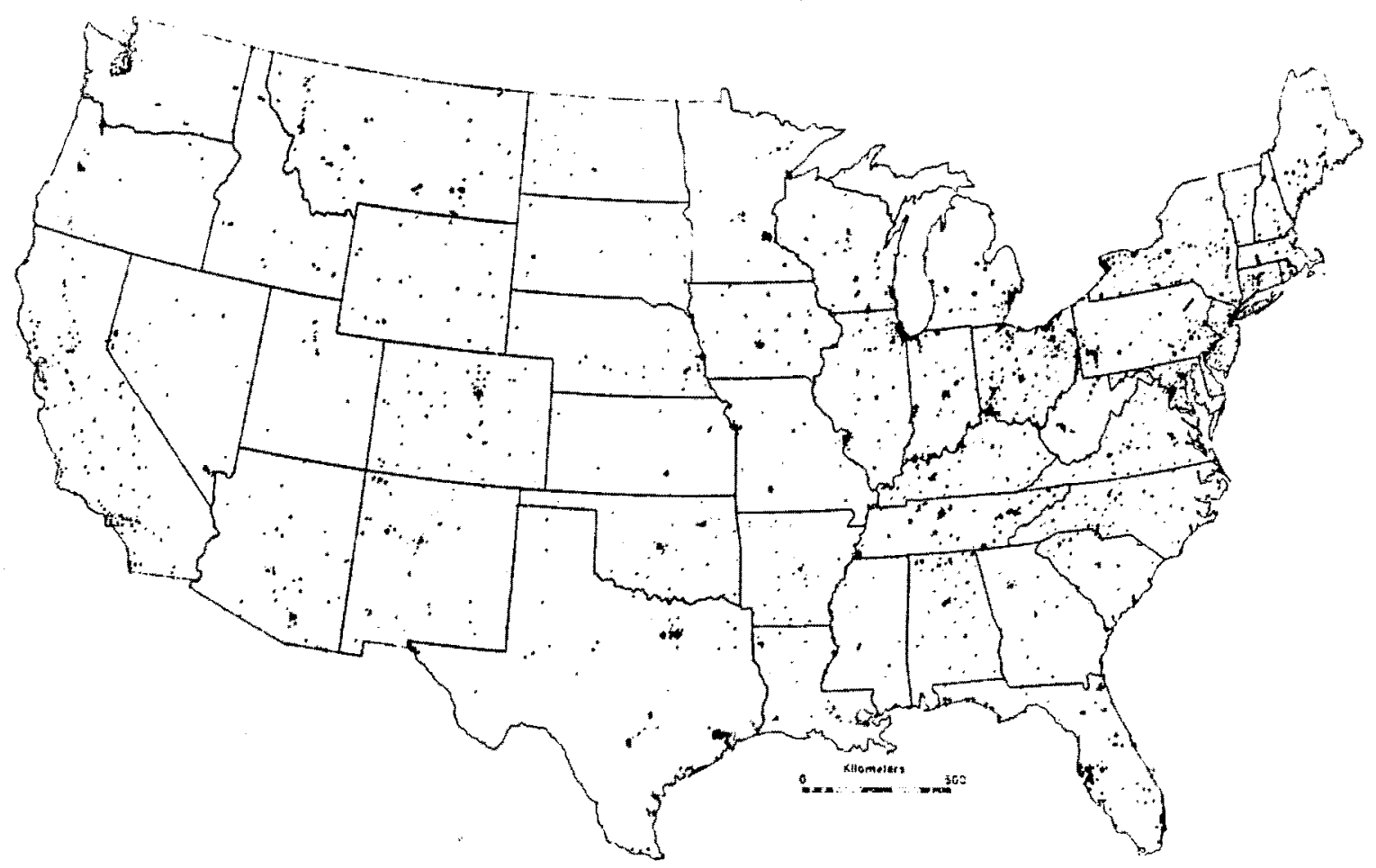

TSP MONITOLING SITES IN SAROAD, 1981-83

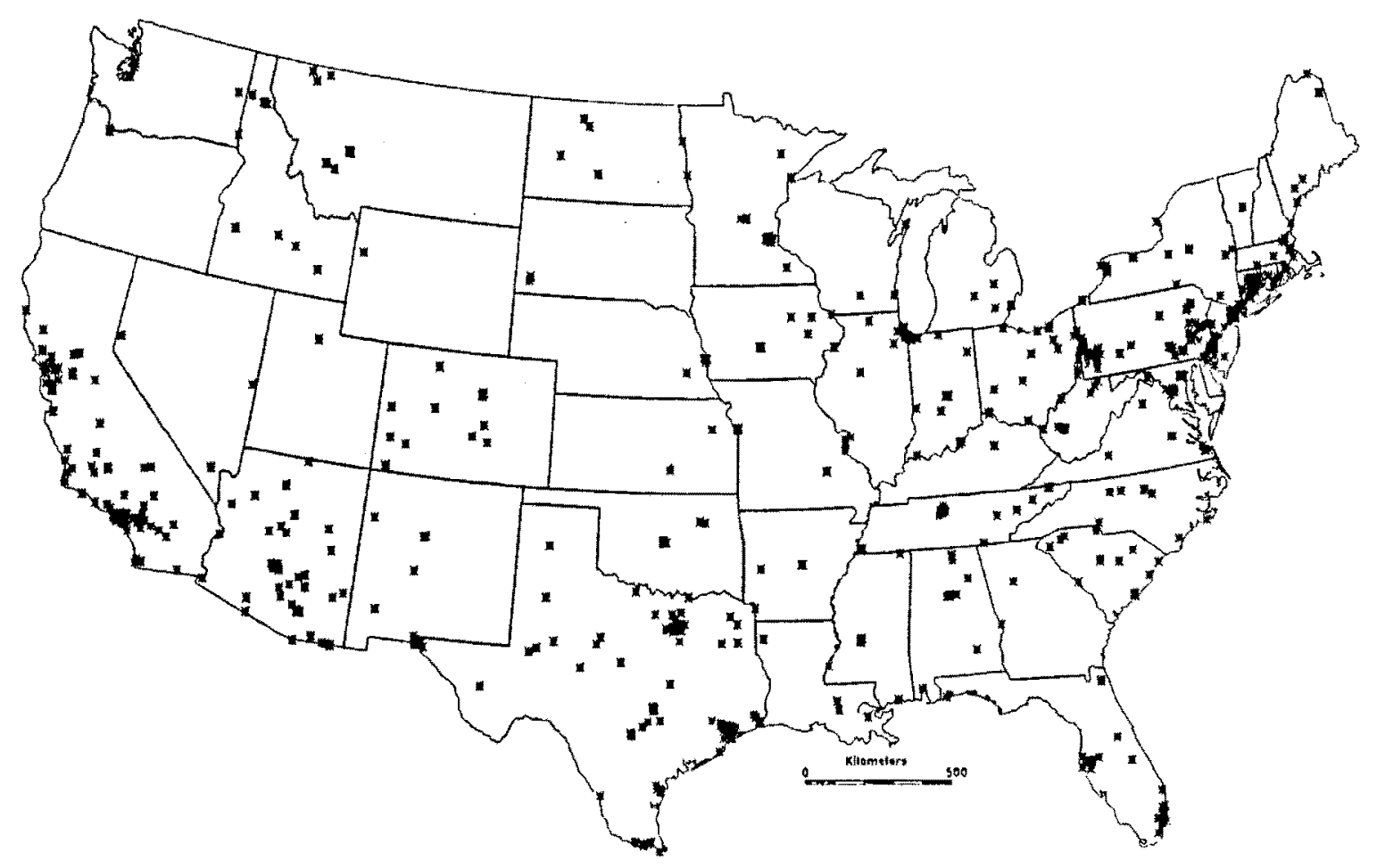

LEAD MONITORING SITES, 1981-83 
Maps Depicting Monitoring Sites for SAROAD

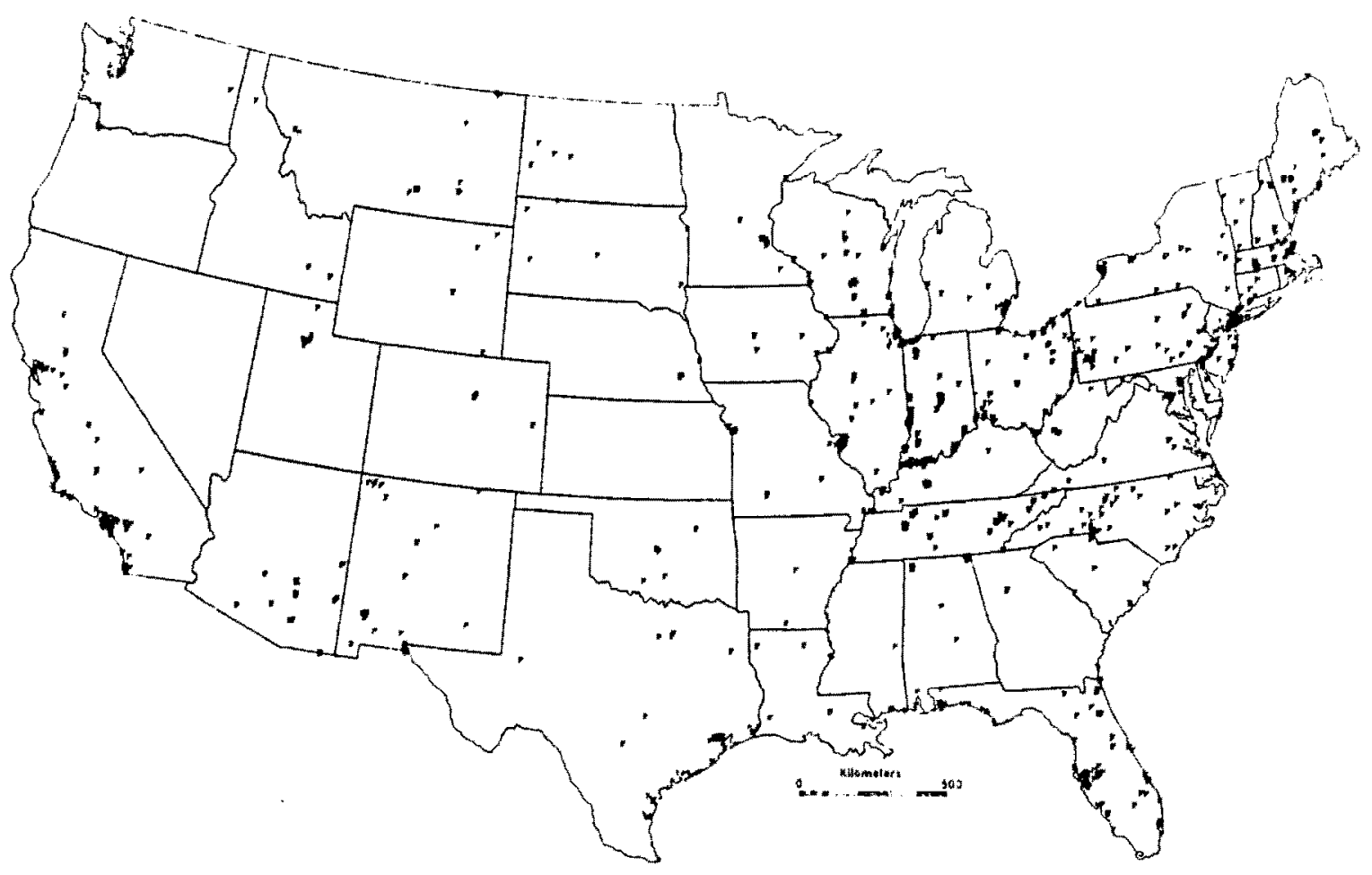

1982 SULFUR DIOXIDE MONITORING NETWORK

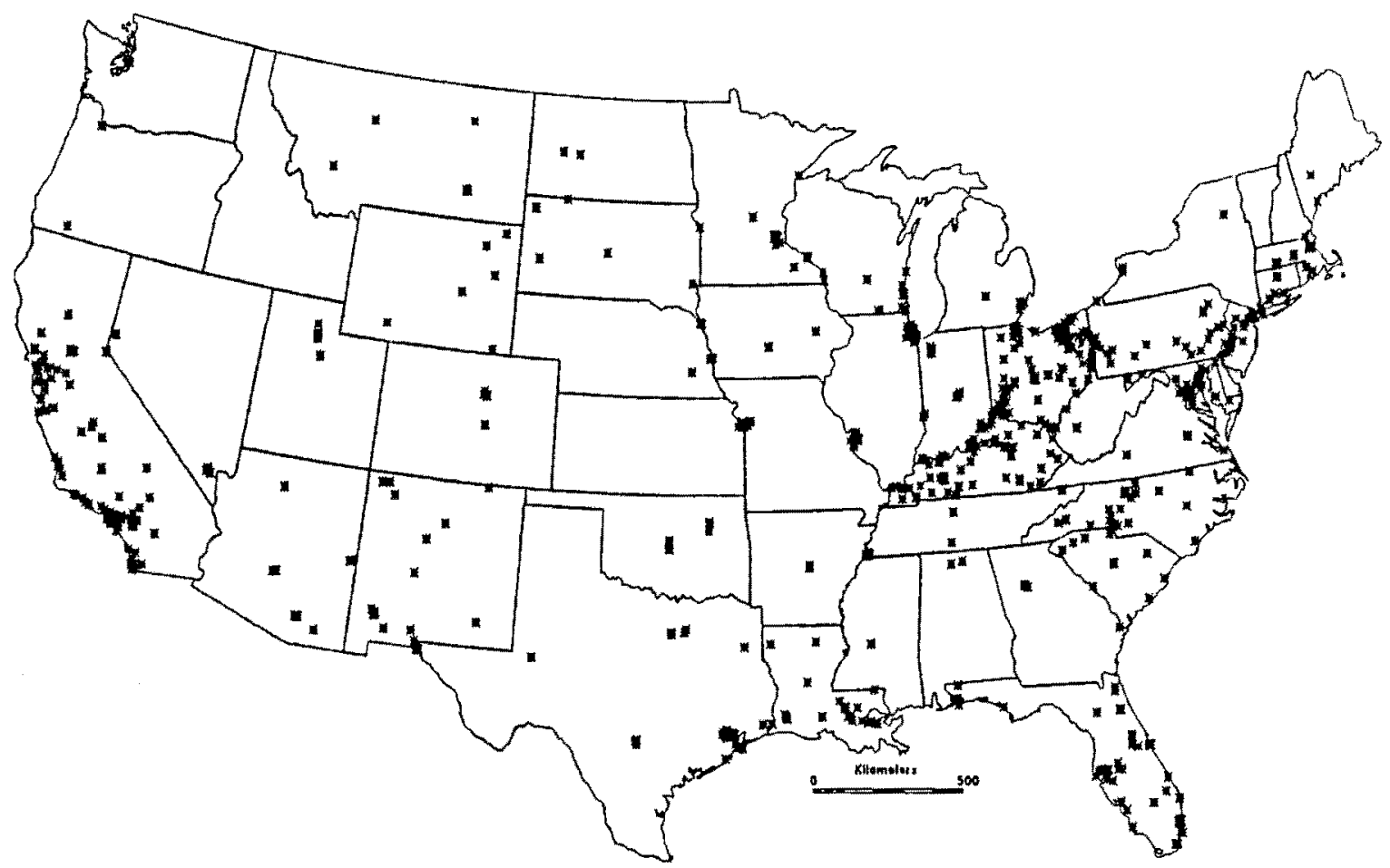

NITROGEN DIOXIDE MONITORING SITES, 1981-83 
Maps Depicting Monitoring Sites for SAROAD

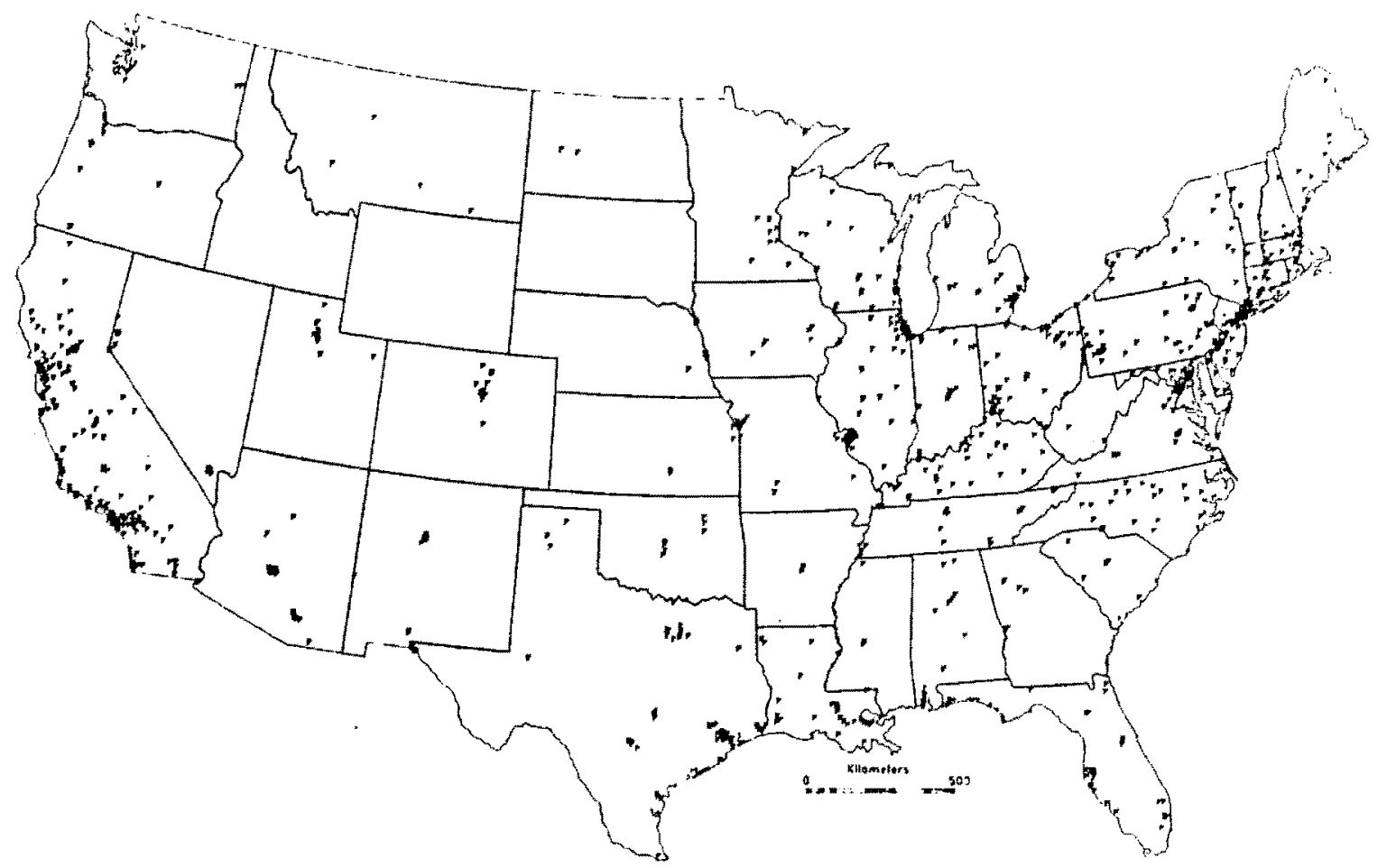

1980-83 OZONE MONITORING NETHORK

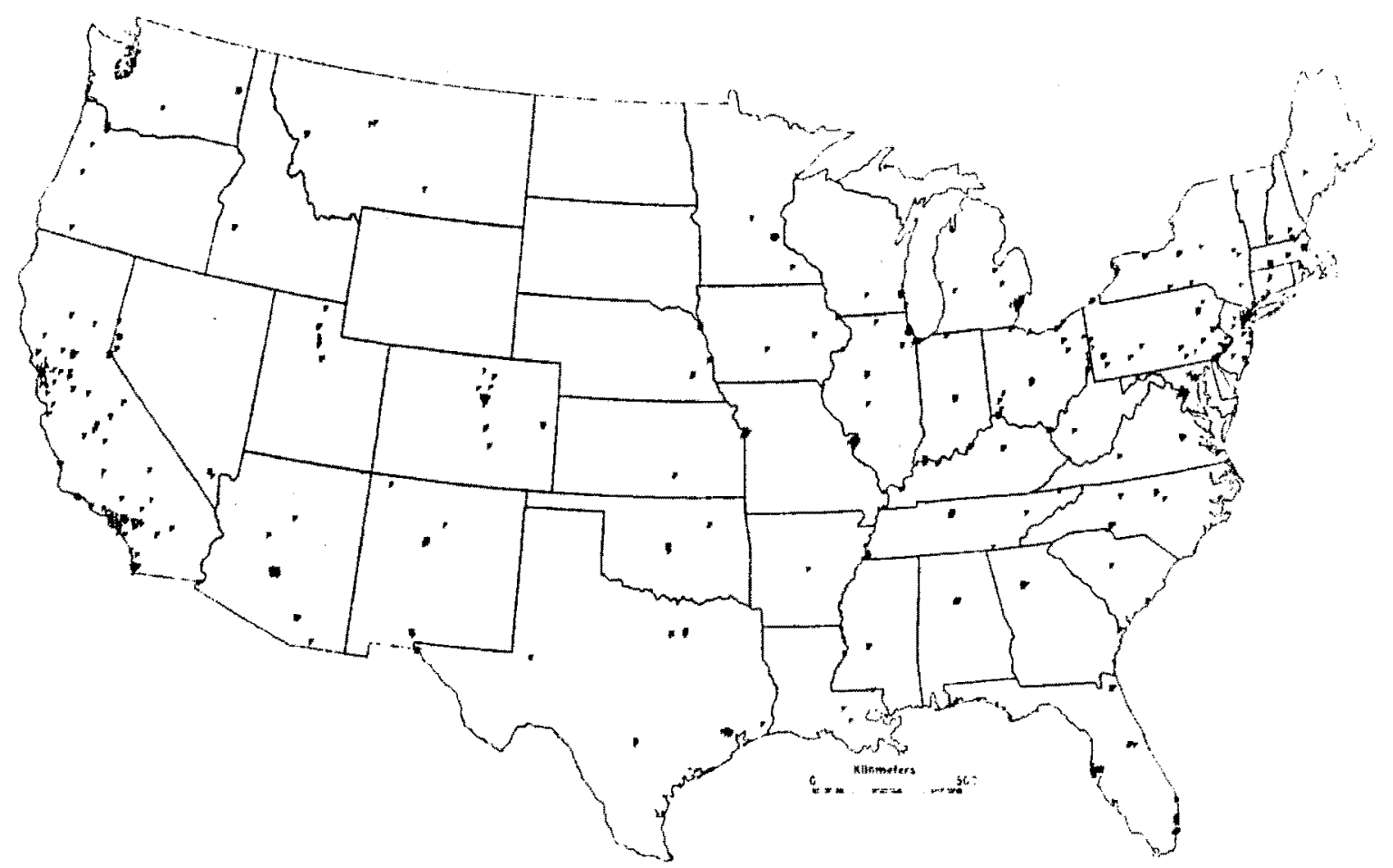

1980-83 CARISON MONORIDE MONTORNG WETHORK 
NAME

ACRONYM

: Air Quality Information System

SPONSOR

: AQUIS

: Ontario Ministry of the Environment

TYPE

GEOGRAPHICAL AREA : Ontario

The system is used primarily to store and analyze the concentration of various air contaminants measured at locations scattered throughout the Province of Ontario. A portion of the data are acquired through a telemetering system on a real-time basis. Presently, the system processes information on up to 40 pollutants including the meteorological measurements, at up to 700 locations. The system reports on the ambient air quality levels in the Province and assists management in determining the compliance of the ambient air quality levels with criteria levels for desirable air quality set under the Province's Environmental Protection Act, 1971.

DATA LOCATION : Ontario Ministry of the Environment, Rexdale, Ontario

CONTACT NAME : Joel Kurtz

ADDRESS

: Air Resources Branch Ministry of the Environment 125 Resources Road Rexdale, Ontario M9W $5 \mathrm{~L} 1$

PHONE

: (416) 248-3245 


$\begin{array}{ll}\text { NAME } & : \text { National Water Quality Data } \\ \text { ACRONYM } & \text { : NAQUADAT } \\ \text { SPONSOR } & : \text { Environment Canada } \\ \text { TYPE } & : \text { Water Quality } \\ \text { GEOGRAPHICAL AREA : Canada }\end{array}$

NAQUADAT contains data primarily from the Water Quality Branch of Environment Canada, but also from other provincial, municipal, and private agencies. For each water quality parameter measured, information on the sampling location, date, sampling time, frequency of measurement, and laboratory where the sample was analyzed are included. Sampling locations numbering in the thousands include rivers, lakes, ground water, and waste water.

DATA LOCATION : EMR Computer Science Centre, Ottawa, Canada

CONTACT NAME : Maureen Lamb

ADDRESS

: Data Systems Section Inl and Waters Directorate Water Quality Branch, 10th Floor

Place Vincent Massey

ottawa, Ontario K1A OE7

PHONE

: (819) $997-3422$

REFERENCE DOC : Whitlow, S, and M. Lamb. 1983. NAQUADAT-Guide to Interactive Retrieval. En 39-16/2-1984E, ISBN 0-662-13045-6, Inl and Waters Directorate, Water Quality Branch, Ottawa, Canada. 


$\begin{array}{ll}\text { NAME } & : \text { Storage and Retrieval } \\ \text { ACRONYM } & : \text { STORET } \\ \text { SPONSOR } & : \text { Environmental Protection Agency } \\ \text { TYPE } & : \text { Water Quality } \\ \text { GEOGRAPHICAL AREA : United States }\end{array}$

STORET is a massive data base that contains water-quality data for both surface and ground waters. Data are stored for several federal agencies and over 40 state agencies. These data include chemical, physical, biological, and radiochemical analyses of water samples. Most of the major water quality research and monitoring projects in the United States are entered into STORET. It provides a centralized location for water quality data, but has a wide variation in data quality. The data are readily available to the public.

DATA LOCATION : Environmental Protection Agency, Research Triangle Park, North Carolina

CONTACT NAME ADDRESS

PHONE

REFERENCE DOC
: Lee Manning

: U.S. Environmental Protection Agency Office of Water and Hazardous Materials Washington, DC 20460

: (202) $382-7220$

: U.S. Environmental Protection Agency. 1982. Water Quality Control Information System STORET User Handbook. U.S. Environmental Protection Agency, Washington, D.C.

Staples, C. A., A. F. Werner, and T. J. Hoogheem. 1984. "Assessment of Priority Pollutant Concentrations in the United States Using STORET Database." Environmental Toxicology and Chemistry. 4:131-142.

U.S. Environmental Protection Agency. Manager's Guide to STORET. U.S. EPA, Washington, D.C. 
NAME

ACRONYM

: Acidification Chemistry Information Data Base

SPONSOR

: ACID

: National Acid Precipitation Assessment Program

TYPE

: Water Quality

GEOGRAPHICAL AREA : United States

ACID is a comprehensive data base that combines data from STORET on low alkalinity waters with data sets from a variety of sources. Over 42,000 stations are represented in ACID with over 30,000 from STORET. Data include hydrology, acidity, water chemistry, limited lake and stream morphometry, station location, and other station identifiers. Data from 1900 through 1980 are included. Quality assurance for data entry and modification into the database are described by Hendrey, Hoogendyk, and Gmur (1983).

DATA LOCATION : Brookhaven National Laboratory, Upton, New York Also in ADDNET

CONTACT NAME ADDRESS
: George Hendrey

: Terrestrial and Aquatic Ecology Division Brookhaven National Laboratory Building 318 Upton, NY 11973
PHONE

REFERENCE DOC
: (516) 282-3262

: Hendrey, G. R., C. G. Hoogendyk, and N. F. Gmur. 1983. Establishing the Acidification Chemistry Information Database (ACID). BNL 51707, Brookhaven National Laboratory, Upton, Long Is land, New York.

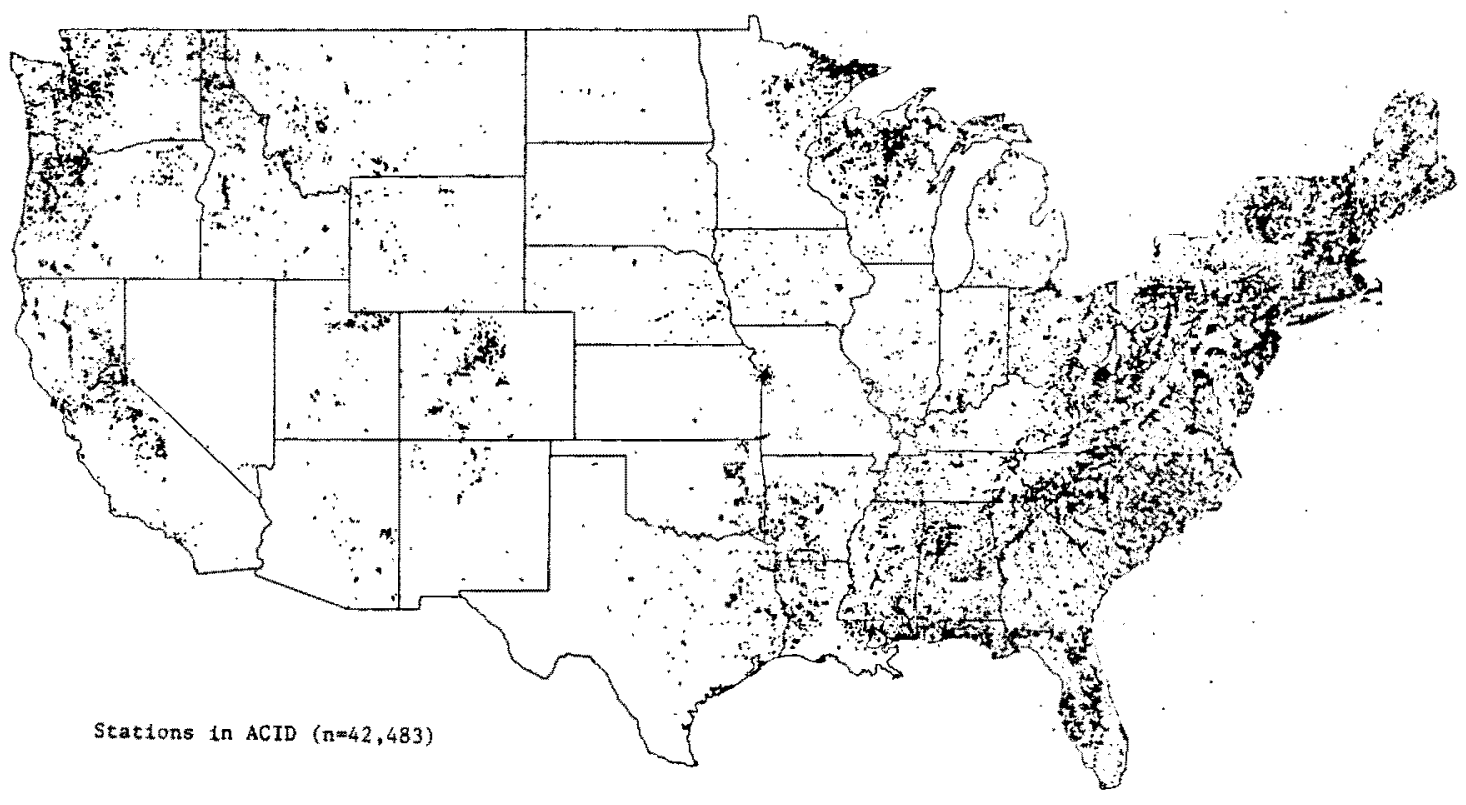




$$
\begin{array}{ll}
\text { NAME } & : \text { National Water Data Exchange } \\
\text { ACRONYM } & : \text { NAWDEX } \\
\text { SPONSOR } & : \text { U.S. Geological Survey } \\
\text { TYPE } & : \text { Water Data and Information } \\
\text { GEOGRAPHICAL AREA : United States, Canada, Mexico }
\end{array}
$$

NAWDEX is a program that assists users of water data in the identification, location, and acquisition of needed data. It contains two data bases. The Water Data Sources Directory identifies over 800 organizations that are sources. of water or water-related data and services, types of data available, and locations from which data or services may be obtained. The Master Water Data Index contains information on over 440,000 sites at which water data are collected, locations of the sites, types of data collected, periods of record, frequency of measurement, and identification of the source organizations. Actual hydrologic data are not provided in NAWDEX, although access is provided to WATSTORE, STORET, several bibliographic data services, several state water data systems, and the Water Resources Document Referral Center of the Inland Waters Directorate, Canadian Department of the Environment. NAWDEX is readily available to the public.

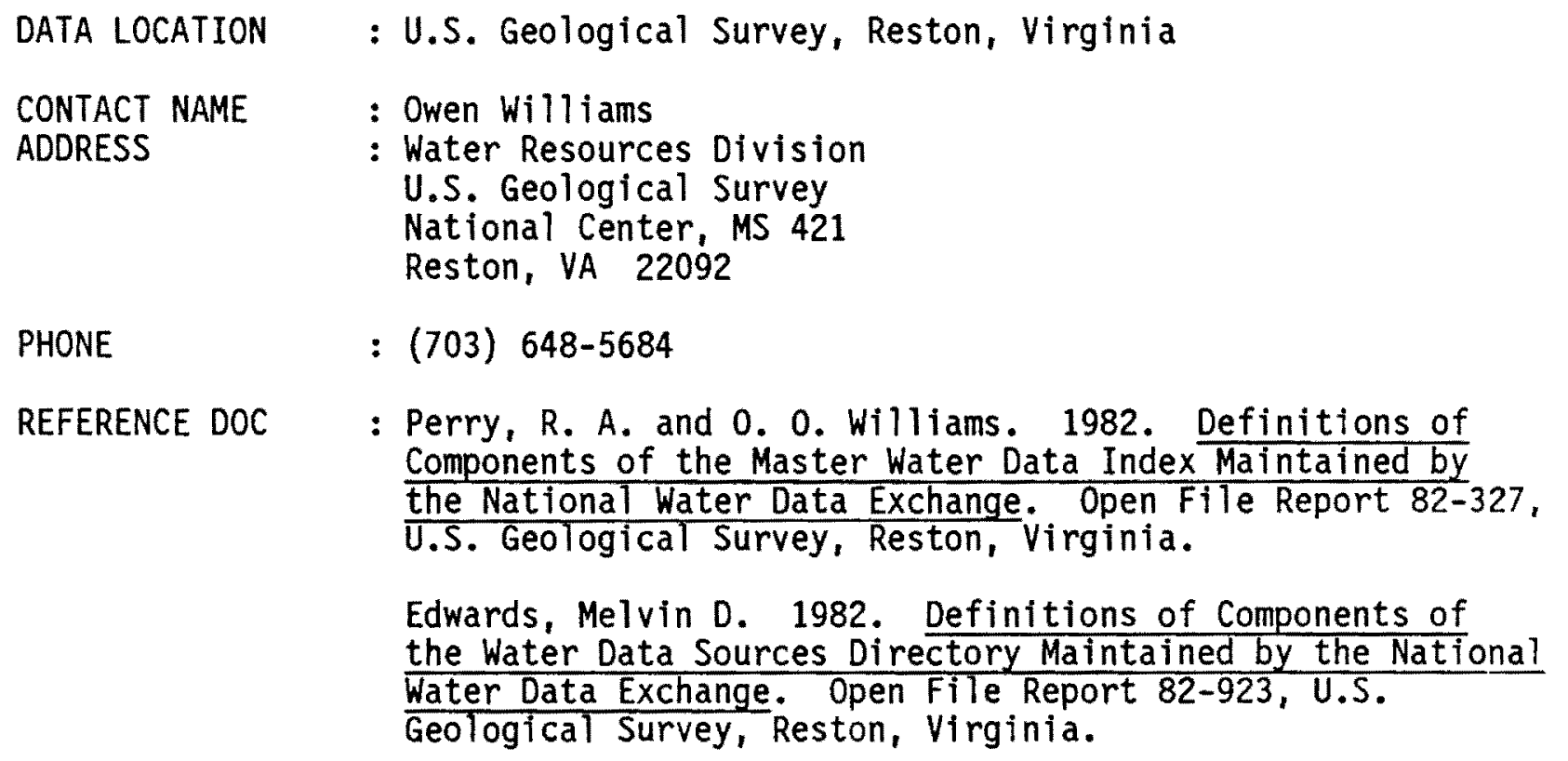




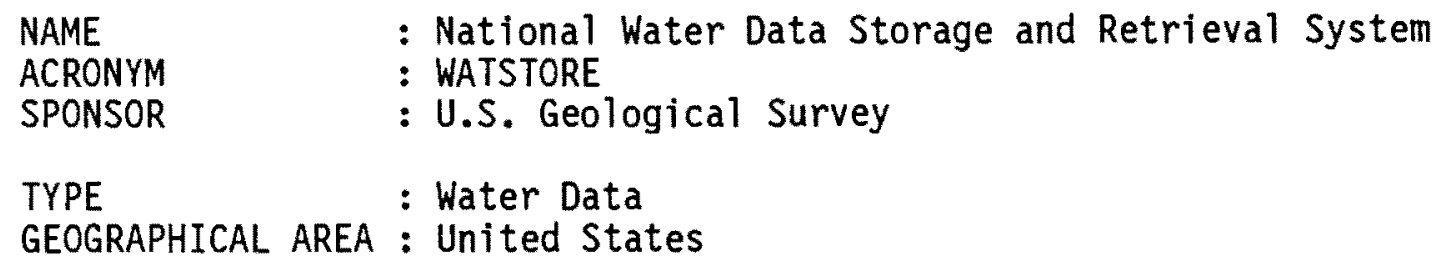

TYPE

: Water Data

GEOGRAPHICAL AREA : United States

WATSTORE contains several files in which extensive hydrologic data collected by the U.S. Geological Survey are entered. The files include a "Daily Values" File with more than 200 million daily observations of stream flow, water quality, sediment discharge, and ground-water level data; a "Water Quality File" that contains more than 1.7 million chemical analyses of both surface and ground water; a "Peak Flow File" that contains over 400,000 annual peak observations of streamflow and river-stage data; and a "Ground Water Site Inventory File" that contains inventory information for over 900,000 wells. Data can be readily obtained through NAWDEX.

DATA LOCATION : U.S. Geological Survey, Reston, Virginia Also available through NAWDEX, STORET, and ADDNET

$\begin{array}{ll}\text { CONTACT NAME } & : \text { Owen Williams } \\ \text { ADDRESS } & \text { Water Resources Division } \\ & \text { U.S. Geological Survey } \\ & \text { National Center, MS 421 } \\ & \text { Reston, VA } 22092\end{array}$

PHONE

: (703) 648-5684

REFERENCE DOC : Hutchison, N. E. and others. 1975. WATSTORE User's Guide: Volumes 1-7, U.S. Geological Survey open File Report 75-426, Reston, Virginia 


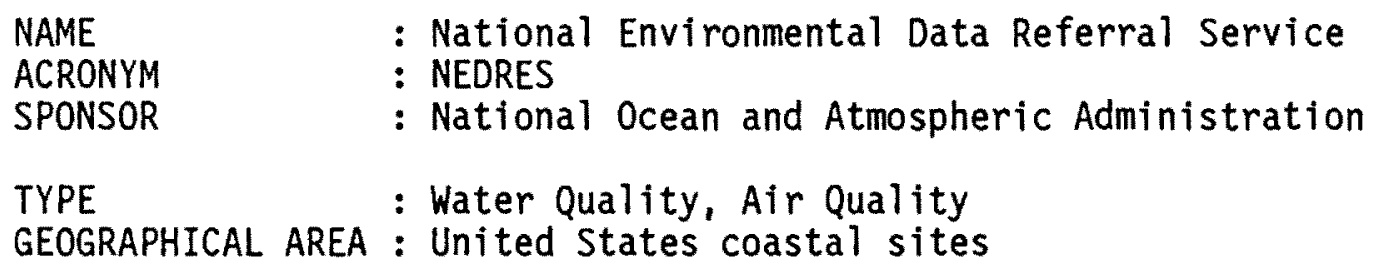

NEDRES contains lists of programs and data bases containing environmental data. It is a publicly available service that identifies the existence, location, characteristics, and availability of environmental data sets. The following types of data are referenced by NEDRES:

-climatological and meteorological

-oceanographic

-geophysical and geological

-geographic

-hydrological and limnological

-terrestrial resources

-toxic and regulated substances.

NEDRES is in the process of being updated with emphasis on climatic data.

$\begin{array}{ll}\text { DATA LOCATION } & \begin{array}{l}\text { National Oceanic and Atmospheric Administration } \\ \text { Washington, DC }\end{array} \\ \text { CONTACT NAME } & \text { Mona Smith } \\ \text { ADDRESS } & \text { NEDRES Program Office, E/AIx3 } \\ & \text { National Oceanic and Atmospheric Administration. } \\ & 3300 \text { Whitehaven Street, NW } \\ & \text { Washington, DC 20235 } \\ \text { : } & (202) 634-7722 \\ \text { PHONE } & \text { U.S. Dept. of Commerce, National Oceanic and Atmospheric } \\ \text { REFERENCE DOC Administration. 1985. Guidelines for Preparation of } & \\ & \text { Input to the NEDRES Database, Washington, D.C. } \\ & \text { U.S. Dept. of Commerce, National Oceanic and Atmospheric } \\ & \text { Administration. 1983. NEDRES Database User Guide, } \\ & \text { Washington, D.C. }\end{array}$


NAME

ACRONYM

: Bank Quality Monitoring Aquatic Data Base

SPONSOR

: BQMA

: Quebec Ministry of the Environment

TYPE

: Water Quality

GEOGRAPHICAL AREA : Quebec

The BQMA data base contains water quality data from the BQMA program. Water chemistry and physical parameters are collected from over 130 water quality stations on rivers, 1000 lakes, and numerous ground water stations in Quebec. A quality assurance program exists in cooperation with Environment Canada. Most of the stations are in the southern part of Quebec. Data have been collected since 1978 .

DATA LOCATION : Department of Environment, St. Croix, Quebec Also available in NAQUADAT

CONTACT NAME : Jacques Deziel

ADDRESS

: Quebec Ministry of the Environment 3900, Marly Street

Ste. Foy, Quebec G1X 4E4

PHONE

: (418) 644-3306 


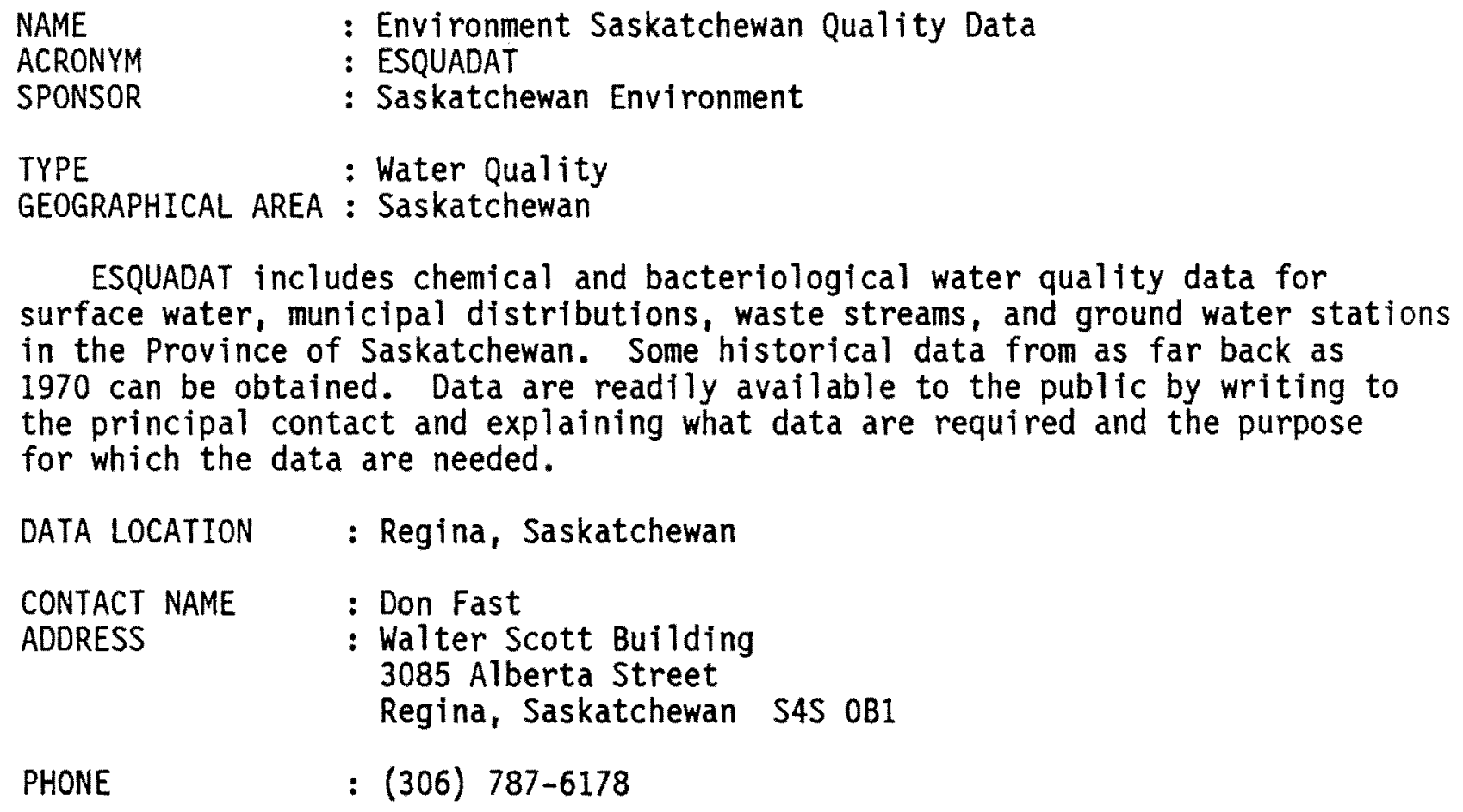

ESQUADAT includes chemical and bacteriological water quality data for surface water, municipal distributions, waste streams, and ground water stations in the Province of Saskatchewan. Some historical data from as far back as 1970 can be obtained. Data are readily available to the public by writing to the principal contact and explaining what data are required and the purpose for which the data are needed.

PHONE

: (306) 787-6178 


$\begin{array}{ll}\text { NAME } & : \text { Acid Deposition System } \\ \text { ACRONYM } & : \text { ADS } \\ \text { SPONSOR } & : \text { Environmental Protection Agency } \\ \text { TYPE } & : \text { Precipitation Chemistry } \\ \text { GEOGRAPHICAL AREA }: \text { North America }\end{array}$

ADS includes data from the following networks: NADP, NTN, CAPMON, CANSAP, MAP3S/PCN, APIOS, UAPSP, APN, WISC, and GLAD. Information is stored for each network, site, and sample. Network data include the method of analysis, protocol, type of instruments used, and detection limit. Site data include site history, location, and protocol. Sample data include date, events, quantity of sample, measurements made in the field and in the lab, components analyzed, and observations. Quality assurance procedures include maintenance of written documentation on the monitoring network and verification of data prior to entry into ADS. A user's manual by Watson and 01 sen (1984) gives more information on quality assurance procedures for the data base. ADS is updated quarterly with the earliest sampling date 1973 (CANSAP). Data are available to the public.

DATA LOCATION : Pacific Northwest Laboratory, Richland, Washington

CONTACT NAME : Anthony 0lsen

ADDRESS : Statistical Information Sciences Section, Sigma 3 Building Pacific Northwest Laboratory

P.0. Box 999

Richland, WA 99352

PHONE

REFERENCE DOC
: (509) $376-4179$

: Watson, C. R. and A. R. 01 sen. 1984. Acid Deposition System (ADS) For Statistical Reporting. System Design and User's Code Manual. EPA-600/8-84-023, Prepared by Battelle Pacific Northwest Laboratories for the U.S. Environmental Protection Agency, Washington, D.C.

SEE INDIVIDUAL PROJECTS IN APPENDIX D FOR SAMPLING LOCATIONS 


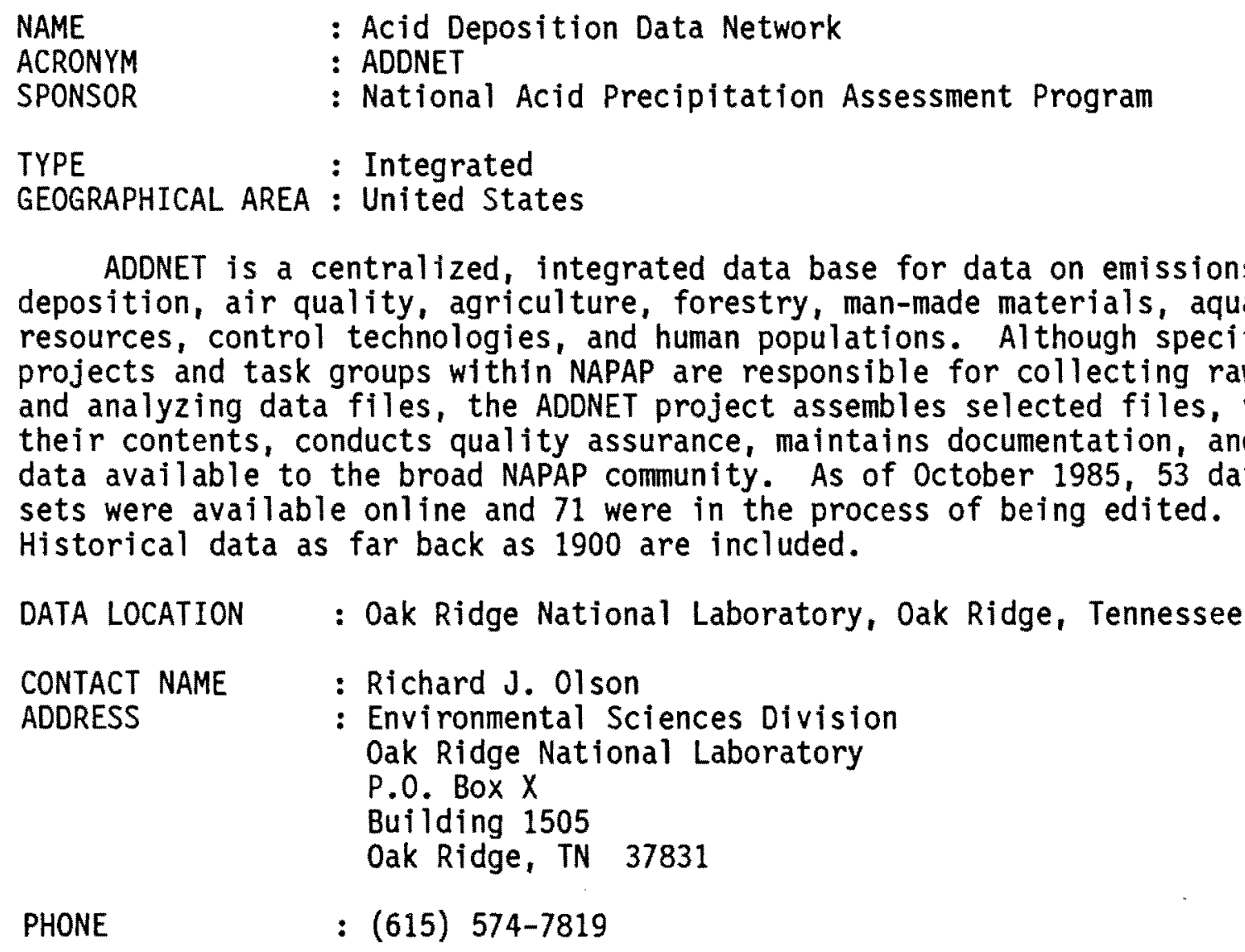


NAME

ACRONYM

SPONSOR

TYPE
: Acid Rain National Early Warning System

: ARNEWS

: Canadian Forestry Service

\section{GEOGRAPHICAL AREA : Canada}

The ARNEWS program started in 1984 as a forest monitoring program with 60 plots distributed over Canada. The ARNEWS data base stores data collected from that program. Tree data gathered from 10-by-40-m plots include number, species, dominance, diameter, height, condition, and acid rain symptoms as defined by the program. Foliage and soil are also to be sampled at 5 year intervals. Procedures and detailed sampling information are described by L. P. Magasi and M. K. Mahendrappa (1984).

DATA LOCATION : Canadian Forestry Service, New Brunswick

CONTACT NAME : M. K. Mahendrappa

ADDRESS

: Canadian Forestry Service

Maritimes Forest Research Centre

P.O. Box 4000

Fredericton, New Brunswick E3B 5P7

PHONE

REFERENCE DOC
: (506) 452-3549

: Magasi, L. P. and M. K. Mahendrappa. 1984. The Canadian Forestry Service Acid Rain National Early Warning System. Maritimes Forest Research Centre, Fredericton, New Brunswick. 


\begin{tabular}{|c|c|}
\hline $\begin{array}{l}\text { NAME } \\
\text { ACRONYM } \\
\text { SPONSOR }\end{array}$ & $\begin{array}{l}\text { : Forest Plot Inventory Database } \\
: \text { U.S. Forest Service }\end{array}$ \\
\hline $\begin{array}{l}\text { TYPE } \\
\text { GEOGRAPHICAL AREA }\end{array}$ & $\begin{array}{l}\text { : Forest/Vegetation } \\
\text { : United States }\end{array}$ \\
\hline $\begin{array}{l}\text { The inventory } \\
\text { on the area, plot, } \\
\text { U.S. Forest Servic } \\
\text { computerized data } \\
\text { periodic national } \\
\text { Data from } 1965 \text { to }\end{array}$ & $\begin{array}{l}\text { includes data from selected one-acre forest plots. Data } \\
\text { soil, trees, and other vegetation are taken. Each } \\
\text { be region maintains its own records and some regions have } \\
\text { base management systems. Regional data are combined for } \\
\text { assessment reports, with the last report published in } 1977 \text {. } \\
\text { the present are also available through ADDNET. }\end{array}$ \\
\hline DATA LOCATION & $\begin{array}{l}\text { : Individual USFS Regional offices } \\
\text { Available through ADDNET }\end{array}$ \\
\hline $\begin{array}{l}\text { CONTACT NAME } \\
\text { ADDRESS }\end{array}$ & $\begin{array}{l}\text { David Dixon } \\
\text { U.S. Forest Service } \\
\text { NE Forest Experiment Station } \\
370 \text { Reed Road } \\
\text { Broomall, PA } 19008\end{array}$ \\
\hline PHONE & : (215) 461-3025 \\
\hline
\end{tabular}




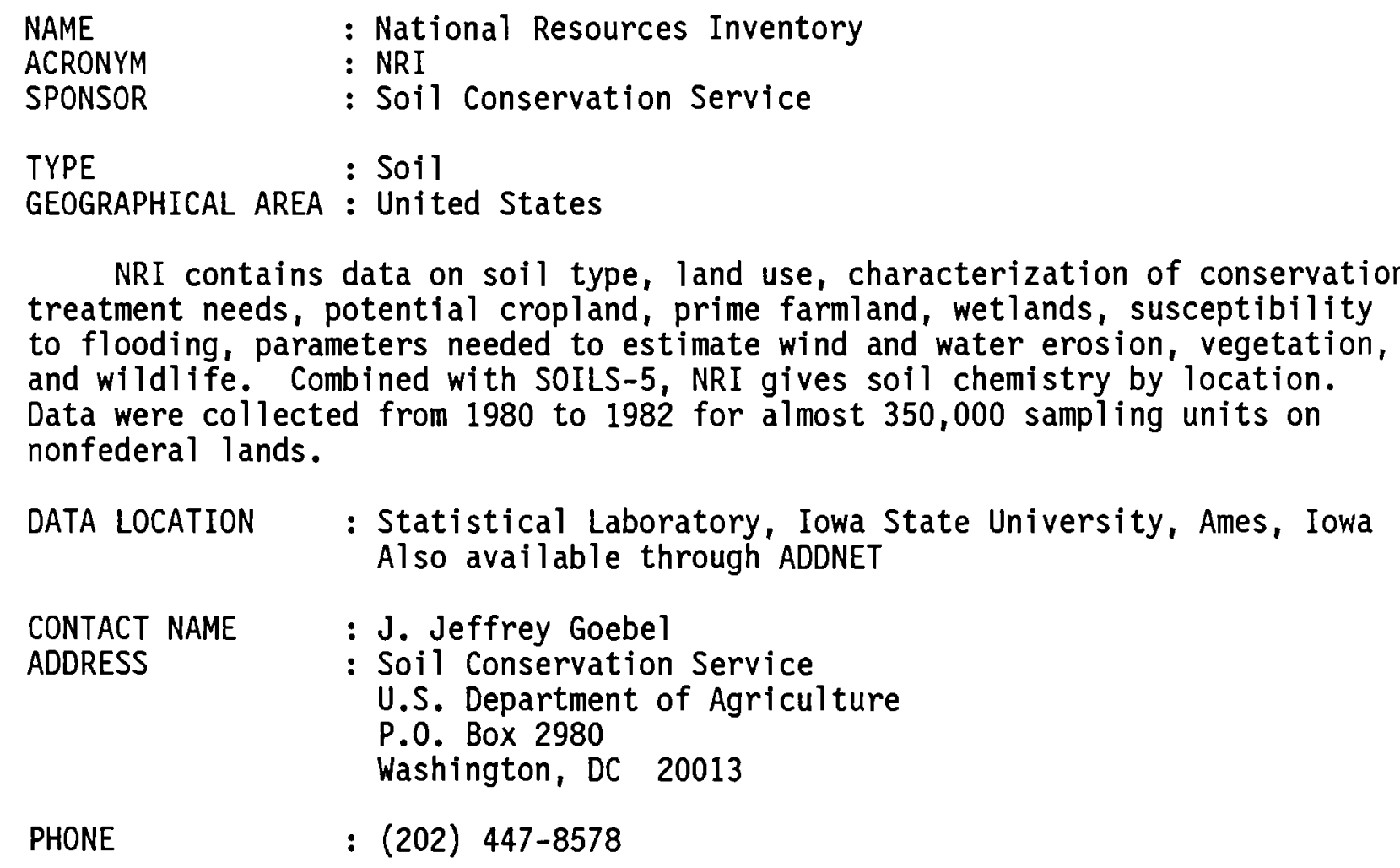




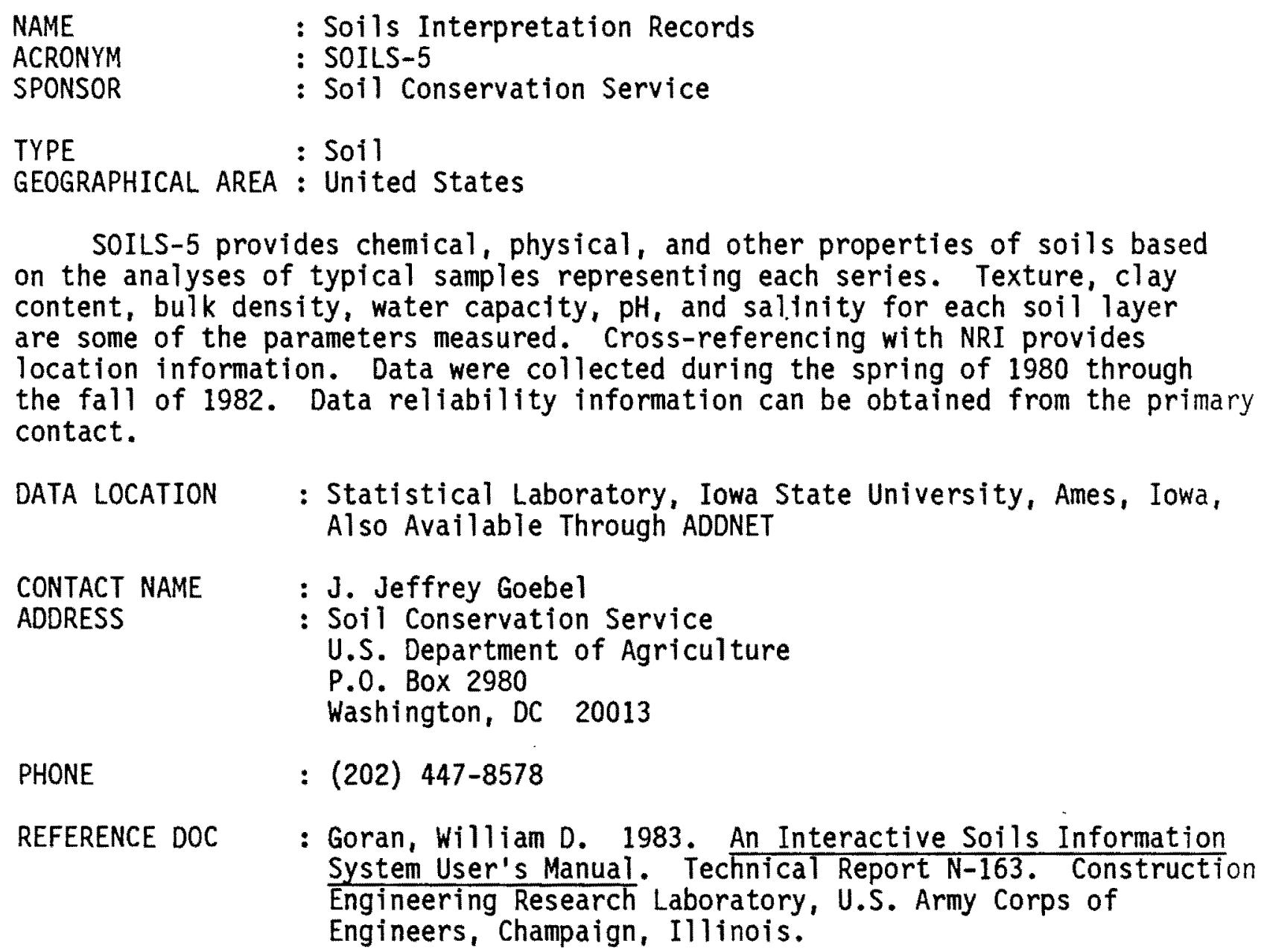


NAME

ACRONYM

SPONSOR

TYPE

GEOGRAPHICAL AREA
: Fish Information Network

: FIN

: National Acid Precipitation Assessment Program

: Ecosystem

Adirondack region of New York, Some sites in Maine, New Hampshire, and Vermont

FIN contains data and information relating to the distribution and status of fish populations in surface waters that are sensitive to, or al ready impacted by, acidic deposition. Besides data on fish species, water chemistry, station and lake demographics, and sampling descriptions are included. The period of data collection is from 1929 to 1984. Some data that are not quality-assured have been included in FIN.

DATA LOCATION : Available through ADDNET

CONTACT NAME : Joan P. Baker

ADDRESS

: Kilkelly Environmental Associates

P.0. Box 31265

Raleigh, NC 27622

PHONE : (919) 781-3150 
NAME

ACRONYM

: Adirondack Watershed Data Base

SPONSOR

: AWDB

: National Acid Precipitation Assessment Program

TYPE

: Integrated

GEOGRAPHICAL AREA : Adirondack State Park, New York

The AWDB is a collection of data from the New York Department of Environmental Conservation (water chemistry and lake characteristics), Adirondack Park Agency (land cover and soils), State University of New York at Plattsburgh (wetlands, beaver activity, forest cover and disturbances), and several databases such as FIN, ACID, and ADS. The period of data collection is from the early 1900 s to the present.

DATA LOCATION : Available through ADDNET

CONTACT NAME : Richard J. Olson

ADDRESS

: Environmental Sciences Division

Oak Ridge National Laboratory

P.0. Box X

Buflding 1505

Oak Ridge, TN 37831

PHONE

: (615) 574-7819

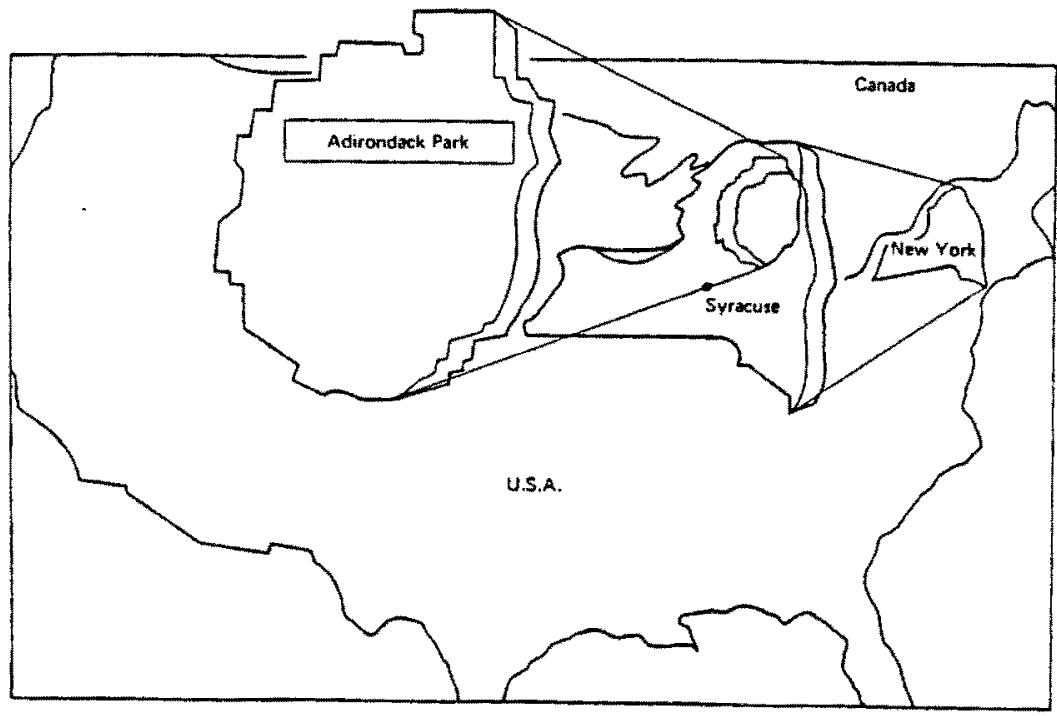


NAME

ACRONYM

SPONSOR

TYPE

GEOGRAP

SIS is a system used to store sampling data analyzed at the Ministry of Ontario analytical laboratories. The master file of sample results contains data from many projects including APIOS, Great Lakes, Inland WQ Monitoring, Surface Water, Ground Water, Terrestrial Effects, and AQUIS.

DATA LOCATION

CONTACT NAME

ADDRESS

PHONE

REFERENCE DOC

: Sample Information System

: SIS

: Ontario Ministry of the Environment

: Integrated

: Ontario

: Ontario Ministry of the Environment, Toronto, Ontario

: V.R. Roxborough

: Office of Systems Development Systems Development Section

135 St. Clair Ave. West, 3rd Floor

Toronto, Ontario M4V 1 P5

: (416) 965-6952

: Maddeaux, N. 1985. Province of Ontario, Ministry of the Environment, Sample Information System User's Manual. Province of Ontario, Ministry of the Environment, Toronto, Ontario. 
NAME

SPONSOR

TYPE

GEOGRAPHICAL AREA : Greater Sudbury Area, Canada

: Water Quality, Ecosystem
: Storage of Lake Chemistry, Zooplankton, and Watershed Characteristics of the Greater Sudbury Area in Digital Form : Ontario Ministry of the Environment

This database contains the following data (Environment Canada 1983):

1. Lake chemistry - extensive monitoring of lakes in the Greater Sudbury area: 209 lakes; 1974-76 data.

2. Zooplankton data, 187 lakes; 1974-76 data.

3. Lake chemistry data; 250 lakes; 1981, 1983 data.

4. Zooplankton data: 249 lakes; 1981 data.

5. Lake chemistry data; 250 lakes; 1982,1983 data.

6. Watershed characteristics; 196 lakes/watersheds.

Data is stored on tapes.

DATA LOCATION

: Laurentian University, Sudbury, Ontario

CONTACT NAME

ADDRESS

: J. Roger Pitblado

: Department of Geography

Laurentian University

Sudbury, Ontario P3E 2C6

PHONE

: (705) 675-1151

REFERENCE DOC
: Environment Canada. 1983. The Canadian Research Activity Catalogue on the Long-Range Transport of Air Pollutants and Acidic Precipitation. Federal LRTAP Liaison Office, Atmospheric Environment Service, Downsview, Ontario.

Pitblado, J. Roger and W. Keller. 1984. Data Report: Monitoring of Northeastern Ontario Lakes, 1981-1983. Ontario Ministry of the Environment, Sudbury, Ontario.

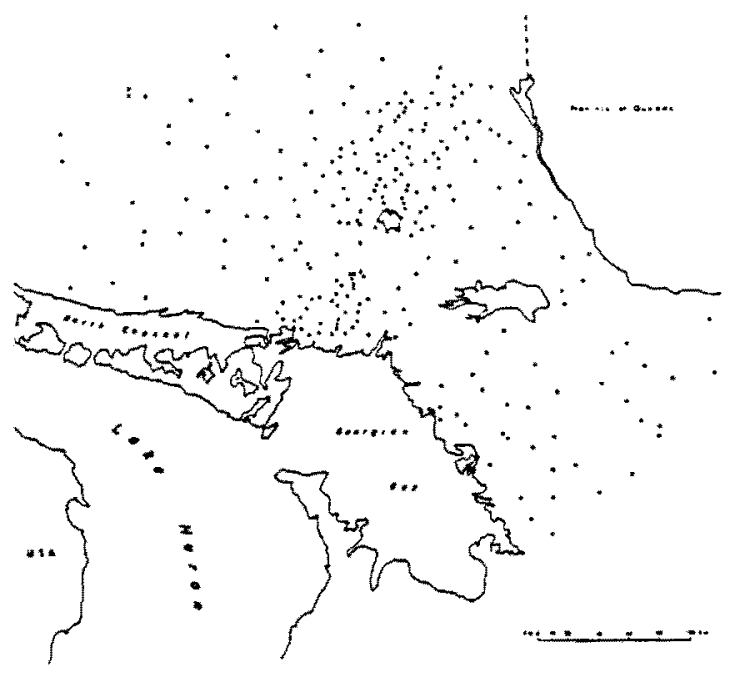

General lacations of the 250 study lakes.

A. 24 


\begin{tabular}{|c|c|}
\hline $\begin{array}{l}\text { NAME } \\
\text { ACRONYM } \\
\text { SPONSOR }\end{array}$ & $\begin{array}{l}\text { : Biological Data } \\
: \text { BIODAT } \\
: \text { Saskatchewan Environment }\end{array}$ \\
\hline $\begin{array}{l}\text { TYPE } \\
\text { GEOGRAPHICAL AREA }\end{array}$ & $\begin{array}{l}\text { : Biological Data } \\
\text { : Saskatchewan }\end{array}$ \\
\hline $\begin{array}{l}\text { BIODAT include } \\
\text { for waterbodies in } \\
\text { on identified alga } \\
\text { writing to the pri } \\
\text { the purpose for wh }\end{array}$ & $\begin{array}{l}\text { s biological data (phytoplankton, Marcophytes, and fish) } \\
\text { Saskatchewan. The biological data has counts and volumes } \\
\text { e species. Data are readily available to the public by } \\
\text { ncipal contact and explaining what data are required and } \\
\text { ich the data are needed. }\end{array}$ \\
\hline DATA LOCATION & : Regina, Saskatchewan \\
\hline $\begin{array}{l}\text { CONTACT NAME } \\
\text { ADDRESS }\end{array}$ & $\begin{array}{l}\text { : Don Fast } \\
\text { : Walter Scott Building } \\
3085 \text { Alberta Street } \\
\text { Regina, Saskatchewan S4S 0B1 }\end{array}$ \\
\hline PHONE & : (306) 787-6178 \\
\hline
\end{tabular}




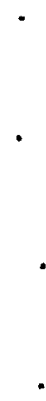




\section{APPENDIX B}

INVENTORY OF TRANSBOUNDARY REGION AMBIENT AIR QUALITY PROJECTS 
. 

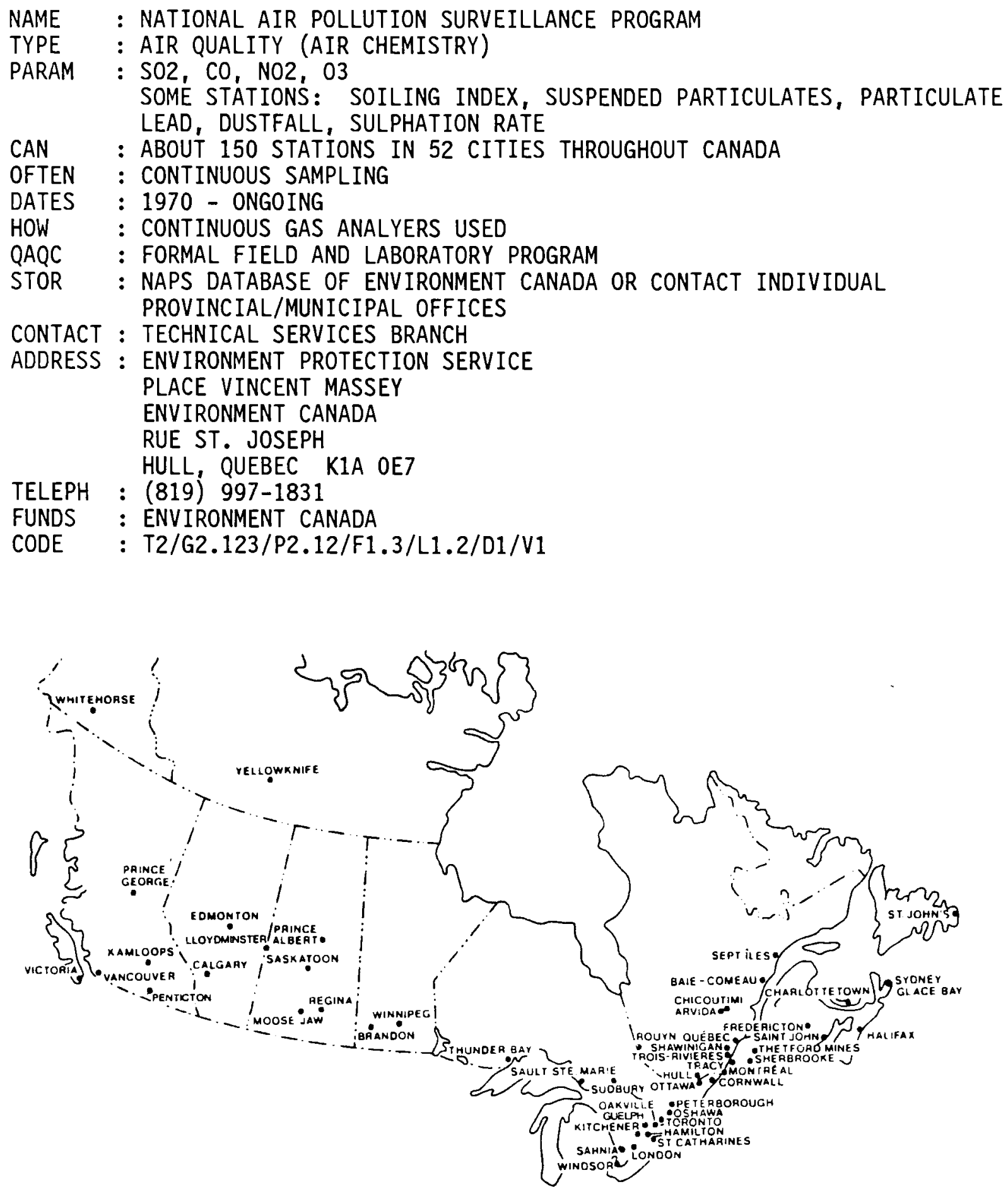

NATIONAL AIR POLLUTION SUR VEILLANCE NETWORK
RÉSEAU NATIONAL DE SURVEILLANCE DE LA POLLUTION ATMOSPHÉRIQUE 


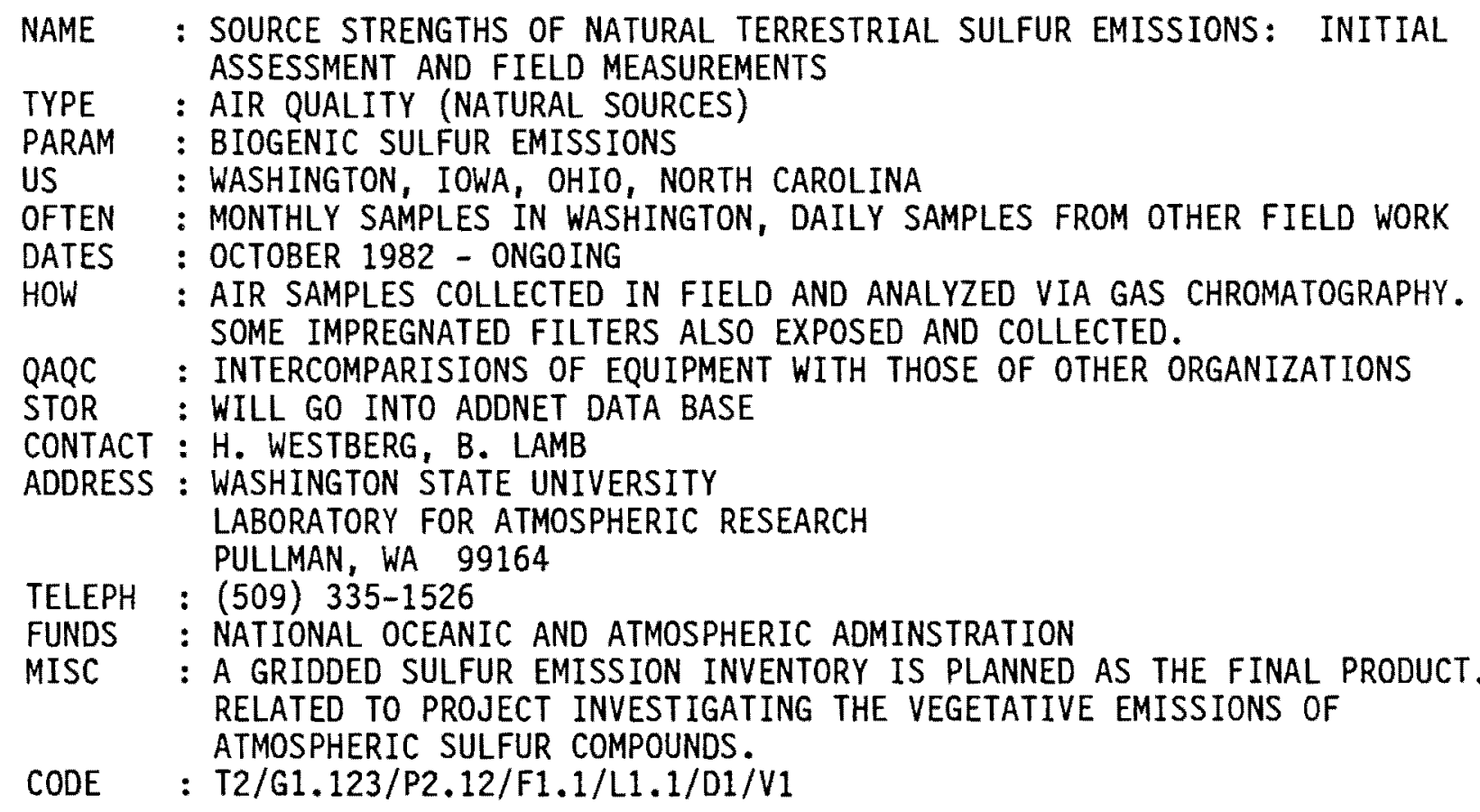




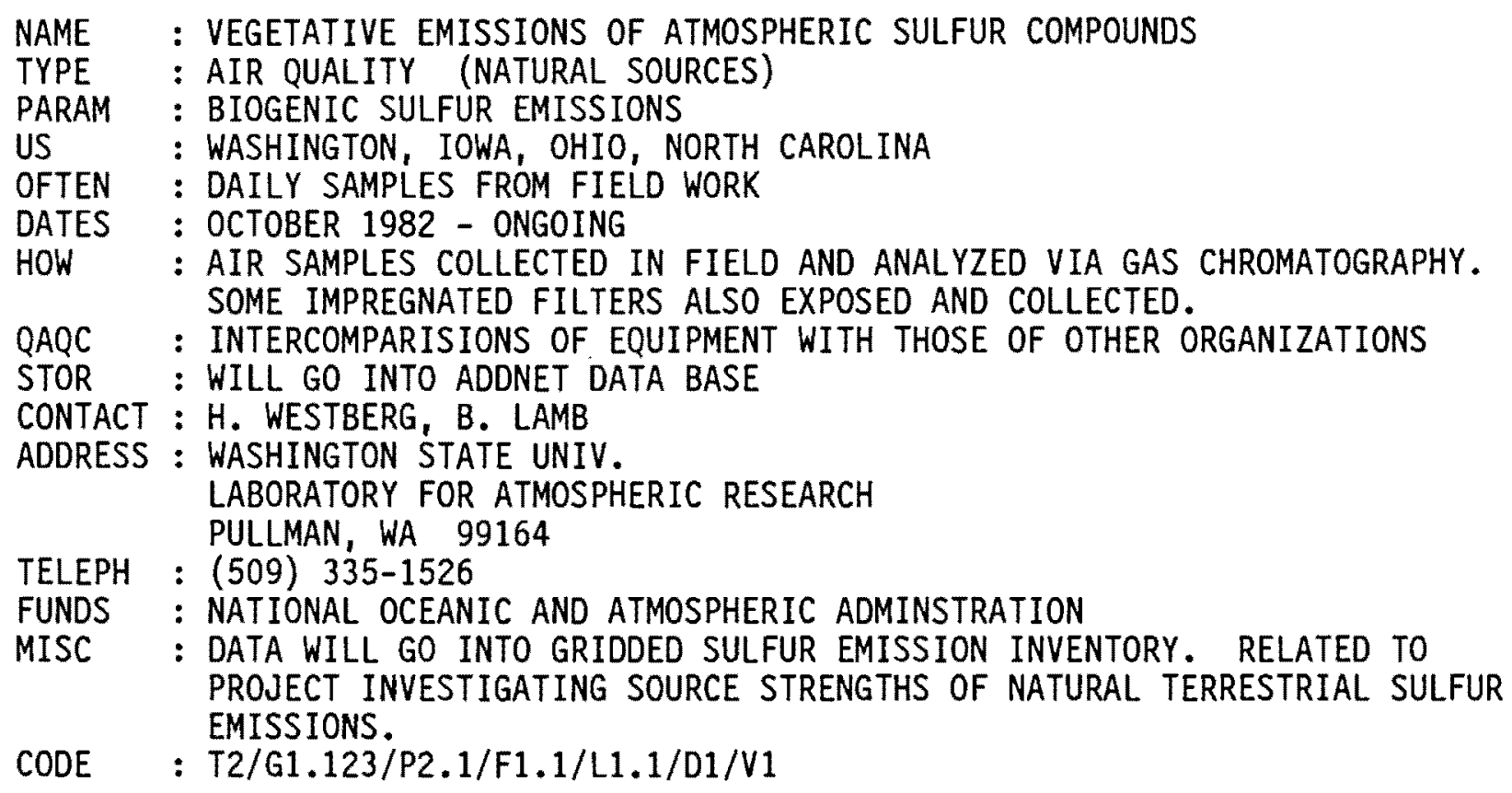




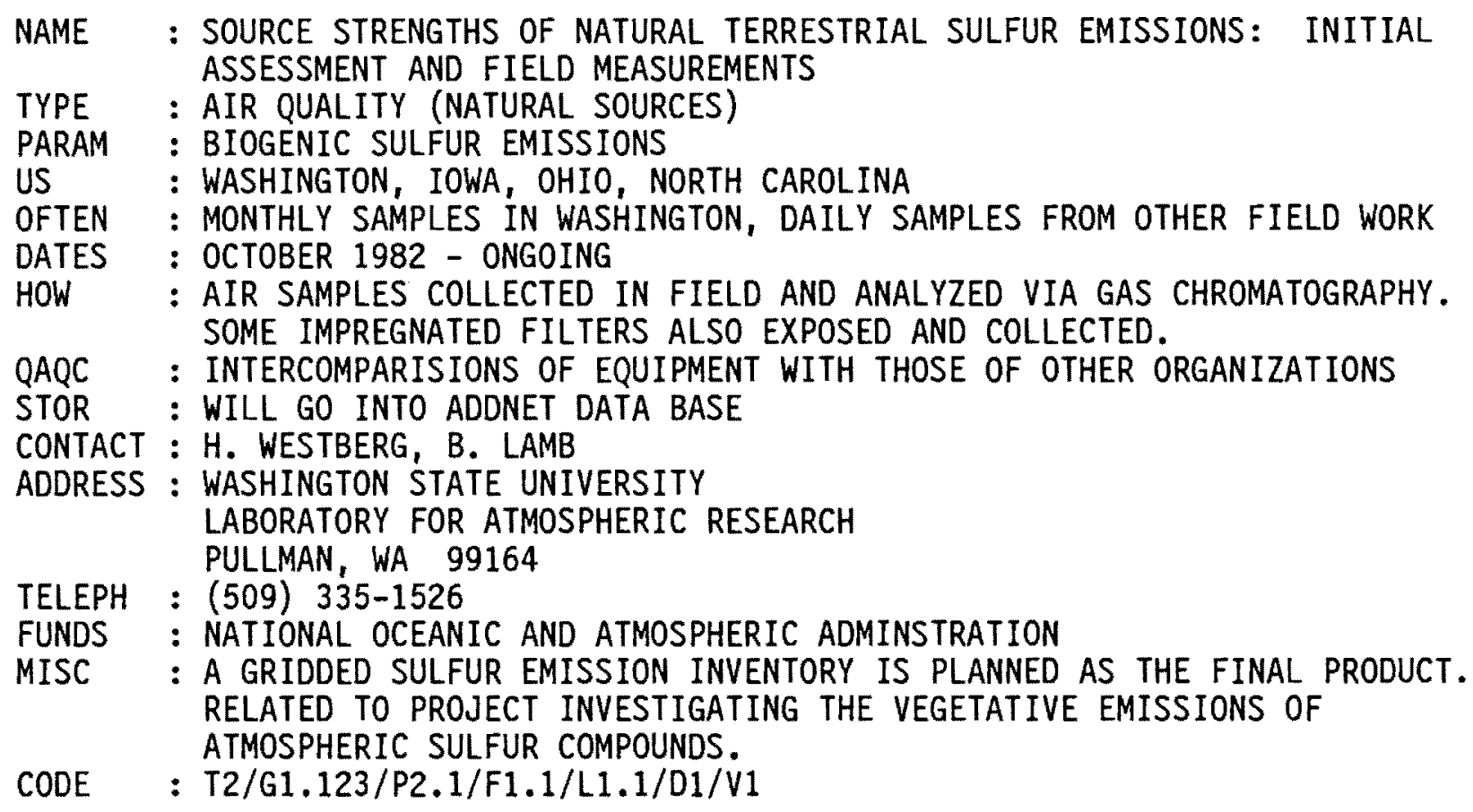




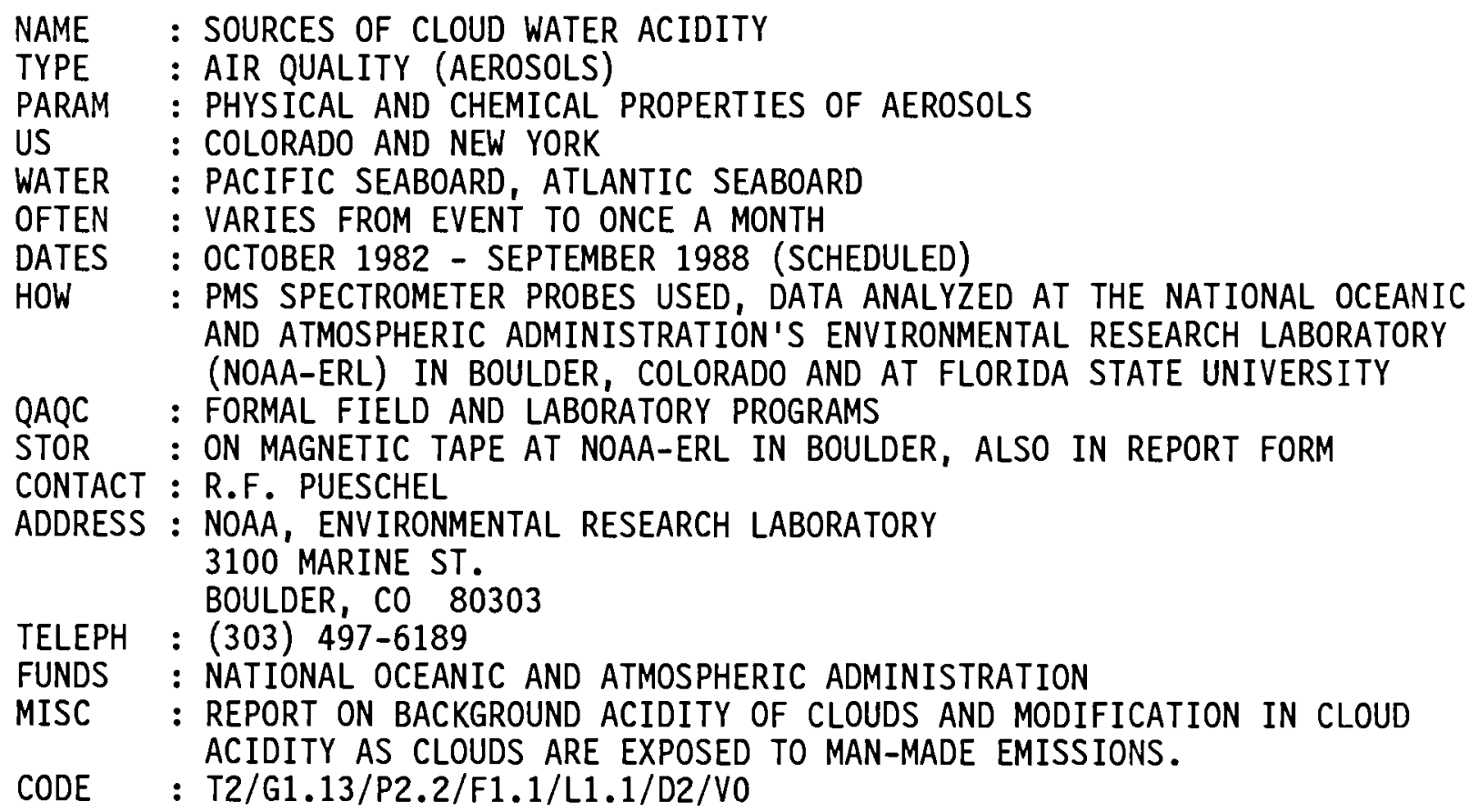



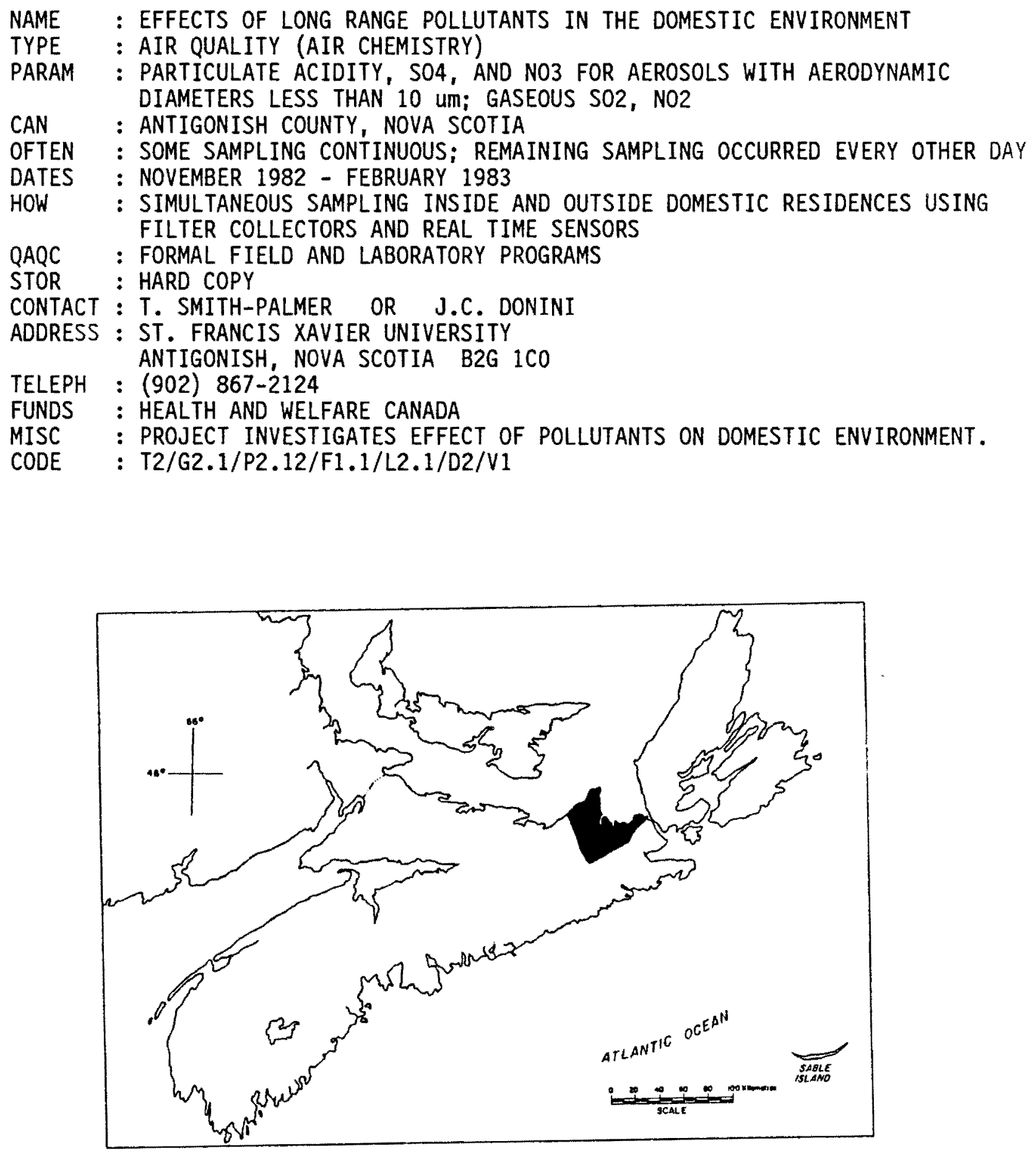

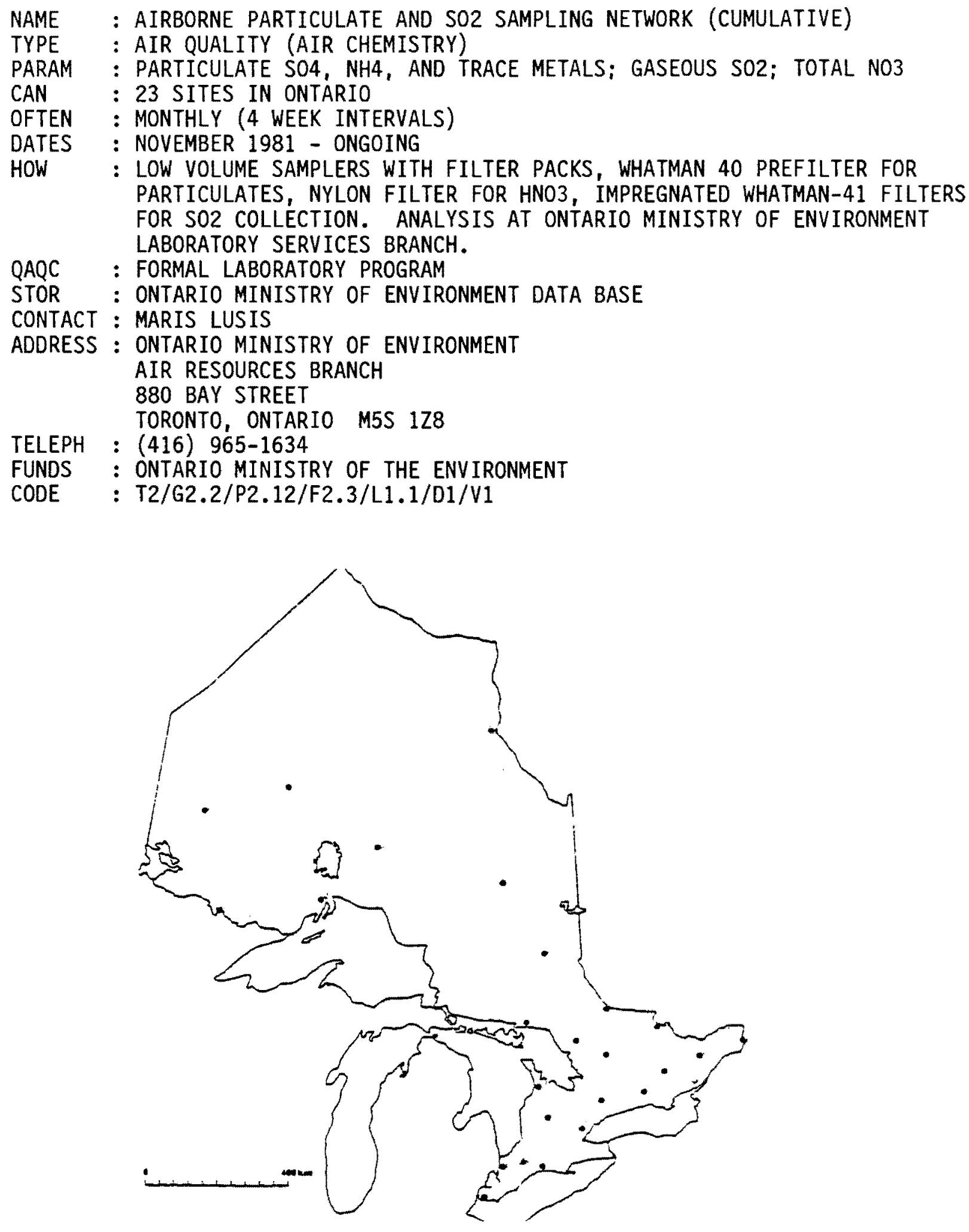


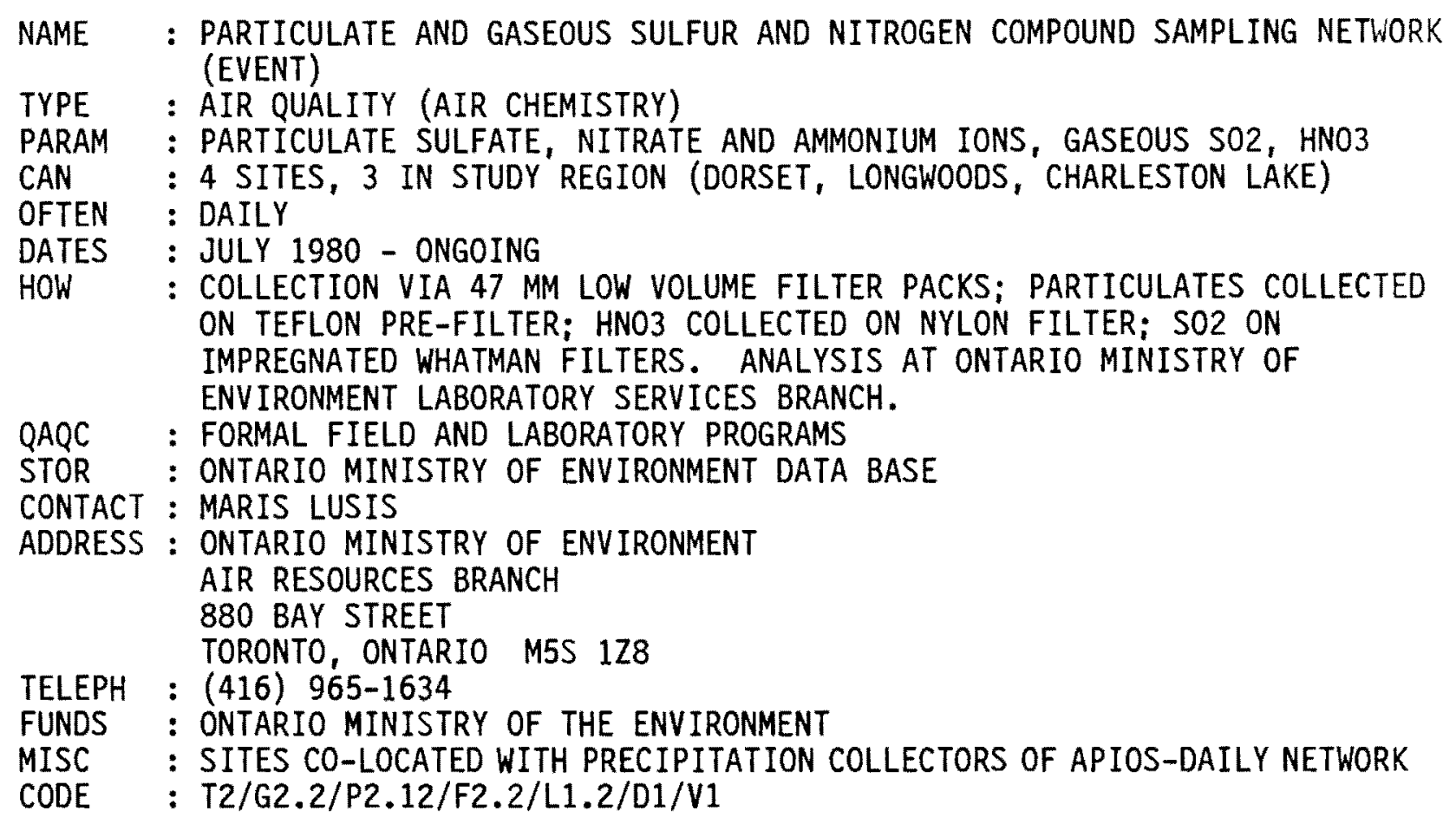




\begin{abstract}
NAME : POPLAR RIVER THERMAL POWER PLANT AMBIENT AIR MONITORING PROGRAM
TYPE : AIR QUALITY (AIR CHEMISTRY)

PARAM : SUSPENDED PARTICULATES, SO2, METEOROLOGICAL DATA

CAN : 1 SITE NEAR THE POPLAR RIVER THERMAL POWER PLANT, CORONACH, SASKATCHEWAN

OFTEN : CONTINUOUS SAMPLING FOR S02 (CONVERTED TO HOURLY AVERAGES); FILTER SAMPLES ARE COLLECTED EVERY 6 DAYS

DATES : APPROX. 1975 - ONGOING

HOW : CONTINUOUS MONITORING OF S02 VIA COMMERCIAL ANALYZER; SUSPENDED PARTICULATES COLLECTED ON FILTERS, ANALYZED AT SASKATECHEWAN ENVIRONMENT LABORATORIES

QAQC : NO FORMAL WRITTEN PROCEDURE, ALTHOUGH MANUFACTURER'S QA/QC AND CALIBRATION PROCEDURES ARE FOLLOWED FOR EQUIPMENT DEPLOYED IN THE FIELD

STOR : HARD COPY, ALTHOUGH MORE RECENT DATA IS ON A HARD DISK

CONTACT : L. J. LECHNER

ADDRESS : POLLUTION CONTROL BRANCH SASKATCHEWAN ENVIRONMENT 3085 ALBERT ST. REGINA, SASKATCHEWAN S4S OB1

TELEPH : (306) 787-6195

FUNDS : SASKATCHEWAN ENVIRONMENT AND SASKATCHEWAN POWER CORP.

REFDOC : POPLAR RIVER BILATERAL MONITORING COMMITTEE. 1985. 1984 ANNUAL REPORT TO THE GOVERNMENTS OF CANADA, UNITED STATES, SASKATCHEWAN, AND MONTANA. SASKATCHEWAN ENVIRONMENT, REG INA, SASKATCHEWAN.

SHEWCHUK, S. R. 1984. AN AIR AND PRECIPITATION QUALITY STUDY FOR THE AGRICULTURAL MONITORING PROGRAMS OF THE POPLAR RIVER STATION. SASKATCHEWAN RESEARCH COUNCIL, SASKATOON, SASKATCHEWAN.
\end{abstract}

CODE $\quad:$ T2/G2.3/P2.12/F4.2/L1.2/D2/V1

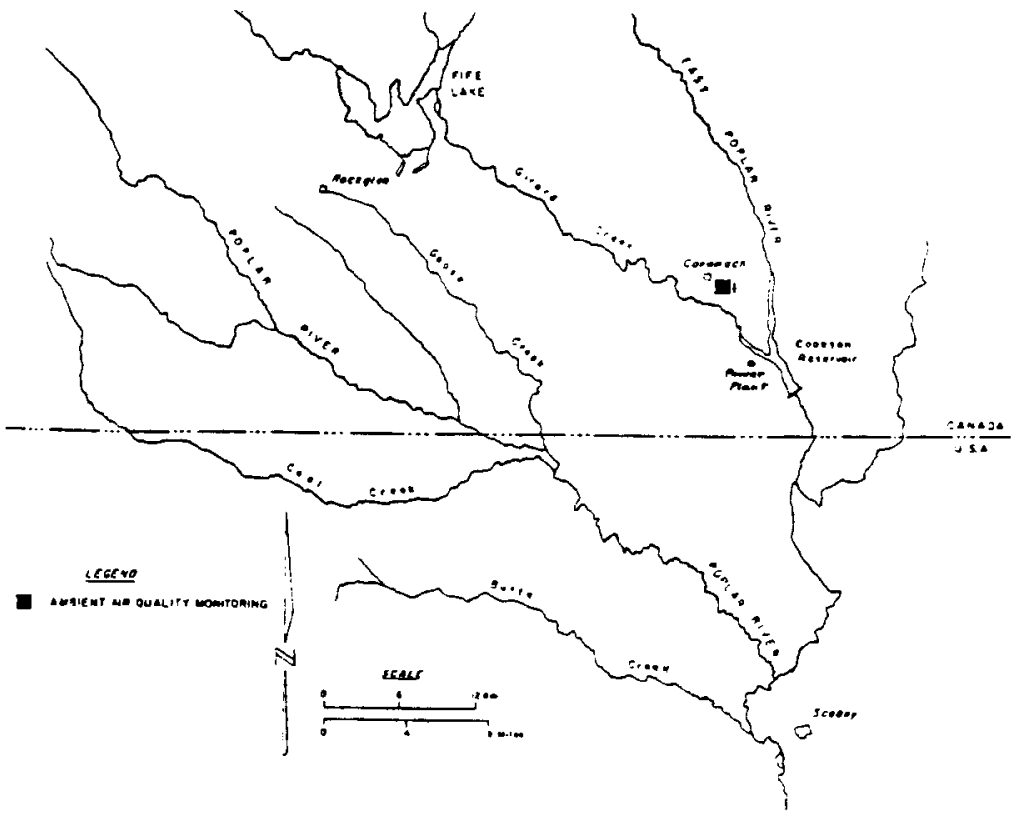

B.9 


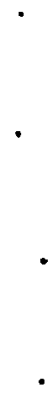




\section{APPENDIX $C$}

INVENTORY OF TRANSBOUNDARY REGION AMBIENT WATER QUALITY PROJECTS 
•

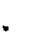

- 

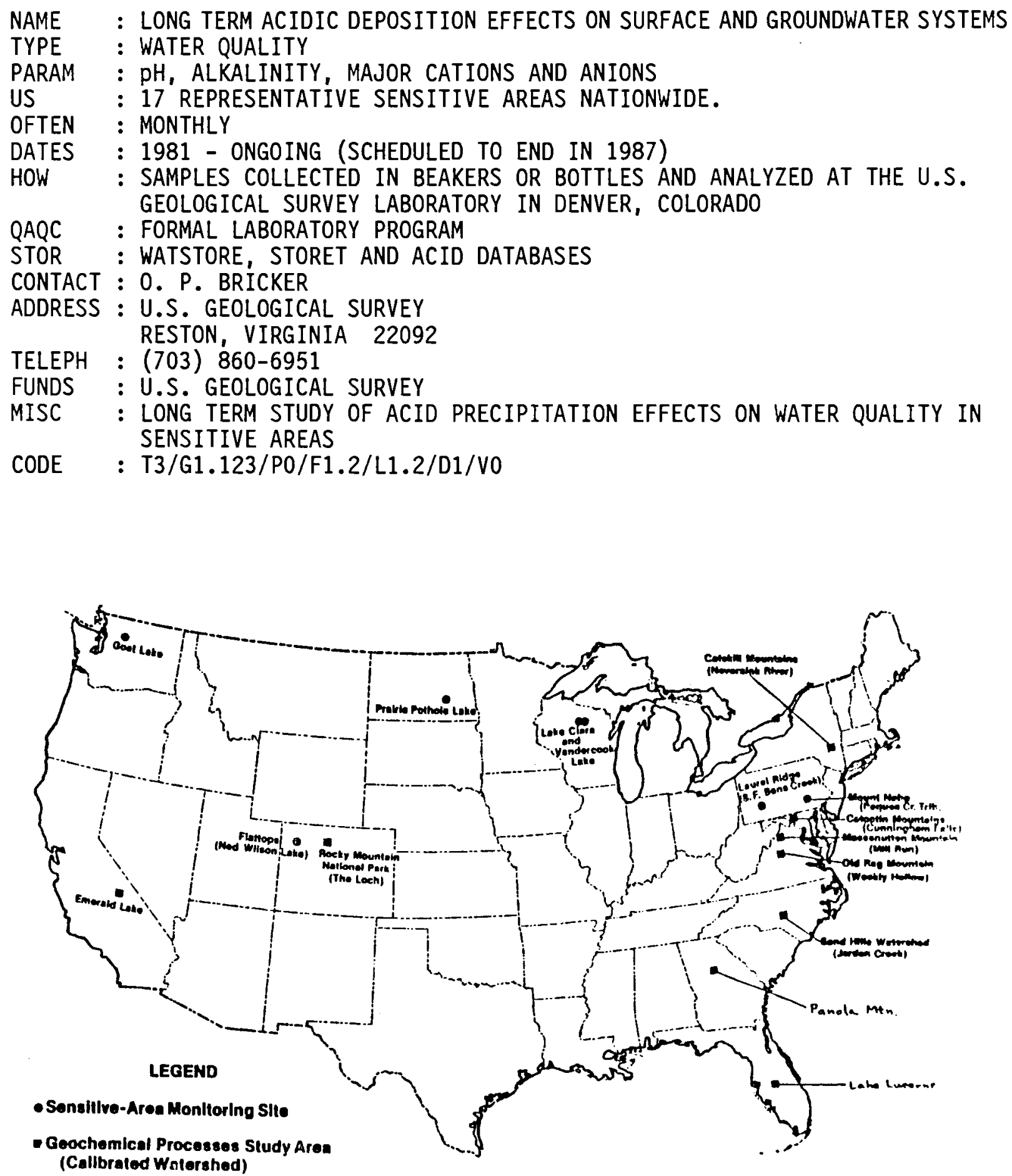


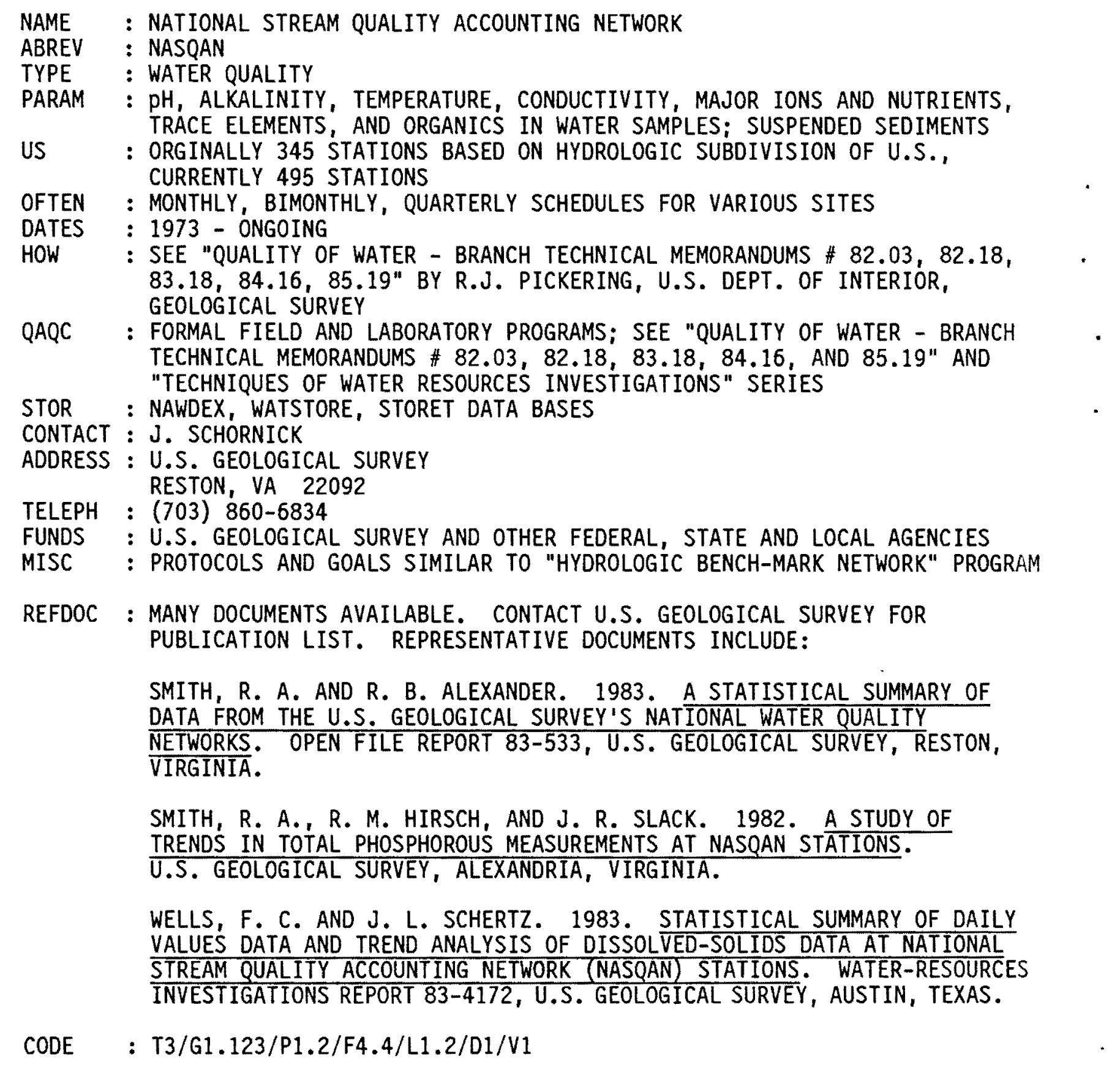




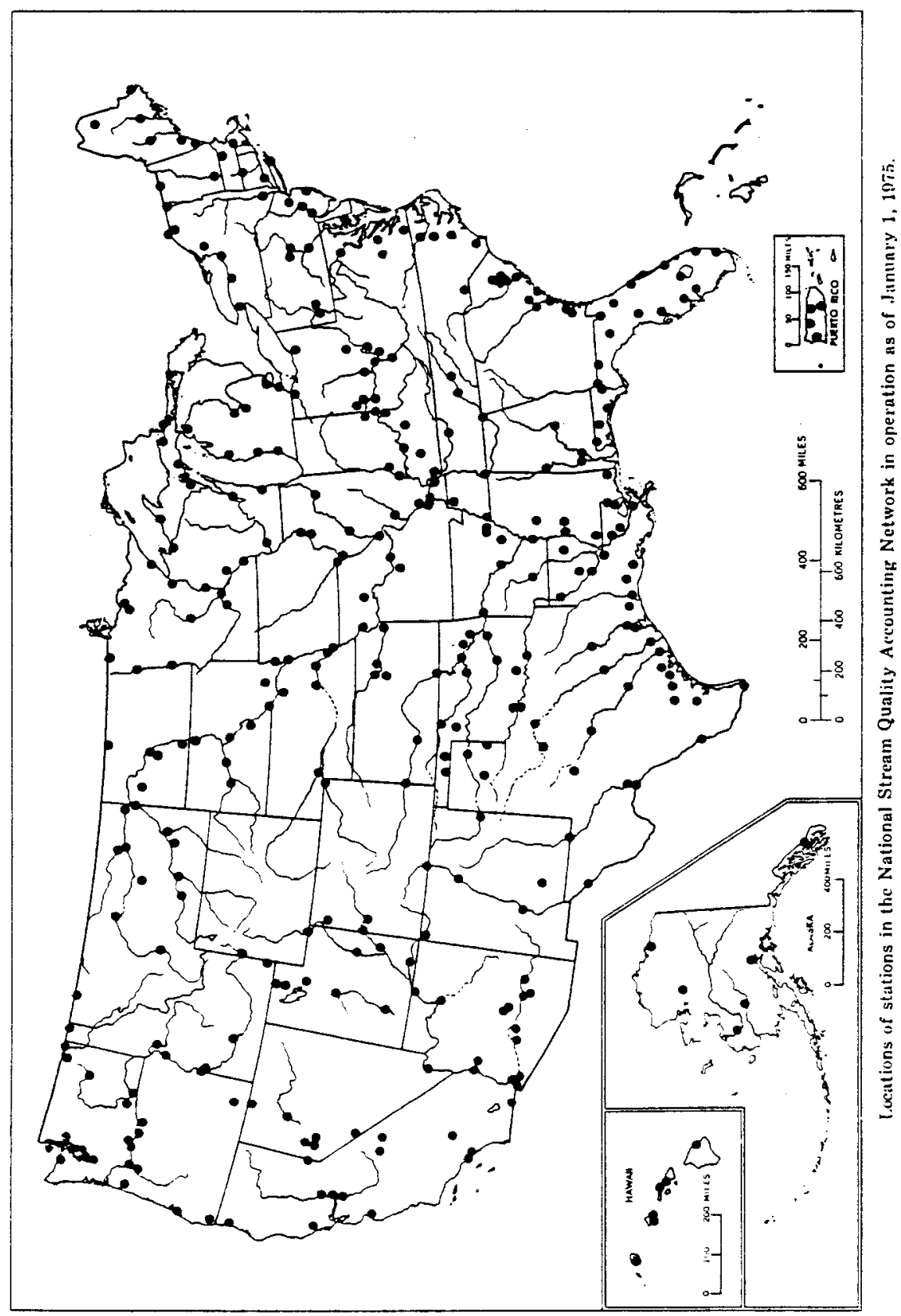

C. 3 


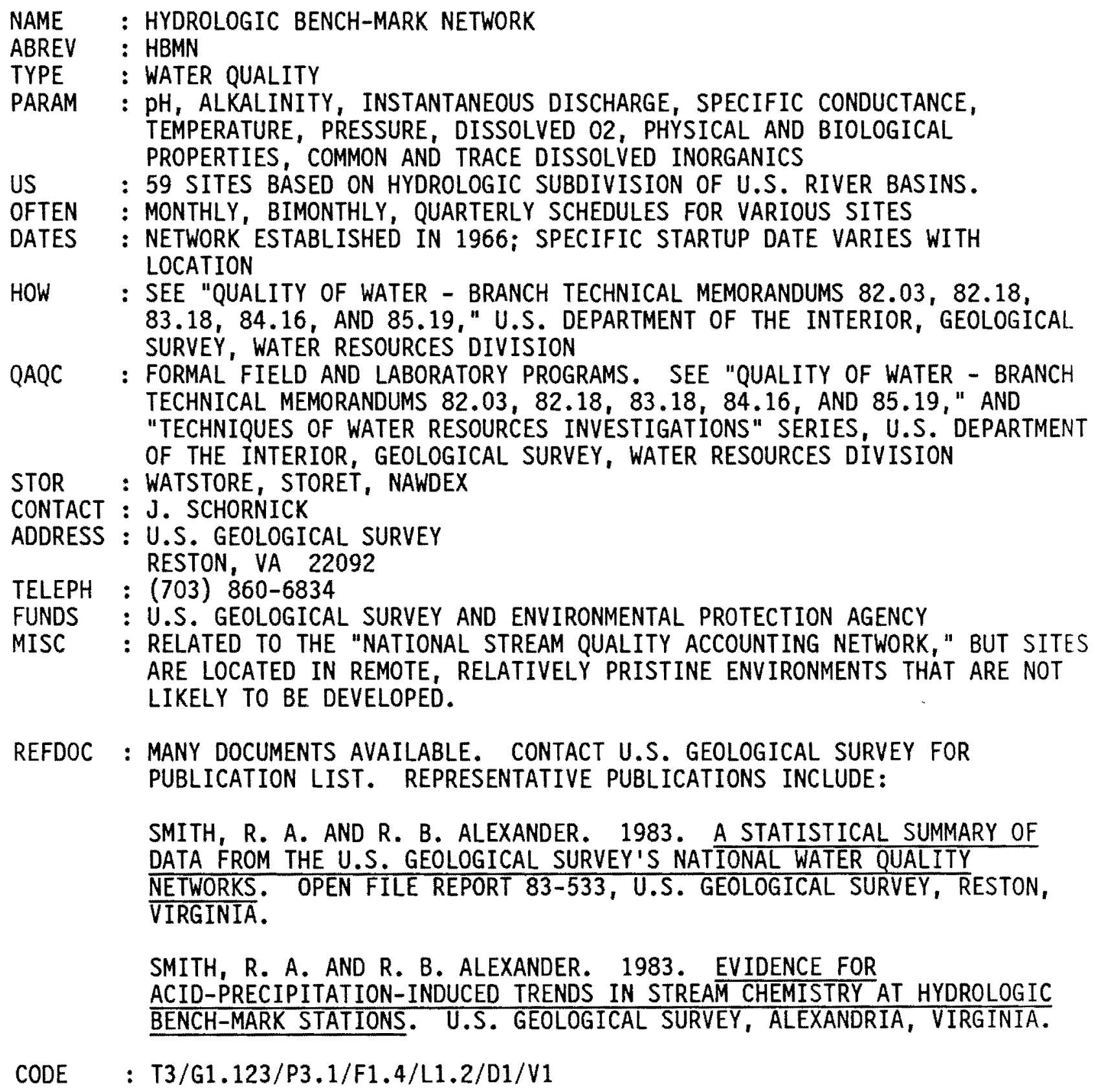


Map of "Hydrologic Bench-Mark Network" stations

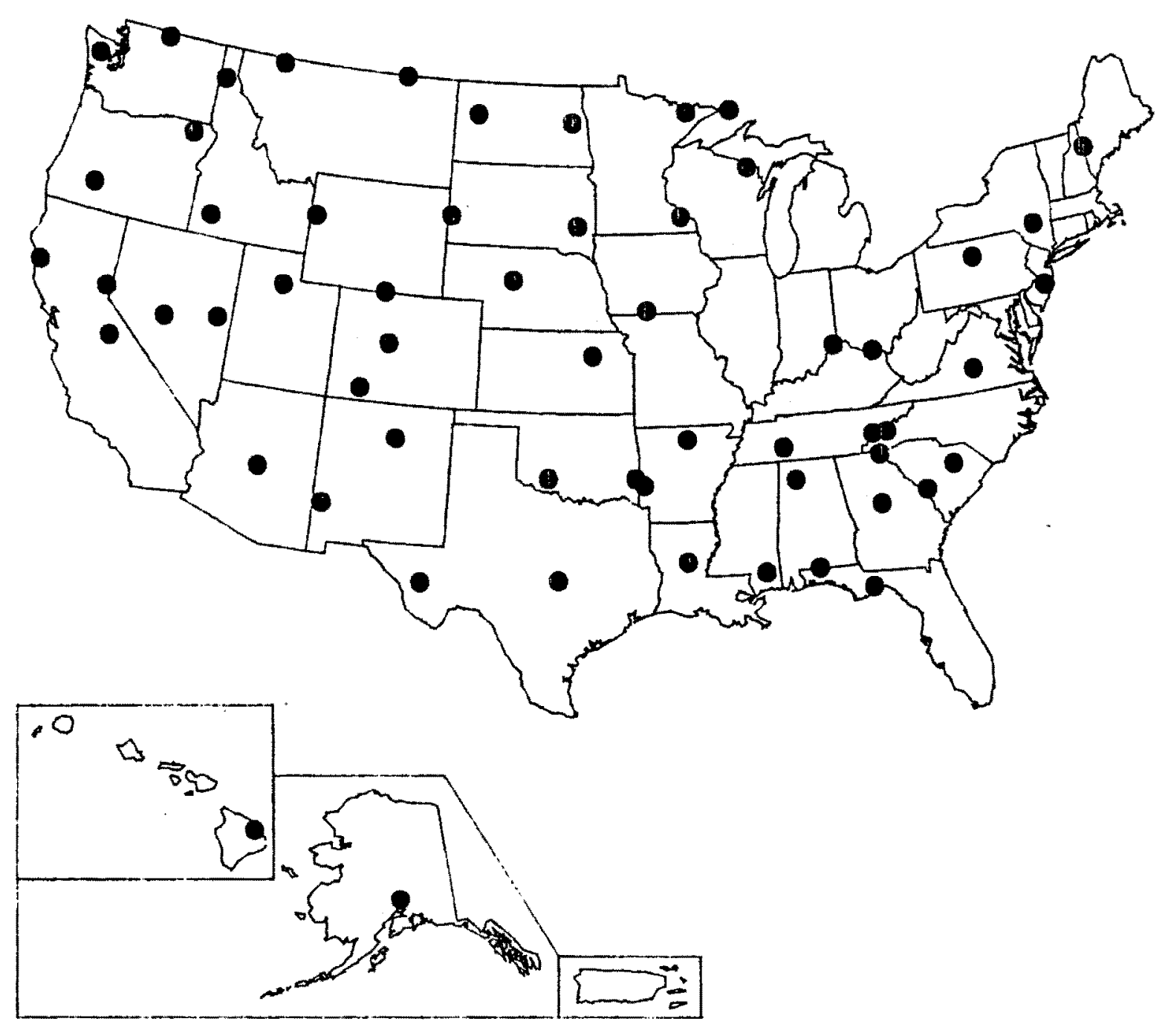

C. 5 


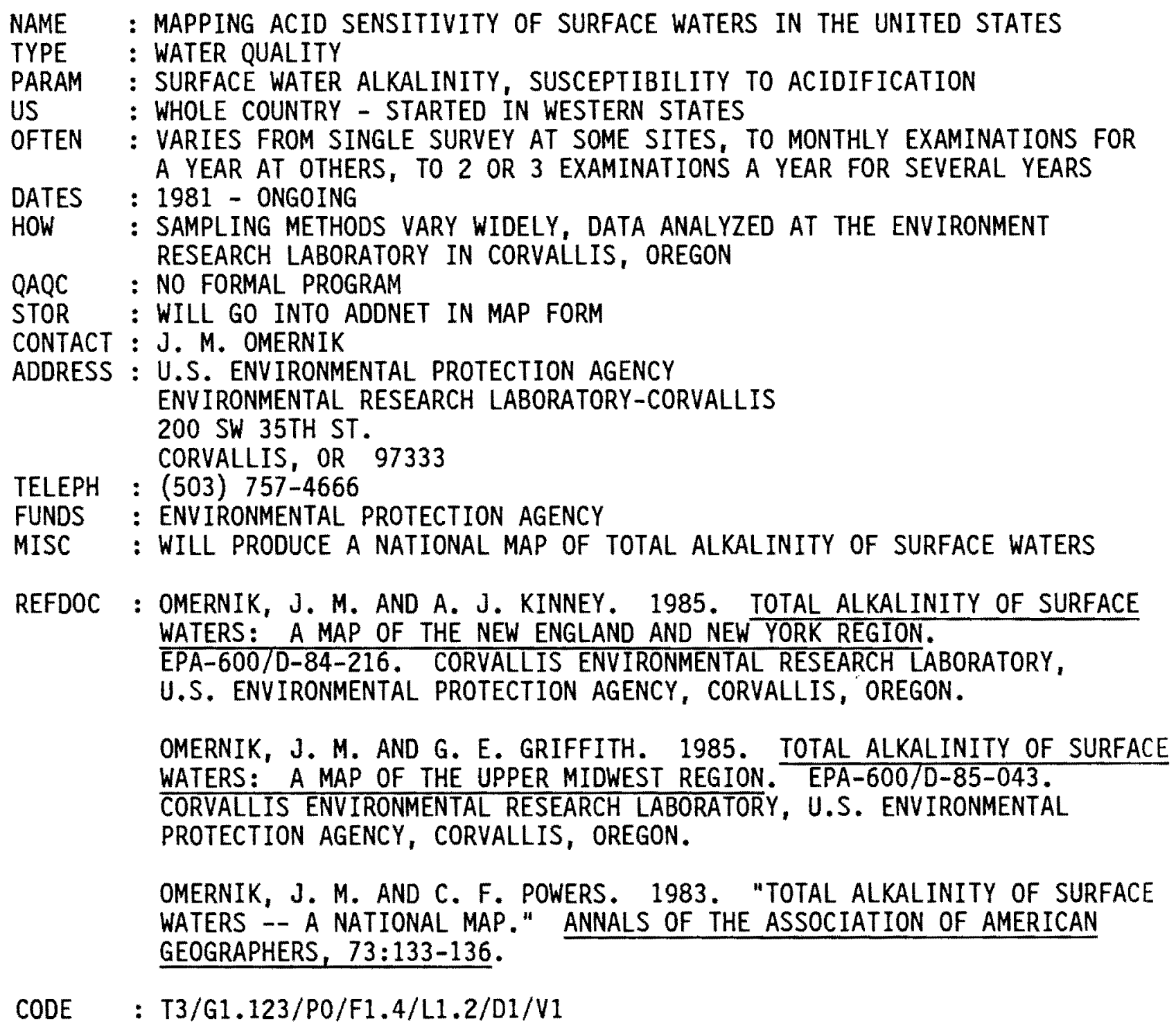


Selected Maps of Measurement Locations for "Mapping Acid Sensitivity of Surface Waters in the United States"

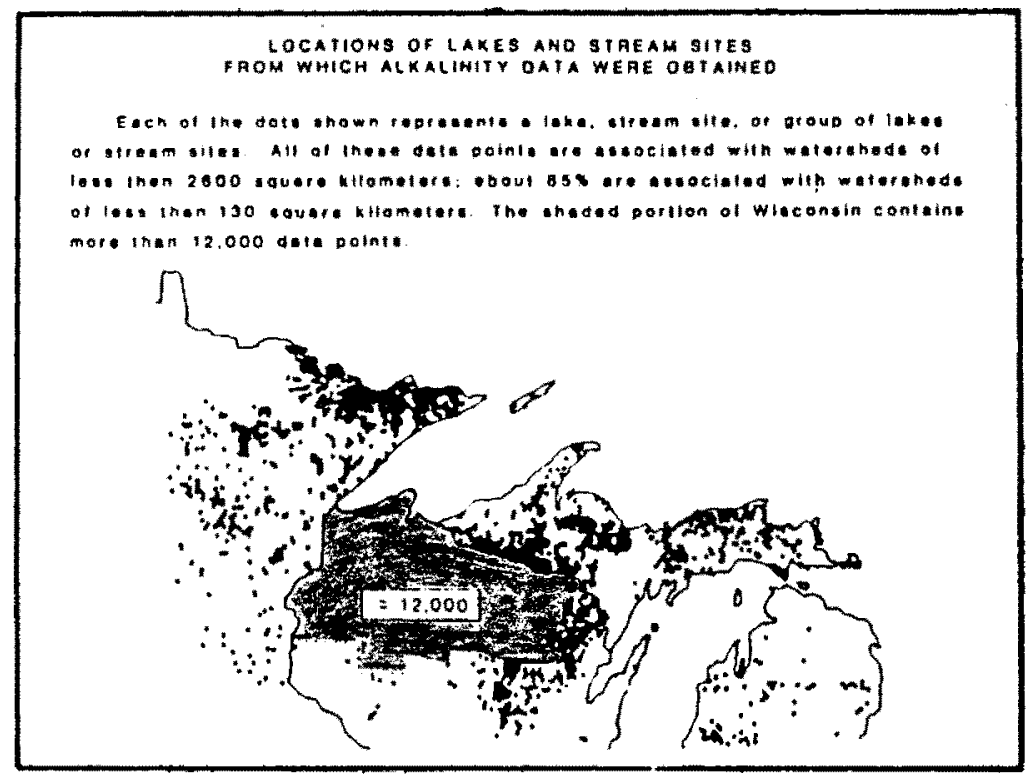

LOCATIONS OF LAKES ANO STREAM SITES FROM WHICH ALKALINITY DATA WERE OBTAINED

Each of the dots shown represents a lake, stream site. or group of lakes or stream sites. All of these data points are associated with watersheds of less than 2600 square kilometers; sbout 80 : are sssociated with watersheas of less than 230 square kiloneters.

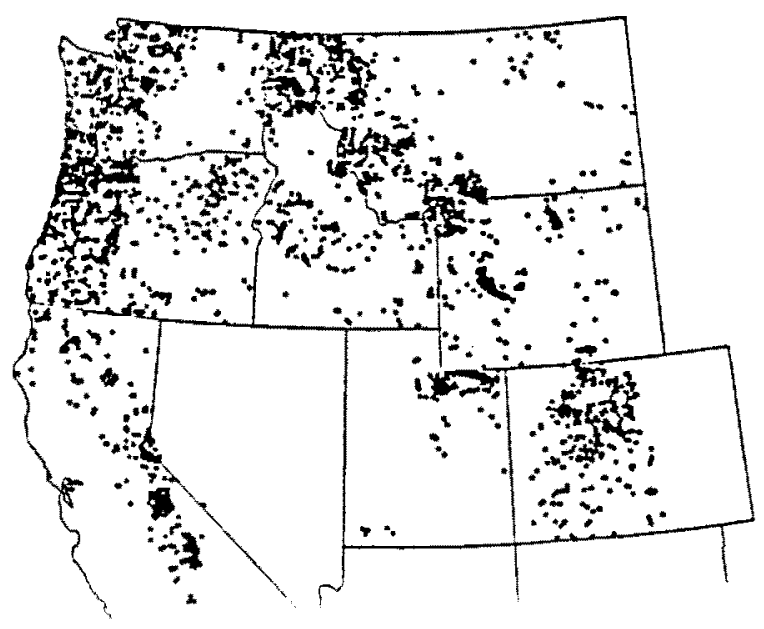

LOCATIONS OF STREAM SITES AND LAKES FROM WHICH ALKALLNTY OATA WEAE OETAINED

Each of the dotk whown reprosents a stream site. lake, or group of atream attes or lekes. All of thease outa points are asociated with watersheds of leas then 1000 aquare miles. About $75 \times$ sre aswockated with wateraheds of les. thun so squere miles.
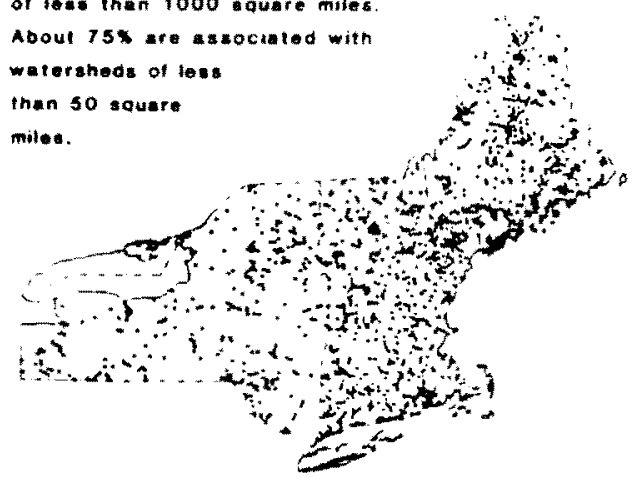


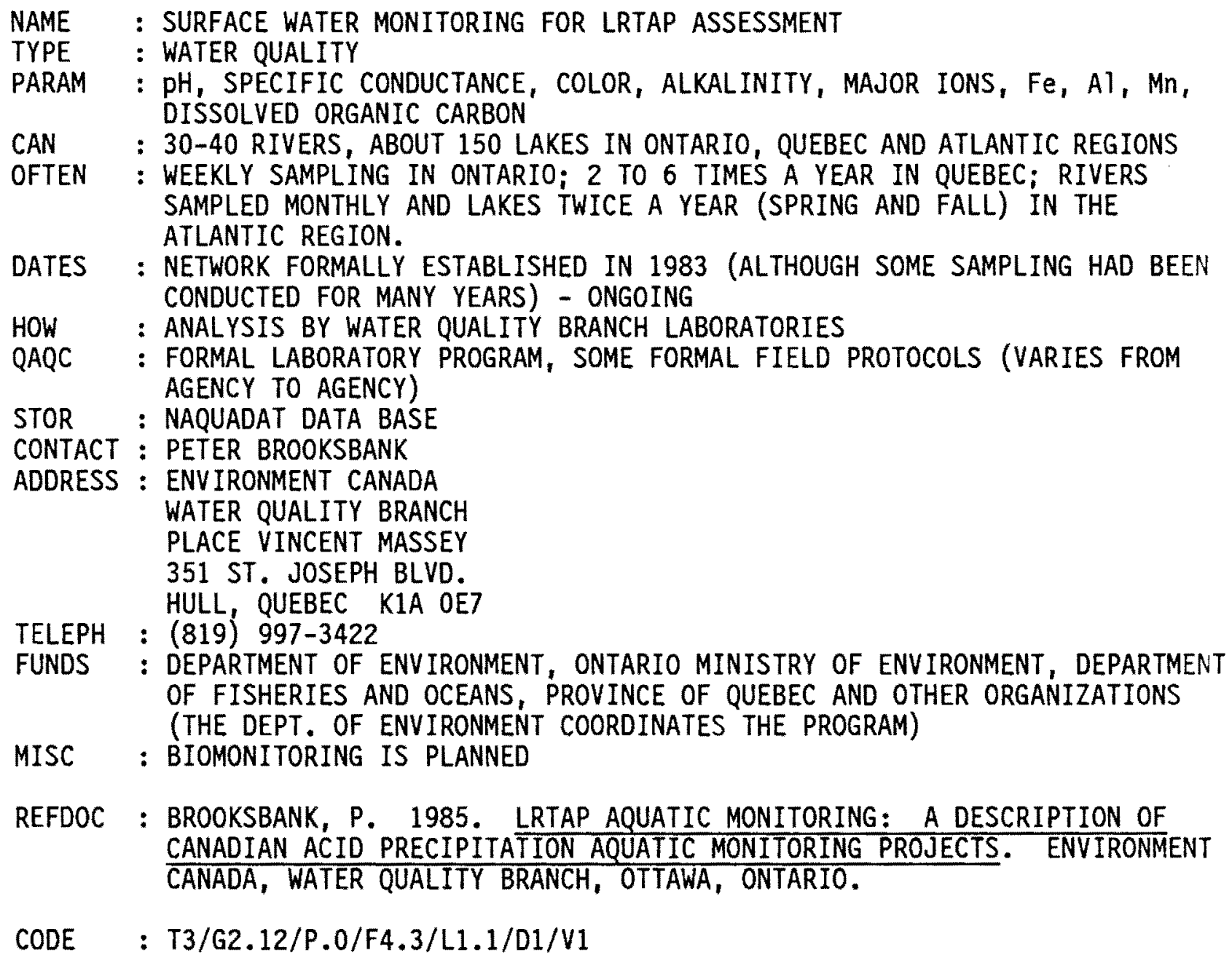




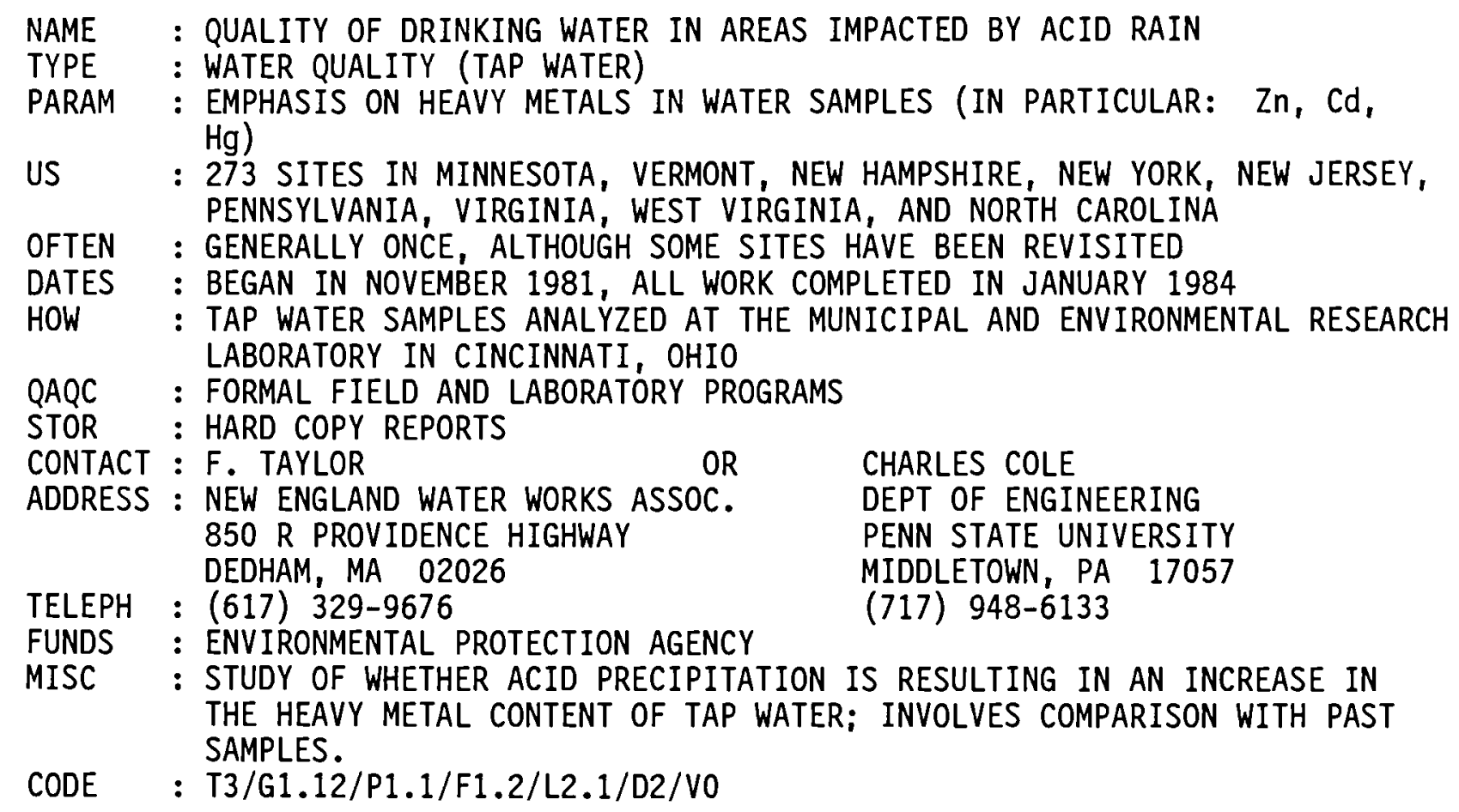




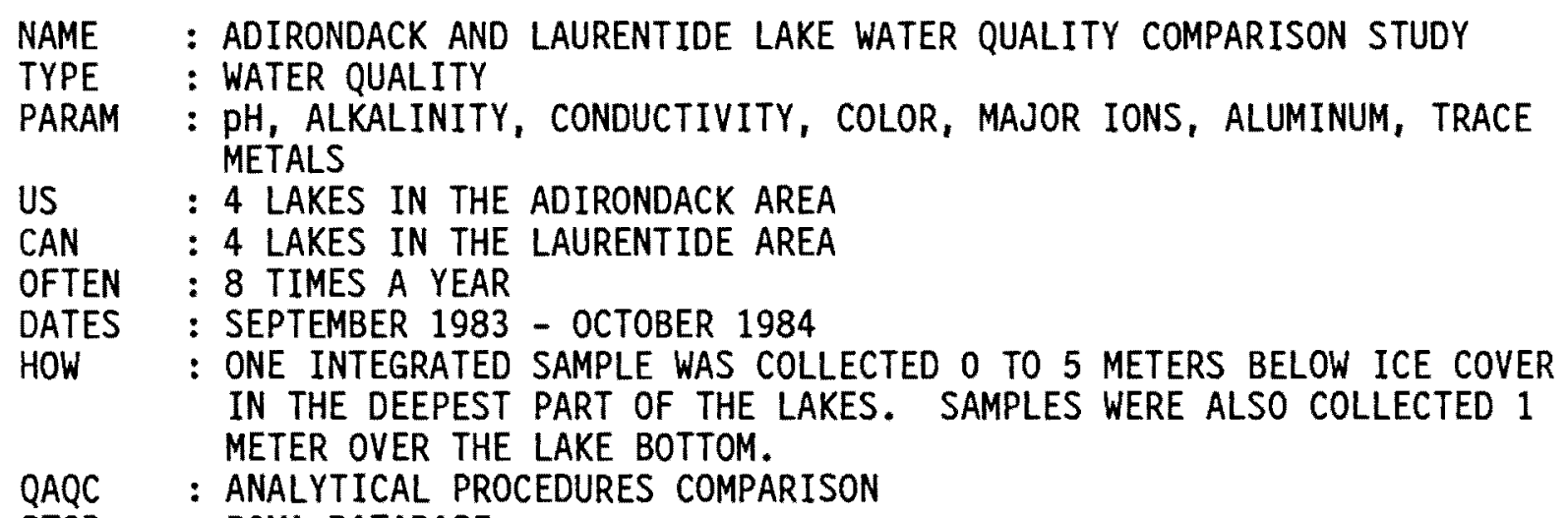



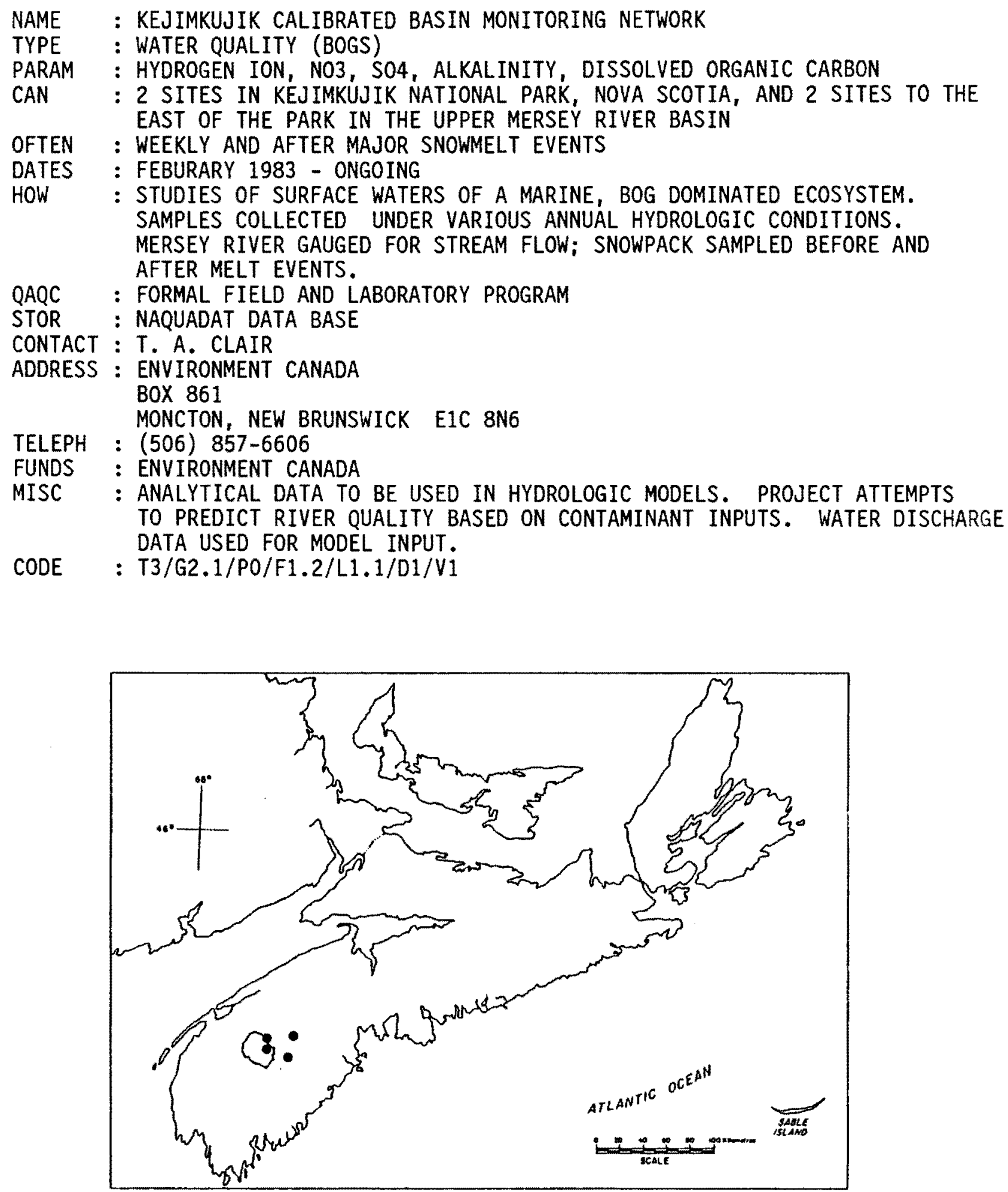


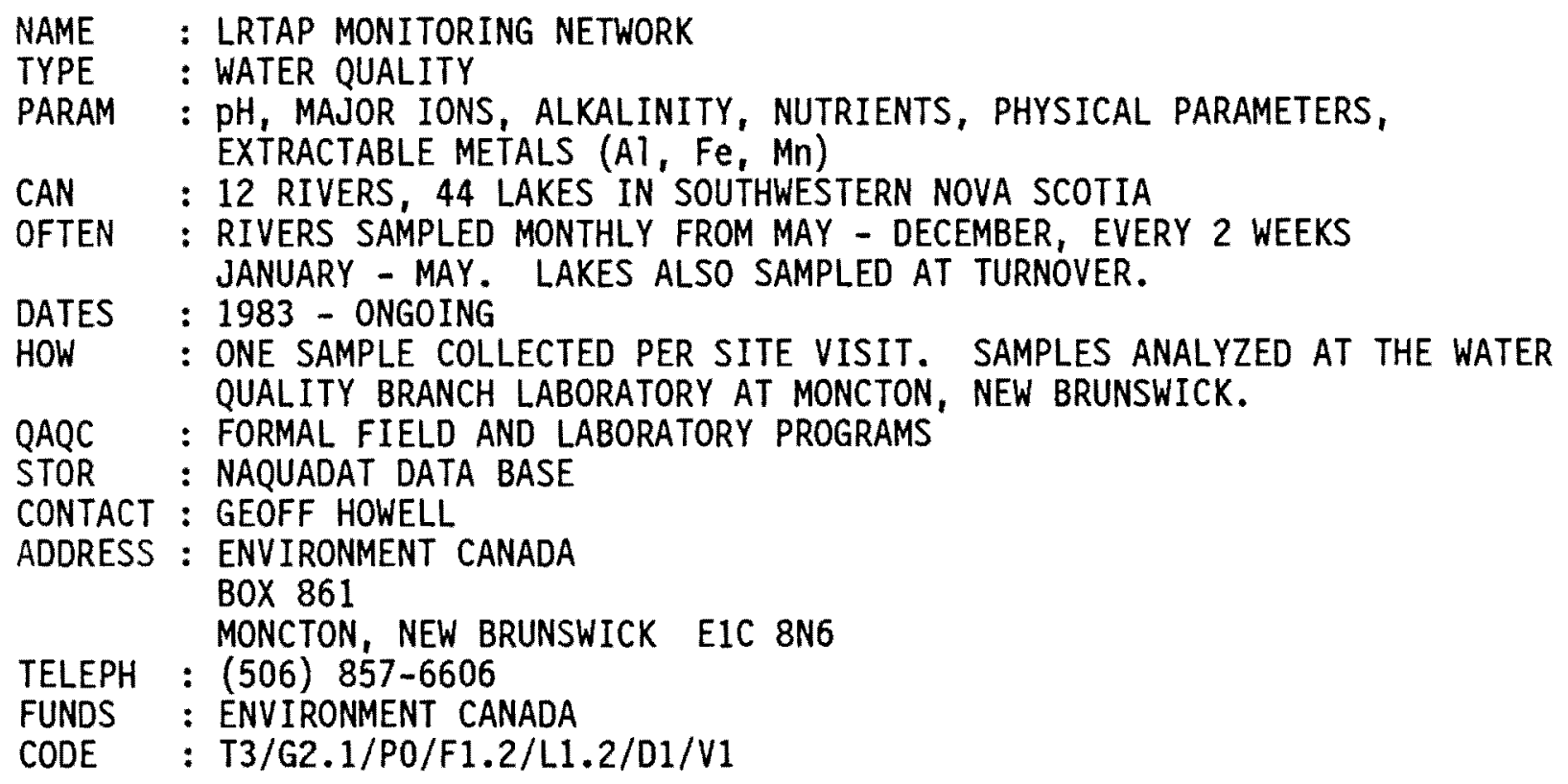




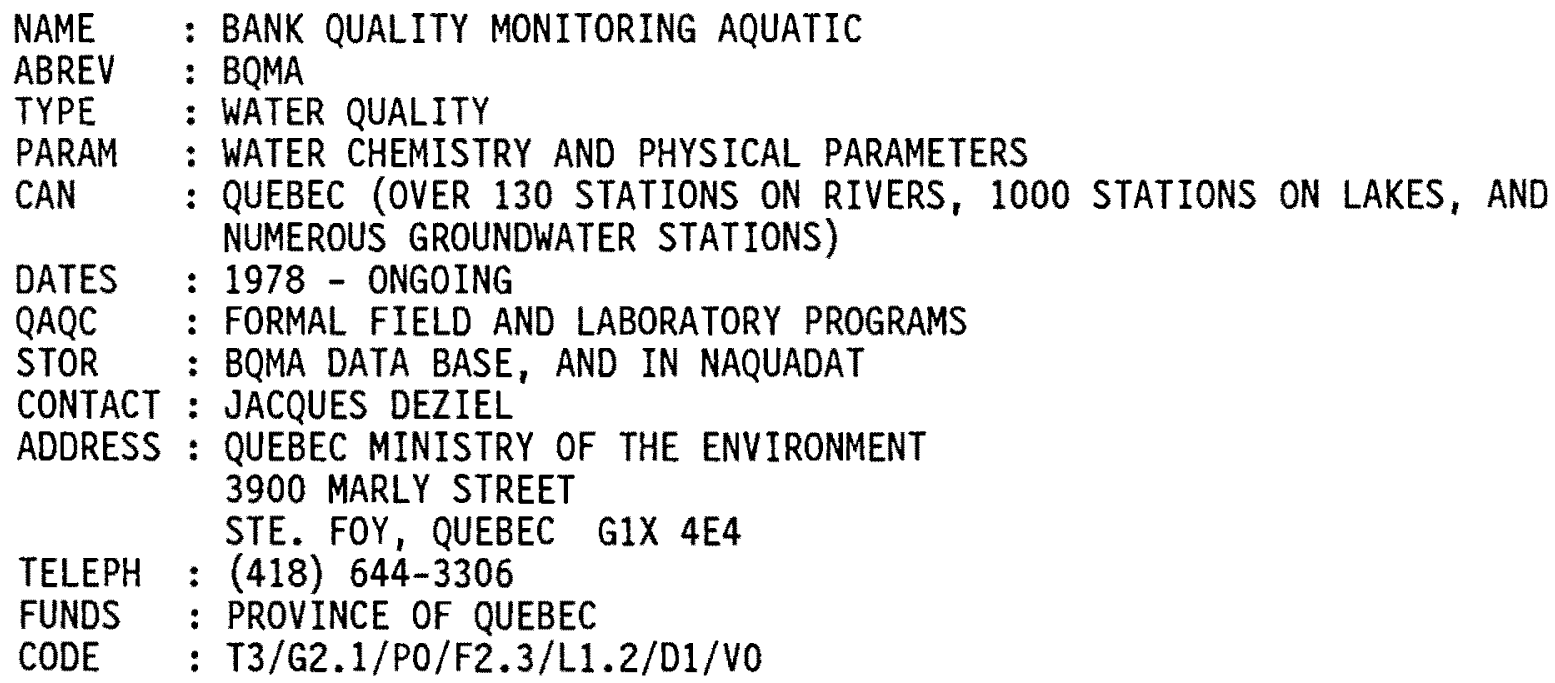




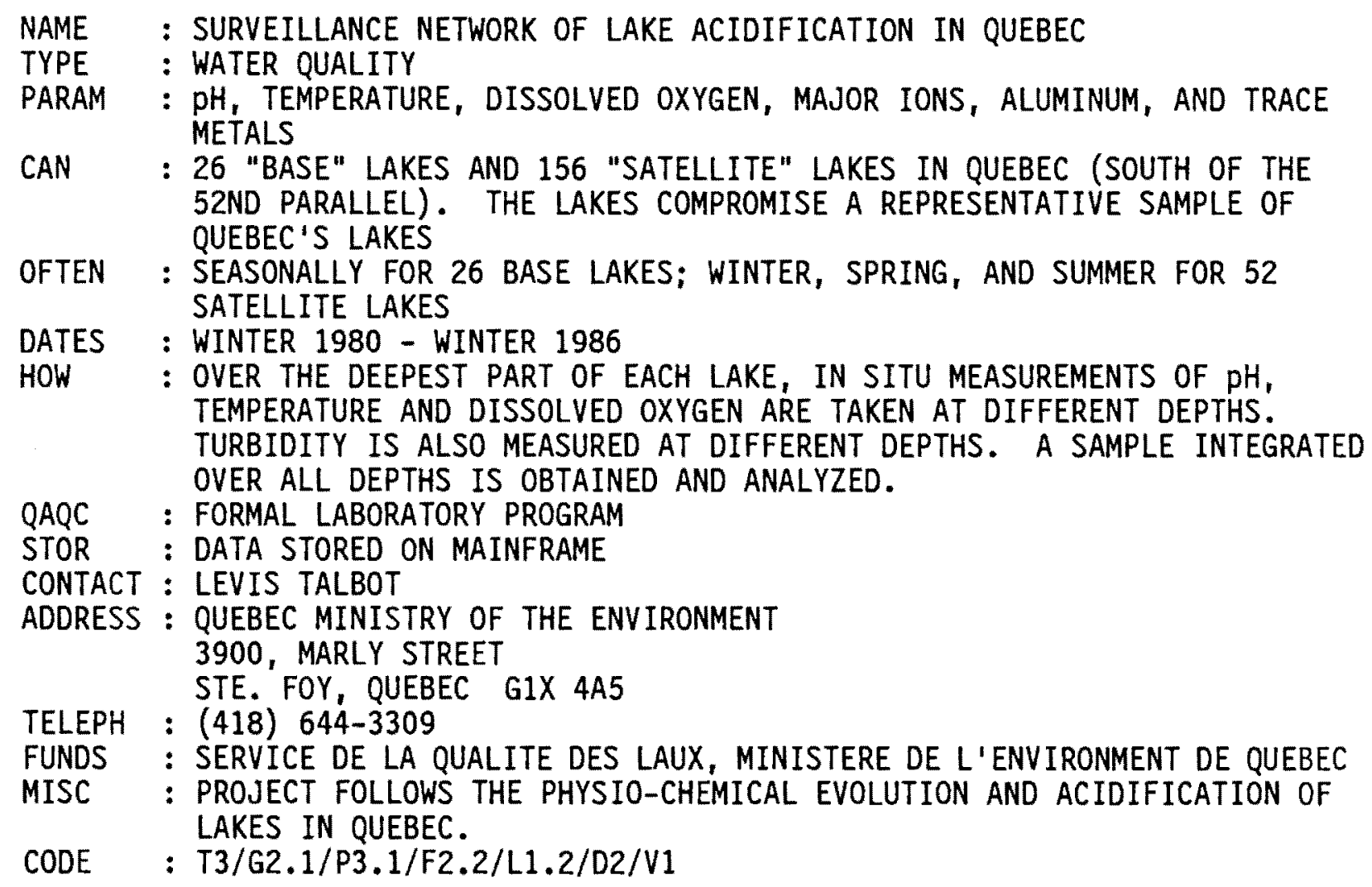




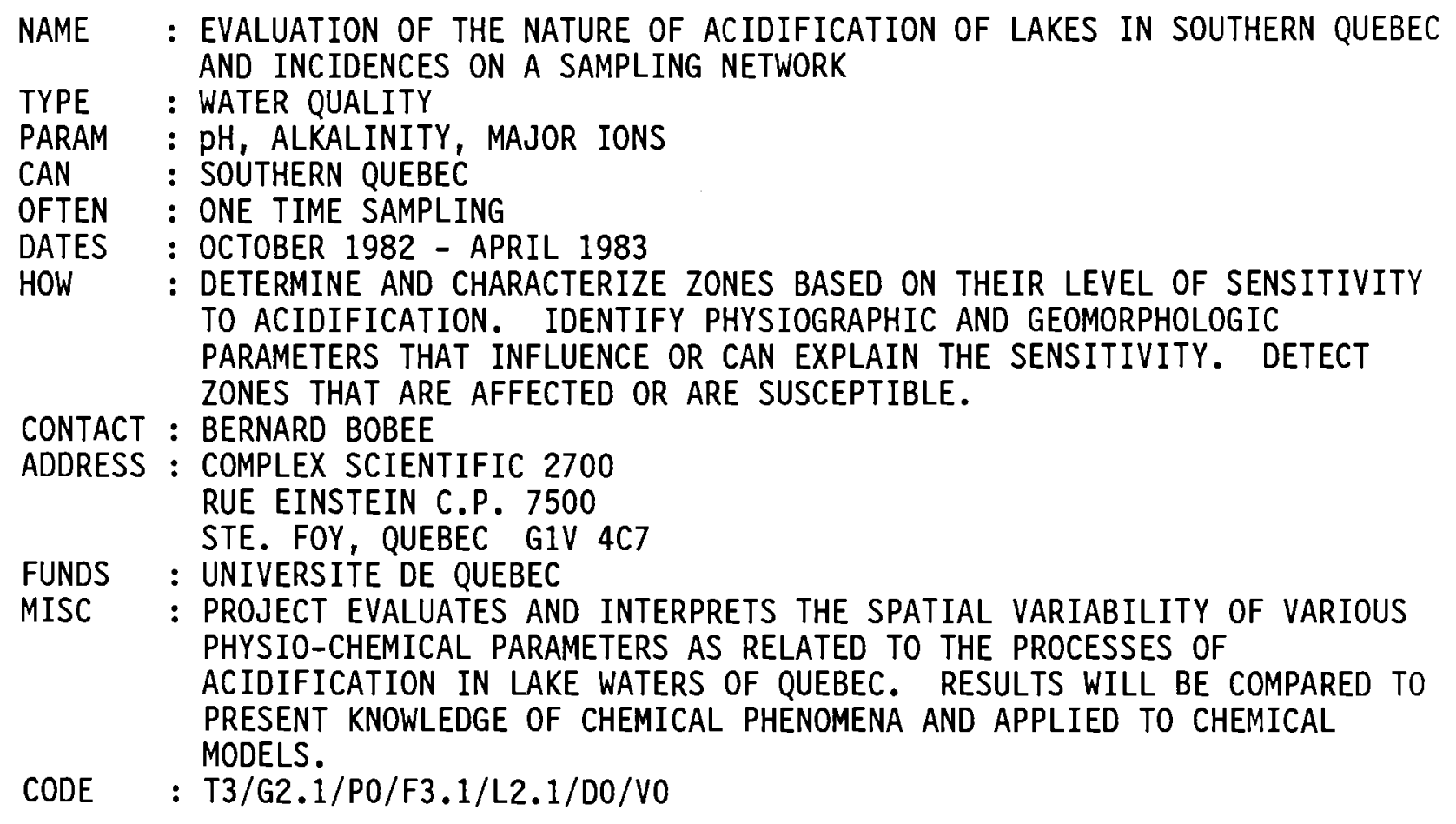




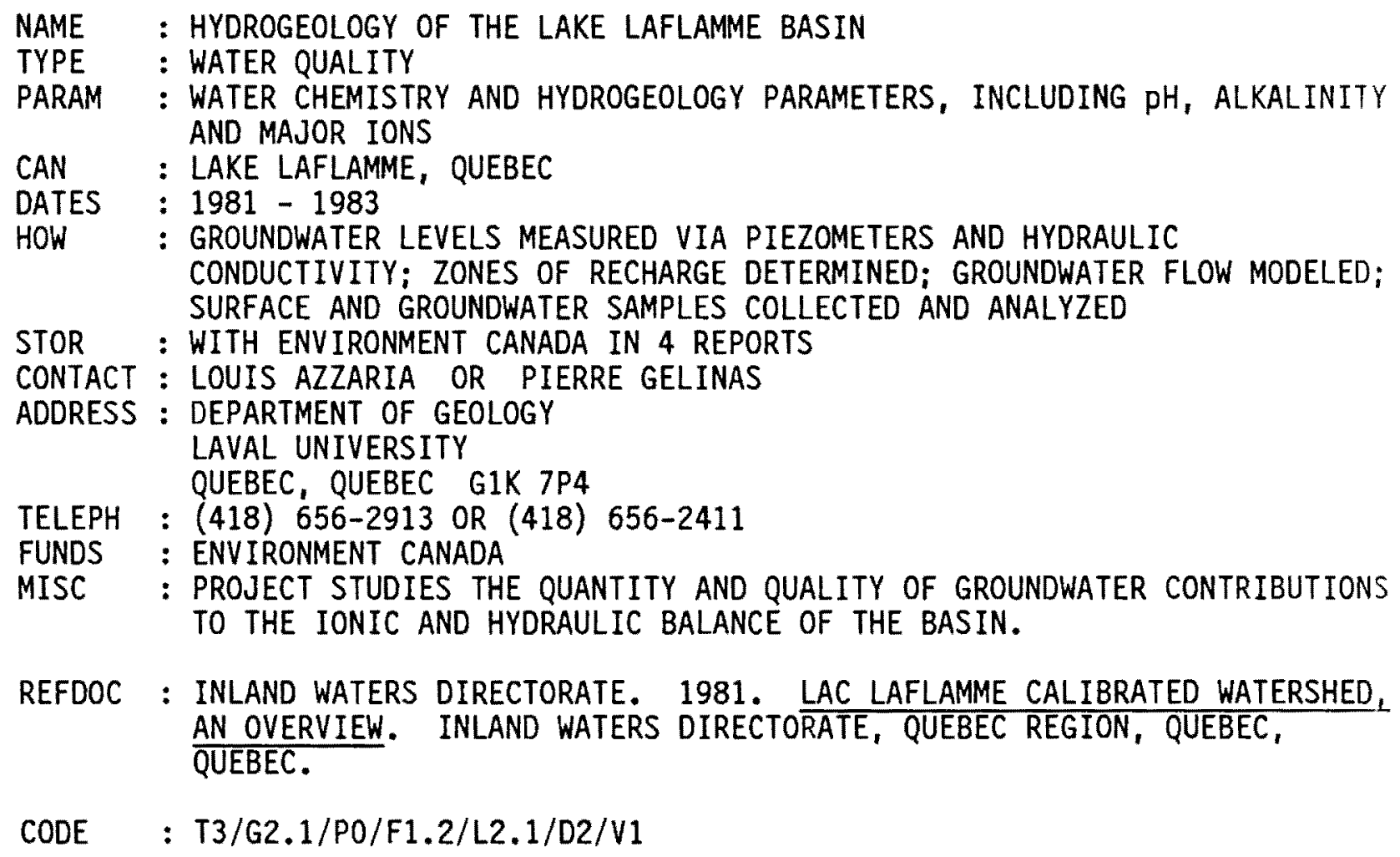

REFDOC : INLAND WATERS DIRECTORATE, 1981. LAC LAFLAMME CALIBRATED WATERSHED, AN OVERVIEW. INLAND WATERS DIRECTORATE, QUEBEC REGION, QUEBEC, QUEBEC.

CODE $\quad: T 3 / G 2.1 / P O / F 1.2 / L 2.1 / D 2 / V 1$

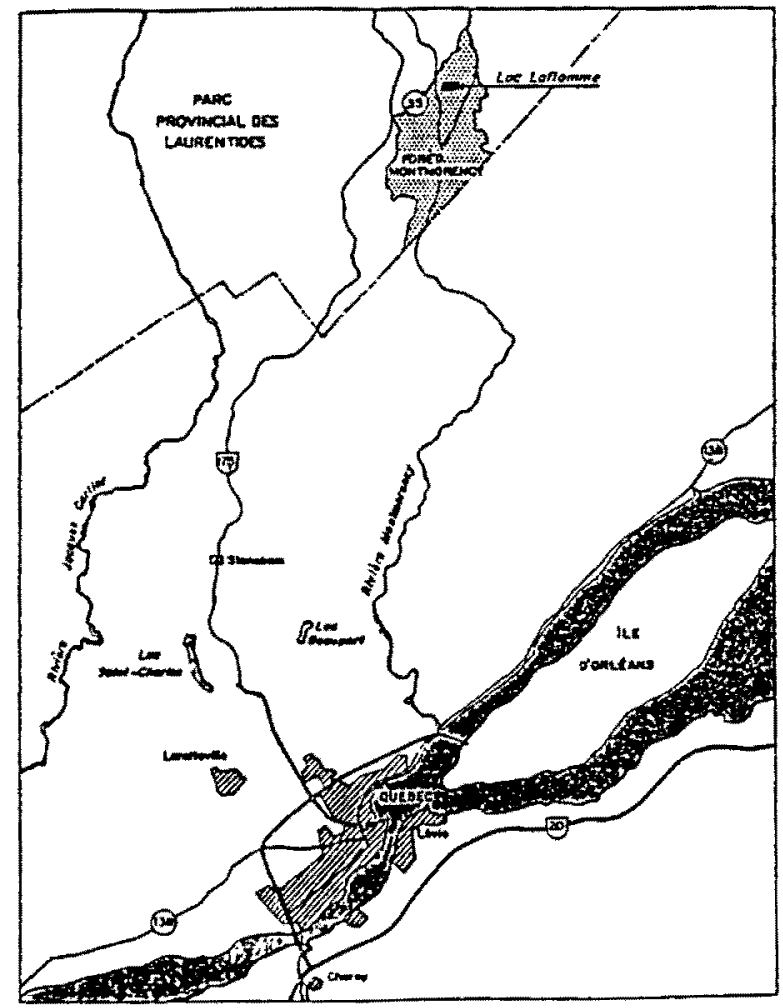

c. 16 

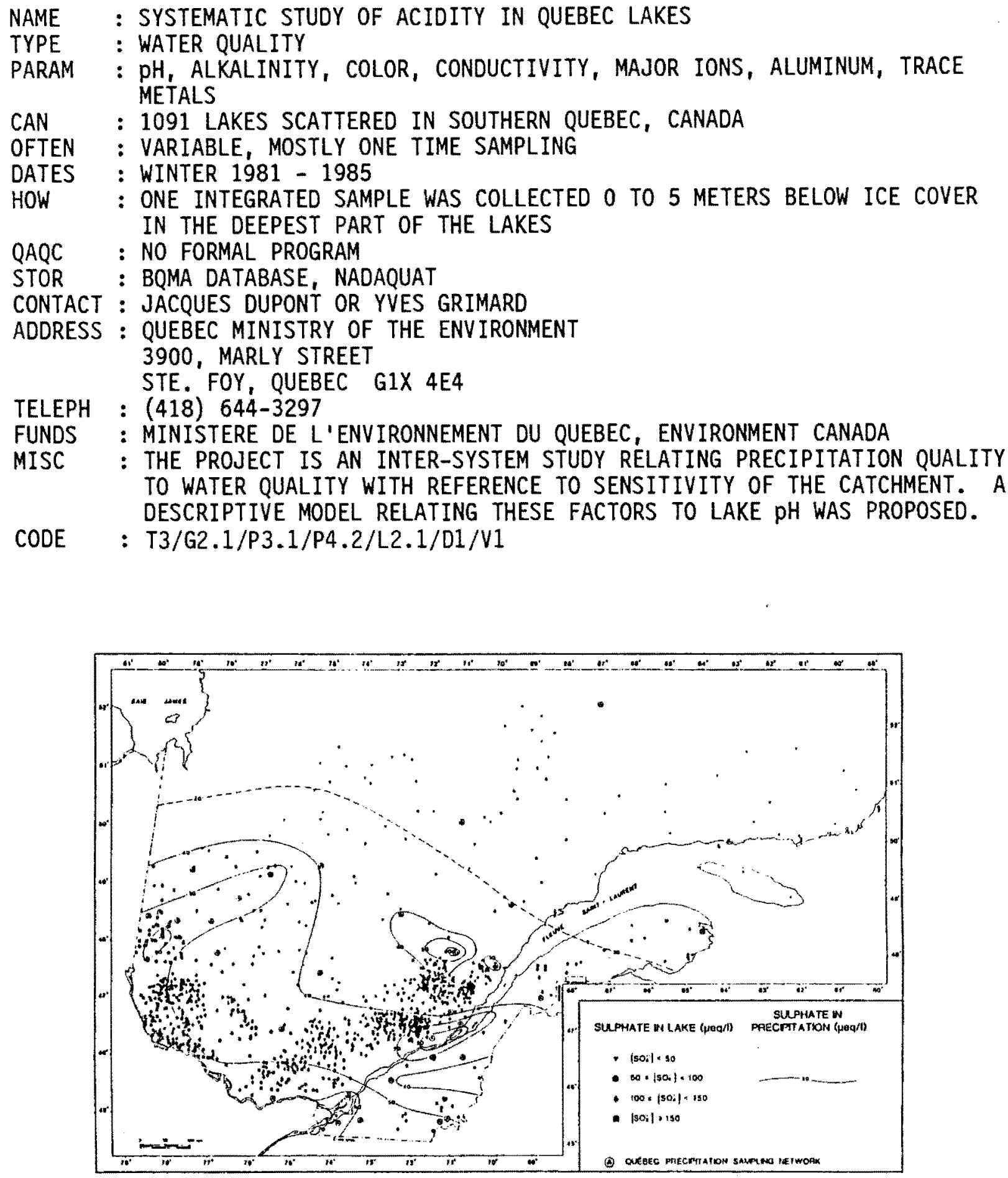

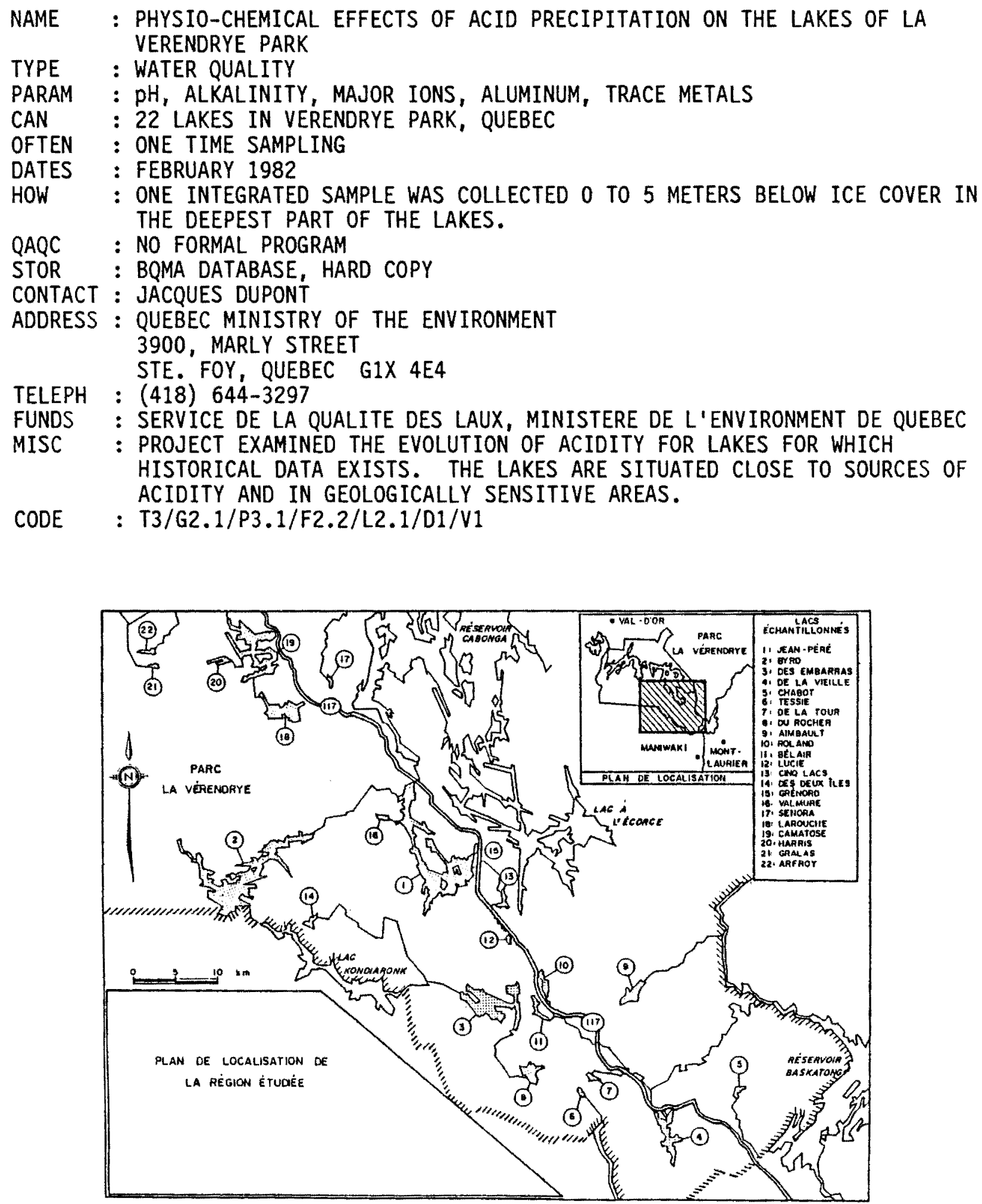
NAME : NATURE AND EXTENT OF ACIDIFICATION IN THE PORTNEUF REGION

TYPE : WATER QUALITY

PARAM : PH, ACIDITY, MAJOR ANIONS AND CATIONS, ALUMINUM

CAN : QUEBEC (PORTNEUF REGION)

OFTEN : ONE TIME SAMPLING

DATES : FEBRUARY 1982

HOW : 100 SMALL HEADWATER LAKES SAMPLED BY HELICOPTER. INTEGRATED SAMPLE

COLLECTED AT THE GEOMETRIC CENTER OF EACH LAKE.

QAQC : NO FORMAL PROGRAM

STOR : BQMA DATABASE

CONTACT : JACQUES DUPONT

ADDRESS : QUEBEC MINISTRY OF THE ENVIRONMENT 3900, MARLY STREET STE. FOY, QUEBEC G1X 4E4

TELEPH : (418) 644-3297

FUNDS : SERVICE DE LA QUALITY DES EAUX, MINISTERE DE L'ENVIRONMENT DU QUEBEC MISC : PROJECT DETERMINES THE AMOUNT OF ACIDIFICATION IN LAKES LOCATED IN ZONES CLASSIFIED AS SUSCEPTABLE

CODE : T3/G2.1/P0/F2.2/L2.1/D1/V1

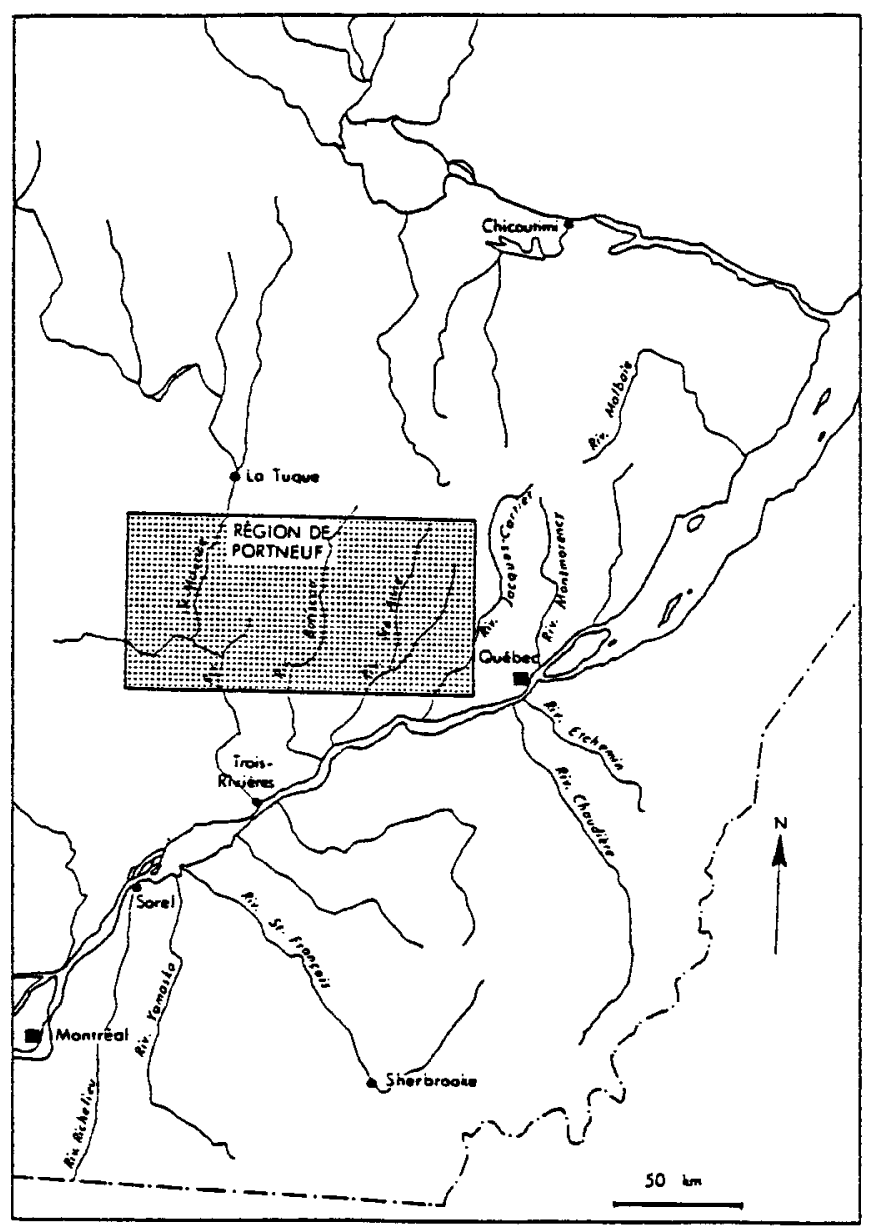



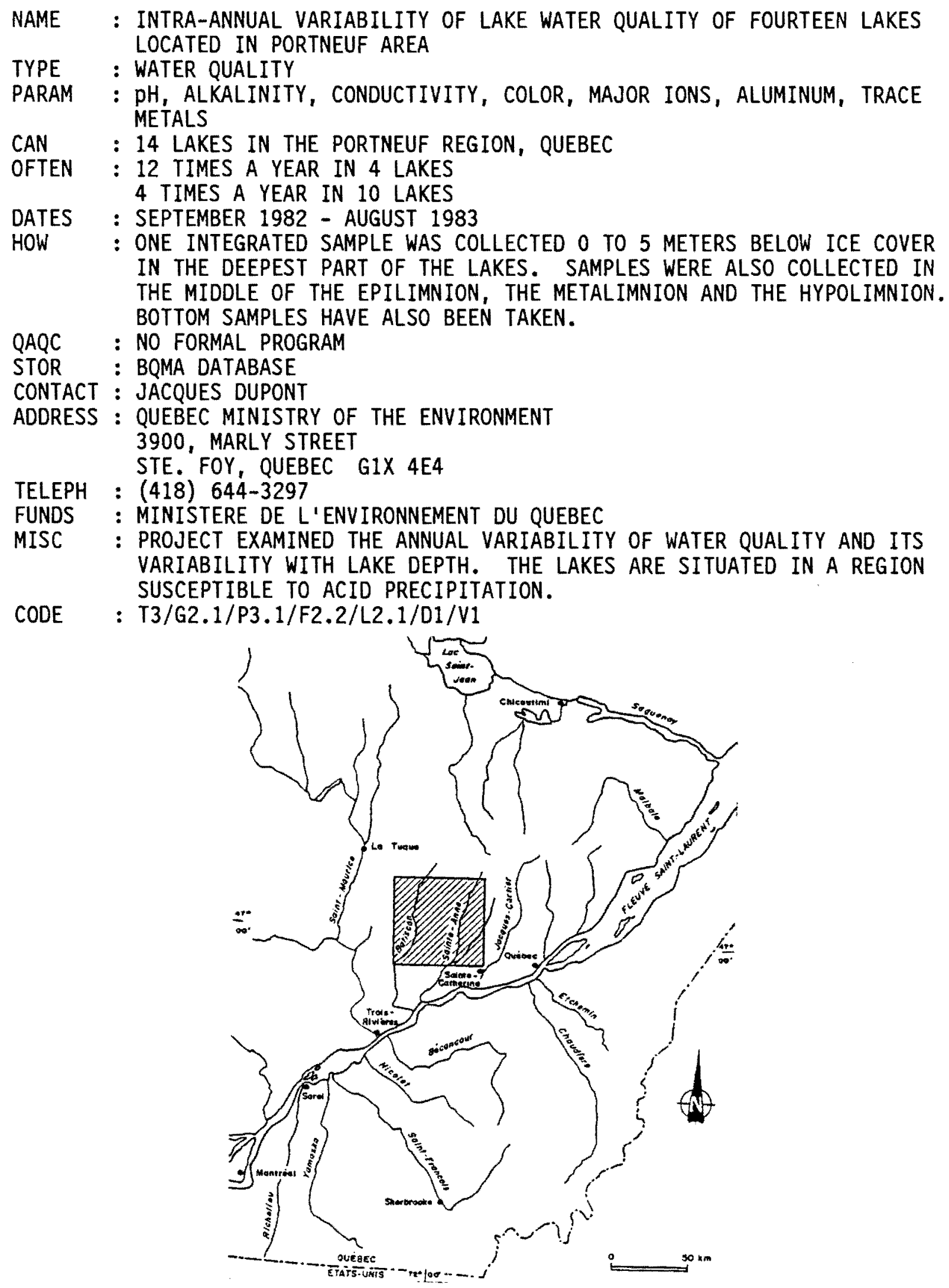
Map of the 14 lakes in the Portneuf Region, Quebec studied in "Intra-Annual Variability of Lake Water Quality of Fourteen Lakes Located in Portneuf Area"

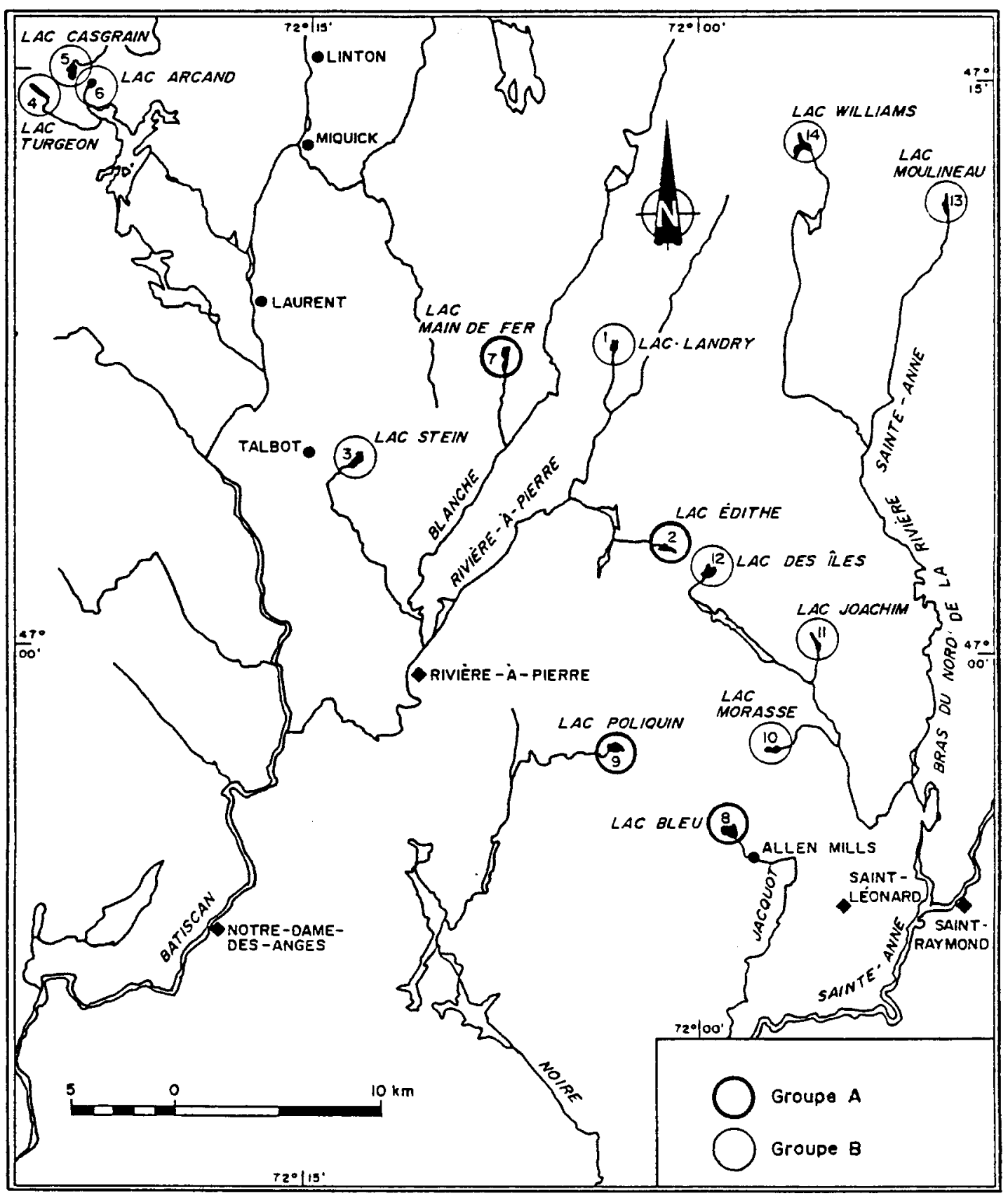



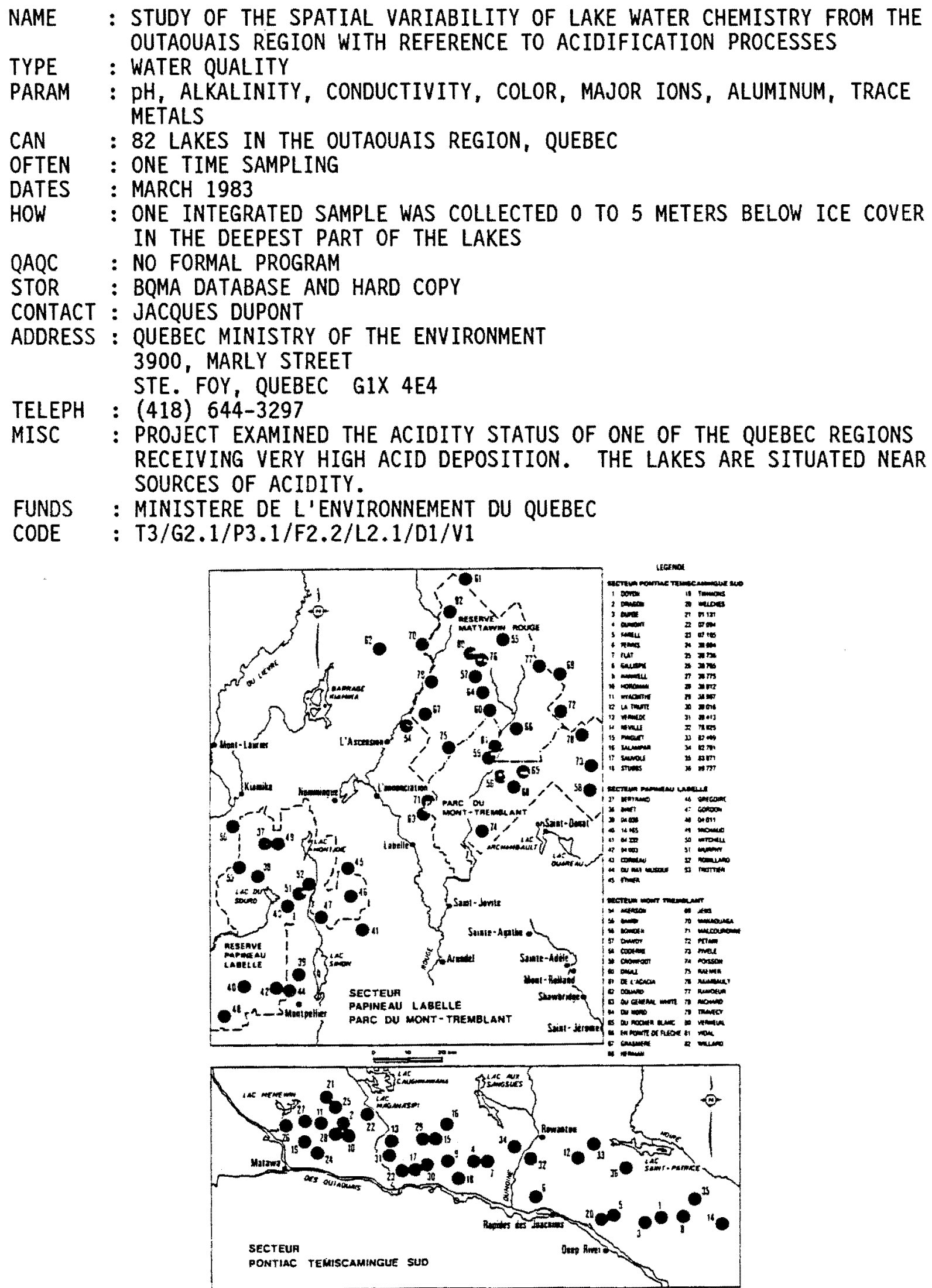


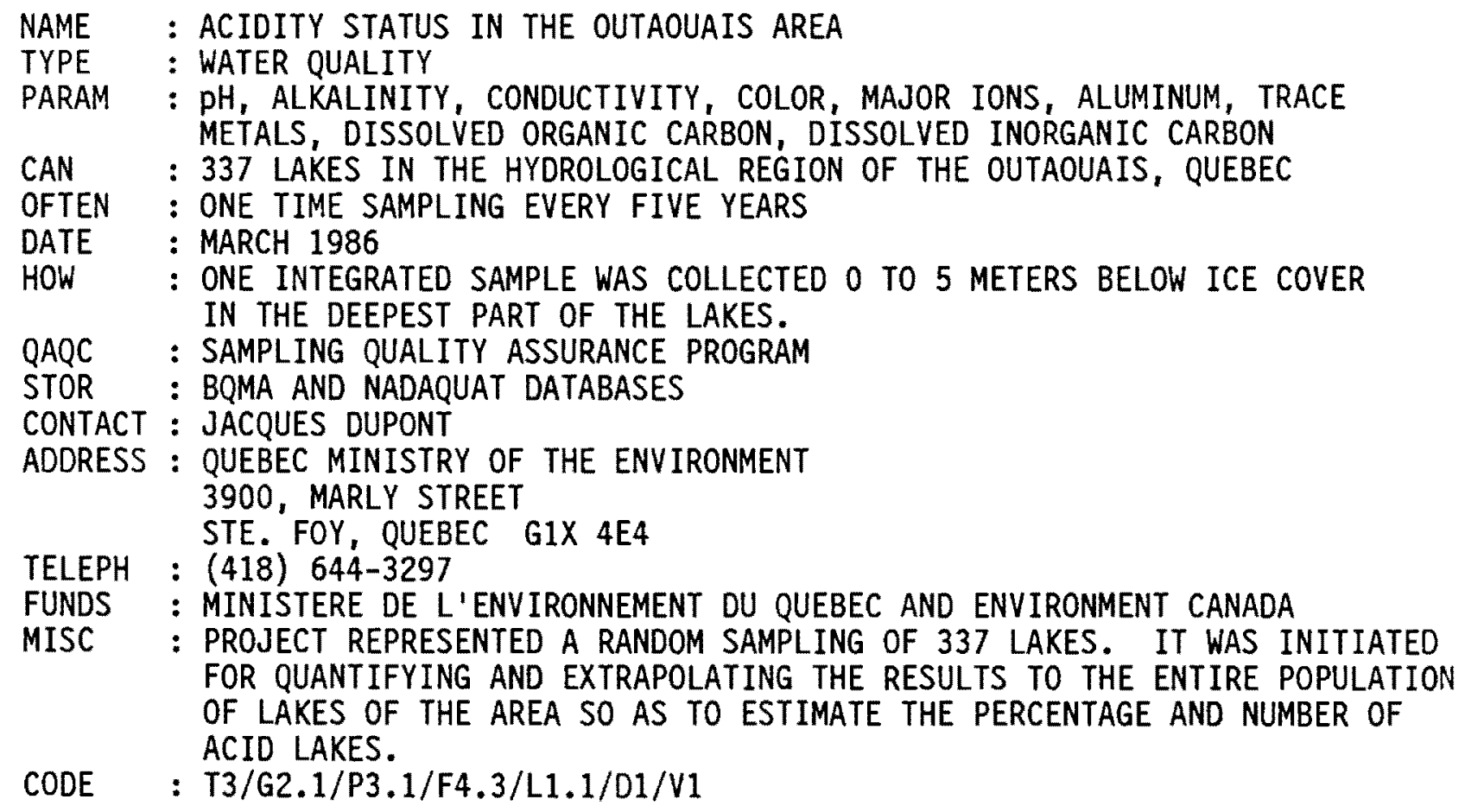


NAME : NATURE AND EXTENT OF ACIDIFICATION IN THE ROUYN-NORANDA REGION

TYPE : WATER QUALITY

PARAM : $\mathrm{PH}$, ACIDITY, MAJOR CATIONS AND ANIONS, ALUMINUM

CAN : QUEBEC (NORANDA REGION)

OFTEN : ONE TIME SAMPLING

DATES : FEBRUARY 1982

HOW : 64 SMALL HEADWATER LAKES SAMPLED BY FLOAT PLANE. INTEGRATED SAMPLE COLLECTED AT THE GEOMETRIC CENTER OF EACH LAKE AND JUST UNDER THE ICE COVER.

QAQC : NO FORMAL PROGRAM

STOR : BQMA DATABASE, HARD COPY

CONTACT : JACQUES DUPONT

ADDRESS : QUEBEC MINISTRY OF THE ENVIRONMENT

3900, MARLY STREET

STE. FOY, QUEBEC G1X 4E4

TELEPH : (418) 644-3297

FUNDS : SERVICE DE LA QUALITE DES LAUX, MINISTERE DE L'ENVIRONMENT DU QUEBEC

MISC : PROJECT EXAMINES THE CONTRIBUTION OF MINE EMISSIONS IN NORANDA TO THE ACIDIFICATION OF LAKES IN THE REGION.

CODE : T3/G2.1/PO/F2.1/L2.1/D1/V1

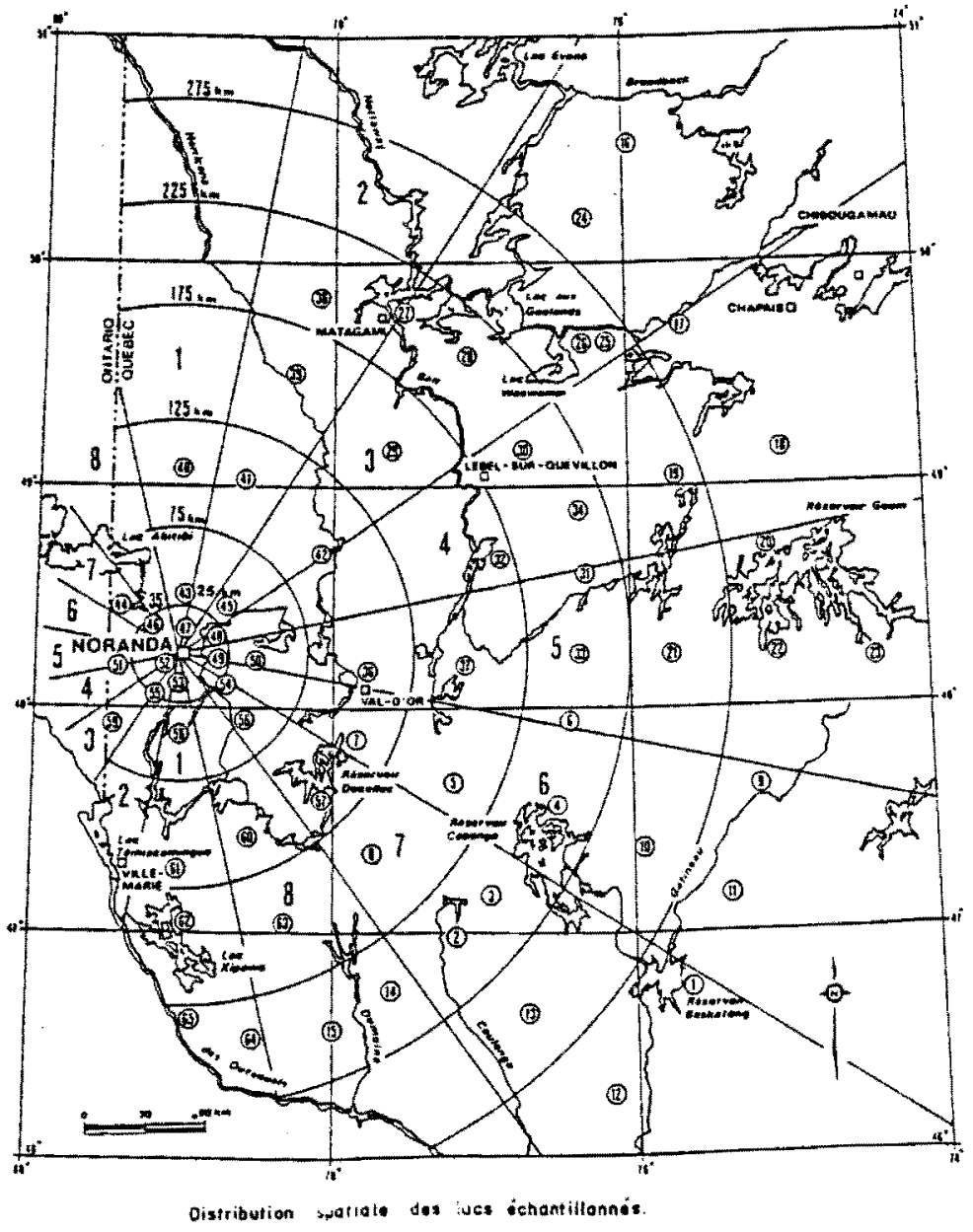



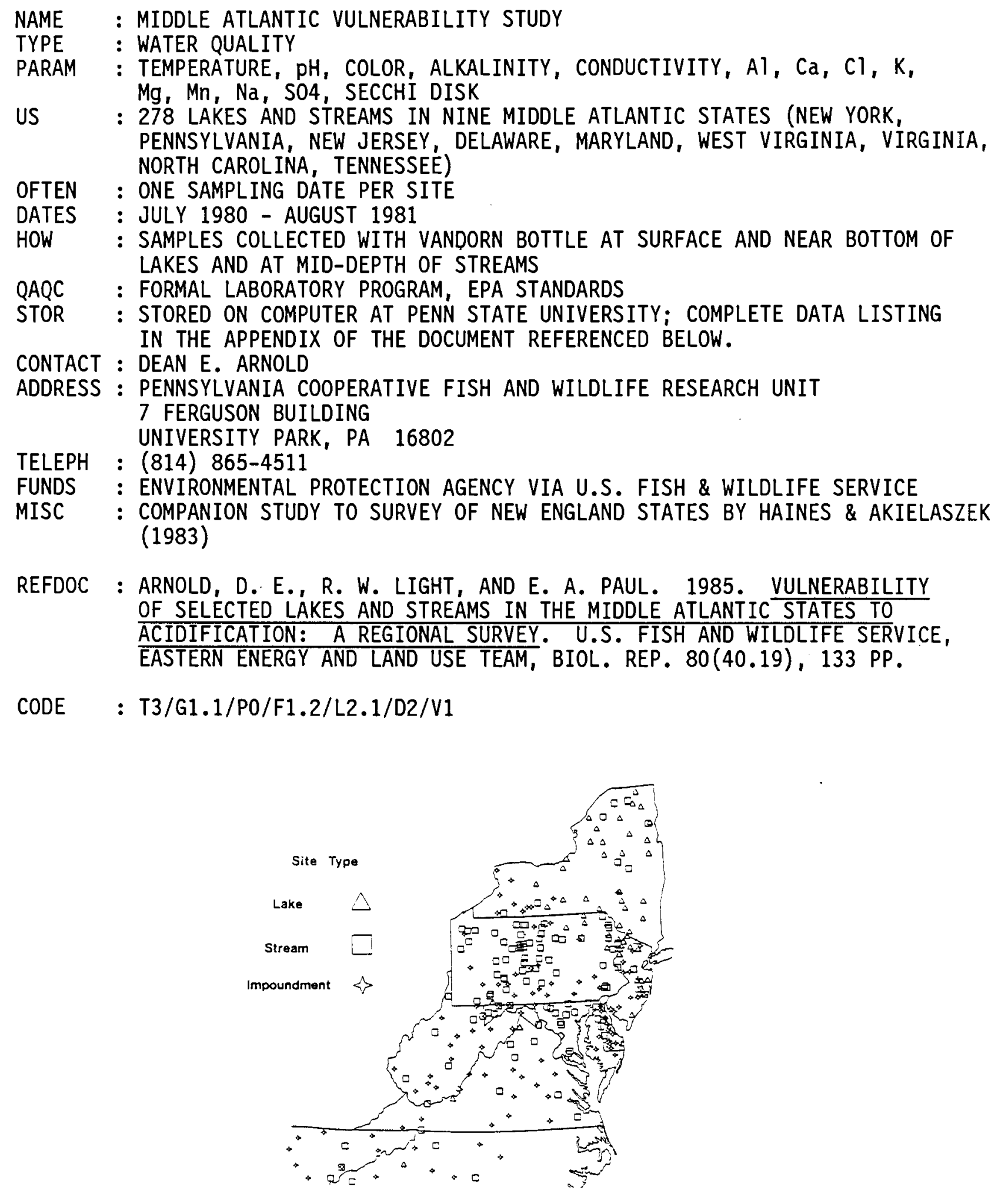

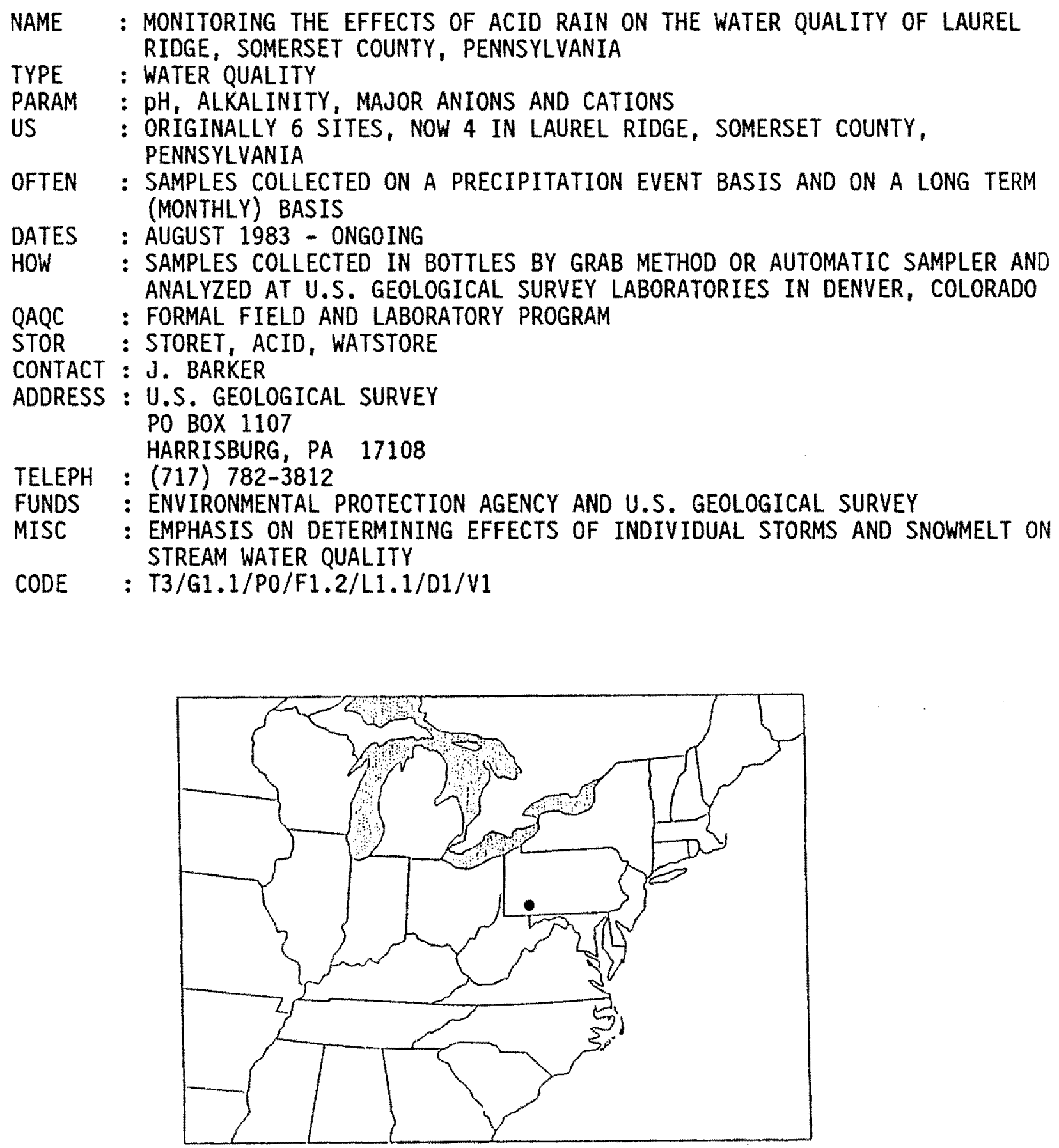


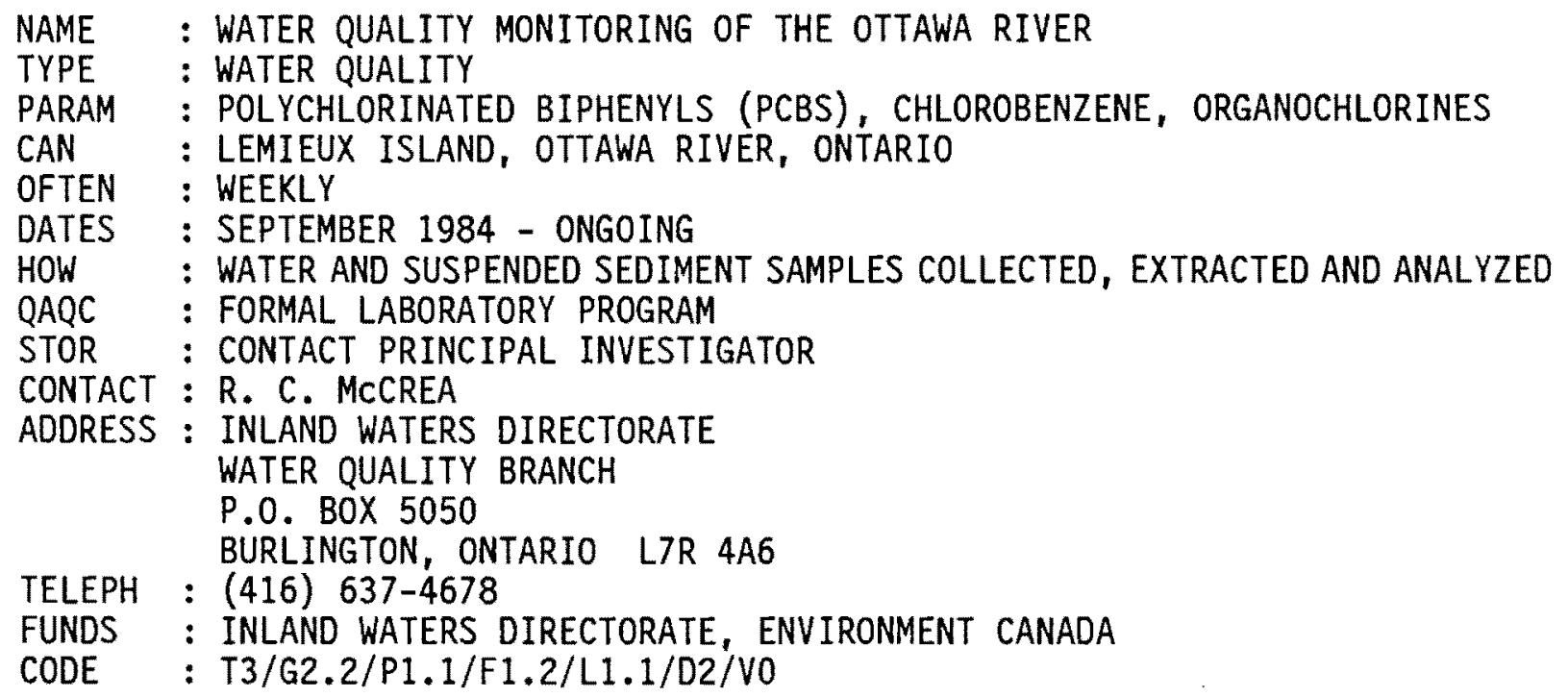



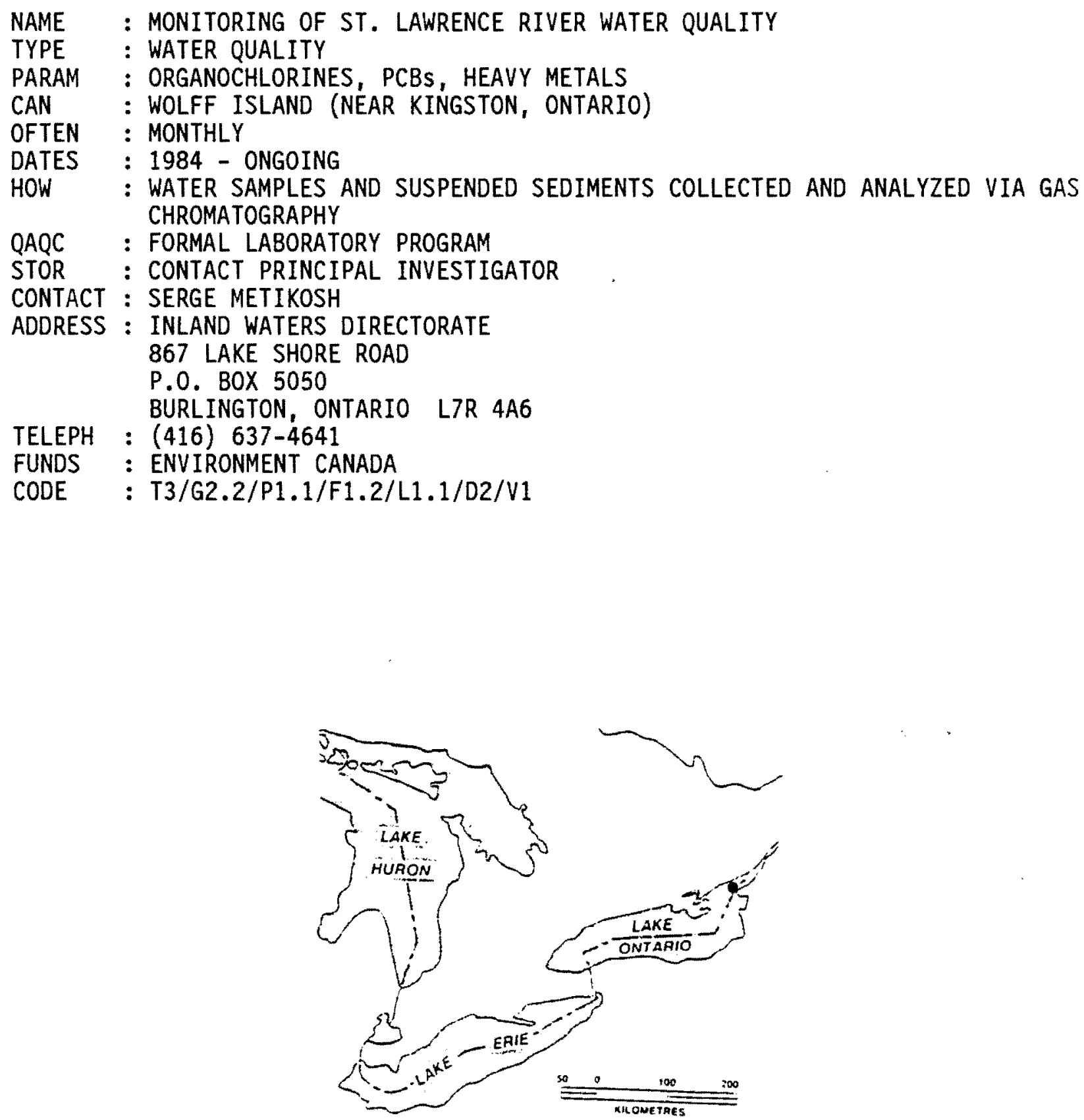

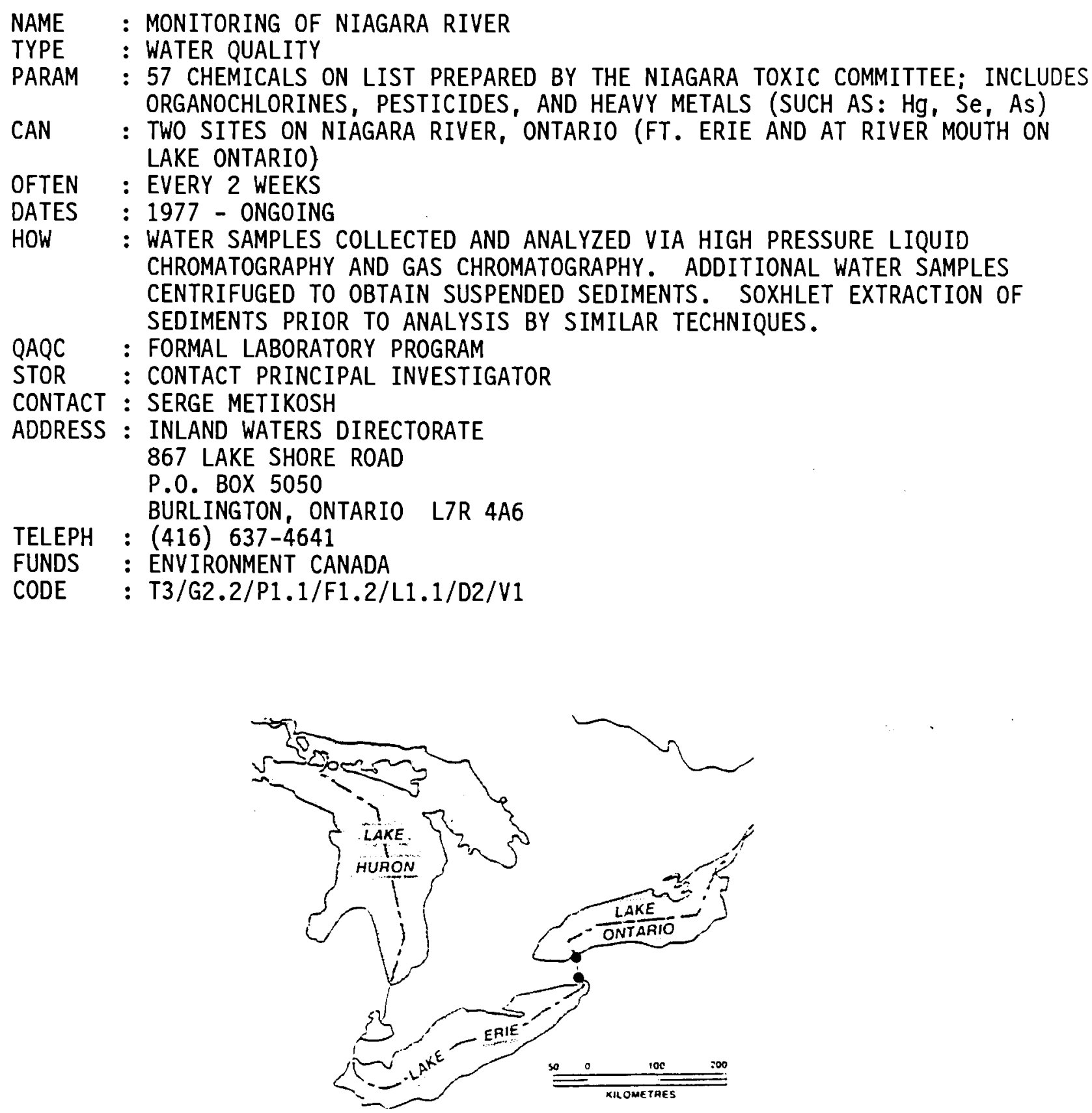


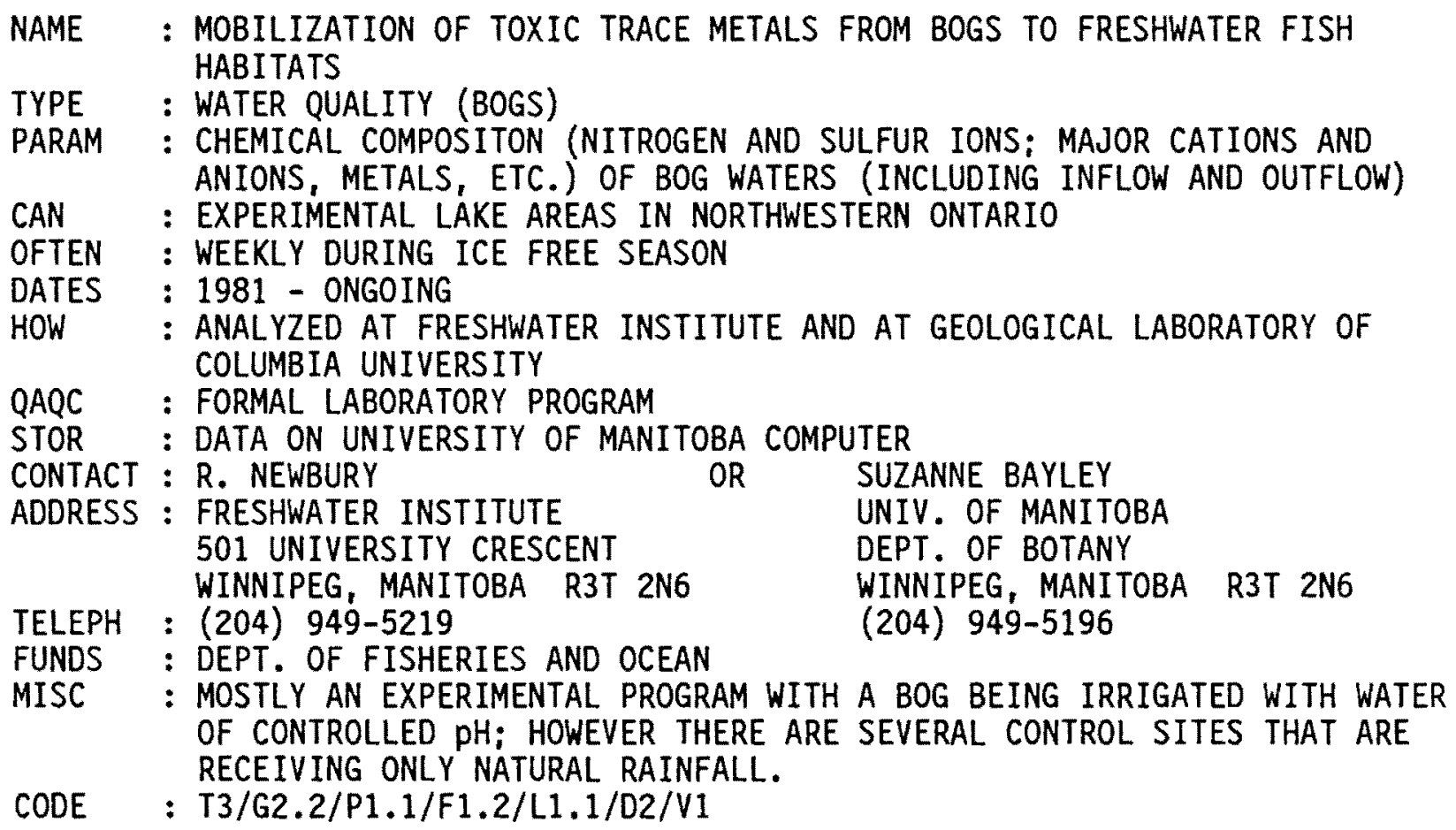




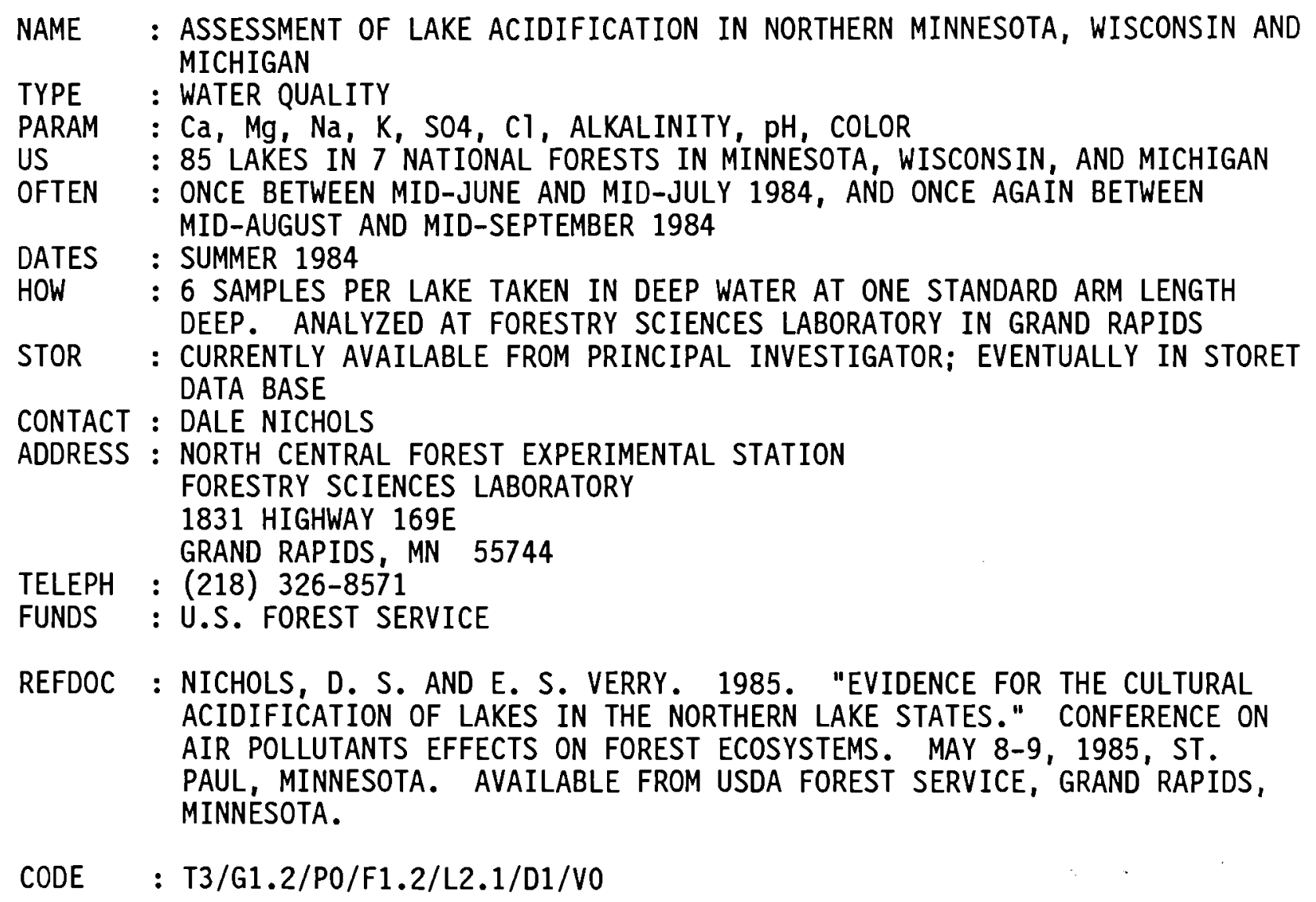




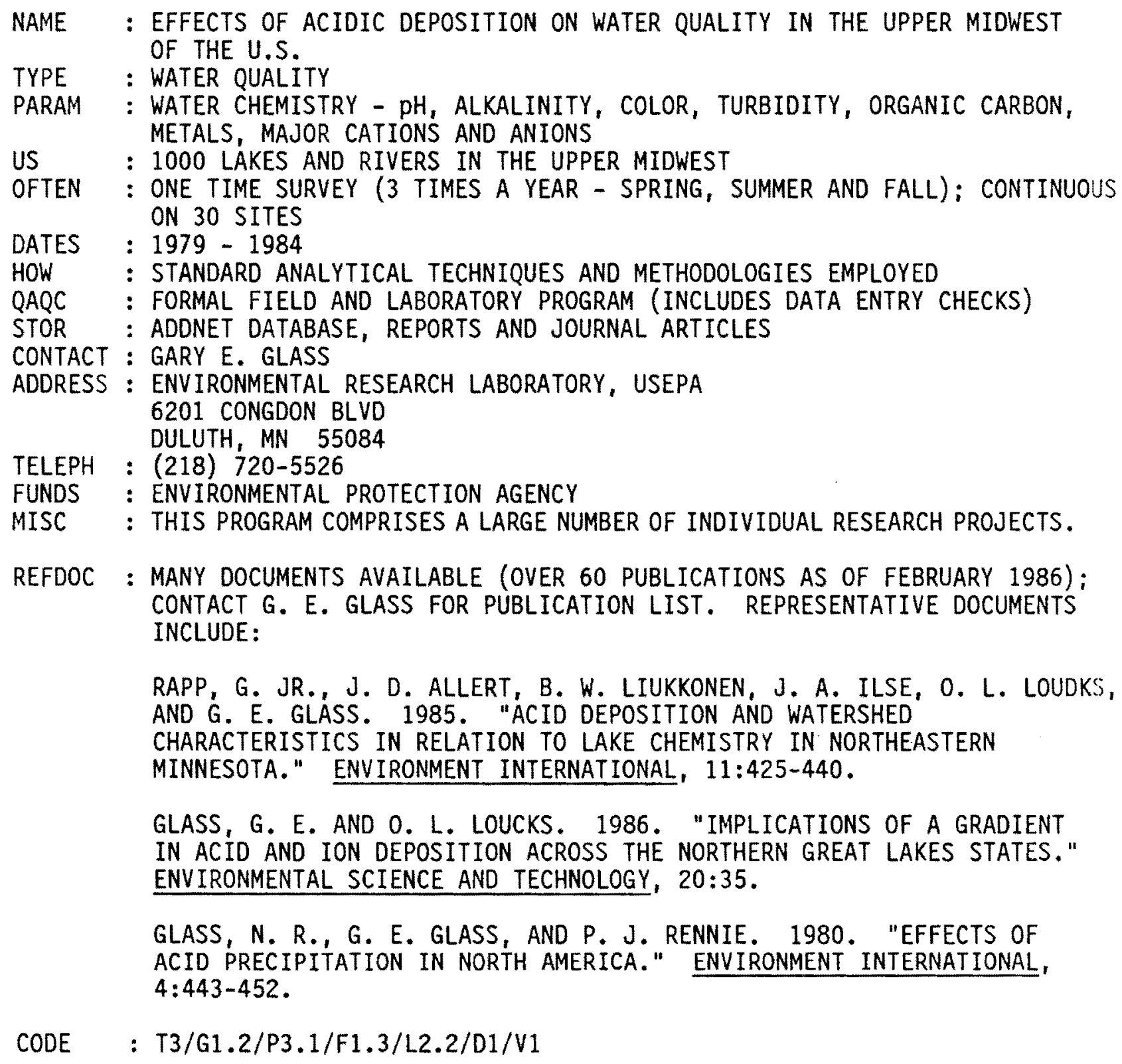


Map of Monitoring Locations for "Effects of Acidic Deposition on Water Quality in the Upper Midwest of the U.S."

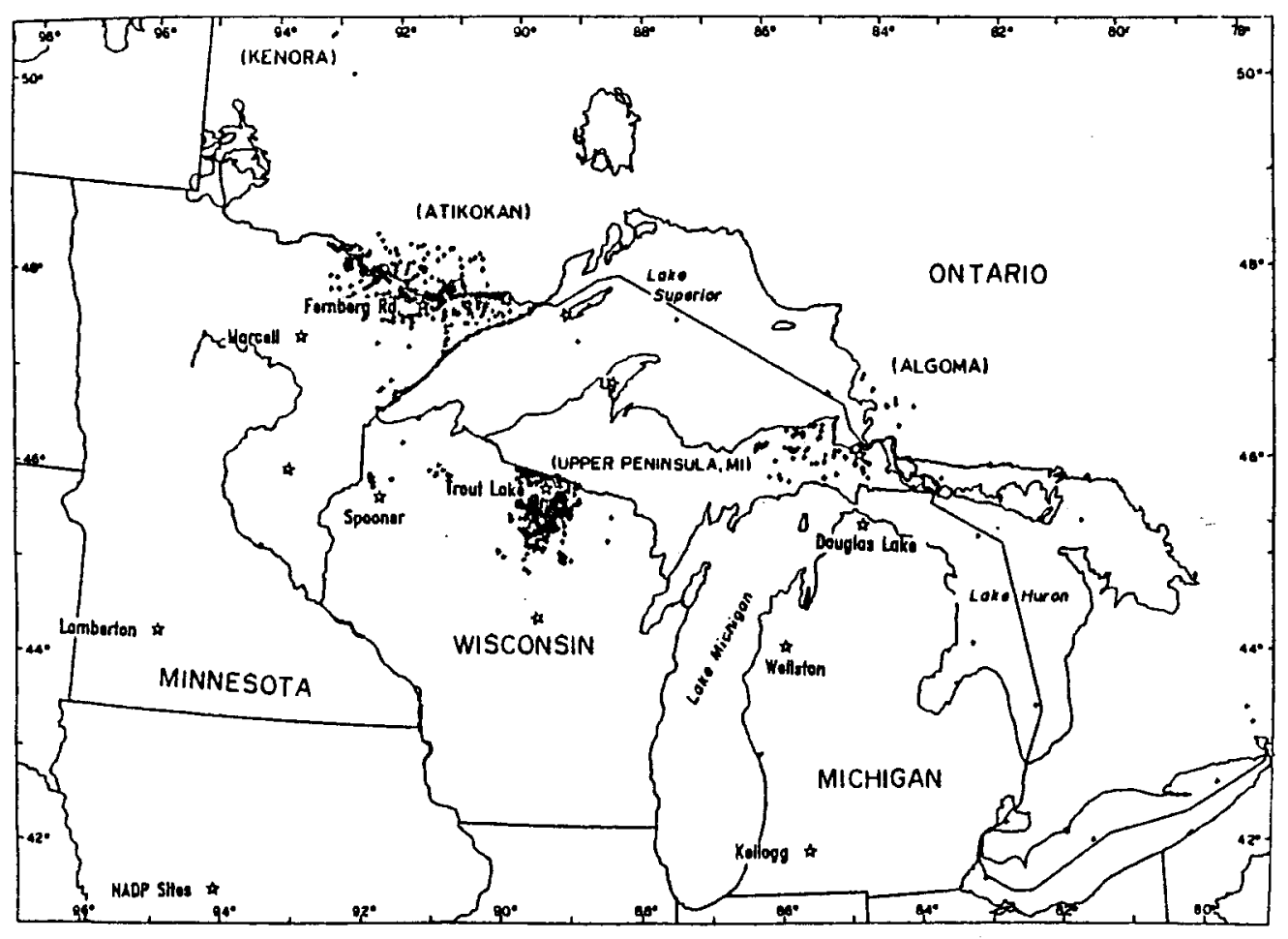




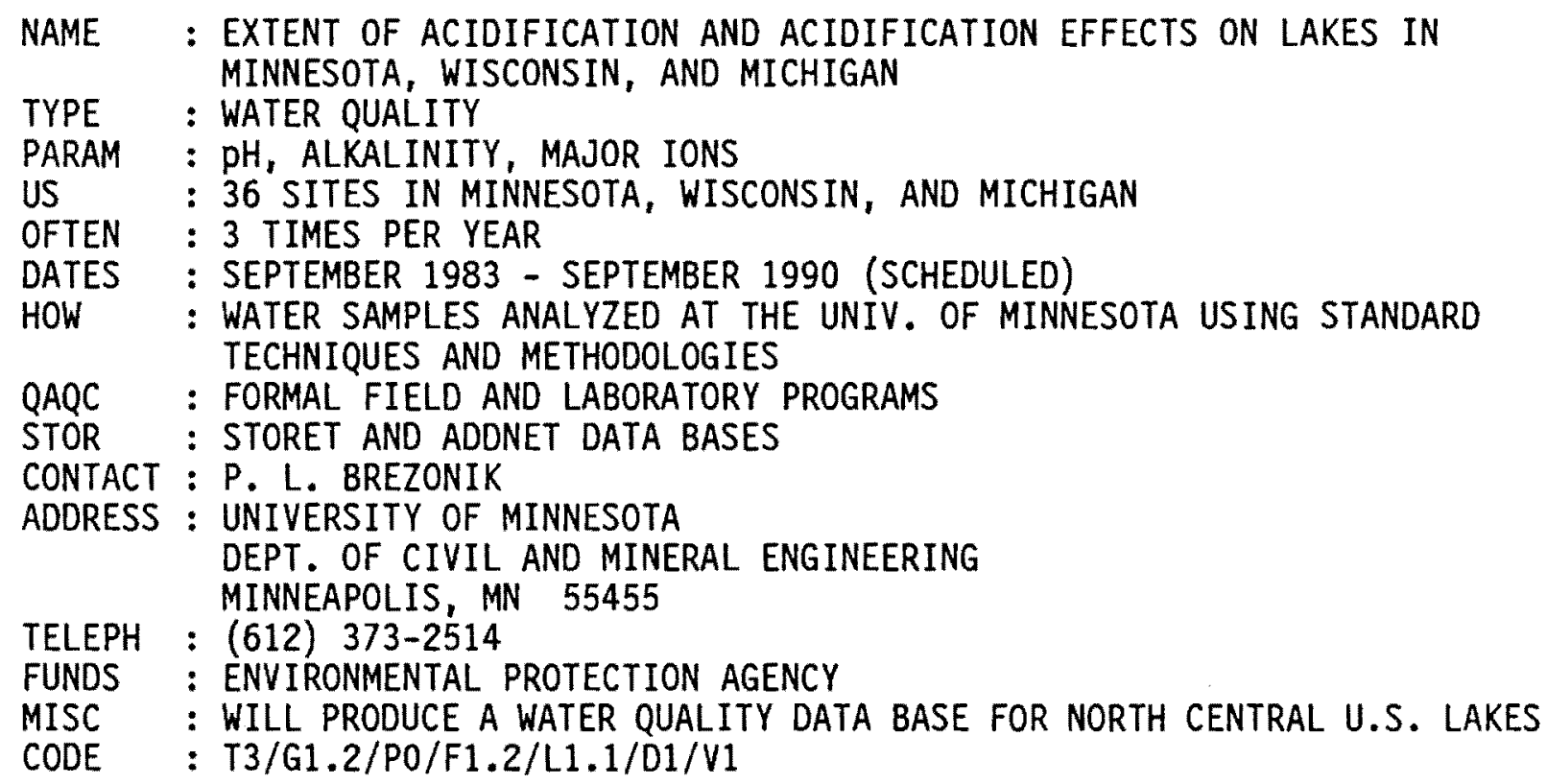




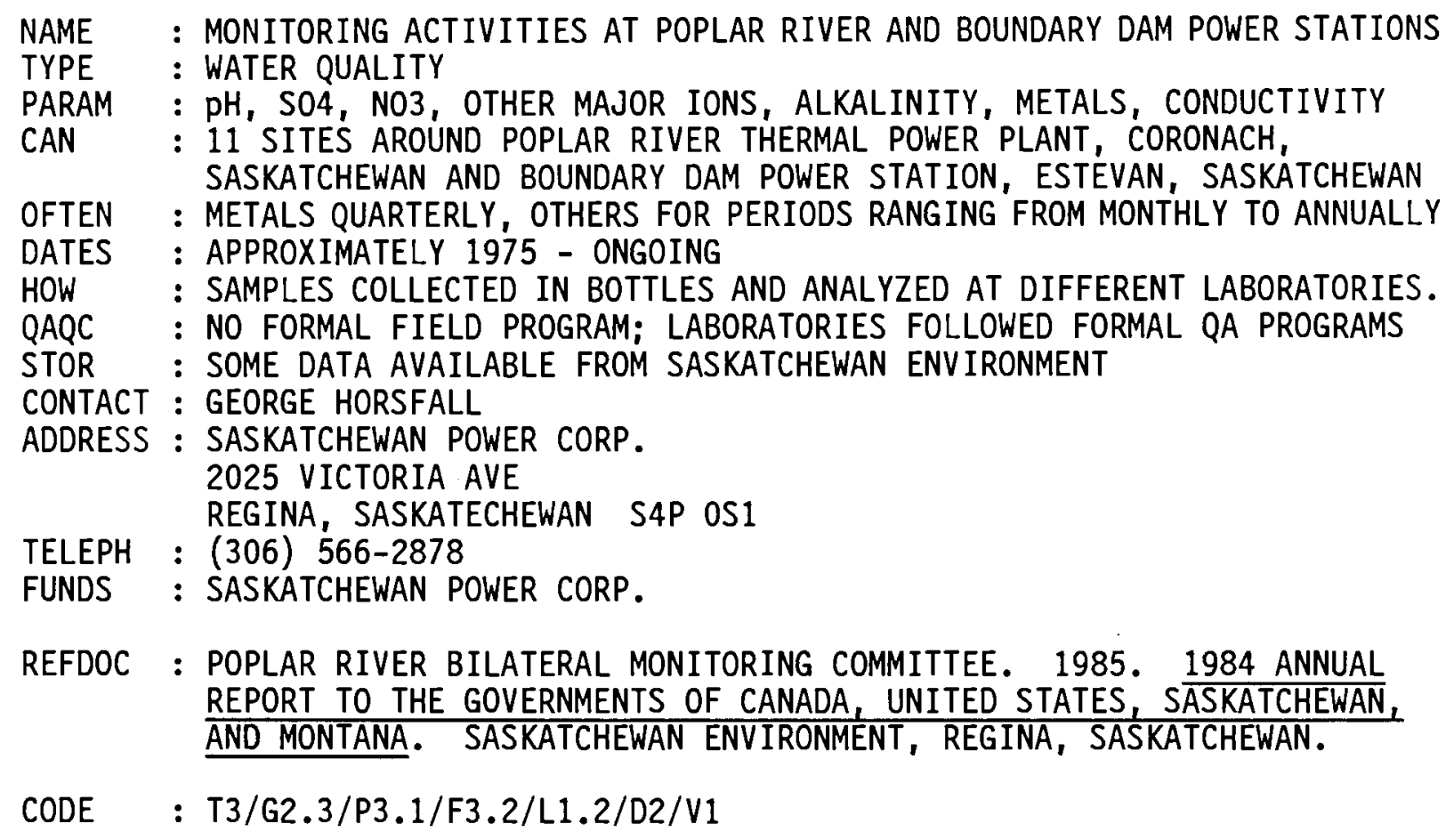




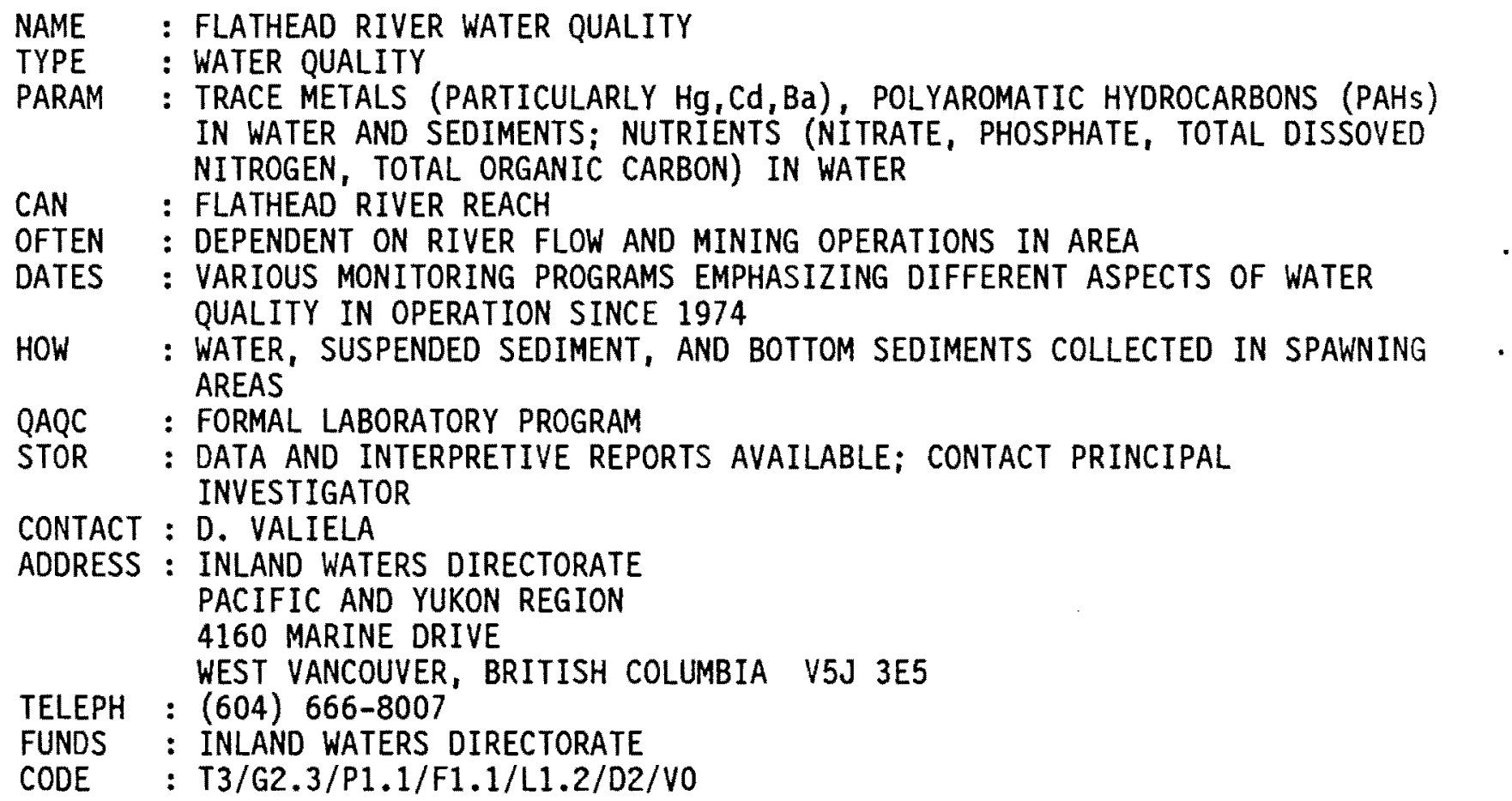




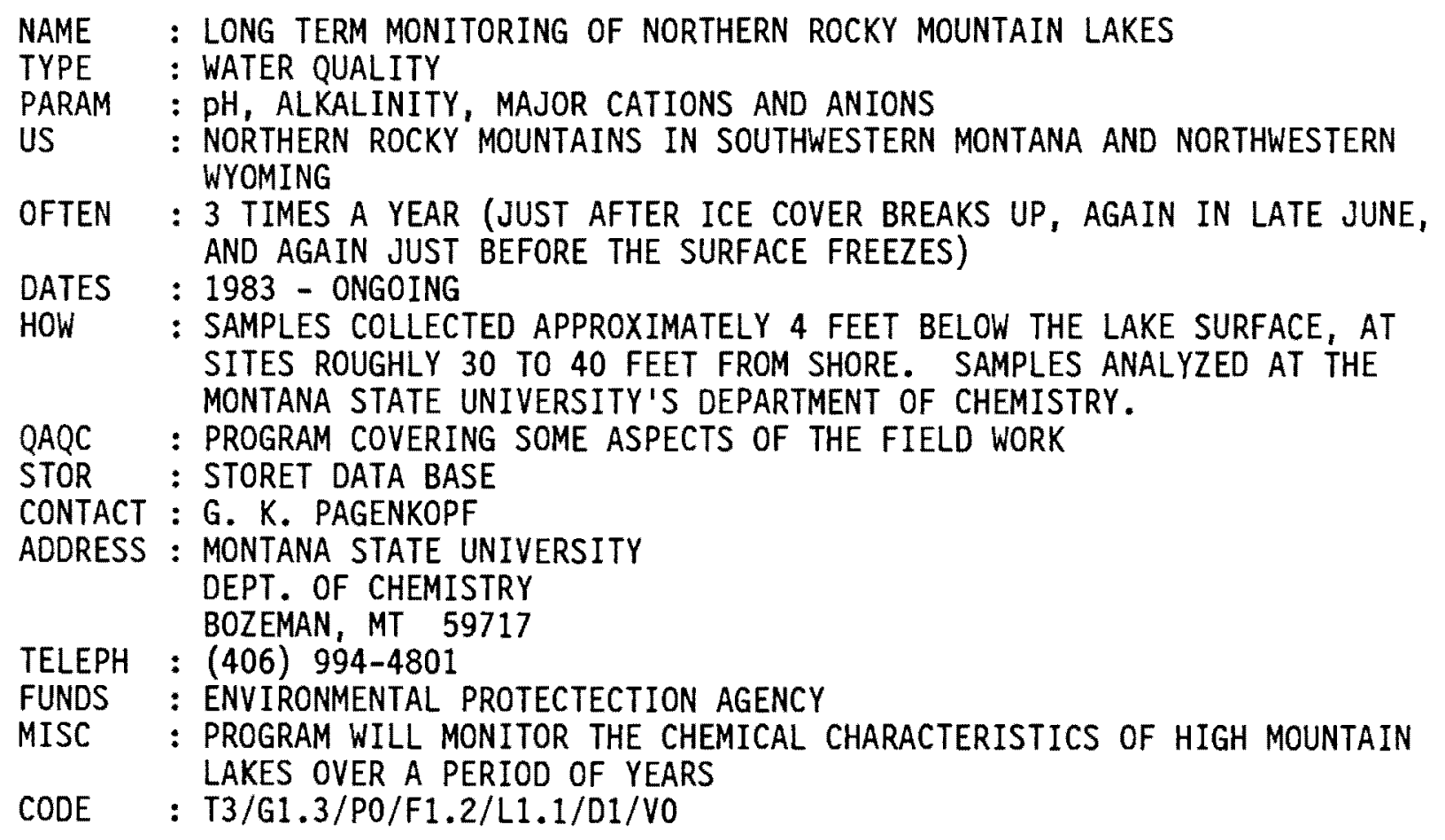




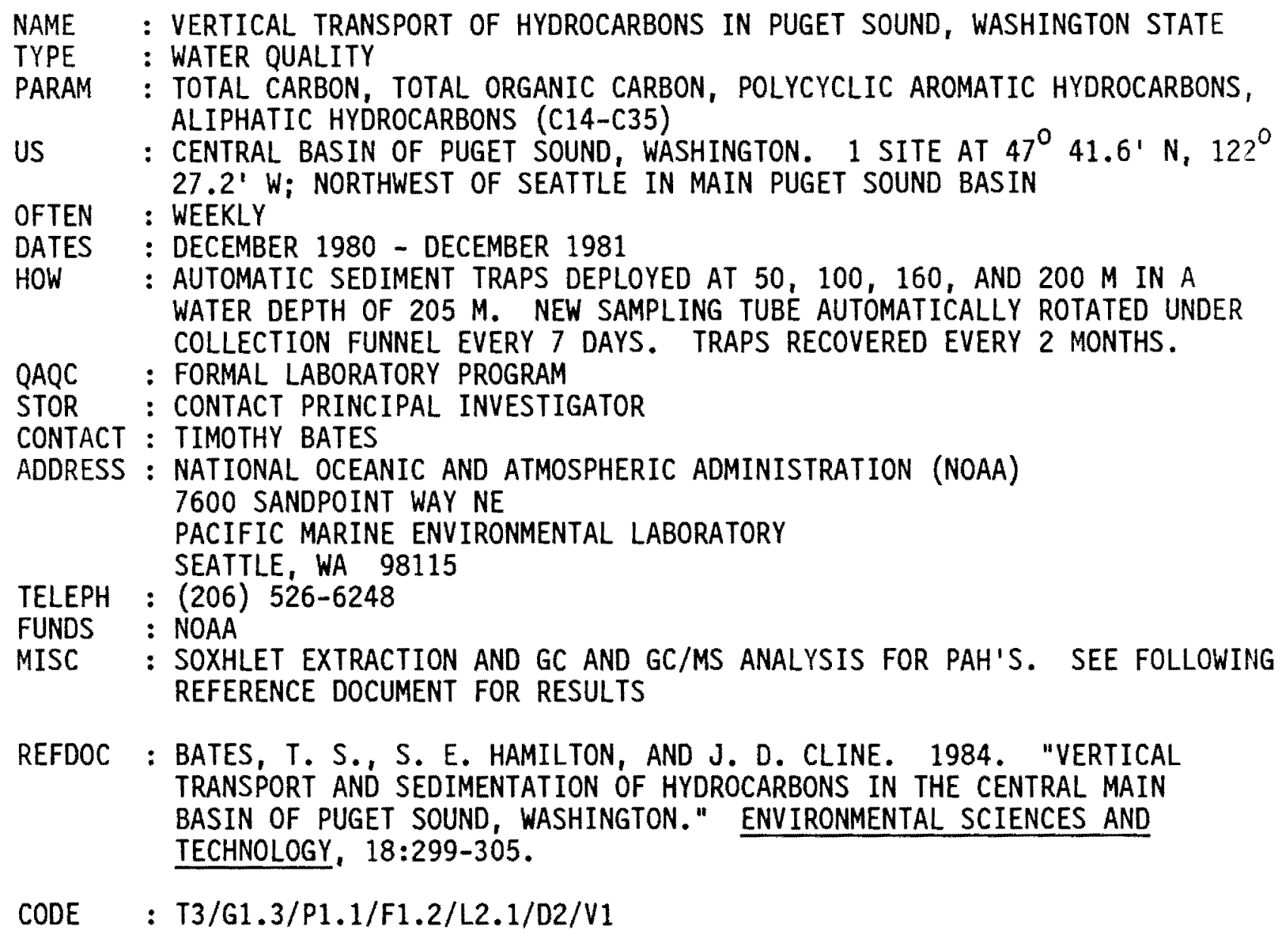


APPENDIX D

INVENTORY OF TRANSBOUNDARY REGION PRECIPITATION CHEMISTRY PROJECTS 


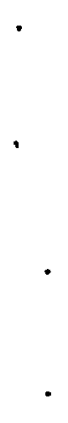



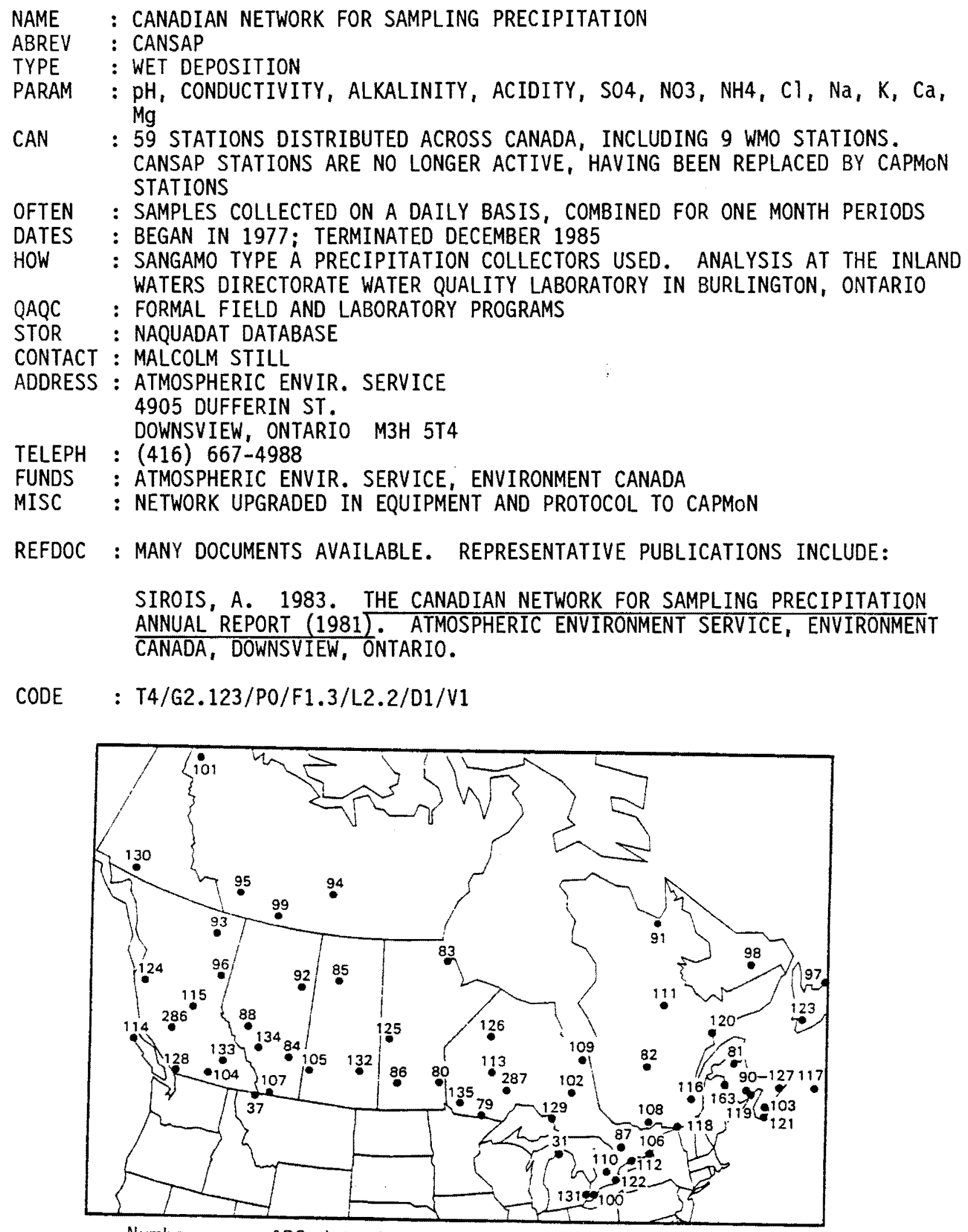

Numbers are ADS data base site identification codes 

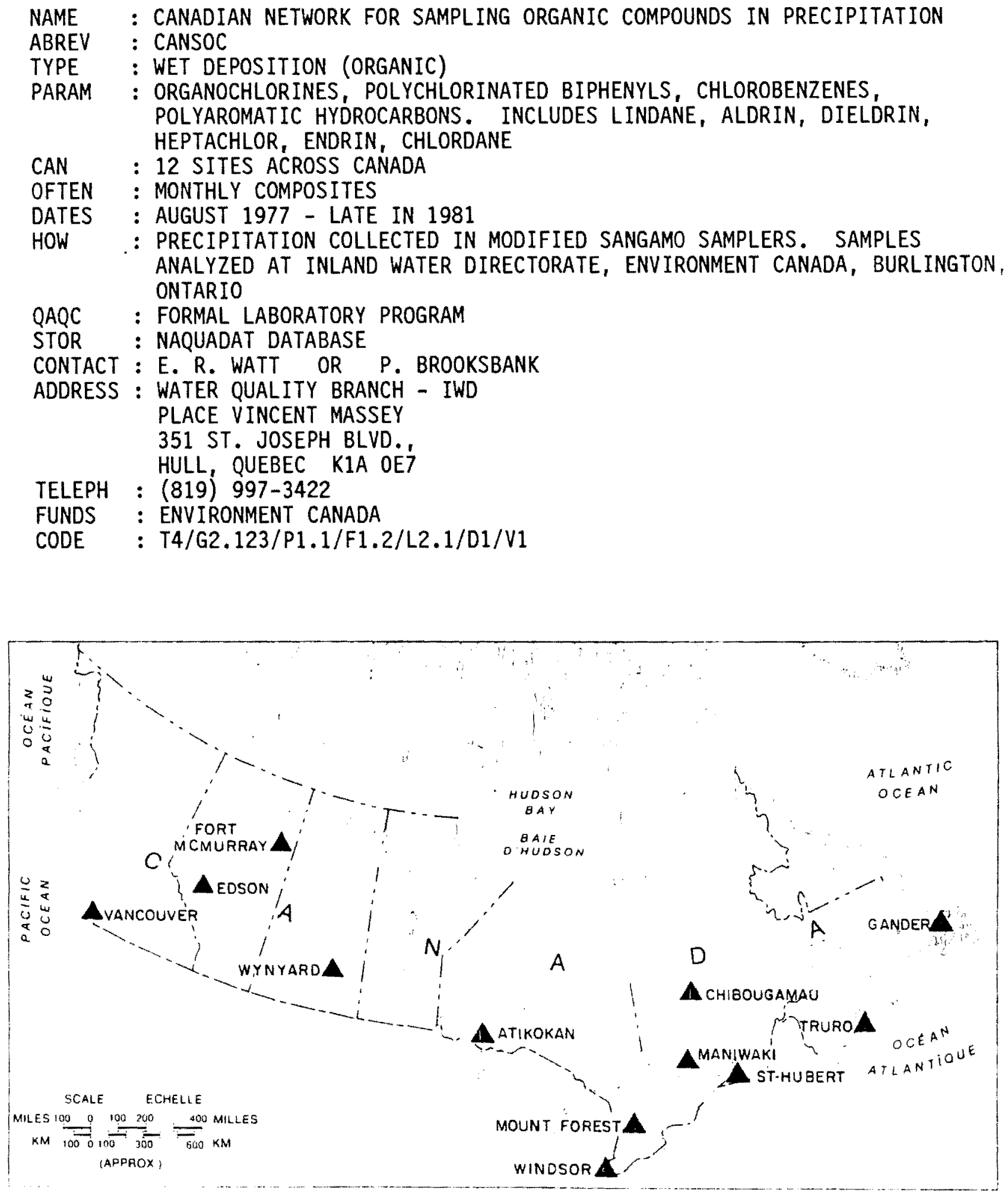


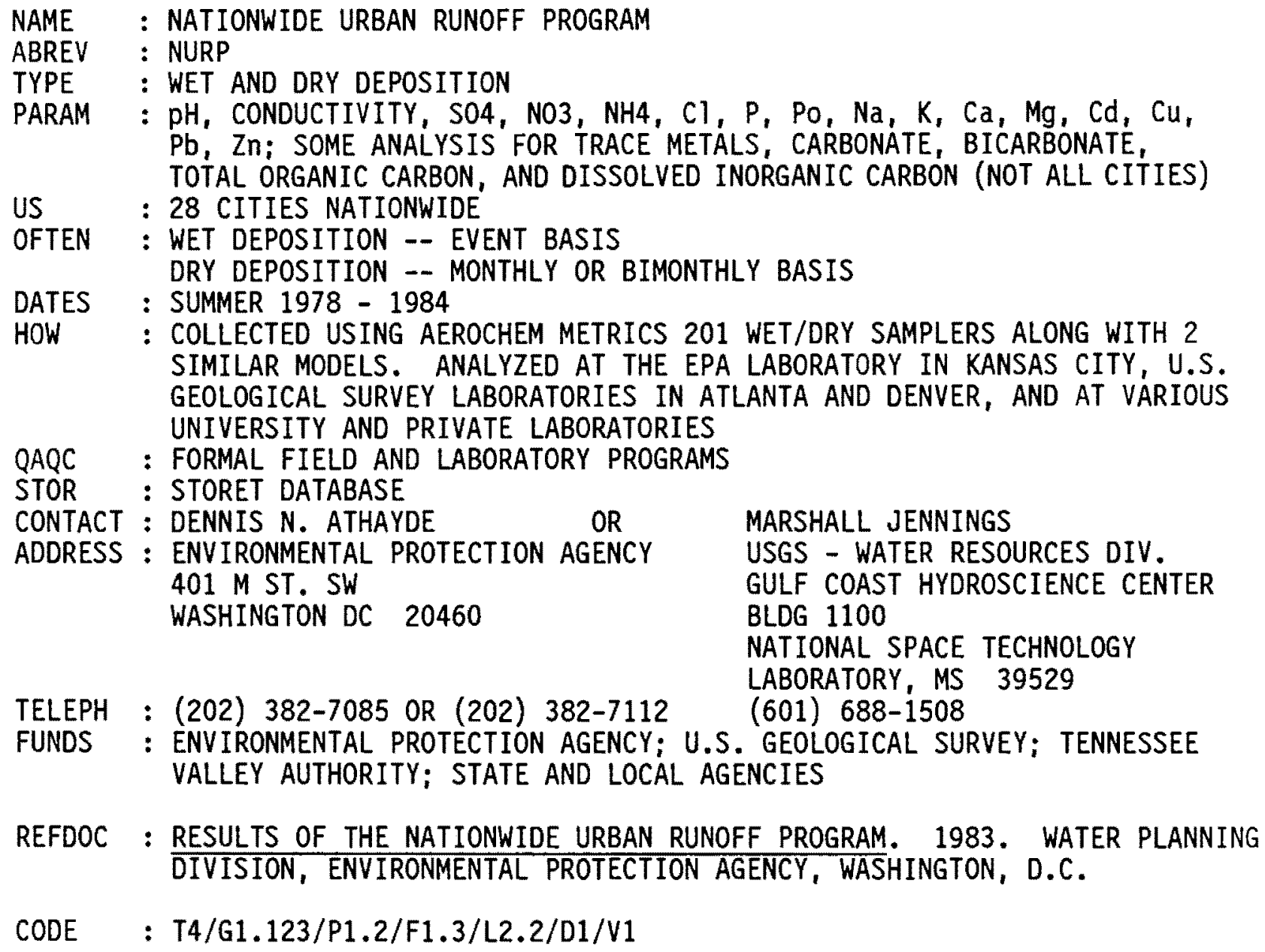

REFDOC : RESULTS OF THE NATIONWIDE URBAN RUNOFF PROGRAM. 1983. WATER PLANNING DIVISION, ENVIRONMENTAL PROTECTION AGENCY, WASHINGTON, D.C.

CODE $\quad:$ T4/G1.123/P1.2/F1.3/L2.2/D1/V1

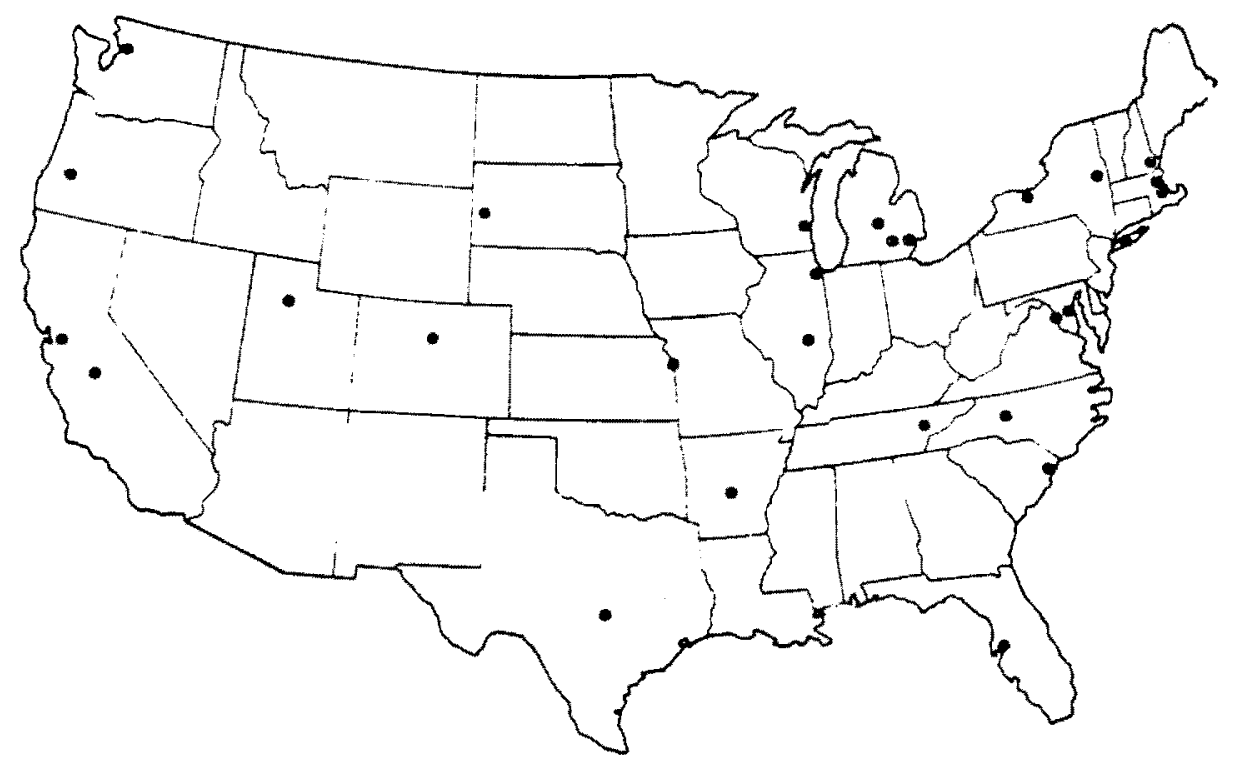


NAME : NATIONAL TRENDS NETWORK (COORDINATED BY THE NATIONAL ATMOSPHERIC DEPOSITION PROGRAM)

ABREV : NTN (NETWORK-NADP/NTN)

TYPE : WET AND LIMITED DRY DEPOSITION

PARAM : $\mathrm{PH}$, CONDUCTIVITY, SO4, NO3, NH4, Cl, PO4, $\mathrm{Na}, \mathrm{K}, \mathrm{Ca}, \mathrm{Mg}$

US : 150 SITES NATIONWIDE (196 IN COMBINED NADP AND NTN NETWORKS). 45 SITES ARE WITHIN THE BORDER STUDY AREA. (SOME SITES ARE COLOCATED WITH OTHER NETWORKS; E.G., MAP3S, UAPSP, STATE NETWORKS. NO SITES ARE CURRENTLY COLOCATED WITH CANADIAN NETWORKS.)

OFTEN : WET DEP: WEEKLY DRY DEP: BIMONTHLY

DATES : OCTOBER 1983 - ONGOING (APPROX. 90 SITES DESIGNATED AS NTN IN 1983 WERE EXISTING NADP SITES WITH LONGER OPERATING HISTORY)

HOW : COLLECTOR: EACH SITE USES AEROCHEM METRICS WET/DRY COLLECTOR. CHEMICAL ANALYSIS: ILLINOIS STATE WATER SURVEY. PROCEDURES: NADP SITING, FIELD, AND LABORATORY PROTOCOLS EXPLOYED (MANUALS AVAILABLE)

QAQC : FORMAL FIELD AND LABORATORY PROGRAMS (NADP MANUAL)

STOR : ADS DATABASE AND NADP/NTN DATABASE

CONTACT : J, H. GIBSON, NADP/NTN COORDINATOR

ADDRESS : NATURAL RESOURCE ECOLOGY LABORATORY COLORADO STATE UNIVERSITY FT. COLLINS, CO 80523

TELEPH : (303) 491-1978, 491-1975, OR 491-1977

FUNDS : U.S. GEOLOGICAL SURVEY, STATE AGRIC. EXP. STATIONS, U.S. DEPT OF AGR., NATIONAL OCEANIC AND ATMOSPHERIC ADMINISTRATION, NATIONAL PARK SERVICE, BUREAU OF LAND MANAGEMENT, AND VARIOUS STATE AGENCIES AND PRIVATE CORPORATIONS

MISC : 150 OF THE 196 SITES ARE DESIGNATED AS NTN BY THE FEDERAL NATIONAL ACID PRECIPITATION ASSESSMENT PROGRAM (NAPAP). THEY ARE ALSO DESIGNATED AS NADP AND THUS IDENTIFIED AS NADP/NTN. THE BALANCE OF 46 SITES ARE SUPPLEMENTARY NADP SITES. ALL 196 NADP/NTN SITES OPERATE WITH IDENTICAL PROTOCOL AND THE DATA ARE FOUND IN A SINGLE DATA BASE. SITE AND PROTOCOL INFORMATION ARE CURRENT AS OF $2 / 13 / 86$

REFDOC : MANY DOCUMENTS AVAILABLE; CONTACT J. H. GIBSON FOR PUBLICATION LIST. REPRESENTATIVE DOCUMENTS INCLUDE:

ROBERTSON, J. K. AND J. W. WILSON. 1985. DESIGN OF THE NATIONAL TRENDS NETWORK FOR MONITORING THE CHEMISTRY OF ATMOSPHERIC PRECIPITATION. U.S. GEOLOGICAL SURVEY CIRCULAR 954, ALEXANDRIA, VIRGINIA.

NATIONAL ATMOSPHERIC DEPOSITION PROGRAM. 1985. NADP/NTN DATA REPORT: PRECIPITATION CHEMISTRY; FOURTH QUARTER 1983; VOL VI, NO. 4. NATURAL RESOURCE ECOLOGY LABORATORY, COLORADO STATE UNIVERSITY, FORT COLLINS, COLORADO.

CODE $\quad: \mathrm{T} 4 / \mathrm{G} 1.123 / \mathrm{P} 0 / \mathrm{F} 4.4 / \mathrm{L} 1.1 / \mathrm{D} 1 / \mathrm{V} 1$ 


\section{LOCATIONS OF NATIONAL TRENDS NETWORK (NTN) STATIONS}

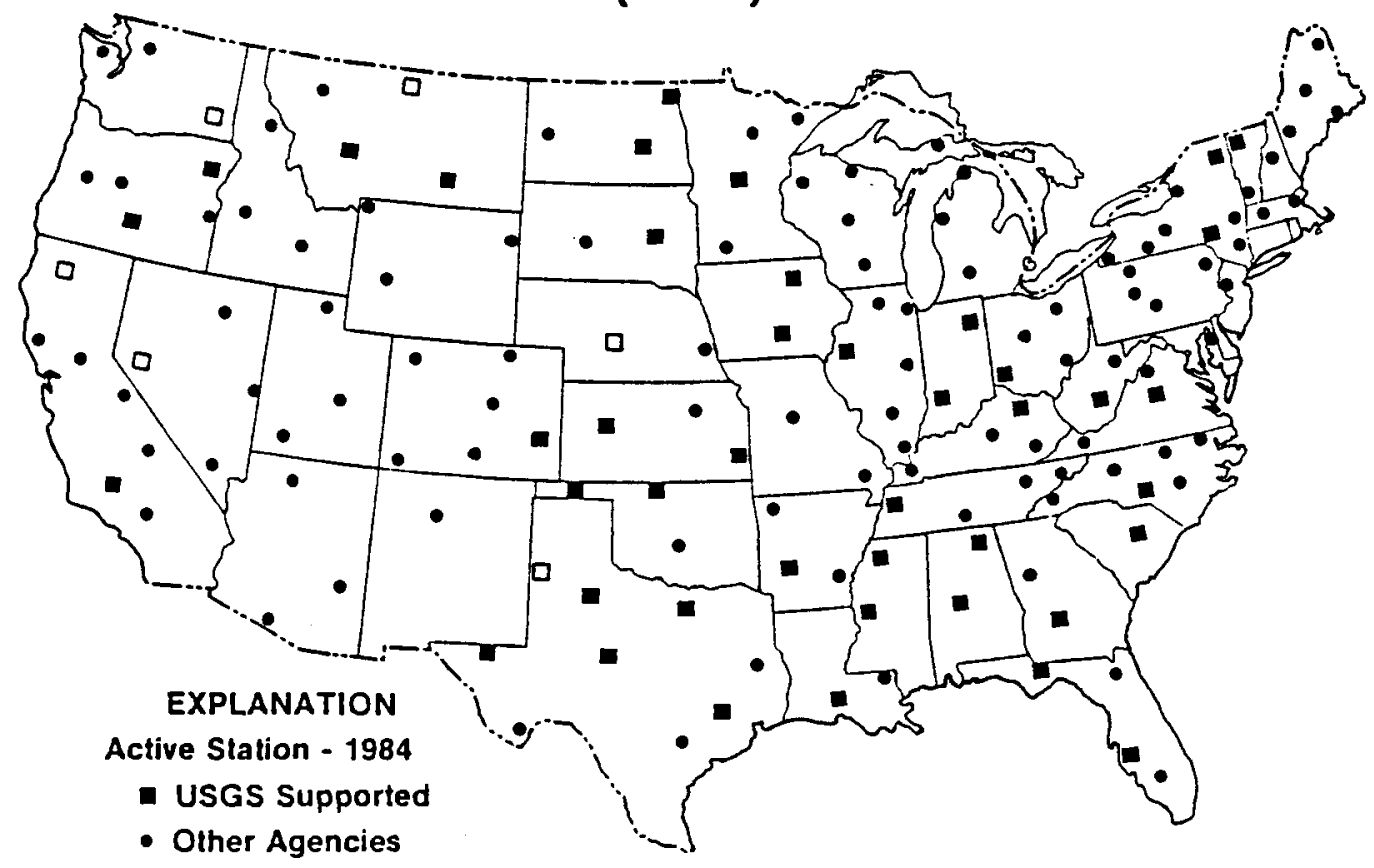

Planned Station - 1985

$\square$ USGS Supported 
NAME : NATIONAL ATMOSPHERIC DEPOSITION PROGRAM (IR-7) (COORDINATES COMBINED NATIONAL ATMOSPHERIC DEPOSITION PROGRAM NETWORK AND NATIONAL TRENDS NETWORK)

ABREV : NADP (NETWORK-NADP/NTN)

TYPE : WET AND LIMITED DRY DEPOSITION

PARAM : $\mathrm{pH}$, CONDUCTIVITY, SO4, NO3, NH4, Cl, P04, $\mathrm{Na}, \mathrm{K}, \mathrm{Ca}, \mathrm{Mg}$

US : 196 SITES NATIONWIDE IN COMBINED NADP AND NTN NETWORK (150 NADP/NTN AND 46 NADP). 59 SITES WITHIN BORDER STUDY AREA. (SITES ARE COLOCATED WITH OTHER NETWORKS; E.G., MAP3S, UAPSP, STATE NETWORKS. NO SITES ARE CURRENTLY COLOCATED WITH CANADIAN NETWORKS, ALTHOUGH 3 WERE PREVIOUSLY COLOCATED WITH CANSAP.)

OFTEN : WET DEP: WEEKLY DRY DEP: BIMONTHLY

DATES : MAY 1978 - ONGOING

HOW : COLLECTOR: EACH SITE USES AEROCHEM METRICS WET/DRY COLLECTOR. CHEMICAL ANALYSIS: ILLINOIS STATE WATER SURVEY. PROCEDURES: NADP SITING, FIELD, AND LABORATORY PROTOCOLS EMPLOYED (MANUALS AVAILABLE)

QAQC : FORMAL FIELD AND LABORATORY PROGRAMS (NADP MANUAL)

STOR : ADS DATABASE AND NADP/NTN DATABASE

CONTACT : J. H. GIBSON, NADP/NTN COORDINATOR

ADDRESS : NATURAL RESOURCE ECOLOGY LABORATORY COLORADO STATE UNIVERSITY

FT. COLLINS, CO 80523

TELEPH : (303) 491-1978, 491-1975, OR 491-1977

FUNDS : STATE AGRIC. EXP. STATIONS, U.S. GEOLOGICAL SURVEY, U.S. DEPT OF AGRICULTURE, ENVIRONMENTAL PROTECTION AGENCY, U.S. FOREST SERVICE, NATIONAL OCEANIC AND ATMOSPHERIC ADMINISTRATION, NATIONAL PARK SERVICE, BUREAU OF LAND MANAGEMENT, AND VARIOUS STATE AGENCIES AND PRIVATE CORPORATIONS

MISC : 150 OF THE 196 SITES ARE DESIGNATED AS NTN BY THE FEDERAL NATIONAL ACID PRECIPITATION ASSESSMENT PROGRAM (NAPAP). THEY ARE ALSO DESIGNATED AS NADP AND THUS IDENTIFIED AS NADP/NTN. THE BALANCE OF 46 SITES ARE SUPPLEMENTARY NADP SITES. ALL 196 NADP/NTN SITES OPERATE WITH IDENTICAL PROTOCOL AND THE DATA ARE FOUND IN A SINGLE DATA BASE. DRYFALL COLLECTION WAS MADE OPTIONAL IN 1984. SITE AND PROTOCOL INFORMATION ARE CURRENT AS OF $2 / 13 / 86$.

REFDOC : MANY DOCUMENTS AVAILABLE; CONTACT J. H. GIBSON FOR PUBLICATION LIST. REPRESENTATIVE DOCUMENTS INCLUDE:

NATIONAL ATMOSPHERIC DEPOSITION PROGRAM. 1985. NADP/NTN DATA REPORT: PRECIPITATION CHEMISTRY; FOURTH QUARTER 1983; VOL VI, NO. 4. NATURAL RESOURCE ECOLOGY LABORATORY, COLORADO STATE UNIVERSITY, FORT COLLINS, COLORADO.

PEDEN, M. E. 1983. "SAMPLING, ANALYTICAL AND QUALITY ASSURANCE PROTOCOLS FOR THE NATIONAL ATMOSPHERIC DEPOSITION PROGRAM." SAMPLING AND ANALYSIS OF RAIN. S. A. CAMPBELL, ED. ASTM SPECIAL TECHNICAL PUBLICATION 823, pp. 72-83, AMERICAN SOCIETY FOR TESTING AND MATERIALS, PHILADELPHIA, PENNSYLVANIA.

CODE : T4/G1.123/P0/F4.4/L1.2/D1/V1 


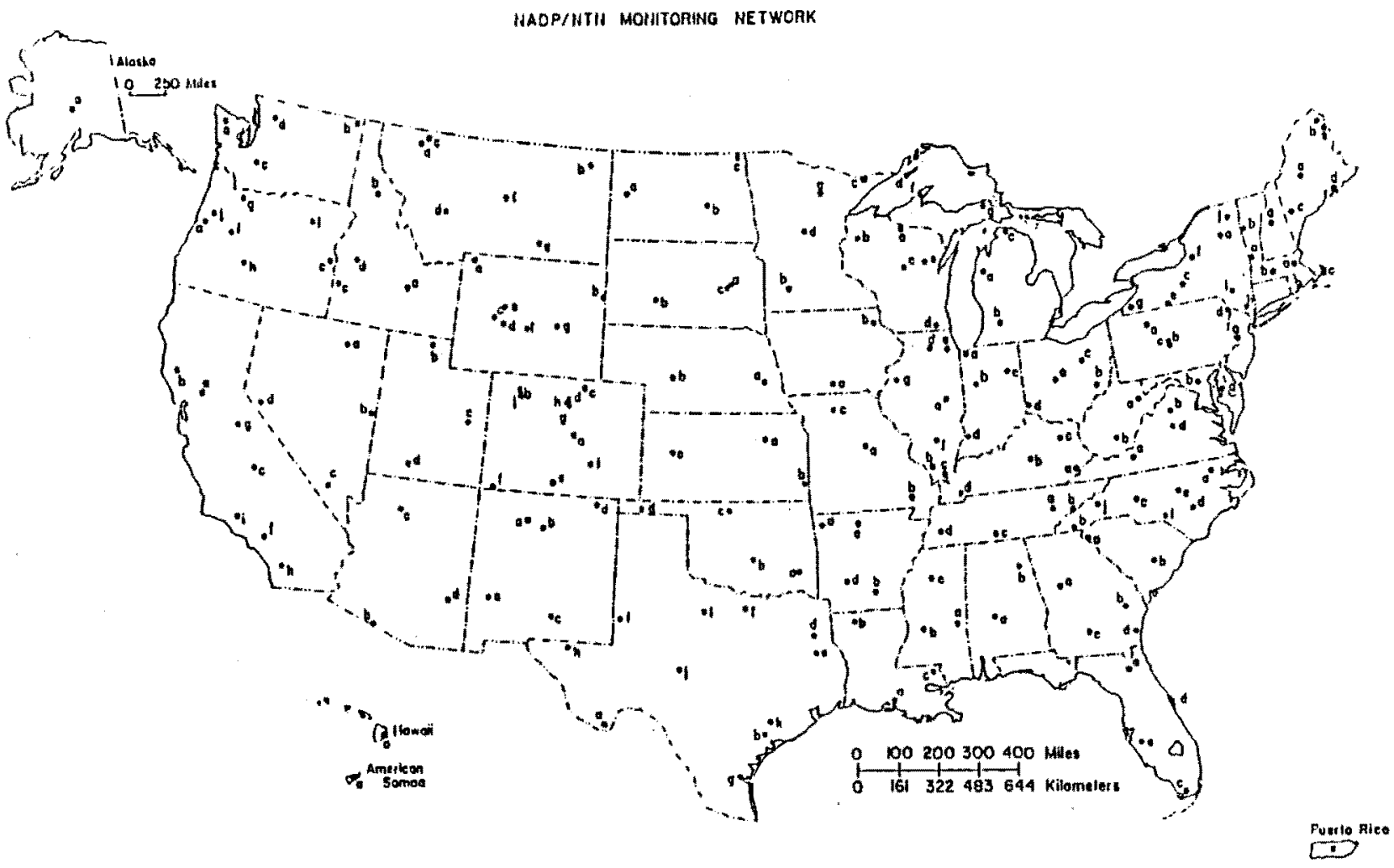




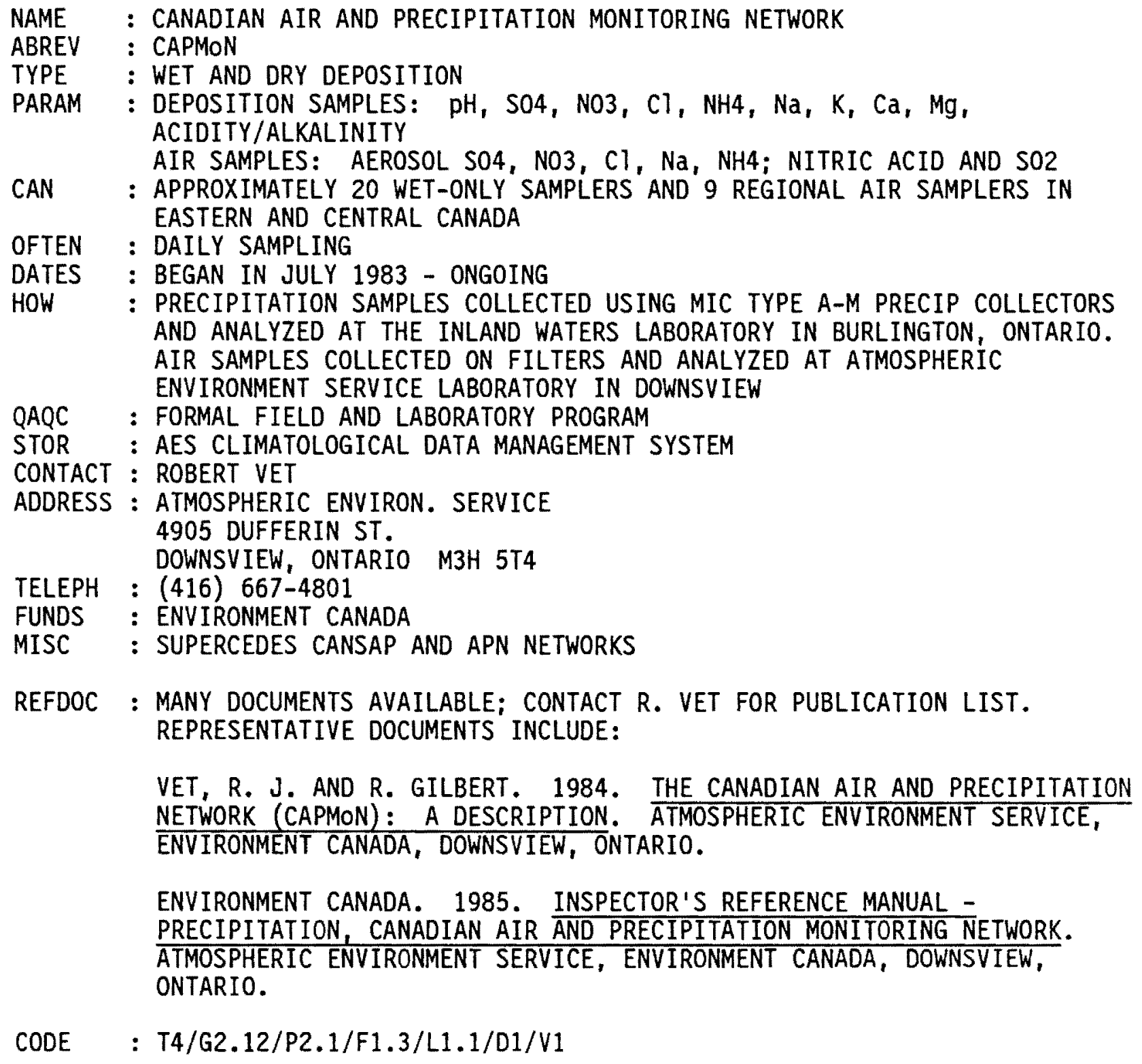




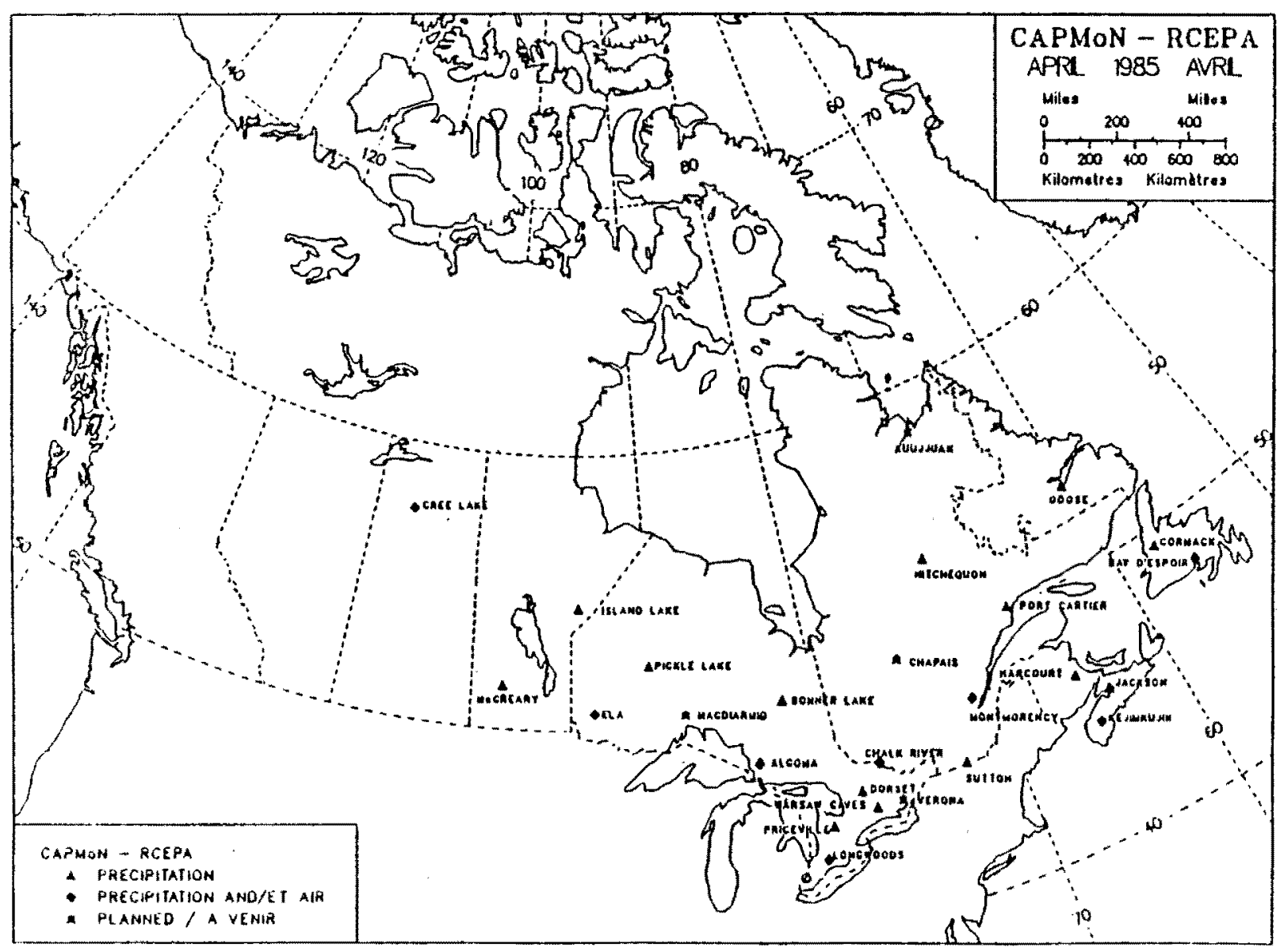



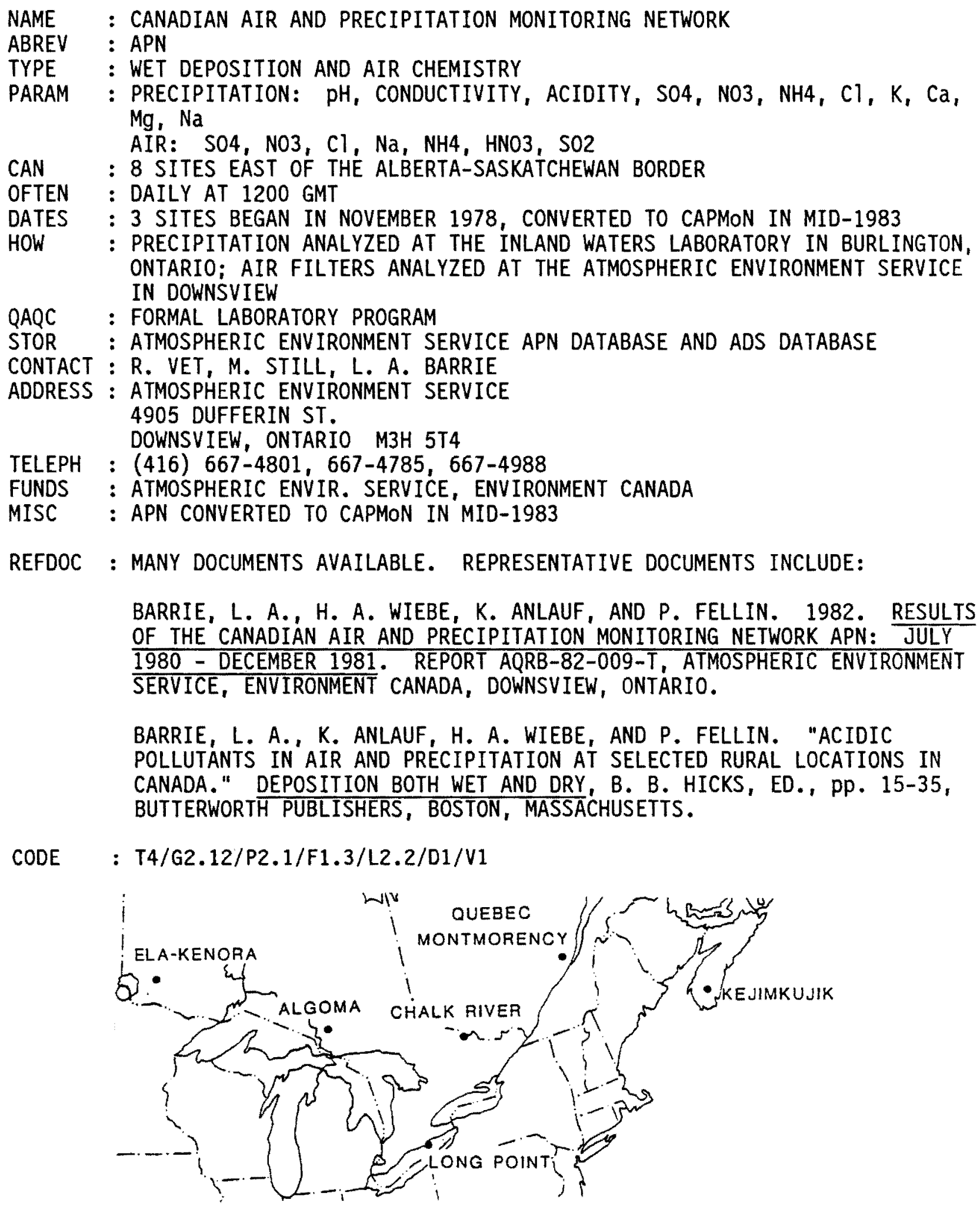


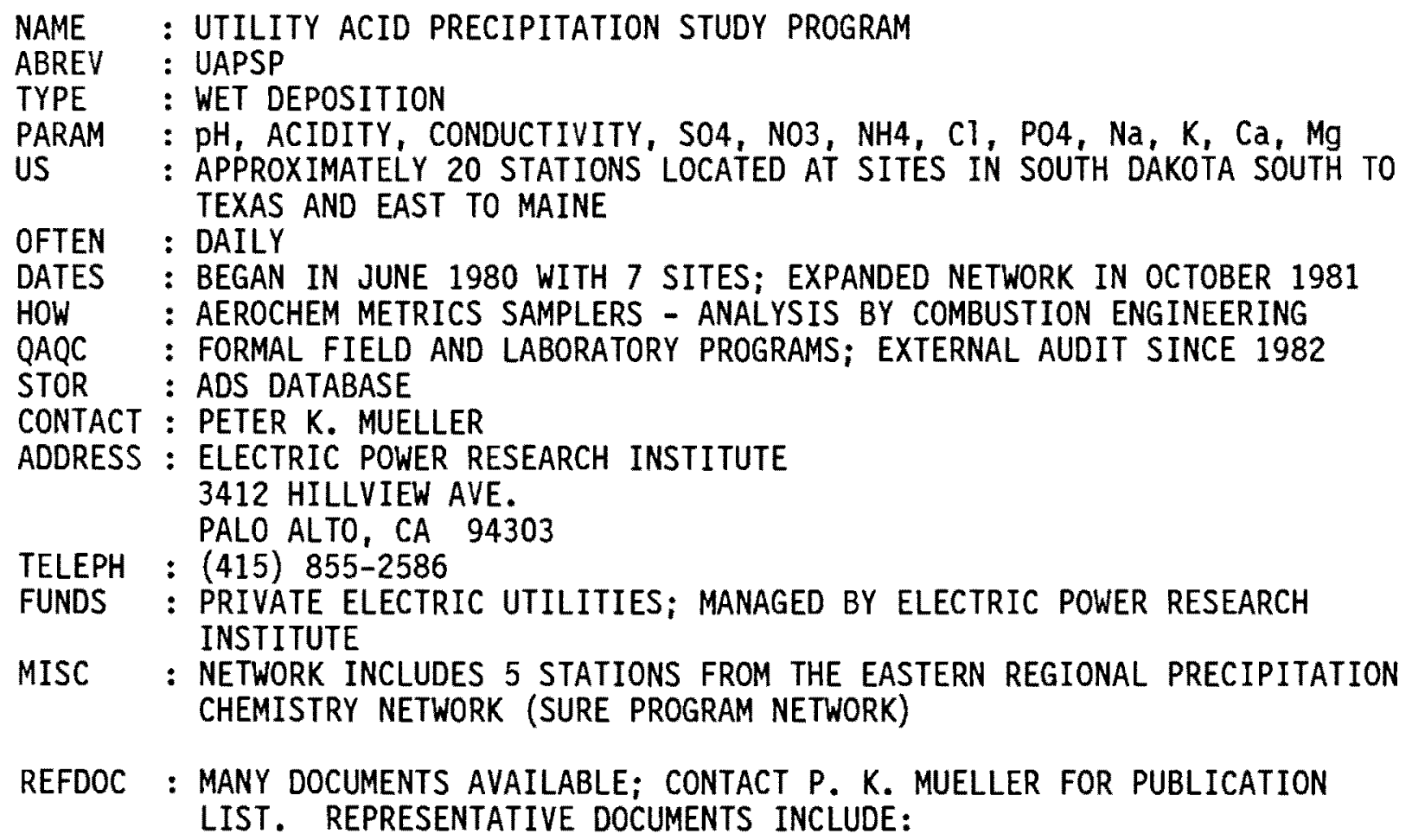

MUELLER, P. K., J. J. JANSEN, AND M. A. ALLEN. 1984. UAPSP SECOND SUMMARY REPORT. UAPSP 109, UTILITY ACID PRECIPITATION STUDY PROGRAM, EDISON ELECTRIC INSTITUTE, WASHINGTON, D.C.

TOPOL, LEO. 1986. "DIFFERENCES IN IONIC COMPOSITIONS AND BEHAVIOR IN WINTER RAIN AND SNOW." ATMOSPHERIC ENVIRONMENT, 20:347-356.

CODE $\quad:$ T4/G1.12/P0/F3.3/L1.2/D1/V1

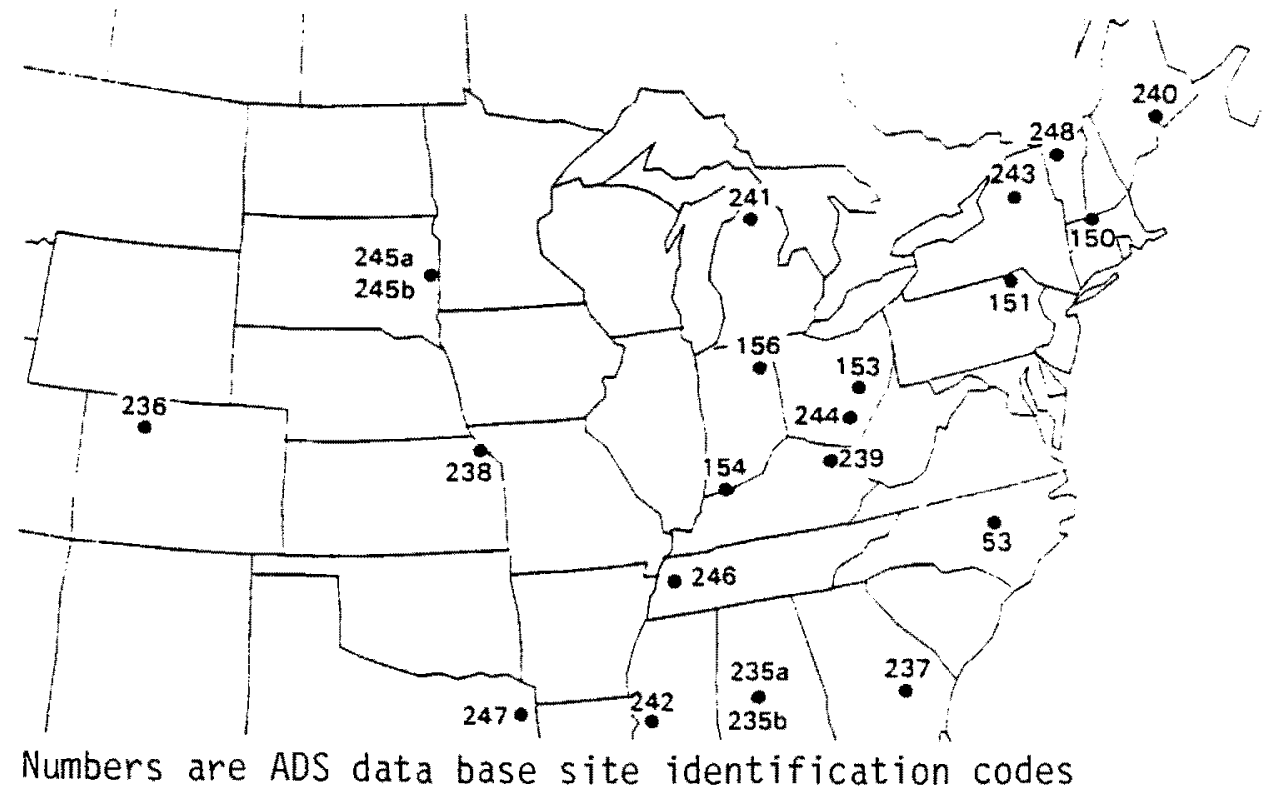




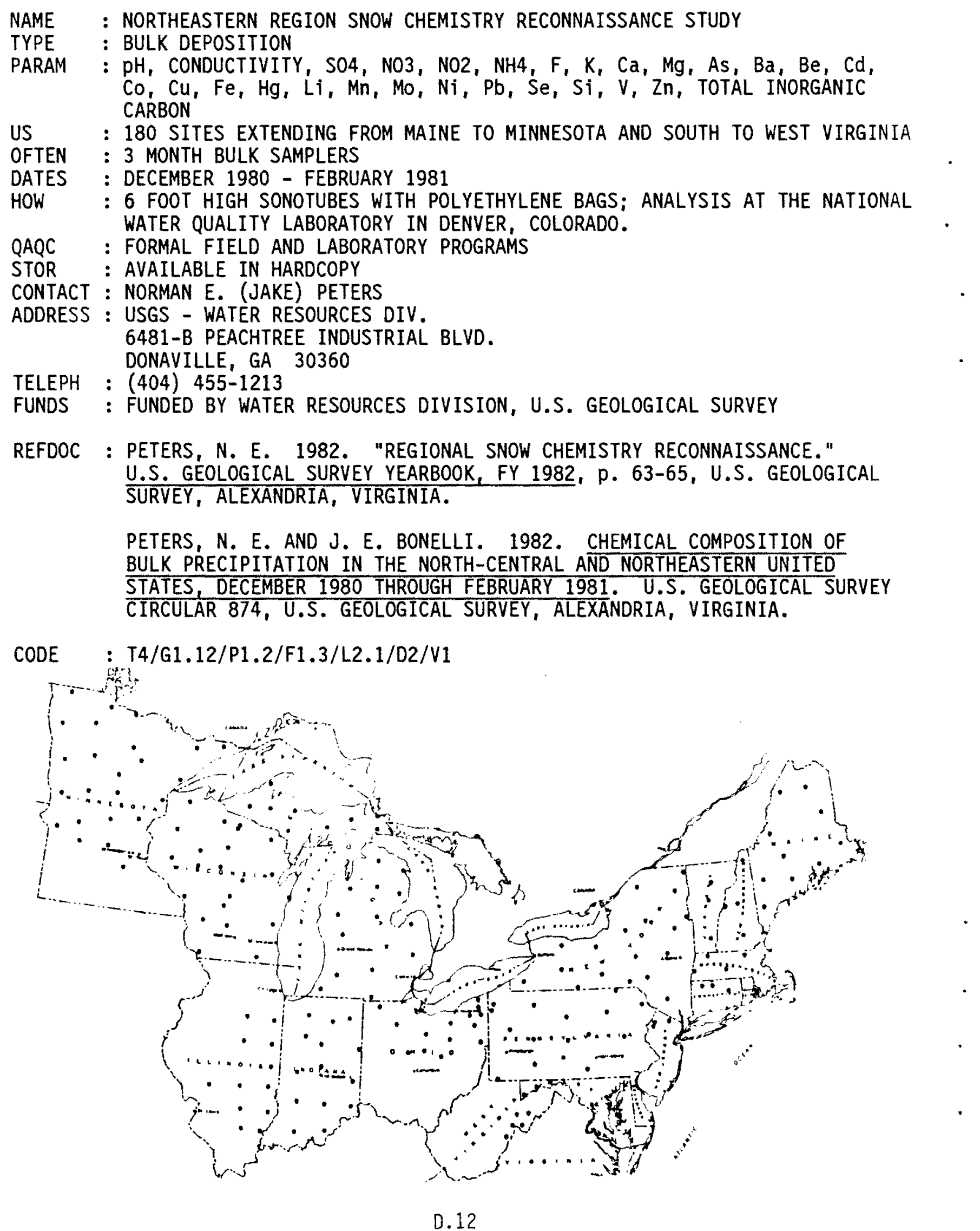



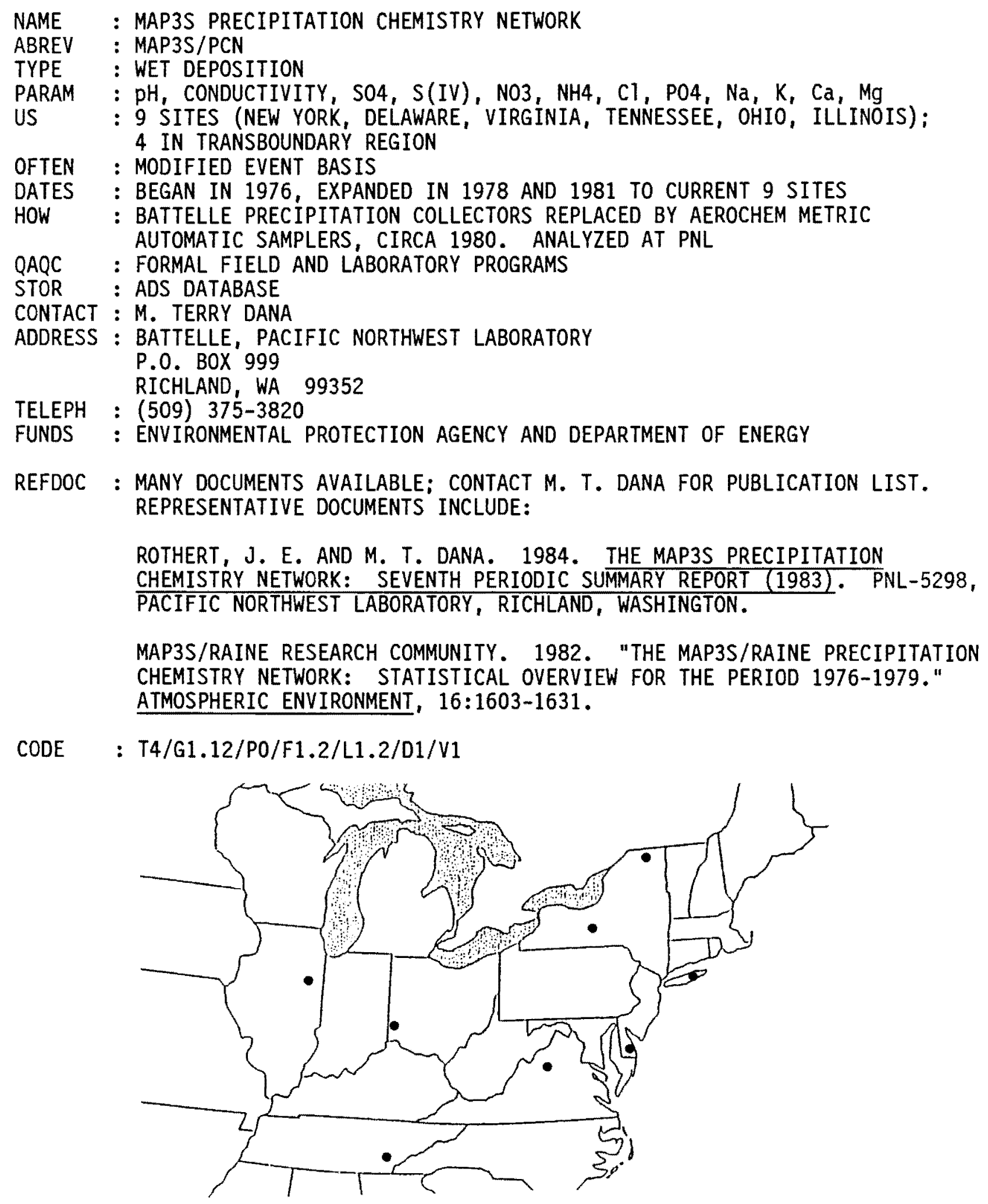


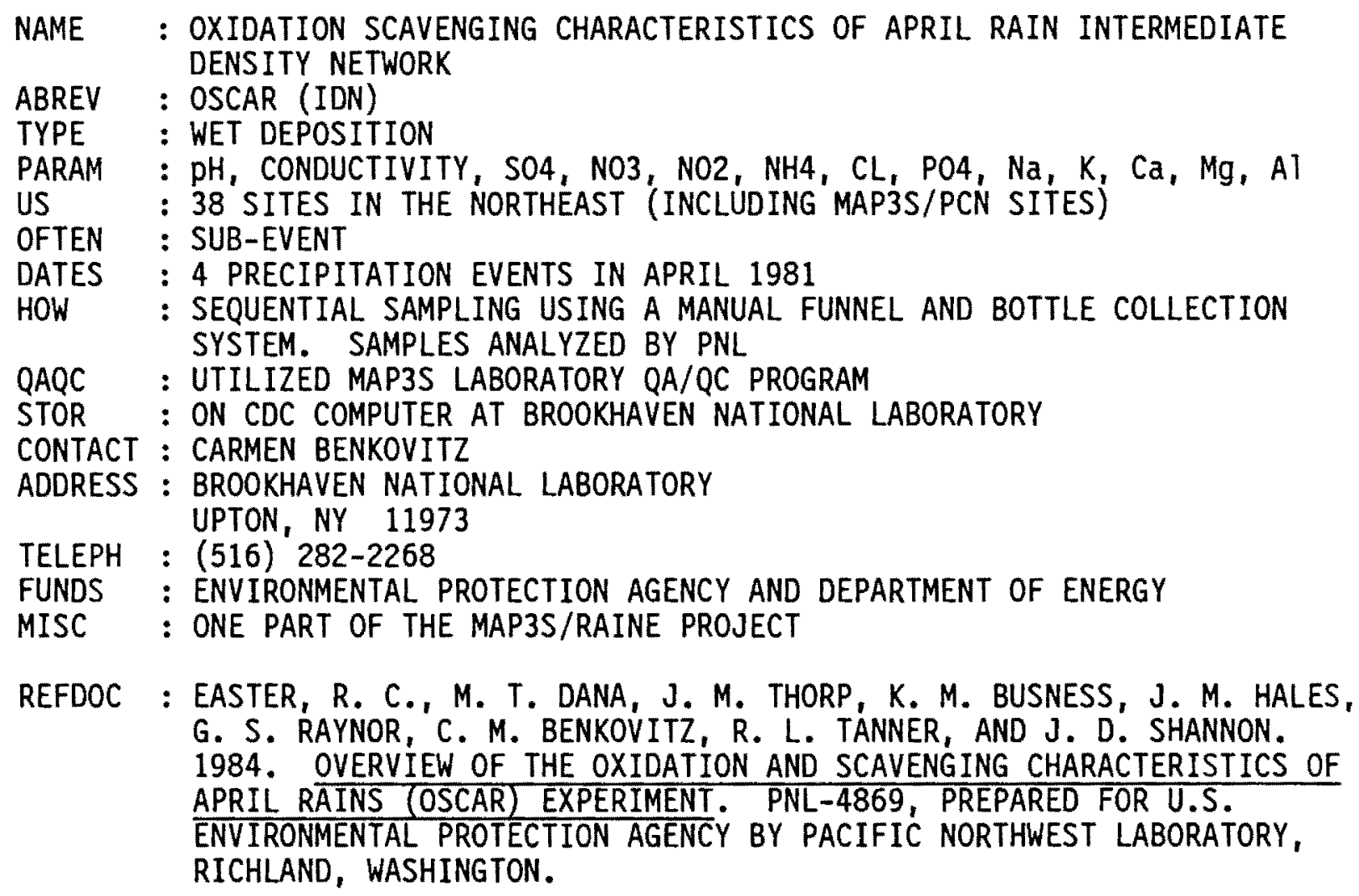

REFDOC : EASTER, R. C., M. T. DANA, J. M. THORP, K. M. BUSNESS, J. M. HALES, G. S. RAYNOR, C. M. BENKOVITZ, R. L. TANNER, AND J. D. SHANNON. 1984. OVERVIEW OF THE OXIDATION AND SCAVENGING CHARACTERISTICS OF APRIL RAINS (OSCAR) EXPERIMENT. PNL-4869, PREPARED FOR U.S. ENVIRONMENTAL PROTECTION AGENCY BY PACIFIC NORTHWEST LABORATORY, RICHLAND, WASHINGTON.

BENKOVITZ, C. M., V. A. EVANS, J. L. TICHLER, J. V. HAYES, AND K. J. NORDEN. 1984. OXIDIZING AND SCAVENGING CHARACTERISTICS OF APRIL RAINS - OSCAR DATA REPORT. BNL-51881, PREPARED FOR U.S. ENVIRONMENTAL PROTECTION AGENCY BY BROOKHAVEN NATIONAL LABORATORY, UPTON, NEW YORK.

CODE $\quad:$ T4/G1.12/PO/F1.3/L2.1/D2/VO

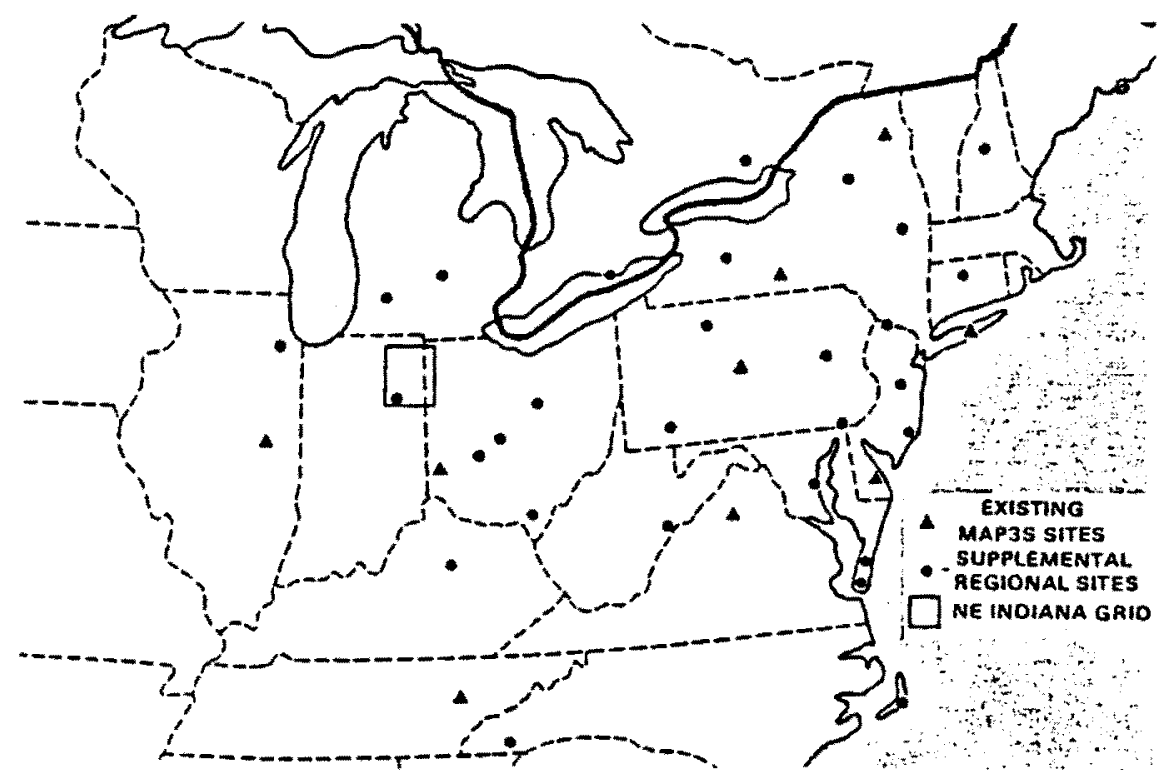

D. 14 

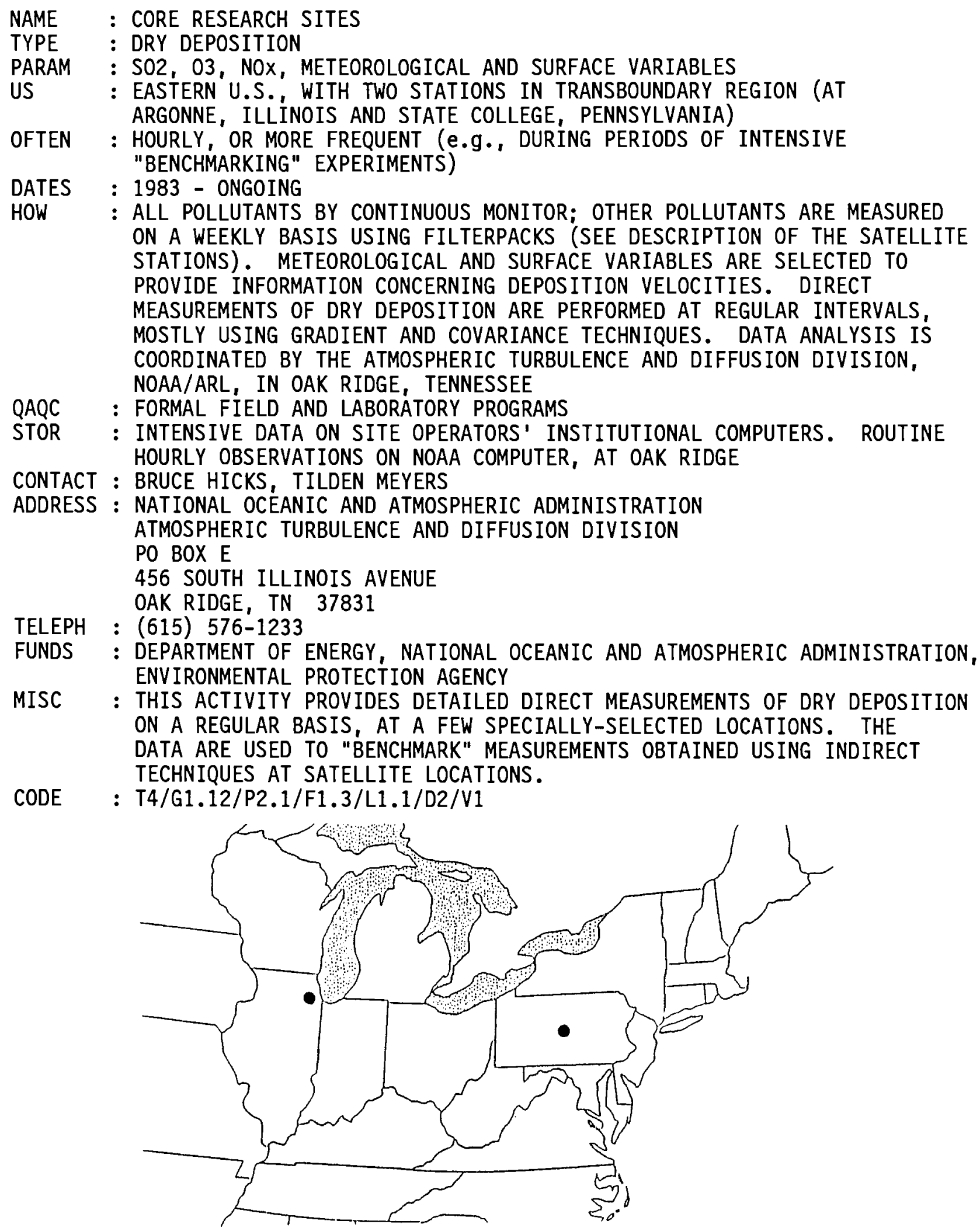

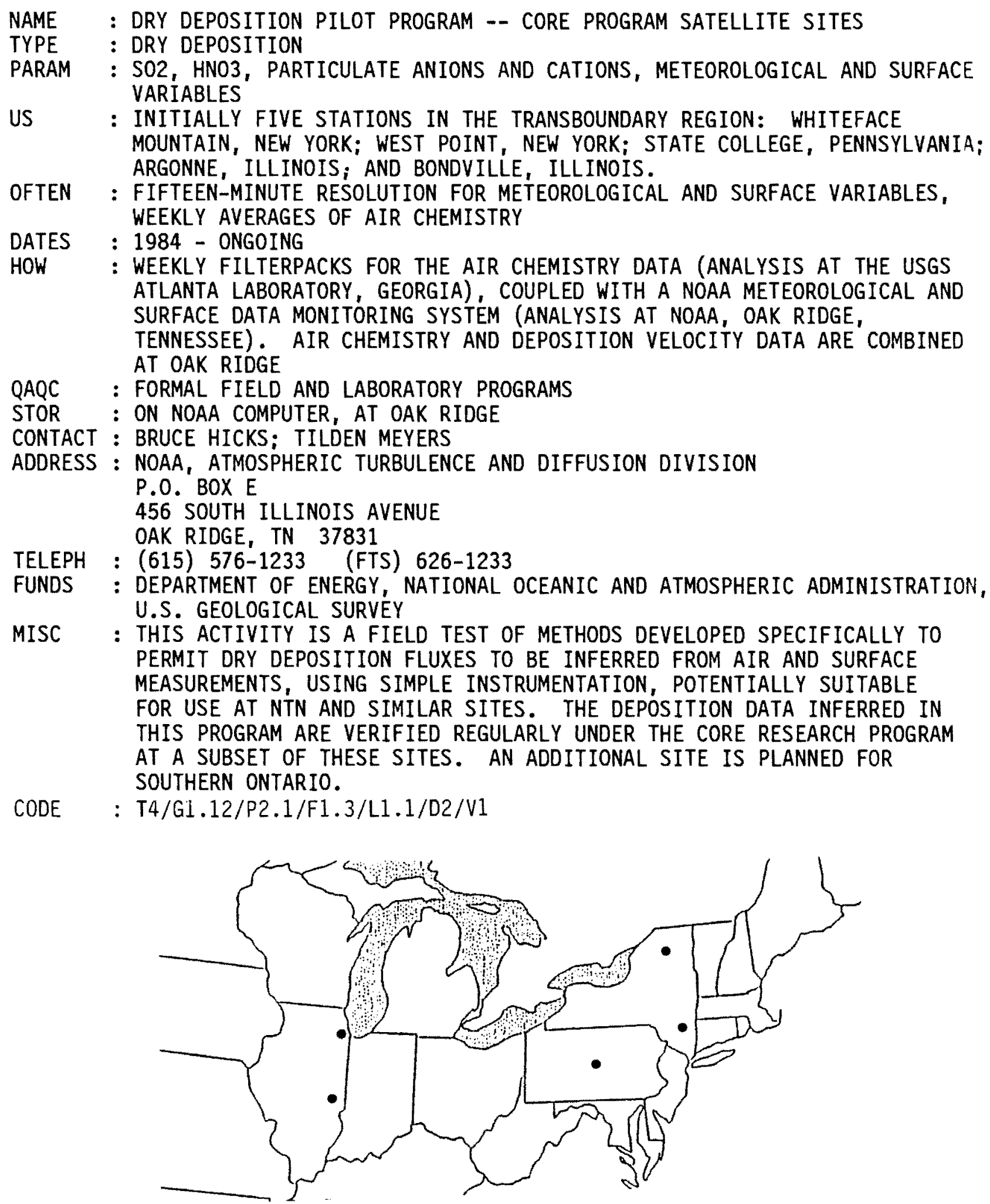

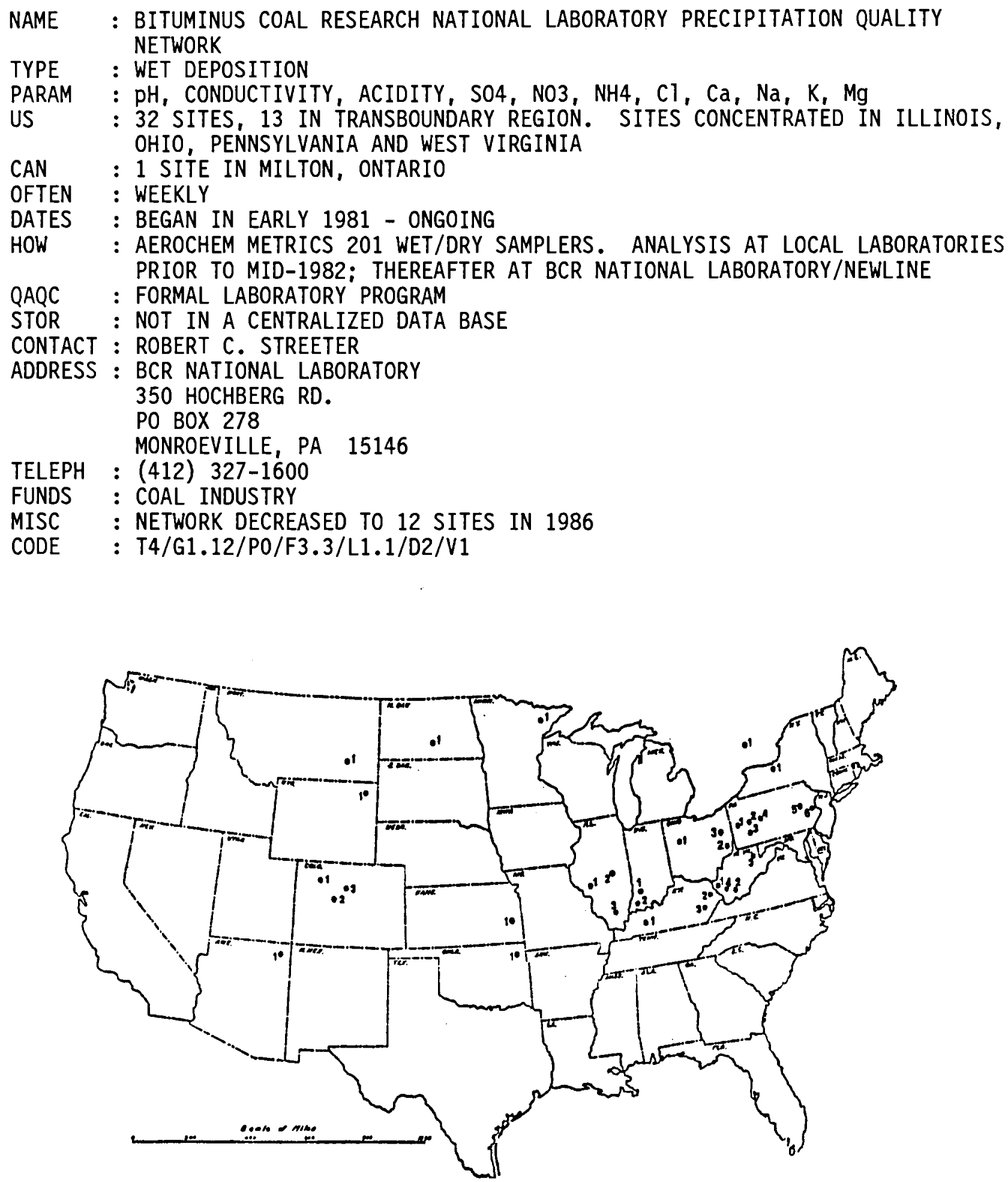
NAME : ELECTRIC POWER RESEARCH INSTITUTE - EASTERN REGIONAL PRECIPITATION

ABREV : SURE

TYPE : WET DEPOSITION

PARAM : $\mathrm{pH}$, CONDUCTIVITY, ACIDITY, SO4, N03, NH4, Cl, P04, $\mathrm{Na}, \mathrm{K}, \mathrm{Ca}, \mathrm{Mg}$,

US $: 9$ SITES THROUGHOUT NORTHEASTERN UNITED STATES

OFTEN : DAILY

DATES : AUGUST 1978 - JUNE 1980

HOW : TWO AEROCHEM METRICS 201 WET/DRY COLLECTORS AT EACH SITE. ANALYZED BY ROCKWELL INTERNATIONAL, INC.

QAQC : FORMAL FIELD AND LABORATORY PROGRAMS

STOR : ADS DATABASE

CONTACT : PETER K. MUELLER

ADDRESS : ELECTRIC POWER RESEARCH INSTITUTE

3412 HILLVIEW AVE

PALO ALTO, CA 94303

TELEPH : (415) 855-2586

FUNDS : ELECTRIC POWER RESEARCH INSTITUTE

MISC : FIVE STATIONS BECAME PART OF THE UAPSP NETWORK

REFDOC : MANY DOCUMENTS AVAILABLE; CONTACT P. K. MUELLER FOR PUBLICATION LIST. REPRESENTATIVE PUBLICATIONS INCLUDE:

MUELLER, P. K. AND G. M. HIDY. 1983. THE SULFATE REGIONAL

EXPERIMENT: REPORT OF FINDINGS. REPORT EA-1901, VOL. 2 , ELECTRIC POWER RESEARCH INSTITUTE, PALO ALTO, CALIFORNIA.

CODE : T4/G1.12/PO/F3.2/L2.1/D1/V1

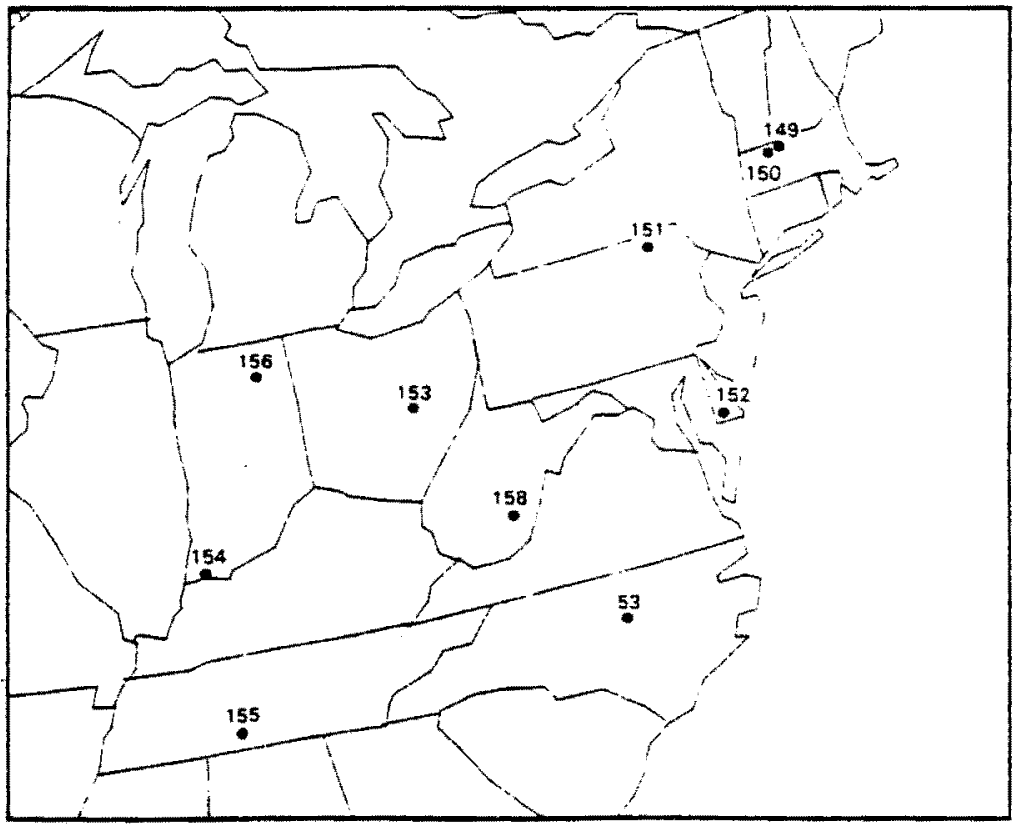

Numbers are ADS data base site identification codes 

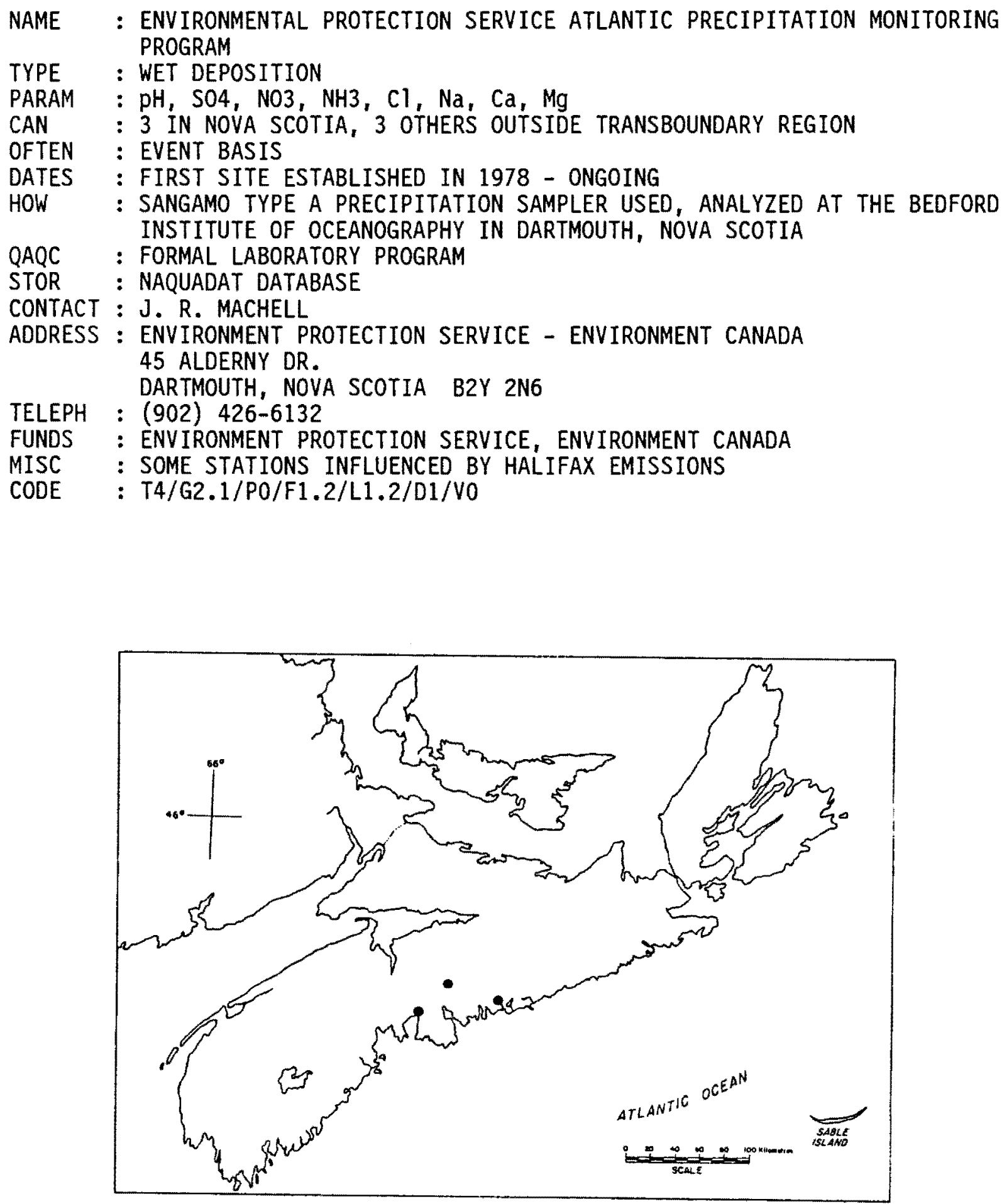
NAME : NOVA SCOTIA DEPARTMENT OF THE ENVIRONMENT PRECIPITATION NETWORK

TYPE : WET DEPOSITION

PARAM : $\mathrm{PH}$, CONDUCTIVITY, ALKALINITY, ACIDITY, SO4, NO3 + N02, NH3, TOTAL N, $\mathrm{Cl}$, TOTAL $\mathrm{P}, \mathrm{Na}, \mathrm{K}, \mathrm{Ca}, \mathrm{Mg}, \mathrm{Al}, \mathrm{As}, \mathrm{Cd}, \mathrm{Co}, \mathrm{Cr}, \mathrm{Cu}, \mathrm{Fe}, \mathrm{Mn}, \mathrm{Ni}, \mathrm{Pb}$, $\mathrm{Se}, \mathrm{Zn}$, TOTAL ORGANIC CARBON

CAN : CURRENTLY 5 SITES IN NOVA SCOTIA; 9 SITES PRIOR TO DECEMBER 1979

OFTEN : WEEKLY SAMPLES

DATES : BEGAN IN SEPTEMBER 1977 - ONGOING

HOW : SANGAMO WET/DRY COLLECTORS USED. ANALYZED AT THE ENVIR. CHEM.

LABORATORY OF THE DEPT. OF HEALTH IN HALIFAX

QAQC : FORMAL LABORATORY PROGRAM; SOME FIELD QA

STOR : ON CDC COMPUTER AT DALHOUSIE UNIVERSITY

CONTACT : J. UNDERWOOD

ADDRESS : NOVA SCOTIA DEPT OF THE ENVIRONMENT

P.0. BOX 2107

HALIFAX, NOVA SCOTIA B3J $3 B 7$

TELEPH : (902) 424-5300

FUNDS : NOVA SCOTIA DEPARTMENT OF THE ENVIRONMENT

CODE : T4/G2.1/P1.2/F2.2/L1.2/D2/V1

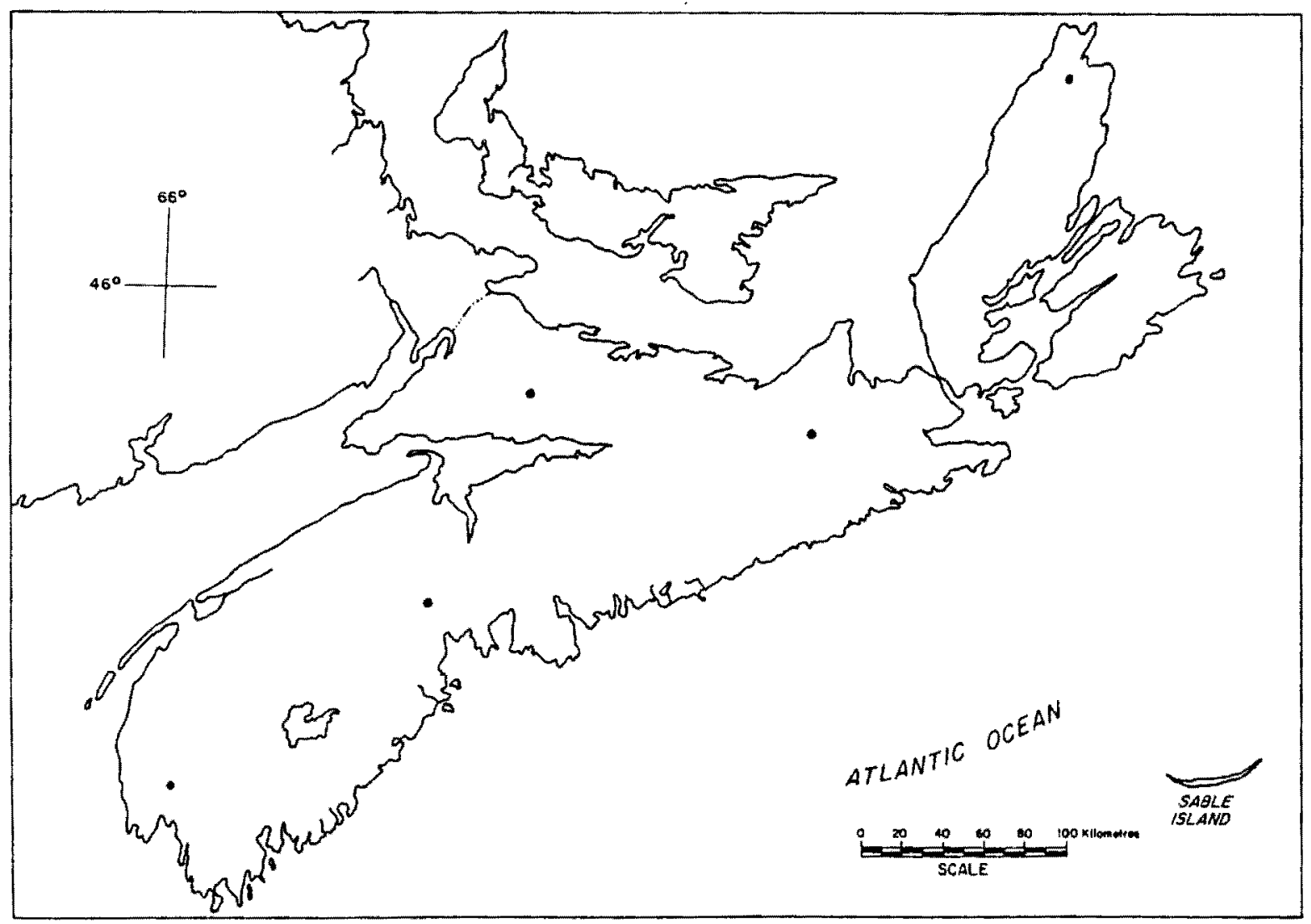



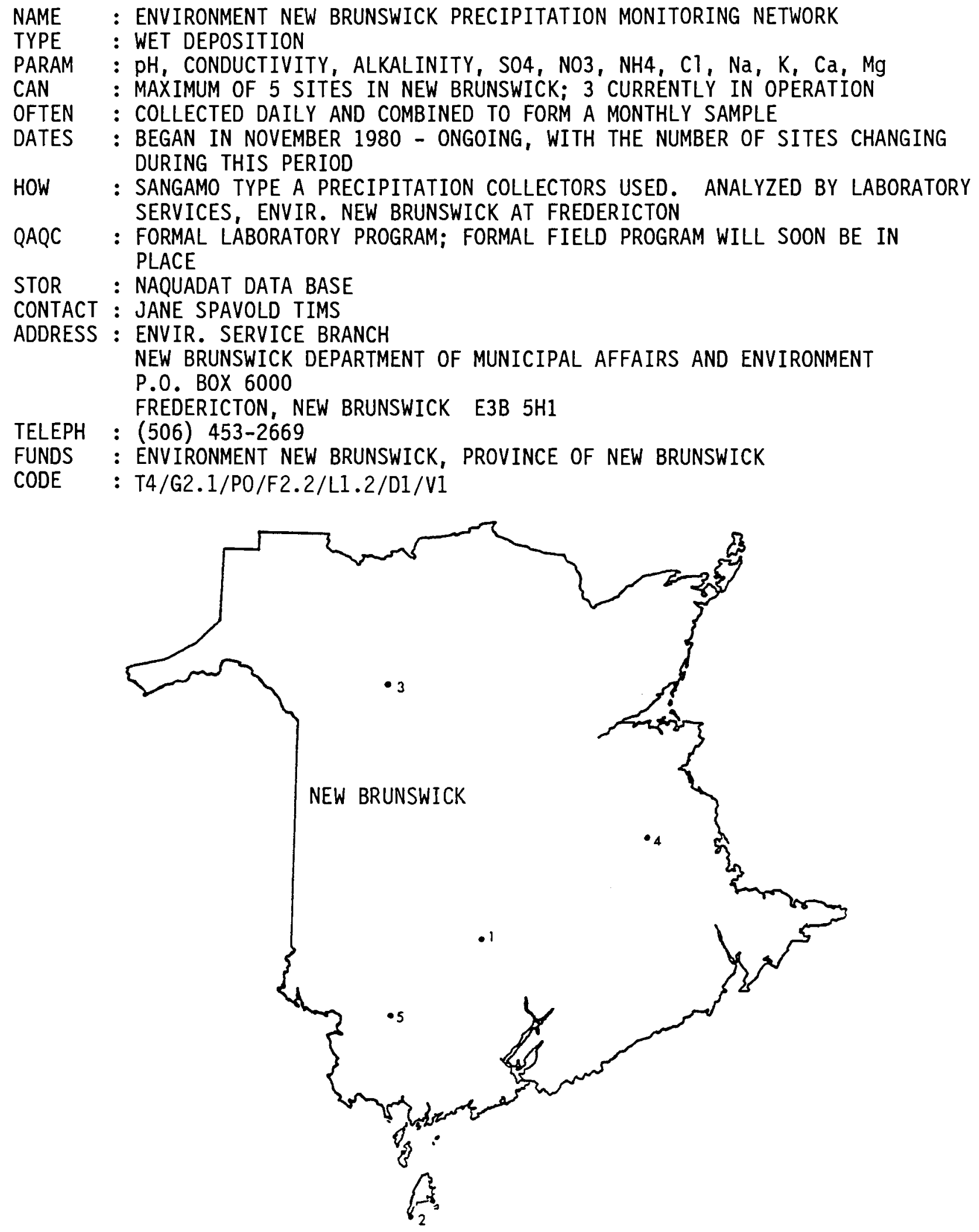


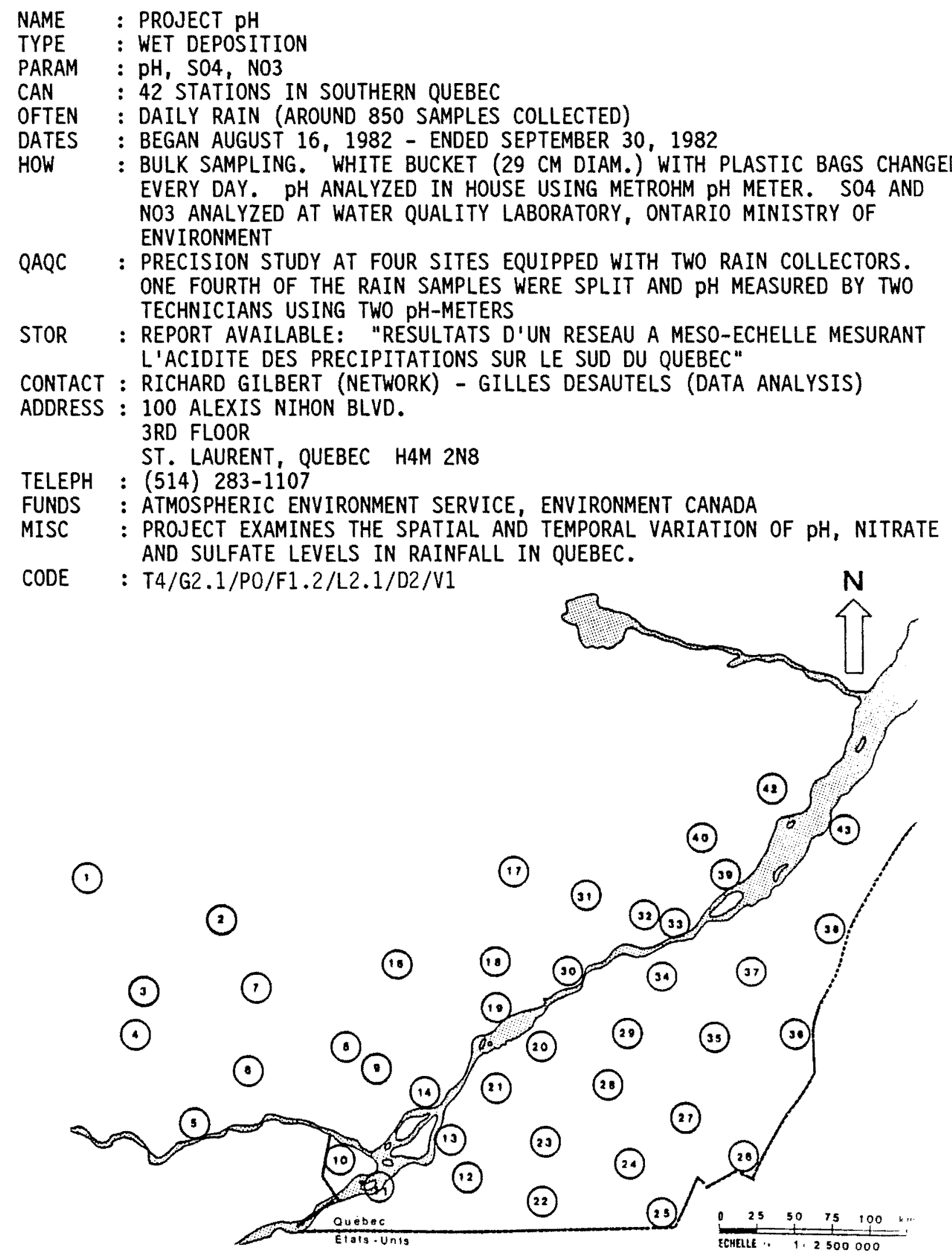




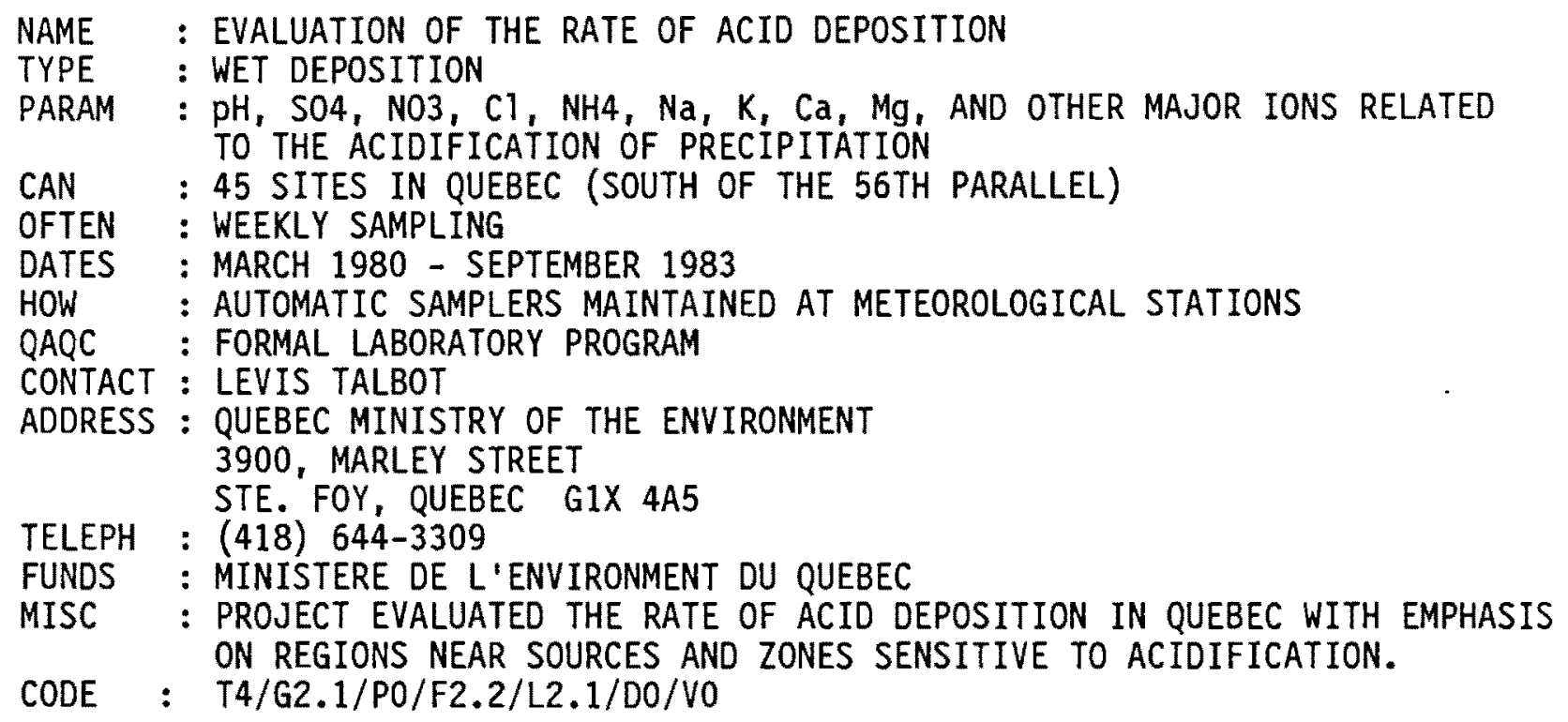




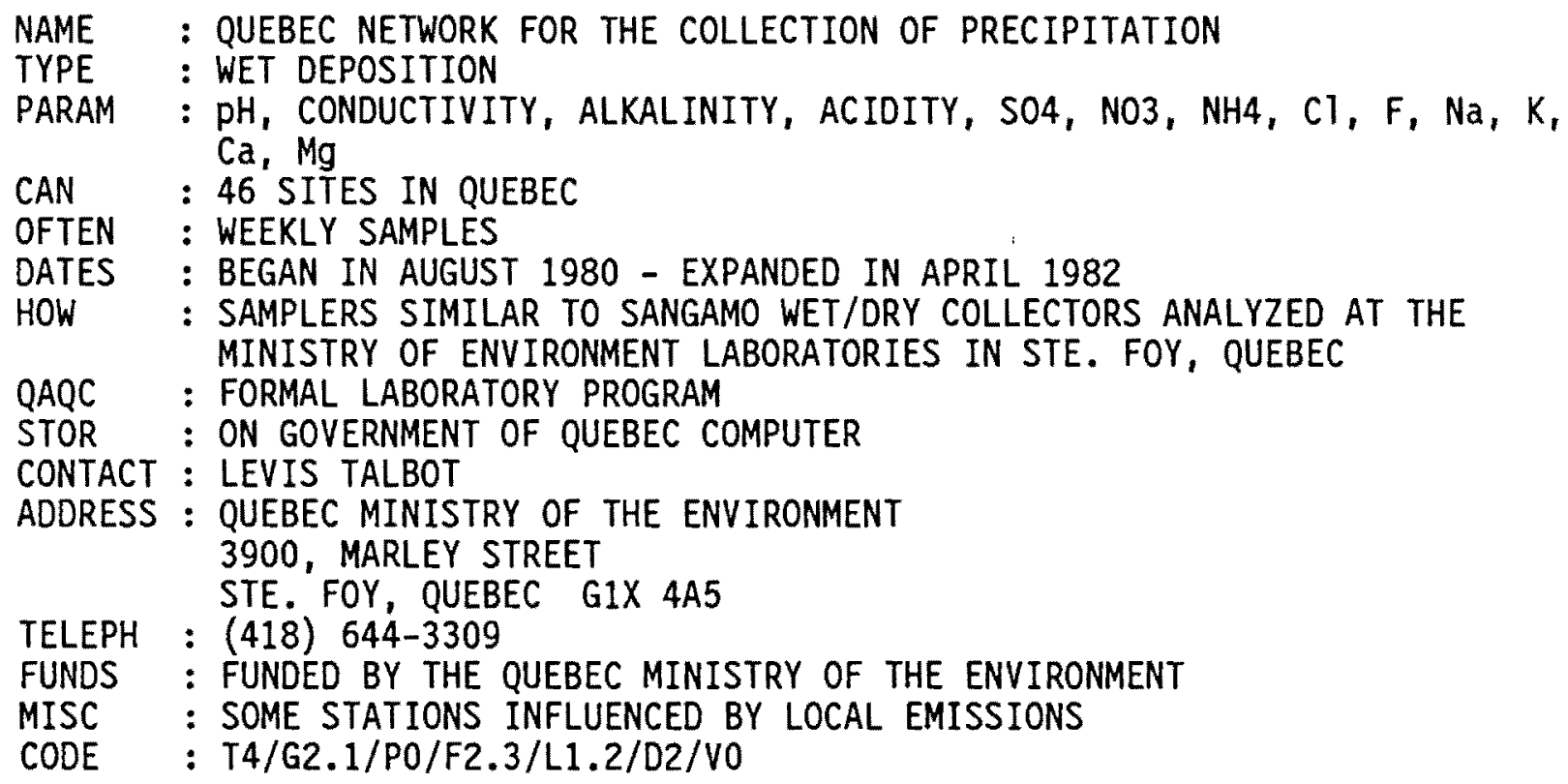


NAME : COASTAL FOG DEPOSITION MONITORING

TYPE : WET DEPOSITION

PARAM : FOG, RAIN, AND CANOPY THROUGHFALL CHEMISTRY ( $\mathrm{pH}$, CONDUCTIVITY, SO4, $\mathrm{N03}, \mathrm{NH} 4, \mathrm{Cl}, \mathrm{Na}, \mathrm{K}, \mathrm{Ca}, \mathrm{Mg}, \mathrm{F}$ )

US : SIX SITES IN MAINE - 4 COASTAL ISLANDS (ROQUE ISLAND, MT. DESERT ROCK, ISLE AU HAUT, DAMARISCOVE ISLAND), SUGAR LOAF MOUNTAIN, AND A SHIP MOORED IN PENOBSCOT BAY

OFTEN : EVENT BASIS JUNE THROUGH OCTOBER; LIMITED BASIS ON SHIP

DATES : JUNE - OCTOBER 1985

HOW : FOG SAMPLES COLLECTED FOR ENTIRE EVENT OR EVERY 5 HOURS, WHICHEVER CAME FIRST. ANALYSIS AT GEOLOGICAL SCIENCES LABORATORY AT UNIV. OF MAINE IN ORONO. NATIONAL ATMOSPHERIC DEPOSITION PROGRAM AND ENVIRONMENTAL PROTECTION AGENCY PROCEDURES USED IN LABORATORY.

QAQC : FORMAL LABORATORY PROGRAM; SAMPLE EXCHANGES WITH INSTITUTE FOR ENVIRONMENTAL STUDIES/CARY ARBORETUM.

STOR : AVAILABLE FROM PRINCIPAL CONTACT

CONTACT : R. JAGELS

ADDRESS : DEPARTMENT OF FOREST BIOLOGY

UNIVERSITY OF MAINE

ORONO, ME 04469

TELEPH : (207) 581-2881

FUNDS : UNIVERSITY OF MAINE AND U.S. GEOLOGICAL SURVEY

CODE : T4/G1.1/P0/F4.2/L2.1/D2/V1

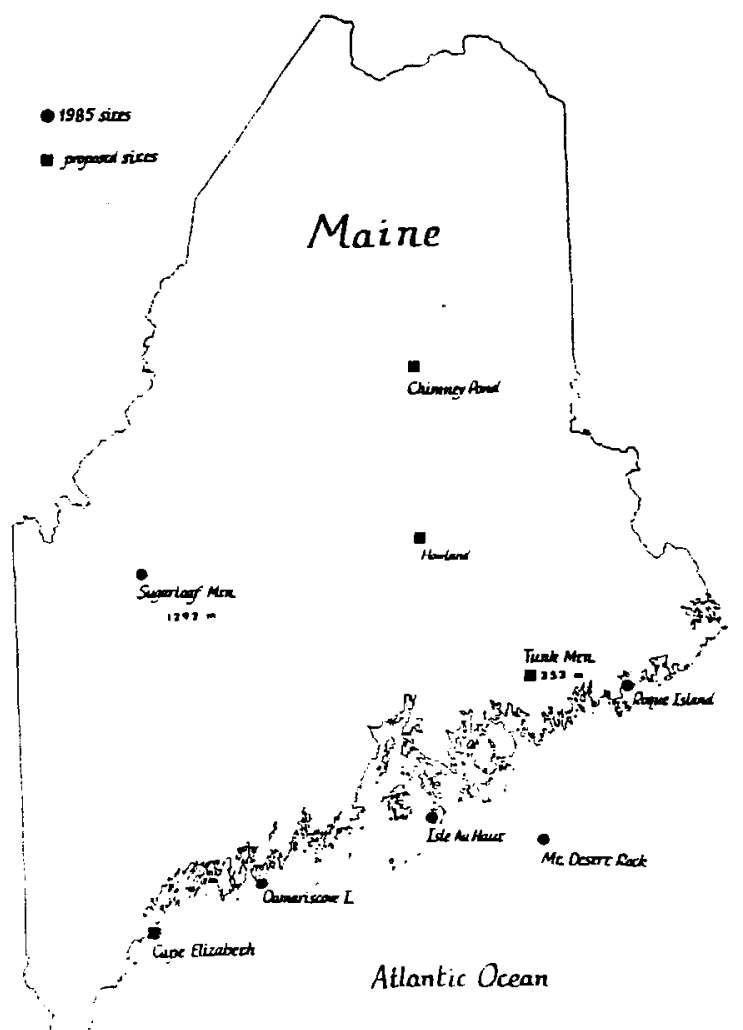



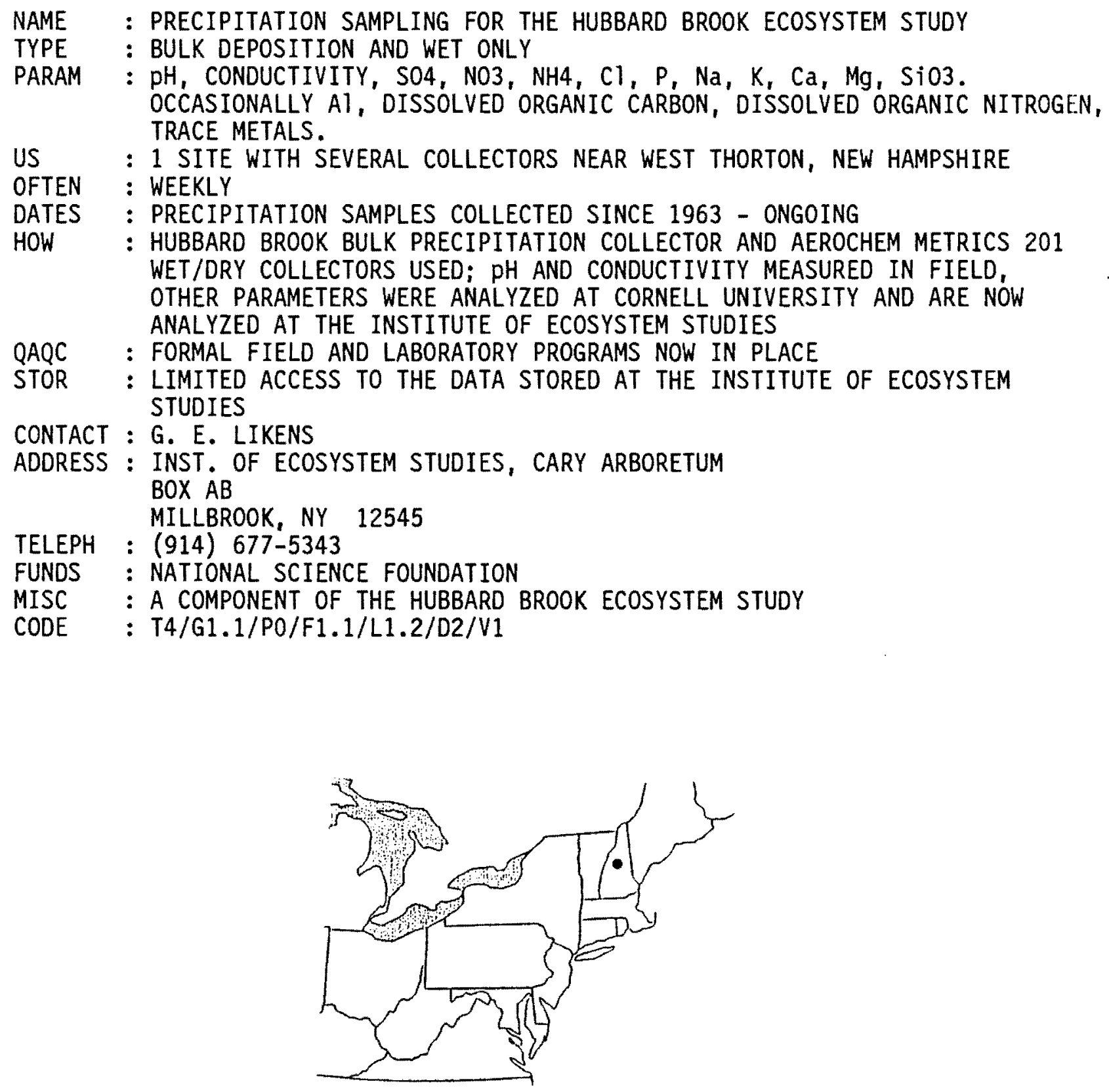
NAME : ENVIRONMENTAL MEASUREMENTS LABORATORY DEPOSITION CHEMISTRY STUDY TYPE : WET DEPOSITION

PARAM : pH, CONDUCTIVITY, S04, N03, NH4, Cl, PO4, $\mathrm{Na}, \mathrm{K}, \mathrm{Ca}, \mathrm{Mg}$; DURING 1978-1981, TRACE METAL ANALYSIS 4 TIMES PER YEAR

US : INITIALLY 7 SITES NATIONALLY, NOW 4 SITES IN NEW YORK AND NEW JERSEY

OFTEN : MONTHLY WET, DRY AND BULK DEPOSITION COLLECTED 1976-1981. DAILY SAMPLING OF PRECIPITATION EVENTS SINCE 1981

DATES : BEGAN IN JULY 1976, RESTRICTED TO NEW YORK-NEW JERSEY AREA AFTER JUNE 1981

HOW : HASL AND AEROCHEM METRICS SAMPLERS - ANALYZED BY COMBUSTION ENGINEERING (EMS. INC)

QAQC : FORMAL PROGRAM FOR LABORATORY QUALITY ASSURANCE

STOR : ON COMPUTER AT EML OFFICE

CONTACT : HERB FEELY

ADDRESS : DEPARTMENT OF ENERGY

ENVIRONMENTAL MEASUREMENTS LABORATORY

376 HUDSON STREET

NEW YORK, NY 10014

TELEPH : (212) 620-3627

FUNDS : DEPARTMENT OF ENERGY

CODE : T4/G1.1/P0/F1.2/L1.2/D2/V1

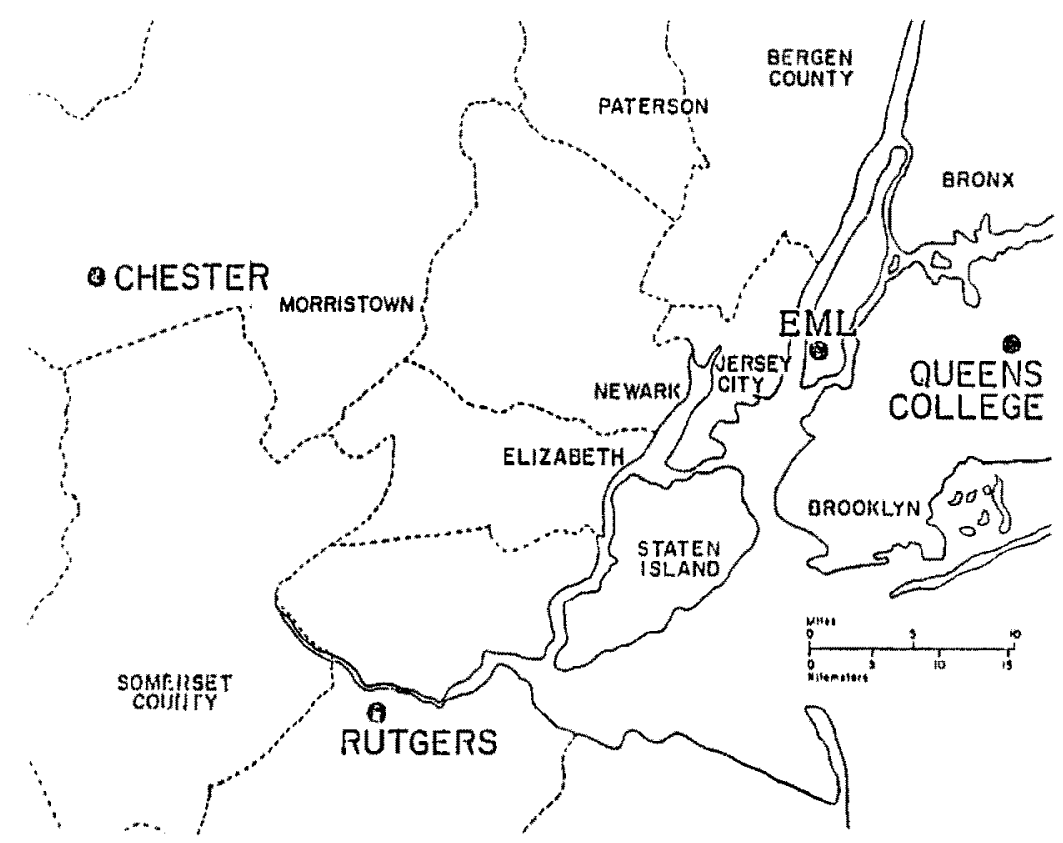




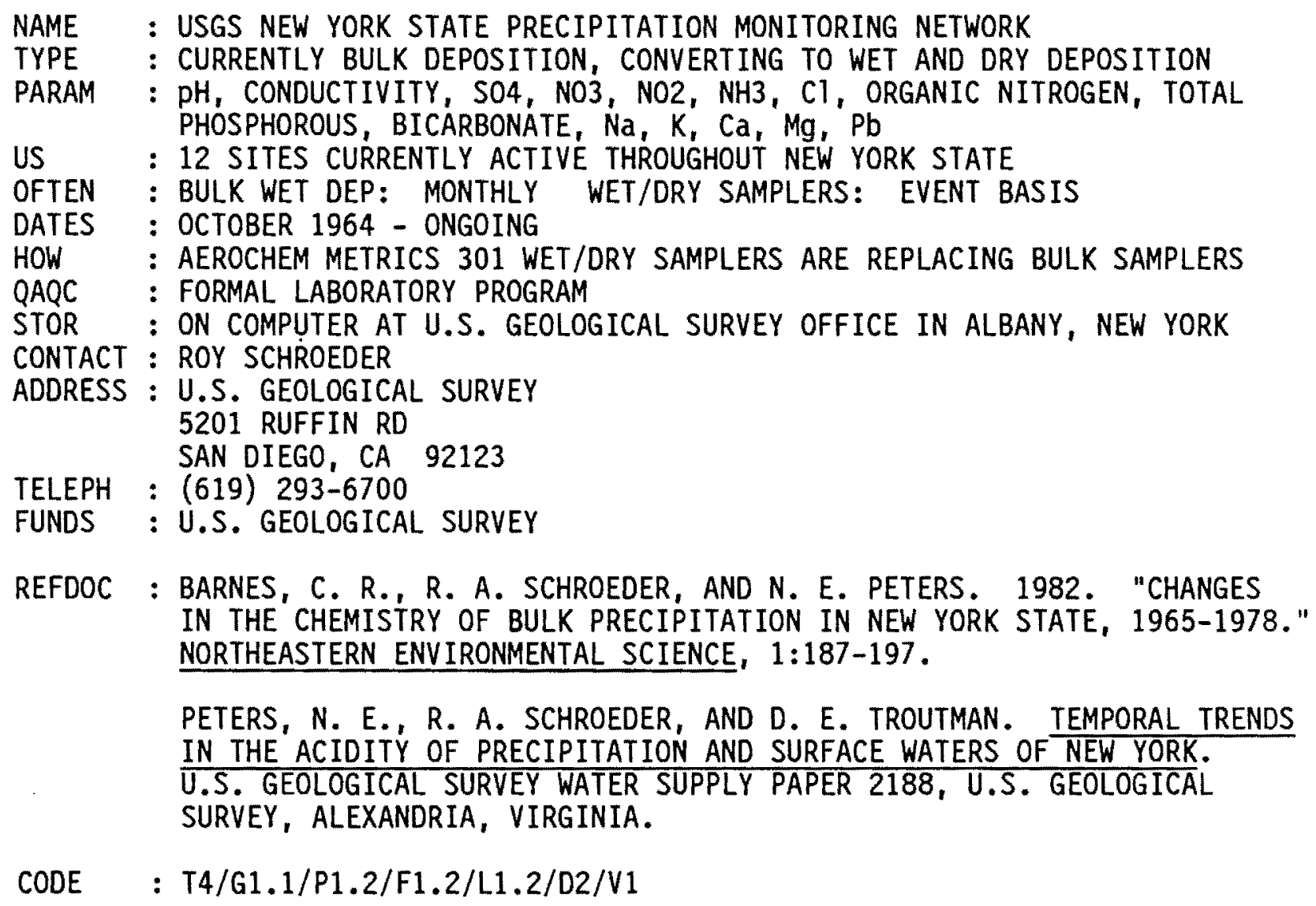




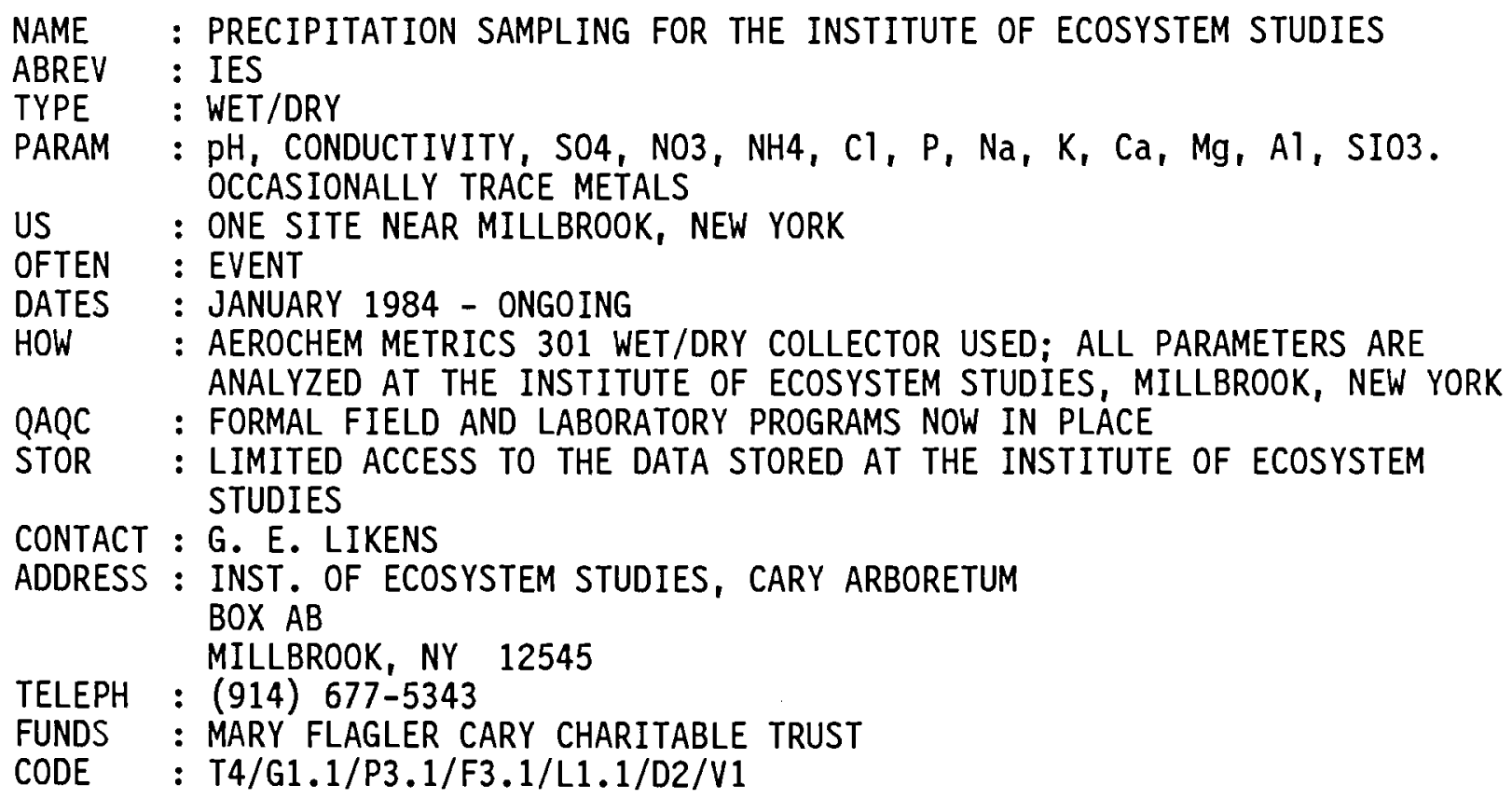




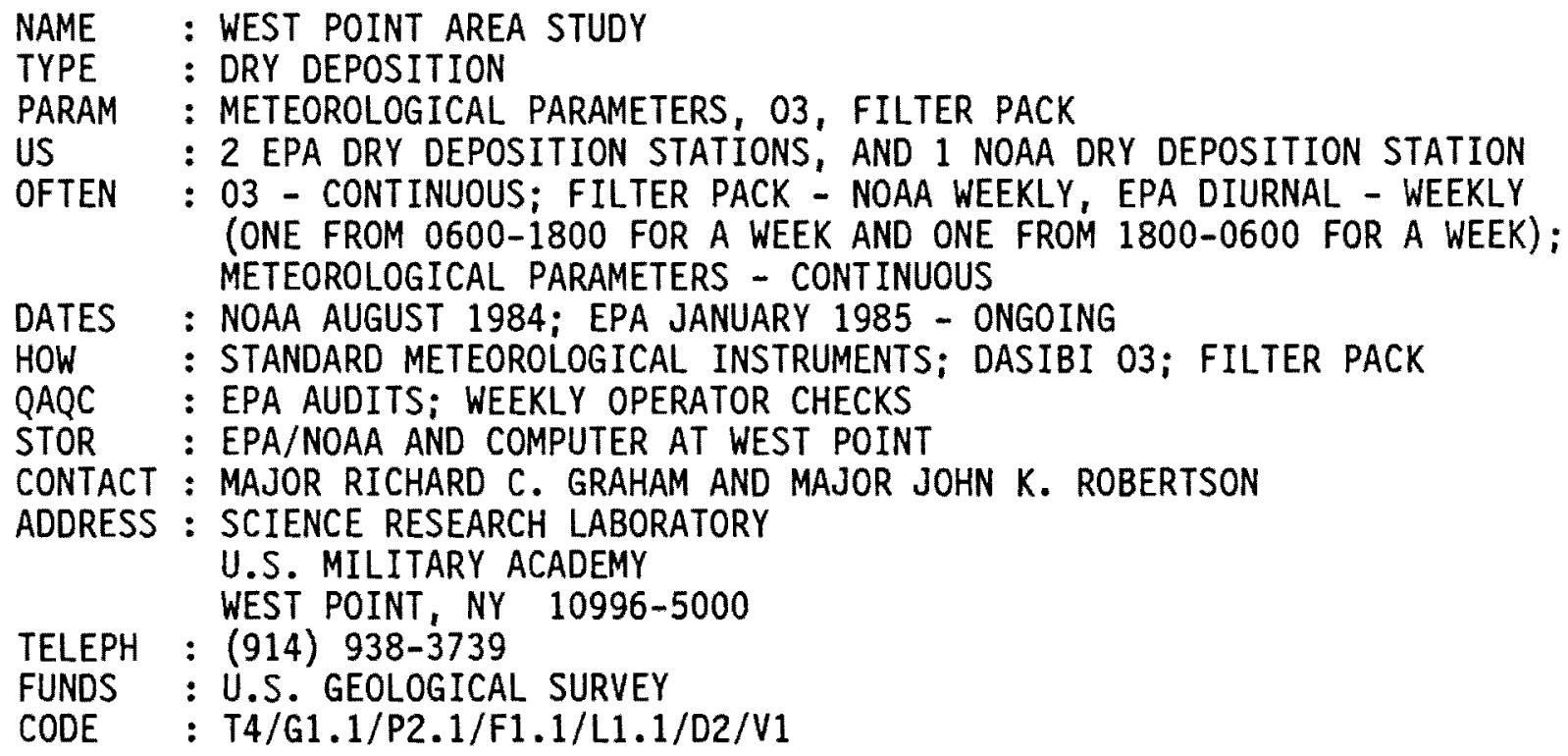

FUNDS : U.S. GEOLOGICAL SURVEY

CODE : T4/G1.1/P2.1/F1.1/L1.1/D2/V1

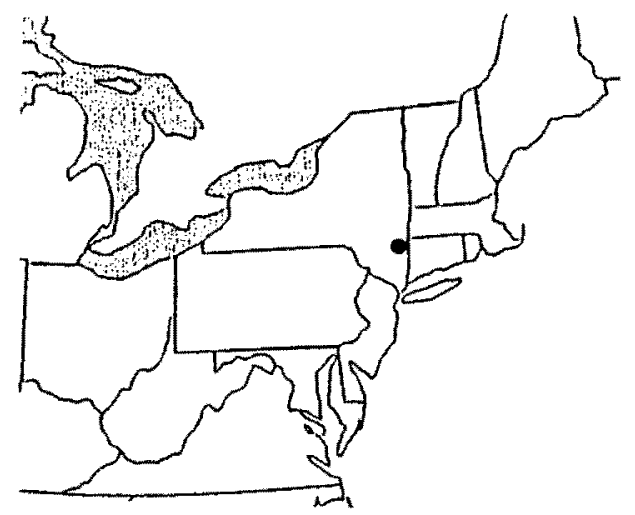



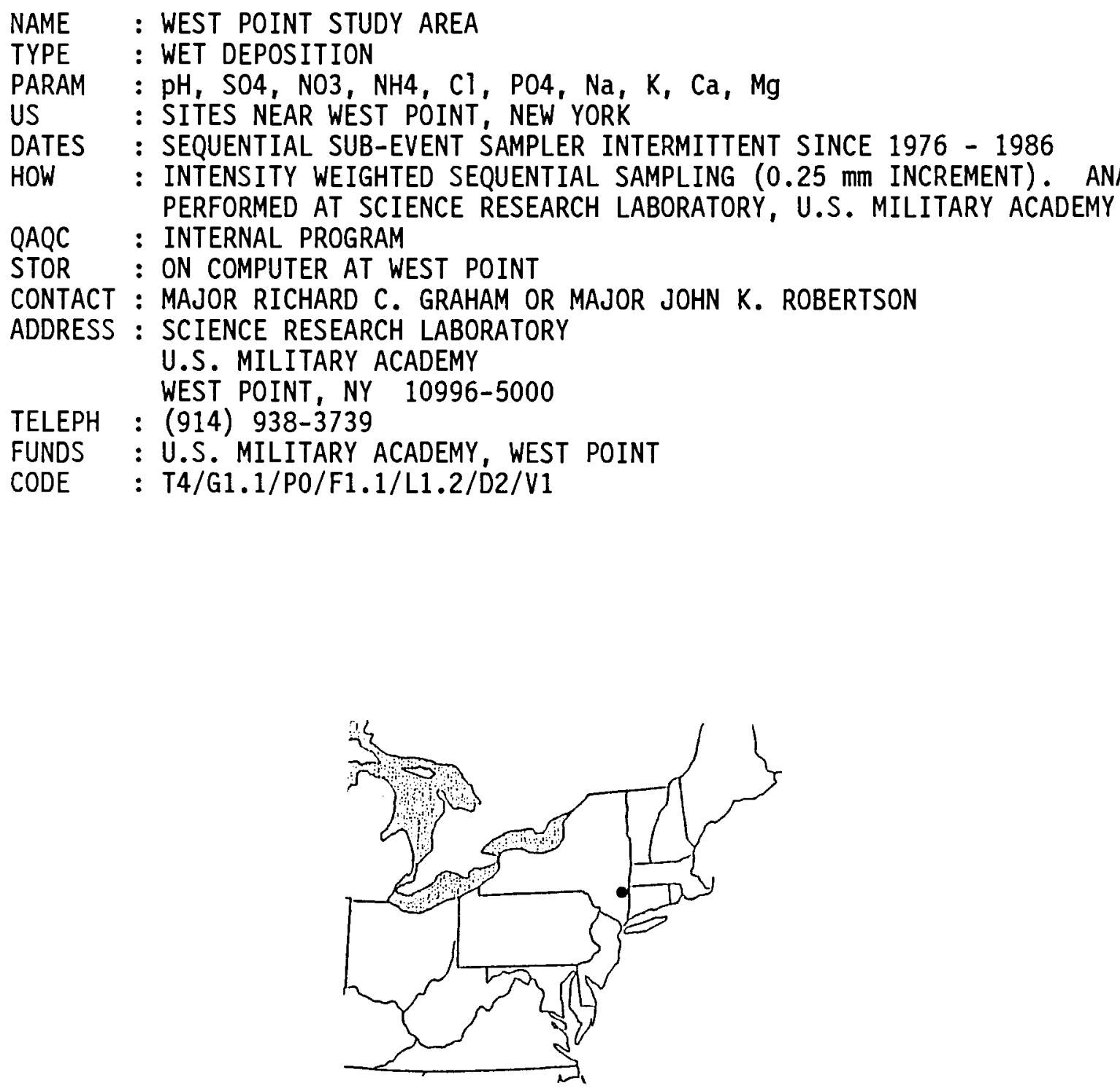

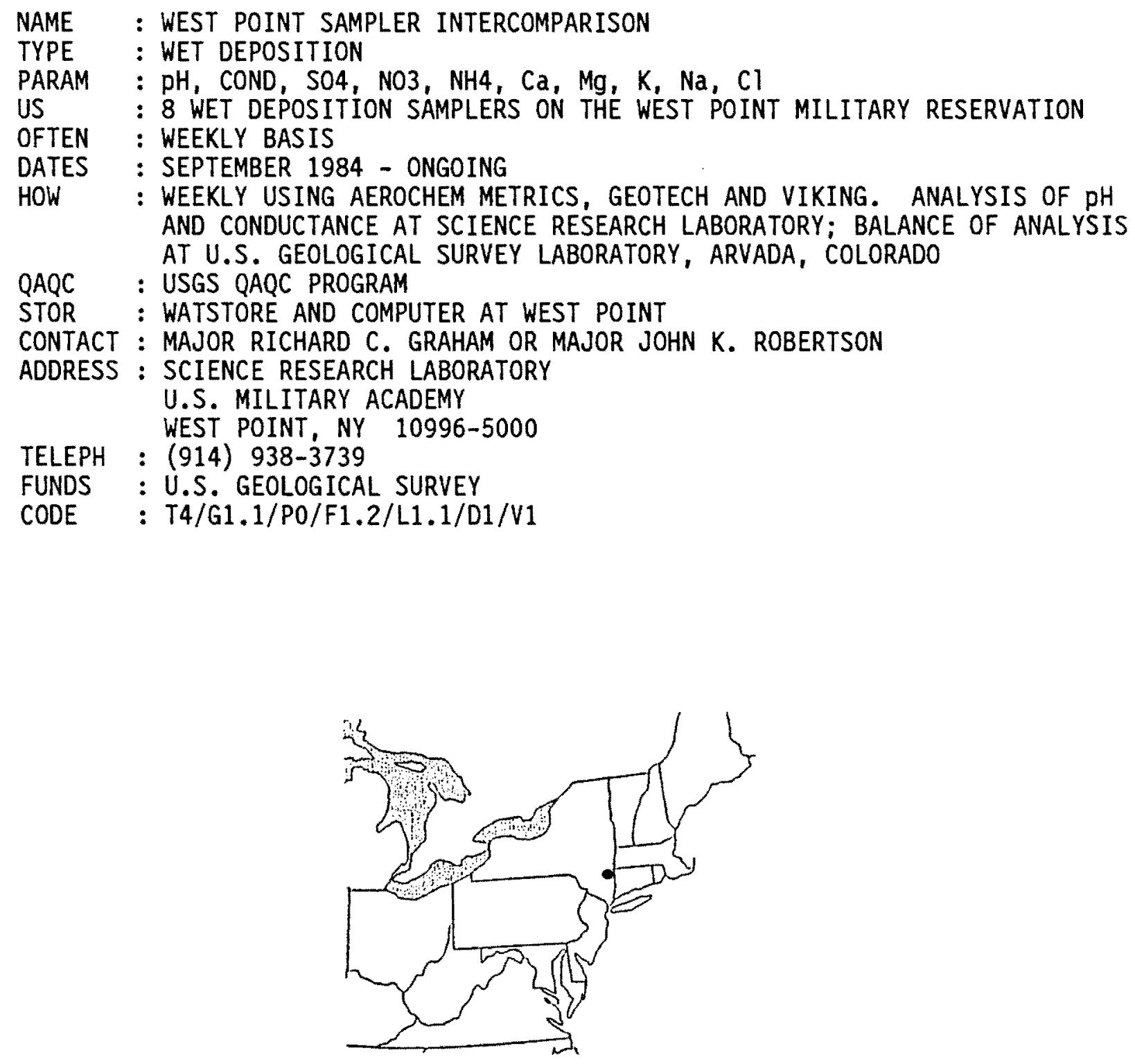

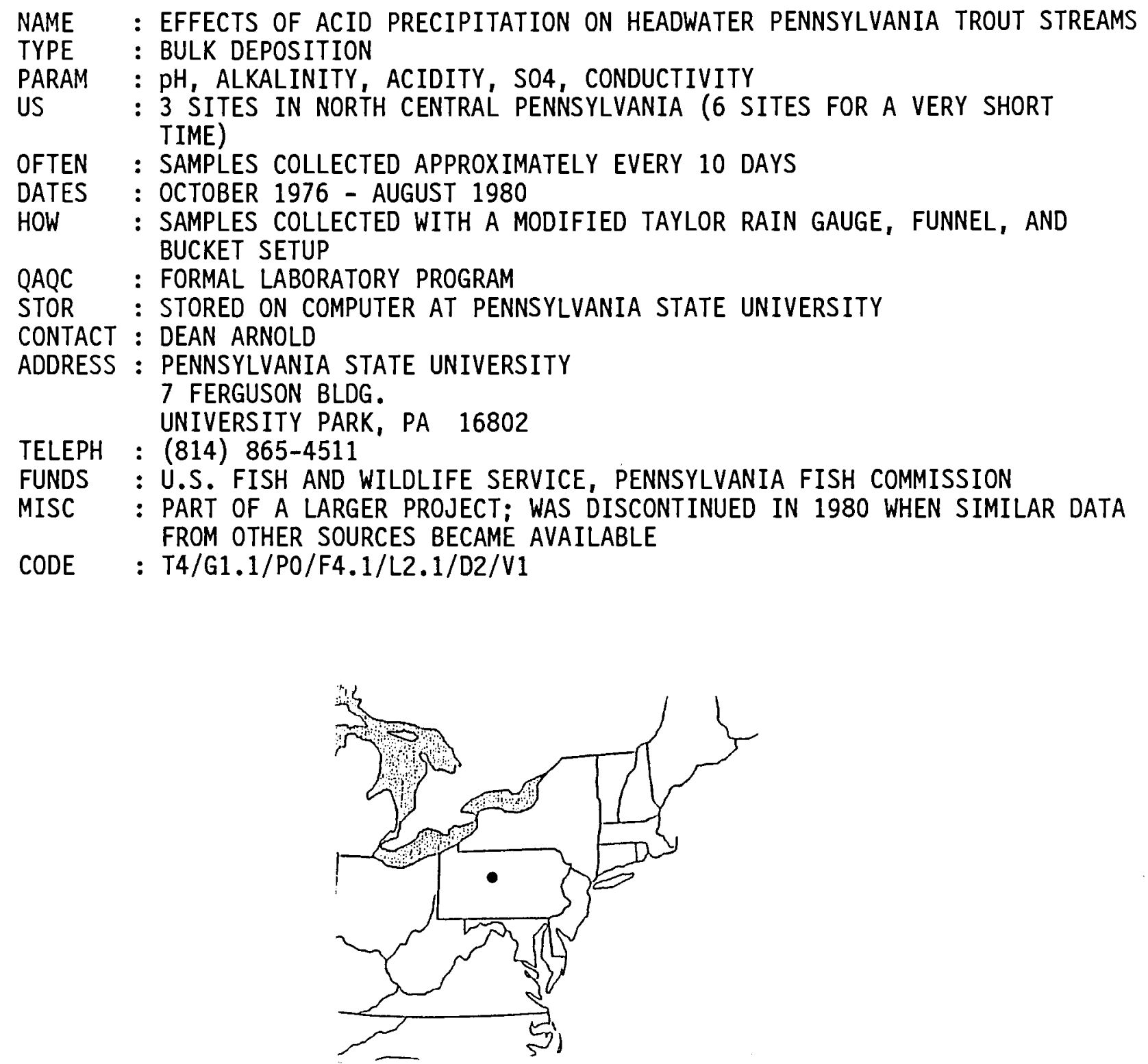


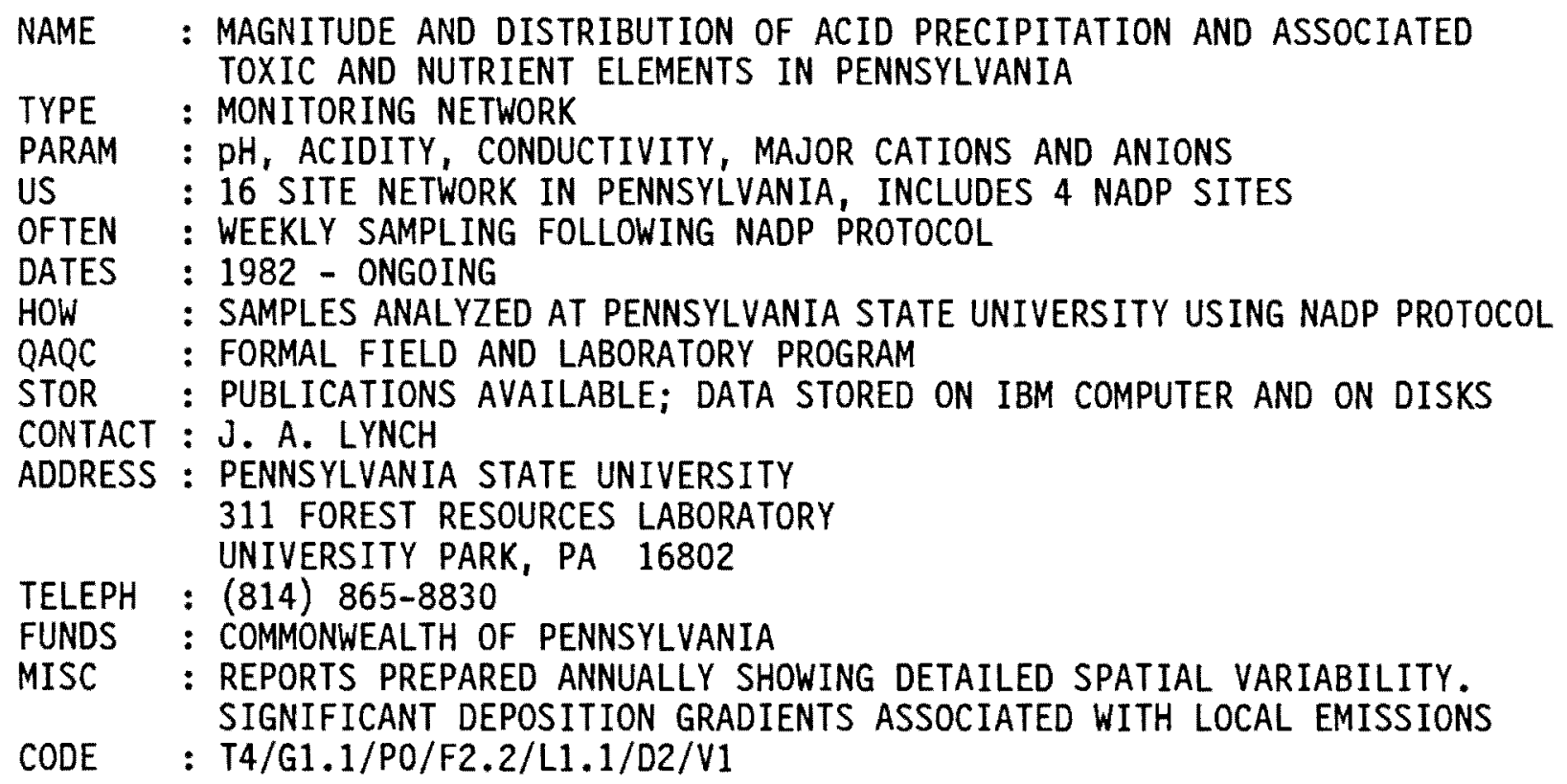
SIGNIFICANT DEPOSITION GRADIENTS ASSOCIATED WITH LOCAL EMISSIONS 

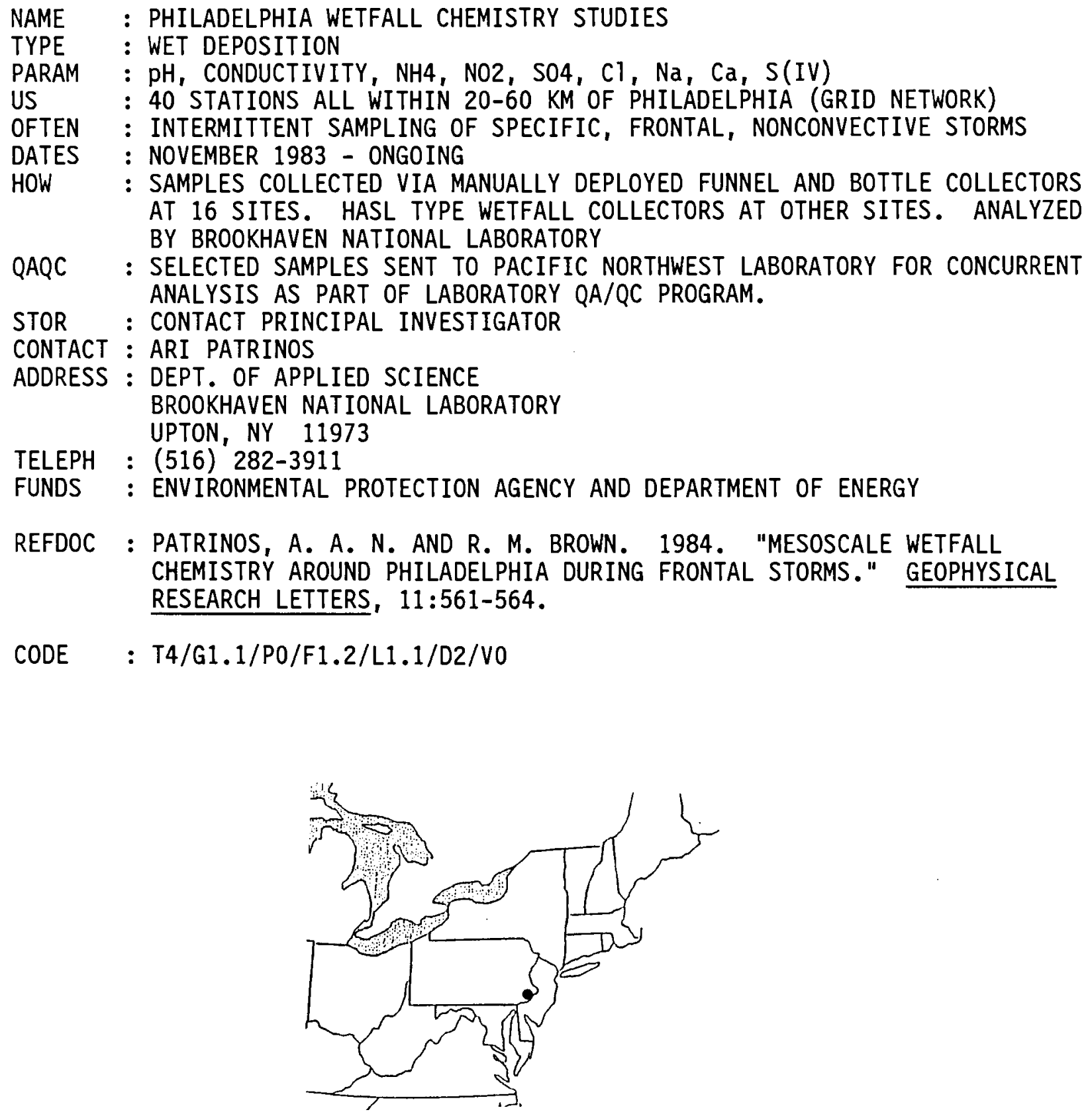


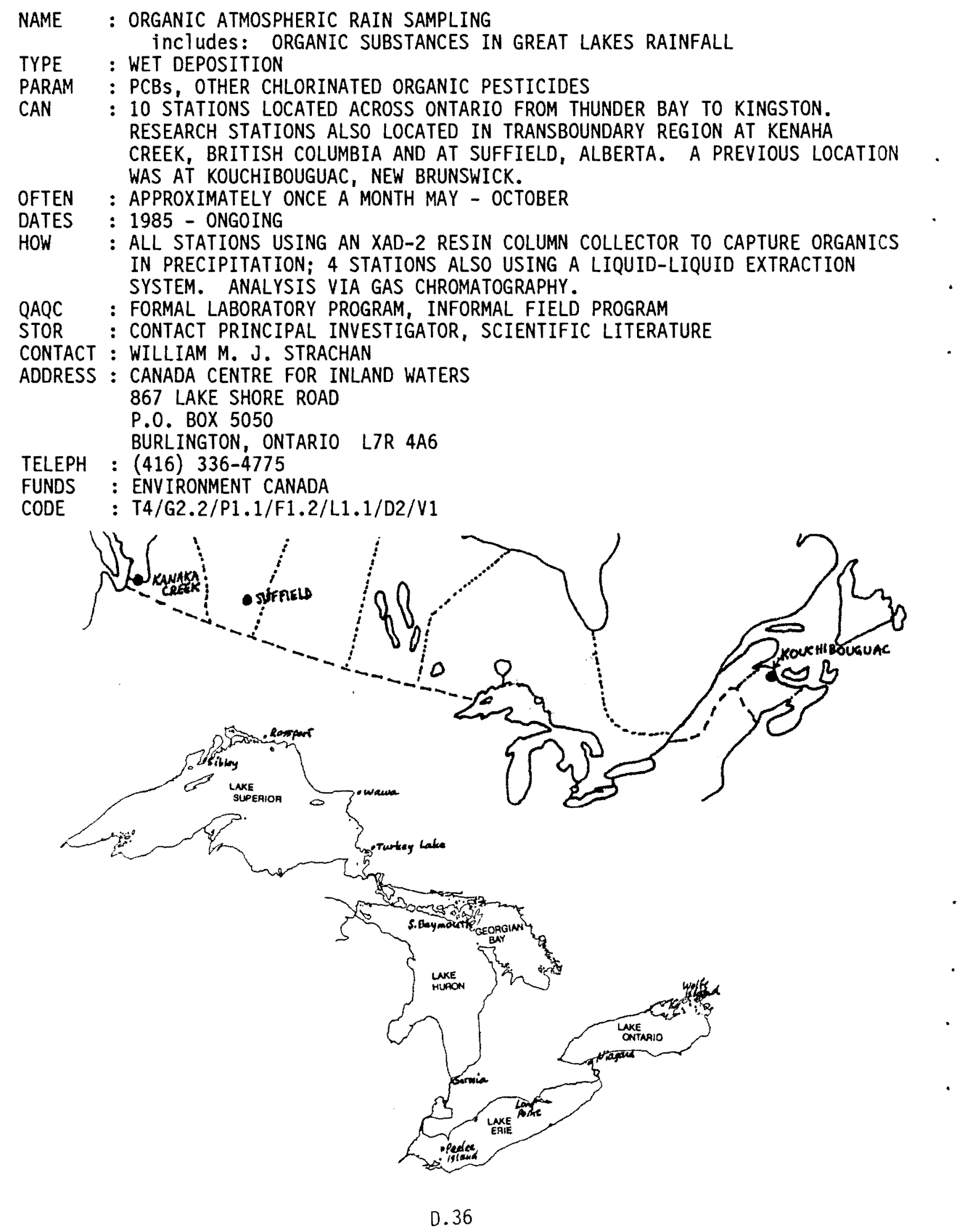




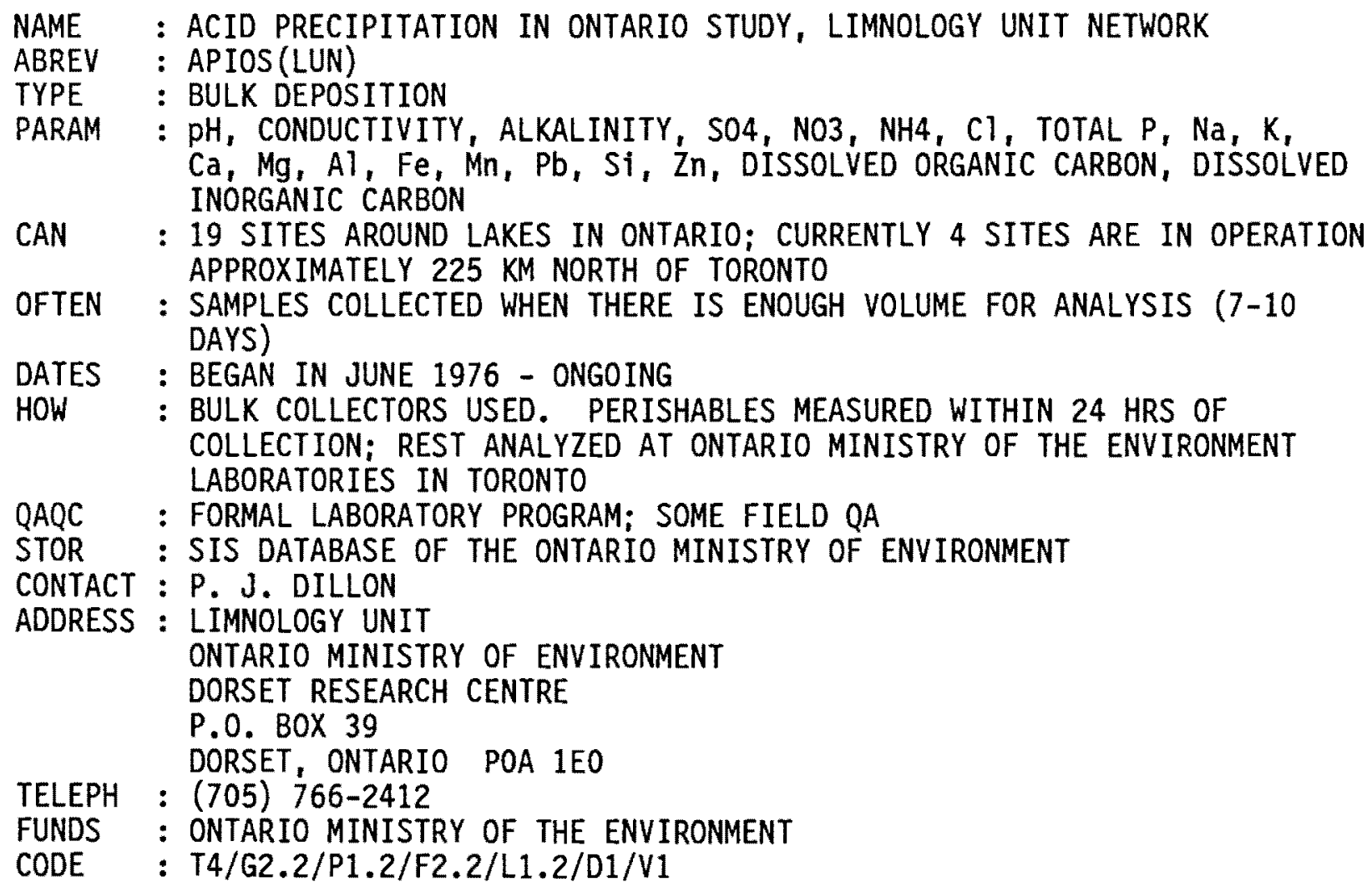



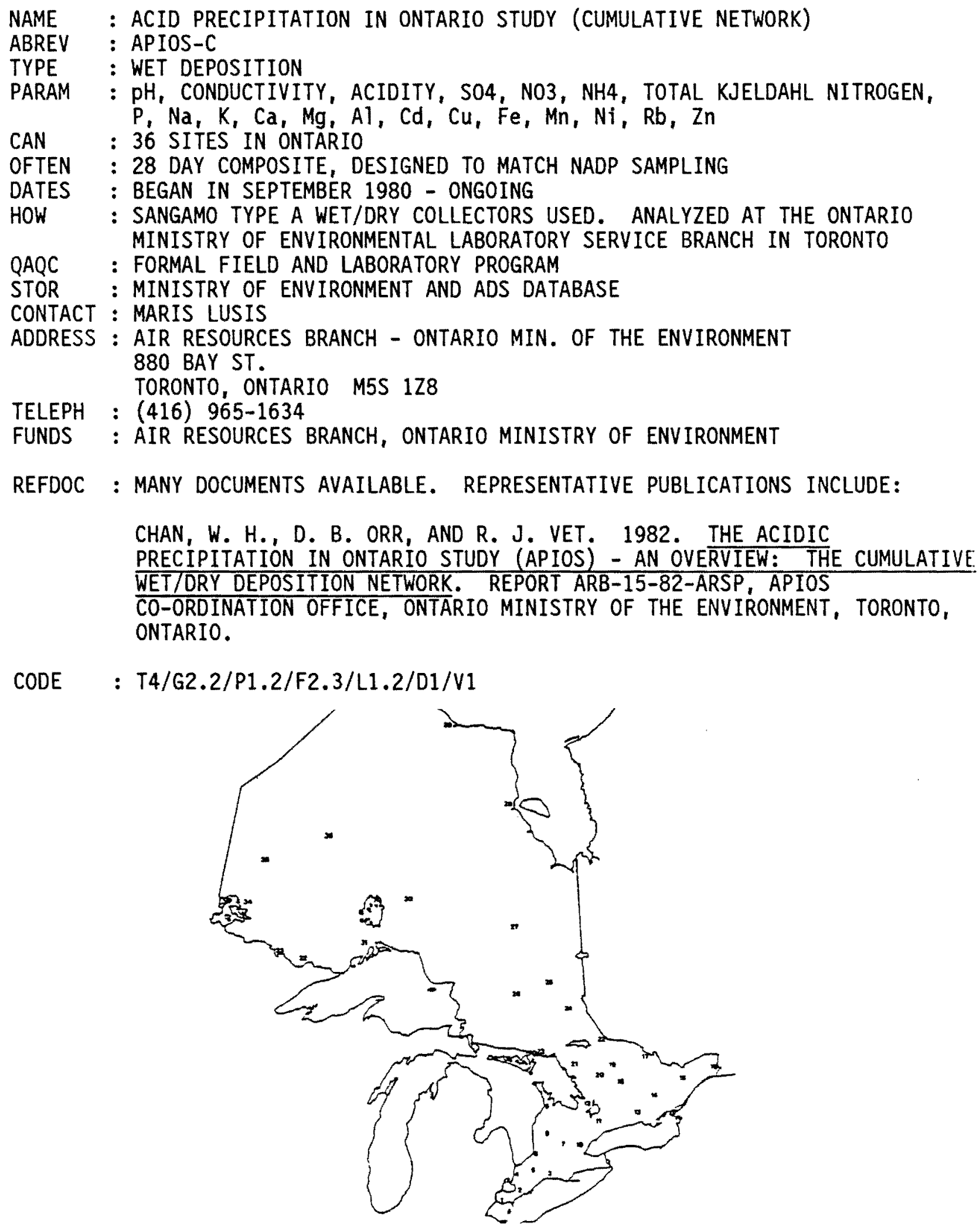

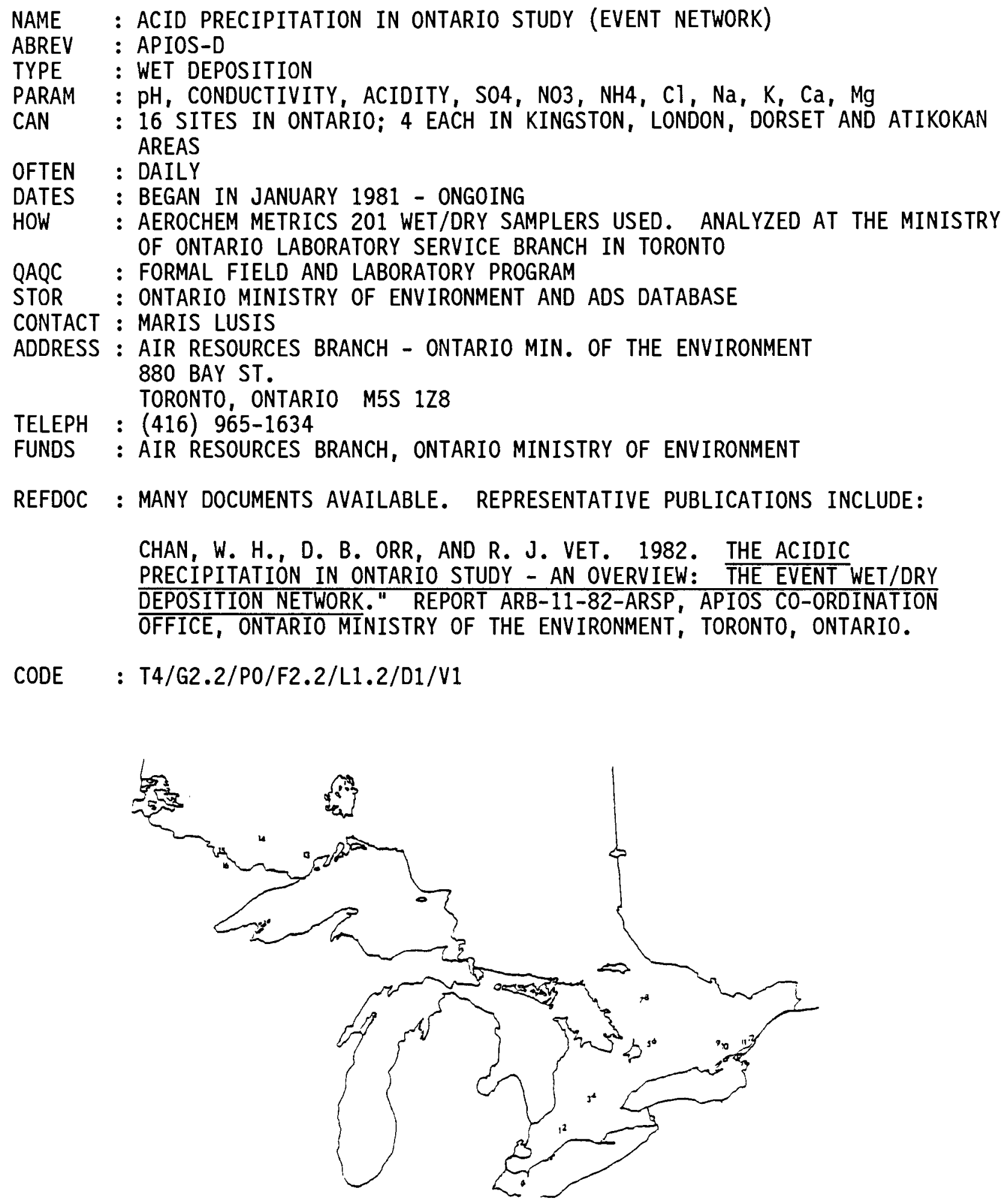

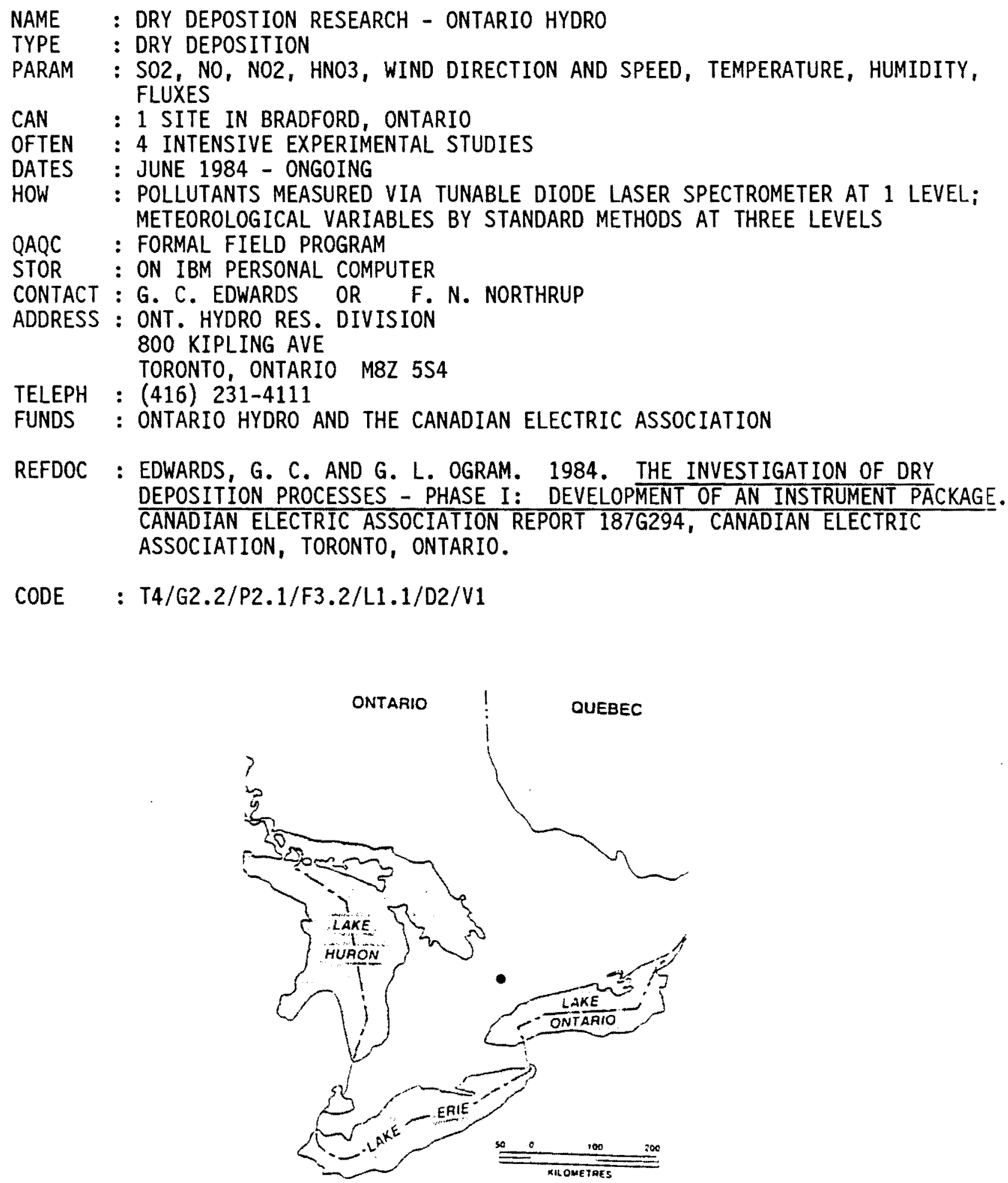

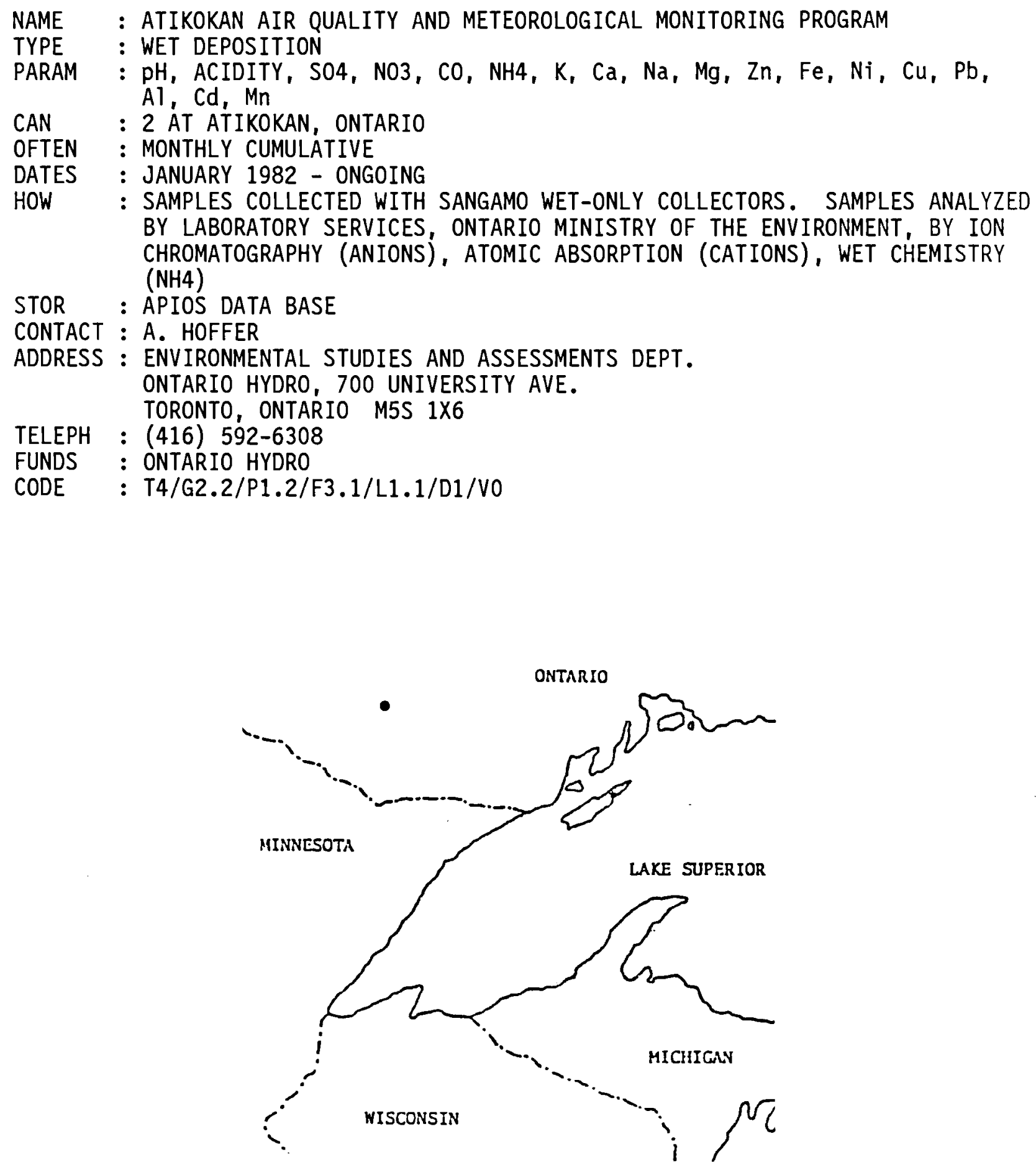

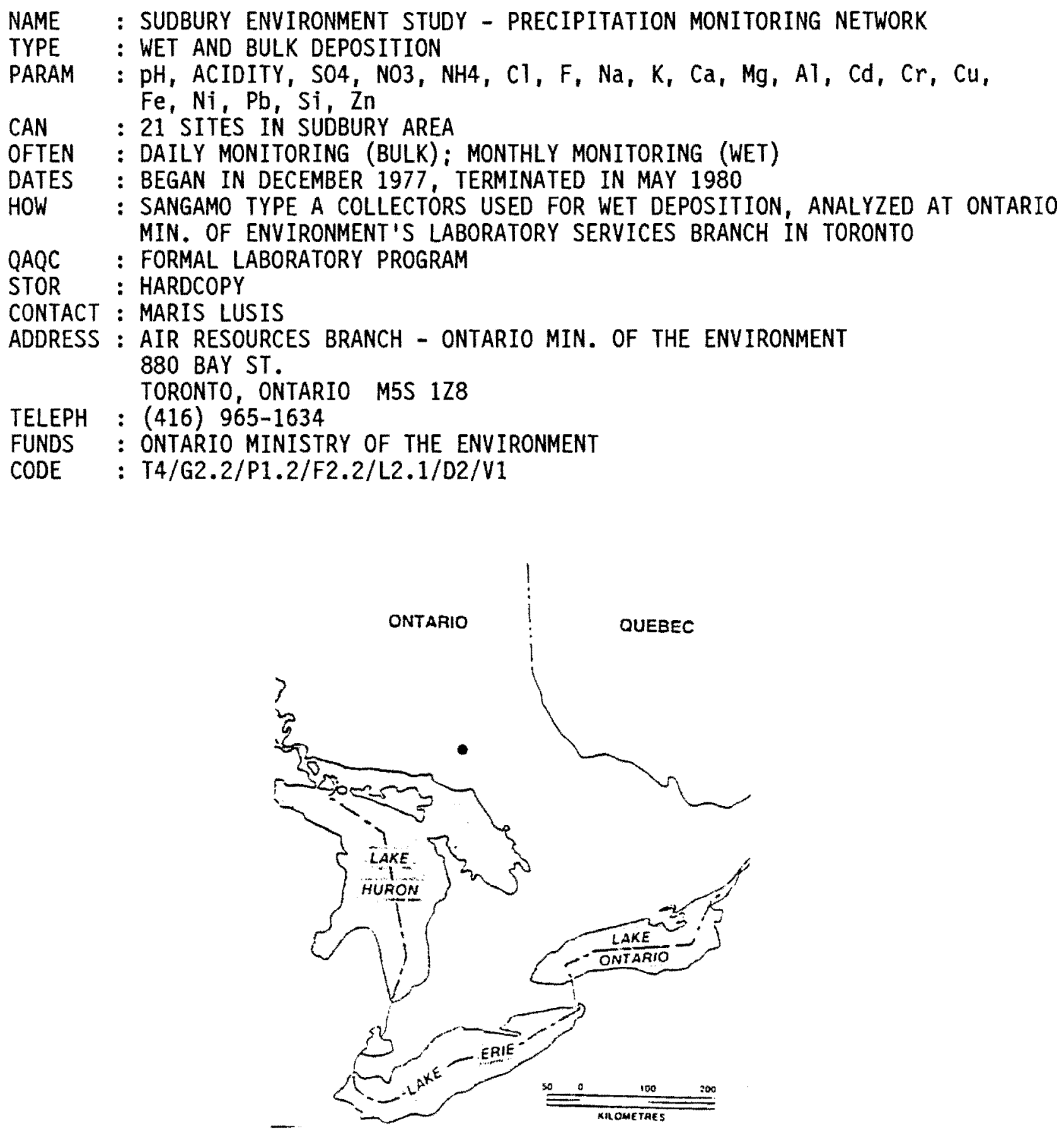

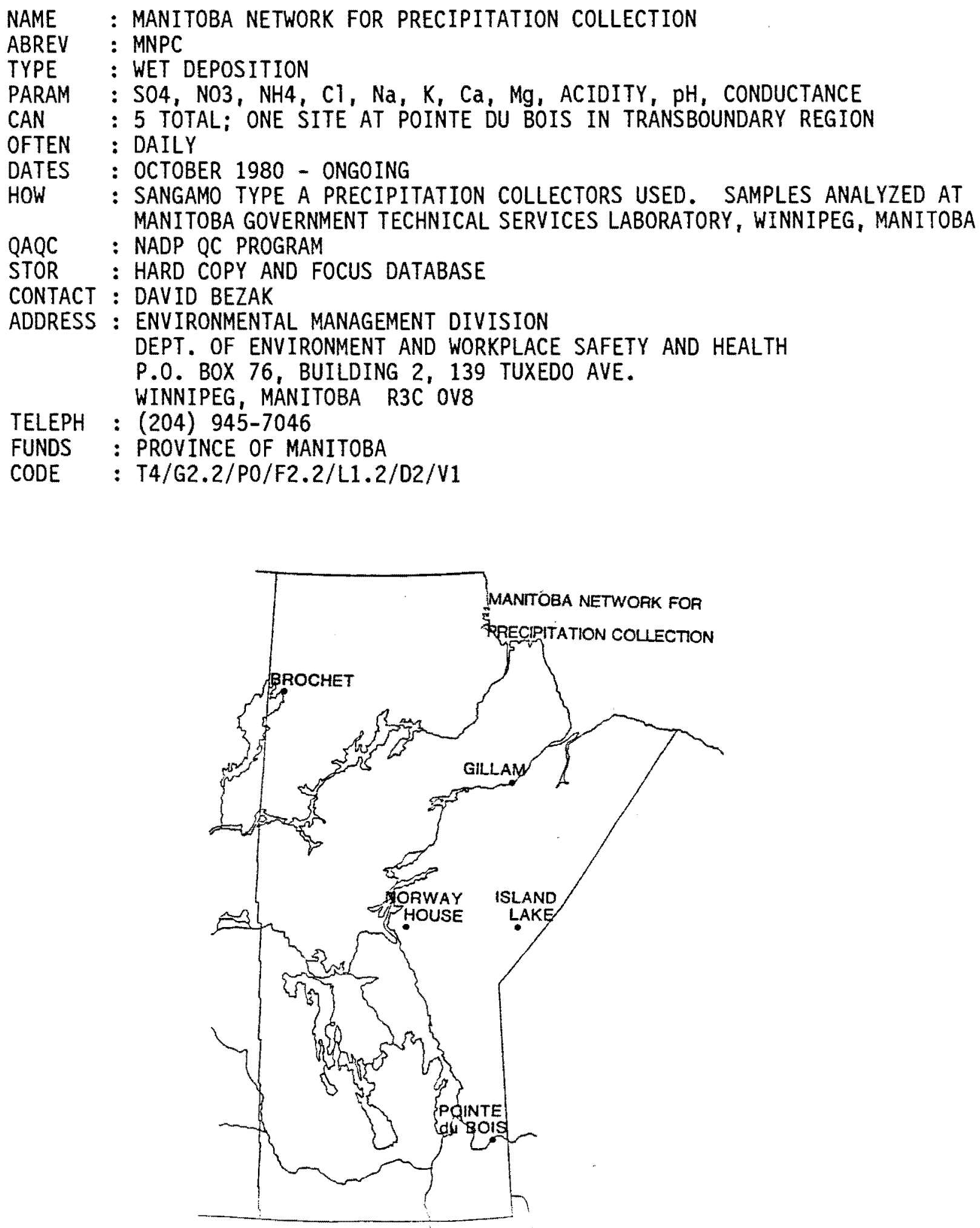


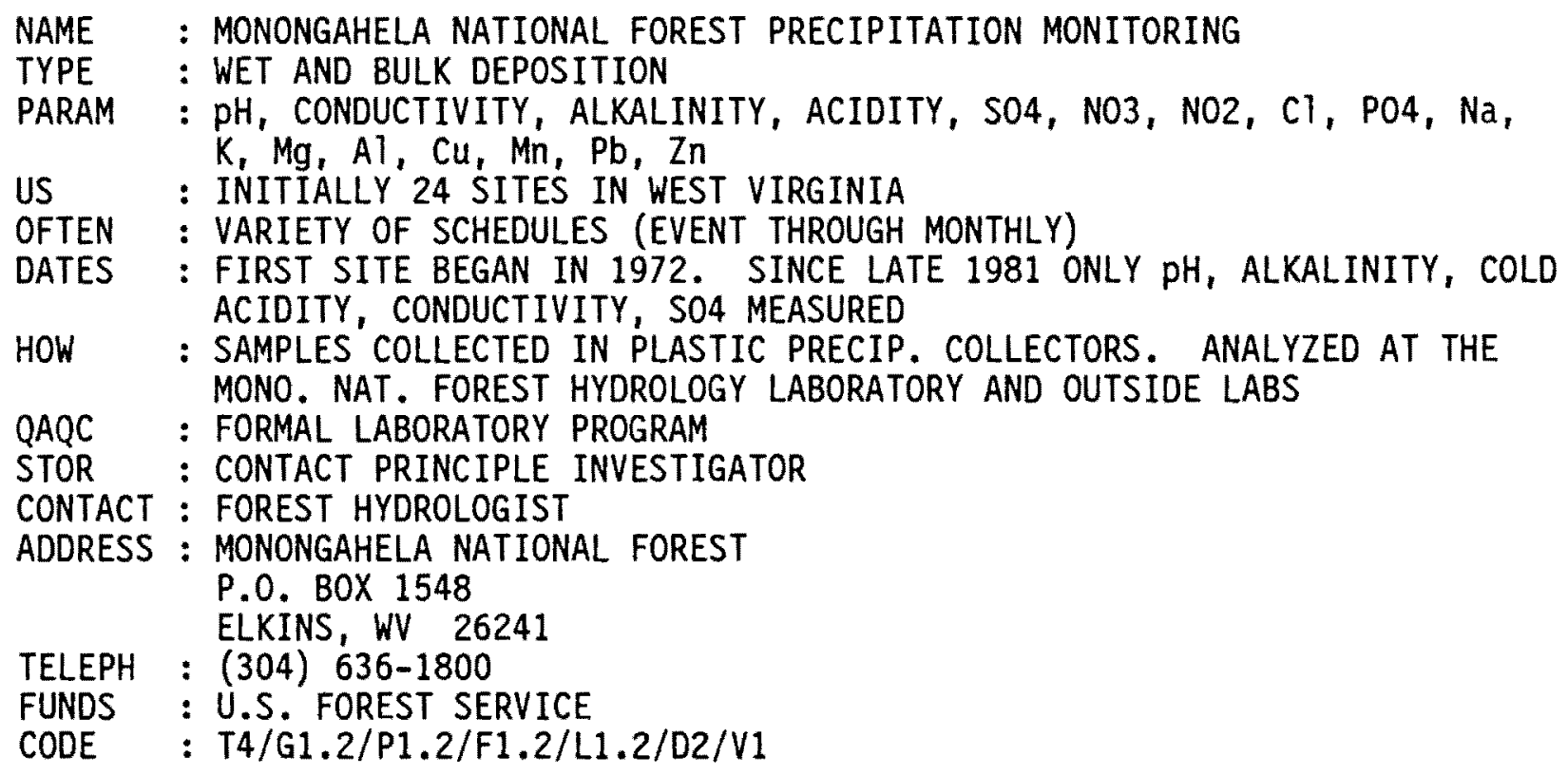



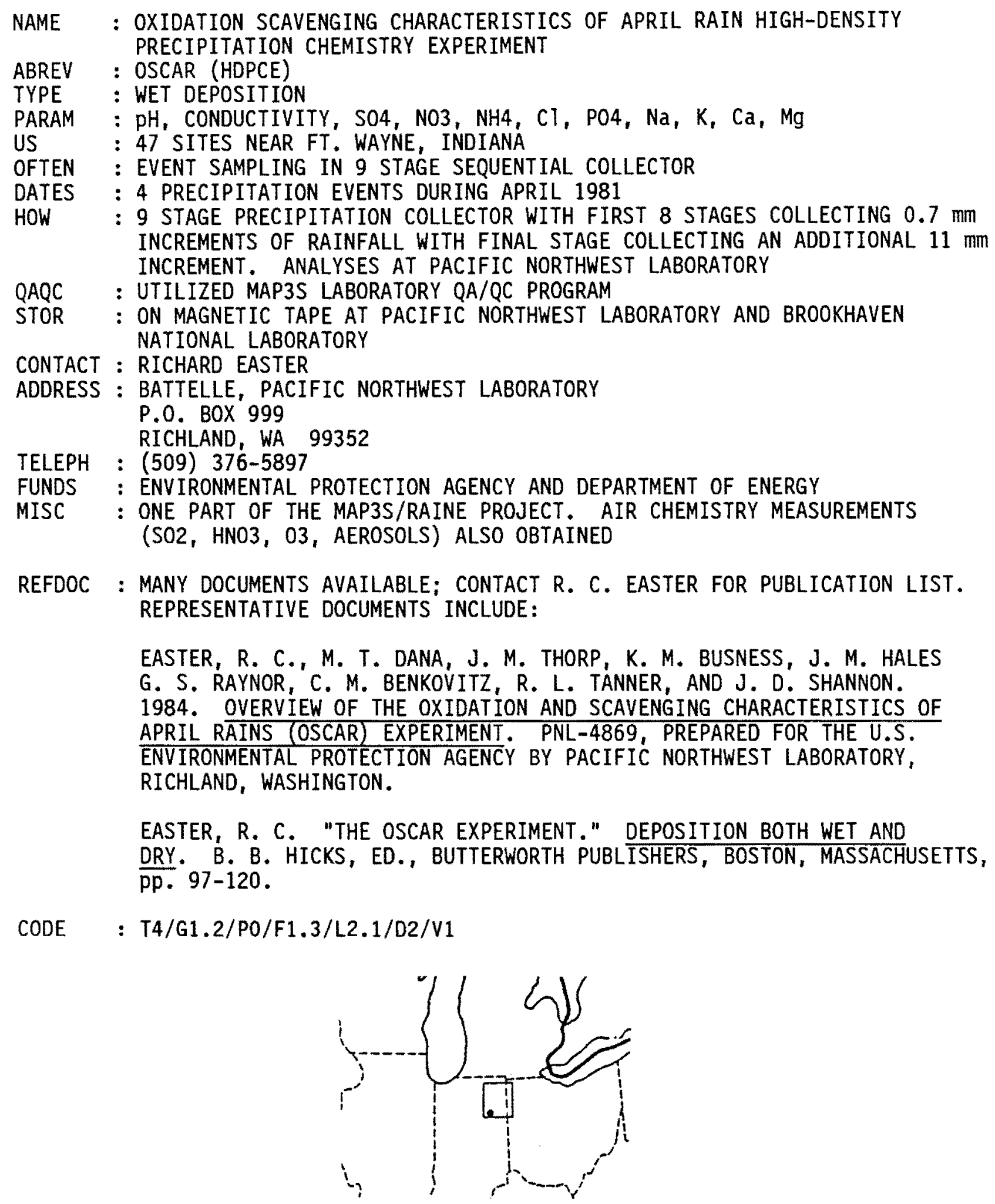


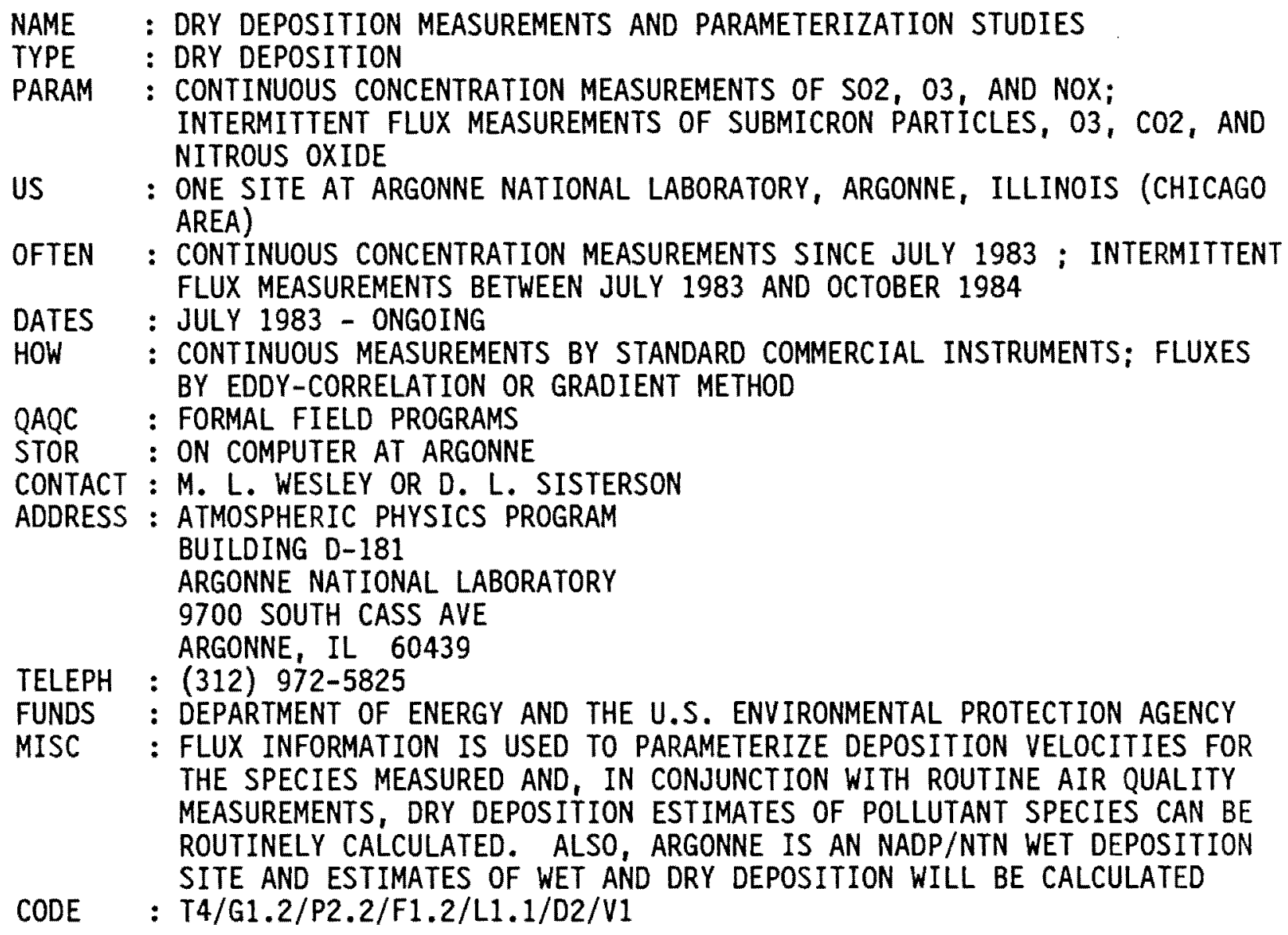
THE SPECIES MEASURED AND, IN CONJUNCTION WITH ROUTINE AIR QUALITY MEASUREMENTS, DRY DEPOSITION ESTIMATES OF POLLUTANT SPECIES CAN BE ROUTINELY CALCULATED. ALSO, ARGONNE IS AN NADP/NTN WET DEPOSITION SITE AND ESTIMATES OF WET AND DRY DEPOSITION WILL BE CALCULATED CODE : T4/G1.2/P2.2/F1.2/L1.1/D2/V1

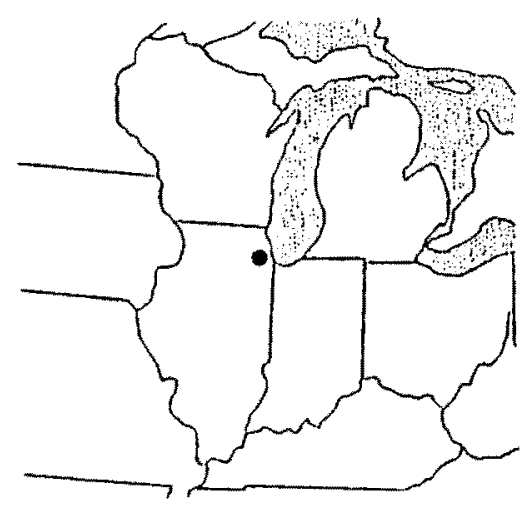


NAME : MINNESOTA/WISCONSIN POWER SUPPLIERS GROUP (M/WPSG) PRECIPITATION MONITORING PROGRAM

TYPE : WET AND DRY DEPOSITION

PARAM : WET: $\mathrm{pH}, \mathrm{SO4}, \mathrm{N03}, \mathrm{N} 02, \mathrm{NH} 4, \mathrm{Br}, \mathrm{Cl}, \mathrm{F}, \mathrm{P} 04, \mathrm{NA}, \mathrm{K}, \mathrm{Ca}, \mathrm{Mg}, \mathrm{A1}, \mathrm{B}$, $\mathrm{Cu}, \mathrm{Fe}, \mathrm{Mn}, \mathrm{Ni}, \mathrm{Pb}, \mathrm{Zn}$

DRY: As, Ba, Hg, Pb, F, Cl, N02, P04, Br, N03, S04, K, Ca, V, Mn, $\mathrm{Fe}, \mathrm{Zn}, \mathrm{NH} 4, \mathrm{~S}, \mathrm{Al}, \mathrm{Si}$

US $\quad: 7$ IN MINNESOTA AND IN WISCONSIN

OFTEN : MID-APRIL TO LATE OCT. WET: SUB-EVENT BASIS DRY: 24 H EVERY 6 DAYS

DATES : BEGAN IN 1977, ENDED 1985 [LAMBERTON (1981 AND 1982), ALMA (1981 AND 1982), SHERBURNE (1981 - 1985, UNREFRIGERATED SAMPLES 1977 - 1980), WRIGHT (1981 - 1985, UNREFRIGERATED SAMPLES 1977 - 1980), GRAND RAPIDS (1) (1981 AND 1982), GRAND RAPIDS (2) (1981), SANDSTONE (1983 - 1985), ELY (1981 - 1985)]

HOW : UNIV. OF MINNESOTA DESIGNED WET/DRY SAMPLER. SAMPLES WERE ANALYZED AT UNIV. OF MINNESOTA AND AT INTERPOLL INC.

QAQC : FORMAL FIELD AND LABORATORY PROGRAMS

STOR : HARDCOPY

CONTACT : BOB EVANS

ADDRESS : NORTHERN STATES POWER CORP. 414 NICOLLET MALL

MINNEAPOLIS, MN 55401

TELEPH : (612) 330-6906

FUNDS : MINNESOTA/WISCONSIN POWER SUPPLIES GROUP, NORTHERN STATES POWER CORP. CODE : T4/G1.2/P1.2/F3.2/L2.2/D2/V1

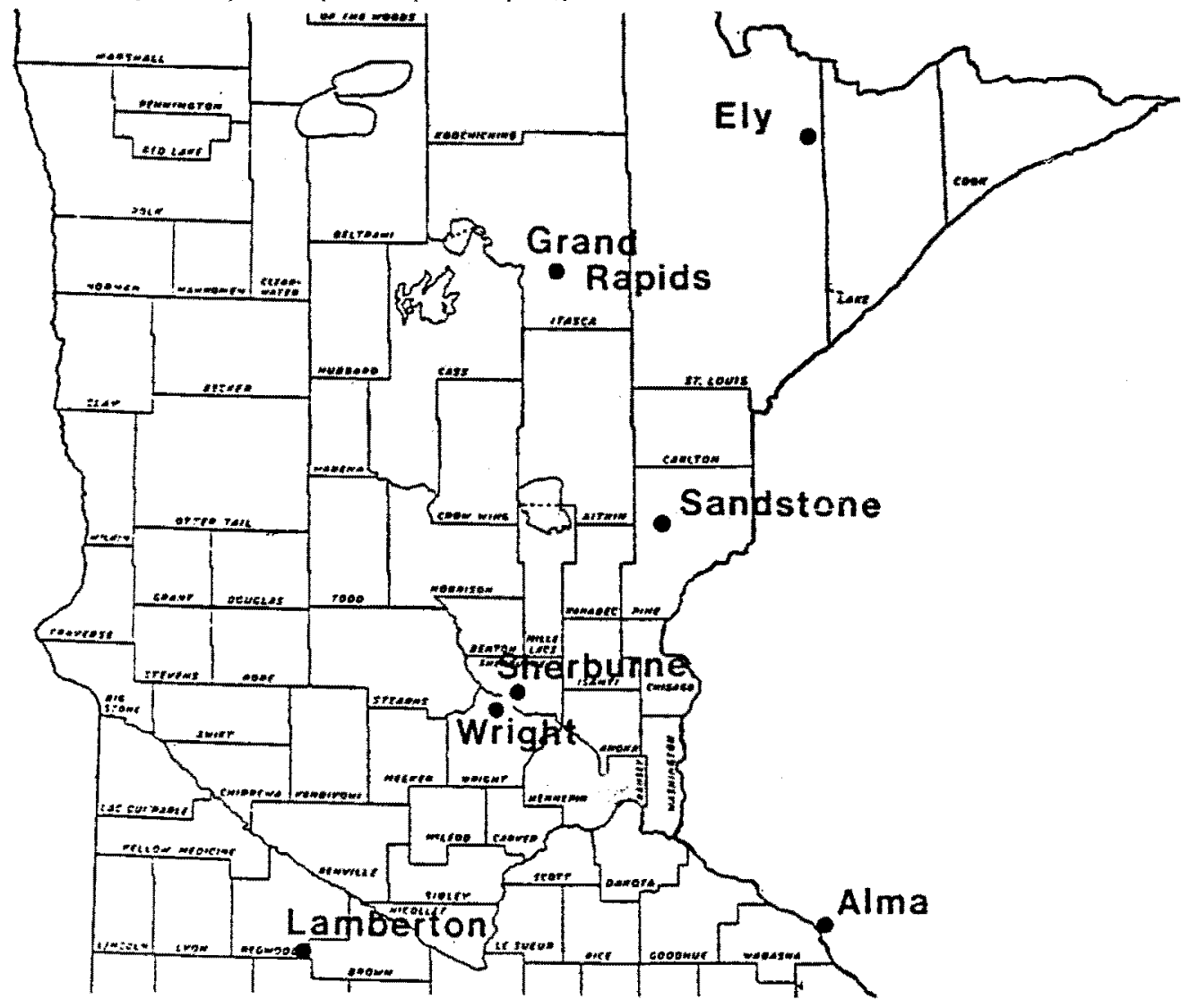



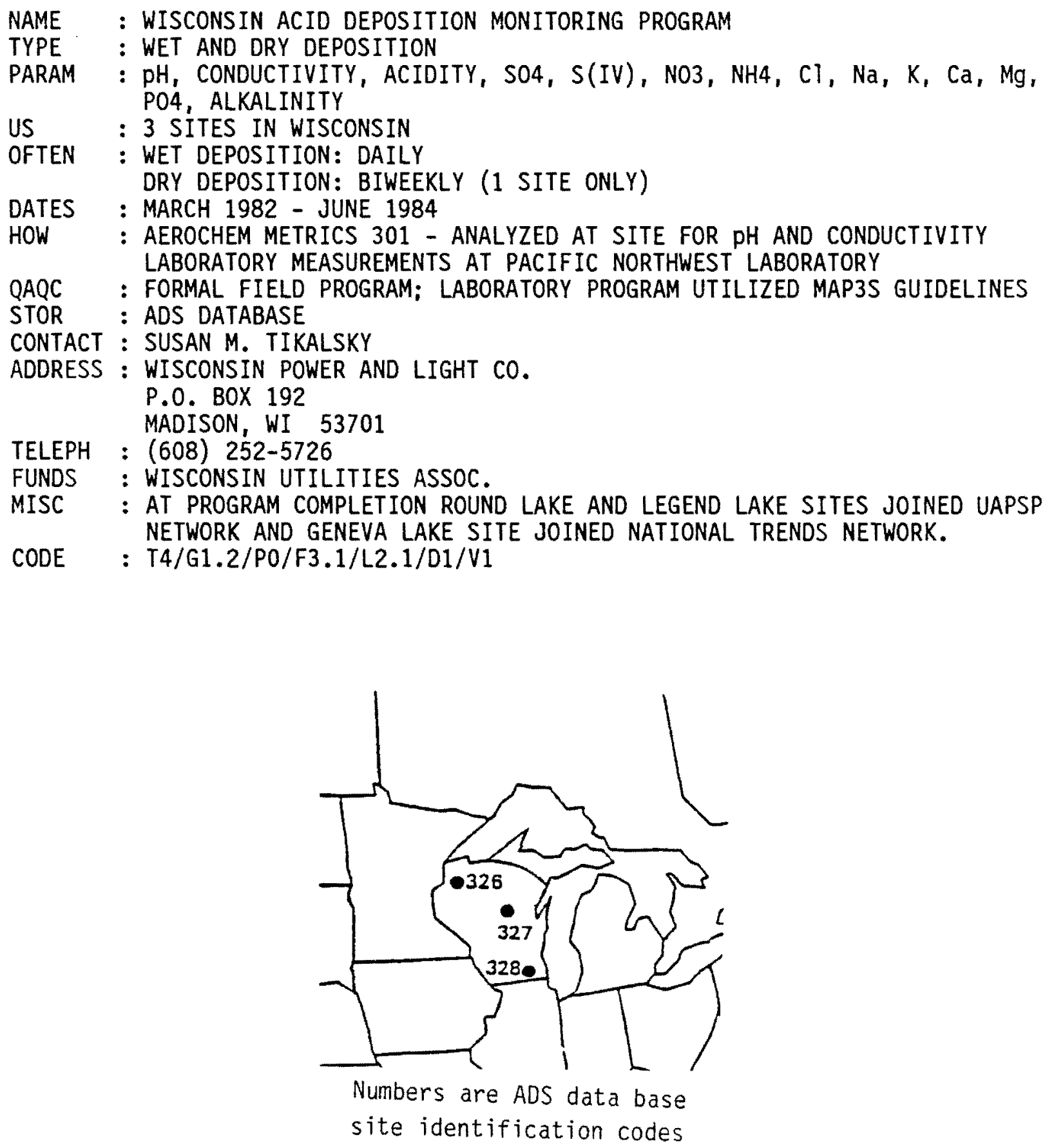
NAME : MINNESOTA-NORTH DAKOTA PRECIPITATION MONITORING NETWORK

TYPE : WET AND DRY DEPOSITION

PARAM : $\mathrm{pH}$, CONDUCTIVITY, ALKALINITY, S04, N03, $\mathrm{NH} 4, \mathrm{Cl}, \mathrm{P}, \mathrm{Na}, \mathrm{K}, \mathrm{Ca}, \mathrm{Mg}$, $\mathrm{Al}, \mathrm{Cd}, \mathrm{Cr}, \mathrm{Cu}, \mathrm{Fe}, \mathrm{Mn}, \mathrm{Ni}, \mathrm{Pb}, \mathrm{Zn}$

US : 1 SITE IN NORTH DAKOTA (TEWAUKON WILDLIFE REFUGE IN SOUTHEASTERN NORTH DAKOTA) AND 2 SITES IN MINNESOTA (NEAR HOVLAND AND ITASCA STATE PARK)

OFTEN : WET DEP: EVENT BASIS DRY DEP: BIWEEKLY OR MONTHLY

DATES : APRIL 1978 - JUNE 1979

HOW : AEROCHEM METRICS 201 WET/DRY SAMPLER - ANALYSIS AT THE UNIVERSITY OF MINNESOTA

QAQC : NO FORMAL PROGRAM

STOR : DATA ARE IN REPORT FORM

CONTACT : E. GORHAM

ADDRESS : DEPT. OF ECOLOGY AND BEHAVIORAL BIOLOGY

UNIVERSITY OF MINNESOTA

ST. PAUL, MN 55455

TELEPH : (612) 376-1743

FUNDS : DEPARTMENT OF ENERGY AND UNIV OF MINNESOTA COMPUTER CENTER

CODE : T4/G1.2/P1.2/F4.2/L2.1/D2/V1

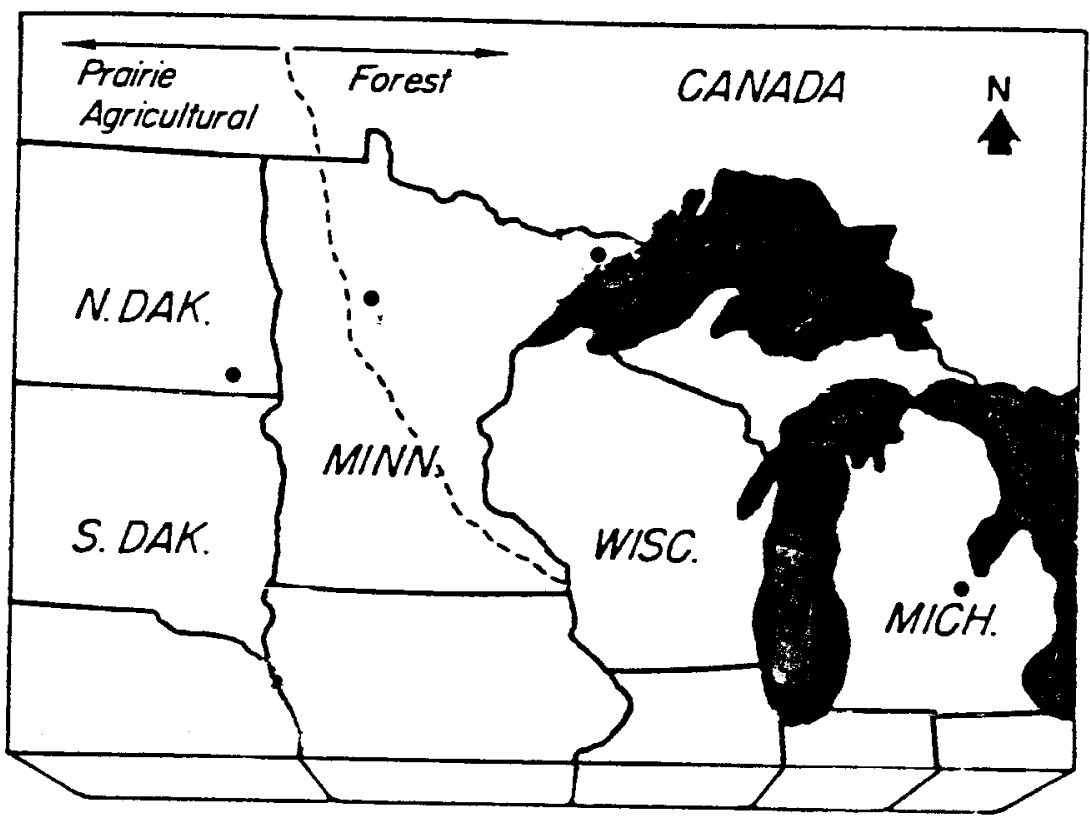



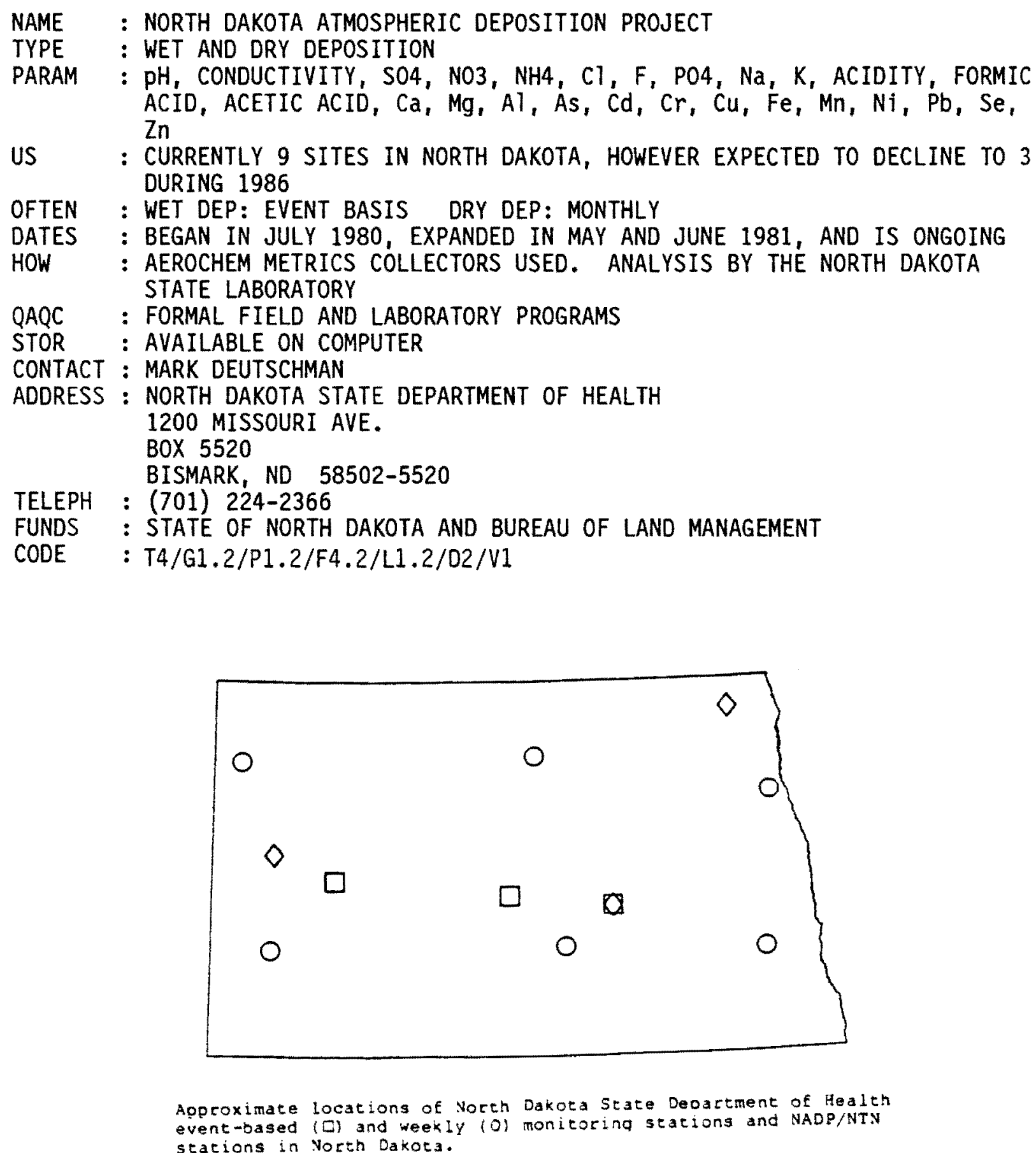

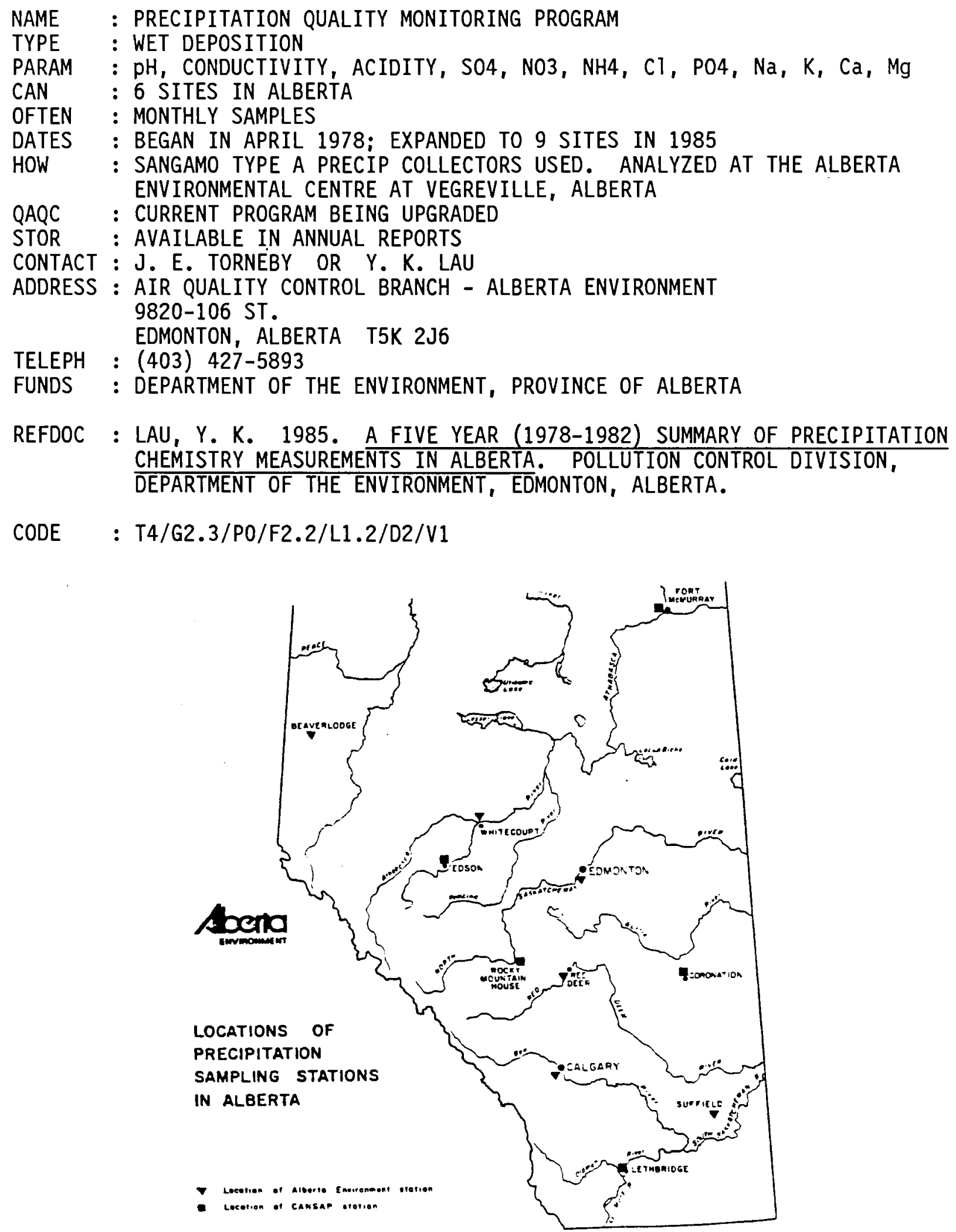

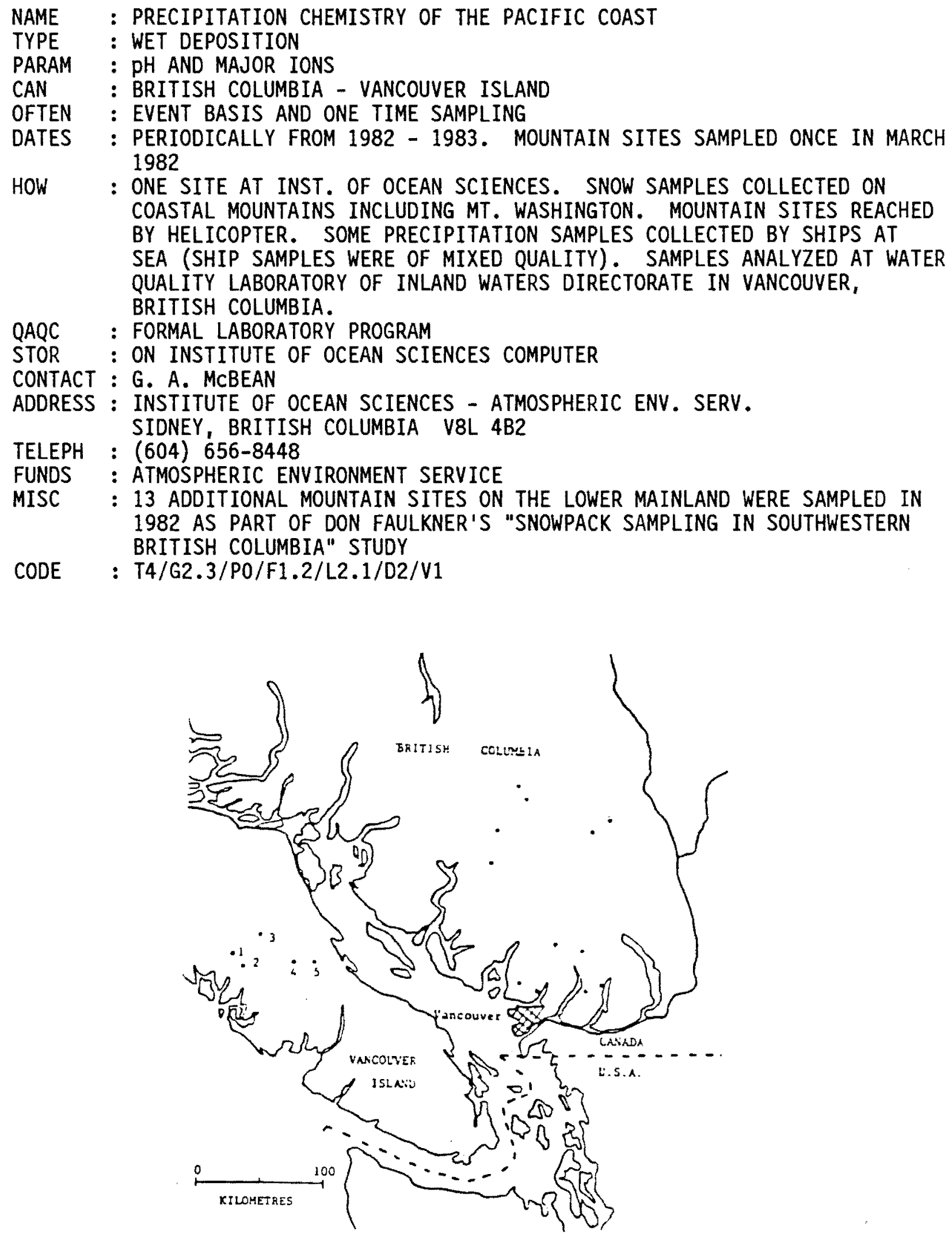

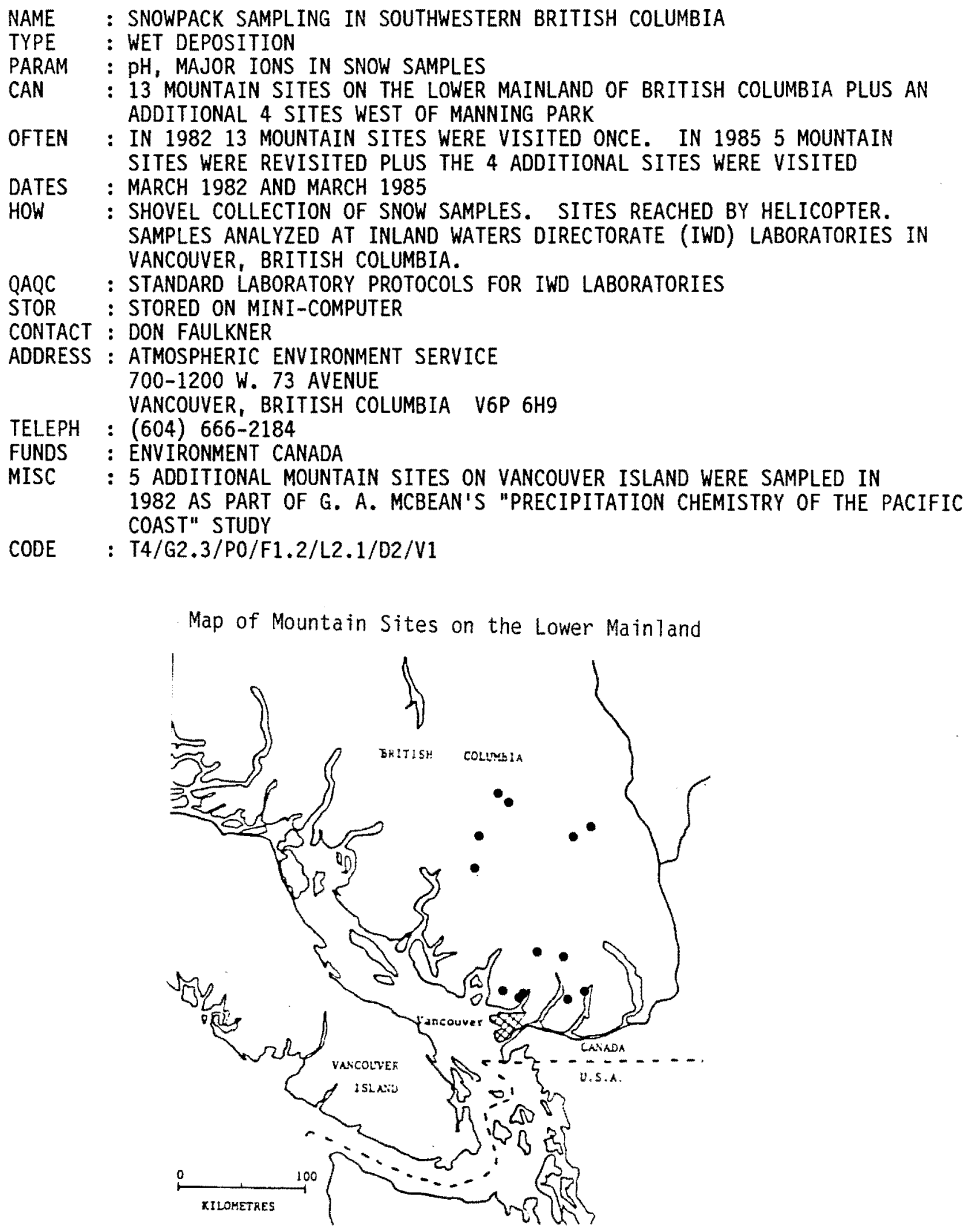

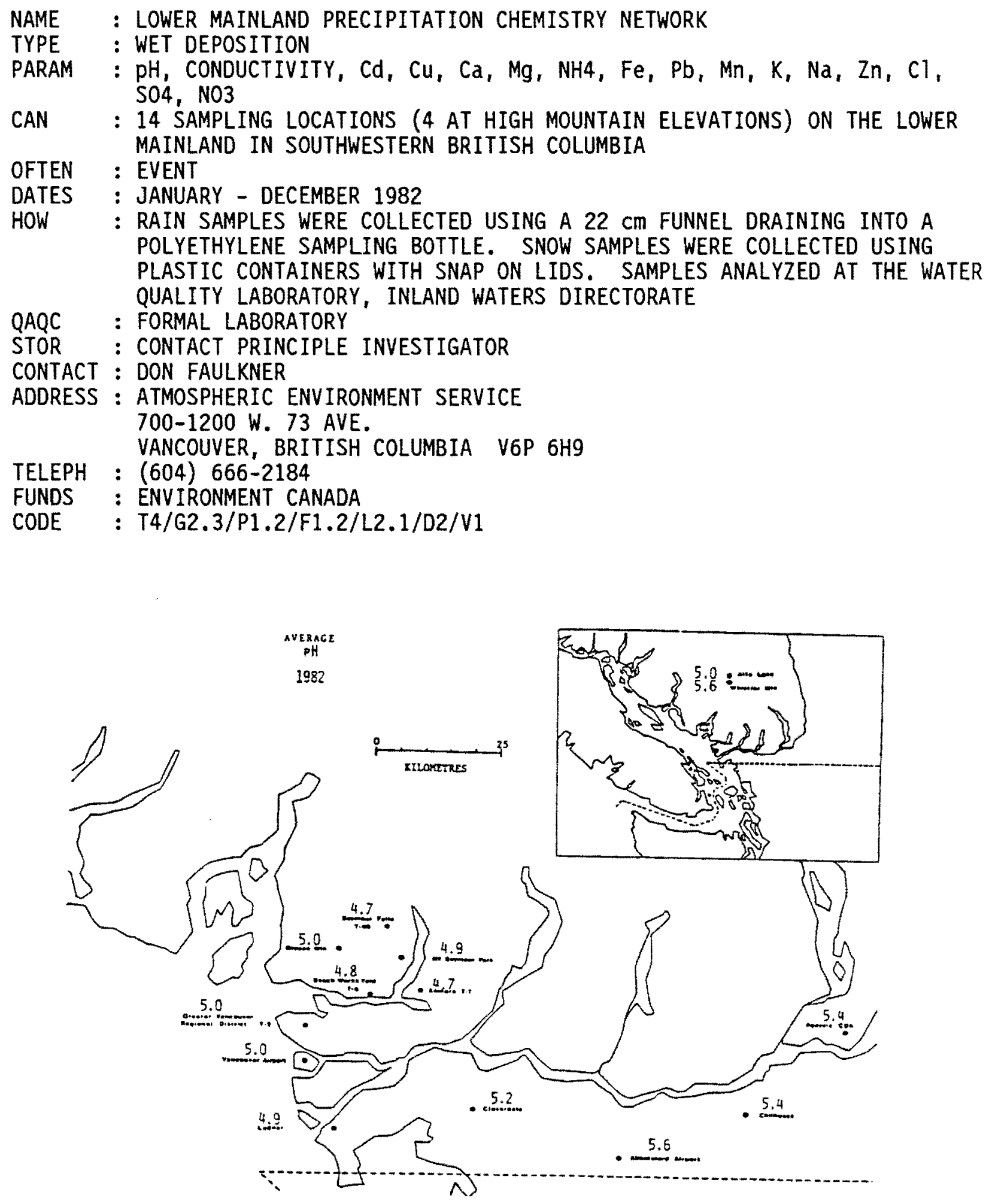

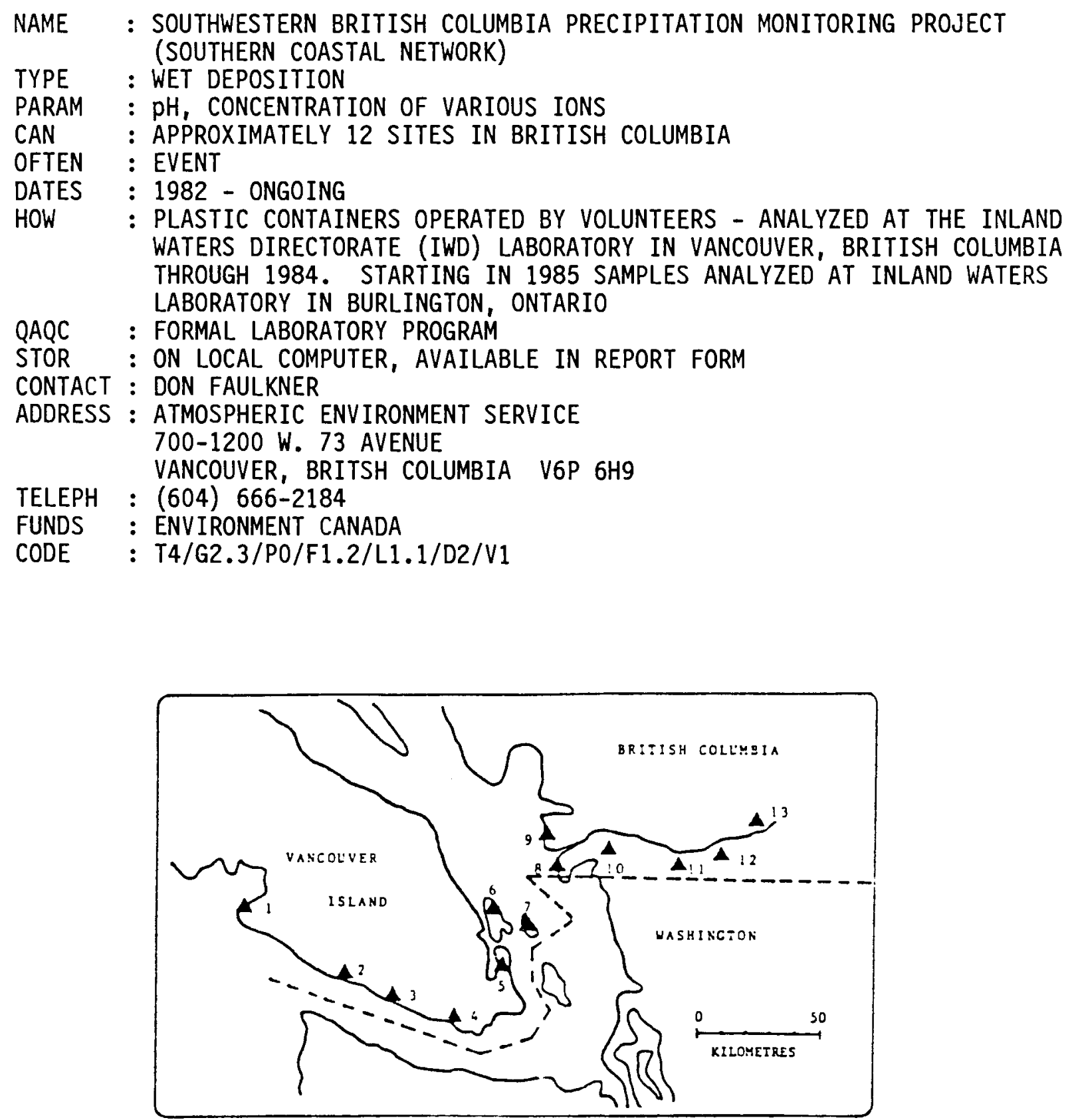

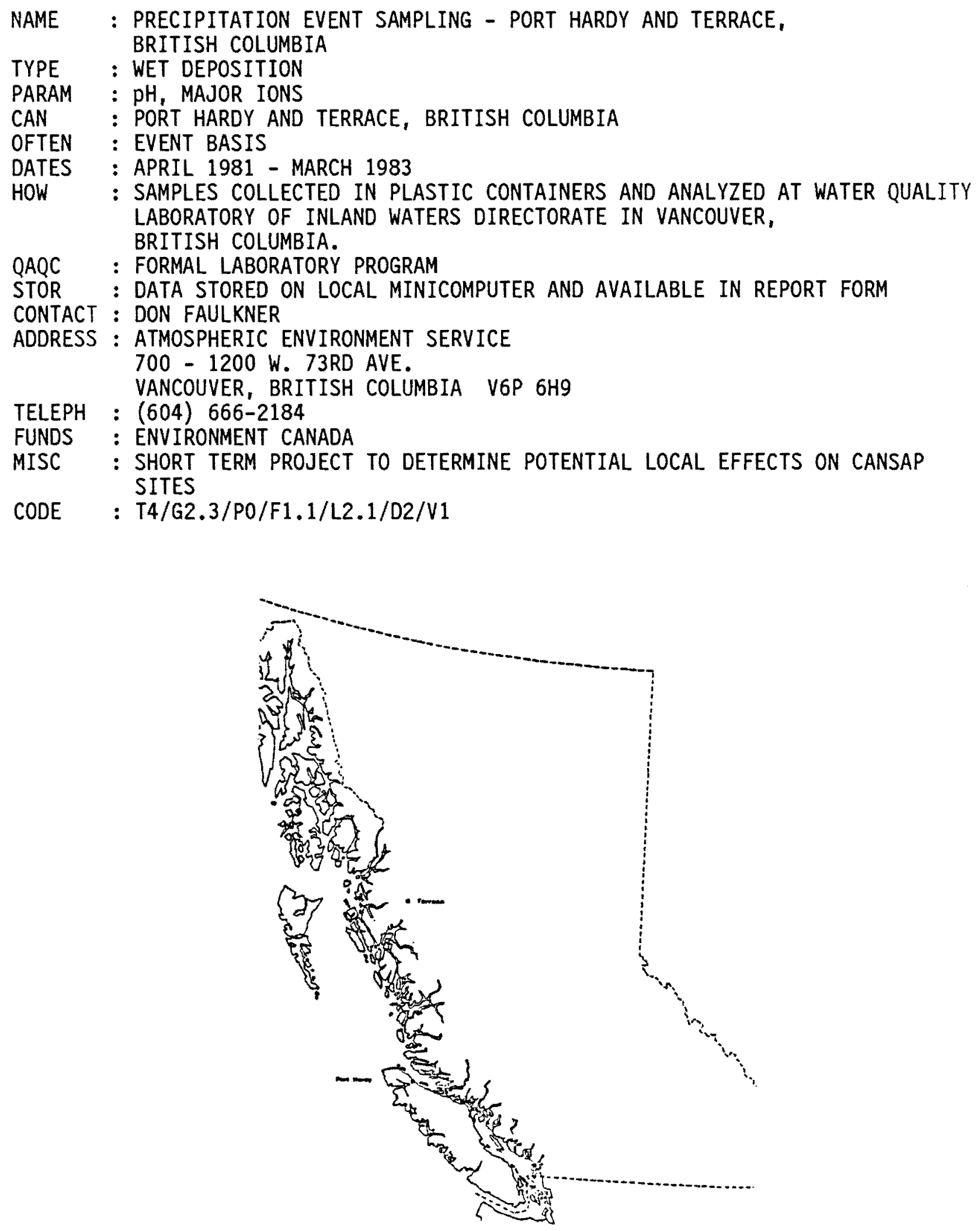

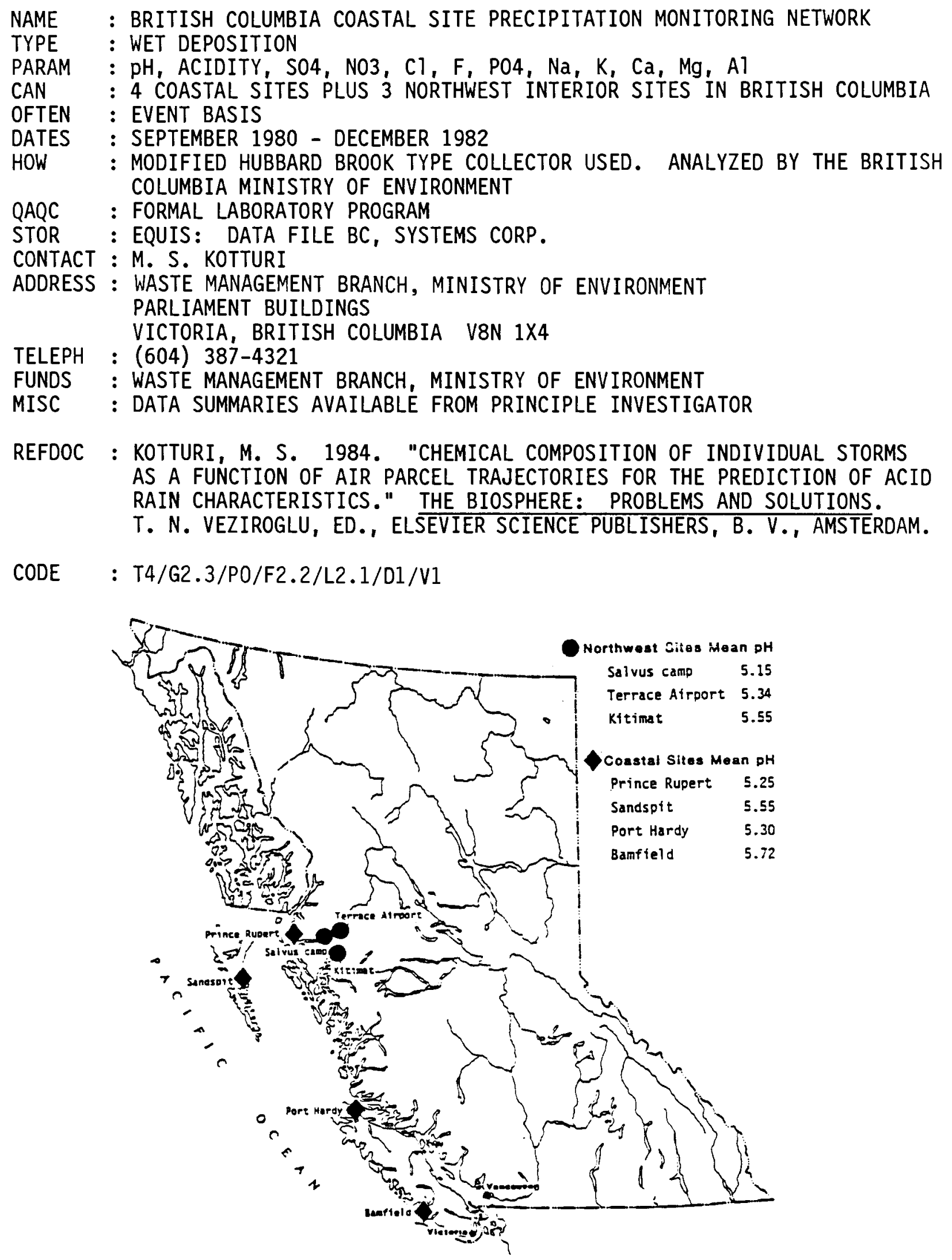

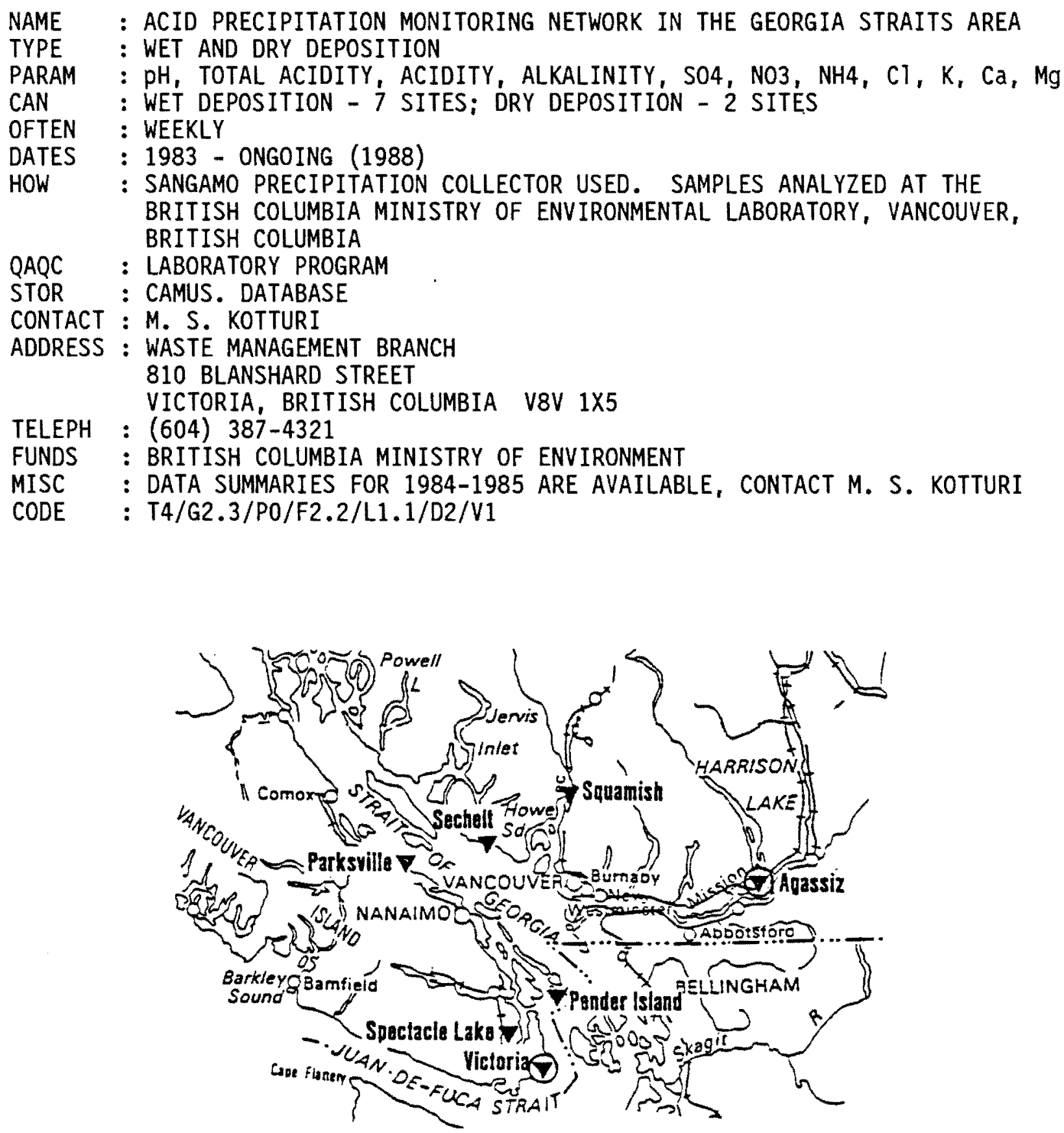

Existing monitoring stations

Ory daposition monitoring stations 


\section{APPENDIX E}

INVENTORY OF TRANSBOUNDARY REGION FOREST/VEGETATION PROJECTS 


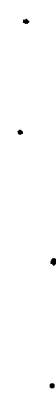




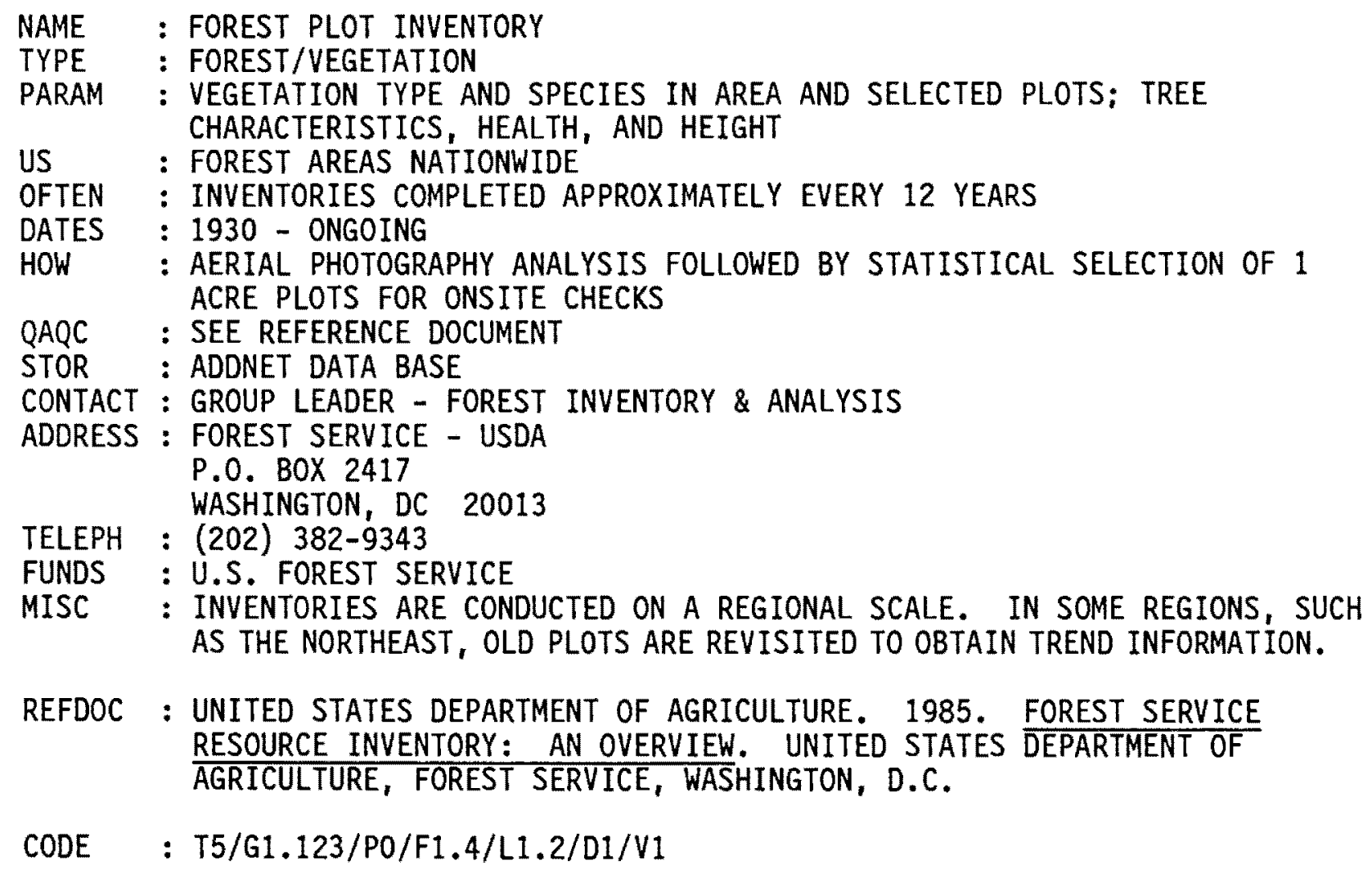




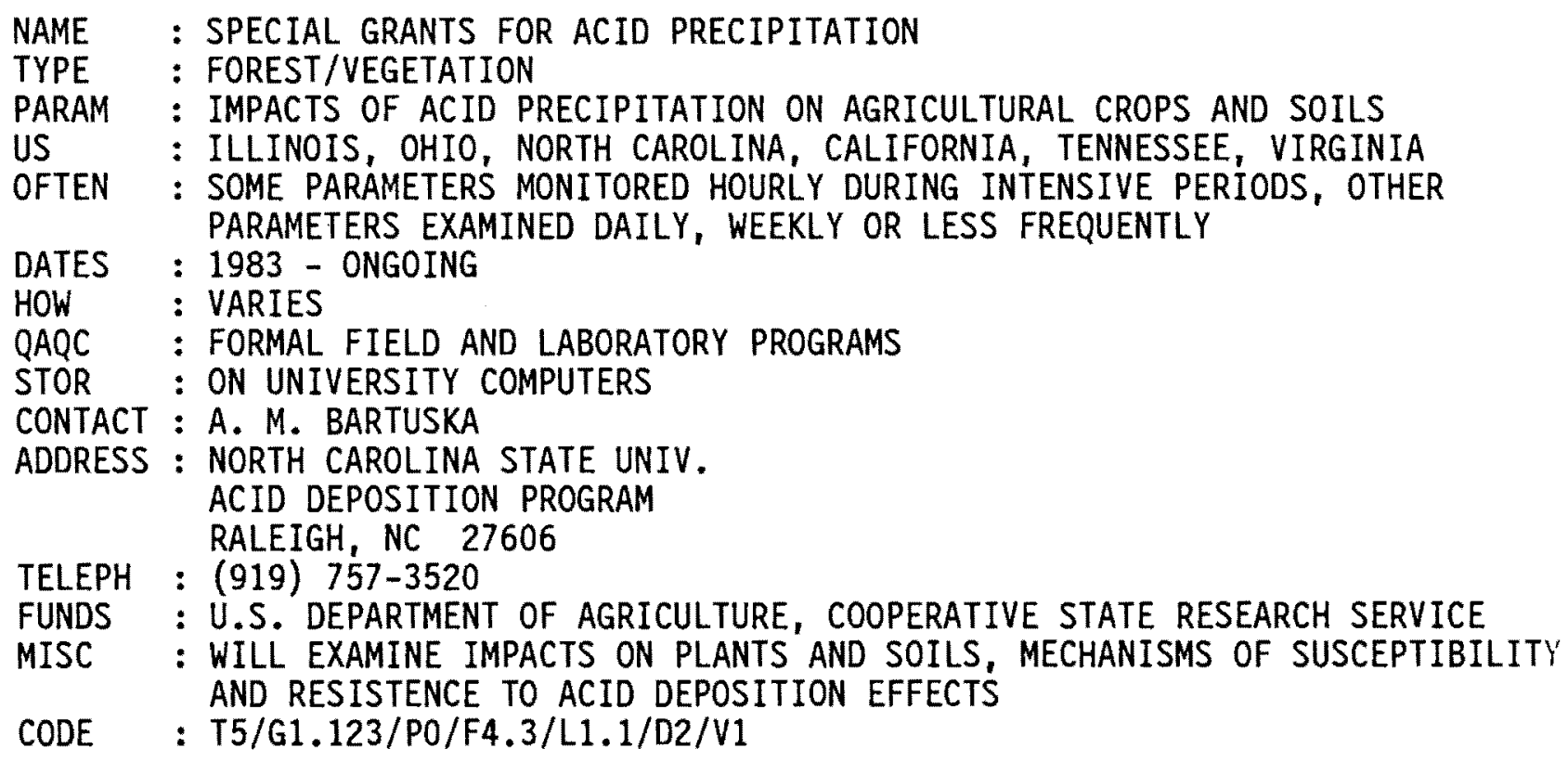




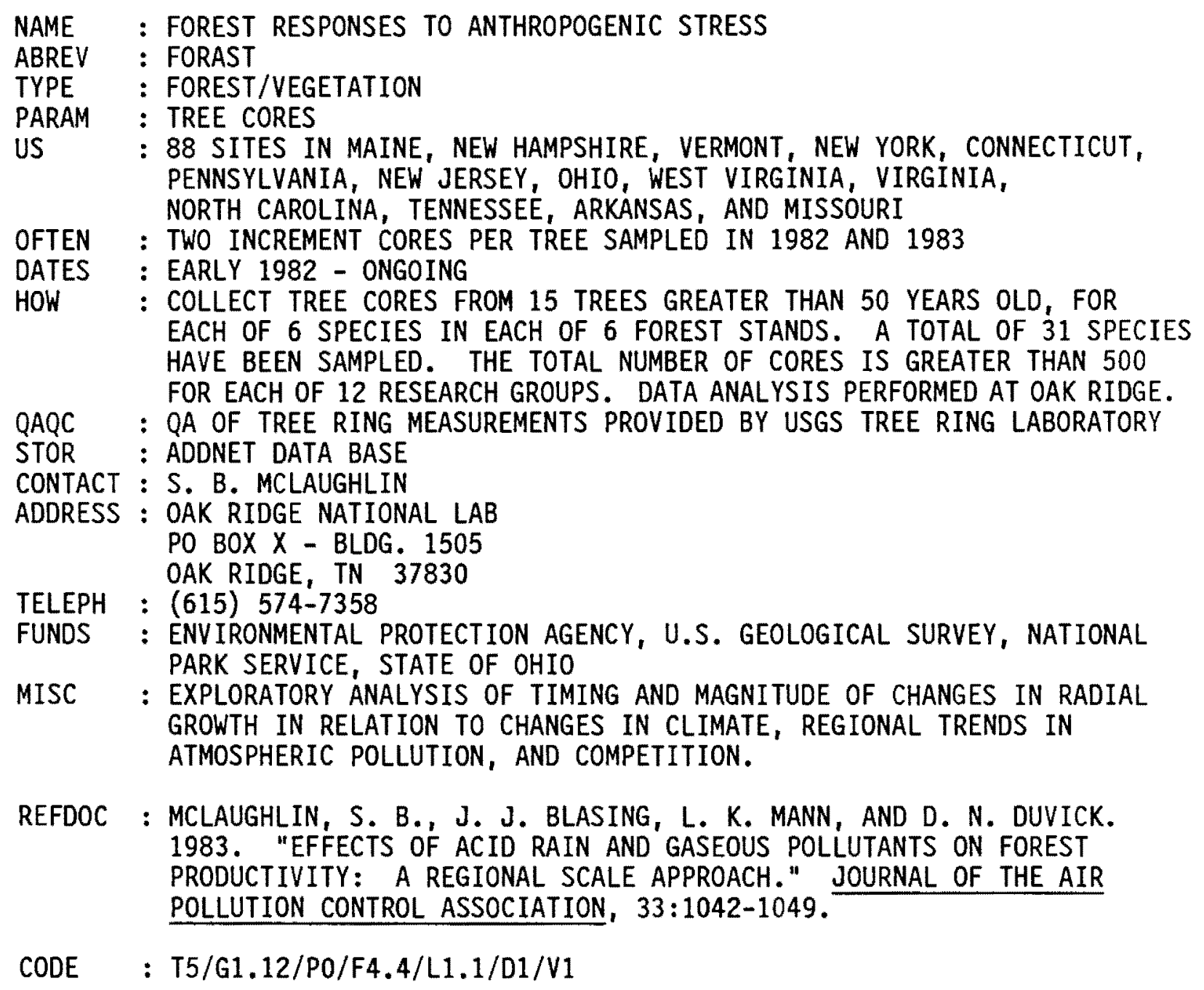




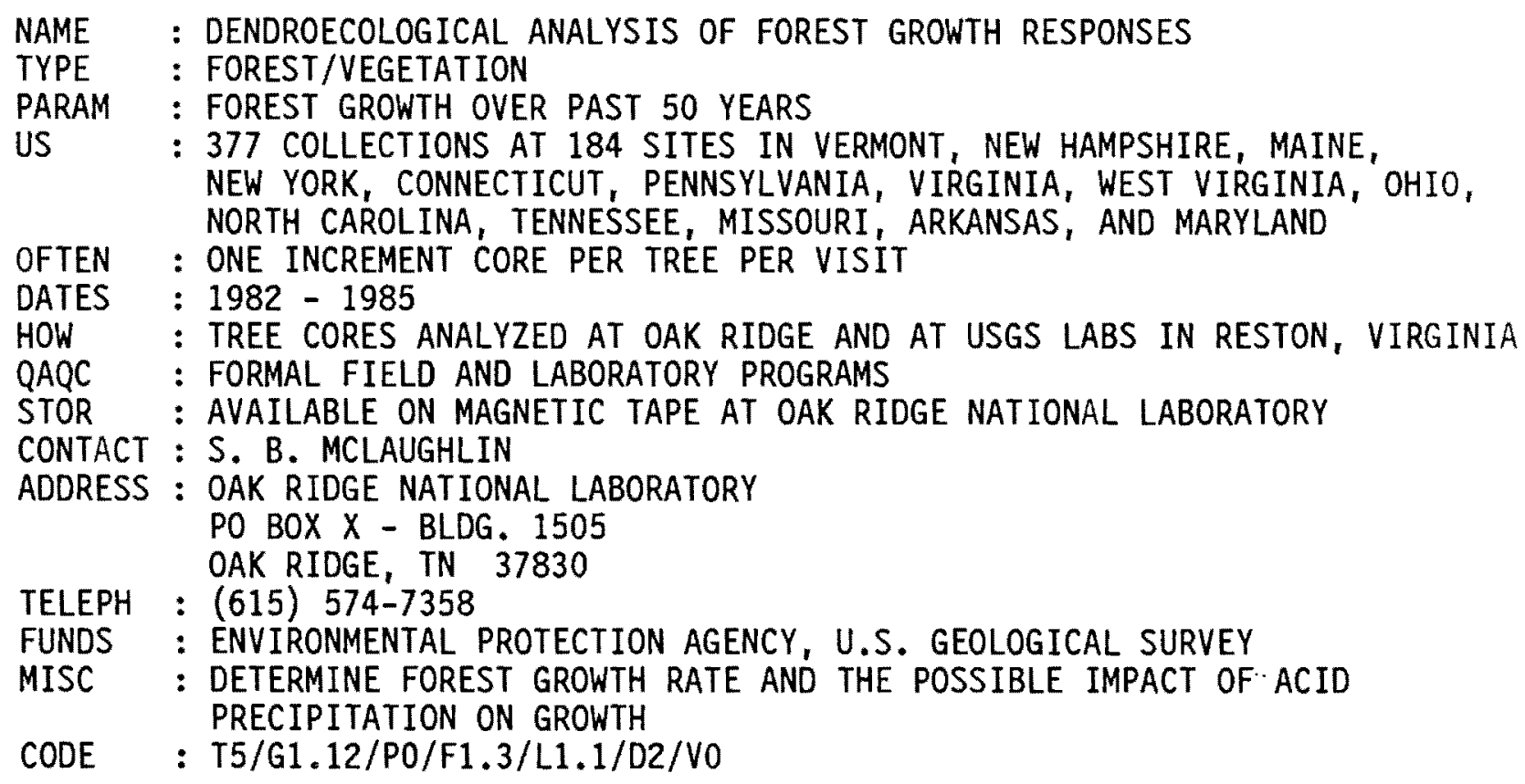






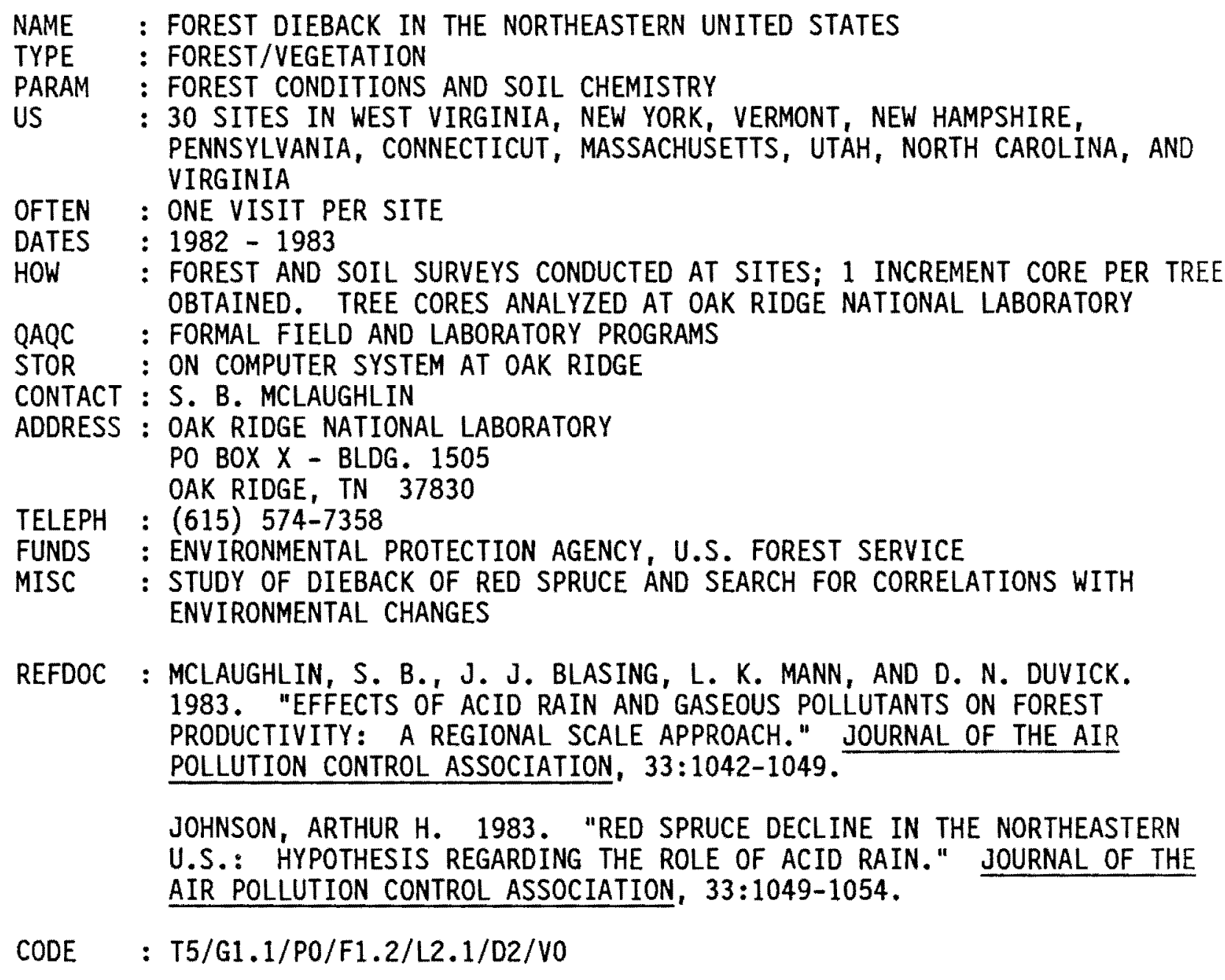


APPENDIX $F$

INVENTORY OF TRANSBOUNDARY REGION SOIL PROJECTS 

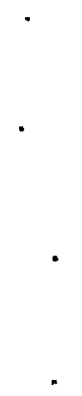


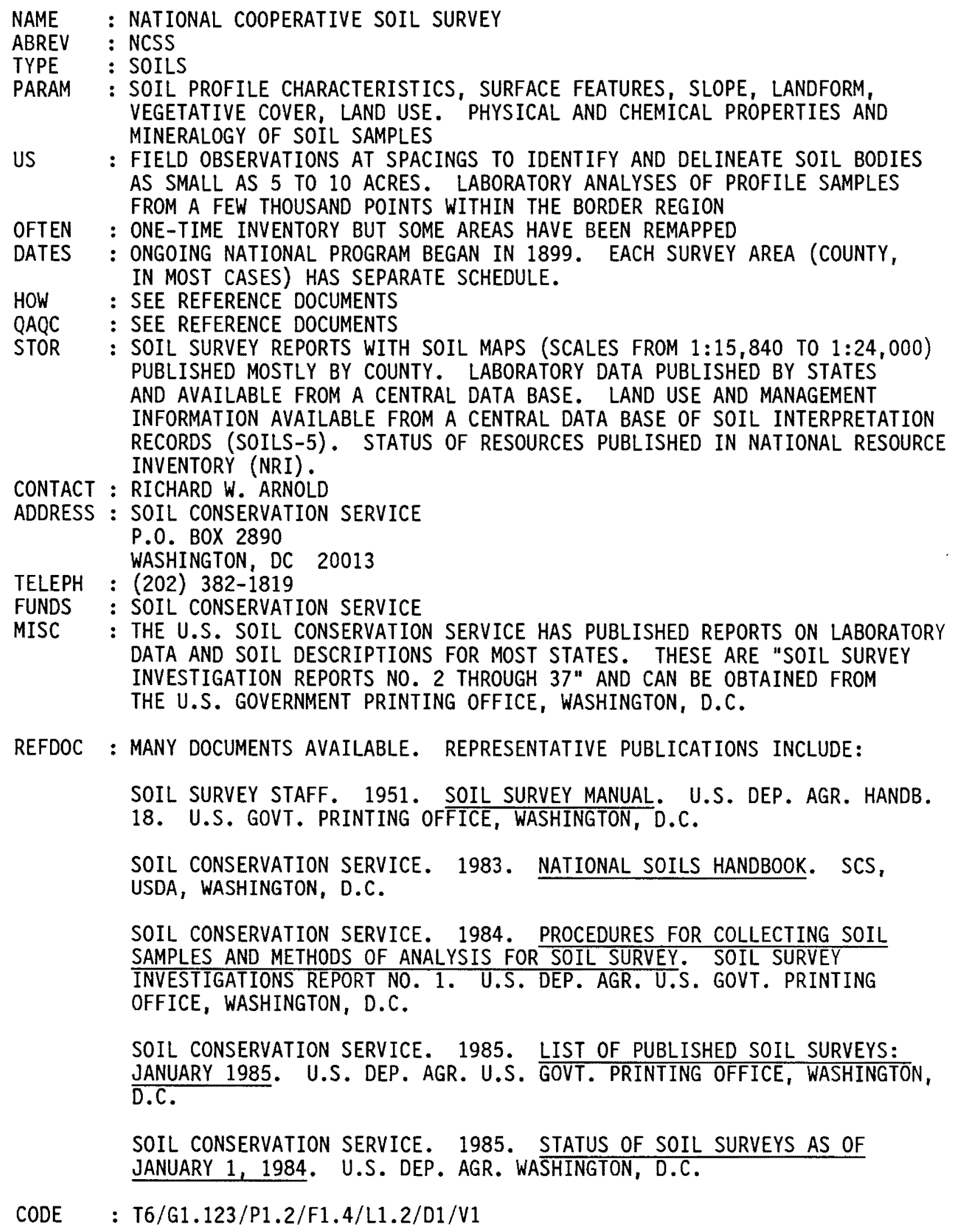




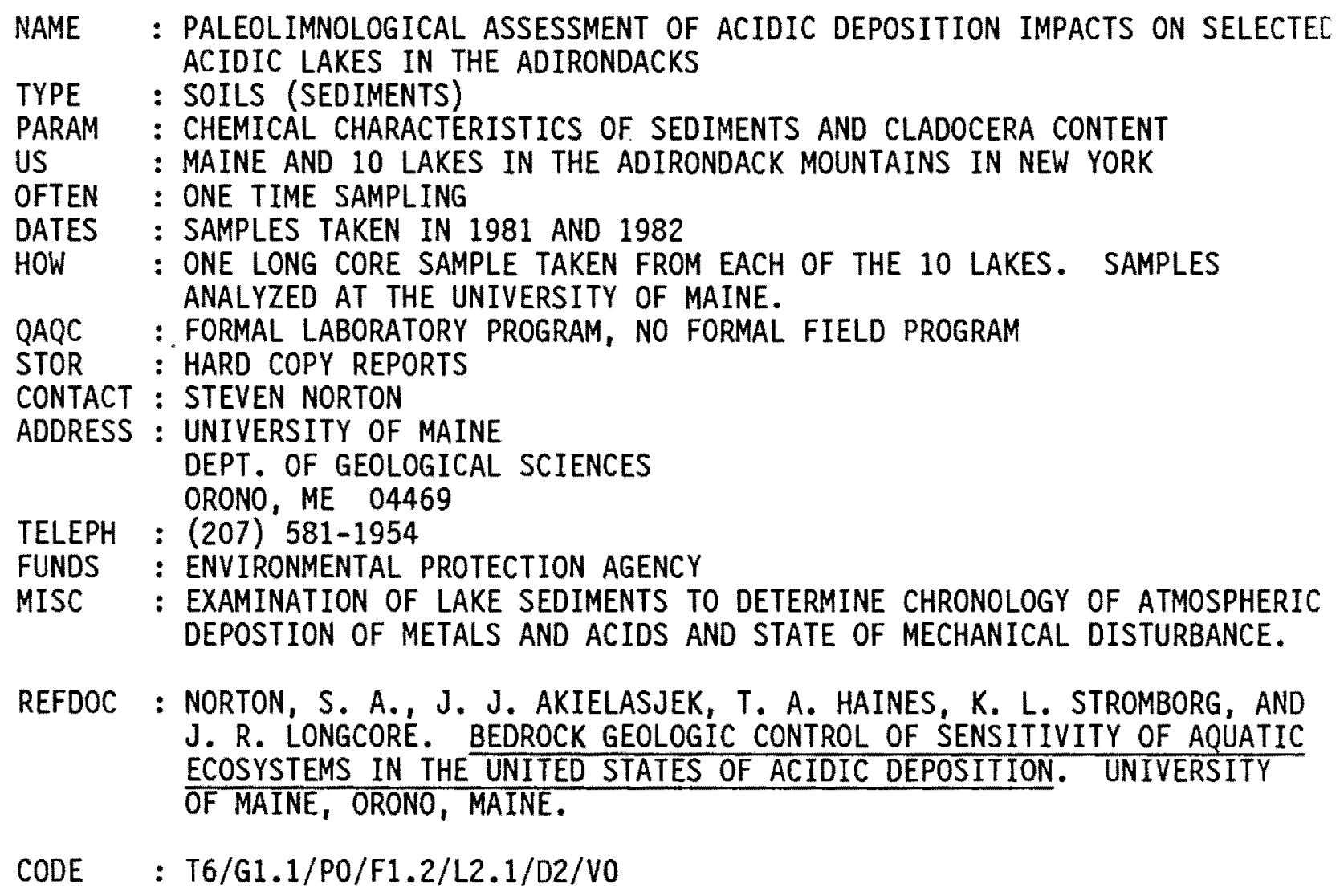

REFDOC : NORTON, S. A., J. J. AKIELASJEK, T. A. HAINES, K. L. STROMBORG, AND J. R. LONGCORE, BEDROCK GEOLOGIC CONTROL OF SENSITIVITY OF AQUATIC ECOSYSTEMS IN THE UNITED STATES OF ACIDIC DEPOSITION. UNIVERSITY OF MAINE, ORONO, MAINE.

CODE $\quad:$ T6/G1.1/PO/F1.2/L2.1/D2/VO 


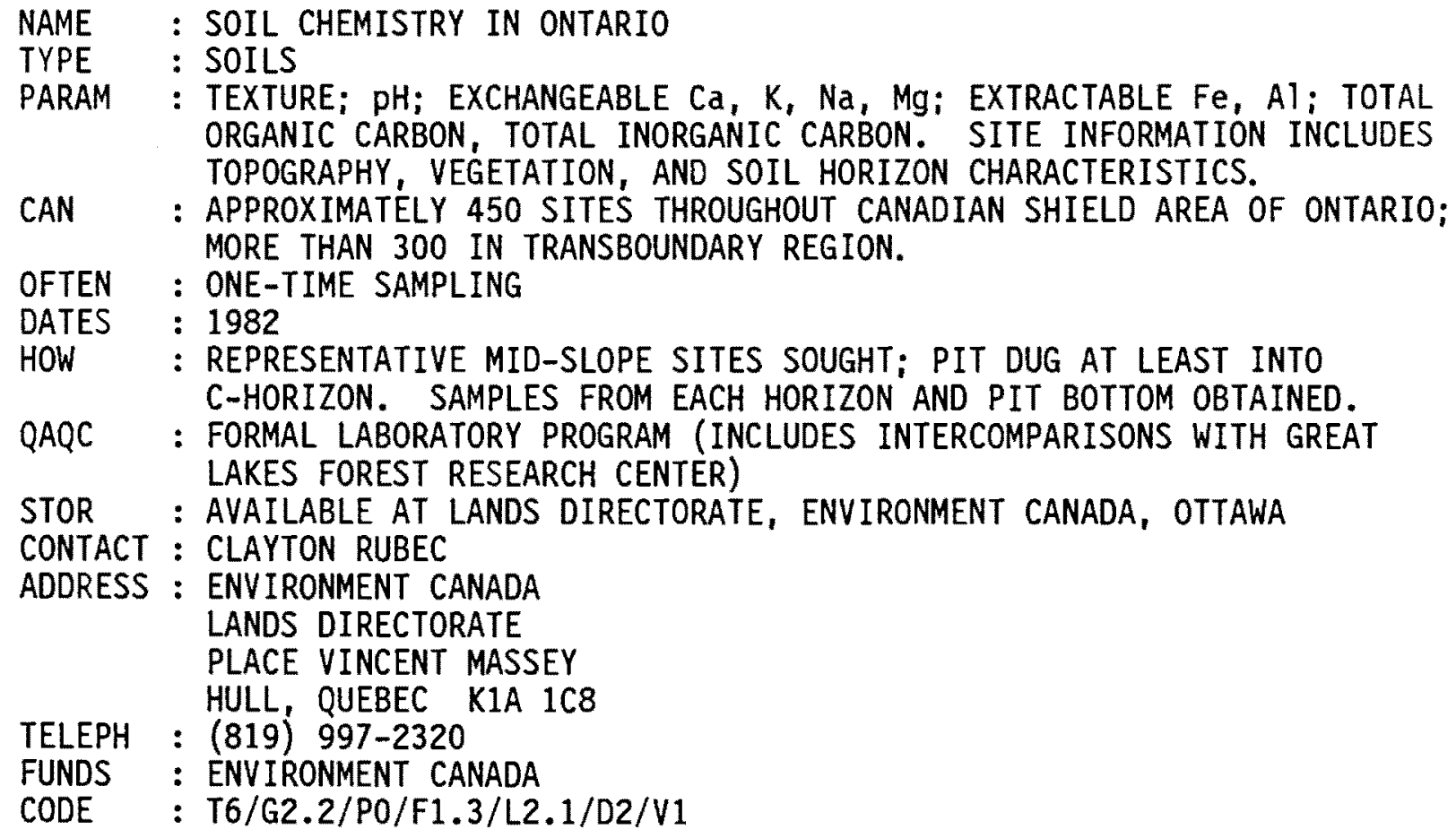




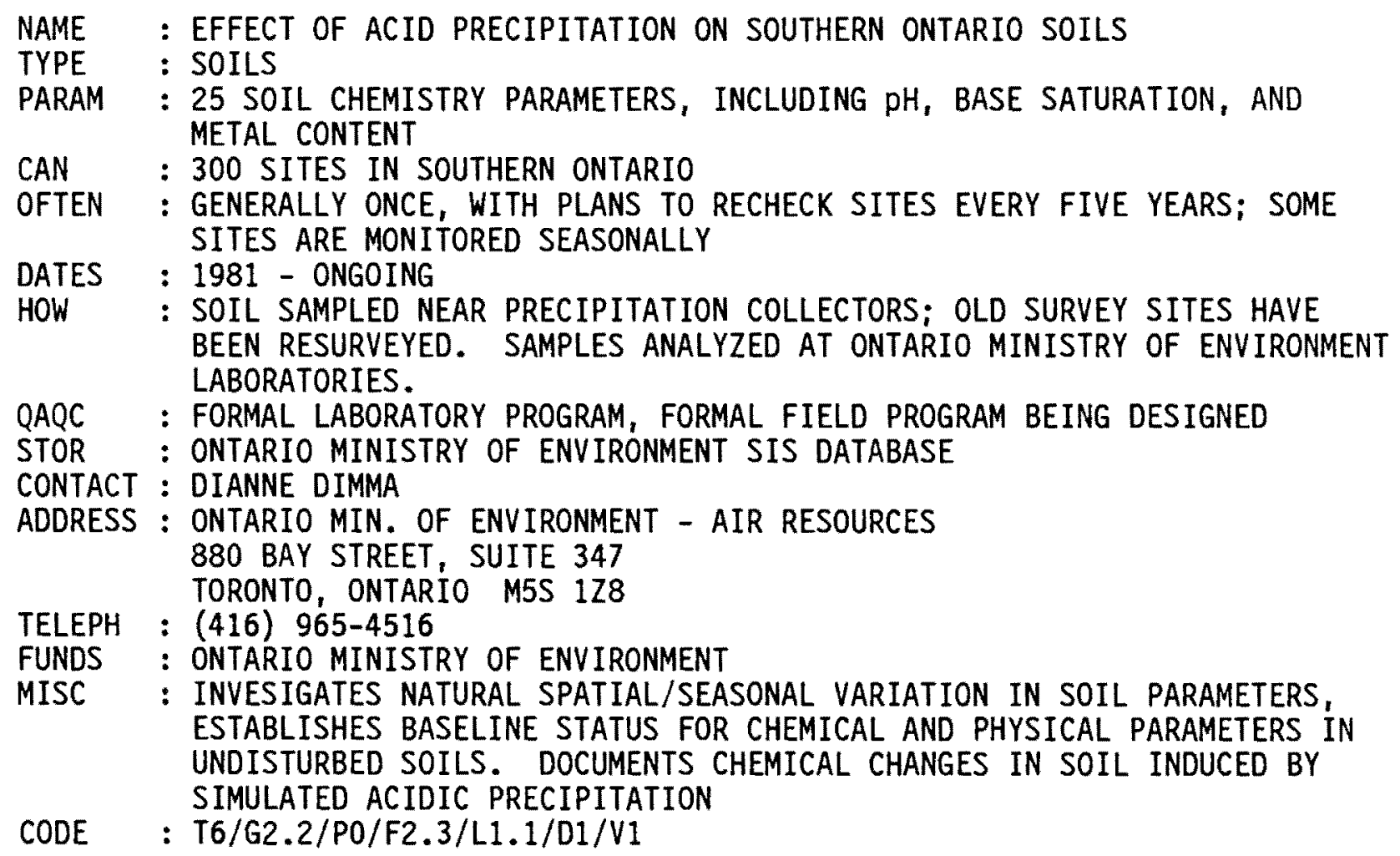




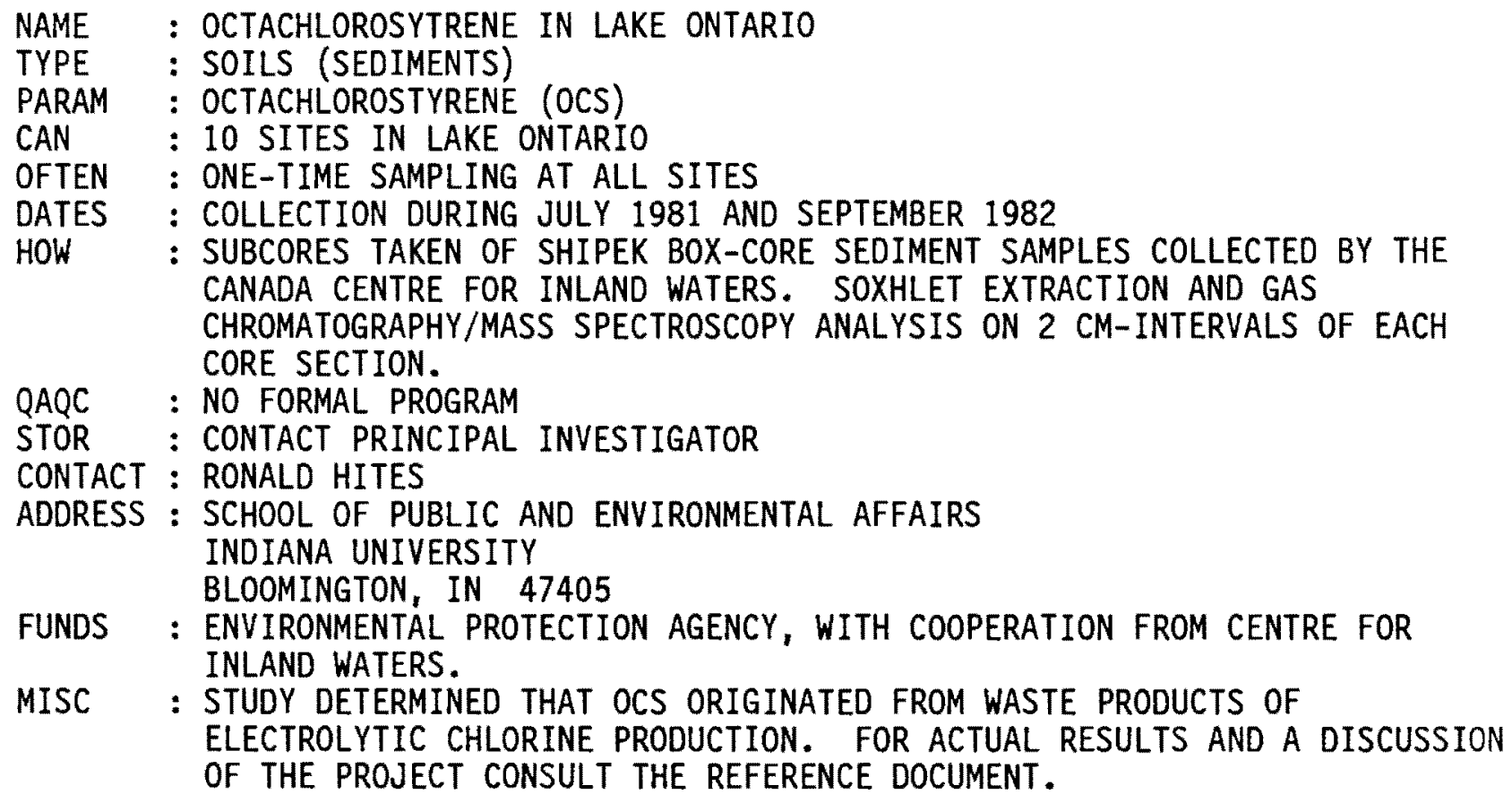

FUNDS : ENVIRONMENTAL PROTECTION AGENCY, WITH COOPERATION FROM CENTRE FOR INLAND WATERS.

MISC : STUDY DETERMINED THAT OCS ORIGINATED FROM WASTE PRODUCTS OF ELECTROLYTIC CHLORINE PRODUCTION. FOR ACTUAL RESULTS AND A DISCUSSION OF THE PROJECT CONSULT THE REFERENCE DOCUMENT.

REFDOC : KAMINSKY, R. AND R. HITES, 1984. "OCTACHLOROSTYRENE IN LAKE ONTARIO: SOURCES AND FATES." ENVIRON. SCI. AND TECH., 18:275-279.

CODE : T6/G2.2/P1.1/F1.2/L2.1/D2/V1

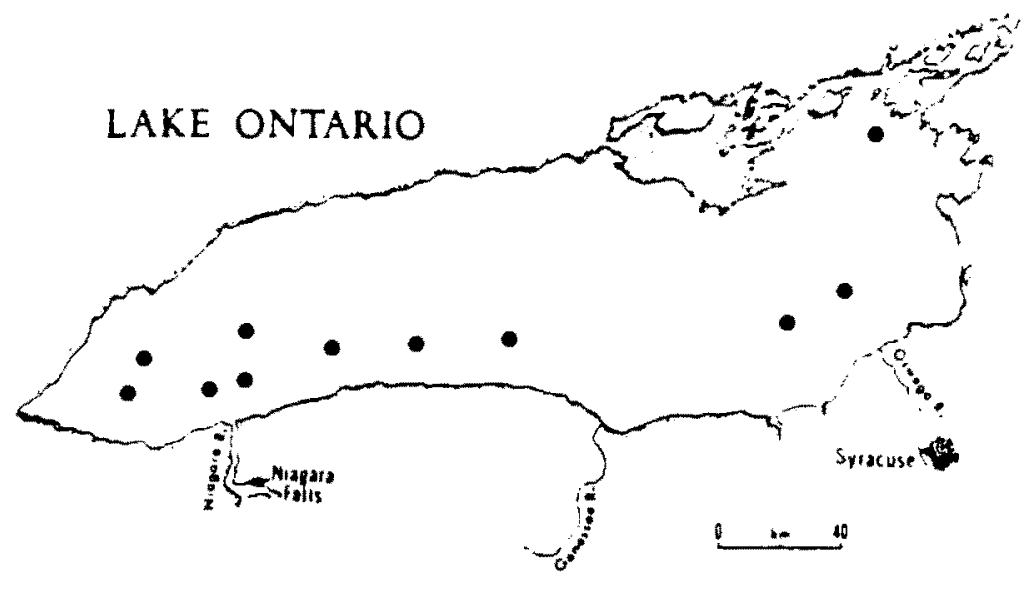




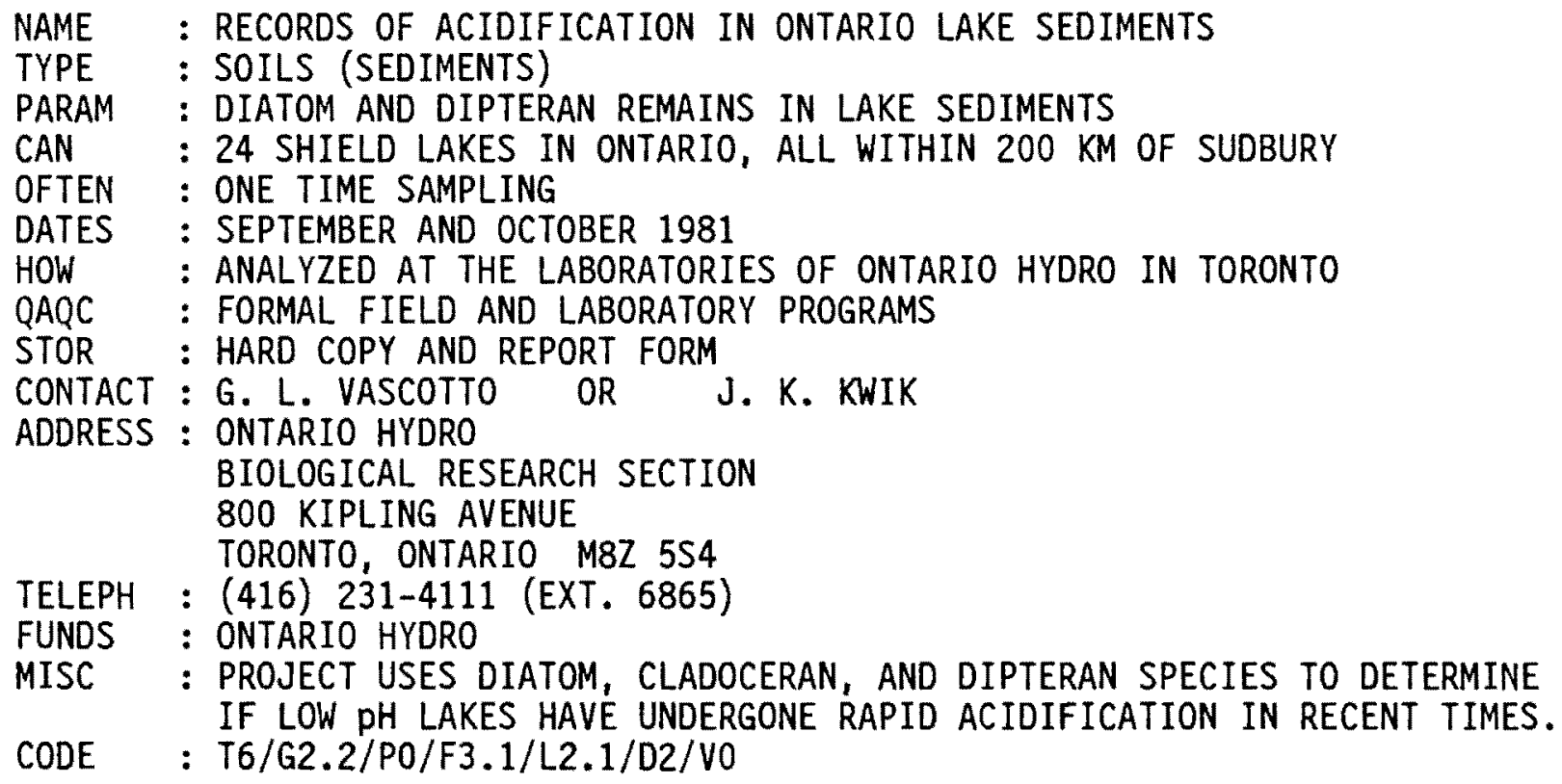



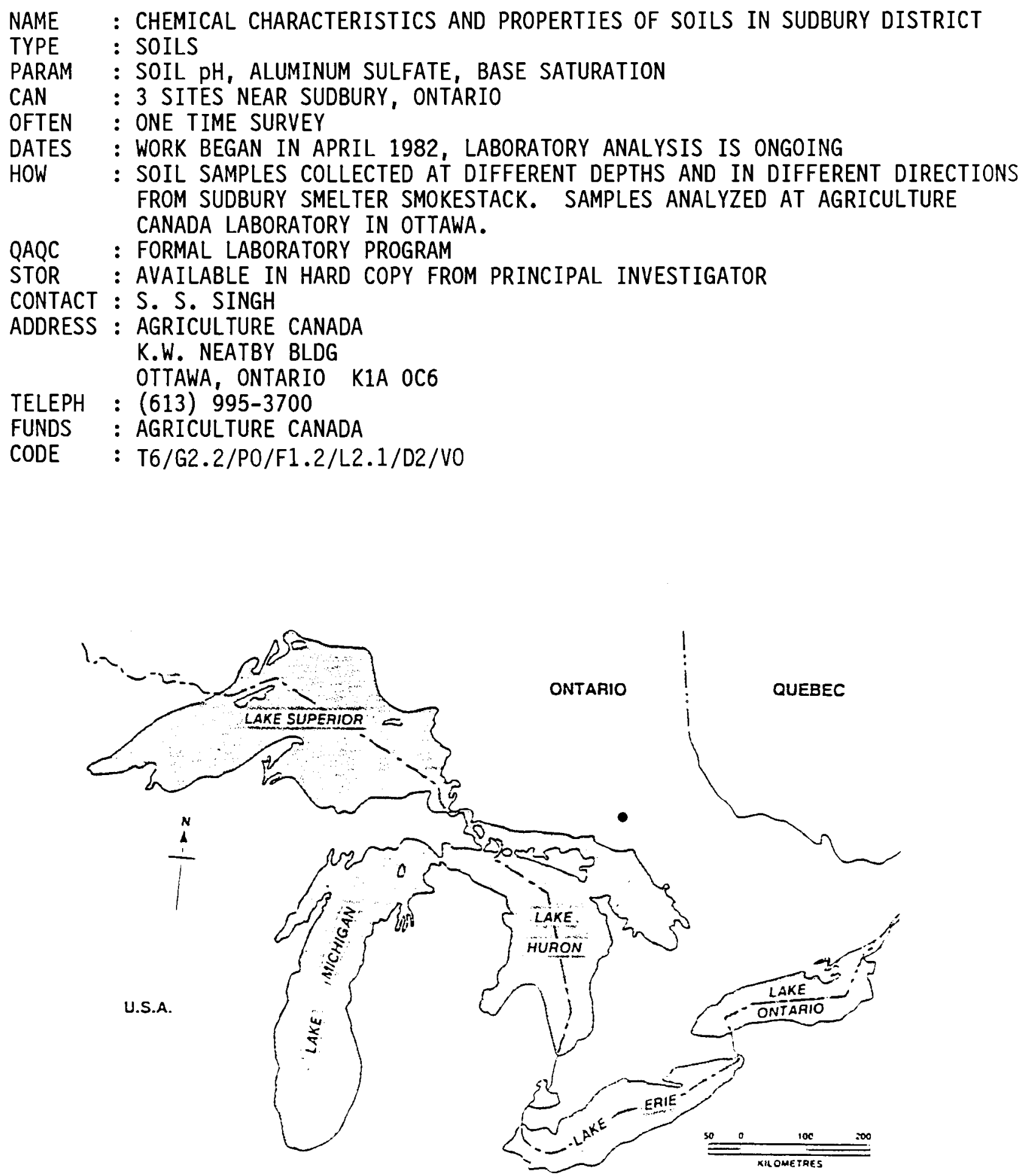

F.7 


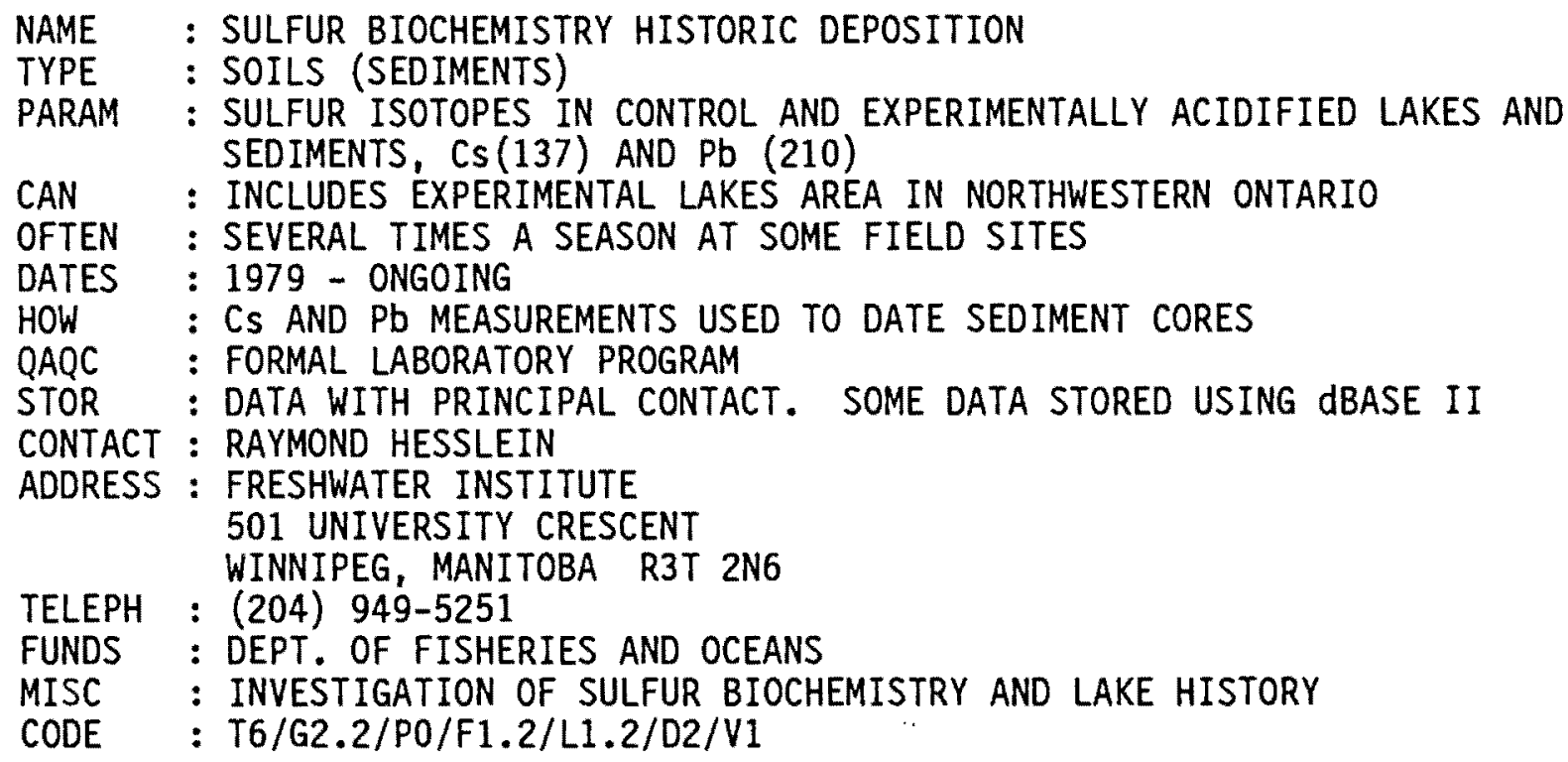




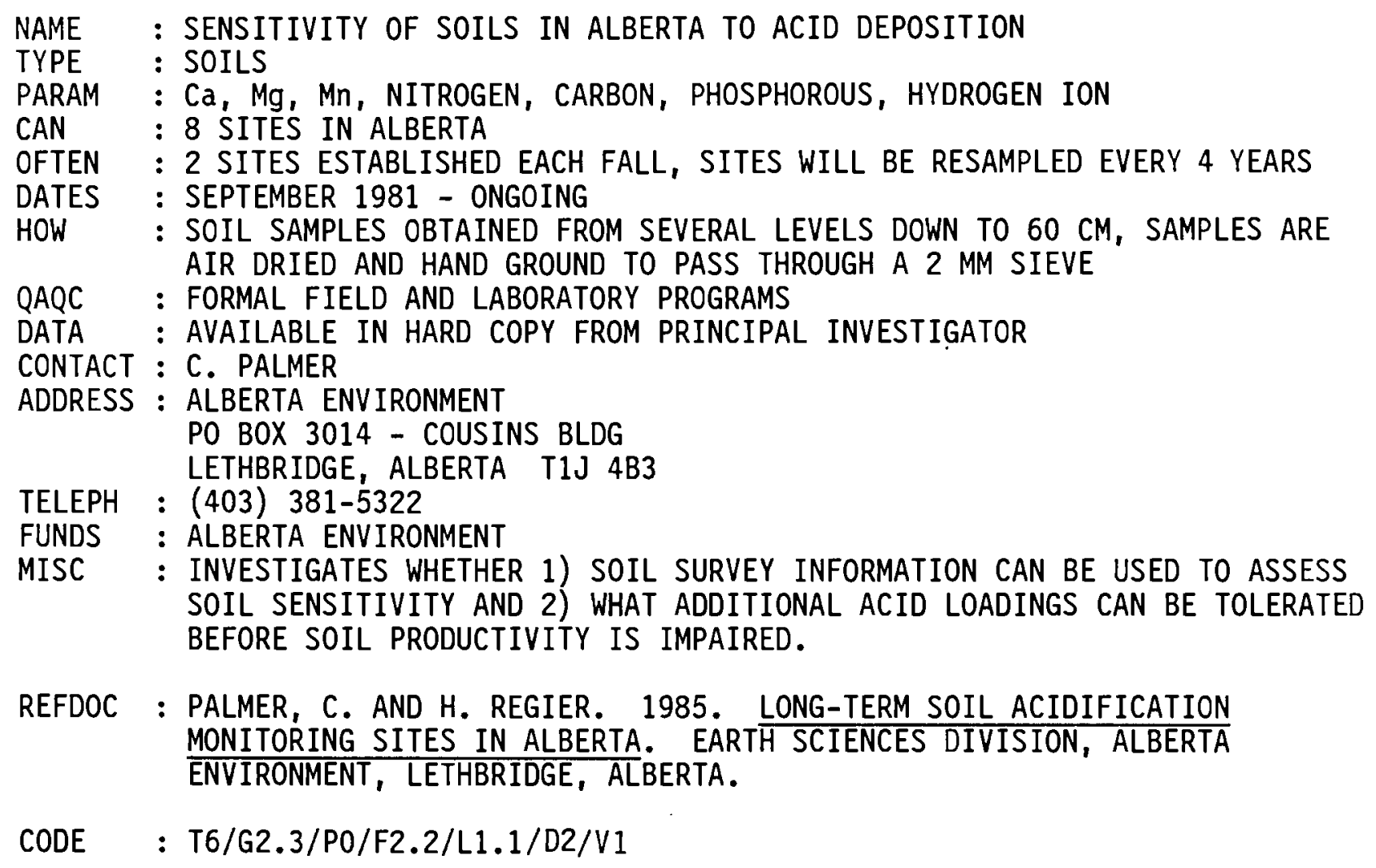

REFDOC : PALMER, C. AND H. REGIER. 1985. LONG-TERM SOIL ACIDIFICATION MONITORING SITES IN ALBERTA. EARTH SCIENCES DIVISION, ALBERTA ENVIRONMENT, LETHBRIDGE, ALBERTA.

CODE : T6/G2.3/P0/F2.2/L1.1/D2/V1

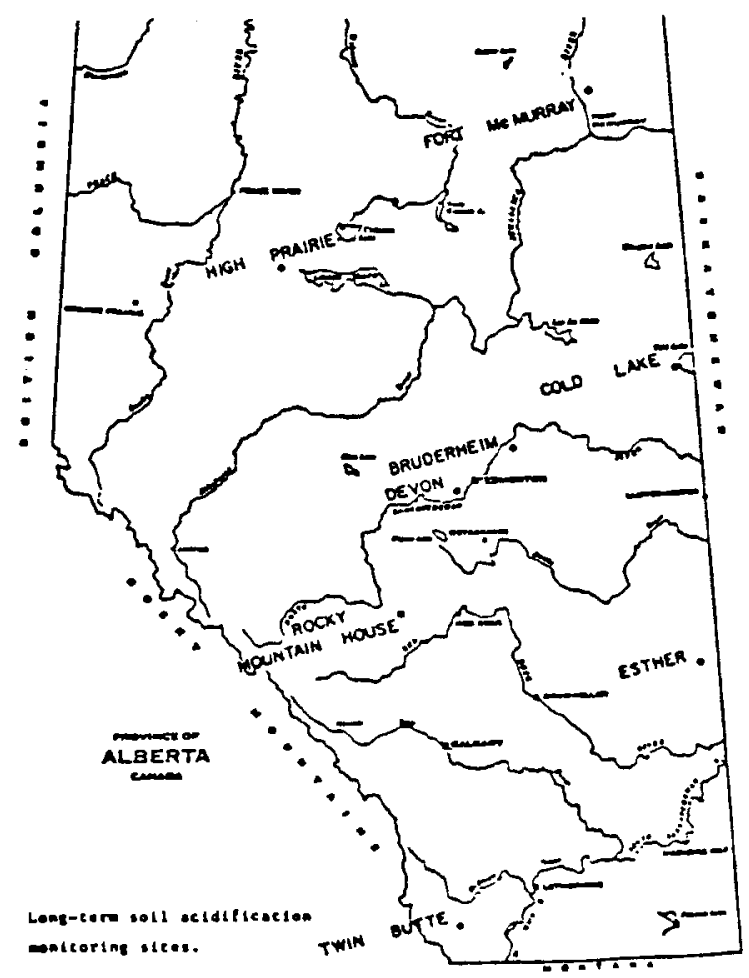




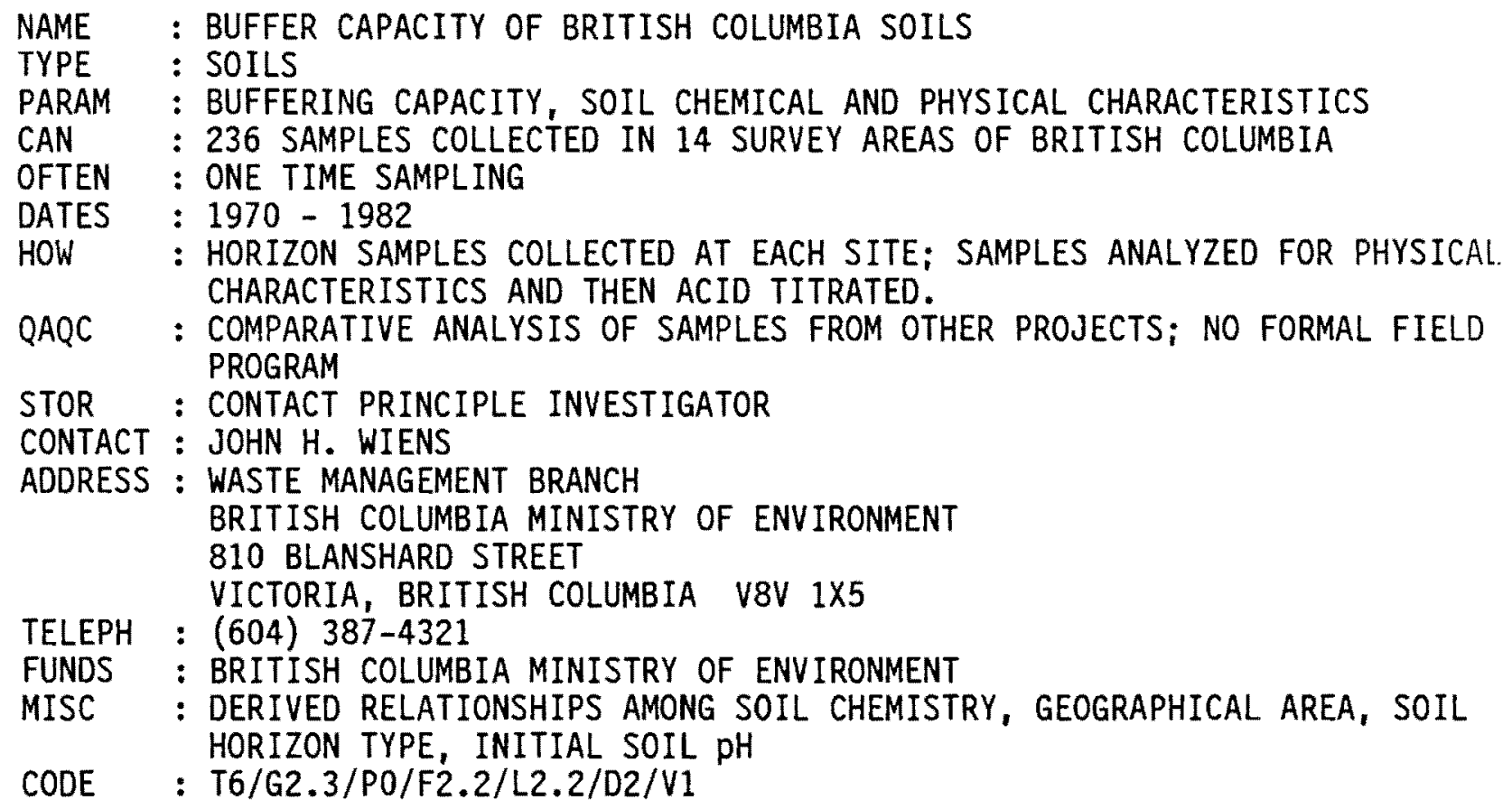


APPENDIX $\mathbf{G}$

INVENTORY OF TRANSBOUNDARY REGION ECOSYSTEM PROJECTS 
.

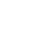

\section{•}




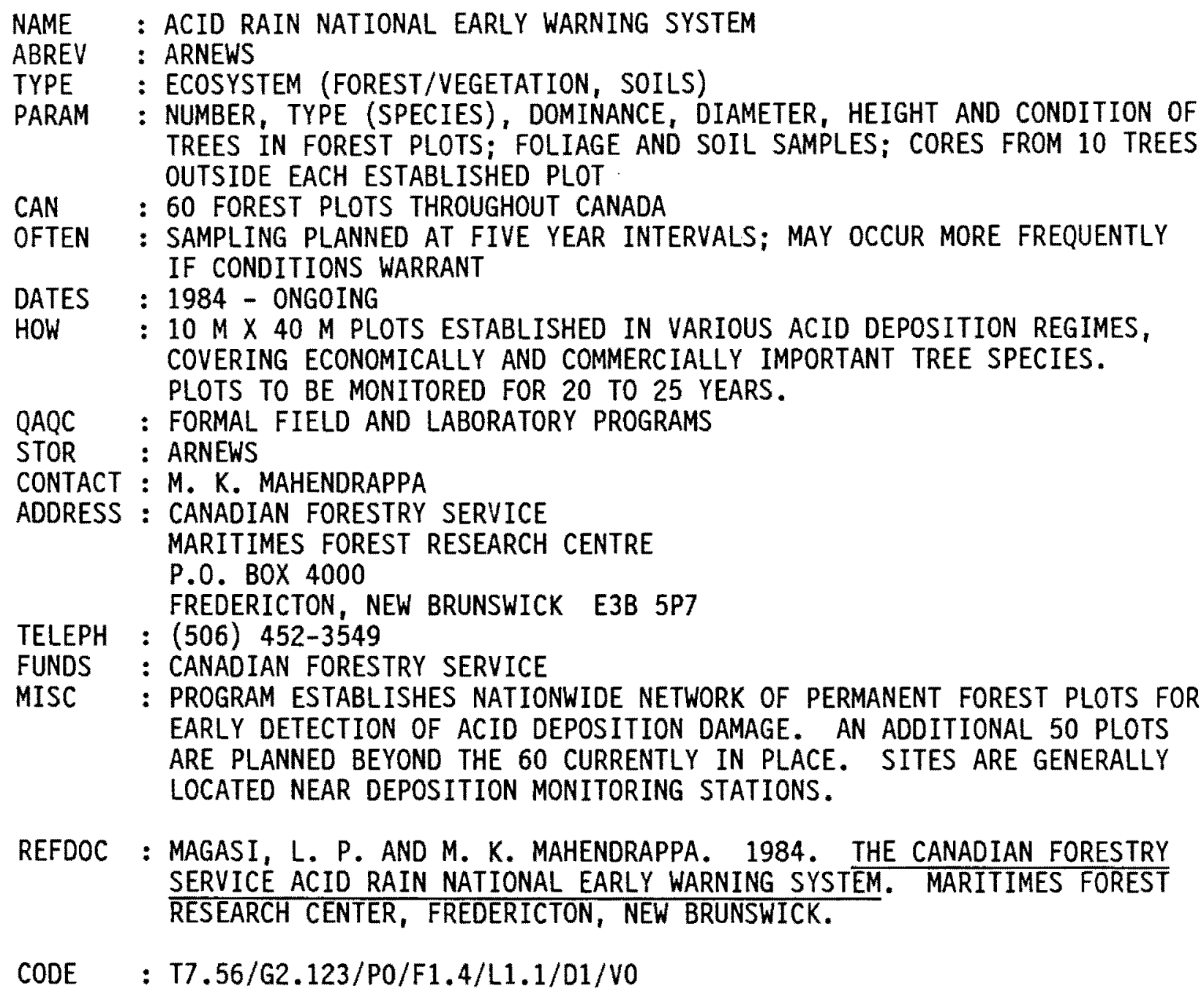




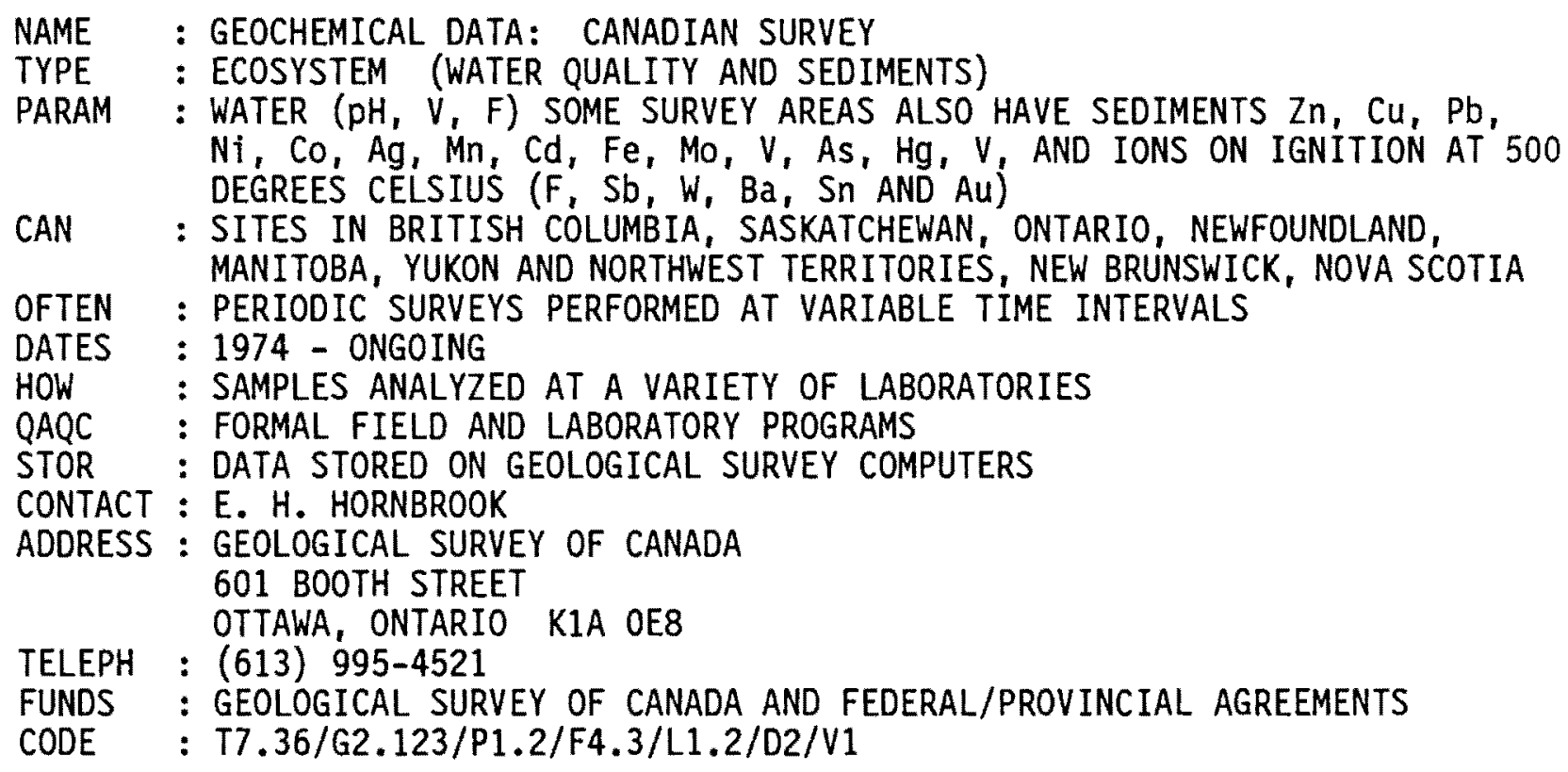




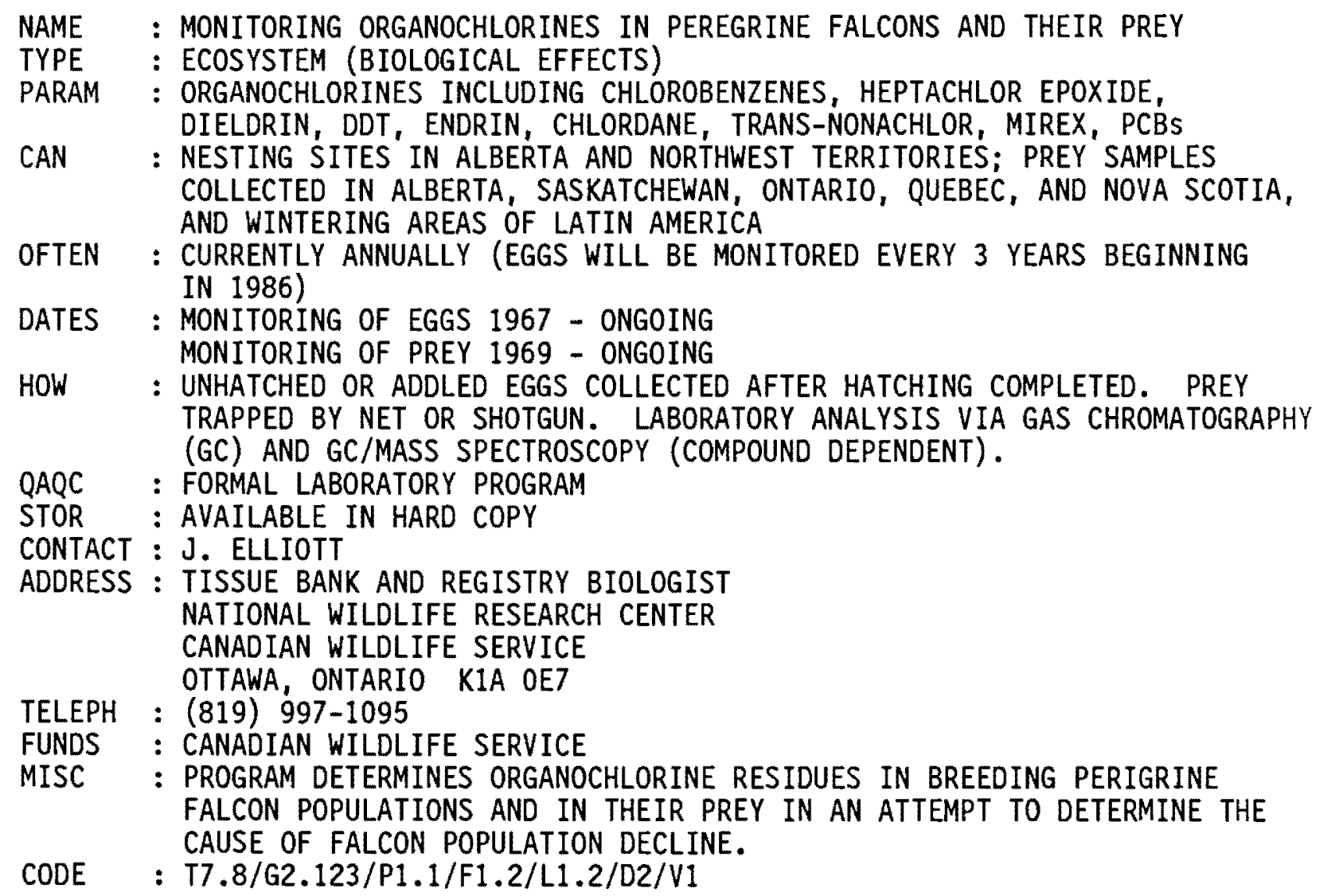




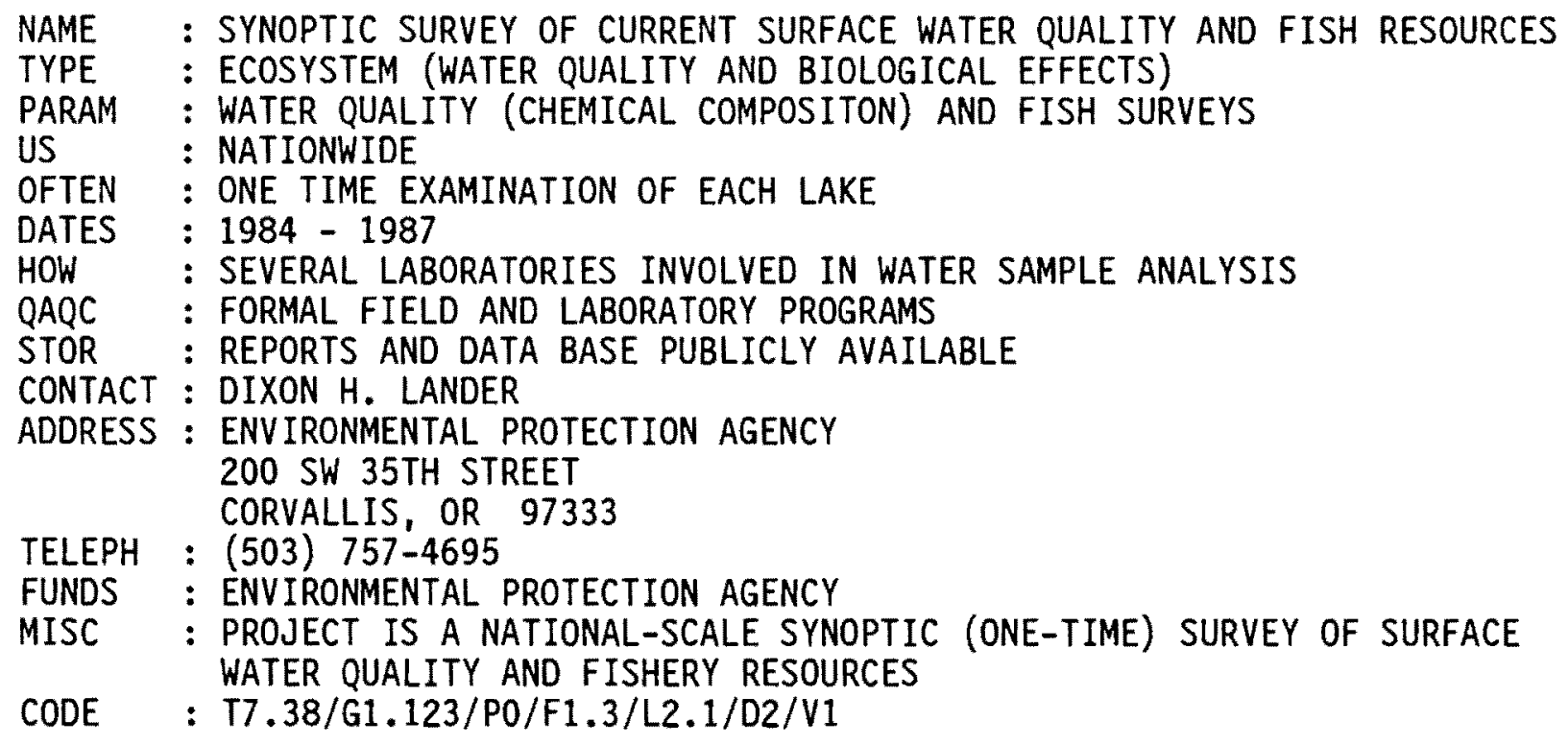




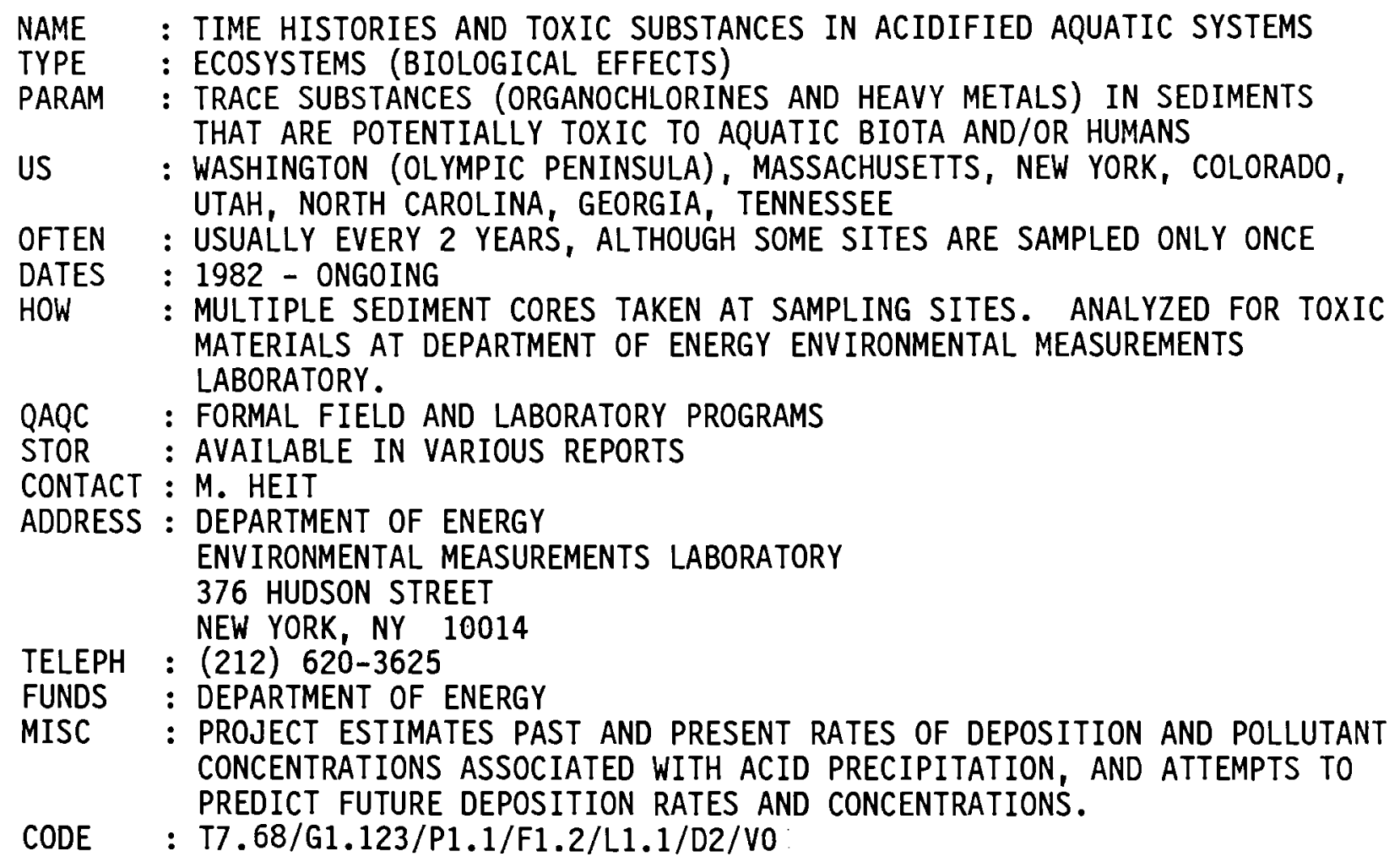




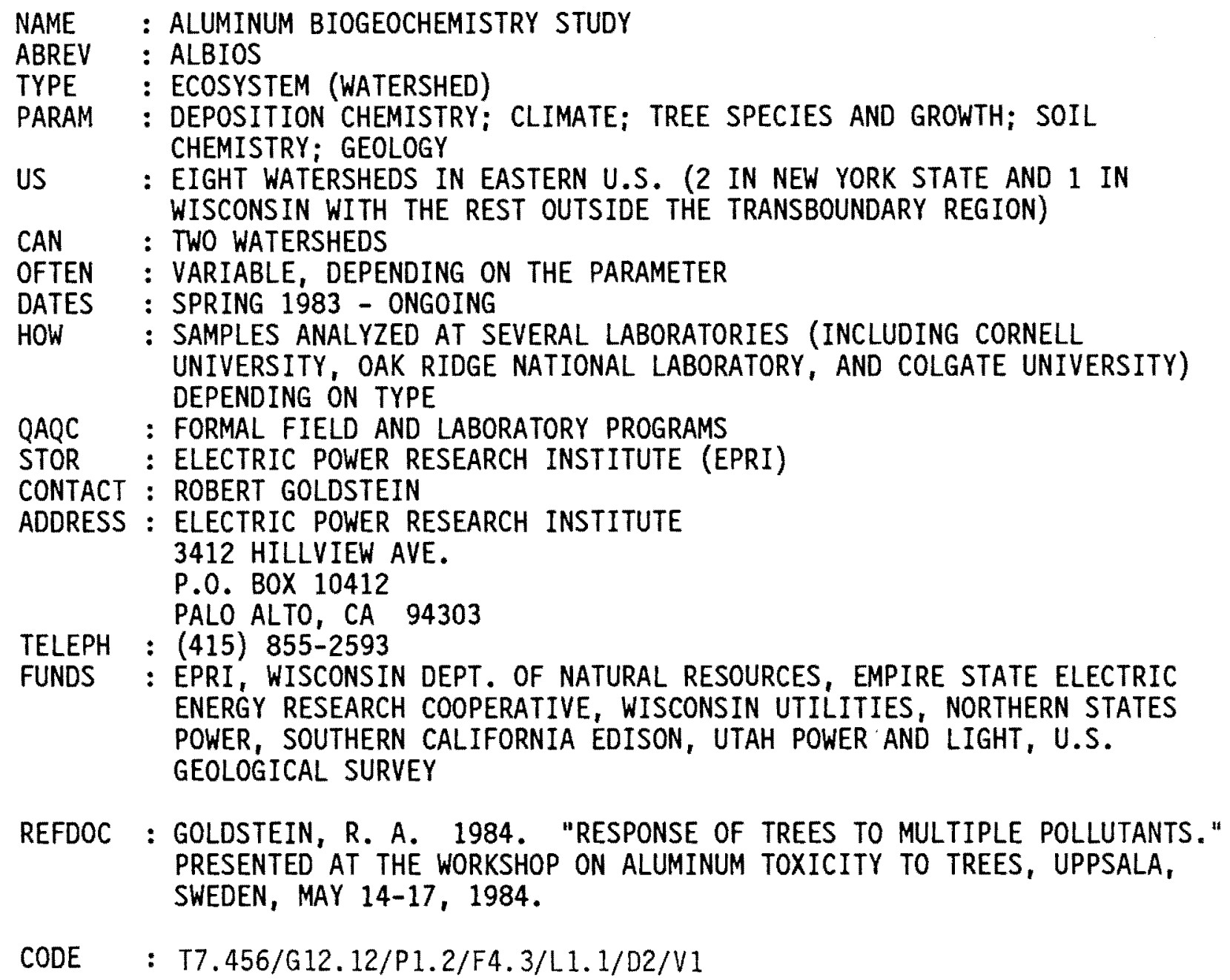

REFDOC : GOLDSTEIN, R. A. 1984. "RESPONSE OF TREES TO MULTIPLE POLLUTANTS." PRESENTED AT THE WORKSHOP ON ALUMINUM TOXICITY TO TREES, UPPSALA, SWEDEN, MAY 14-17, 1984.

CODE $\quad:$ T7.456/G12.12/P1.2/F4.3/L1.1/D2/V1

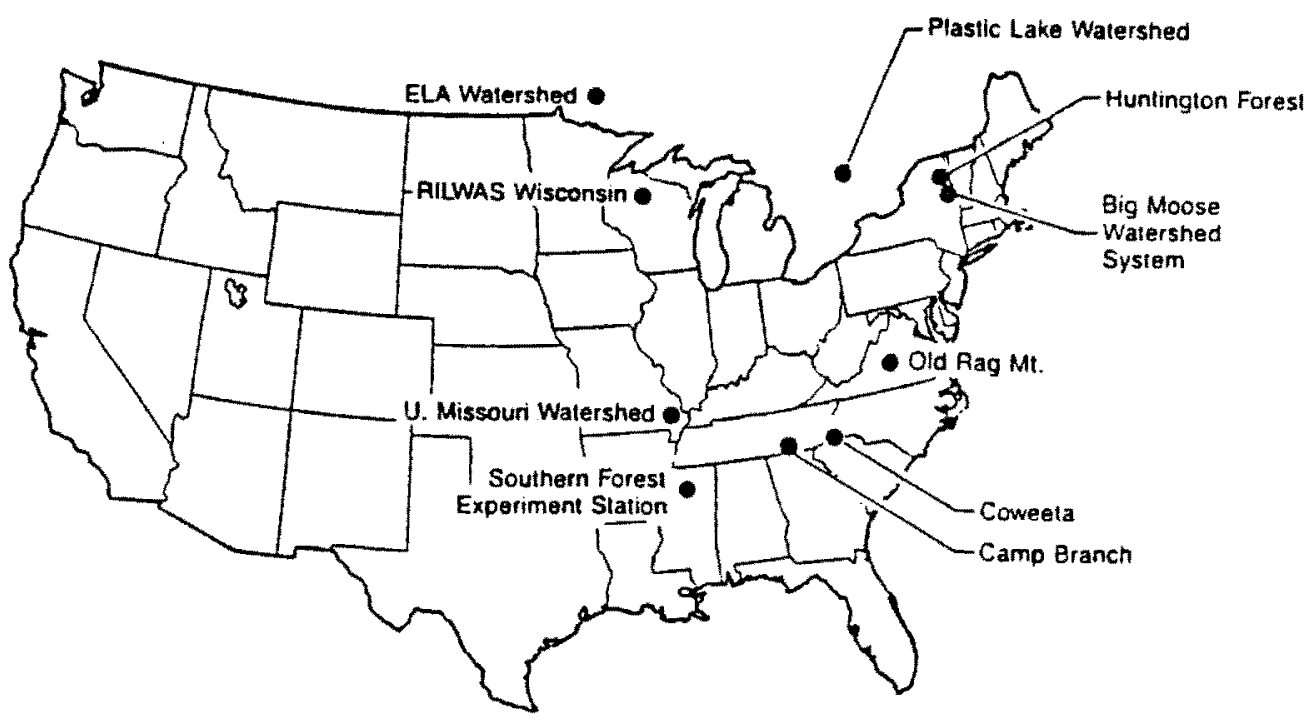

G.6 


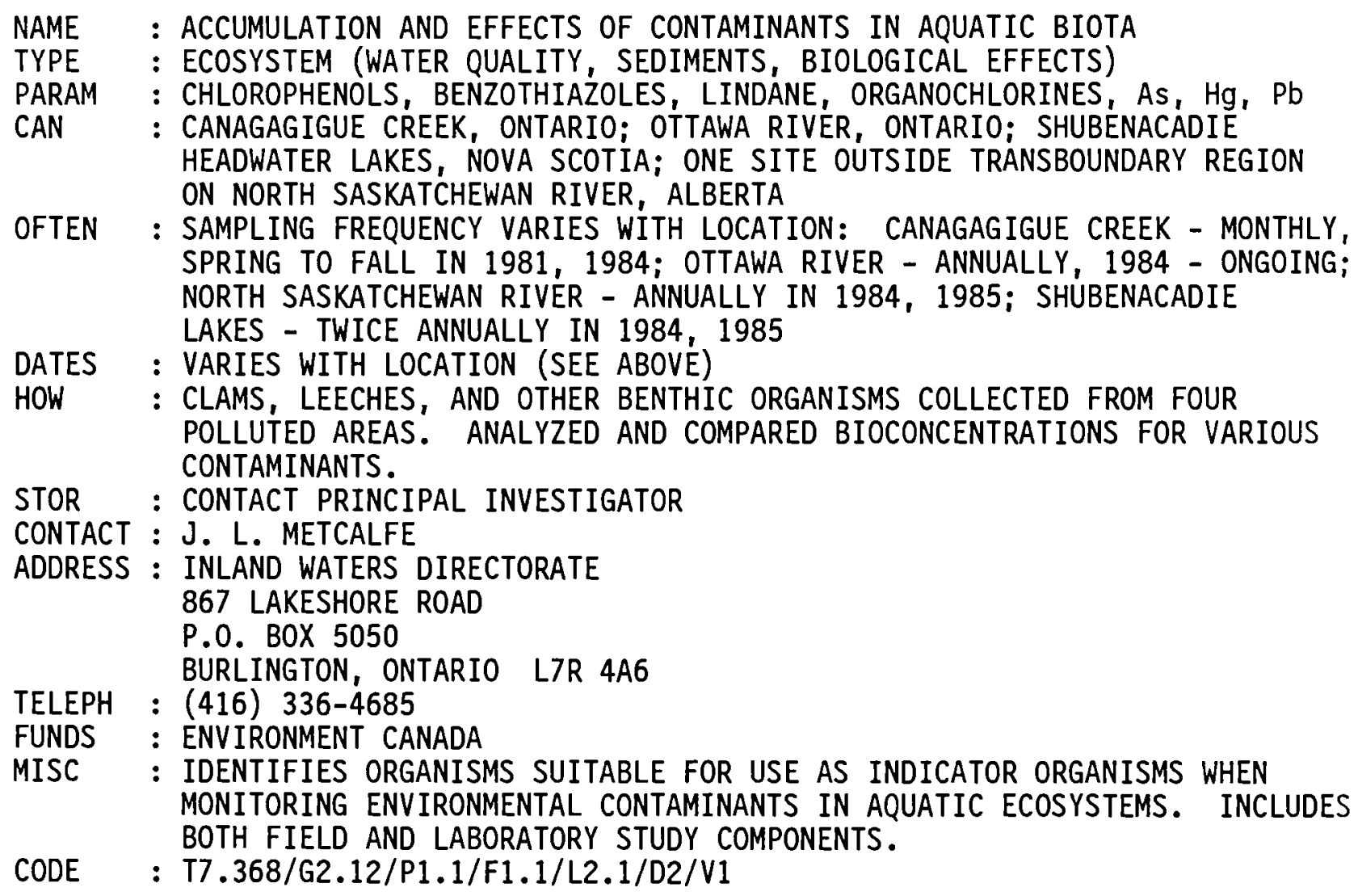




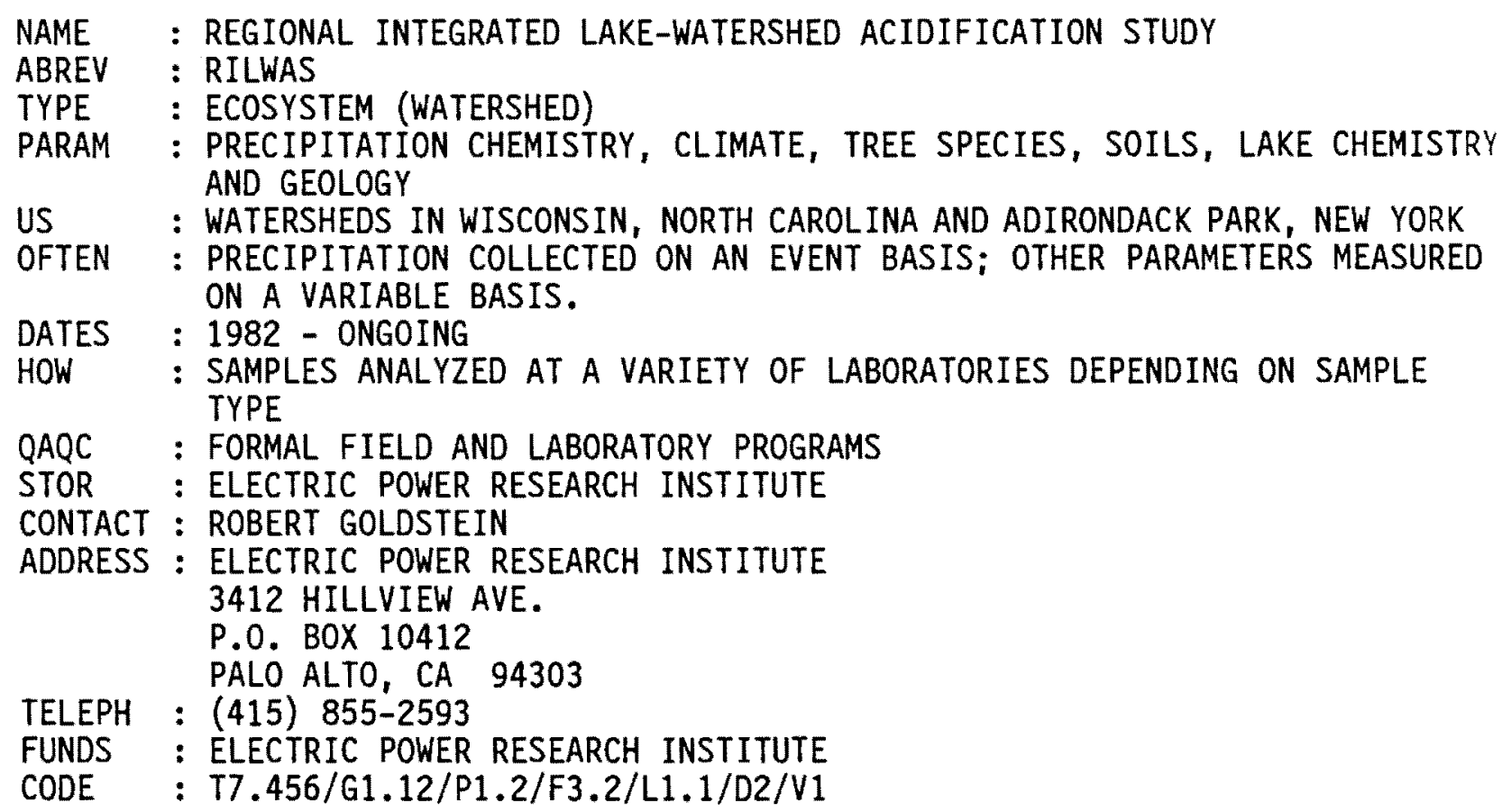




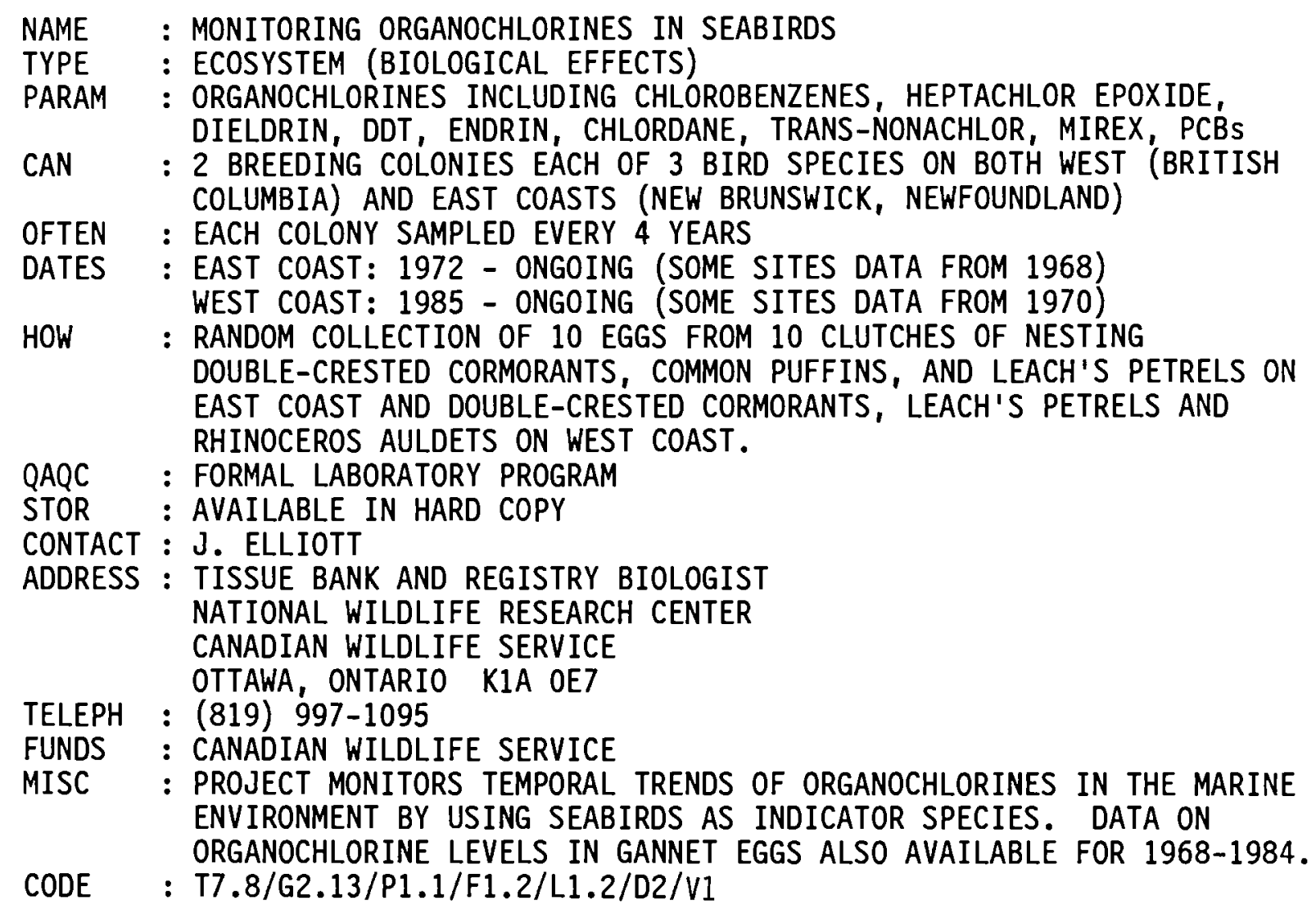

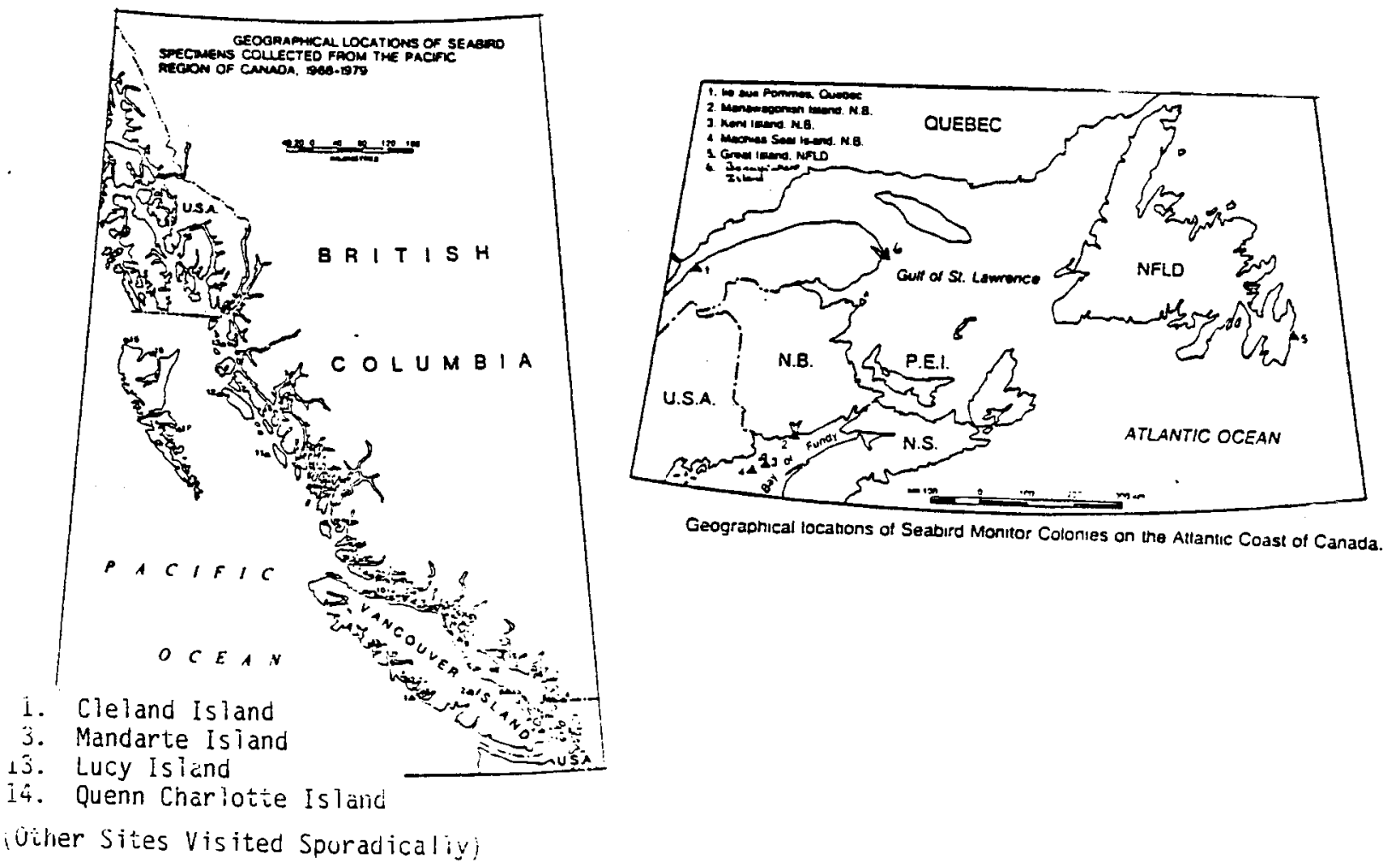

G.9 


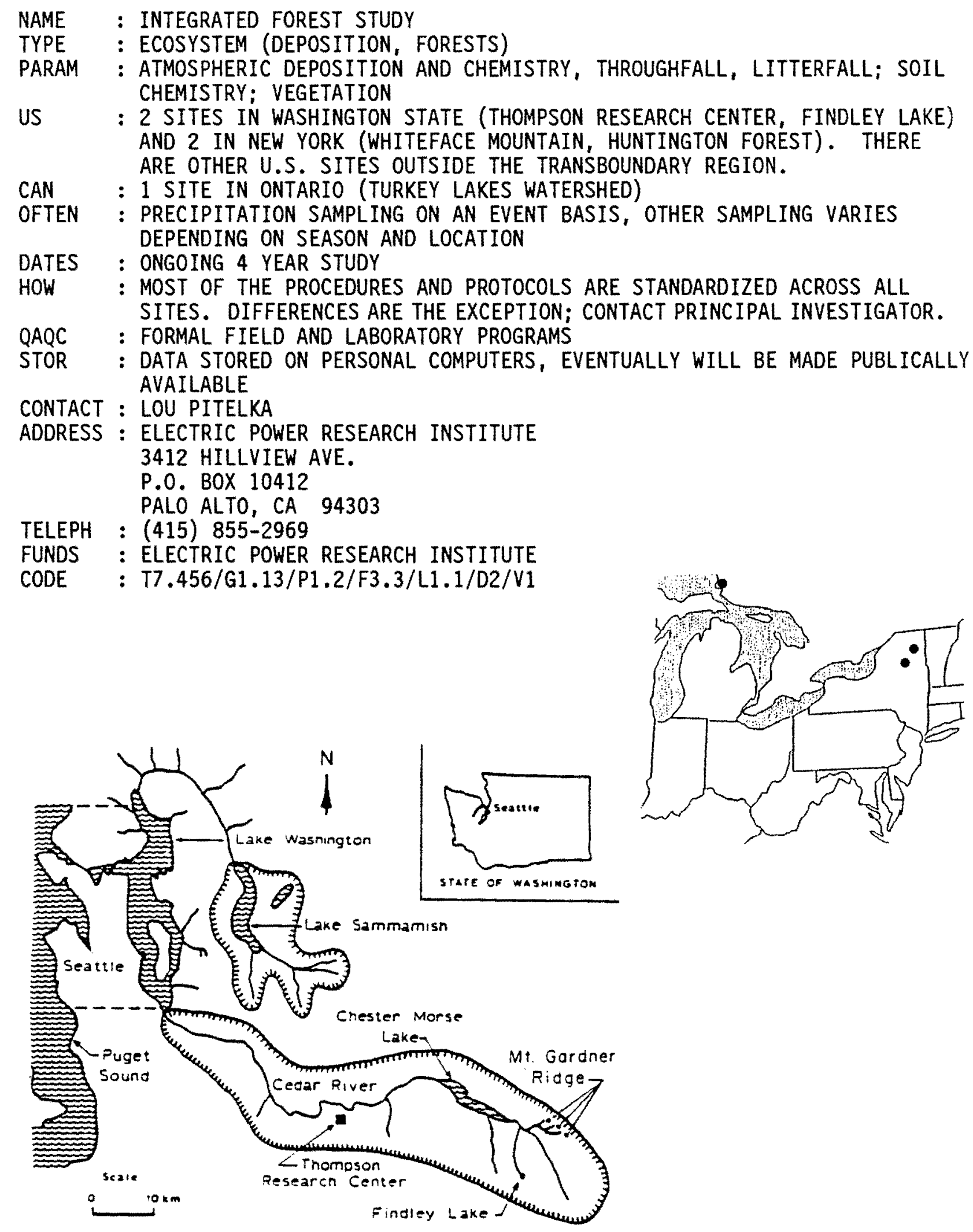




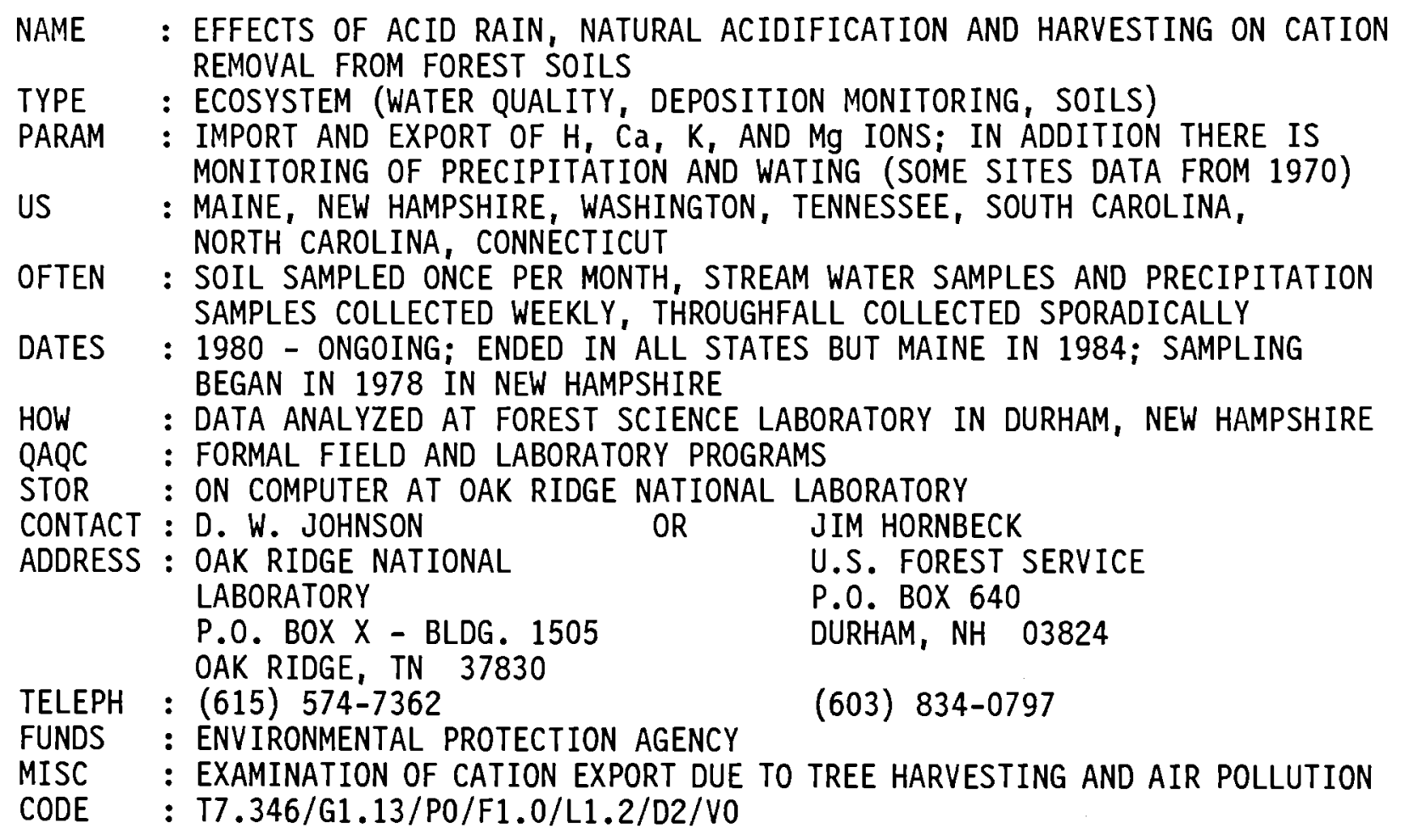


NAME : NEW BRUNSWICK AND NOVA SCOTIA HEADWATER LAKE SURVEY

TYPE : ECOSYSTEM (WATER QUALITY, BIOLOGICAL EFFECTS)

PARAM : WATER CHEMISTRY, FISH CONTAMINANT LEVELS ( $\mathrm{Cu}, \mathrm{Zn}, \mathrm{Pb}, \mathrm{Hg}, \mathrm{Cd}$, AND SEVERAL ORGANICS), PLANKTON SURVEYS, FISH SPECIES (PRESENCE-ABSENCE)

CAN : 145 LAKES IN NEW BRUNSWICK AND NOVA SCOTIA

OFTEN : ONE TIME SAMPLE

DATES : $1981-1982$

HOW : COLLECTION INCLUDED ONE VERTICAL PLANKTON TOW AND FIVE BENTHIC GRAB SAMPLES PER LAKE

QAQC : WATER CHEMISTRY AND FISH SAMPLING PROTOCOLS SAME AS FOR ONTARIO HEADWATERS STUDY

STOR : DATA AVAILABLE IN REPORT FORM

CONTACT : R. H. PETERSON OR S. RAY

ADDRESS : DEPT. OF FISHERIES AND OCEANS

ST. ANDREWS BIOLOGICAL STATION

ST. ANDREWS, NEW BRUNSWICK EOG $2 \times 0$

TELEPH : (506) 529-8854

FUNDS : CANADA FISHERIES AND OCEANS

CODE : T7.38/G2.1/P1.1/F1.2/L2.1/D2/V1

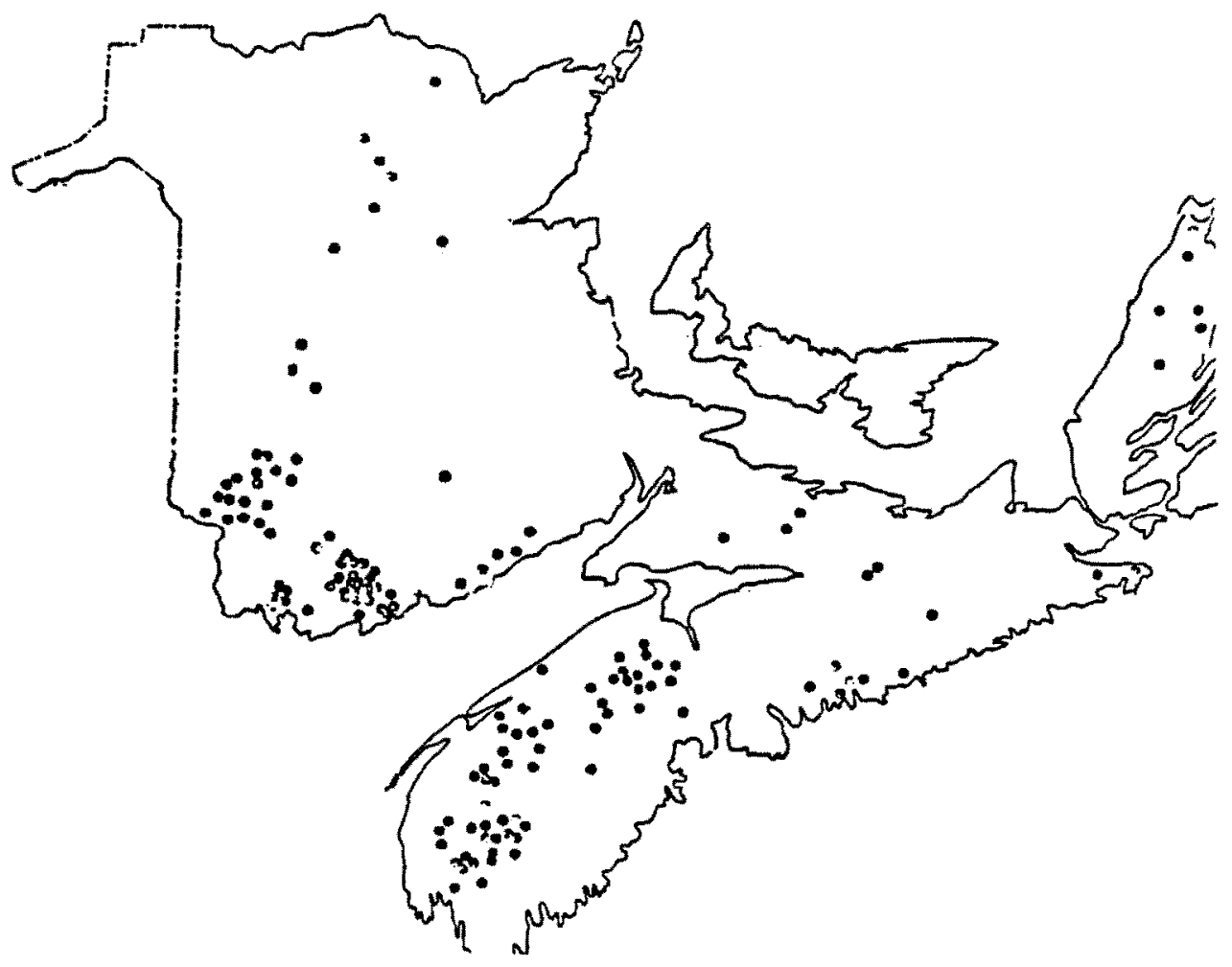



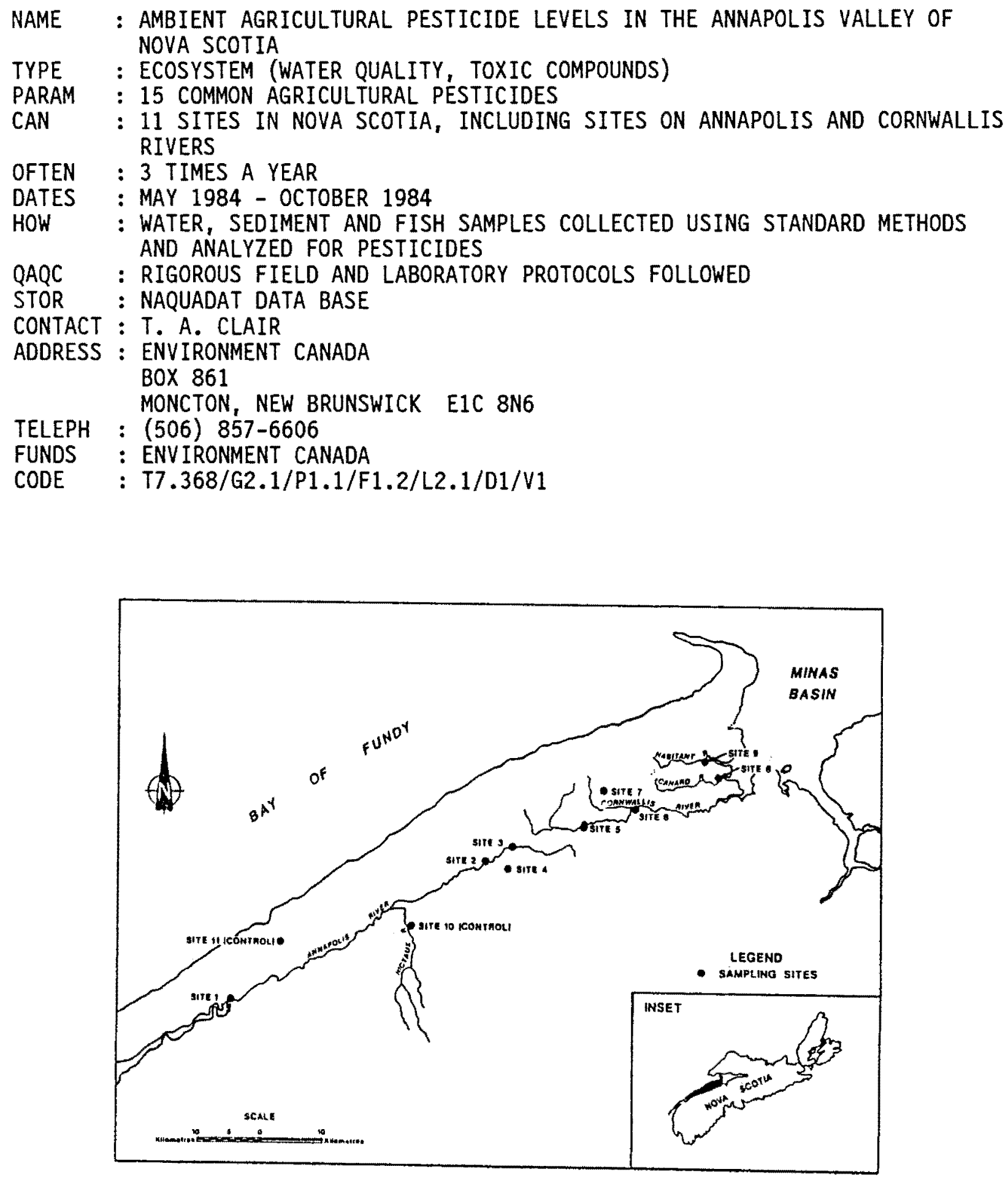


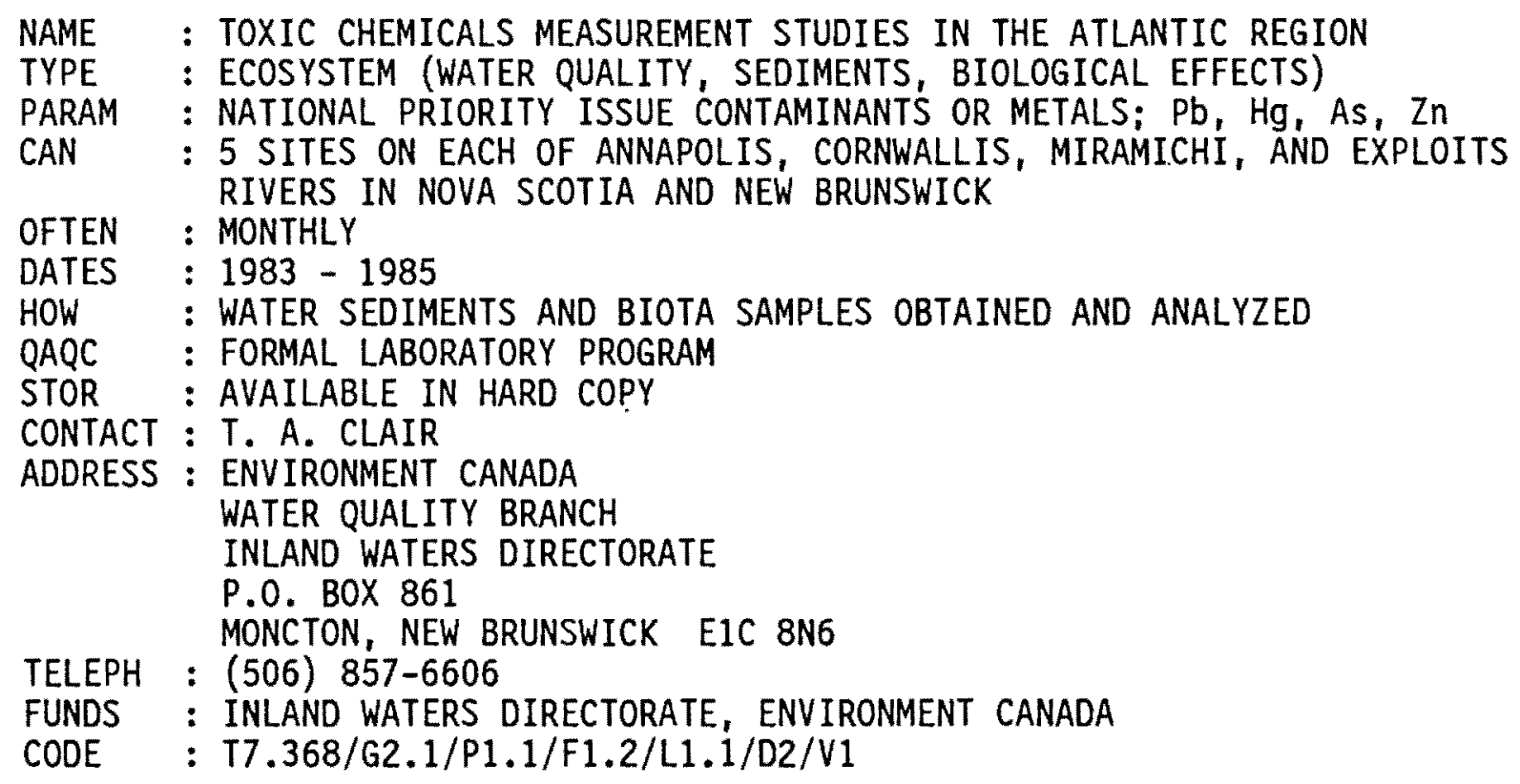




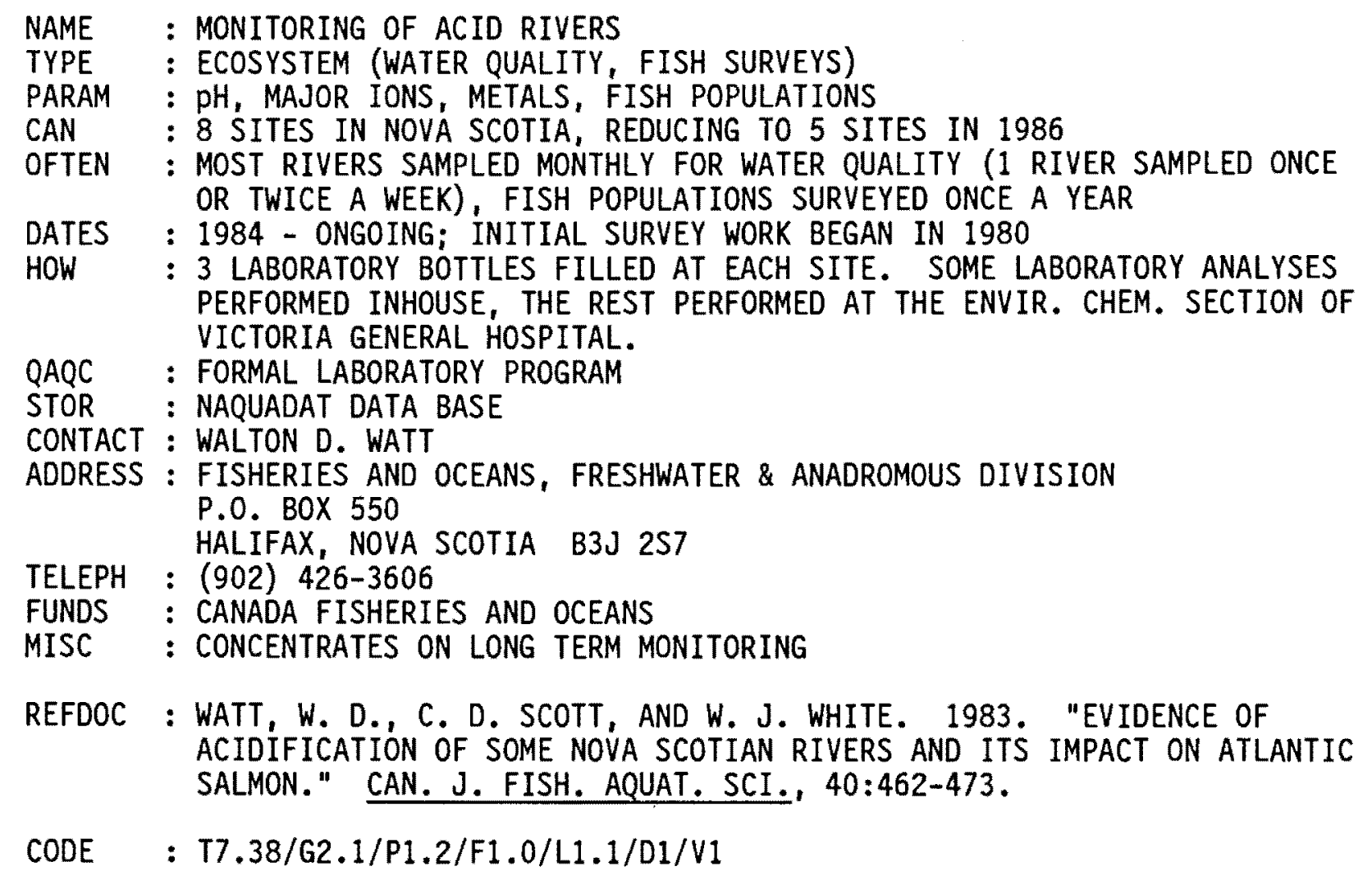




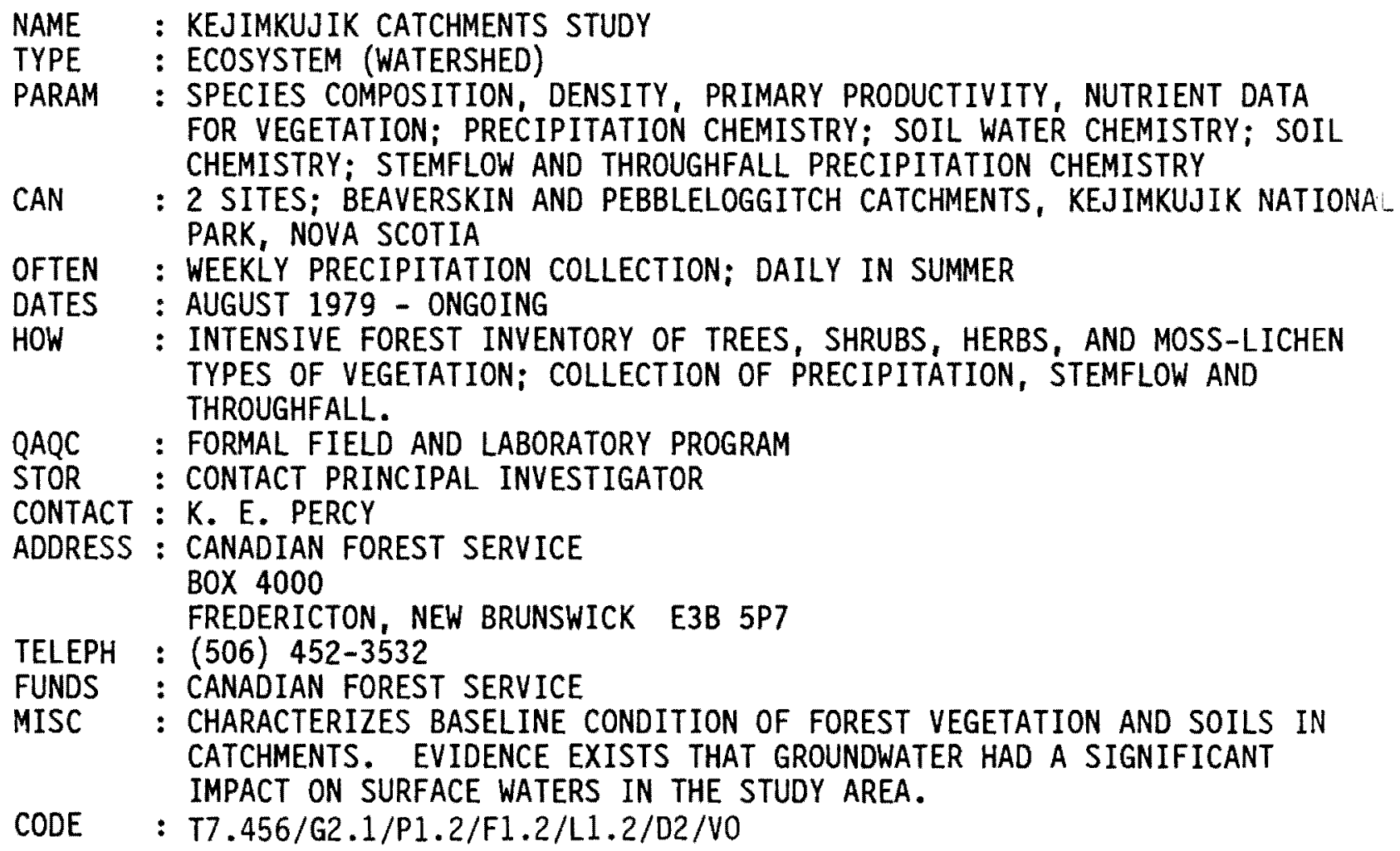
FOR VEGETATION; PRECIPITATION CHEMISTRY; SOIL WATER CHEMISTRY; SOIL CHEMISTRY; STEMFLOW AND THROUGHFALL PRECIPITATION CHEMISTRY

CAN : 2 SITES; BEAVERSKIN AND PEBBLELOGGITCH CATCHMENTS, KEJIMKUJIK NATIONAL PARK, NOVA SCOTIA

OFTEN : WEEKLY PRECIPITATION COLLECTION; DAILY IN SUMMER

DATES : AUGUST 1979 - ONGOING

HOW : INTENSIVE FOREST INVENTORY OF TREES, SHRUBS, HERBS, AND MOSS-LICHEN TYPES OF VEGETATION; COLLECTION OF PRECIPITATION, STEMFLOW AND THROUGHFALL.

QAQC : FORMAL FIELD AND LABORATORY PROGRAM

STOR : CONTACT PRINCIPAL INVESTIGATOR

CONTACT : K. E. PERCY

ADDRESS : CANADIAN FOREST SERVICE

BOX 4000

FREDERICTON, NEW BRUNSWICK E3B 5P7

TELEPH : (506) 452-3532

FUNDS : CANADIAN FOREST SERVICE

MISC : CHARACTERIZES BASELINE CONDITION OF FOREST VEGETATION AND SOILS IN CATCHMENTS. EVIDENCE EXISTS THAT GROUNDWATER HAD A SIGNIFICANT IMPACT ON SURFACE WATERS IN THE STUDY AREA.

CODE : T7.456/G2.1/P1.2/F1.2/L1.2/D2/VO

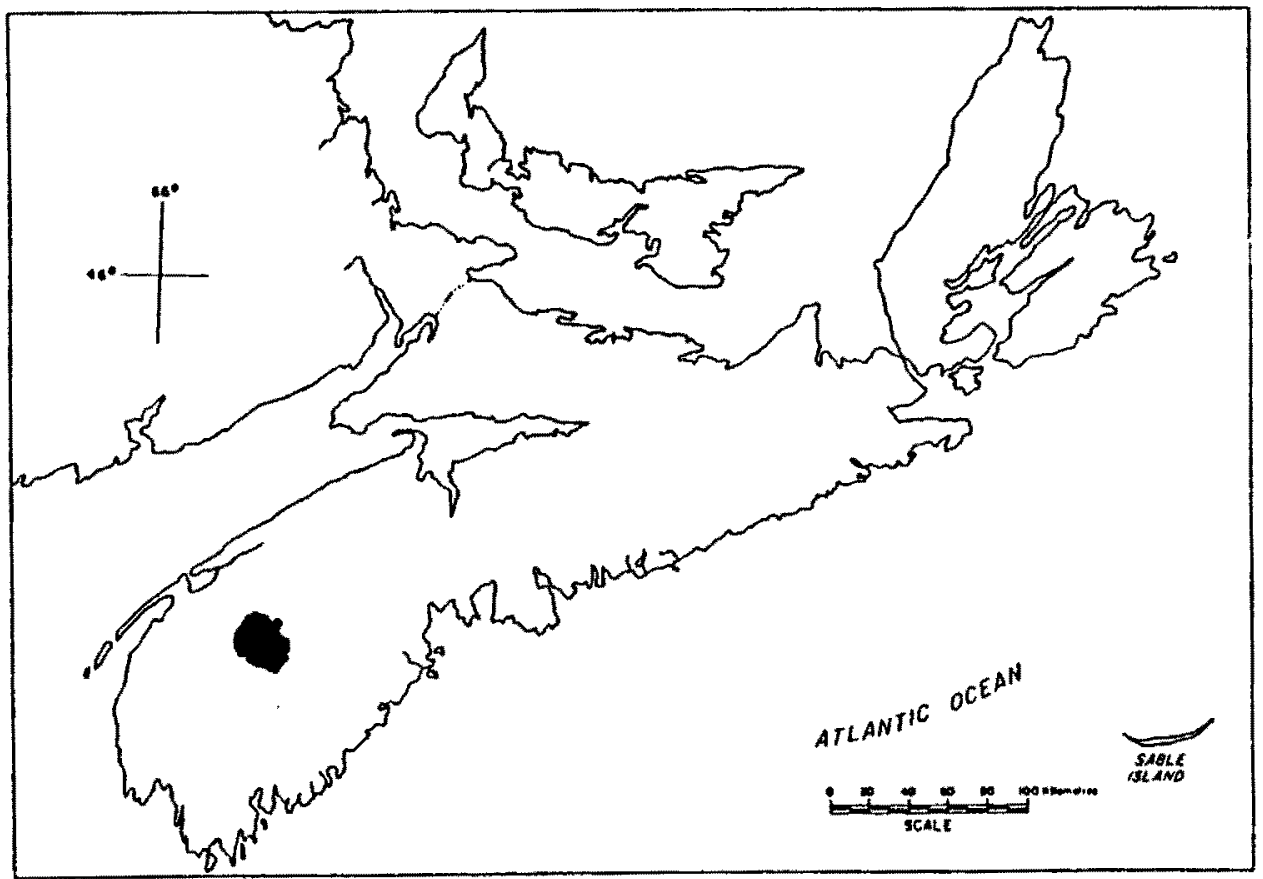


NAME : FIELD STUDIES ON AQUATIC MACROPHYTES, AMPHIBIANS AND STEMFLOW AND THROUGHFALL CHEMISTRY

TYPE : ECOSYSTEM (WATERSHED)

PARAM : STEMFLOW AND THROUGHFALL CHEMISTRY IN DIFFERENT FORESTS; SURVEY 11 TREE SPECIES IN 4 FOREST TYPES IN DIFFERENT WATERSHEDS; SURVEY AMPHIBIAN HABITAT TO DETERMINE MAJOR CHARACTERISTICS, PERFORM LABORATORY BIOASSAYS TO DETERMINE PH EFFECTS ON AMPHIBIANS; IDENTIFY AQUATIC MACROPHYTES IN LAKES OF DIFFERENT ACIDITIES.

CAN : KEJIMKUJIK NATIONAL PARK, NOVA SCOTIA

OFTEN : SAMPLING EVERY WEEK FOR PRECIPITATION

DATES : MAY - OCTOBER 1981

HOW : PRECIPITATION SAMPLES COLLECTED IN BUCKETS; ANALYZED AT DALHOUSIE UNIVERSITY.

QAQC : NO FORMAL PROGRAM

STOR : DATA AVAILABLE IN HARD COPY REPORTS

CONTACT : BILL FREEDMAN

ADDRESS : DEPT. OF BIOLOGY

DALHOUSIE UNIVERSITY

HALIFAX, NOVA SCOTIA B3H 4J1

TELEPH : (902) 424-3829

FUNDS : MARITIME FOREST RESEARCH CENTER - CANADIAN FORESTRY SERVICE, CANADIAN WILDLIFE SERVICE

REFDOC : DOLE, J., B. FREEDMAN, AND J. KESEKEV. 1985. "ACIDITY AND ASSOCIATED WATER CHEMISTRY OF AMPHIBIAN HABITATS IN NOVA SCOTIA." CAN. J. ZOOL., 63:97-105.

KESEKEV, J., B. FREEDMAN, G. HOWELL, AND P. CLIFFORD. 1984. "COMPARISON OF THE CHARACTERISTICS OF AN ACIDIC EUTROPHIC AND AN ACIDIC OLIGOTROPHIC LAKE NEAR HALIFAX, NOVA SCOTIA." WATER POLL. RES. J. CAN., 19:1-10.

CODE $\quad:$ T7.48/G2.1/P0/F1.2/L2.1/D2/V1

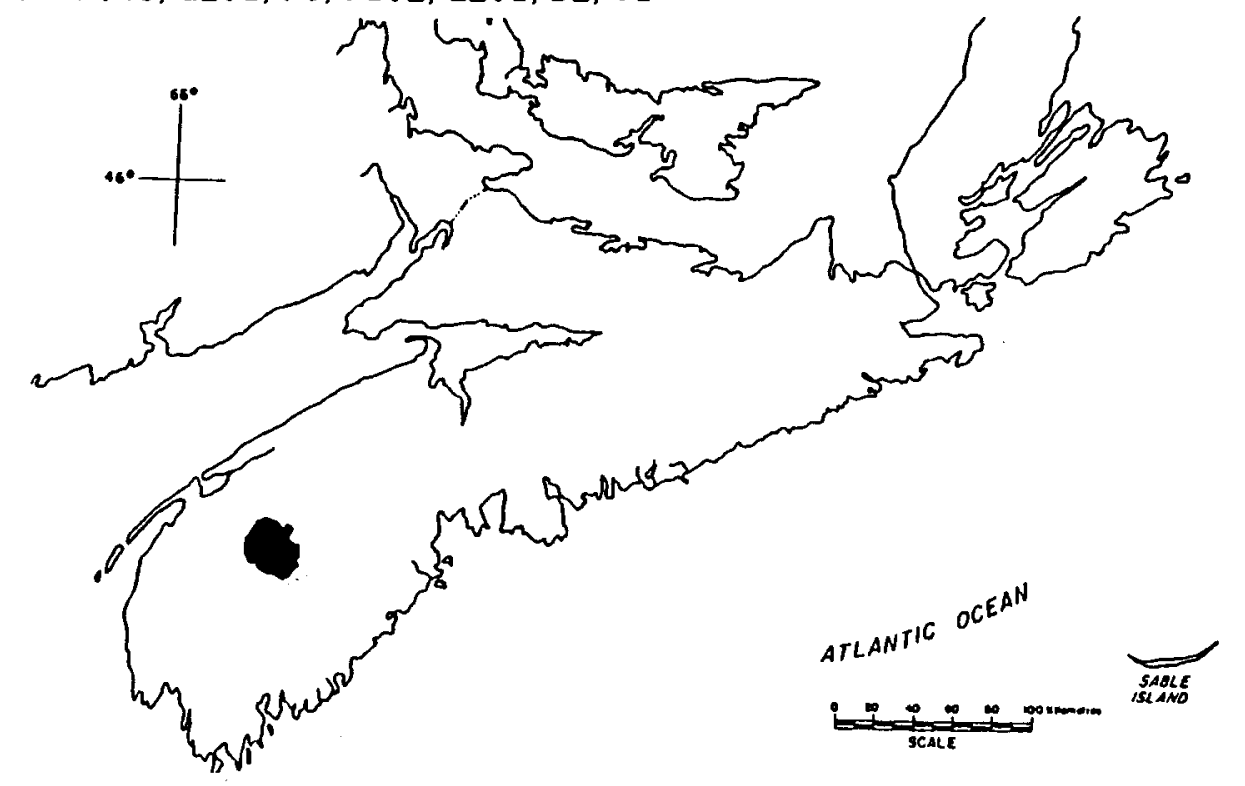



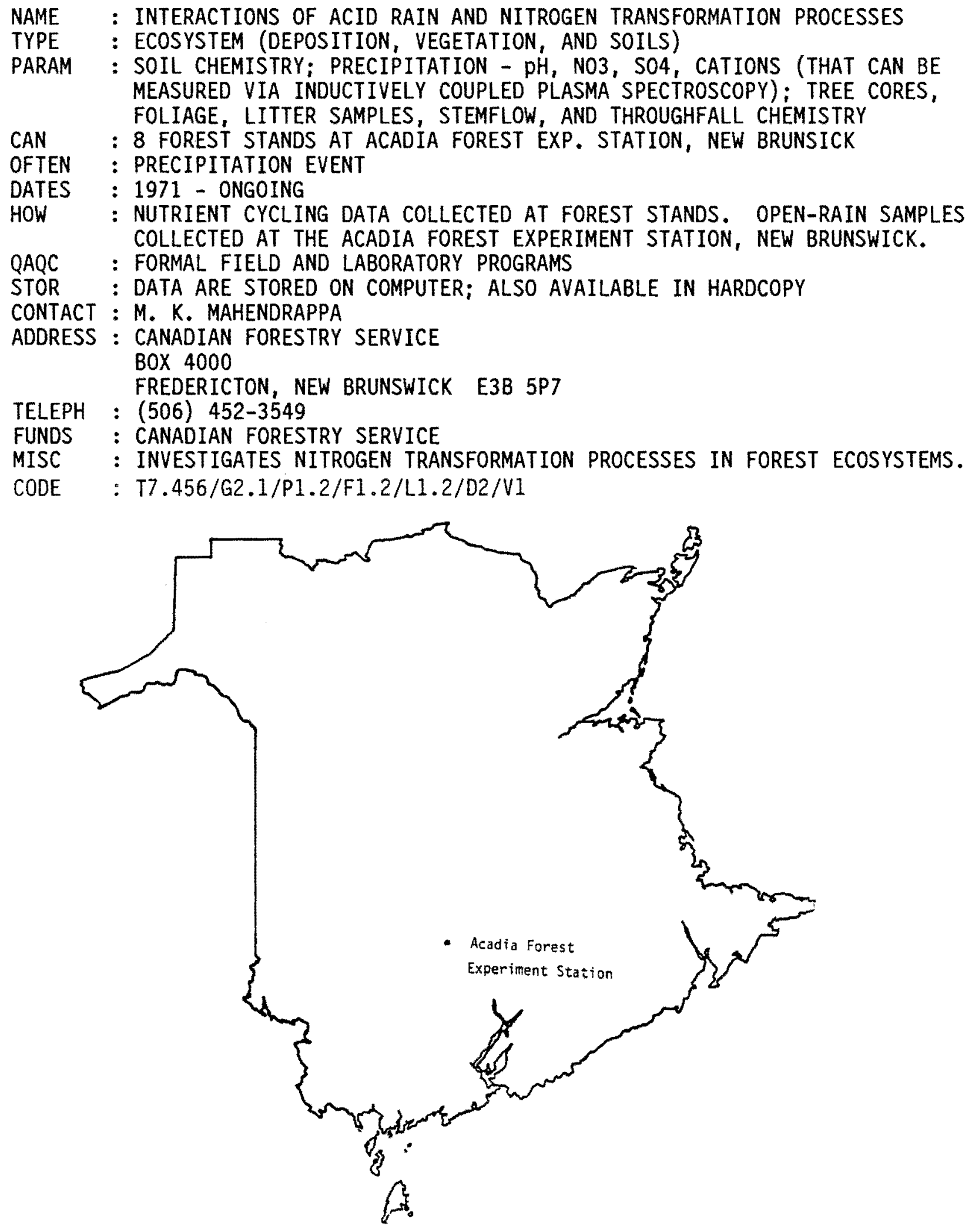


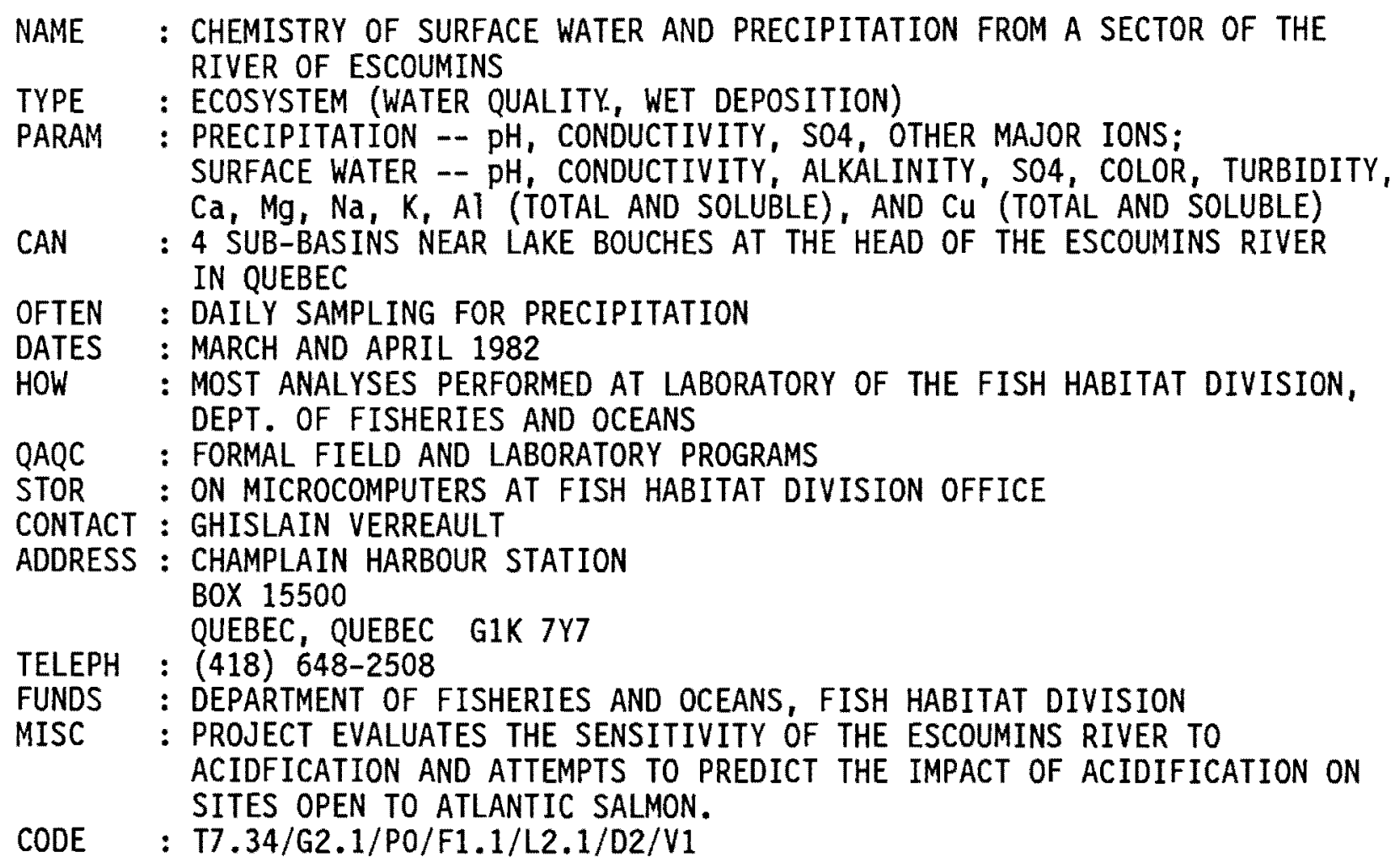



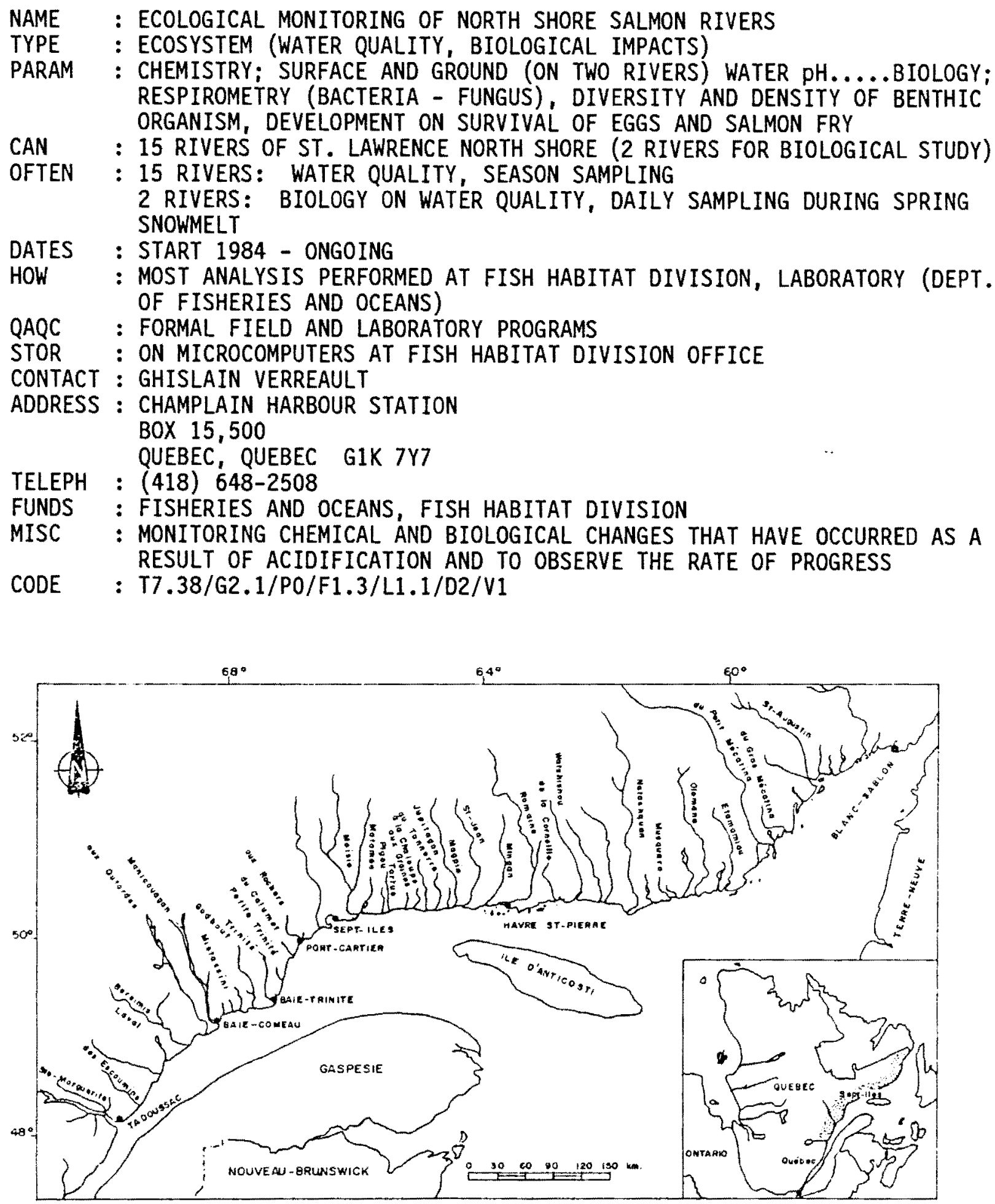

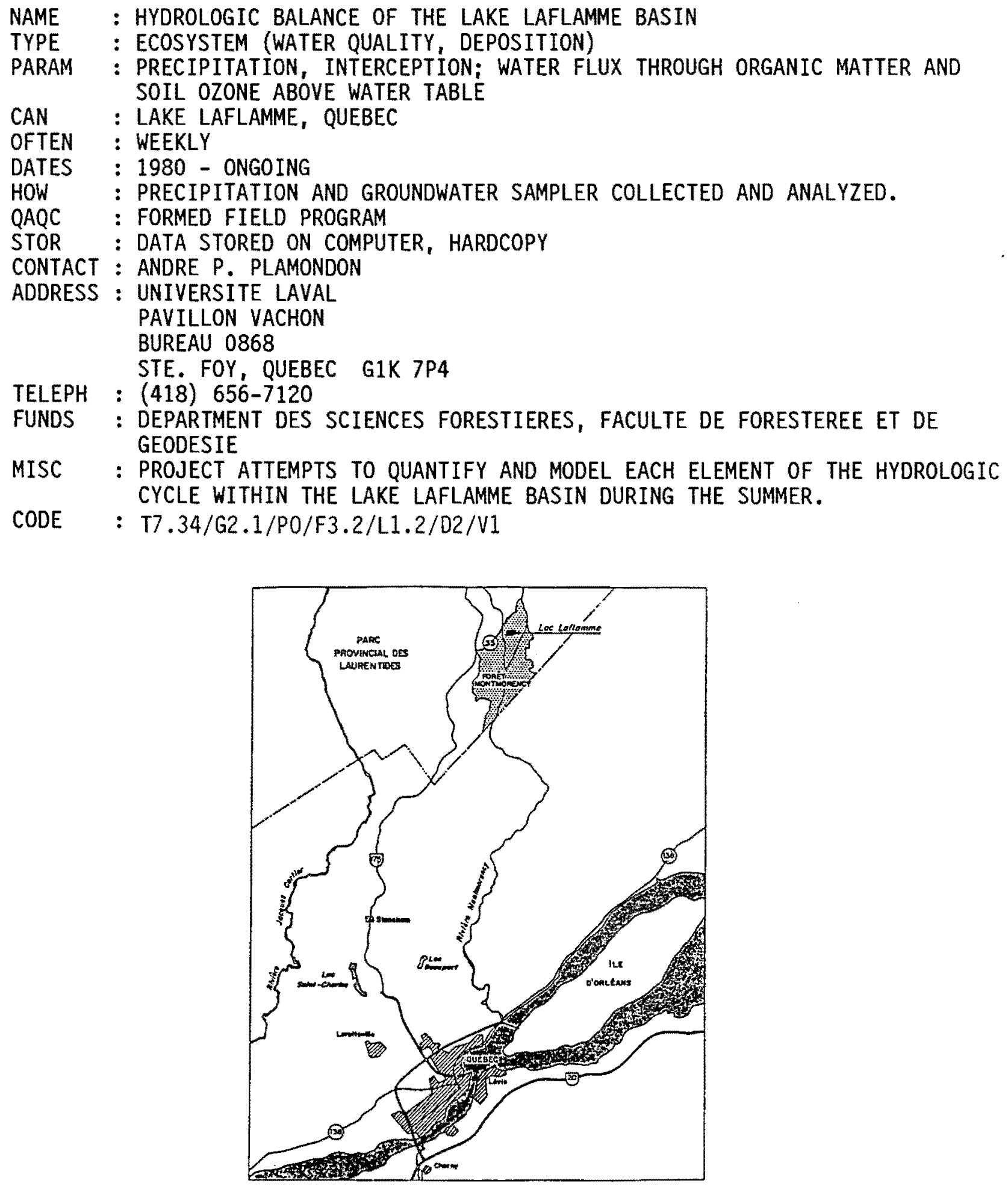
NAME : CHEMICAL CHARACTERISTICS OF SNOWFALL AND SEASONAL SNOWCOVERS

TYPE : ECOSYSTEM (WATERSHED, DEPOSITION)

PARAM : SNOWFALL CHEMICAL BUDGETS, CHEMICAL DYNAMICS OF SNOWCOVERS, SNOWMELT PROCESSES, FOREST CANOPY - SNOWPACK INTERACTIONS, MAJOR IONS, ORGANICS, METALS

CAN : LAURENTIAN PARK QUEBEC (LAKE LAFLAMME)

OFTEN : WEEKLY (WINTER COLD PERIODS) DAILY (SPRING MELT)

DATES : MARCH 1983 - ONGOING

HOW : FIELD MEASUREMENTS (PHYSICAL CHARACTERISTICS OF SNOWFALL AND SNOWCOVERS). LABORATORY ANALYSIS AT INRS-EAU, QUEBEC ( $\mathrm{pH}$, CONDUCTIVITY, MAJOR IONS, Fe, Al, Mn, ORGANICS)

STOR : MAINFRAME COMPUTERS I) CYBER 830, UNIVERSITE DU QUEBEC, QUEBEC;

II) VAX/VMS, INRS, QUEBEC

CONTACT : $H$. GERALD JONES

ADDRESS : INSTITUT NATIONAL DE LA RECHERCHE SCIENTIFIQUE (INRS-EAU) 2700 RUE EINSTEIN

CASA POSTALE 7500

STE. FOY, QUEBEC GIV $4 C 7$

TELEPH : (418) 654-2533

FUNDS : NSERC (CAN), ENVIRONMENT CANADA (INLAND WATERS DIRECTORATE, ATMOSPHERIC ENVIRONMENT SERVICE)

REFDOC : INLAND WATERS DIRECTORATE. 1981. LAC LAFLAMME CALIBRATED WATERSHED: AN OVERVIEW. INLAND WATERS DIRECTORATE, STE. FOY, QUEBEC.

CODE $\quad:$ T7.45/G2.1/P3.1/F1.2/L1.1/D2/V1

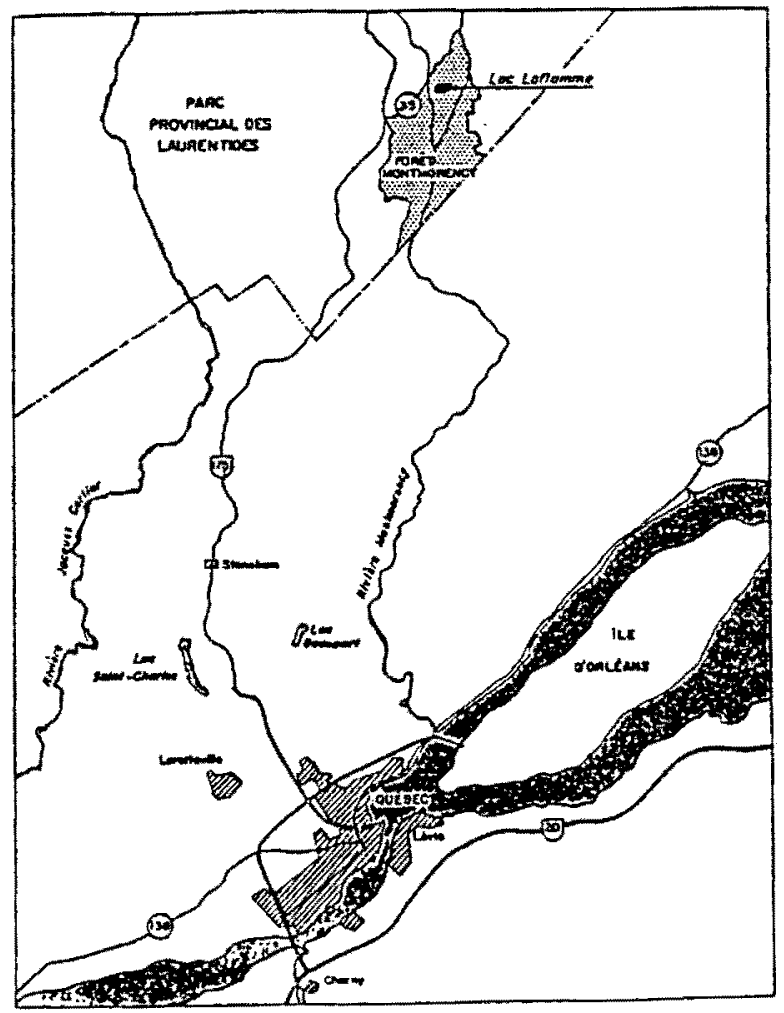


NAME : PREDICTION OF SNOWMELT ACIDITY AT THE BASE OF A SNOWPACK

TYPE : ECOSYSTEM (WATERSHED)

PARAM : SNOWPACK DYNAMICS, SO4, NH3, H, SNOW PHYSICS, MELT

CAN : LAKE LAFLAMME, QUEBEC

OFTEN : PHYSICAL: HOURLY OR DAILY, CHEMISTRY: DAILY

HOW : DATA ACQUISITION SYSTEM, GRAB SAMPLES. HYDROMETEOROLOGICAL DATA.

QAQC : FORMAL FIELD AND LABORATORY PROGRAMS

STOR : ON MAINFRAME AND MICROCOMPUTERS AT LAVAL UNIVERSITY

CONTACT : J. STEIN

ADDRESS : LAVAL UNIVERSITY

SCHOOL OF FORESTRY

PAVILLON VACHON

BUREAU 0870

STE. FOY, QUEBEC G1K 7 P4

TELEPH : (418) 656-2945

FUNDS : DEPARTMENT OF ENVIRONMENT CANADA, LAVAL UNIVERSITY, NSERC ETC...

MISC : G. H. JONES OF INRS-EAU IS IN CHARGE OF THE SNOWMELT QUALITY ASPECTS OF THIS PROJECT

CODE : T7.34/G2.1/PO/F4.2/L1.1/D2/V1

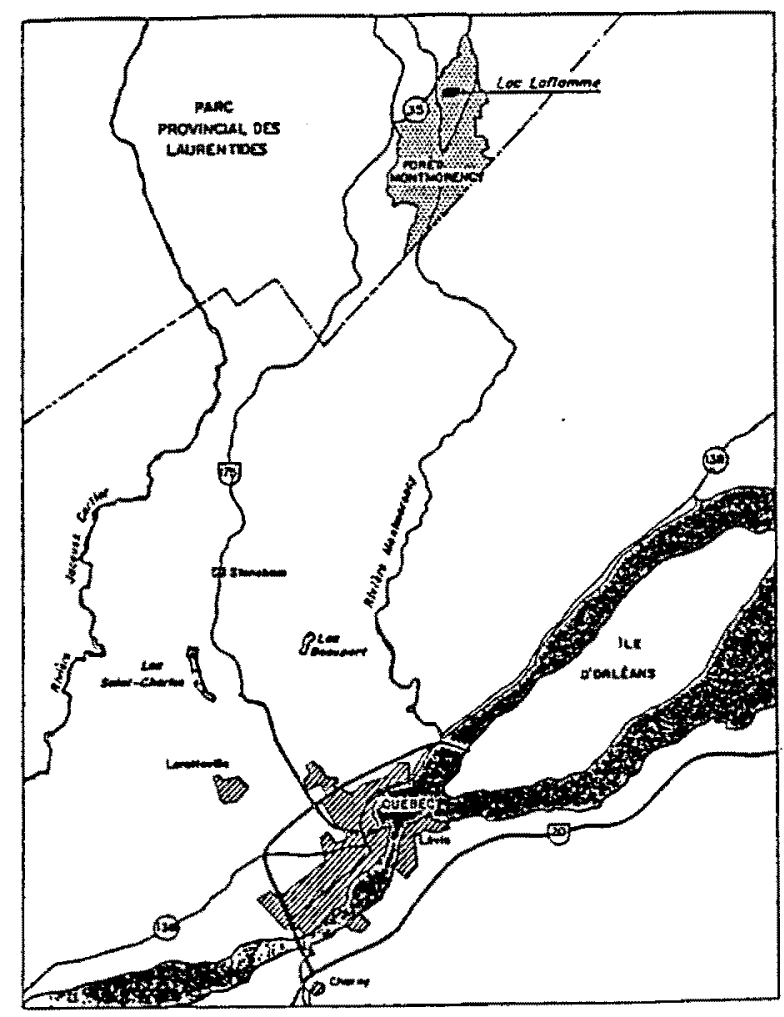

6.23 

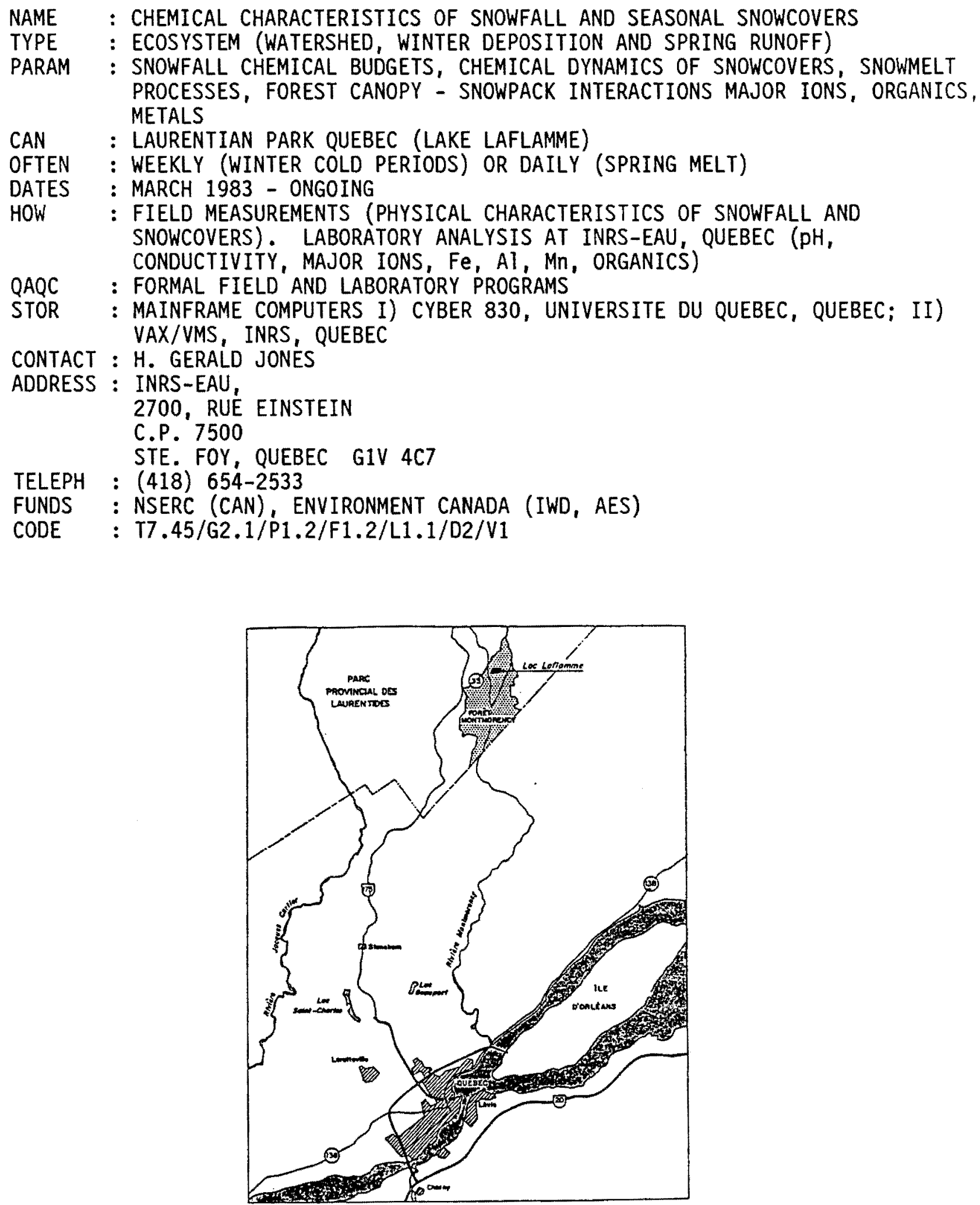


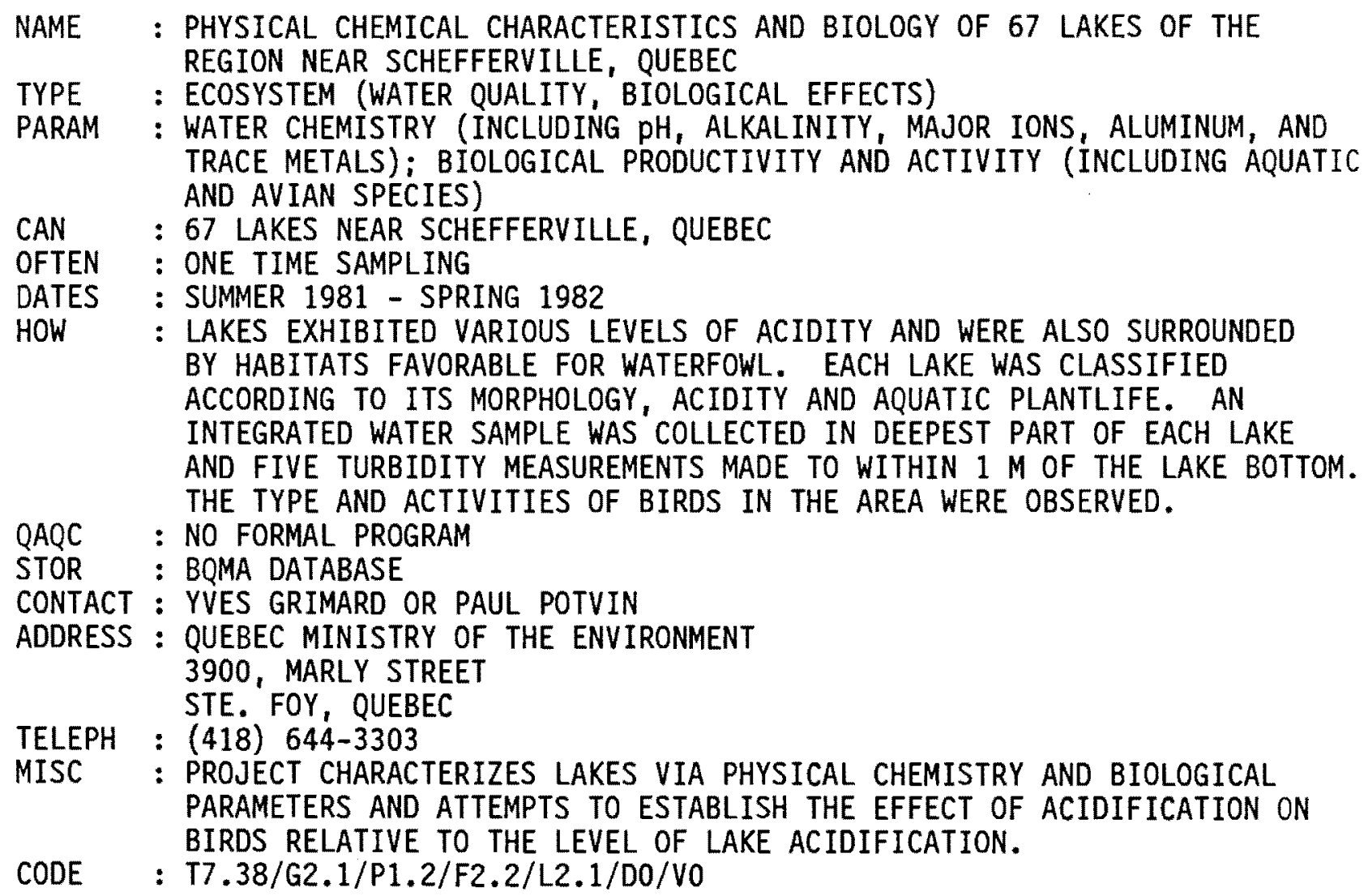




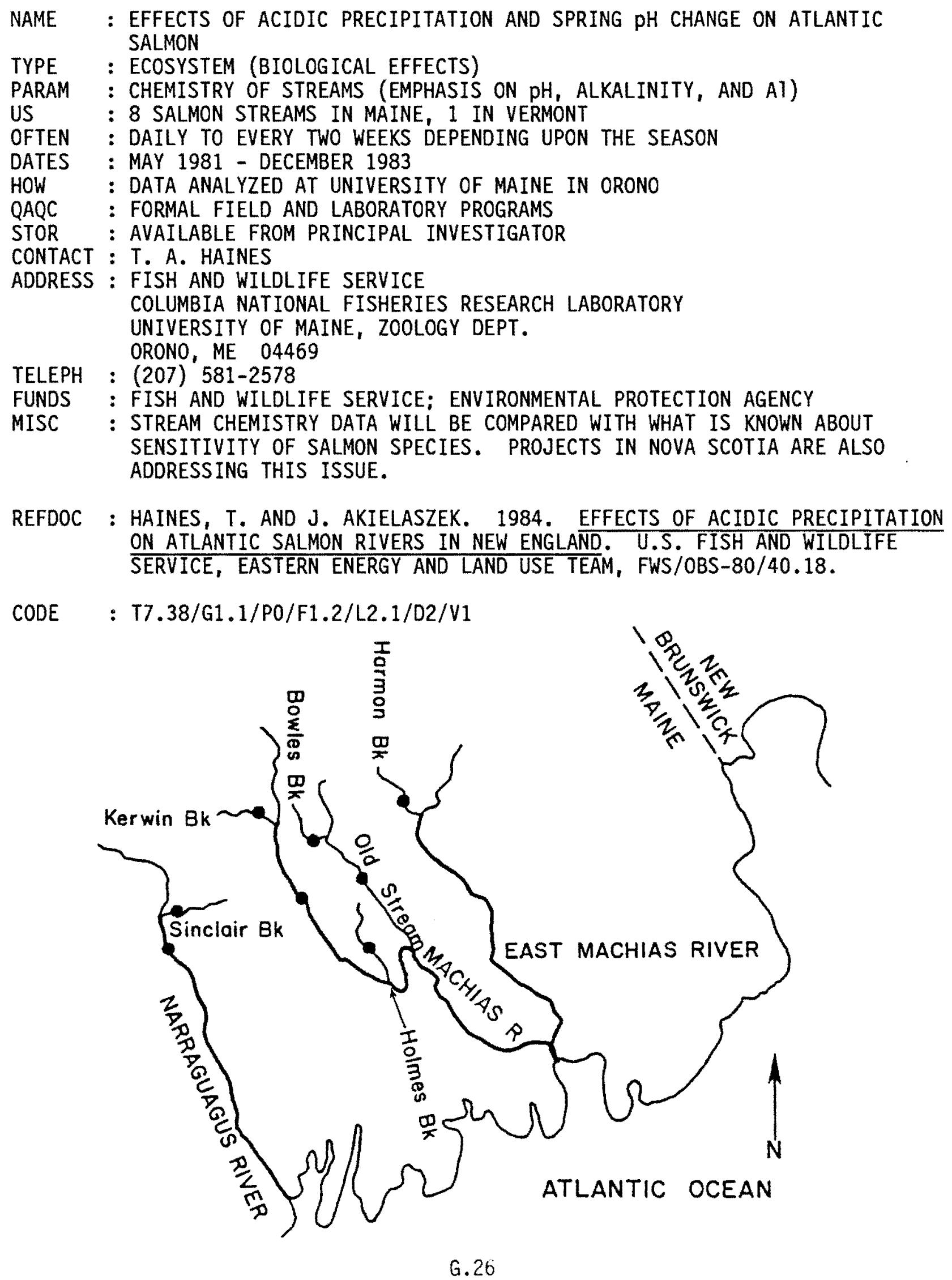




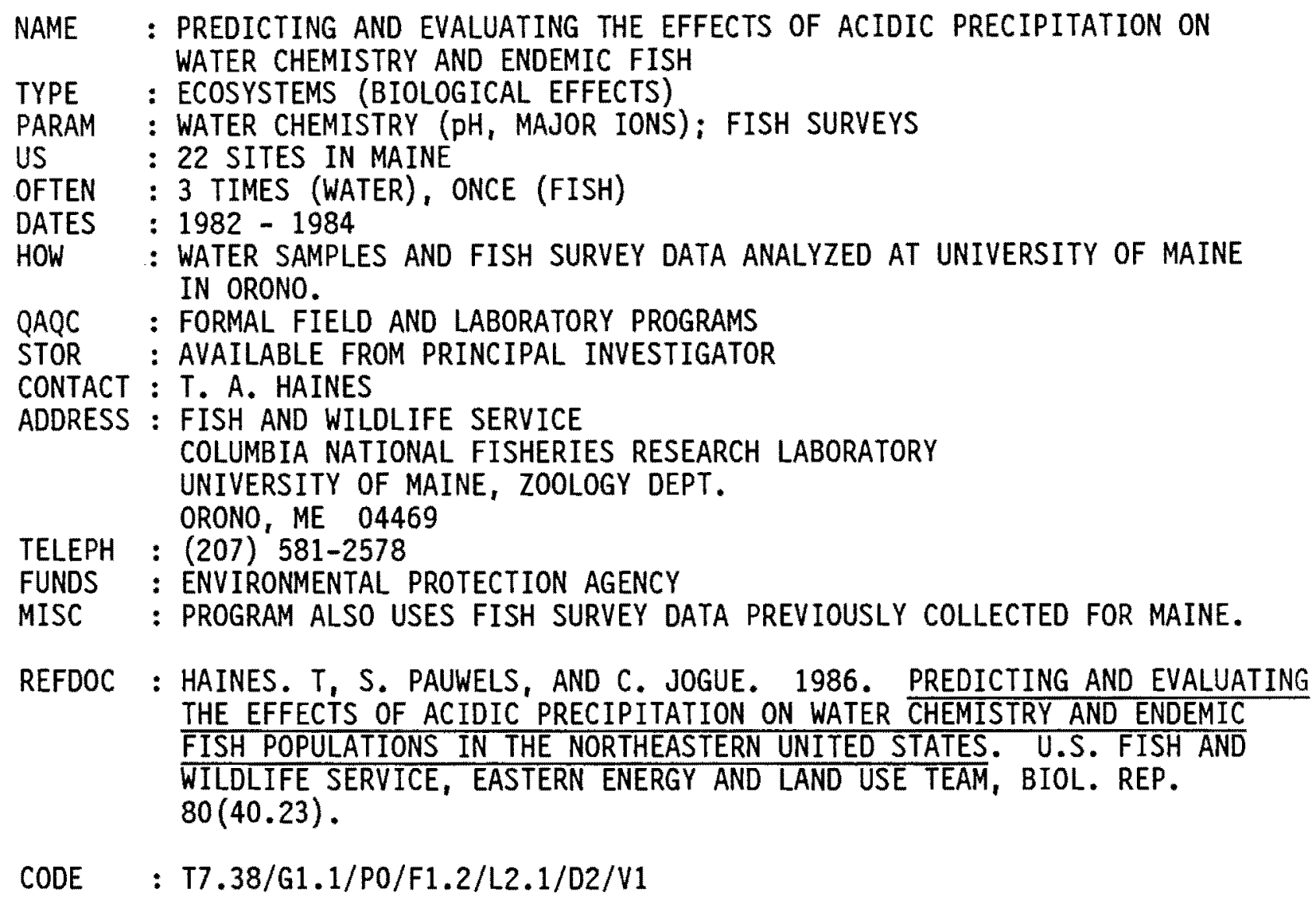




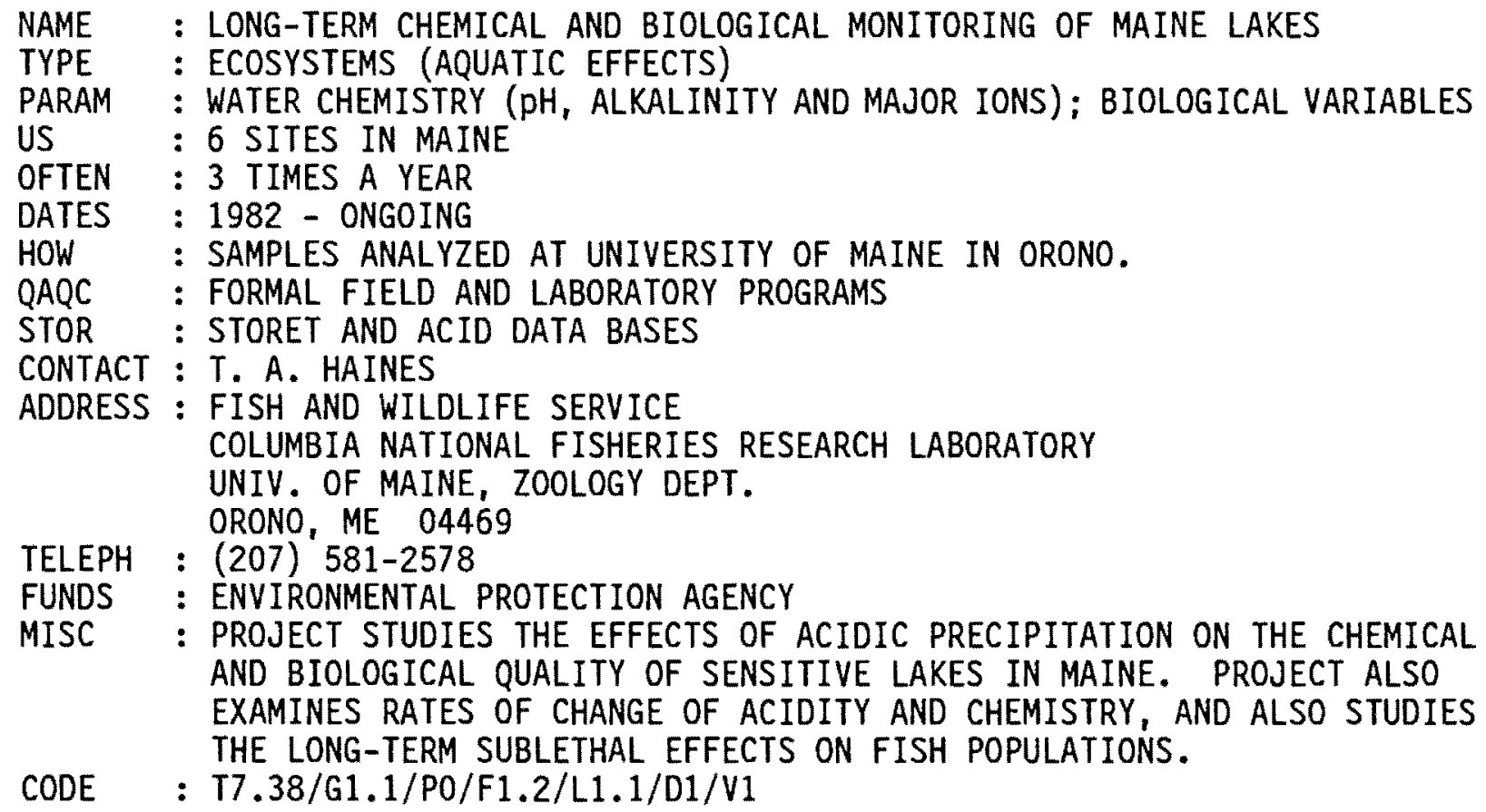




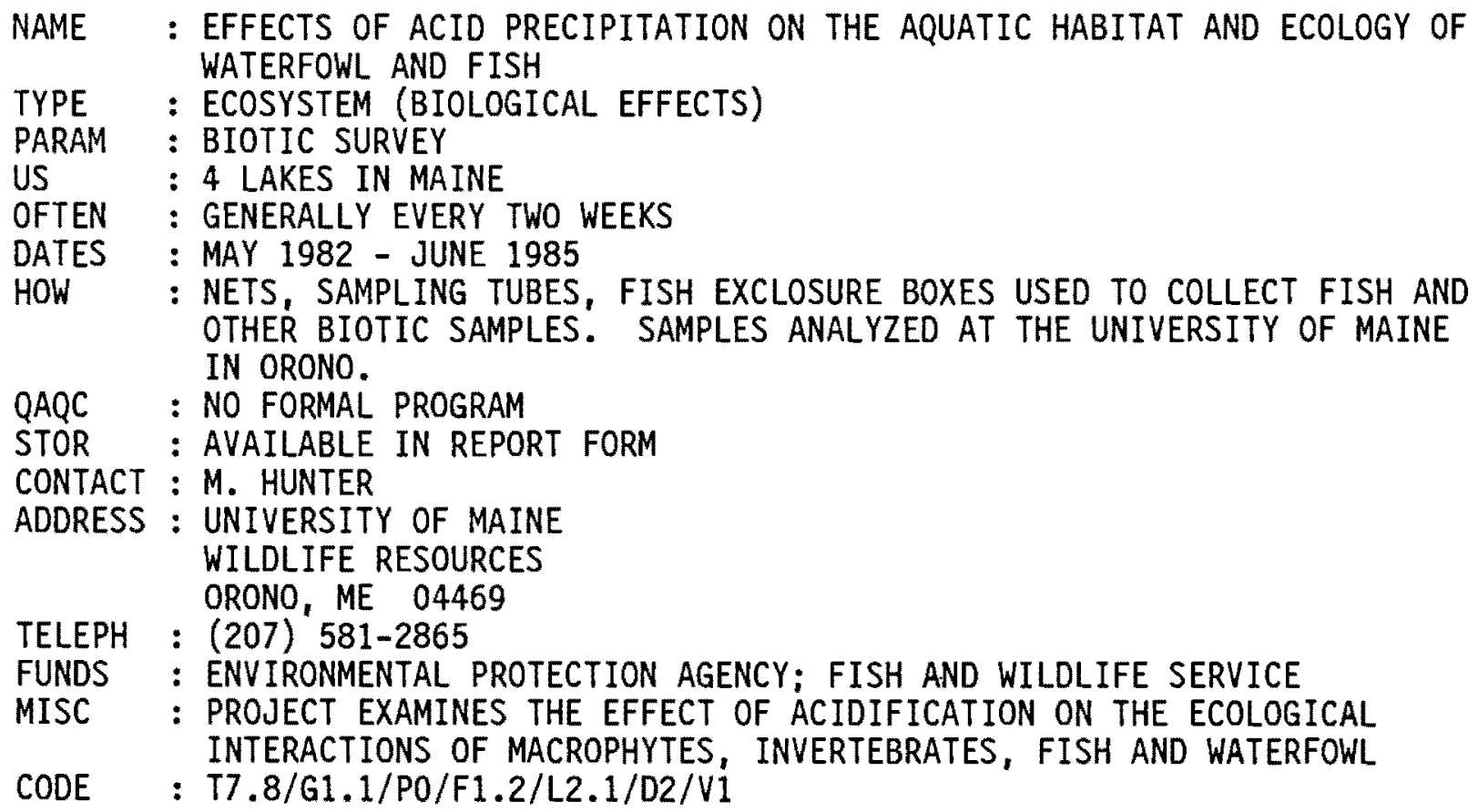




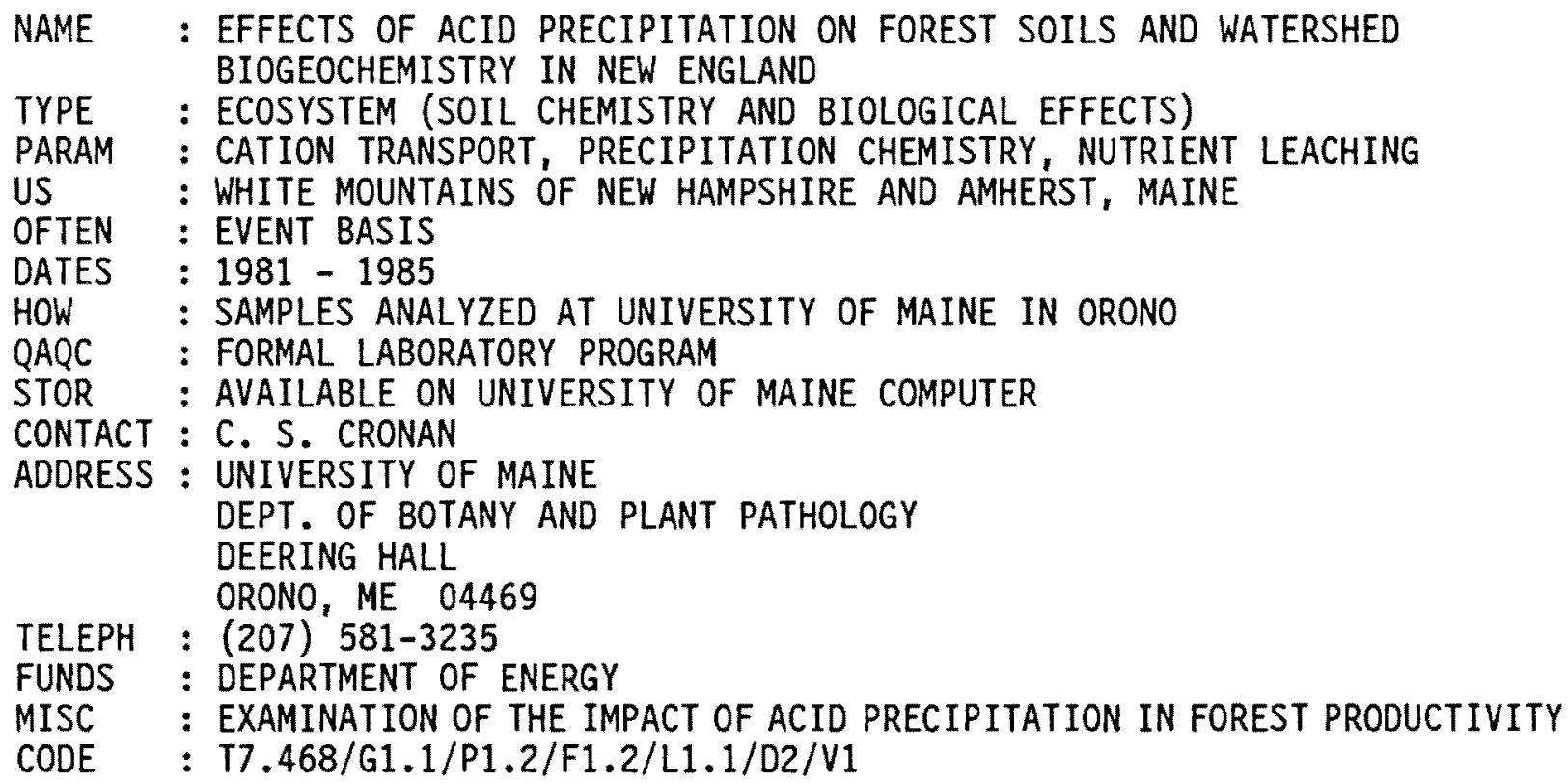




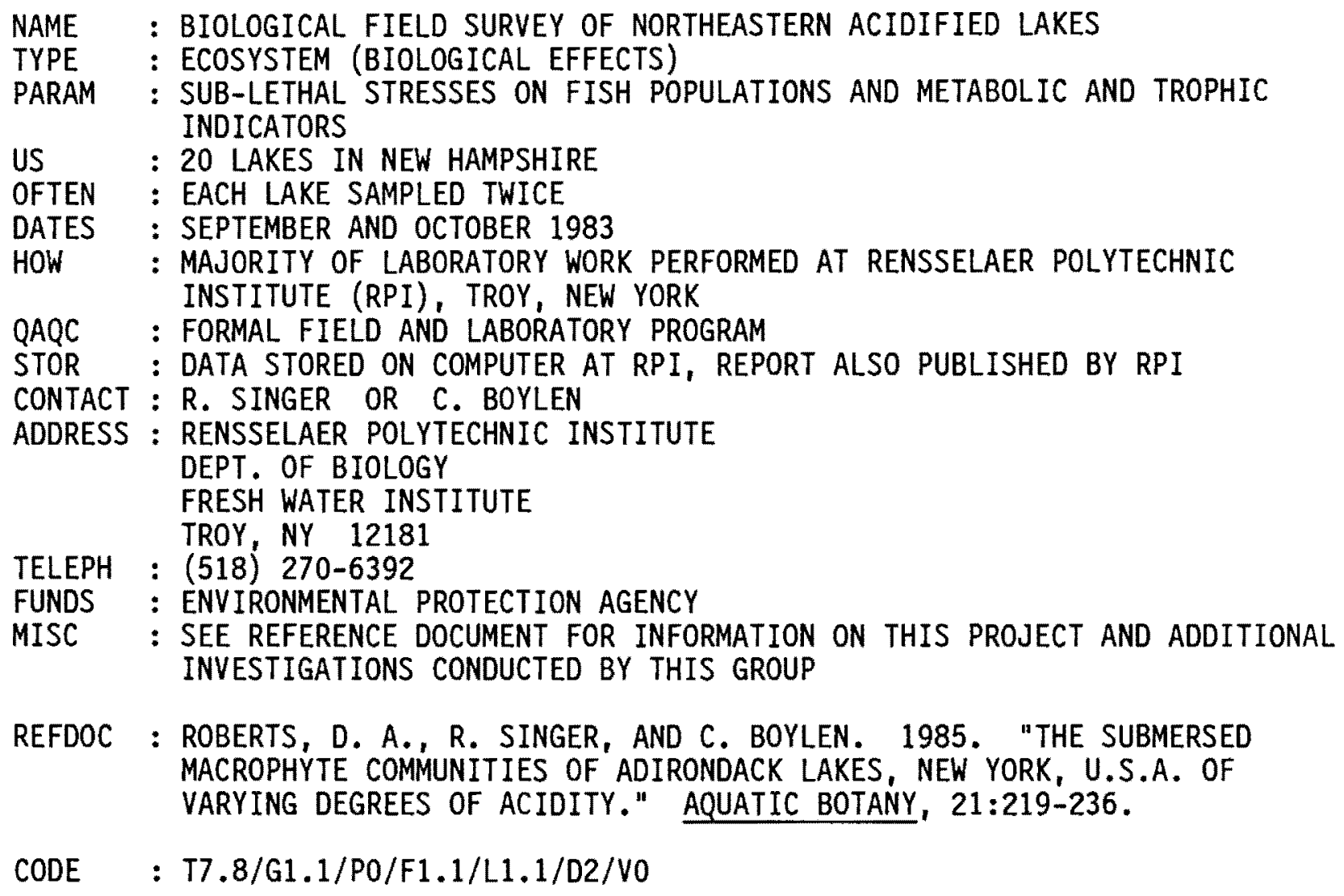

REFDOC : ROBERTS, D. A., R. SINGER, AND C. BOYLEN. 1985. "THE SUBMERSED MACROPHYTE COMMUNITIES OF ADIRONDACK LAKES, NEW YORK, U.S.A. OF VARYING DEGREES OF ACIDITY." AQUATIC BOTANY, 21:219-236.

CODE $\quad:$ T7.8/G1.1/PO/F1.1/L1.1/D2/V0 

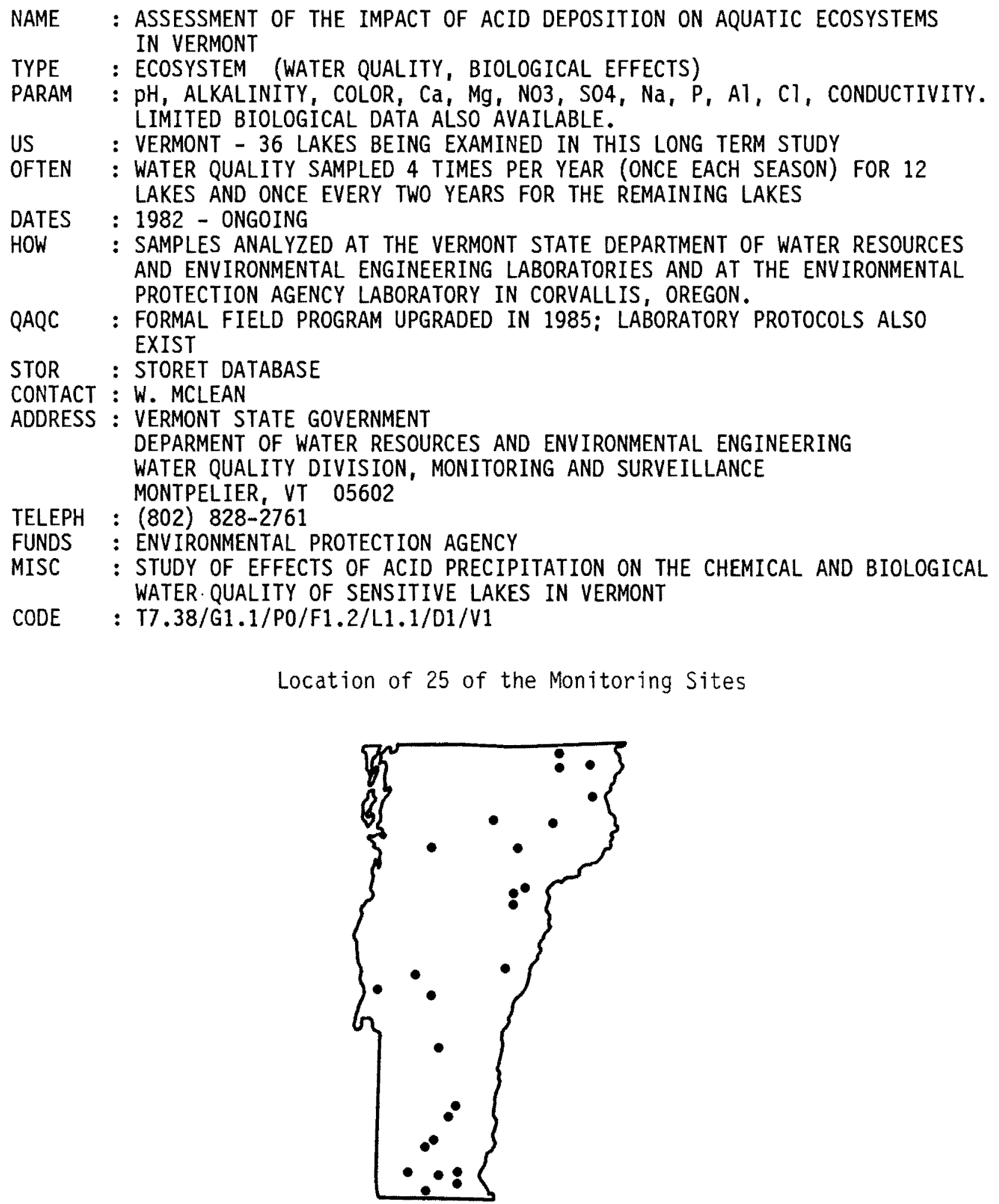


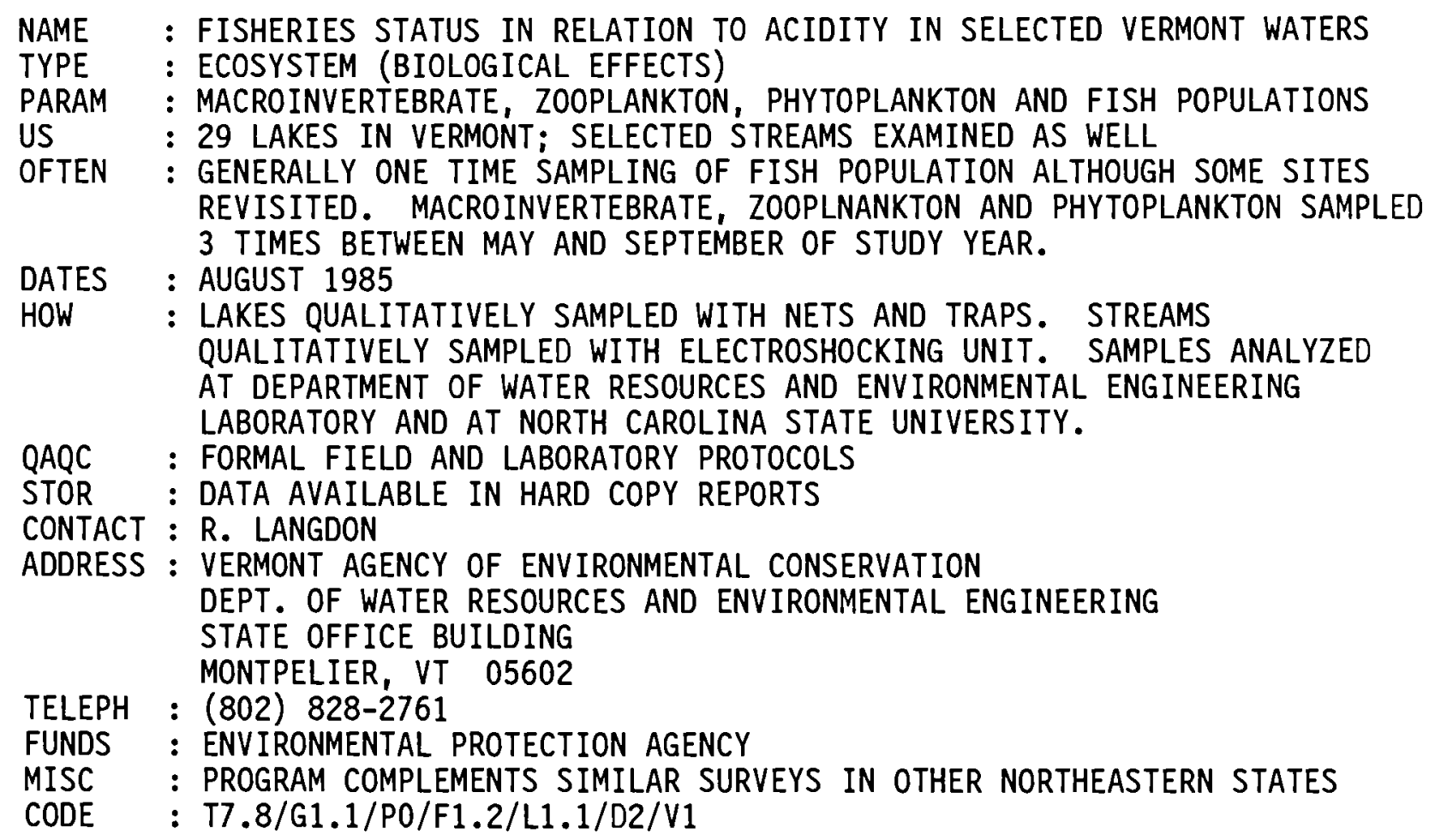




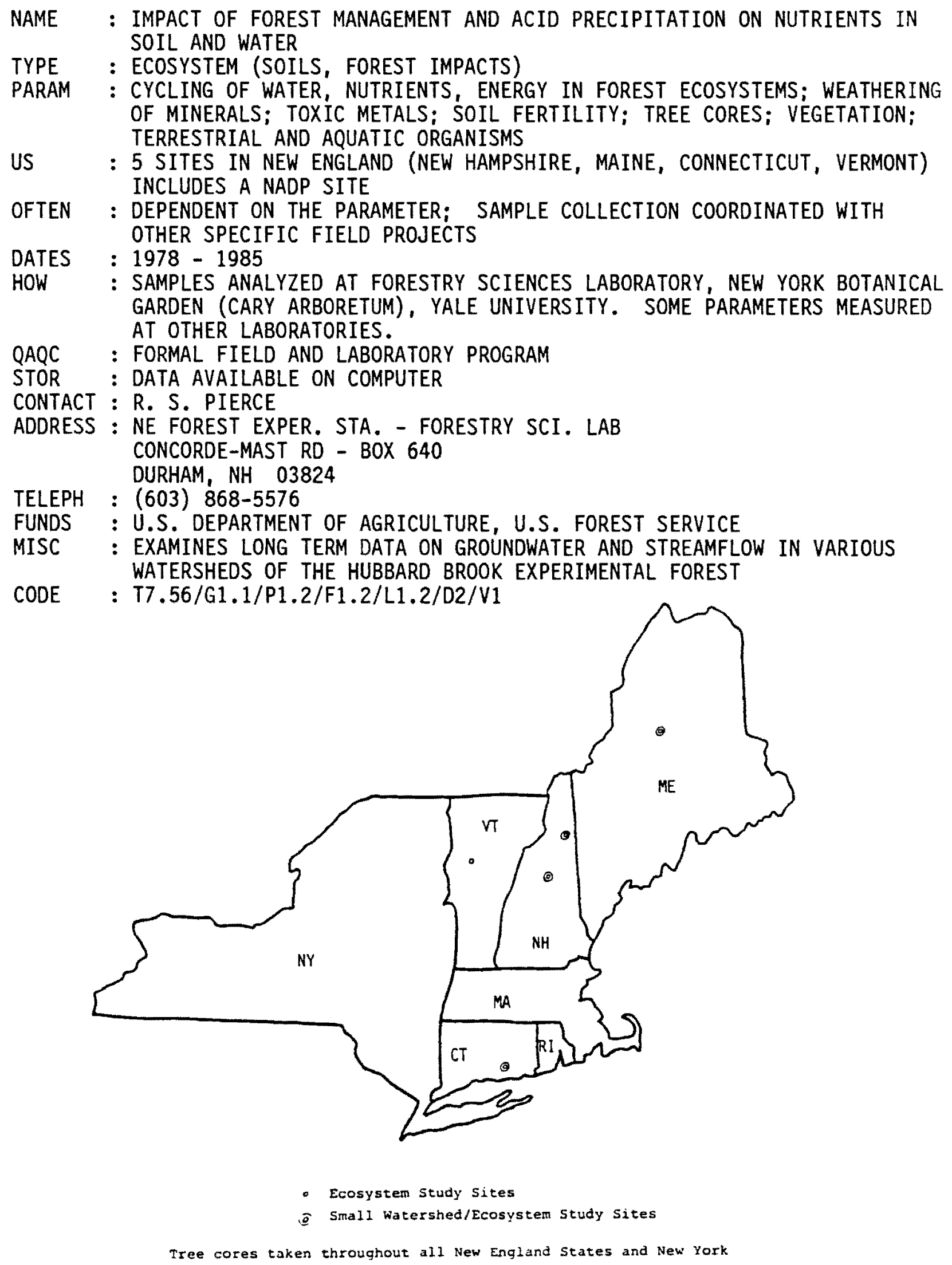

G. 34 

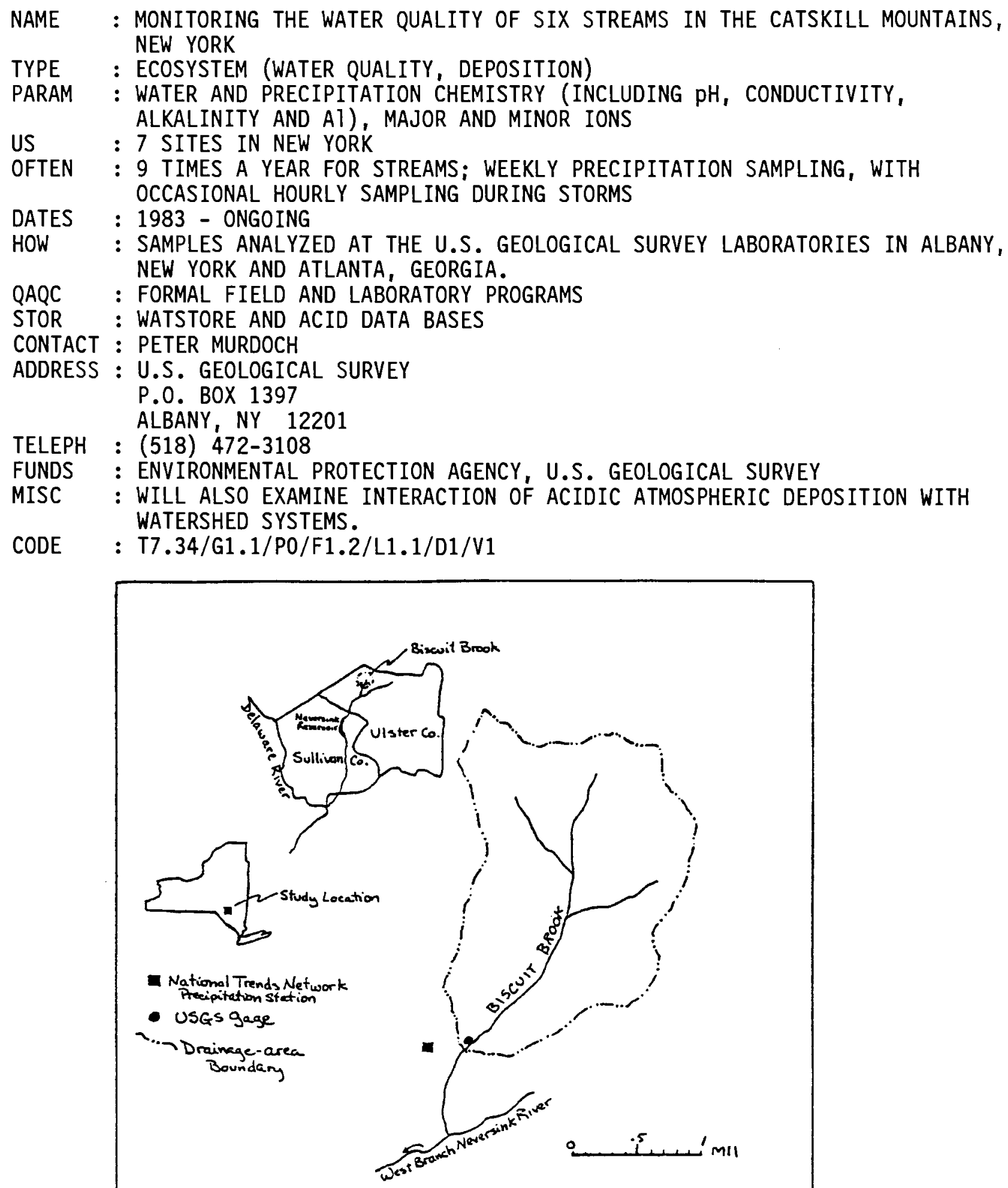

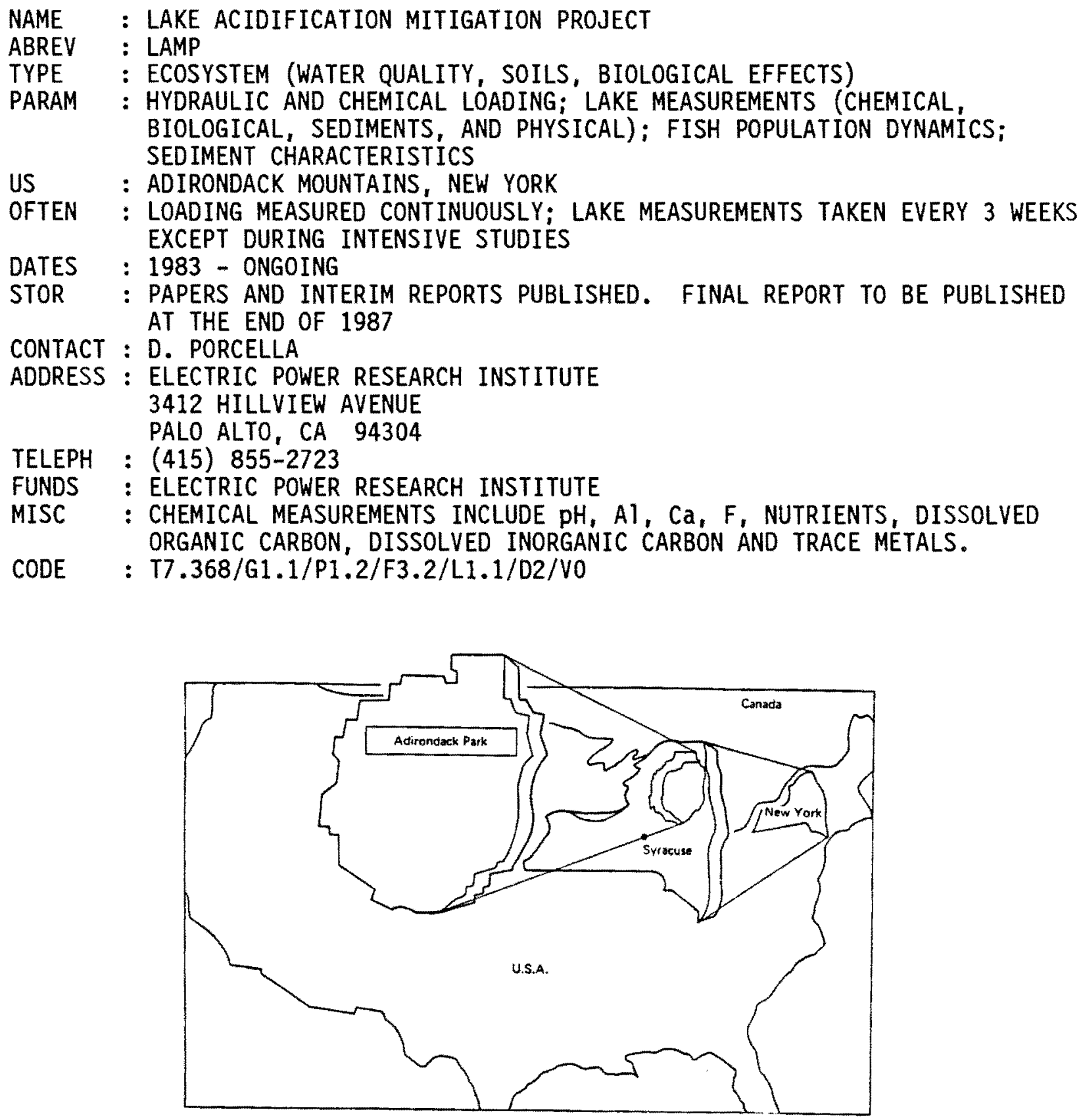


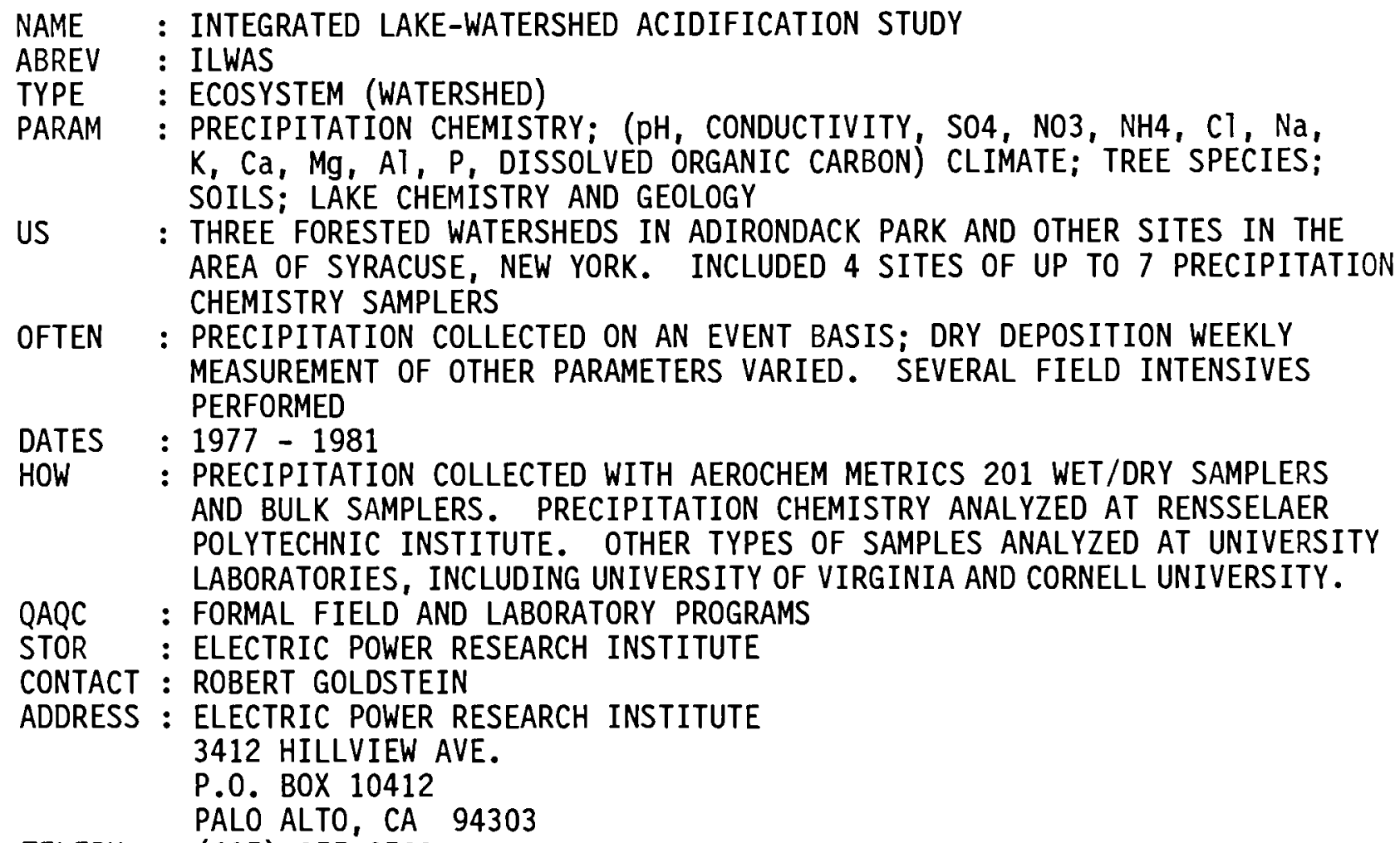

GOLDSTEIN, R. A. AND S. A. GHERINI. 1984. THE INTEGRATED LAKE WATERSHED ACIDIFICATION STUDY, VOL. 4: SUMMARY OF MAJOR RESULTS. EPRI EA-3221 VOL. 2, ELECTRIC POWER RESEARCH INSTITUTE, PALO ALTO, CALIFORNIA.

CODE

: T7.456/G1.1/P1.2/F3.2/L2.1/D2/V1

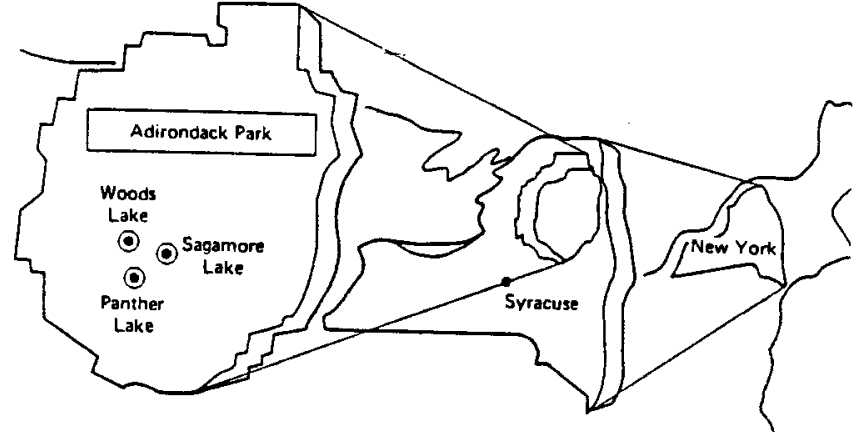

G. 37 


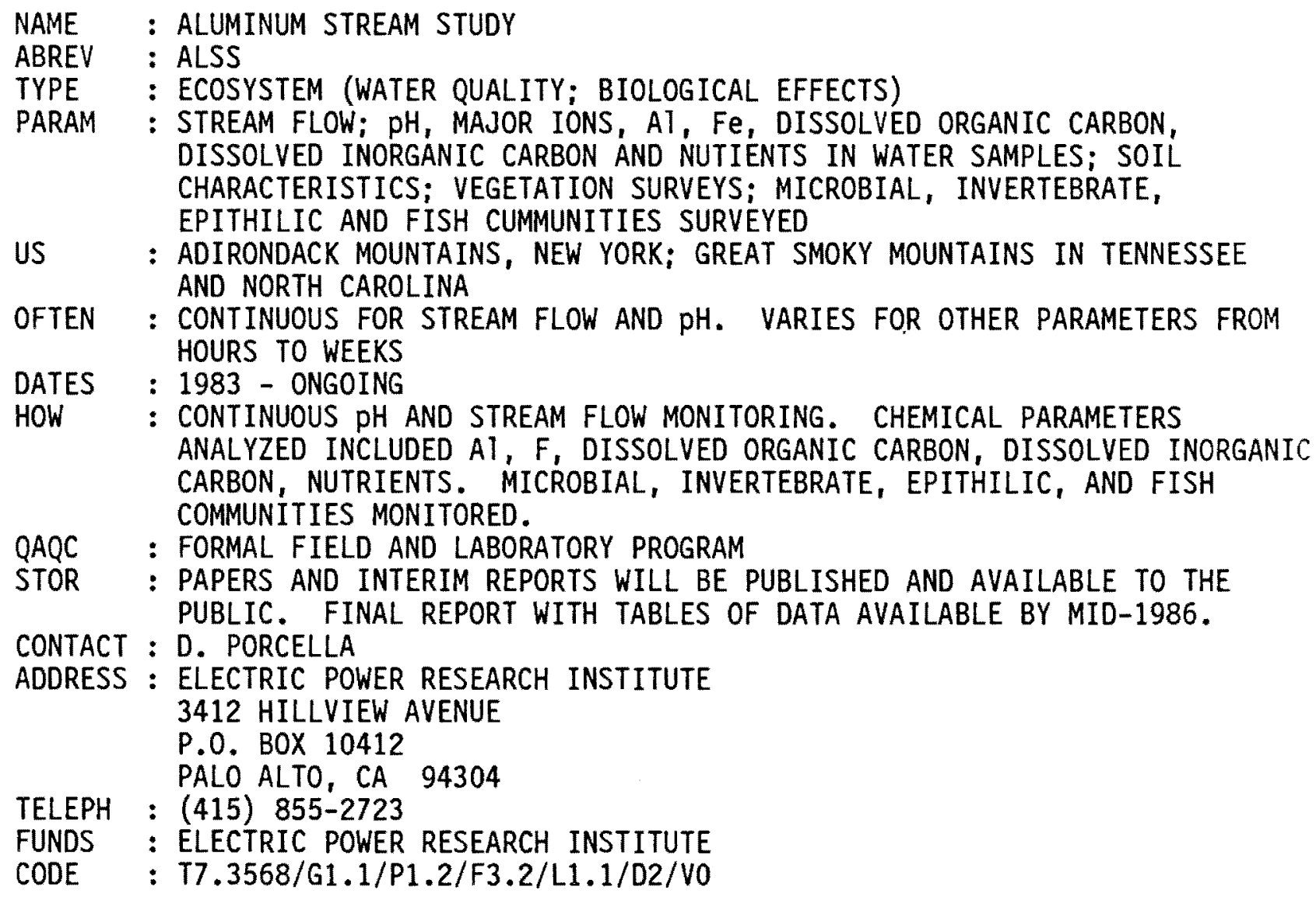




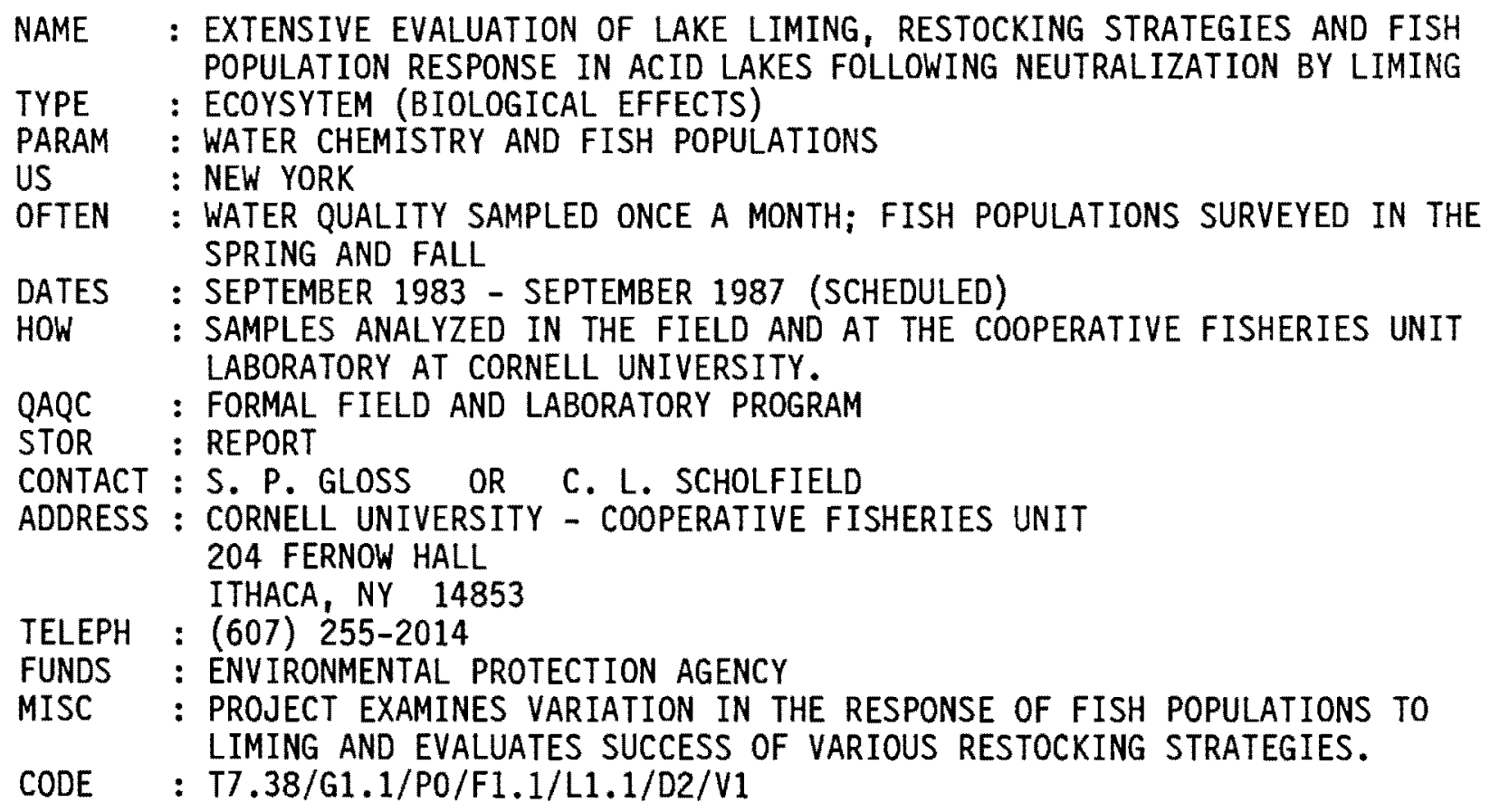




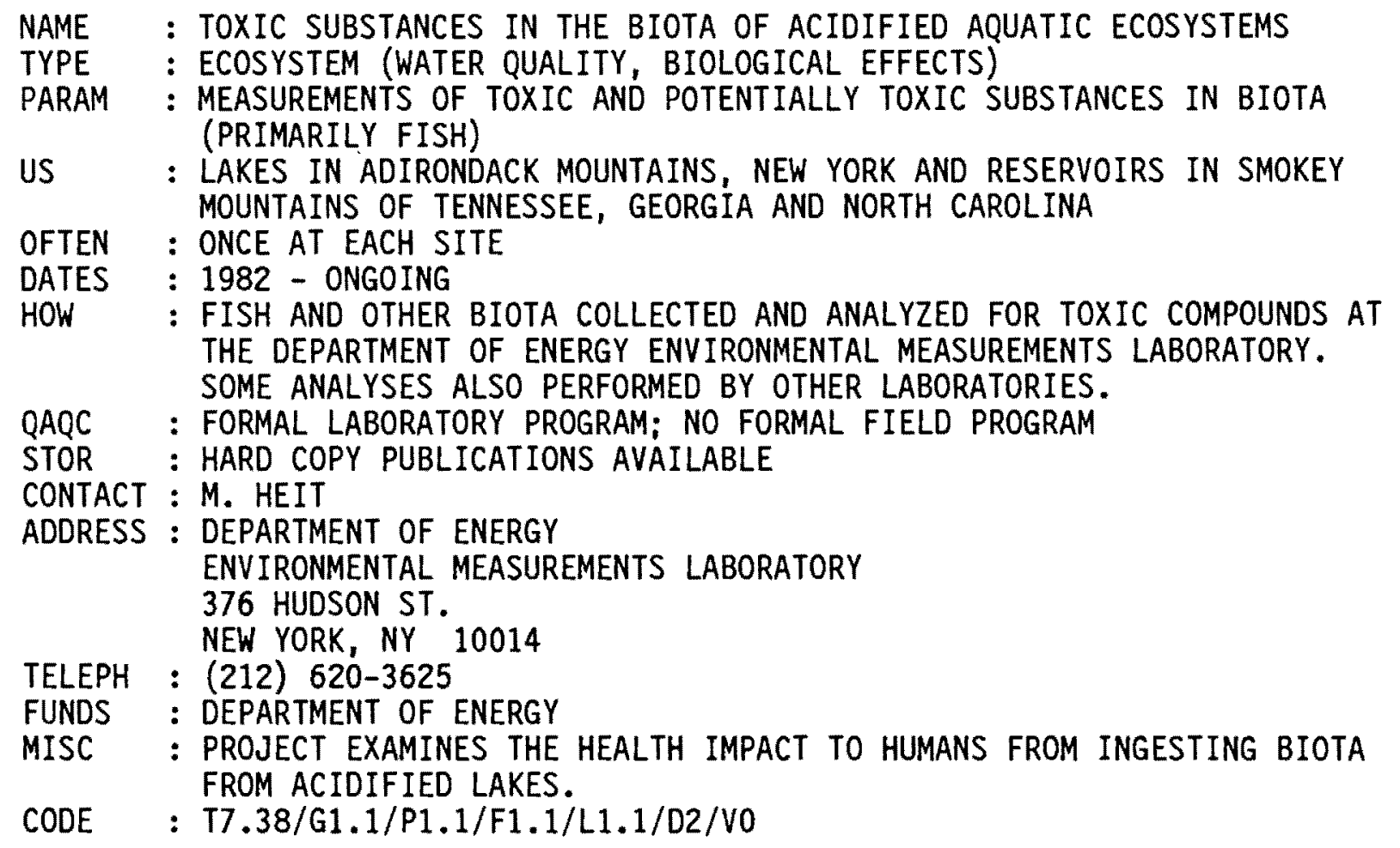


NAME : A FIELD SURVEY OF BIOTA AND SELECTED WATER CHEMISTRY PARAMETERS IN ACIDIFIED WATERS OF THE ADIRONDACK MOUNTAIN REGION OF NEW YORK STATE TYPE : ECOSYSTEM (BIOLOGICAL EFFECTS)

PARAM : WATER CHEMISTRY (MAJOR IONS); PHYTOPLANKTON, ZOOPLANKTON, MACROPHYTES AND FISH POPULATION SURVEYS

US : 50 LAKES AND PONDS IN NEW YORK

OFTEN : 20 WATERS 3 TIMES; 30 WATER 1 TIME

DATES : MAY 1984 - NOVEMBER 1984

HOW : CHEMISTRY SAMPLES ANALYZED AT NEW YORK STATE DEPARTMENT OF HEALTH; BIOLOGICAL SAMPLES ANALYZED AT NEW YORK STATE DEPARTMENT OF ENVIRONMENTAL CONSERVATION AND NEW YORK STATE MUSEUM AND SCIENCE SERVICE

QAQC : PROJECT FOLLOWS ENVIRONMENTAL PROTECTION AGENCY GUIDELINES

STOR : DATA BEING PLACED INTO A FORM COMPATIBLE WITH STORET DATA BASE

CONTACT : J.W. SUTHERLAND

ADDRESS : NEW YORK STATE DEPT. OF ENVIRONMENTAL CONSERVATION BUREAU OF TECHNICAL SERVICES AND RESEARCH 50 WOLF ROAD ALBANY, NY 12233-0001

TELEPH : (518) $457-7470$

FUNDS : NATIONAL ACID PRECIPITATION ASSESSMENT PROGRAM (ENVIRONMENTAL PROTECTION AGENCY)

MISC : PROJECT STUDIES THE RELATIONSHIP BETWEEN WATER CHEMISTRY AND BIOLOGICAL POPULATIONS.

CODE : T7.38/G1.1/P1.2/F1.2/L1.1/D2/V1

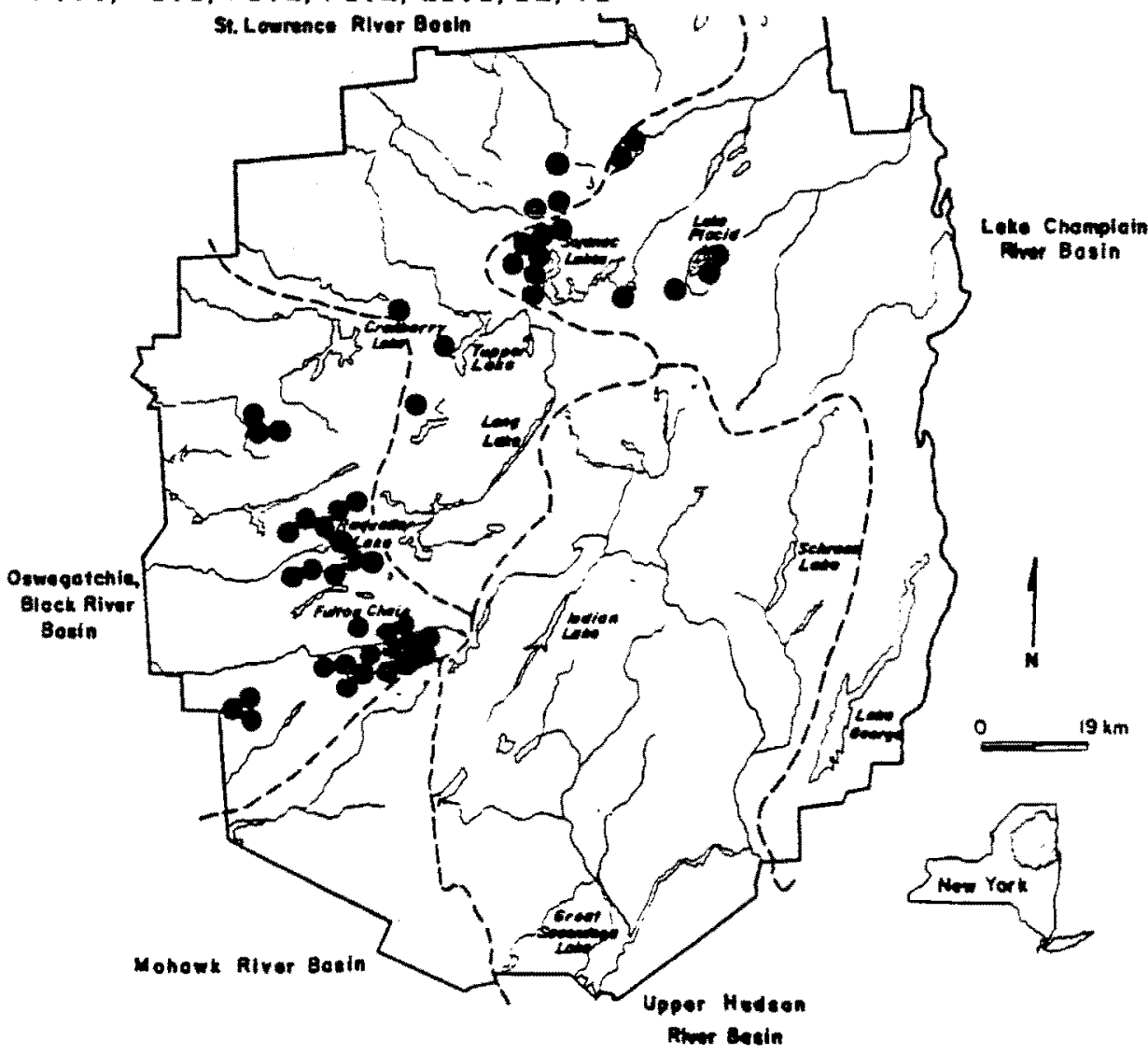

G.41 

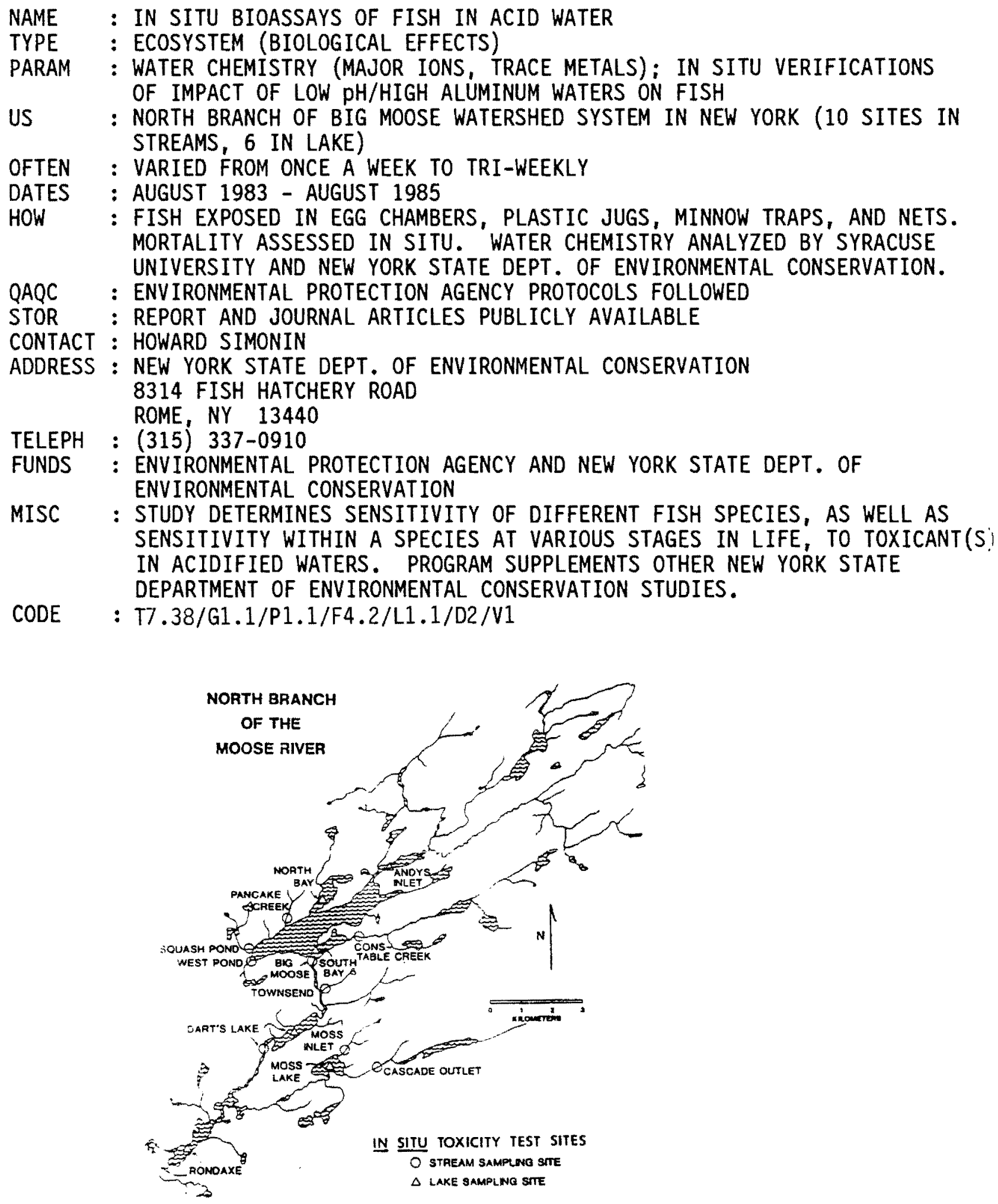


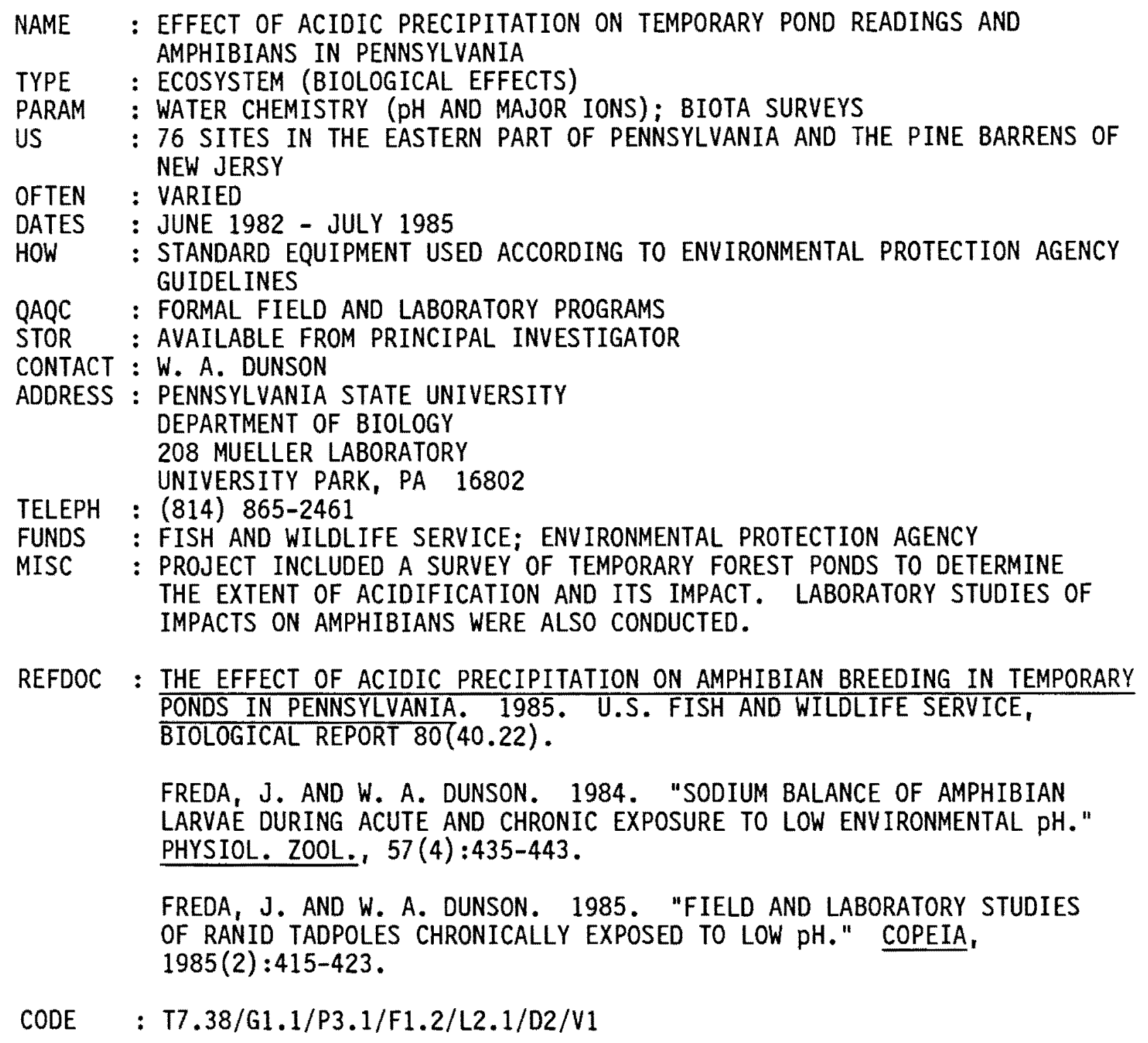



NAME : BIOLOGICAL AND CHEMICAL IMPACT OF ACID PRECIPITATION ON POCONO
MOUNTAIN LAKES

TYPE : ECOSYSTEM (WATER QUALITY, BIOLOGICAL EFFECTS)

PARAM : $\mathrm{pH}$, ALKALINITY, CONDUCTIVITY, NO3, Cl, HARDNESS, Ca, Fe, SOL. A1, $\mathrm{Mg}, \mathrm{Mn}, \mathrm{SO4}, \mathrm{K}$, DISSOLVED ORGANIC CARBON, P04, SECCHI DISK, PHYTOPLANKTON, ZOOPLANKTON, MACROPHYTES, ZOOBENTHOS, FISH, WATERSHED FACTORS

US : TEN LAKES IN PRELIMINARY SURVEY, THREE LAKES IN MAIN STUDY

OFTEN : MOST FACTORS SAMPLED SEASONALLY (CA. 3X/YR)

DATES : NOVEMBER 1980 - AUGUST 1983

HOW : STANDARD SAMPLING METHODS; SURFACE, MID-DEPTH, AND BOTTOM WATER SAMPLED FOR CHEMISTRY.

QAQC : STANDARDS AND REPLICATES

STOR : ON FILE AT LEHIGH UNIVERSITY EXCEPT FISH - ON COMPUTER AT PENNSYLVANIA STATE UNIVERSITY

CONTACT : PATRICIA T. BRADT

ADDRESS : CHANDLER-ULLMANN \#17

LEHIGH UNIVERSITY

BETHLEHEM, PA 18015

TELEPH : (215) 861-3650

FUNDS : PENNSYLVANIA POWER AND LIGHT COMPANY

MISC : THREE-YEAR CHARACTERIZATION OF LAKES OF HIGH, MEDIUM, AND LOW SENSITIVITY TO ACIDIFICATION

REFDOC : BRADT, P. T., M. B. BERG, D. S. BARRASSO, J. L. DUDLEY, D. E. ARNOLD, E. A. PAUL, J. F. P. COTTER, P. B. MYERS JR., P. SITKOWSKI, AND R. N. WEISMAN, 1984. THE BIOLOGICAL AND CHEMICAL IMPACT OF ACID PRECIPITATION ON POCONO MOUNTAIN LAKES. DEPARTMENT OF BIOLOGY, LEHIGH UNIVERSITY, BETHLEHEM, PENNSYLVANIA, 215 PP.

CODE : $\quad$ T7.38/G1.1/P0/F3.2/L2.1/D2/V1

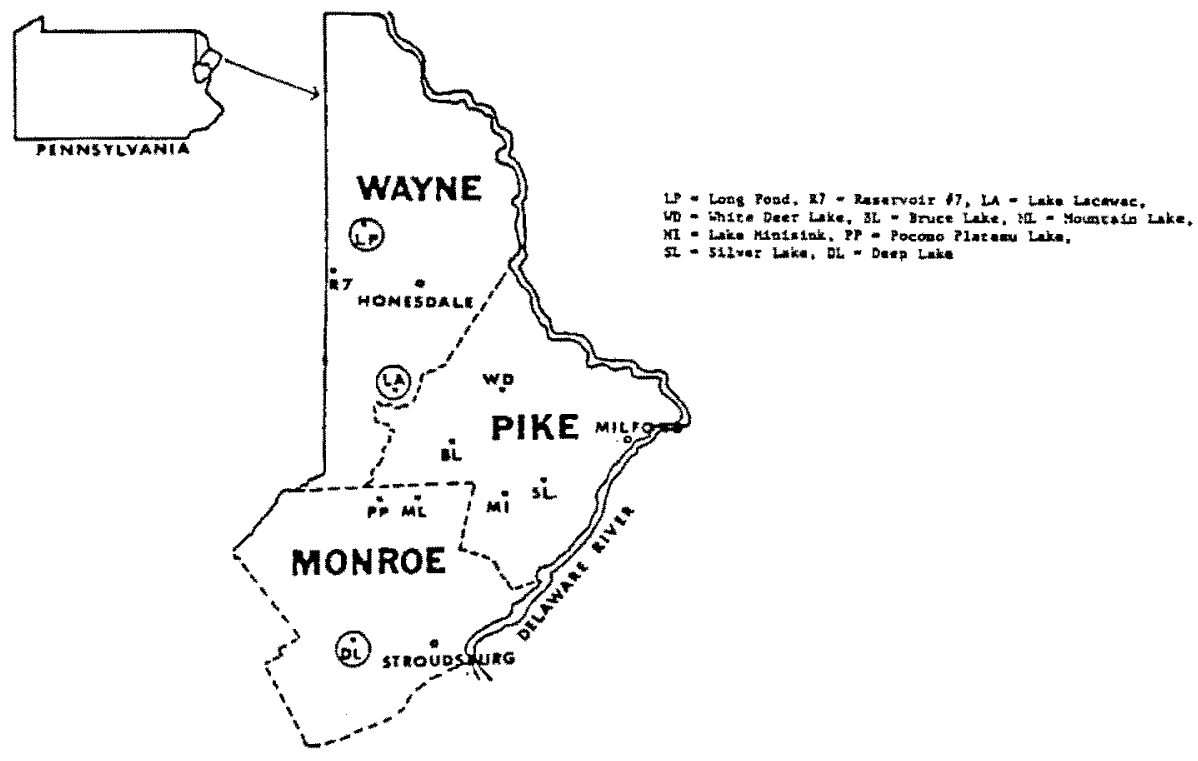




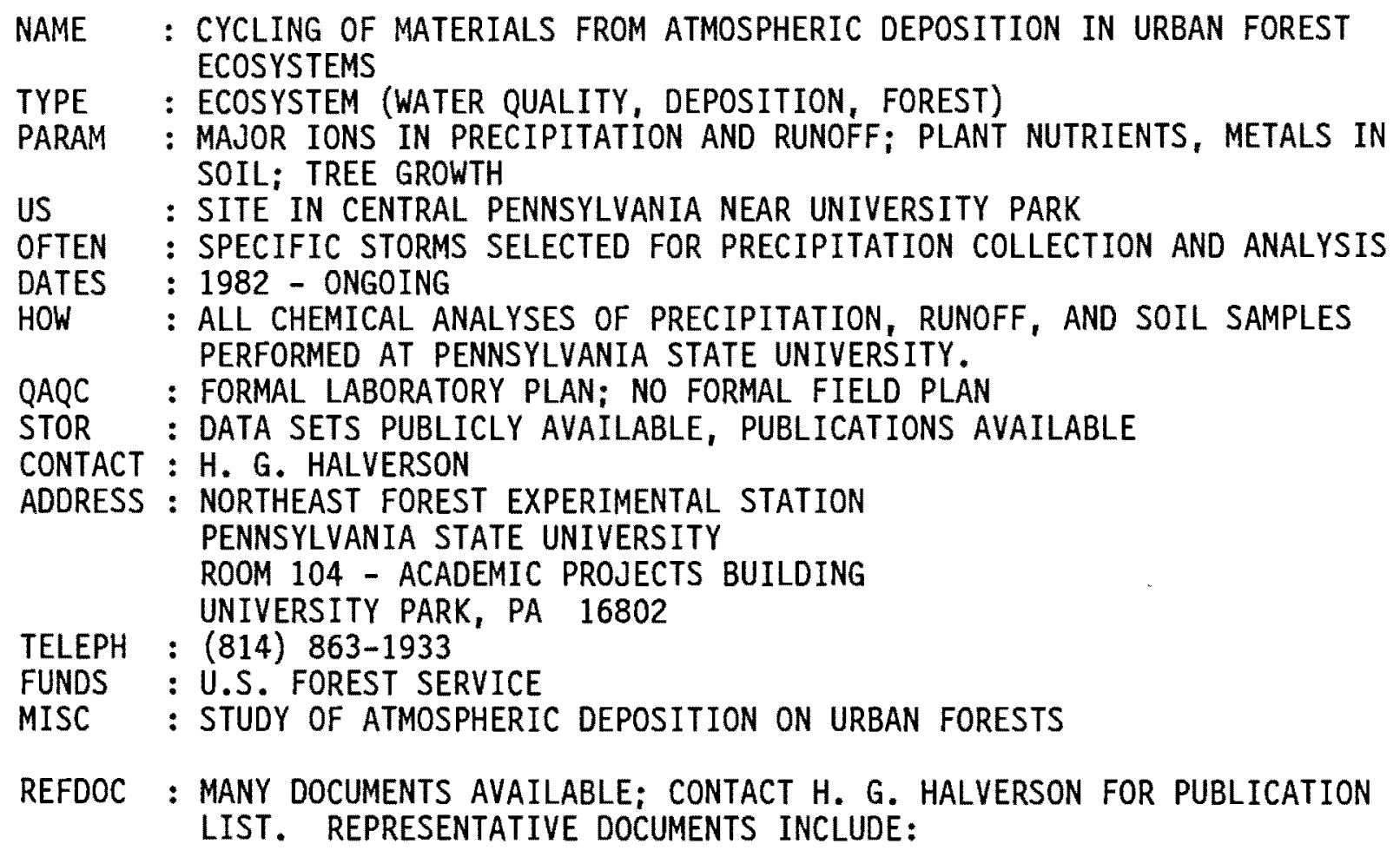

REFDOC : MANY DOCUMENTS AVAILABLE; CONTACT H. G. HALVERSON FOR PUBLICATION LIST. REPRESENTATIVE DOCUMENTS INCLUDE:

HALVERSON, H. G., D. R. DEWALLE AND W. E. SHARPE. 1984. "CONTRIBUTION OF PRECIPITATION TO QUALITY OF URBAN STORM RUNOFF." WATER RESOURCES BULLETIN, 20(6):859-864.

HALVERSON, H. G., E. S. CORBETT AND G. M. HEISLER. 1983. "USDA STUDIES URBAN FORESTS AND MUNICIPAL WATERSHEDS." SCI. AGRIC., $30(2): 13$.

CODE $\quad: T 7.45 / \mathrm{G} 1.1 / \mathrm{PO} / \mathrm{F} 1.1 / \mathrm{L} 2.1 / \mathrm{D} 2 / \mathrm{V} 1$

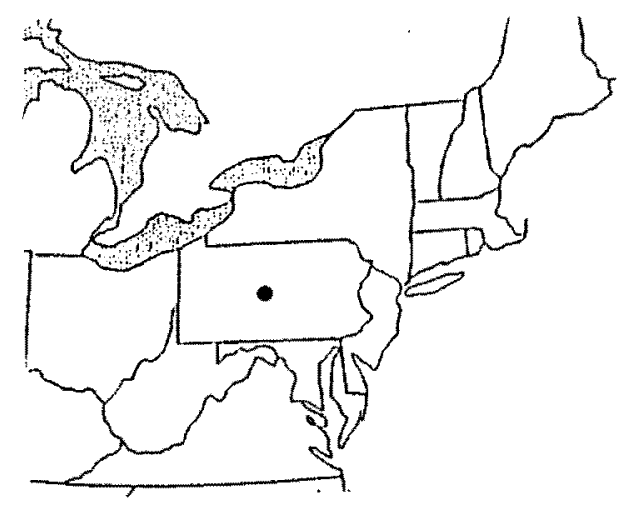




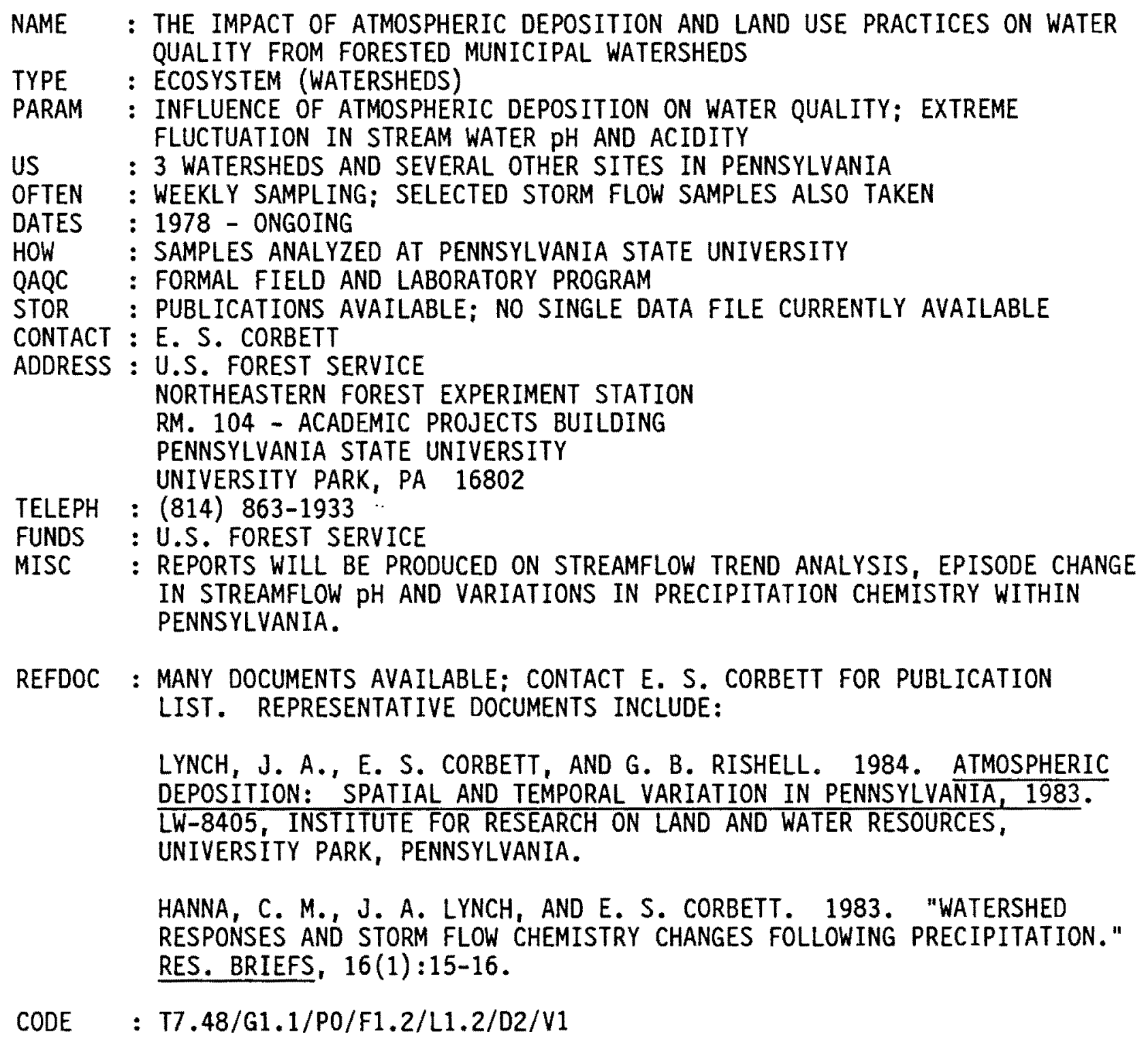



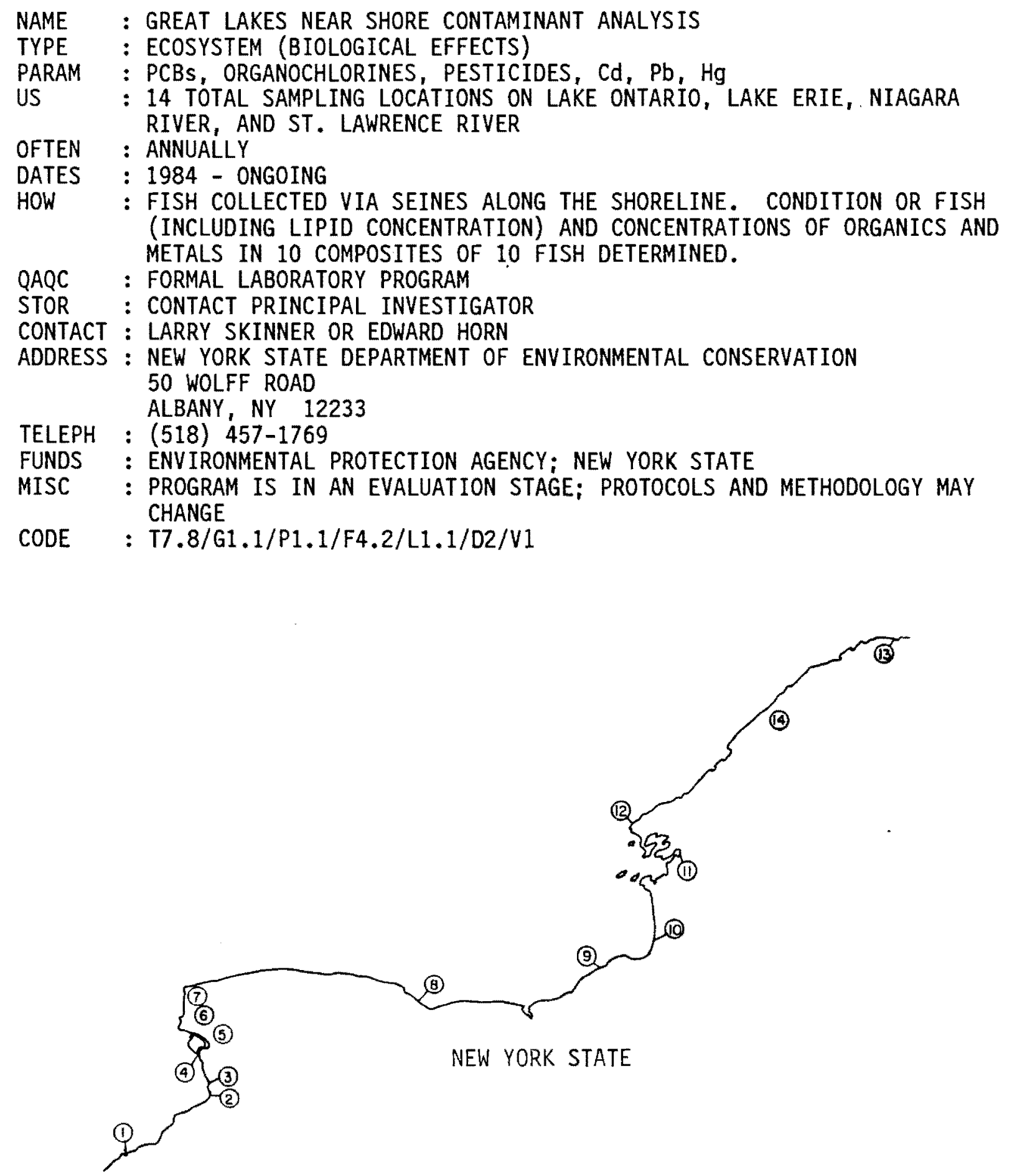


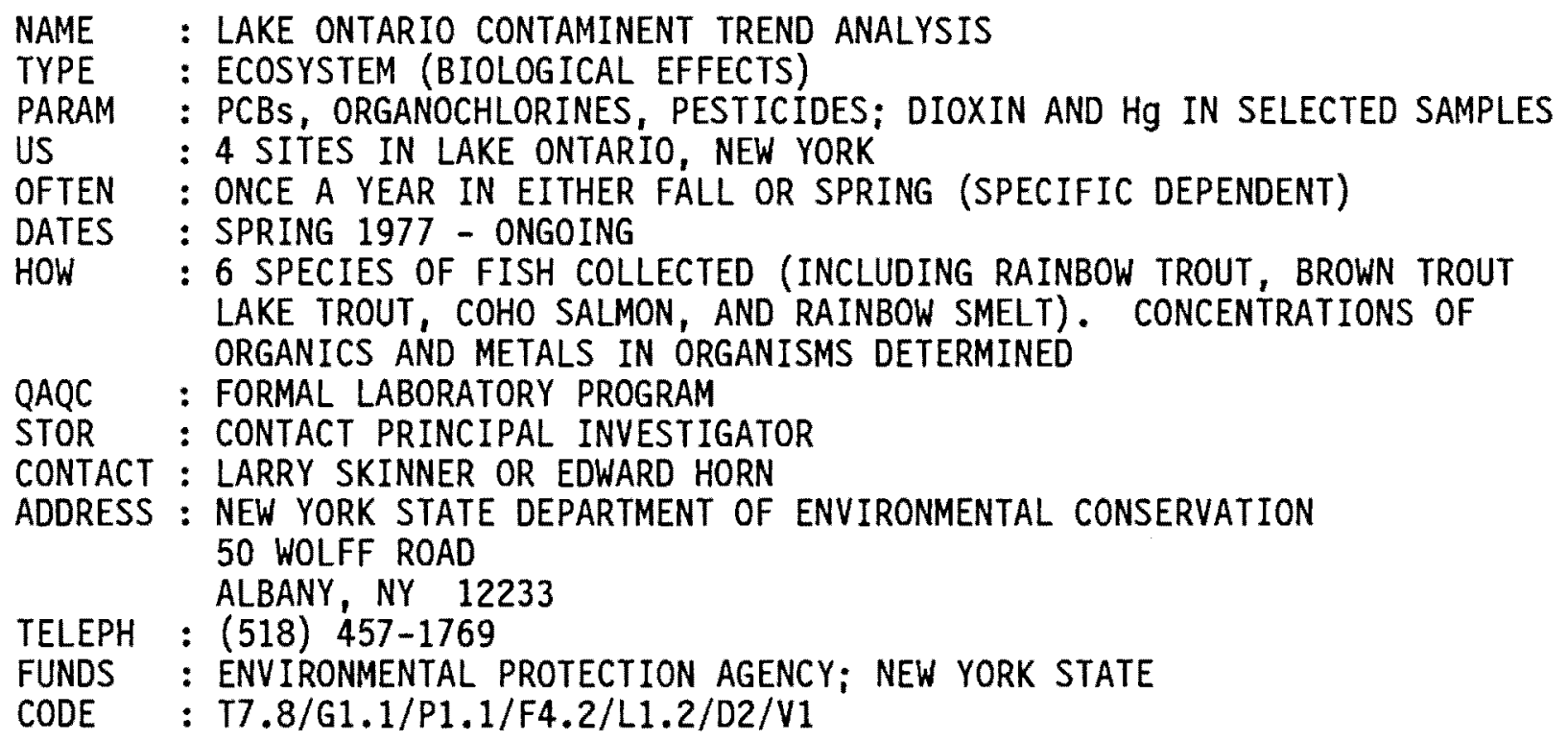




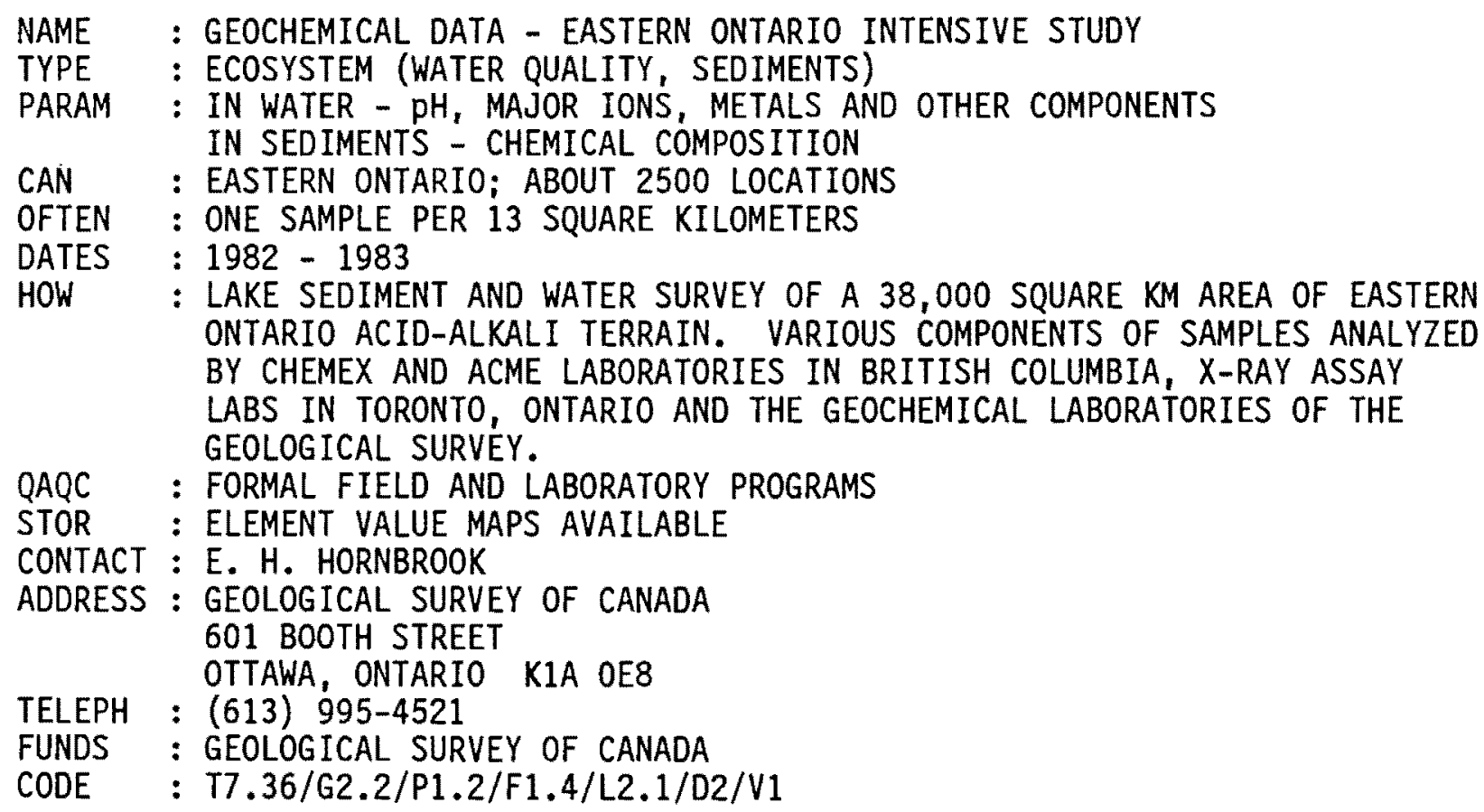




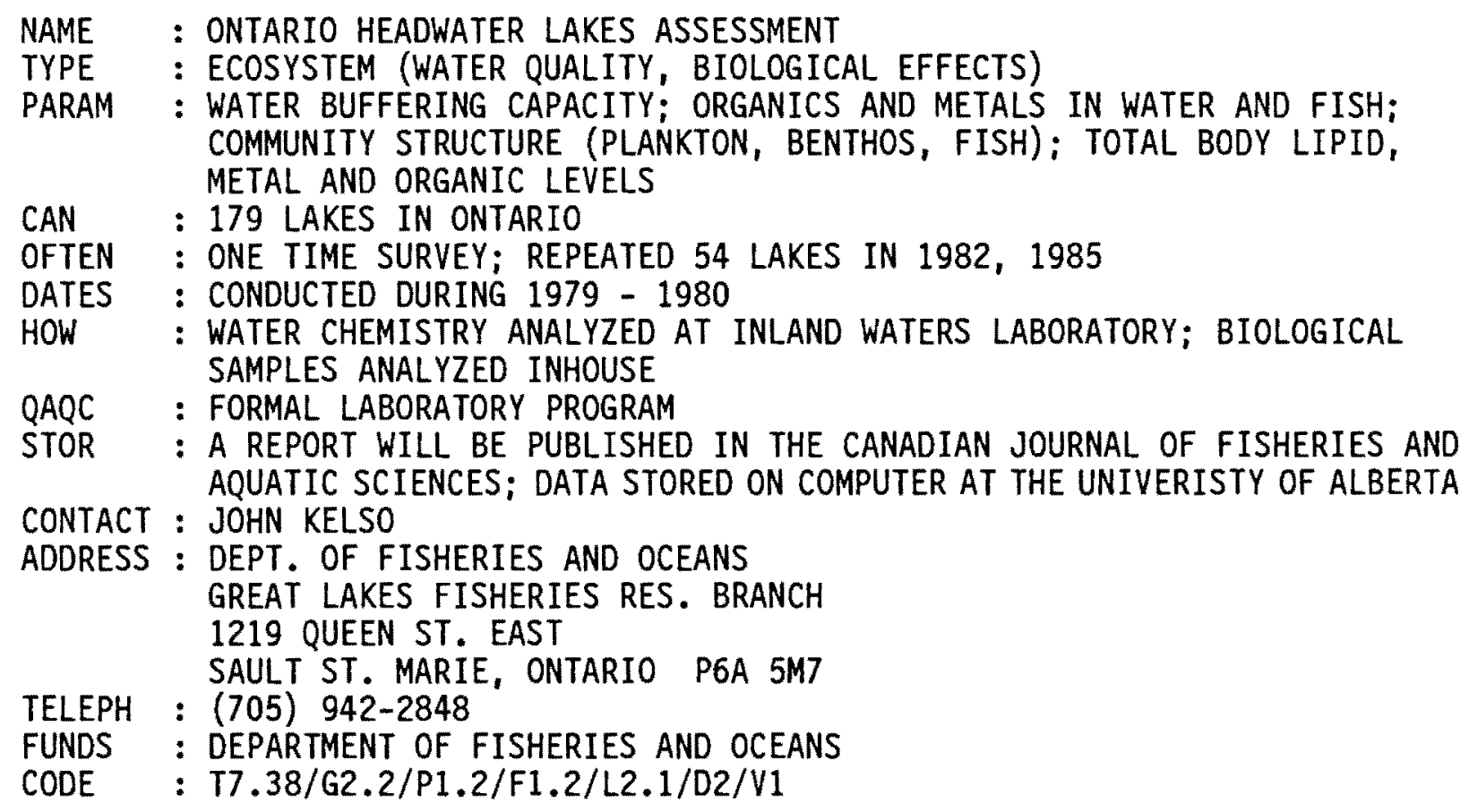




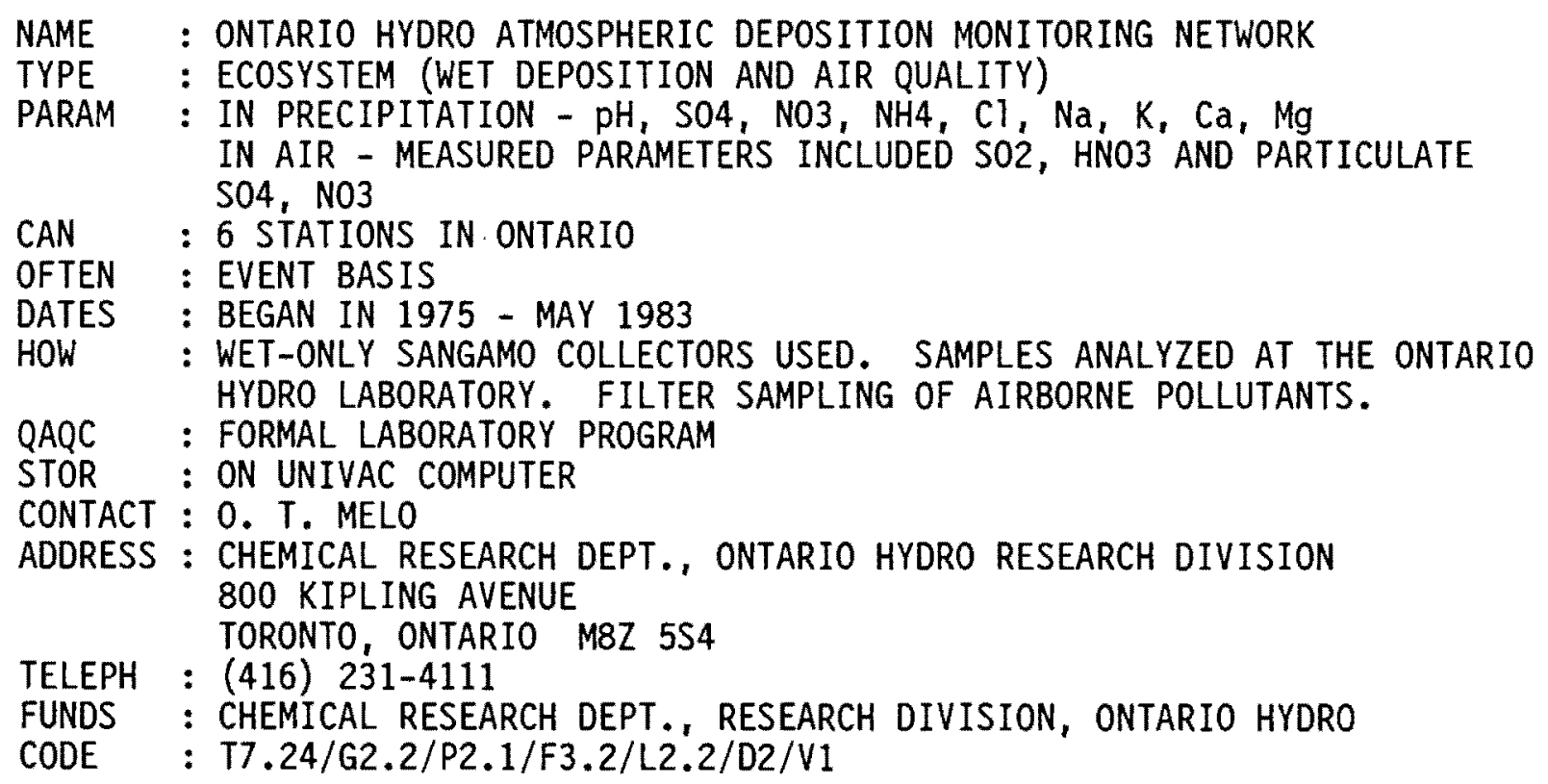

FUNDS : CHEMICAL RESEARCH DEPT, RESEARCH DIVISION, ONTARIO HYDRO

CODE : T7.24/G2.2/P2.1/F3.2/L2.2/D2/V1

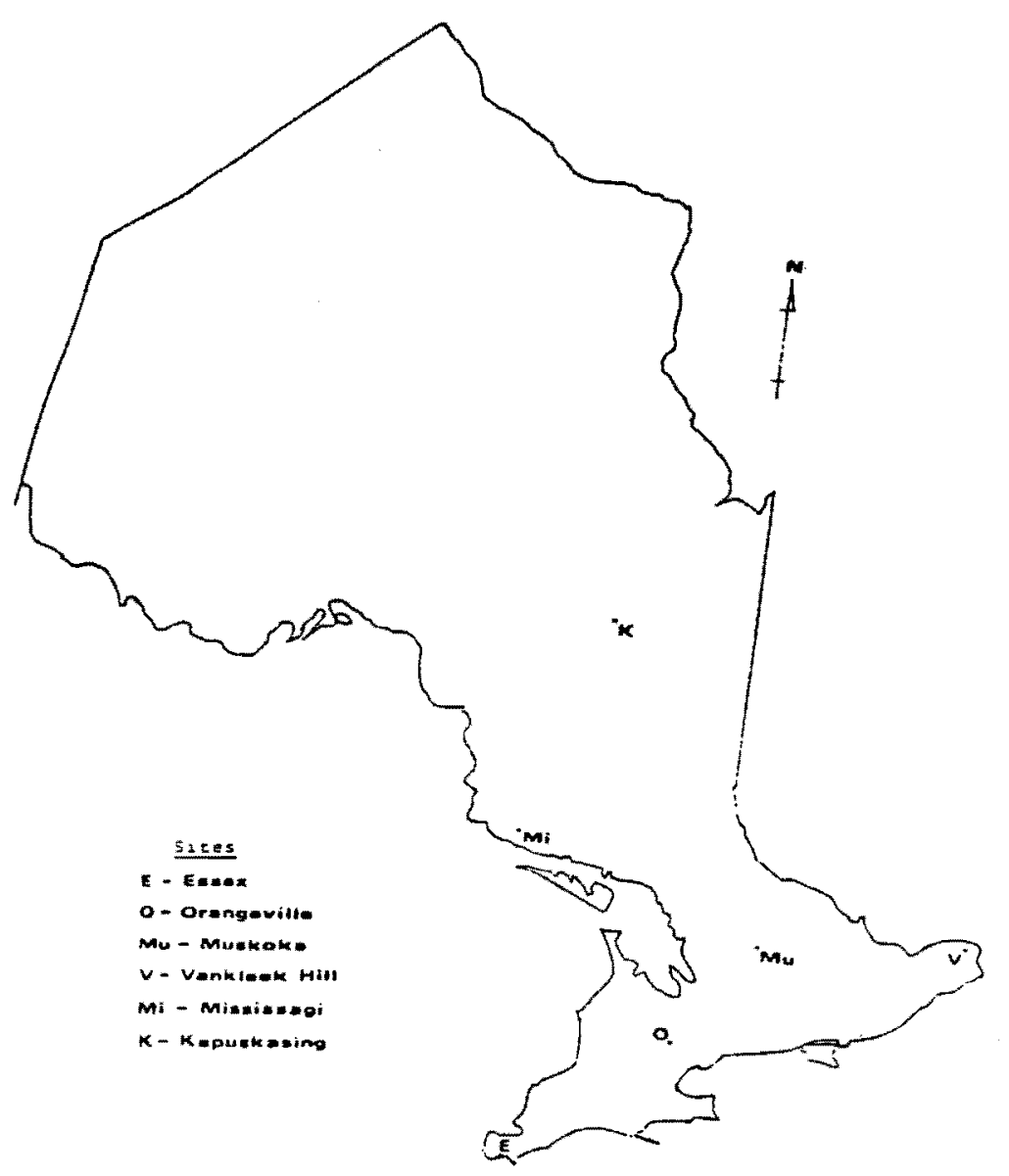




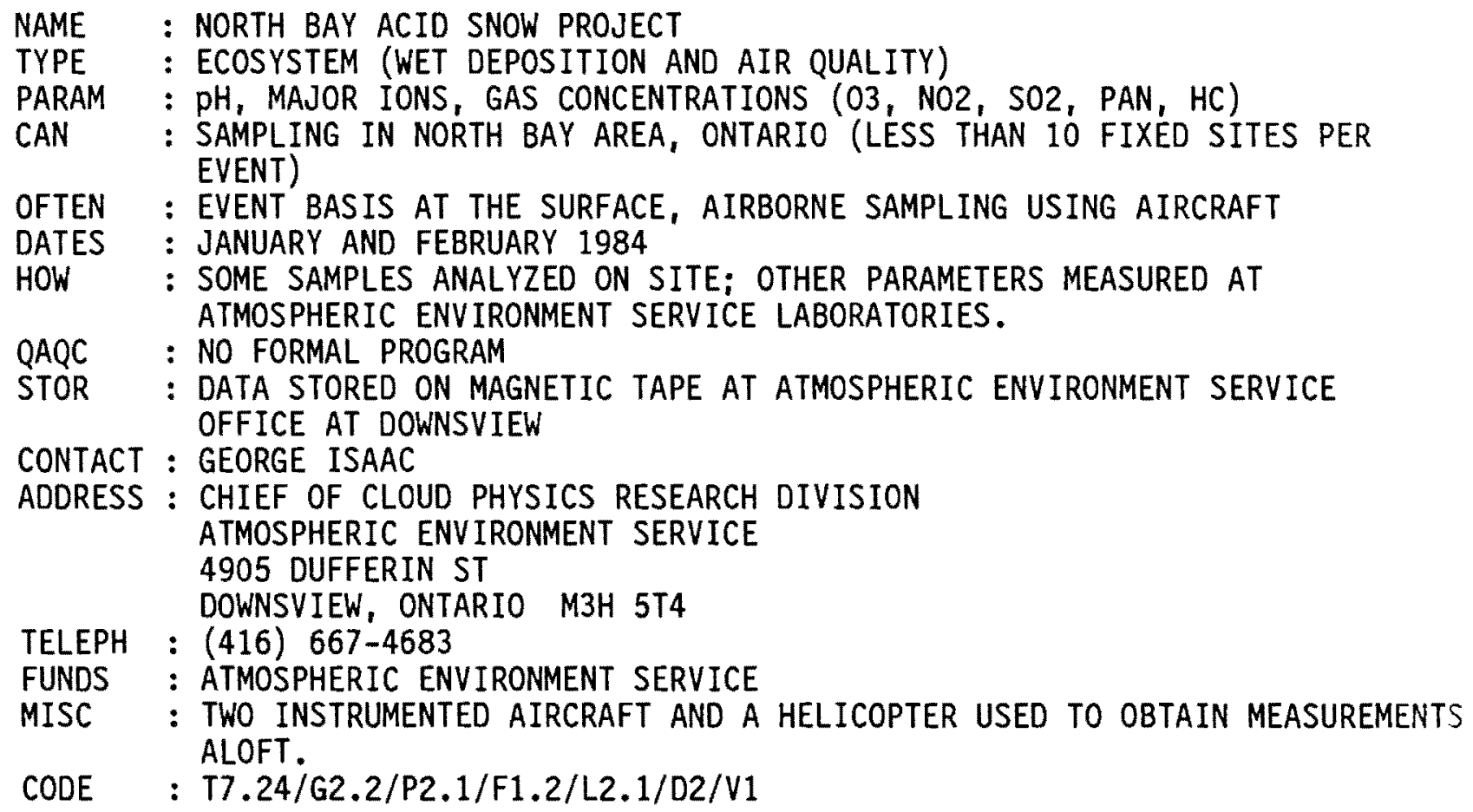

SAMPLING LOCATIONS

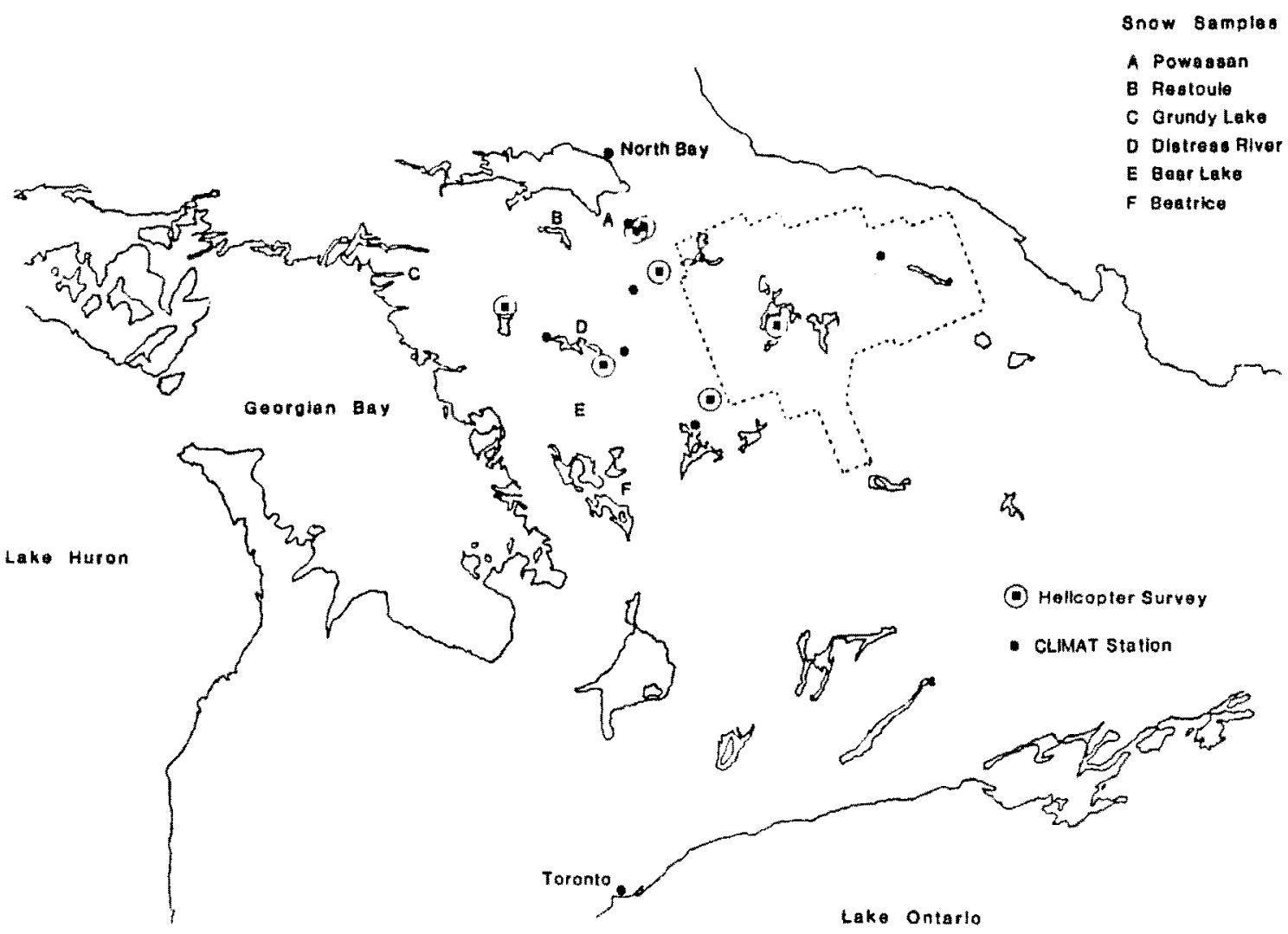



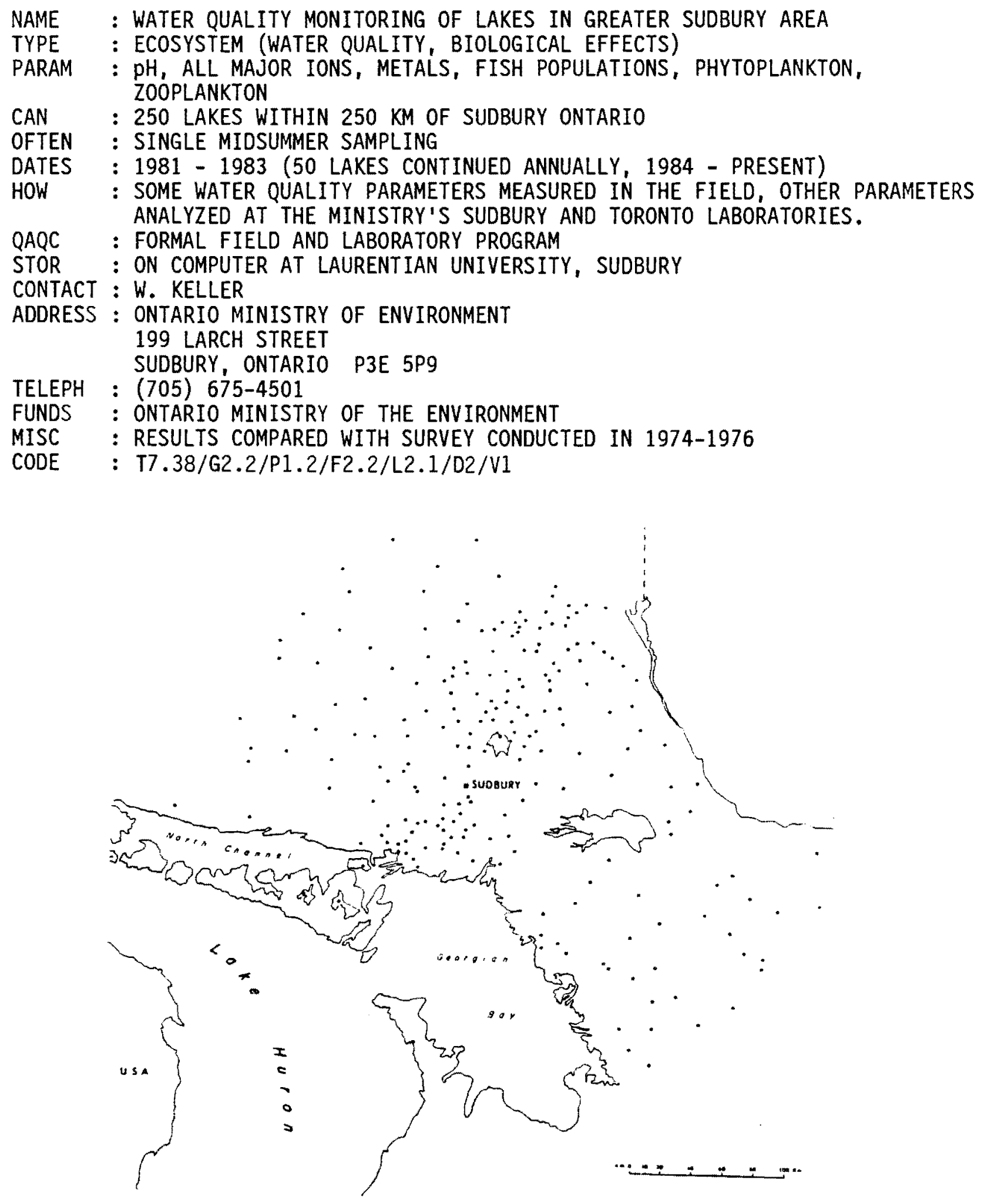
NAME : EFFECTS OF ACIDIFICATION ON LAKE AND STREAM CHEMISTRY AND BIOLOGY

TYPE : ECOSYSTEM (WATER QUALITY AND BIOLOGICAL EFFECTS)

PARAM : $\mathrm{PH}$, ALKALINITY, MAJOR IONS, NUTRIENTS, DISSOLVED ORGANIC CARBON, DISSOLVED INORGANIC CARBON, Al, Fe, Mn, Zn IN WATER; PLANKTON COMMUNITIES SURVEYED

CAN : 8 STUDY LAKES AND 24 STREAMS IN ONTARIO

OFTEN : LAKE WATER CHEMISTRY EXAMINED EVERY 2 WEEXS (ONLY ONCE A MONTH DURING THE ICE SEASON). FISH POPULATIONS SURVEYED EVERY FEW YEARS; STREAM CHEMISTRY EXAMINED WEEKLY TO 3 TIMES PER WEEK DEPENDING ON SITE

DATES : 1976 - ONGOING

HOW : WATER CHEMISTRY ANALYZED AT THE ONTARIO MINISTRY OF ENVIRONMENT LABORATORIES IN TORONTO; PHOTOPLANKTON STUDIED INHOUSE; ANALYSIS FOR ZOOPLANKTON PERFORMED BY EXTERNAL CONTRACTORS; FISH STUDIES PERFORMED BY UNIVERSITY AND MINISTRY OF NATURAL RESOURCES PERSONNEL.

QAQC : FORMAL FIELD AND LABORATORY PROGRAM

STOR : WATER QUALITY DATA IN ONTARIO MINISTRY OF ENVIRONMENT SIS DATABASE; BIOLOGICAL DATA STORED INHOUSE ON AN HP 1000 COMPUTER

CONTACT : P. DILLON

ADDRESS : ONTARIO MIN. OF ENVIRONMENT

DORSET RESEARCH CENTRE

P.O. BOX 39

DORSET, ONTARIO POA $1 E 0$

TELEPH : (705) 766-2412

FUNDS : ONTARIO MINISTRY OF THE ENVIRONMENT

CODE : T7.38/G2.2/P3.1/F2.3/L1.2/D1/V1

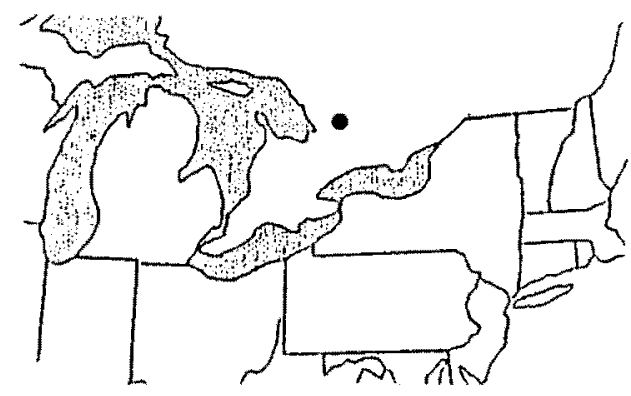

- Dwight

-Huntsville

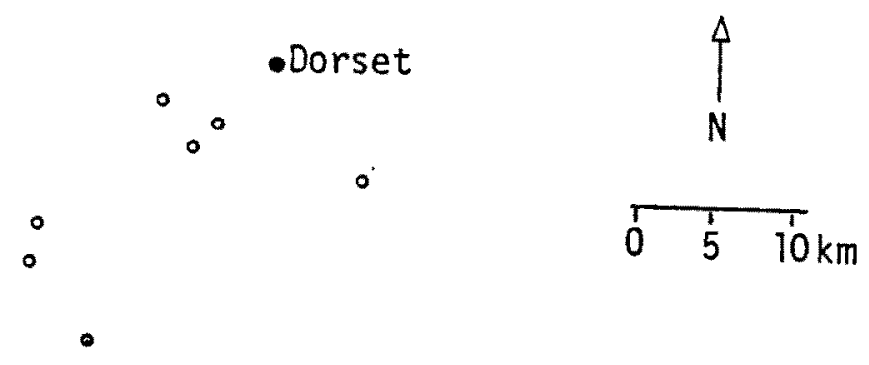

-Bracebridge

- Carnarvon

The 24 streams in this study drain into the 8 study lakes (0). 


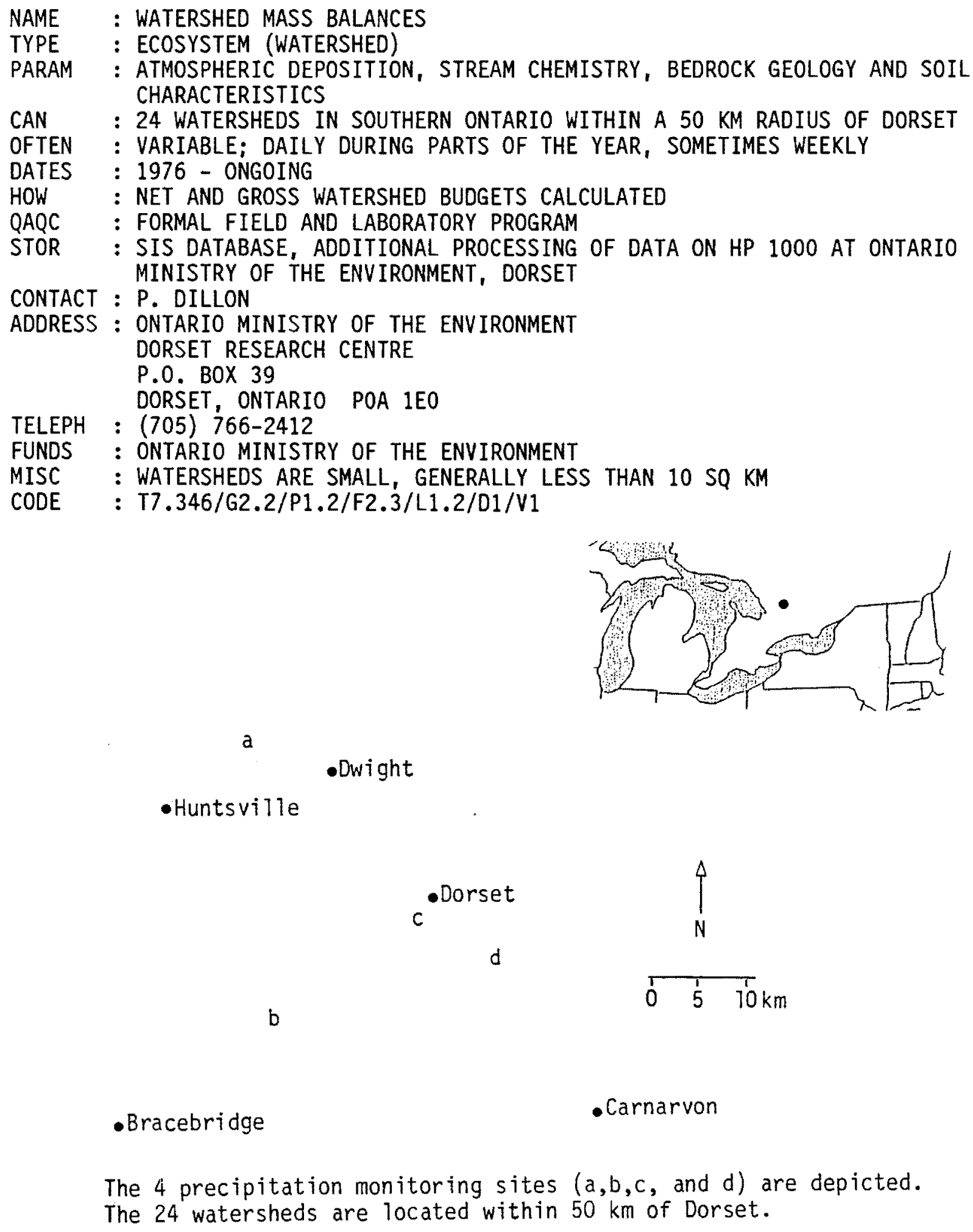

a

-Dwight

-Huntsville

$d$

b

- Bracebridge

- Carnarvon

The 4 precipitation monitoring sites (a,b,c, and d) are depicted. The 24 watersheds are located within $50 \mathrm{~km}$ of Dorset. 


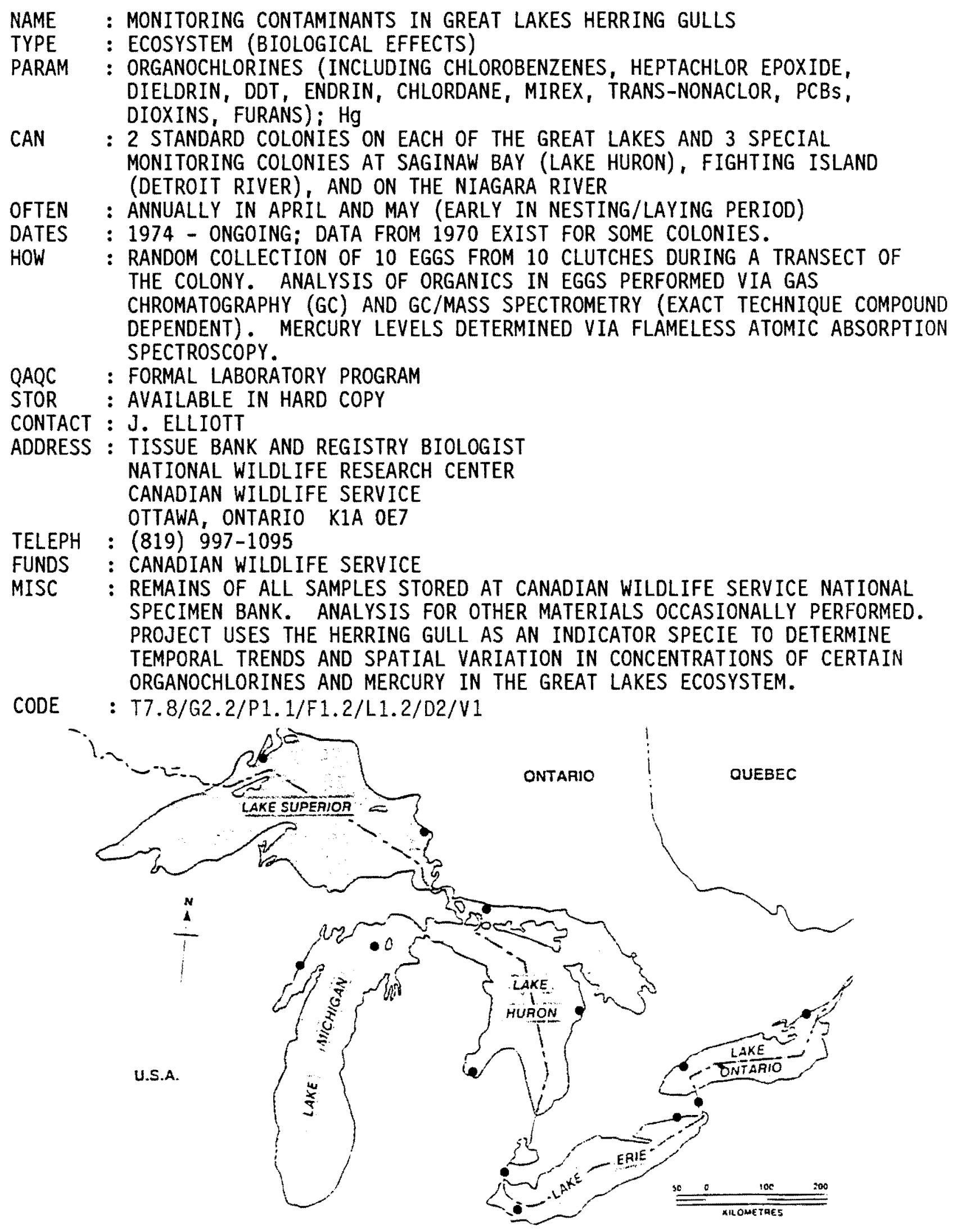




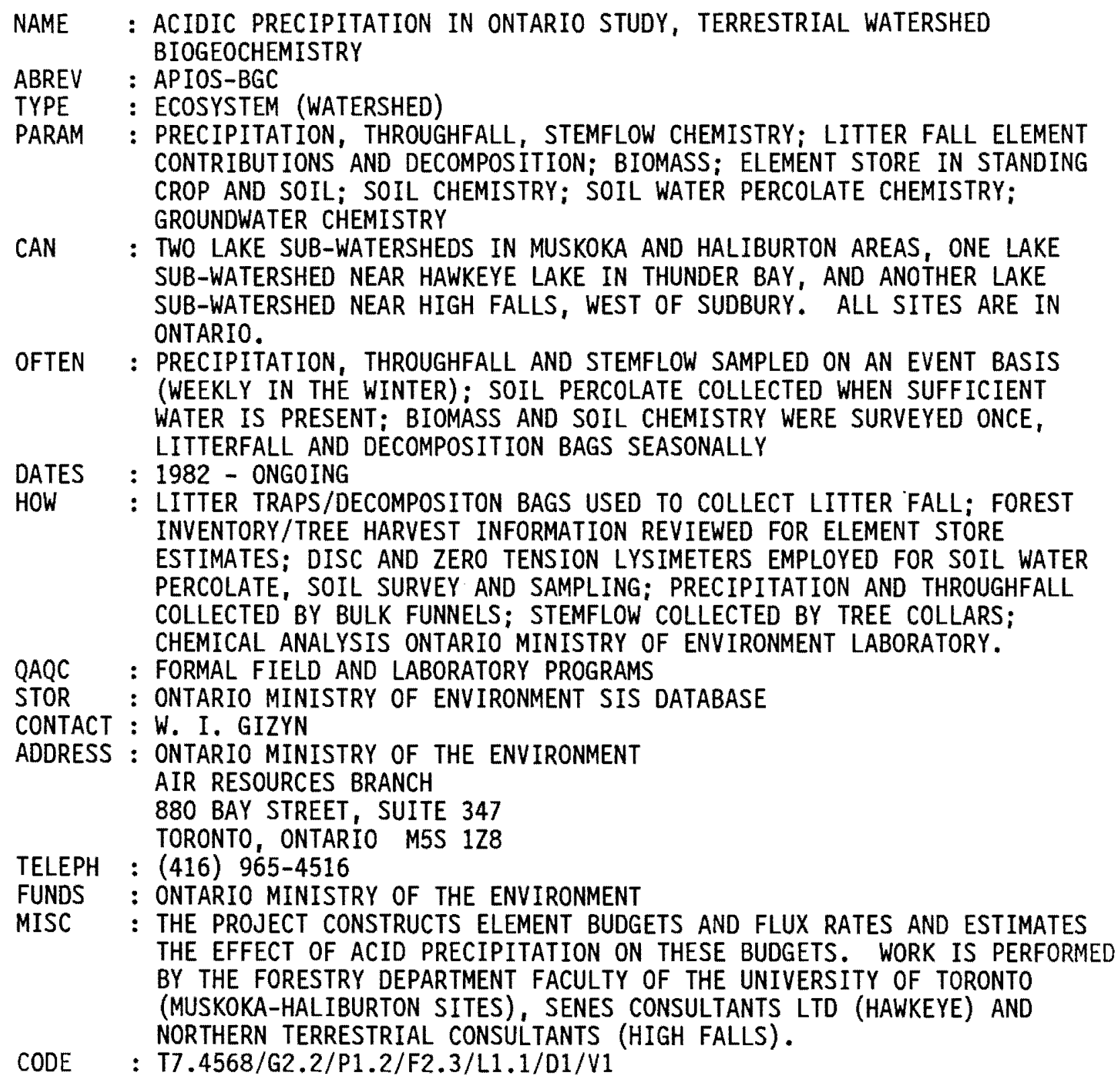

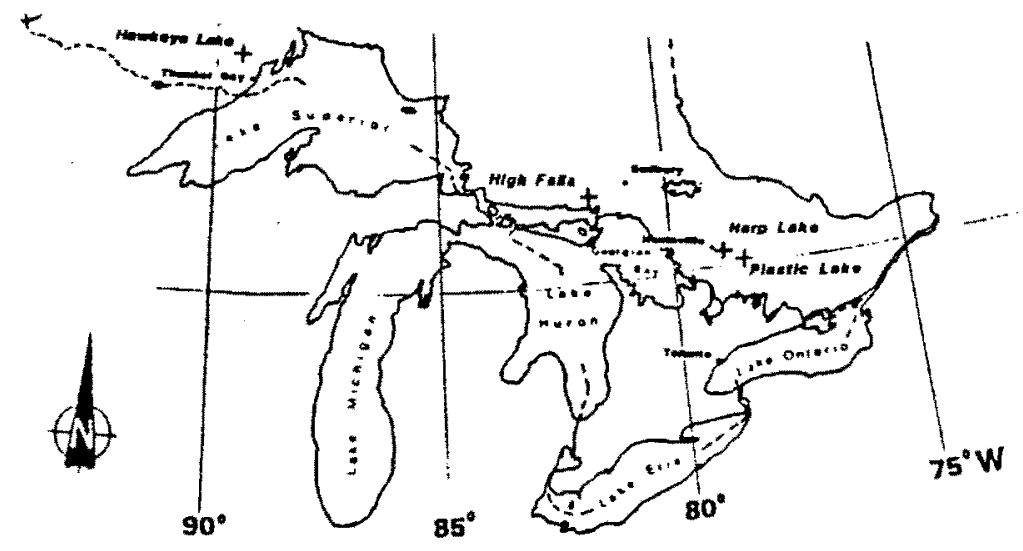



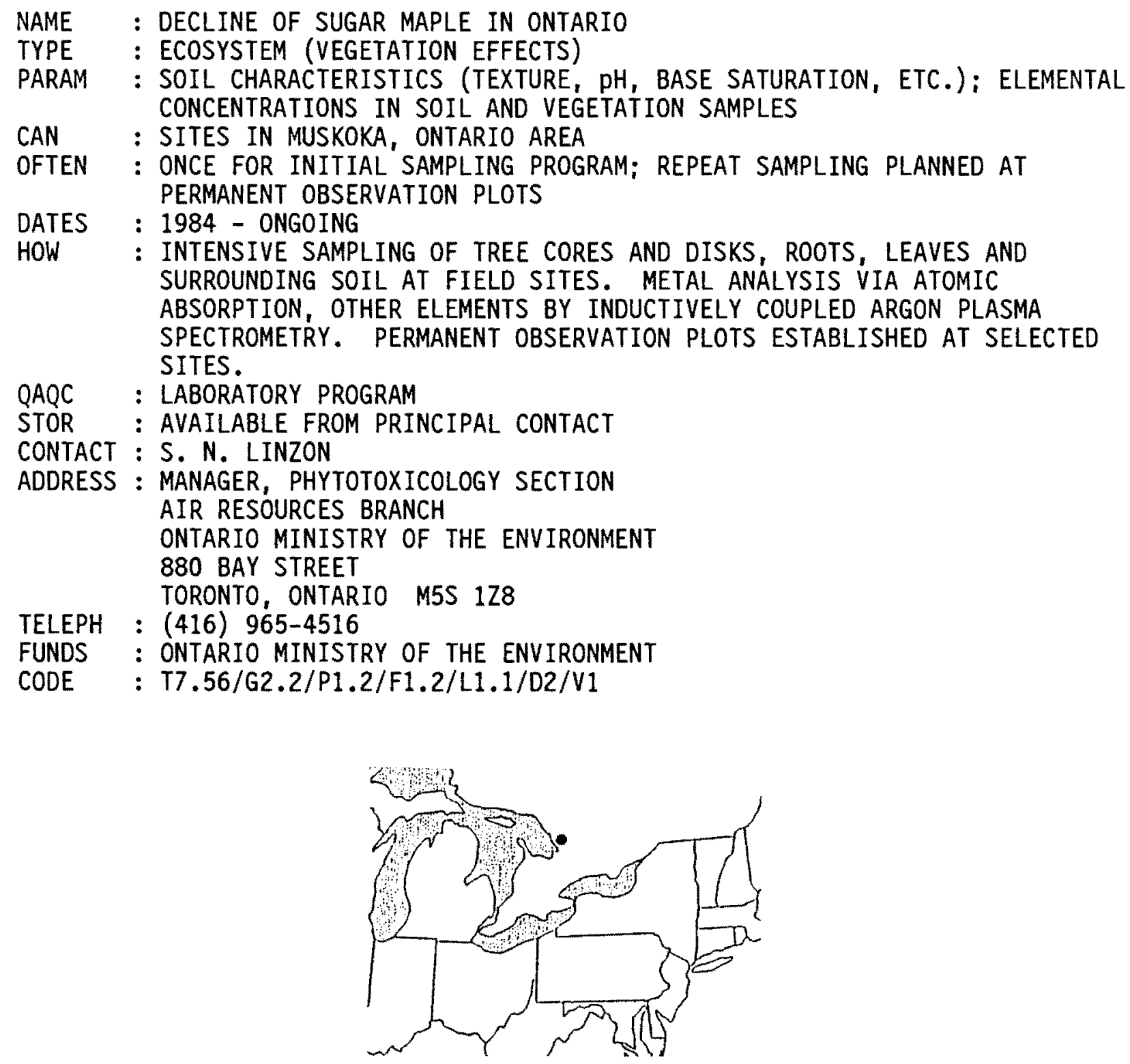

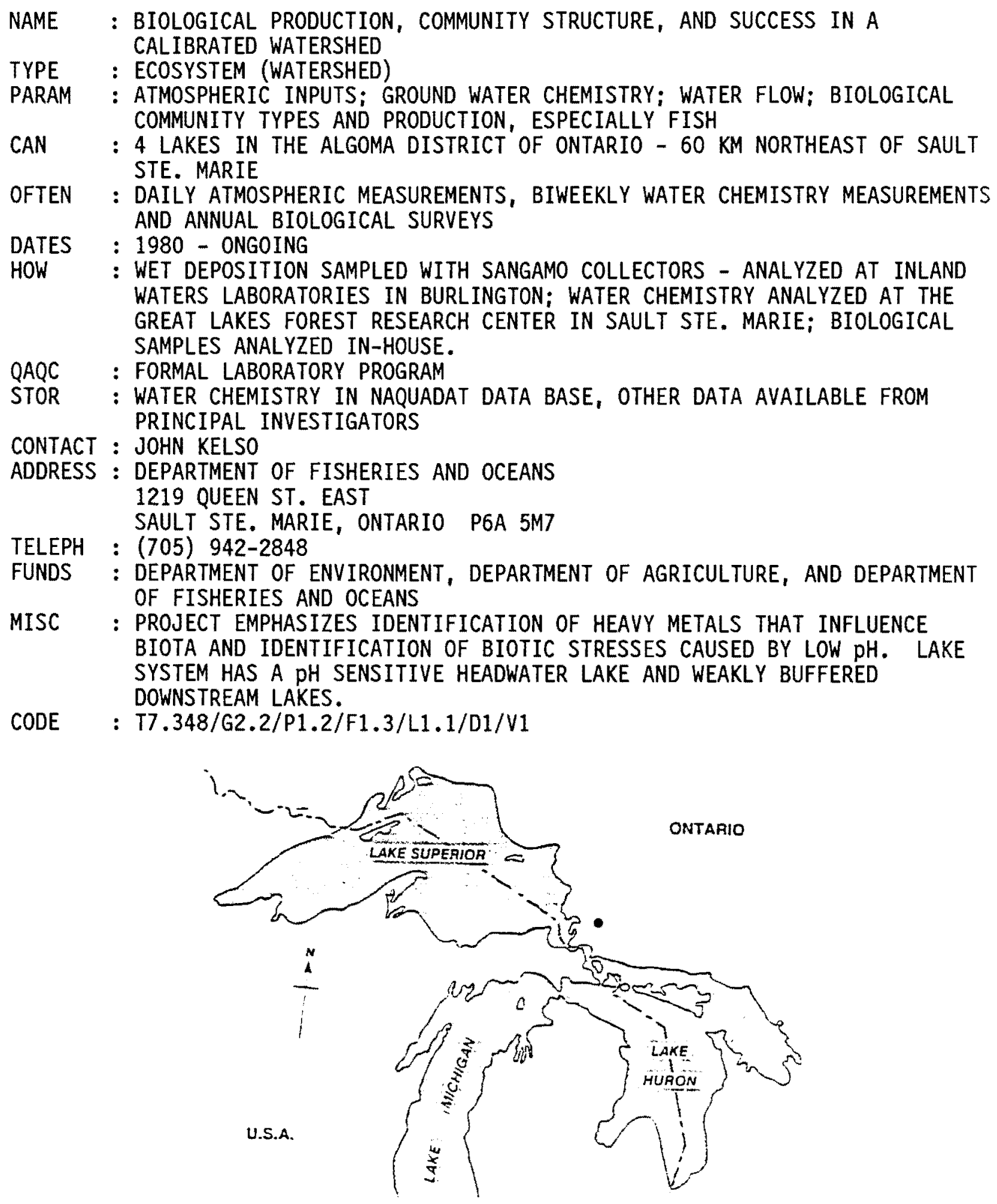

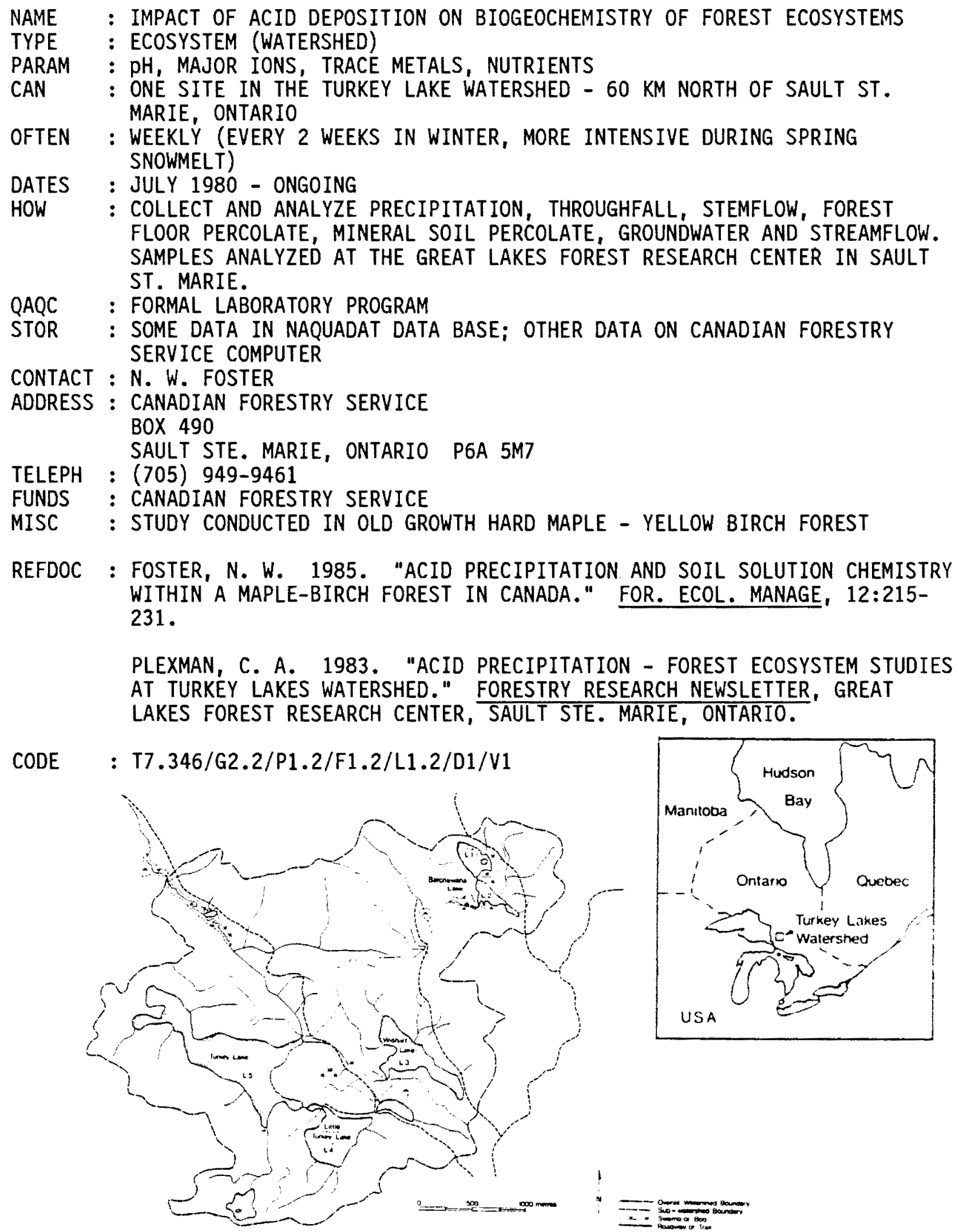


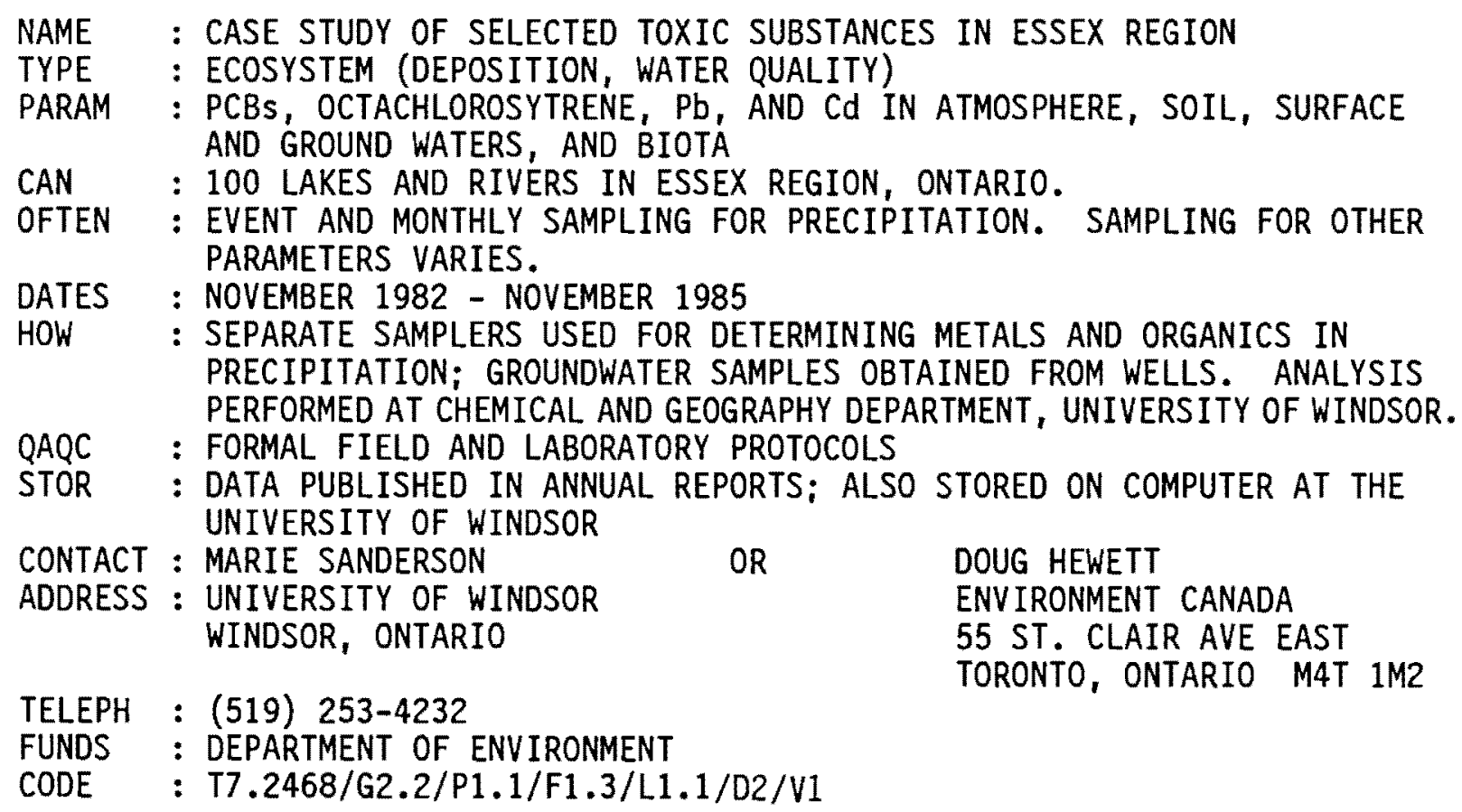

TELEPH : (519) 253-4232

FUNDS : DEPARTMENT OF ENVIRONMENT

CODE : T7.2468/G2.2/P1.1/F1.3/L1.1/D2/V1

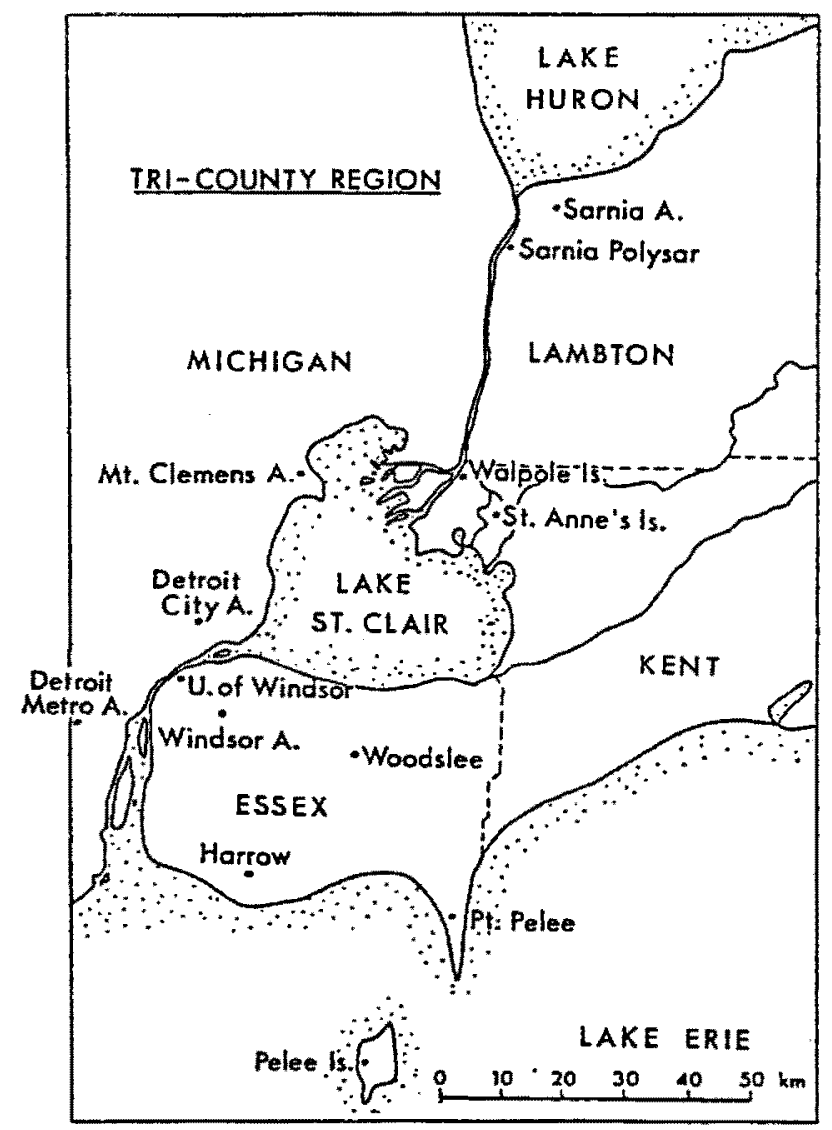



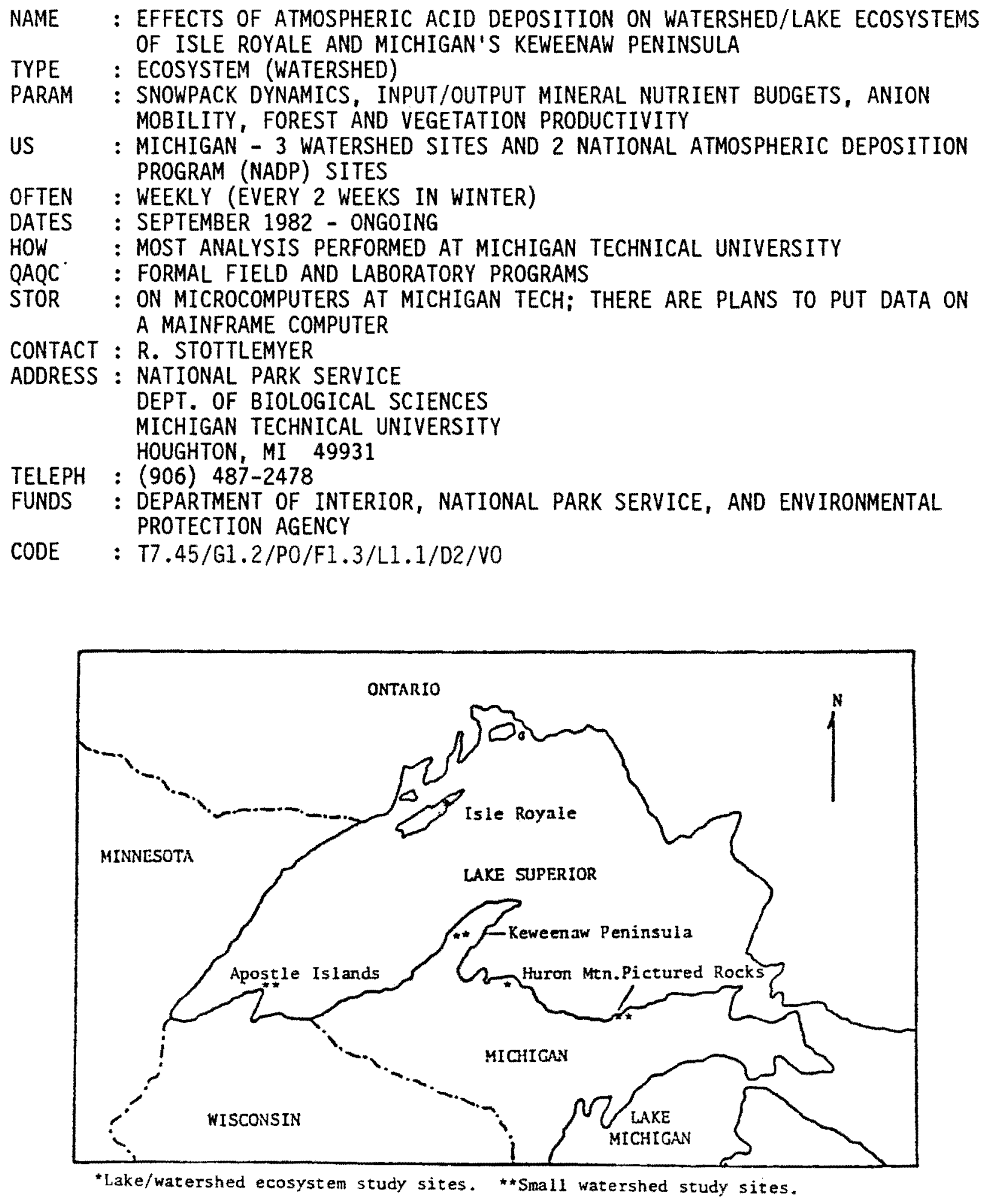

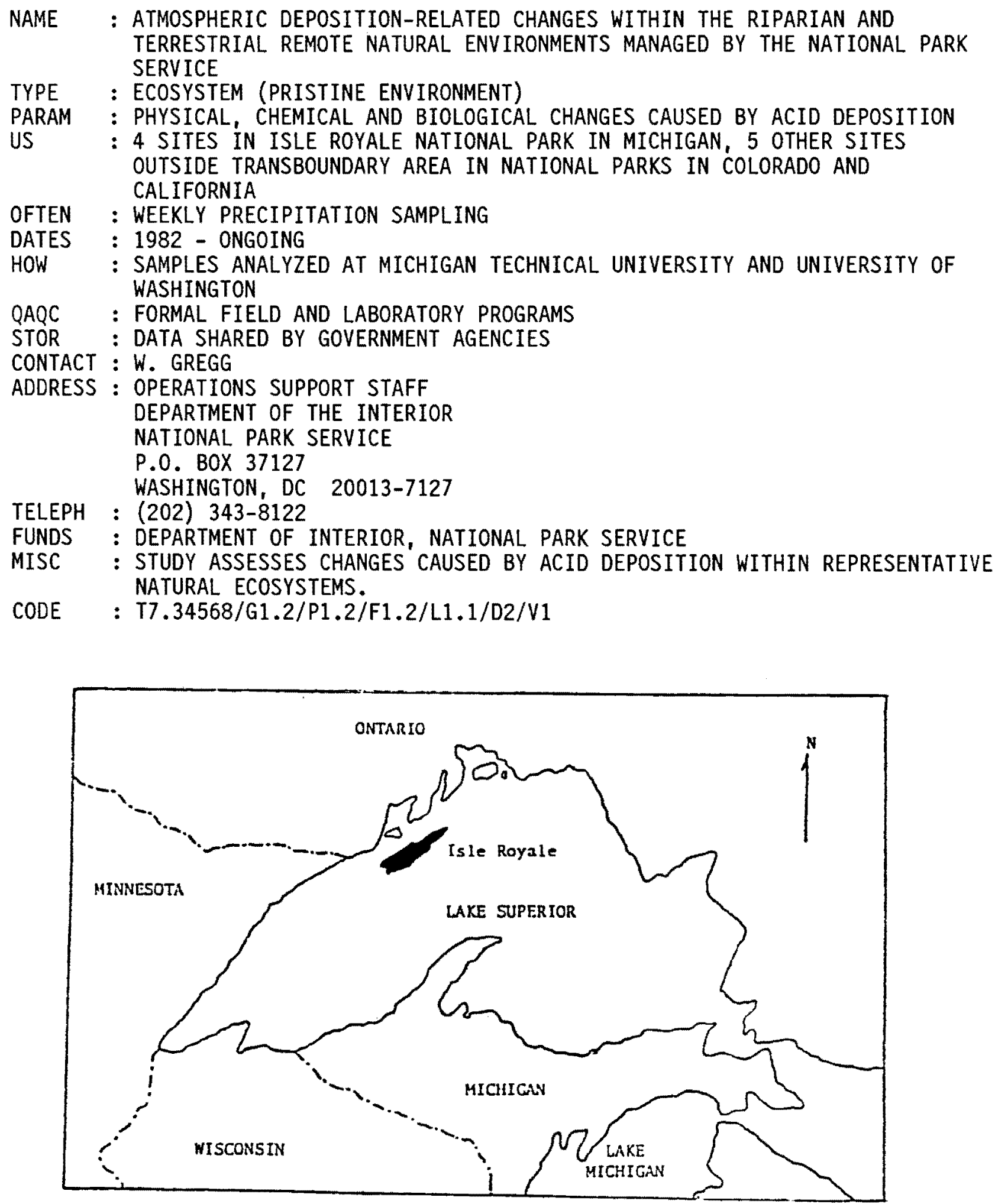

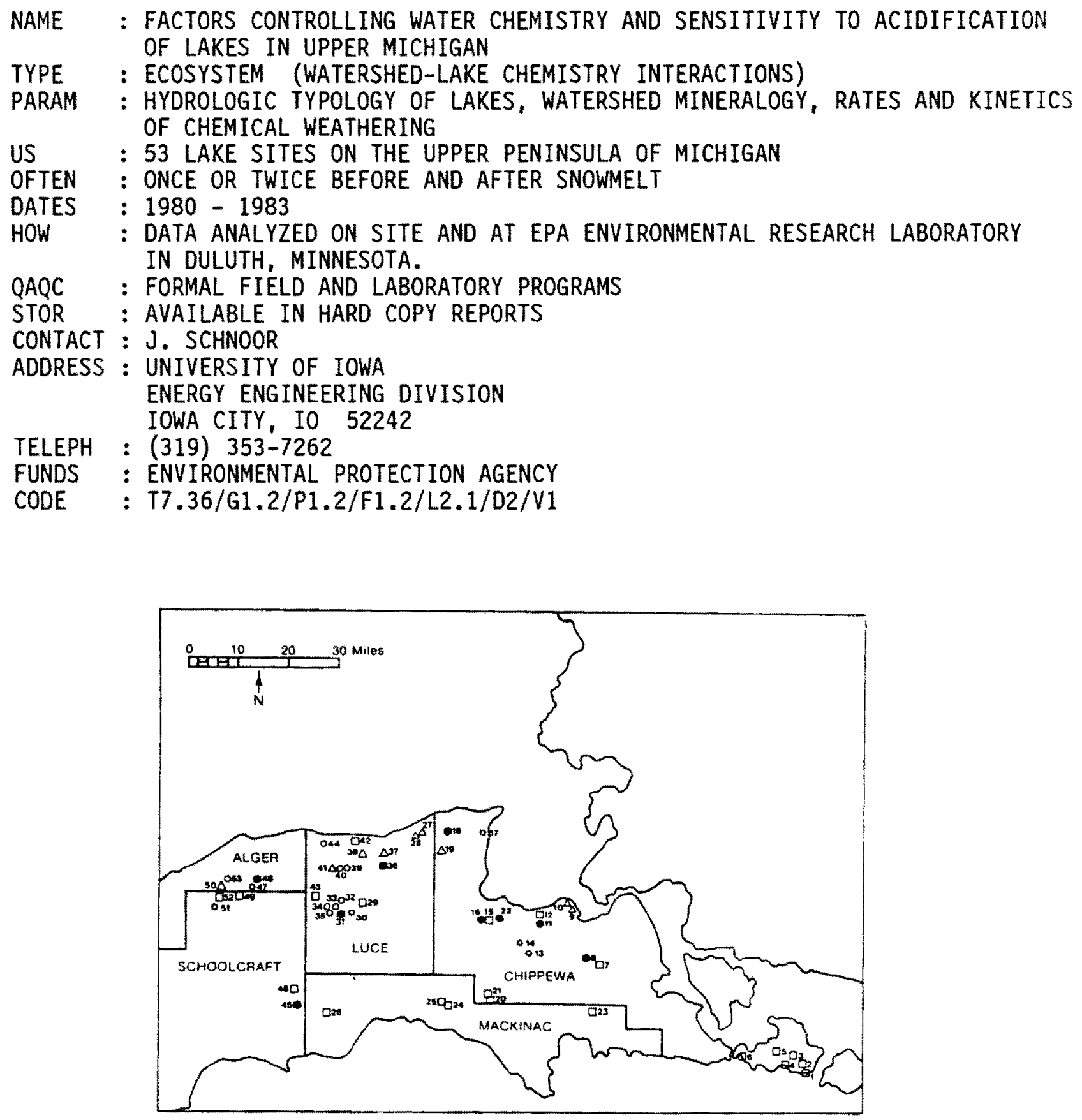

Distribution of sites and akkalinity clusters for 53 lakes in upper peninsula of Michigan

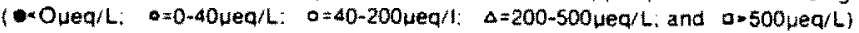


NAME : STATUS OF FISHERY RESOURCES IN SUSCEPTIBLE AND NONSUSCEPTIBLE SURFACE WATERS IN NORTHERN WISCONSIN

TYPE : ECOSYSTEM (BIOLOGICAL EFFECTS)

PARAM : WATER CHEMISTRY ( $p H$, MAJOR IONS); LAKE SEDIMENT COMPOSITION; FISH SURVEYS

US : 12 LAKES IN WISCONSIN

OFTEN : WATER CHEMISTRY ANALYZED REGULARLY EVERY QUARTER; SPECIAL SAMPLING ALSO CONDUCTED AS DEEMED NECESSARY. FISH SURVEYS CONDUCTED IN THE SUMMER OF 1980; ADDITIONAL FISH SAMPLING IN 1981.

DATES : SUMMER 1980 - SUMMER 1983

HOW : SAMPLES ANALYZED AT THE UNIVERSITY OF WISCONSIN-LA CROSSE, RIVER STUDIES CENTER

QAQC : FORMAL FIELD PROGRAM

STOR : AVAILABLE FROM PRINCIPAL INVESTIGATOR

CONTACT : J. WIENER

ADDRESS : FISH AND WILDLIFE SERVICE

COLUMBIA NATIONAL FISHERIES RESEARCH LABORATORY

ROUTE 1

COLUMBIA, MO 65201

TELEPH : (314) 875-5399

FUNDS : FISH AND WILDLIFE SERVICE; ENVIRONMENTAL PROTECTION AGENCY; UNIVERSITY OF WISCONSIN-LA CROSSE

MISC : PROJECT WAS DESIGNED TO ASSESS EFFECTS OF ACID PRECIPITATION AND TRACE METALS ON FISHERY RESOURCES IN NORTH CENTRAL WISCONSIN.

REFDOC : WIENER, J. G. 1983. COMPARATIVE ANALYSES OF FISH POPULATIONS IN NATURALLY ACIDIC AND CIRCUMNEUTRAL LAKES IN NORTHERN WISCONSIN. U.S. FISH AND WILDLIFE SERVICE, KEARNEYSVILLE, WEST VIRGINIA.

CODE $\quad: T 7.368 / G 1.2 / P 1.1 / F 1.2 / L 2.1 / D 2 / V 1$
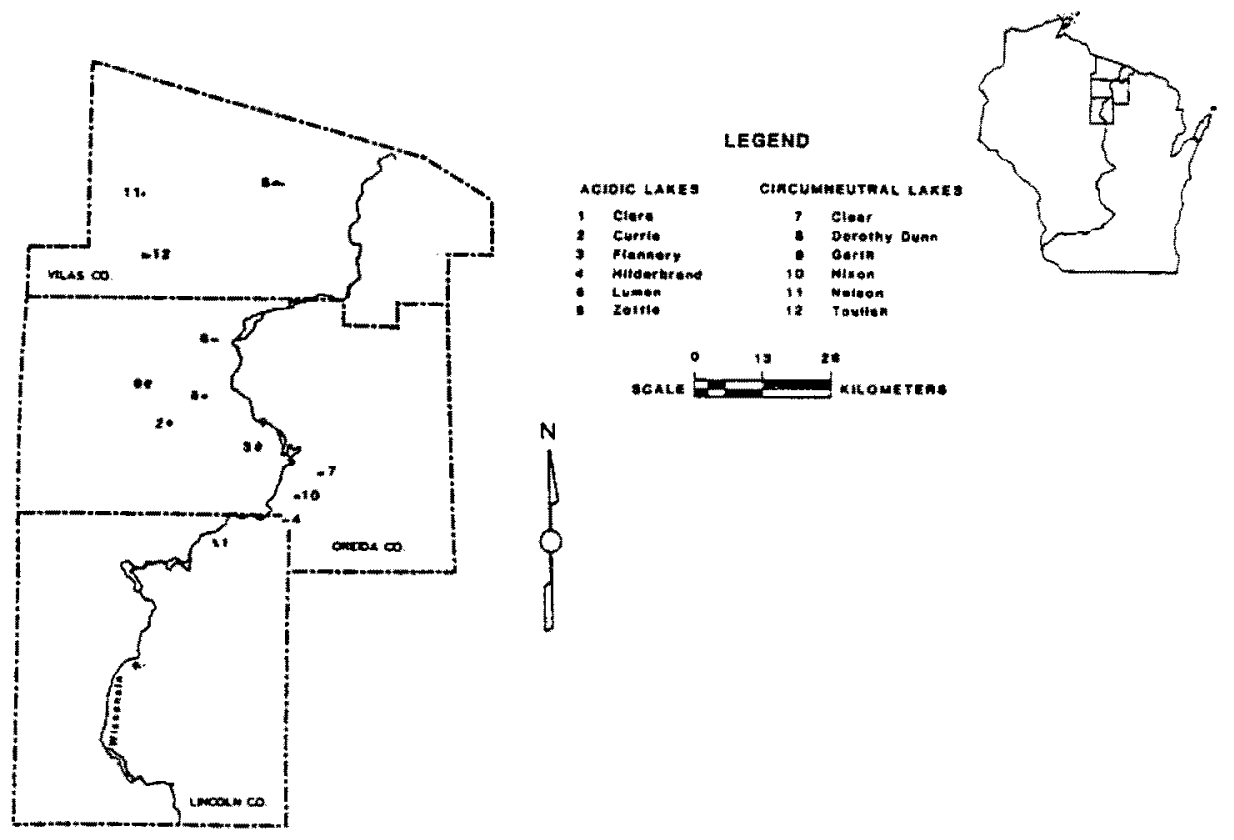


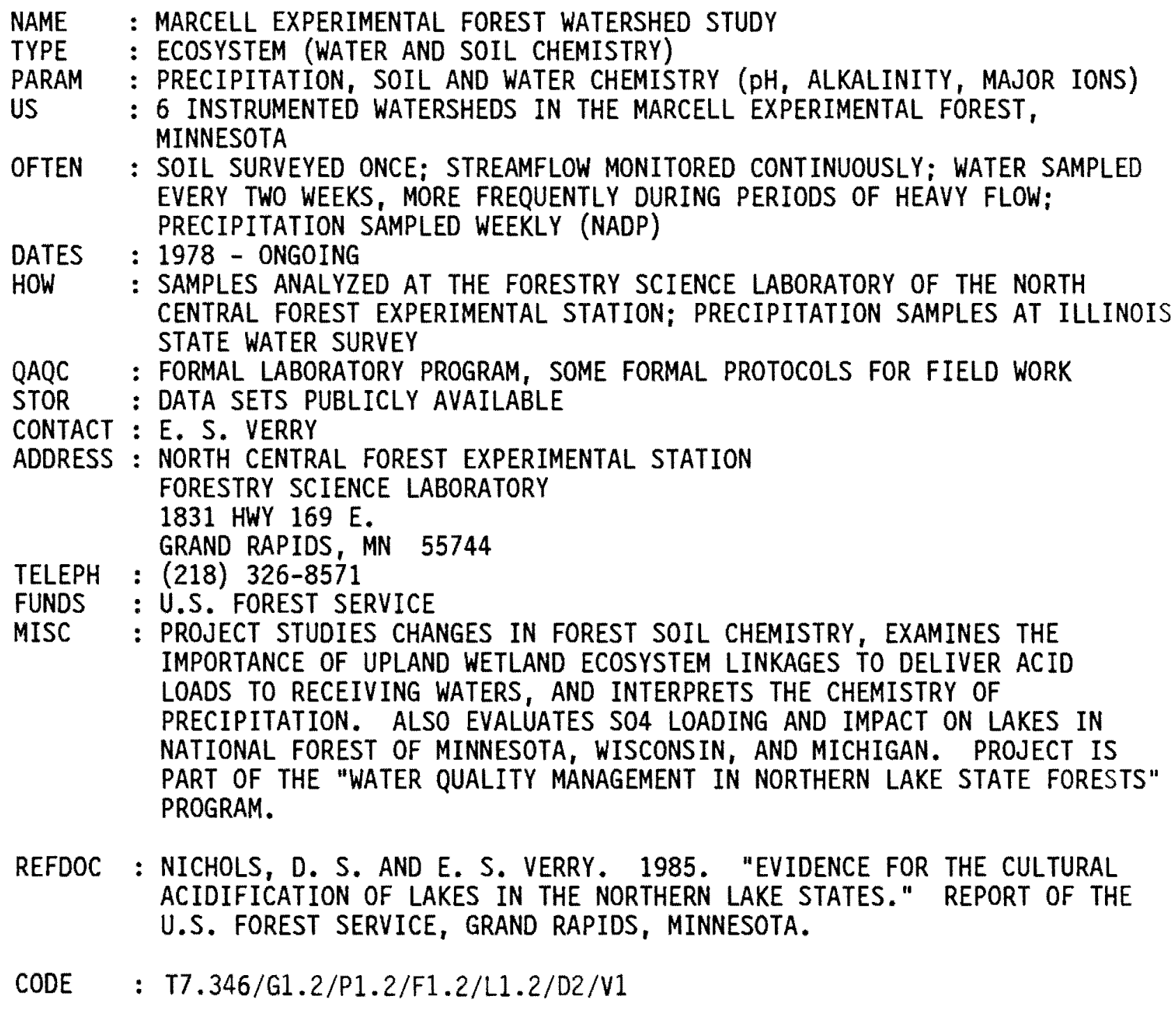

REFDOC : NICHOLS, D. S. AND E. S. VERRY. 1985. "EVIDENCE FOR THE CULTURAL ACIDIFICATION OF LAKES IN THE NORTHERN LAKE STATES." REPORT OF THE U.S. FOREST SERVICE, GRAND RAPIDS, MINNESOTA.

CODE : T7.346/G1.2/P1.2/F1.2/L1.2/D2/V1

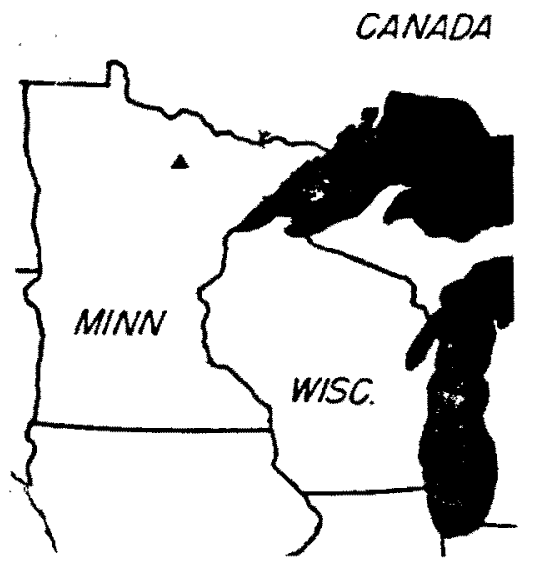




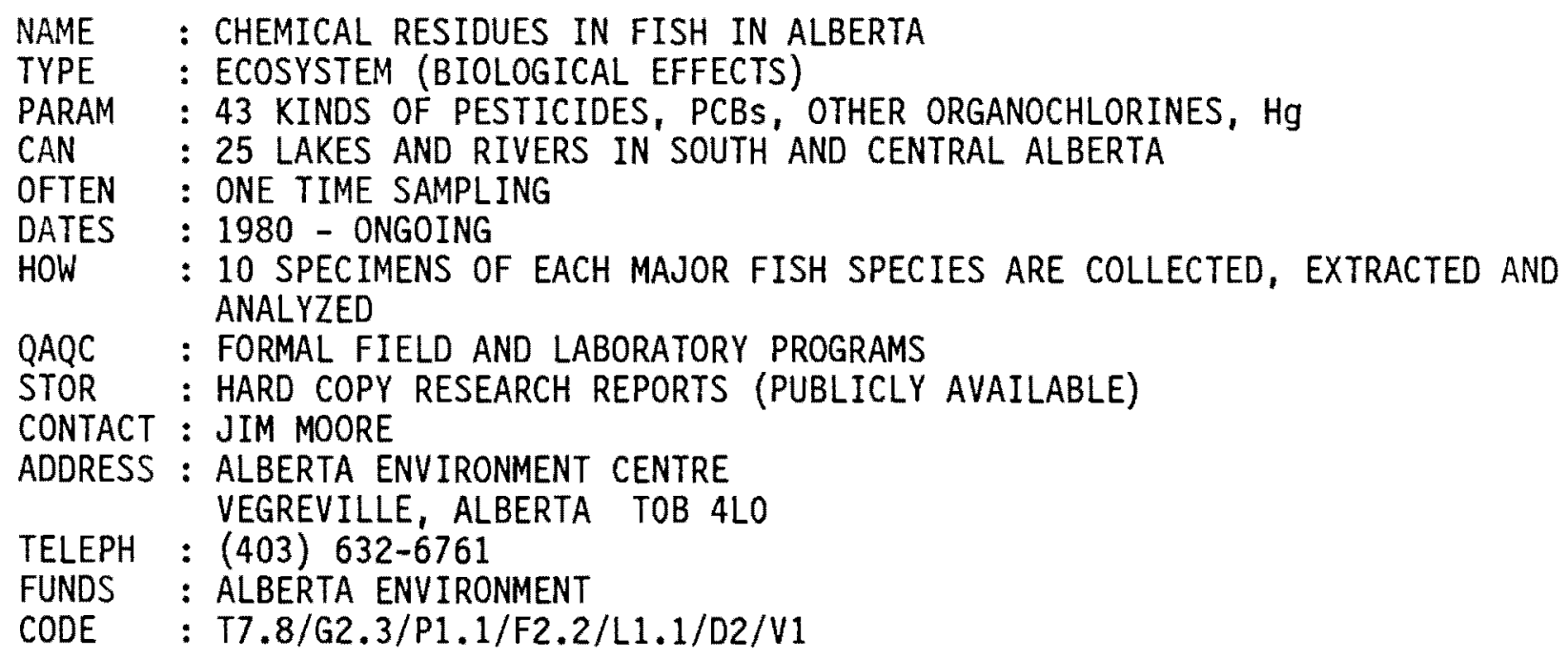



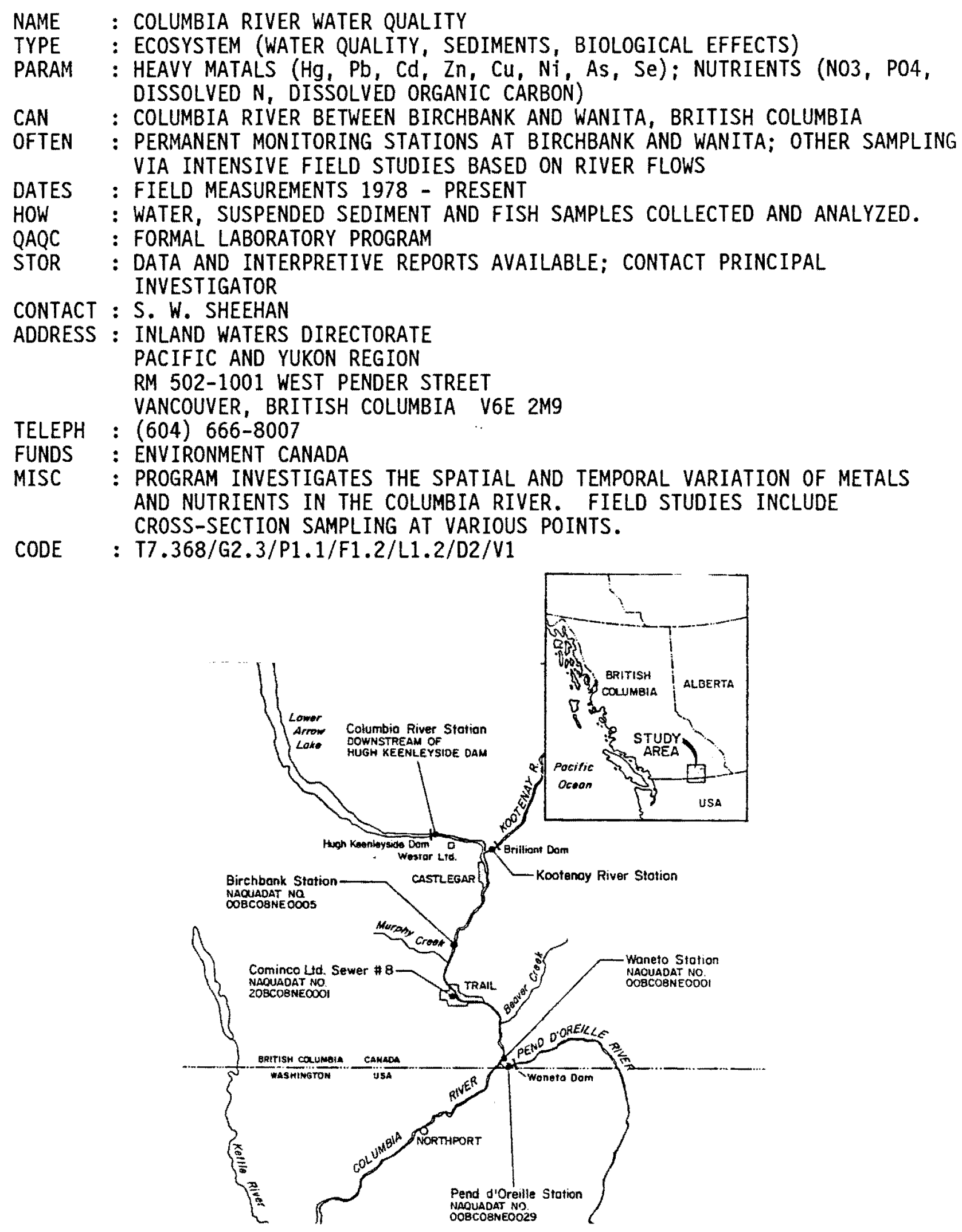


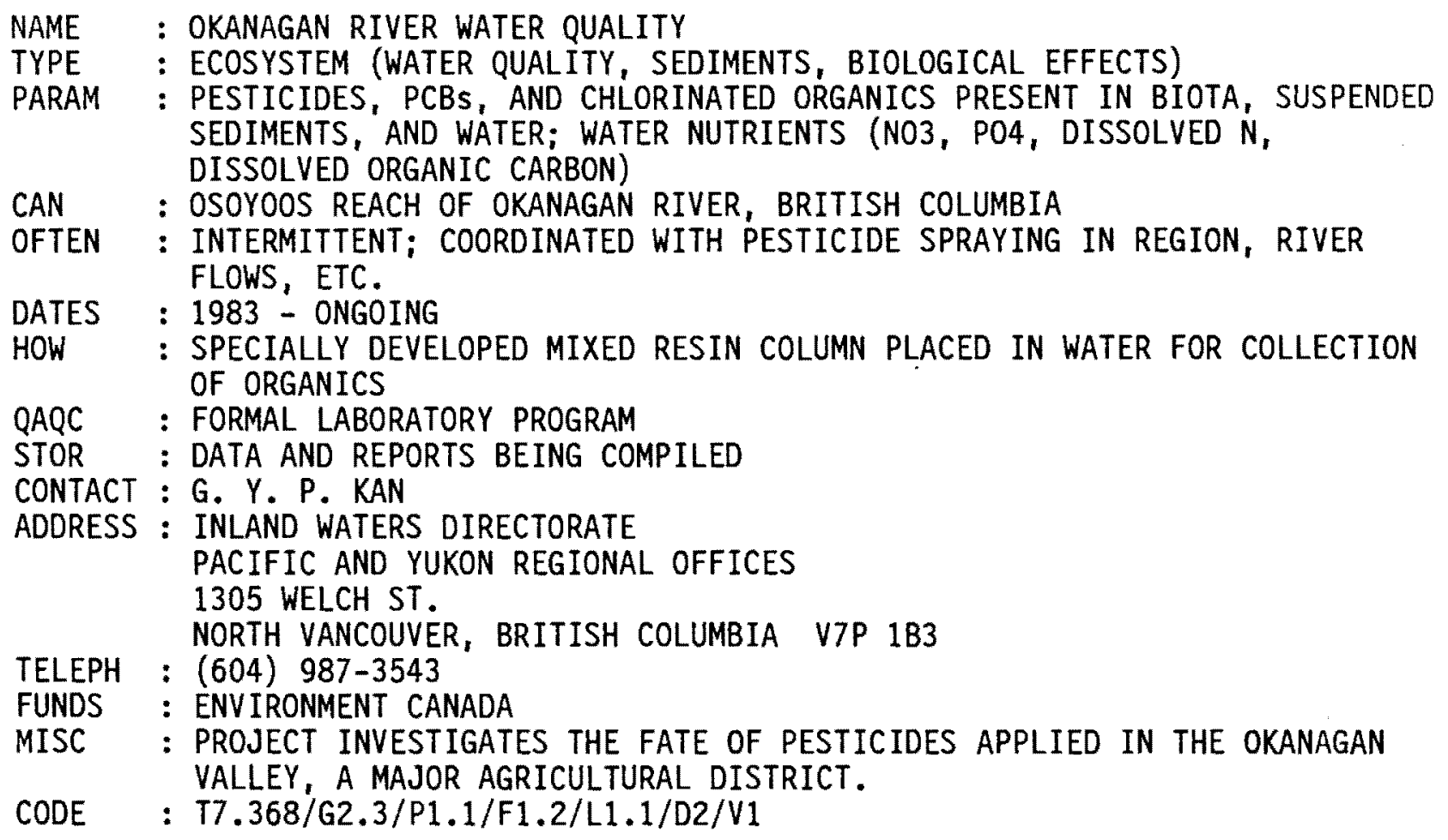




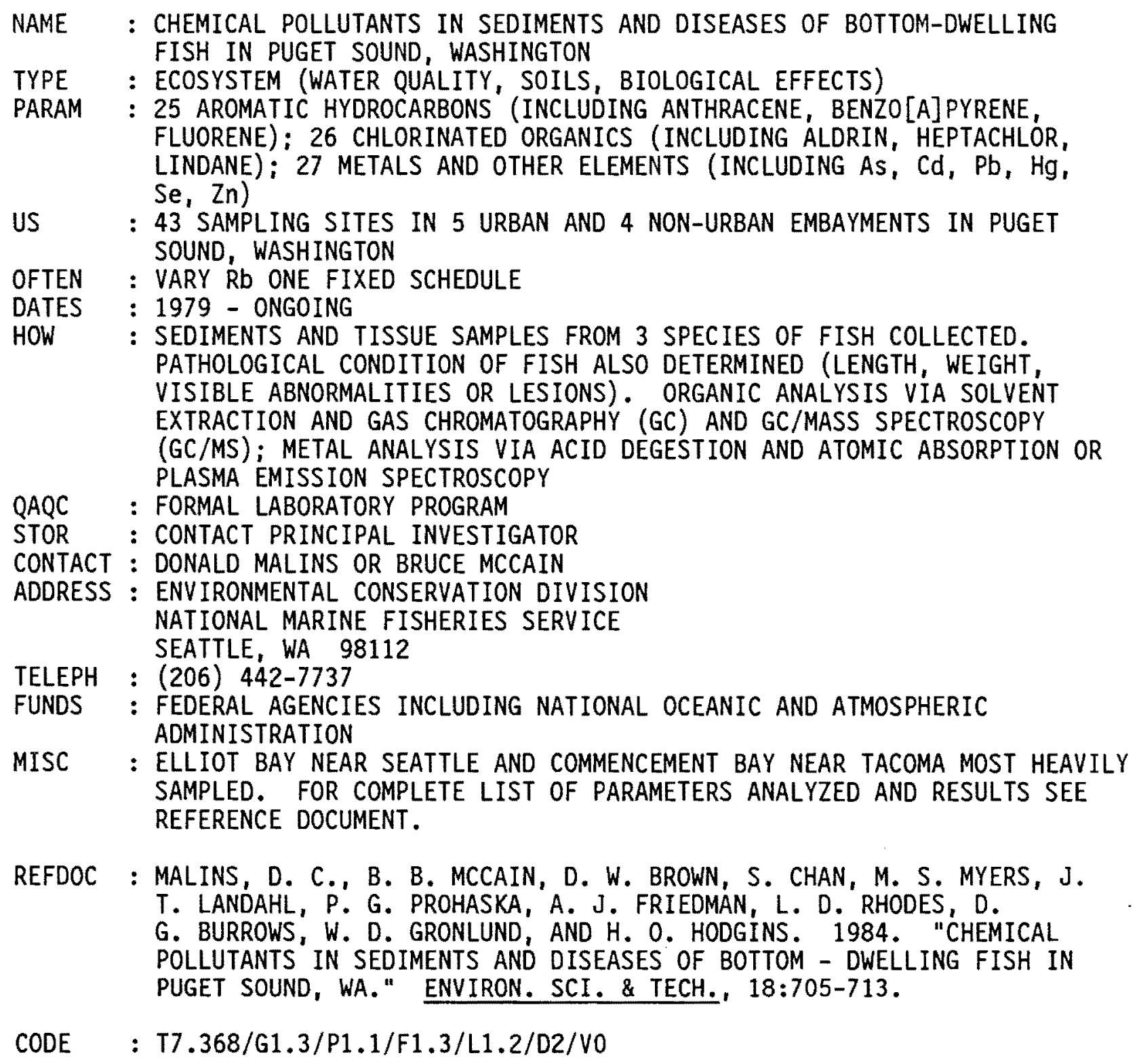




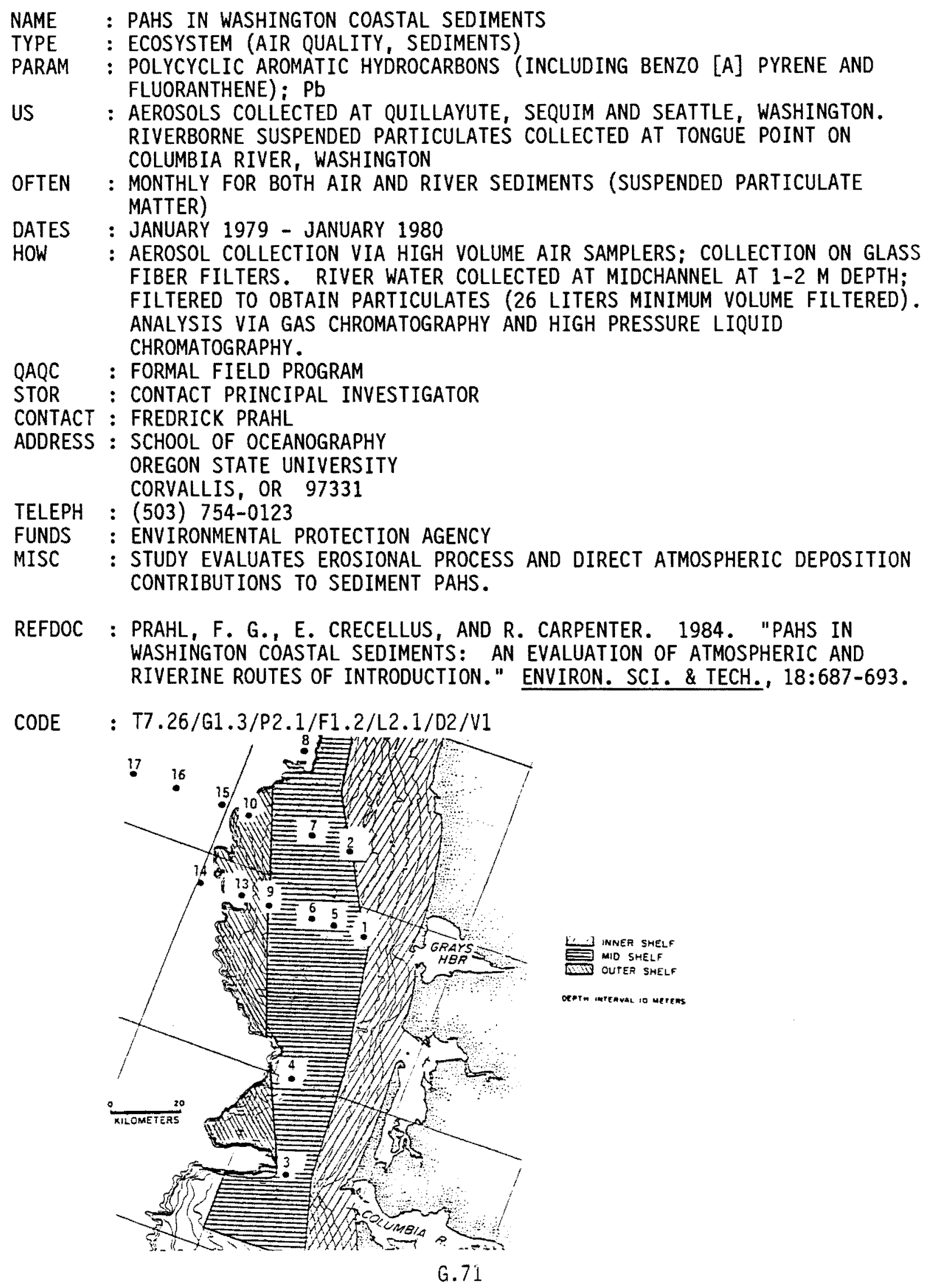




\section{DISTRIBUTION}

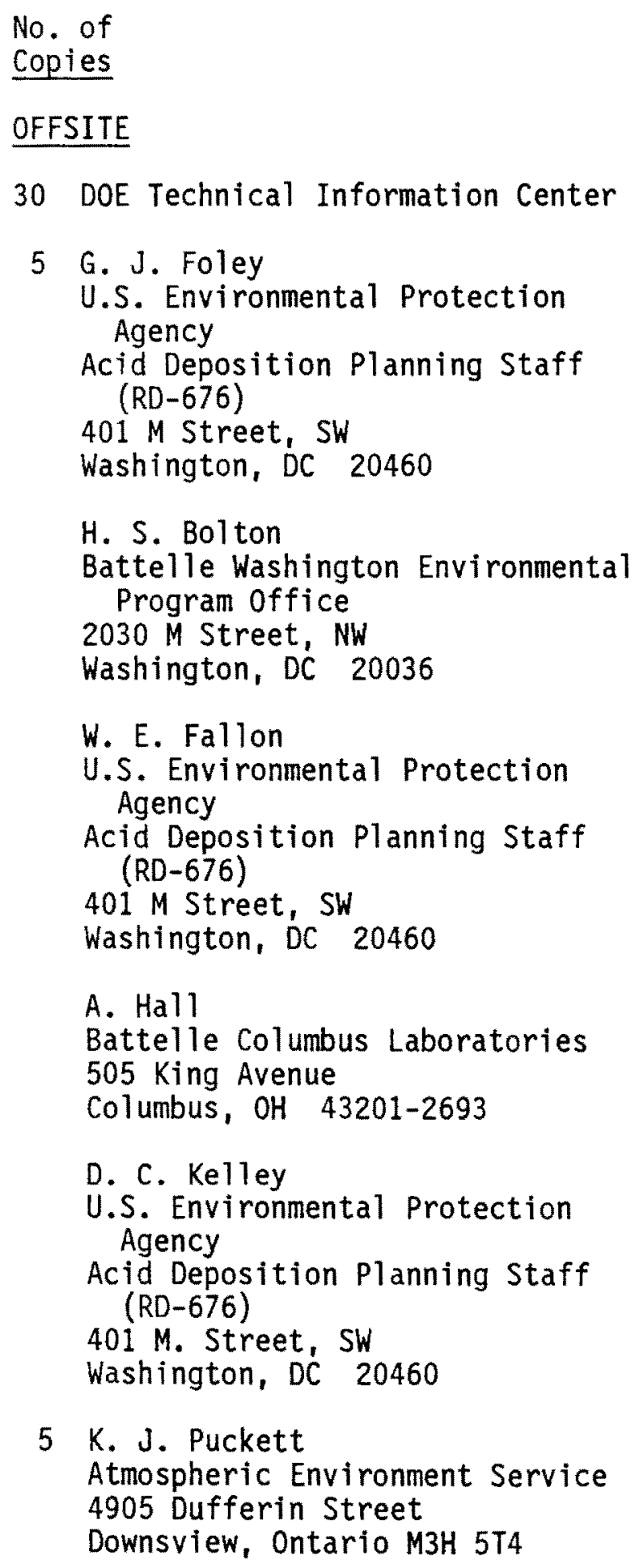

No. of

Copies

ONSITE

DOE Richland Operations office

J. J. Sutey/P. K. Clark

35 Pacific Northwest Laboratory

M. Y. Ballinger

W. R. Barchet

E. G. Chapman (4)

D. W. Dragnich

C. E. Elderkin

C. S. Glantz (15)

J. M. Hales

P. C. Hays

N. S. Laulainen

A. R. 01sen

B. L. Steelman

Publishing Coordination (2)

Technical Services (5) 


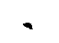

